\title{
A Century on the Northern Plains: the University of North Dakota at 100
}

D. Jerome Tweton

University of North Dakota

Robert P. Wilkins

University of North Dakota

Thomas W. Howard

University of North Dakota

Lee Bohnet

University of North Dakota

James F. Vivian

University of North Dakota

See next page for additional authors

How does access to this work benefit you? Let us know!

Follow this and additional works at: https://commons.und.edu/und-books

Part of the Higher Education Commons

\section{Recommended Citation}

Tweton, D. Jerome; Wilkins, Robert P.; Howard, Thomas W.; Bohnet, Lee; Vivian, James F.; and Rylance, Dan F., "A Century on the Northern Plains: the University of North Dakota at 100" (1983). UND

Publications. 2.

https://commons.und.edu/und-books/2

This Book is brought to you for free and open access by the Elwyn B. Robinson Department of Special Collections at UND Scholarly Commons. It has been accepted for inclusion in UND Publications by an authorized administrator of UND Scholarly Commons. For more information, please contact und.commons@library.und.edu. 
Authors

D. Jerome Tweton, Robert P. Wilkins, Thomas W. Howard, Lee Bohnet, James F. Vivian, and Dan F. Rylance

This book is available at UND Scholarly Commons: https://commons.und.edu/und-books/2 

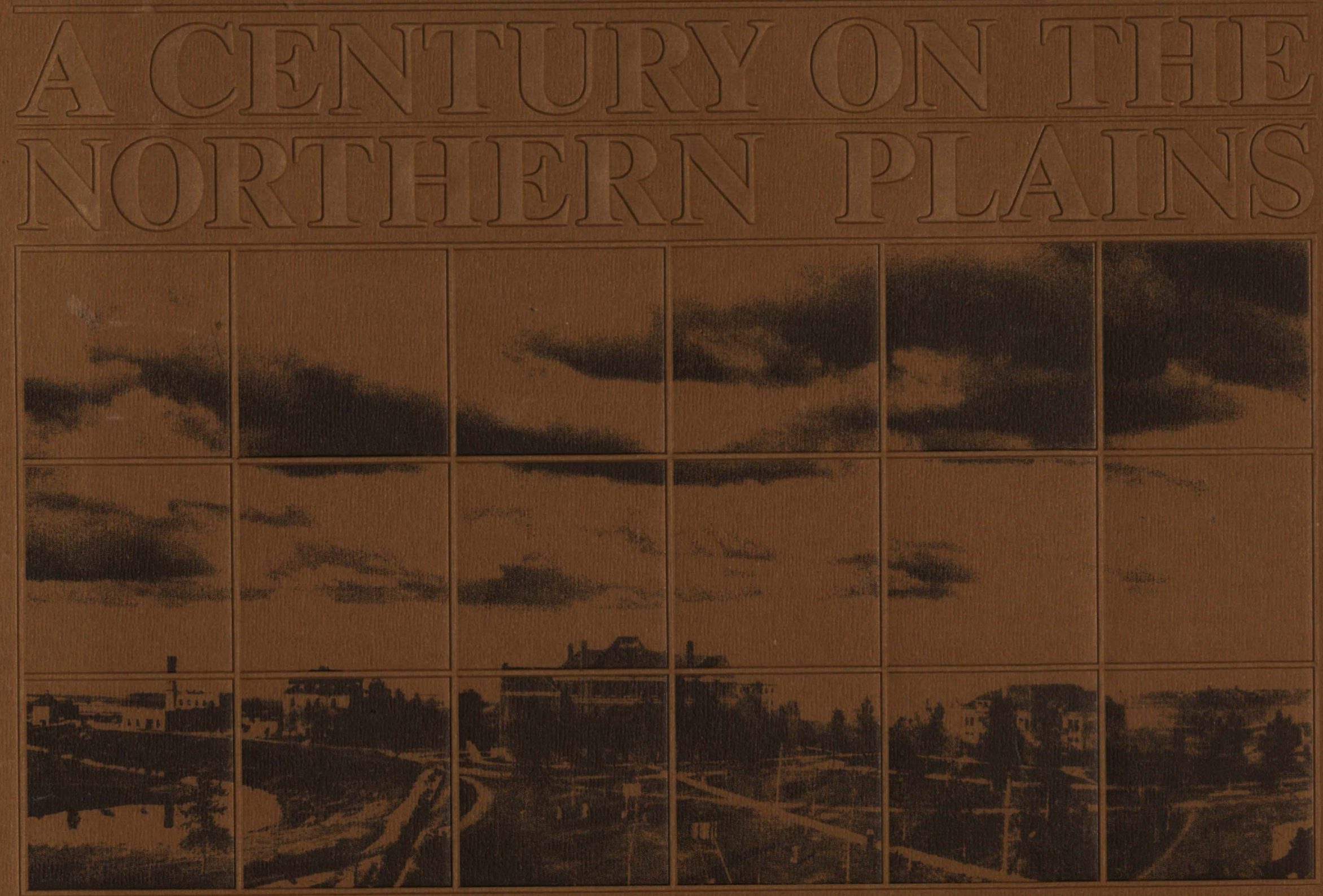

The Uninersitys of Norit Dateria at I00 


\section{A Century}

on the

Northern

Plains

The University of North Dakota

at 100

Essays by

D. Jerome Tweton

Robert P. Wilkins

Thomas W. Howard

Lee Bohnet

James F. Vivian

Dan F. Rylance

Edited by

Robert P. Wilkins

The University of North Dakota Press 
A Century on the Northern Plains: The University of North Dakota at 100

Copyright (c) 1983 by the Office of the President, The University of North Dakota, Grand Forks, North

Dakota 58202

All rights reserved.

Printed in the United States of America, Associated

Printers, Inc., Grafton, North Dakota

A project of the University Centennial Committee

supported entirely with nonstate funds. 


\section{Contents}

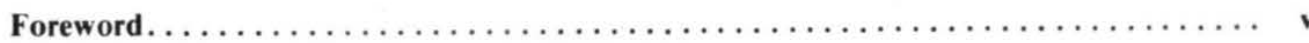

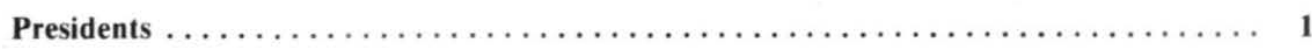

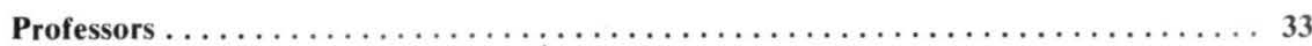

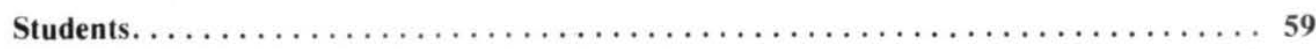

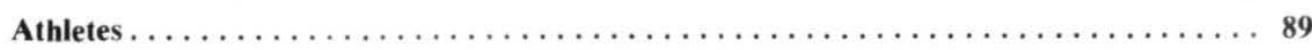

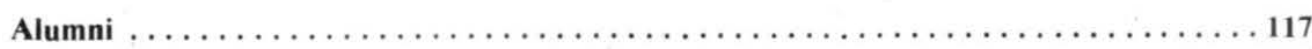

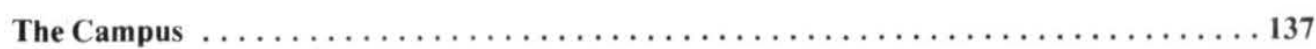

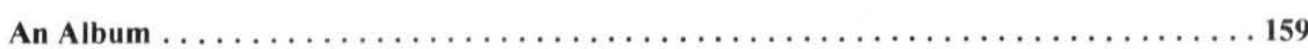

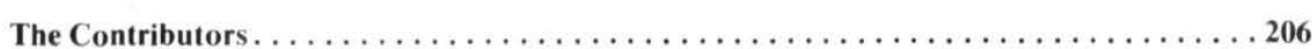




\section{Foreword}

The University of North Dakota in 1958 observed its 75th anniversary with

enthusiasm and in varied ways, including lectures by distinguished authorities in many fields, concerts, and fine arts

displays. The most valuable of them was publication of the book, University of the Northern Plains, in which Louis G. Geiger gave shape and meaning to the history of

the institution. With the approach of the University's 100th anniversary, the suggestion of a 25-year supplement to Prof. Geiger's work failed to find support on the Centennial committee, chaired by Dean Emeritus D. J. Robertson. In part this recognized that Elwyn B.

Robinson had dealt in great detail with the period 1954-1971 in "The Starcher Years," North Dakota Quarterly, Spring 1971. Instead, it was decided to review the story of UND's first century in several short chapters, each dealing with a single facet of its life but in a highly selective way which would omit many persons, groups and events. Six authors, five of them members of UND's history faculty, were commissioned by the Centennial committee to produce the essays found in this book.
No attempt has been made to give the chapters a uniformity of structure,

language, or point of view. Each author puts his observations on his subject in the shape he deems most effective and presents his own understanding of the issues involved. All of them are indebted to Prof Geiger's pioneering work in one degree or another, while themselves adding to the corpus of available information about personalities and events of the great adventure in higher education. The reader will find certain episodes and issues dealt with in more than one chapter, inasmuch as they concerned administrators, faculty, and students alike.

The authors and David H. Vorland, director of the Office of University Relations, selected the photographs which are an important part of this book. The pictures are primarily from the archives collection of the Chester Fritz Library's Department of Special Collections and the files of the Office of University Relations. The State Historical Society of North Dakota provided several rare photographs. A special acknowledgment is extended to the Milwaukee Public Museum of
Milwaukee County, which granted reproduction rights to Summer W. Mattson's fine 1904 picture of the campus at

harvest time. The University's appreciation also goes to the many alumni and friends who have contributed photographs to the

UND archives, some of which are published herein.

The selection of photographs, as well as the preparation of the text, was expedited by the work of Audrey Kazmierczak and Coleen Oihus of the Chester Fritz Library. Carol Taylor and Liz Hamill of the Department of History typed the manuscript and made suggestions. Vorland and Richard Larson of the Office of

University Relations prepared the photo captions and miscellaneous informative matter. Kathryn Sweney assisted the University Relations staff in proofreading

the galleys. The graphic design of a $\mathbf{A}$ Century on the Northern Plains is by James Hughes, also of the Office of

University Relations.

\section{Robert P. Wilkins}

Editor

December 15,1982 


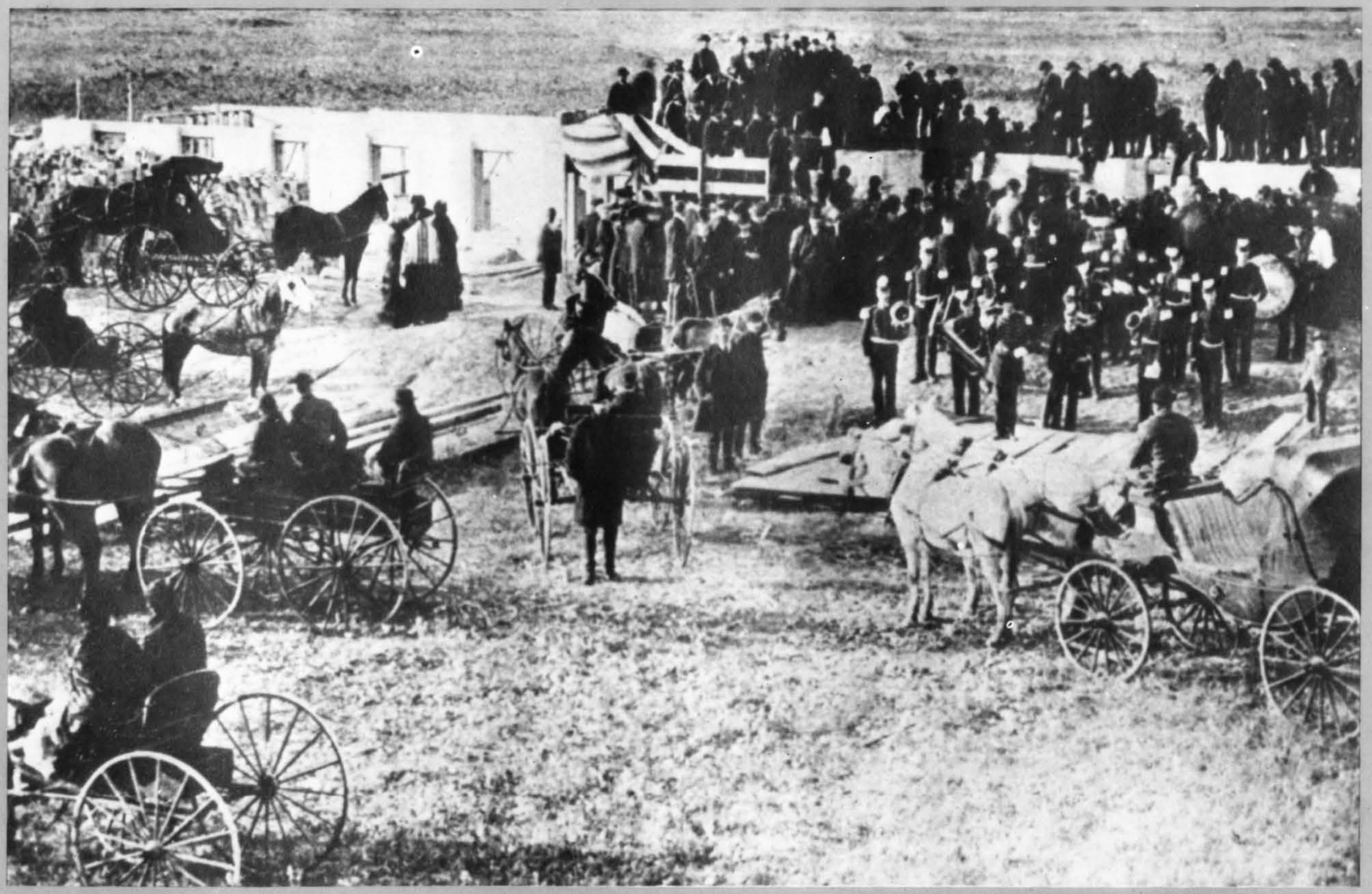




\section{Presidents}

By D. Jerome Tweton

Professor of History

$\mathbf{M}$ any people played crucial roles in launching and sustaining that bold

educational venture on the bleak prairie to the west of Grand Forks. George Walsh, frontier boomer and crafty politico, steered the necessary bill through the territorial legislature. The first Board of Regents James Twamley, a Grand Forks merchant; William T. Collins and Charles E. Teel, Grand Forks physicians; R. M. Evans, Minto physician; E. W. Healey, a Grafton clergyman - carefully laid the

foundations. William Budge, Grand Forks entrepreneur and trustee from 1891-1907, gave financial, political, and moral support whenever called upon. Henry Montgomery, the first faculty appointee, lent his talents to vigorous teaching and, for two years, administ rative leadership. William

Blackburn and Homer Sprague provided their best efforts as presidents. But, it was the slight and quiet Webster Merrifield who dominated the first 25 years of the University of North Dakota.

At age 33 he joined the tiny faculty that first year. A graduate of Yale (A.B., 1878), he had served on the faculty of Siglar School for Boys in New York for two years before becoming a tutor in Greek and Latin at Yale in 1880. His family's land interests near Grand Forks and an acquaintance with the Twamley family led him to North Dakota. Even before he assumed the presidency in 1891, his mark was on the new University. His philosophy of education prevailed; his

recommendations concerning faculty appointments were followed; his hand in the selection of Sprague, the University's second president, was evident.

The Board of Regents chose for its first president a 55-year-old clergyman from Cincinnati - the distinguished William

Maxwell Blackburn, a graduate of Hanover College. He had taught at a Presbyterian seminary and had gained a national reputation when his history of the

Christian Church was published in 1879 . In Blackburn, the regents found a polished public speaker to spread the word about the new University, a scholar to enhance the classroom experience, and a moral leader to set a high example for students.

The problems that confronted Blackburn must have seemed insurmountable. The University had no program, incomplete facilities, few books, little equipment, and no students who were qualified for college study. In spite of the many shortcomings, the University opened its doors in 1884 , and 79 students enrolled during the year. The four teachers - the president,

Montgomery, Merrifield, and Mrs. Emma Mott - inaugurated a preparatory

program, conducting the first year on an experimental basis.

Although the preparatory function would remain central to the University's mission for some time, Montgomery and Merrifield spent long hours devising a college program: a two-year preparatory program, a three-year normal course to provide elementary teachers, and a university program leading to the Bachelor of Arts and Bachelor of Science degrees.

Most schools were beginning to move away from classical and toward practical education, but the Montgomery-Merrifield plan did not reflect the new approach. For example, the B.A. required three years of Greek, Latin, French, English, German, and mathematics. President Blackburn
Laying the cor nerstone of the Main 
William Blackburn, president, 1884-1885.

Henry Montgomery, member and acting president, 1885-1887.

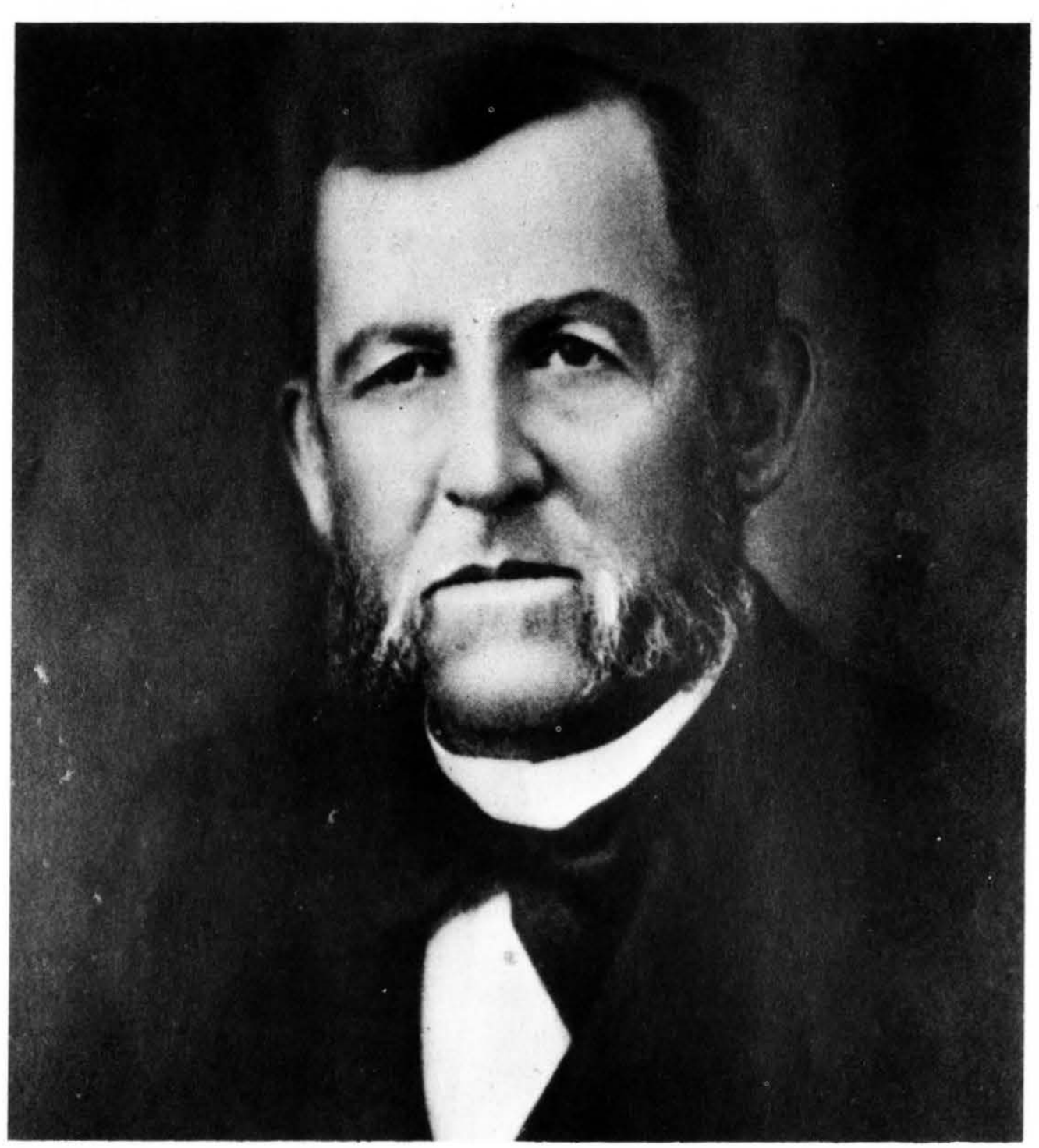

thought that the program was

inappropriate for a frontier school, but the

regents approved it in spite of presidential and public opposition.

The squabble over curriculum, however, was not Blackburn's most serious problem. He constantly clashed with the janitor and Mott, who he claimed began eating before he could finish his prayer of blessing. (She retorted that the prayers did not improve the quality of the food.) After a heated board hearing and a swirl of public

controversy, the Board, which had earlier fired the janitor, terminated both Blackburn and Mott.

When Merrifield refused the presidency, the Board appointed Montgomery as acting president. He proved to be a successful caretaker of the University's affairs.

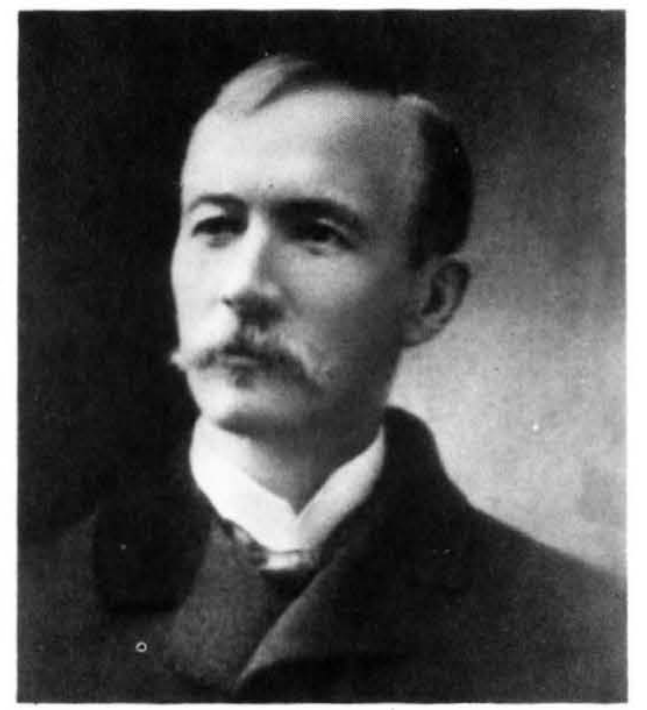


Although enrollment slumped to 48 in 1885 , the University began offering the first two years of college study. Workers completed the main building, library books began to arrive, and the Legislature approved the first dormitory. In matters that would influence the University's future, it was Merrifield who had the ear of the regents. The 1885 appointments to the faculty were broadly educated men who buttressed his philosophy of education. And, after Territorial Gov. Gilbert A Pierce accepted and then rejected, at the last hour, the presidency in 1887 , it was Merrifield whom the Board sent east in search of someone to fill it.

In October 1885, the Board announced that 58-year-old Homer B. Sprague would take over the presidential duties. Sprague's national reputation and multi-faceted career must have caused many to ask, "Why Dakota?" Among other activities and accomplishments, Sprague had taught Greek and Latin, practiced law, served in the Connecticut legislature, been a professor of rhetoric and literature at Cornell University, administered public schools, and held the presidency of Mills College in California. Sprague seemed to possess the ideal qualities to lead the University toward respectability. He had a well-defined educational philosophy, understood the world of politics, could explain the University to the public in a powerful way, and knew what life on a campus should be like.

The new president believed that a university should educate for citizenship and that a student should be exposed to more than the traditional classics. A new program leading to the bachelor of letters

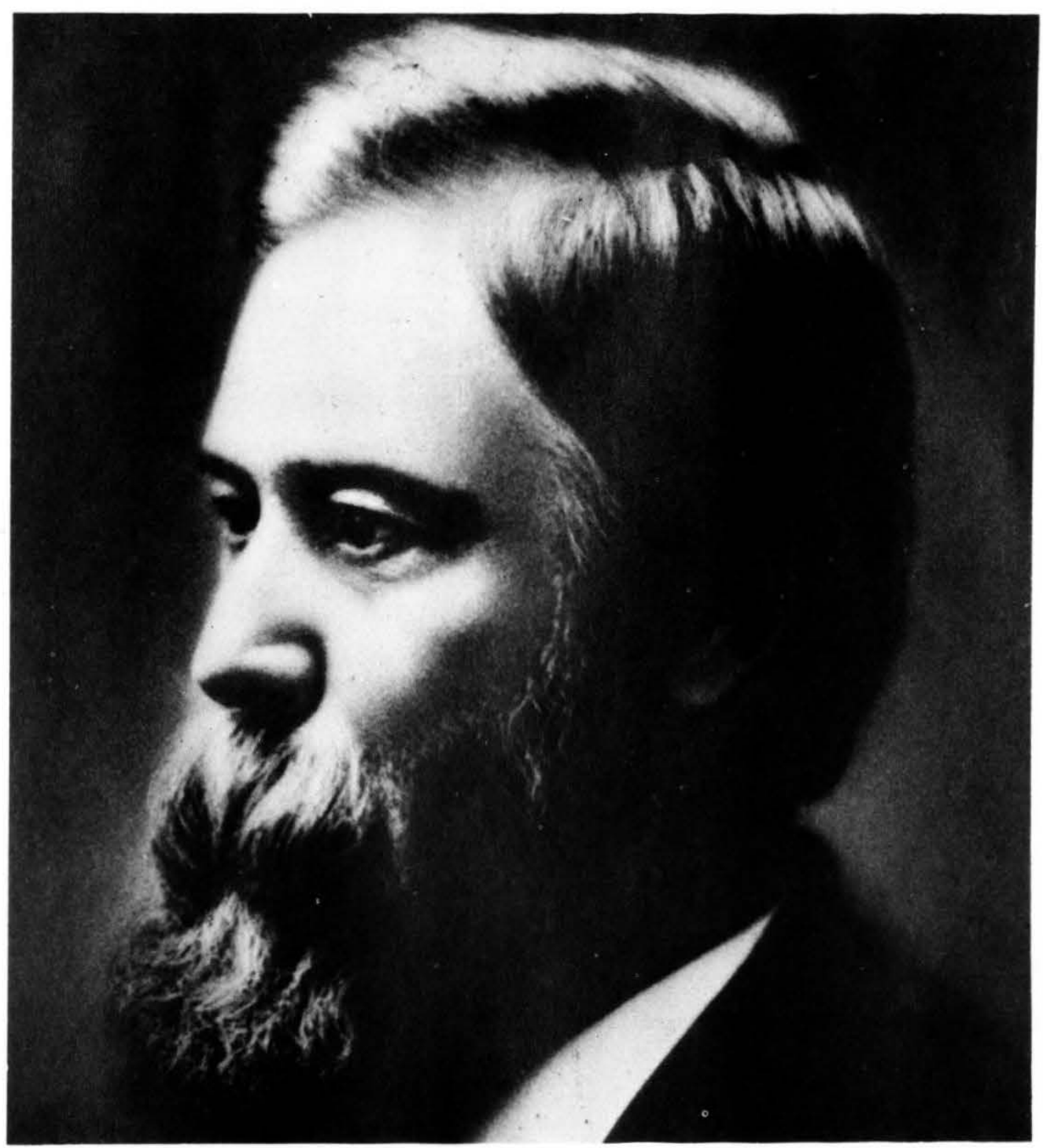


$A$ rare photograph of the Main Building.

taken before the

destructive windstorm

of June 16, 1887.

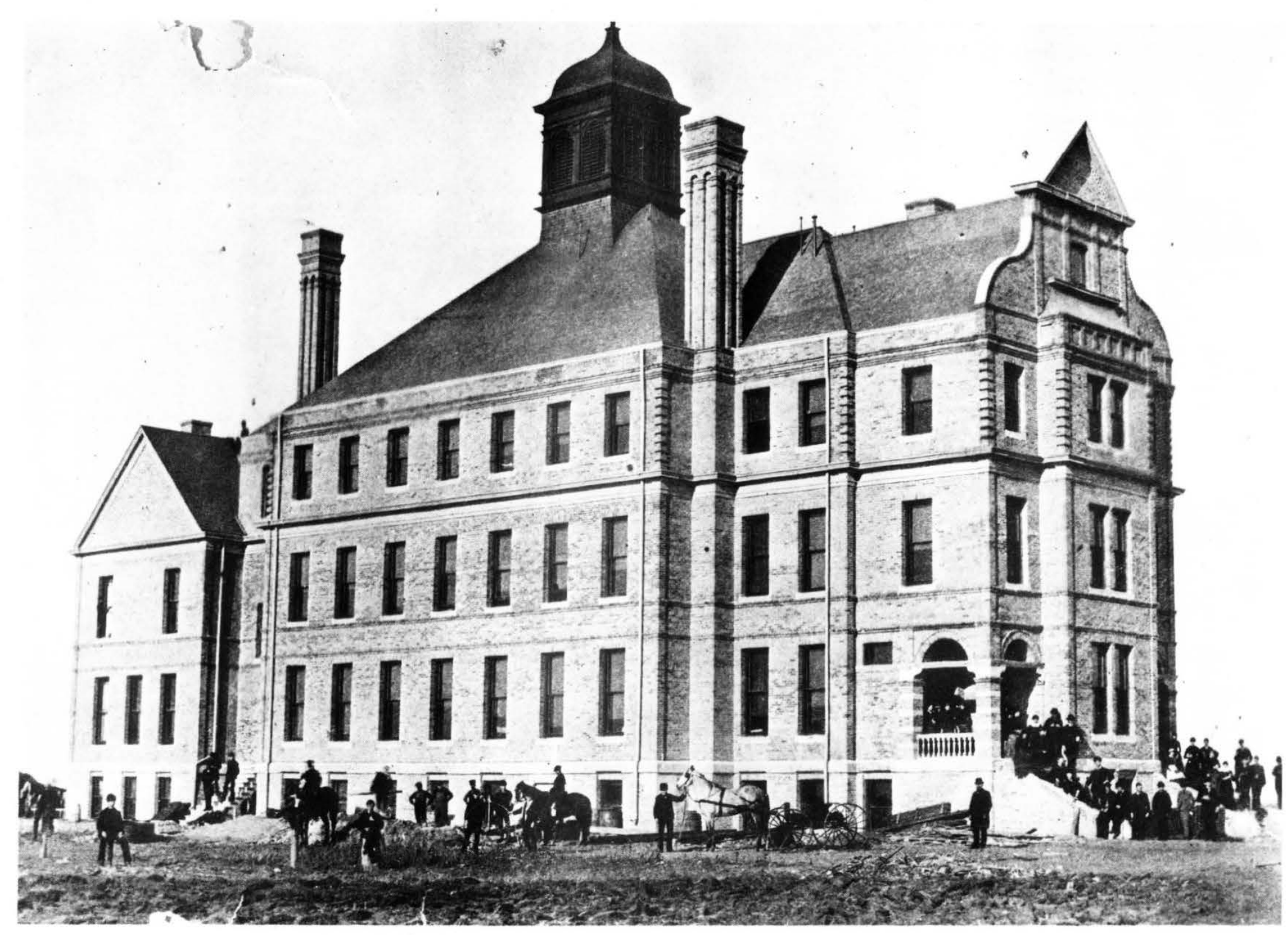




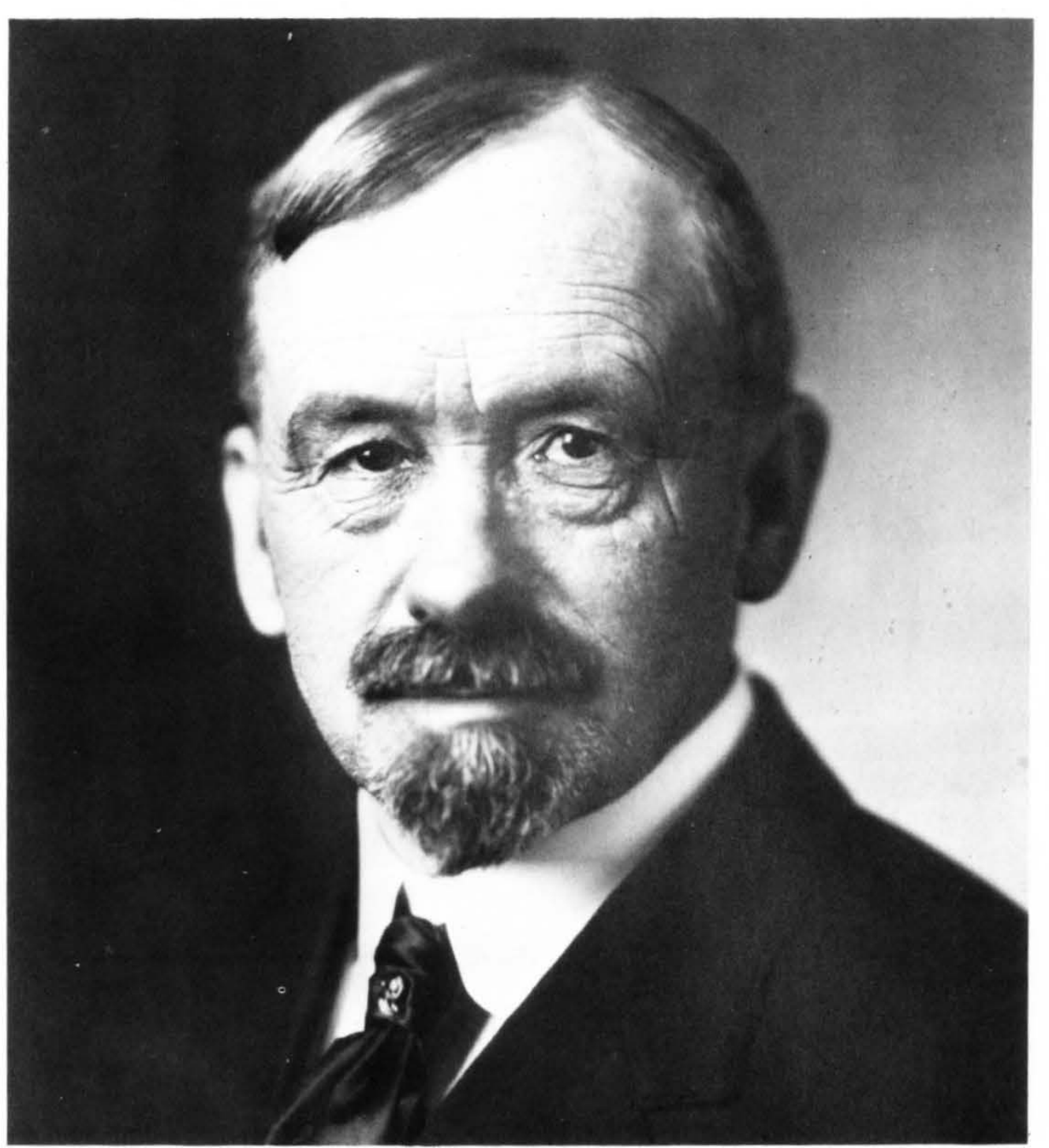

emphasized modern language and history when it began in 1888; science came into its own when the University provided new laboratories and hired three young scientists (one replaced Montgomery)

Sprague's oratory filled Dakota's halls as he lectured on his favorite subjects: Milton, Shakespeare, and the University. Due largely to the president's efforts enrollment doubled in 1889 - the year that the

University graduated its first class, and the year North Dakota became a state.

Sprague also gave students a broader sense of university. To the president, university life went beyond the classroom.

He gave the campus some of the trappings

of eastern schools: organized sports,

student societies, a monthly student

magazine, a faculty lecture series. Many

students thought he was an inflexible man, but few questioned his devotion to their intellectual development.

Statehood brought political changes that Sprague believed would work against him and the University. The new political climate, the worsening condition of the state's economy, and personal

disappointments caused him to resign in March 1891. This time Merrifield was ready to accept the presidency. He took over at a difficult time. With statehood, the University became North Dakota's leading educational institution, but the opening of the Agricultural College in

Fargo and normal schools at Mayville and Valley City created competition -

sometimes bitter - for students and for appropriations. When the normals contended that the constitution granted them exclusive control of elementary and 


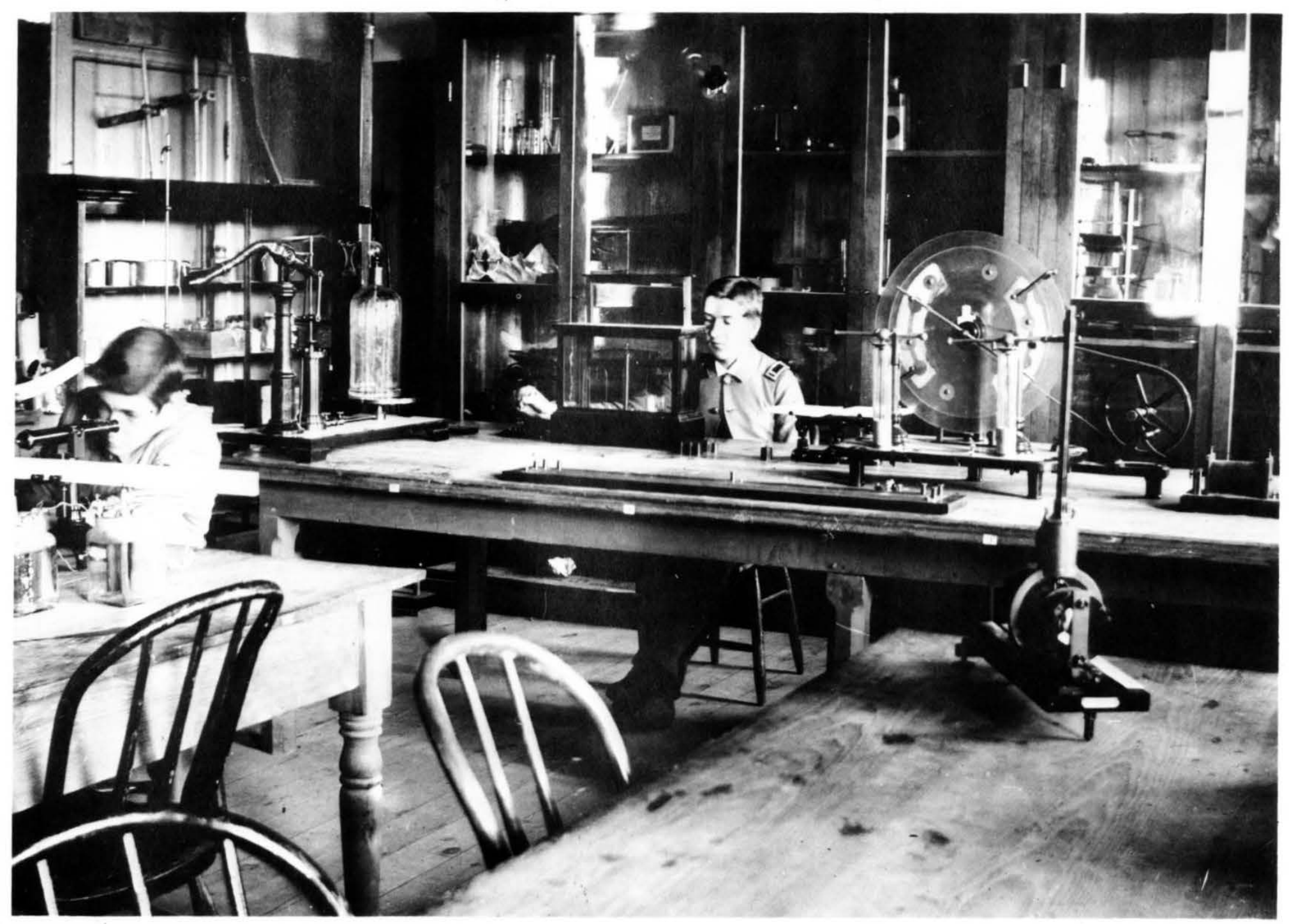


rural teacher training, the University countered with the appointment of Joseph Kennedy as a teacher of pedagogy and principal of the normal department, affirming the University's intention to strengthen its teacher program. The rivalry for appropriations meant little by the mid1890s because the severe agricultural depression forced the state to the brink of bankruptcy. Governor Roger Allin's austerity budget slashed funding from $\$ 73,920(1893-1895)$ to a meager $\$ 15,980$ for $1895-1897$. The meaning was clear: close the University. It was Merrifield's severest test.

The Board, however, did not panic and resolved that any decision about closing would be made when "public sentiment shall indicate. . . what course to pursue., The public responded; a committee of Grand Forks leaders started a fund drive to keep the University open. "Close the door for two years" the committee declared in its appeal, "and if they ever open again you cannot regather in ten years your scattered forces." The committee did not exaggerate the adverse effects of a closing. The president and faculty agreed to a 25 percent salary cut as their contribution to maintaining the school. By May 1897 , almost $\$ 27,000$ had been raised - due largely to the dogged determination and boundless energy of William Budge. The University had been saved.

The budgetary nightmare of the $1890 \mathrm{~s}$ retarded program development and faculty growth. In spite of that, under Merrifield the University continued to progress

during North Dakota's "gray nineties." Merrifield seemed to have a knack for recruiting faculty who were exceptional teachers and devoted people. The teaching staff was small but broadly competent and genuinely concerned about students and the University. In 1894, it undertook a major curriculum revision that swept away the rigid Montgomery-Merrifield plan of 1885 . The B.S. was dropped, and the B.A. made an umbrella for a classical course, a Latinscience course, and à science course. Required languages remained but much less than in the old programs. Mirroring the national climate, the University moved toward an elective system and graduate study, granting the first Master of Arts in 1894.

Merrifield was keenly aware that the future of the University depended upon the development of a sound high school system. As a result of his work at conferences and with the North Dakota Education Association, the schools accepted a three-year minimum for graduation, a general course of study, and a classification system. Merrifield served as inspector and examiner; any student who passed a prescribed examination administered and graded by Merrifield would be admitted to the University for college study. Because of his foresight, the University controlled the high schools its source of students. It fended off normal-school attempts to restrict its hold on the preparation of teachers until 1907.

That year the college presidents agreed that the University would maintain a model high school for teacher training and its Teachers College, but that it would terminate its preparatory program. The normals would offer no more than two years of college work. Merrifield agreed to step down as high school inspector, ending the University's control of the high schools. His astute leadership, however, had given his University a prominent place in the preparation of teachers.

In 1899, the passage of a special mill levy for higher education assured the University of a more stable financial foundation. Reflecting the return of good times that sparked "the golden age of agriculture," the University's income increased almost sixfold during Merrifield's last 10 years. The faculty, which began to reflect specialization in training, tripled from 17 to 51 . College enrollees quadrupled from just over 100 to 422 . Seven new buildings broadened the University's skyline. The University that almost closed in 1895 was in the process of becoming truly a university.

Nowhere was that more evident than in the organizational changes that took place between 1897 and 1906. In 1897, the University formally opened the School of Mines with Earle J. Babcock, an authority on coals and clay, as director. Mandated by the state's constitution, the new school served as a "utilitarian link" to the people. In 1901 the faculty, as part of a larger

reorganization plan, approved the College of Mines and Engineering with Babcock as dean. Uncomfortable with the arrangement because Babcock had no engineering training, Merrifield went east to hire a theoretical engineer. He engaged Calvin $\mathrm{H}$ Crouch, a Cornell graduate, then working for Baldwin Locomotive. Upon Crouch's arrival the college was split - School of Mines (College of Mining Engineering) under Babcock and the College of 
The University's library in the Main Building at the turn of the century. A new structure donated by Andrew Carnegie

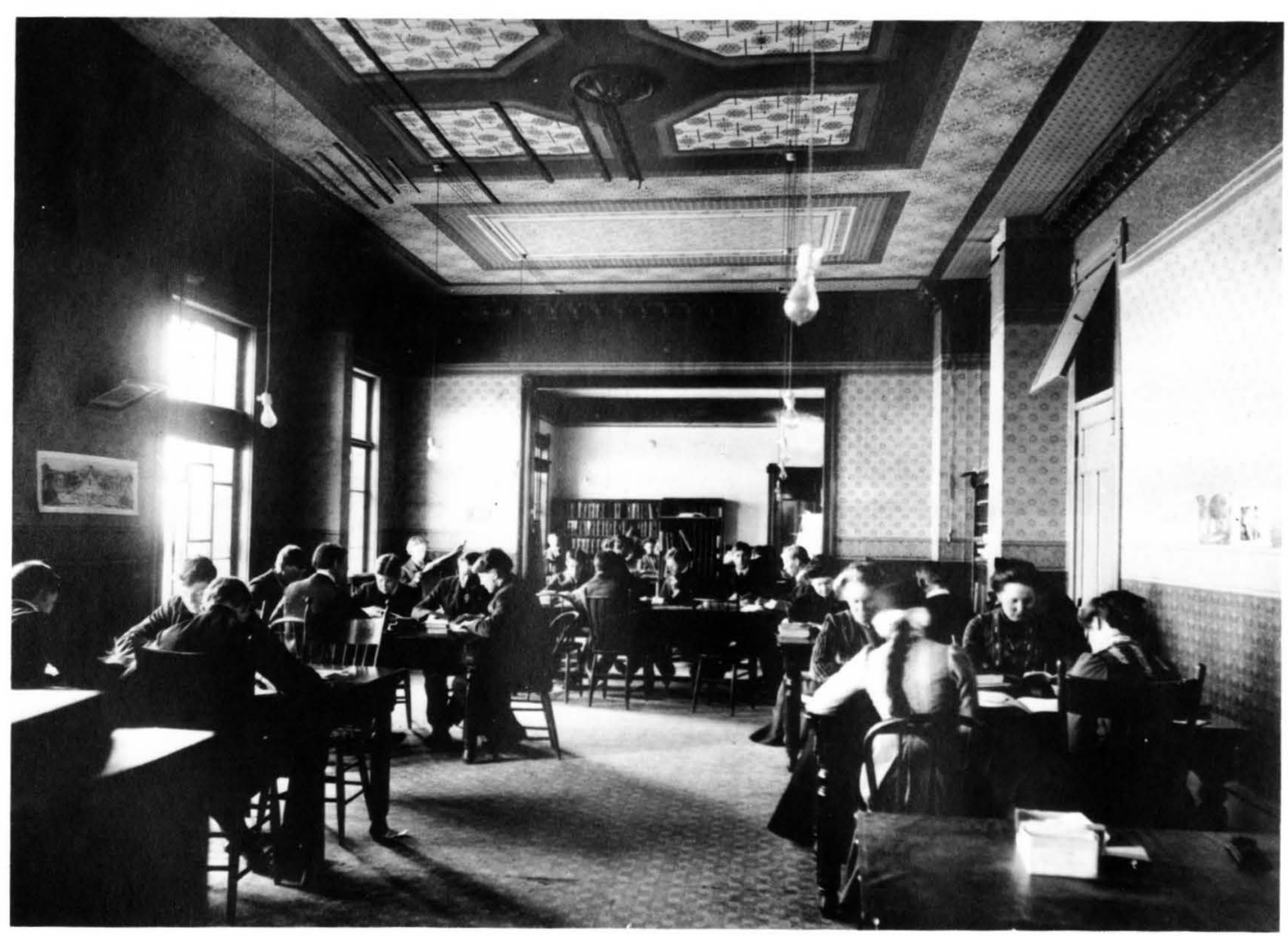


Mechanical and Electrical Engineering under Crouch. North Dakota's engineering endeavors were launched with three facuity and woefully inadequate equipment. By

1909 , the faculty numbered eight; that year 10 engineers graduated.

The School of Law opened its doors in 1899 with a dean, Guy H. Corliss, one fulltime teacher, and with seven part-time local lawyers serving as instructors. Located in rented quarters in downtown Grand Forks, the school maintained itself largely on its own fees and the good will of the legal community which provided library books and classroom help. Anyone who was age 18 or older and who had finished grammer school could enter the fledgling law school. By 1909, the School of Law boasted three full-time faculty and graduates who were practicing in 78 North Dakota towns.

The 1901 reorganization plan also established the College of Liberal Arts and the Normal College. Since its founding, the University had been essentially a liberal arts college. The College of Liberal Arts was and has remained, under differen names, at the heart of the University's academic life. George S. Thomas, who arrived in 1893 as professor of Greek and Latin, quickly established himself as a faculty leader. With high academic credentials (Ph.D., Leipzig), Thomas was the logical person to lead the new college. When Merrifield was off campus (more frequently and for longer stretches as he approached retirement), Thomas was accepted as "acting president" -

testimony to the centrality of his college.

The Normal College, headed by Kennedy, was convereted into a full-blown four-year

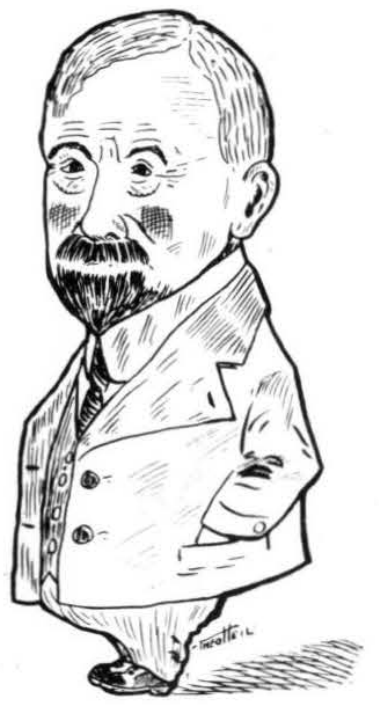

program as the Teachers College which was patterned after the one at Columbia University - evidence of UND's leadership in teacher training.

In 1905, a two-year School of Medicine began accepting students. As with law and engineering, its beginnings were humble: Dean Melvin Brannon, one full-time professor, donated equipment and books, and Grand Forks physicians who taught on a part-time basis. Admission standards, however, were high; North Dakota was one of only 16 medical schools that required as much as two years of college. With support from the newly established public health laboratory and the University's biology department, the Medical School graduated its first student in 1909. The Association of American Medical Schools accredited the program in 1907, and the "graduates" had no difficulty gaining admission to other schools to complete their medical studies.

Merrifield's administrative skills

broadened the scope of the University even further when he entered into an agreement with Edward P. Robertson, president of Wesley College (formerly Red River

University at Wahpeton) in 1907 when the Methodist Church opened the college's new campus adjacent to the University. Both agreed to accept up to 30 hours from the other school toward a degree. Merrifield cherished affiliation with a church college; it gave students access to more courses in religion and music, and it identified the University, in the minds of the public, with the church. To the president that was sound public relations.

When Merrifield retired in 1909, the University had developed its departmental and college structure; the faculty began to represent more specialized training; financial support was more secure; and high school students were much better qualified for university study. Merrifield had been a strong voice in promoting all these changes. His efforts made the University of North Dakota into a university - one that represented and served the entire state. It was small, and some of its new ventures may have seemed puny to the world of academia; but in the Merrifield years the University advanced to respectability.

The University's first 25 years belonged to Webster Merrifield. Melvin A. Brannon captured that idea when he wrote: "His great cathedral monument is the University of North Dakota. That institution, viewed as a physical unit, and measured by the productive citizenship of the youth who 


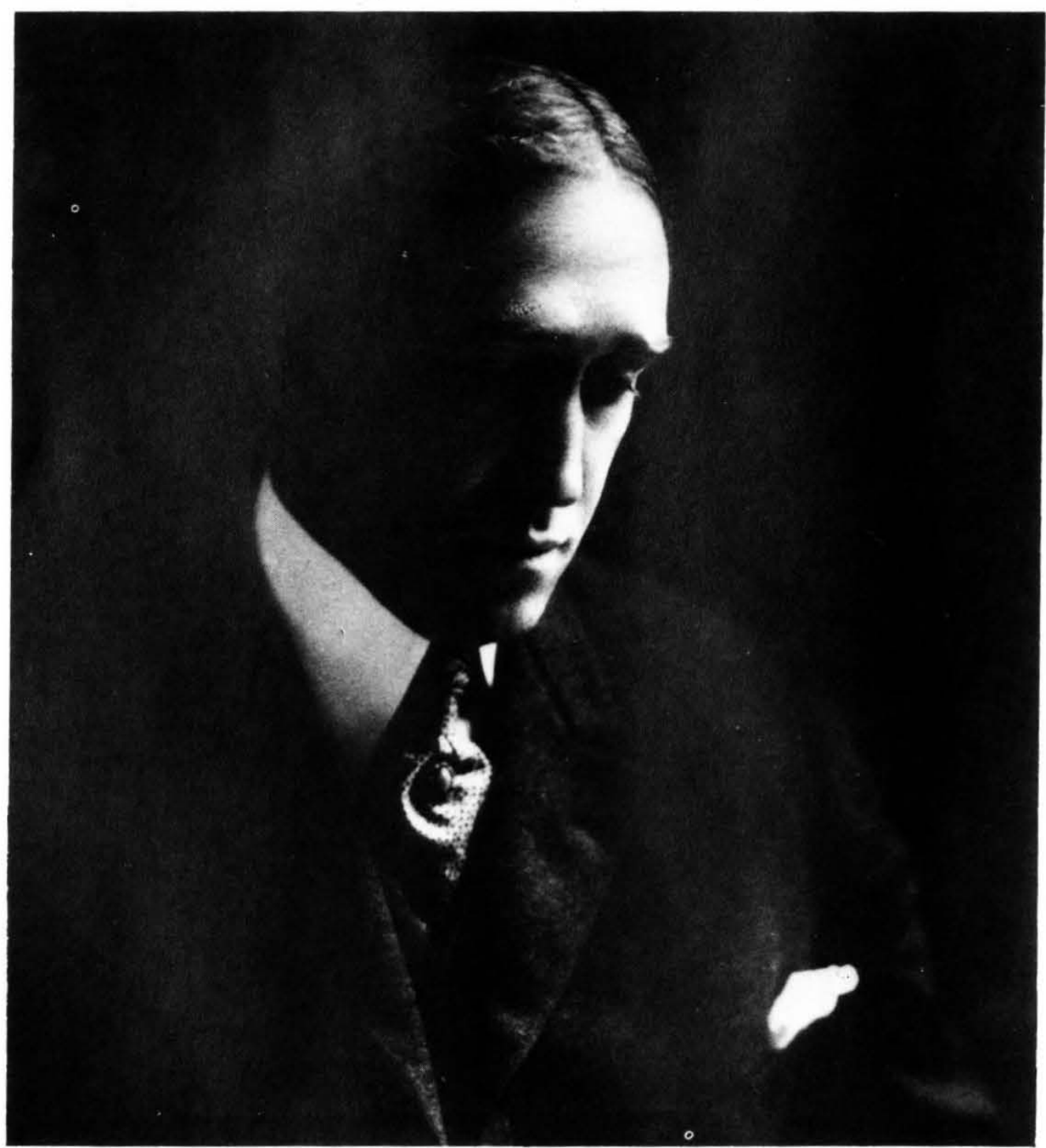

were privileged to companion with him, must serve to commemorate Dr. Webster Merrifield as St. Paul's Cathedral in London perpetuates the life and services of Sir Christopher Wren. For Dr. Webster Merrifield we use the same suggestive statement made by Sir Christopher himself, when his friends asked what monument would be adequate to immortalize his life and his work - 'Si monumentum

requiris, circumspice' - if you require a monument, look around.'

At heart Merrifield had been a teacher who was more at home with the classics than with administrative detail. His successor was quite the opposite. A tall, forceful, and eloquent man, Frank McVey embodied the spirit of the new education - an economist who placed a premium upon research and writing. He had a flair for administration and strong views about the nature of a university and its role in society. He was not a reluctant candidate for the presidency. After his interview with the trustees, he was confident of his selection. But when he returned home to St. Paul, he discovered that John Gray, chairman of economics at the University of Minnesota, was claiming the North Dakota job. "Somewhere between Fargo, Grand Forks, and Minneapolis a university presidency has been lost," McVey wrote to Judge Charles F. Amidon on Dec. 19, 1908. McVey complained that Gray "was selected by President Merrifield for his successor." When in early January the selection was still uncertain, McVey informed the trustees "I am in no sense a contestant for the position and do not like the idea of reducing the selection for a great position to a high school principal 
basis." The Board finally offered McVey the presidency in mid-January; he turned it down but agreed to reconsider if the trustees would agree to presidential approval for all building plans, a $\$ 500$ travel allowance, necessary clerical assistance to maintain his office, the provision of house furnishings including an electric stove, and a salary of $\$ 6,000$ (figured as only an economist would with a formula that included cost-of-living differentials and inconvenience factors). After a week of negotiations, the Board announced McVey's appointment.

The 39-year-old economist became the University's youngest president. Born in 1870 in Ohio, McVey grew up in Iowa and attended Ohio Wesleyan University. In 1895, Yale University granted him the Ph.D. in economics. McVey rose rapidly from instructor to professor in his 11 years in the Department of Economics at the University of Minnesota. He published extensively and in 1907 was appointed to the chairmanship of the Minnesota Tax Commission. His reputation as an ambitious and energetic person earned him a limerick in Minnesota's year book:

\section{An industrious man is McVey}

He labors so hard night and day

Writing books, meeting classes, Uplifting the masses,

We feel he will soon pass away.

The University of North Dakota soon realized that the students at the University of Minnesota had not exaggerated. His administrative day began at 4 a.m., and he usually worked in his office until noon. McVey set aside the afternoon for his own writing which resulted in three books and
20 articles during his eight-year presidency. He attacked the problems of the University in an aggressive, but understanding way. What the new president wished to accomplish became clear within a few months: to raise faculty morale and upgrade faculty scholarship, to organize the University in a more logical way, to set higher standards for students, to bring the University into a closer relationship with the people of North Dakota, and to intensify the campus intellectual life.

McVey was genuinely concerned about improving faculty status and morale; he also understood that without faculty support no president could expect to accomplish great things. Working through faculty committees, he established a formal salary schedule, a tenure policy, and a sabbatical leave program. In every way he encouraged his faculty to publish. He often helped them secure publishers and

inaugurated campus publications, the Quarterly Journal and the School of Education Record. Those faculty, who at first were skeptical about McVey's motives, came to appreciate his reforms.

The new president attempted to bring the University's organization more into tune with national developments. Graduate study became more formalized. He introduced graduate scholarships, and nine departments began offering the Master of Arts. Graduate enrollment rose from two in 1909 to 24 in 1917. In teacher training, McVey separated the Model School from the School of Education, giving it an independent administration and faculty. In 1912, the Teachers College was converted into the School of Education with close ties to the College of Liberal Arts. Engineering posed a thorny dilema: two colleges and two deans for 10 students. In 1912, all engineering students were required to take a uniform first-year course of study. Finally in 1916 McVey made his move and consolidated the two colleges under the deanship of Babcock - something Merrifield had refused to do.

The move toward higher standards under McVey is best illustrated by the School of Law. Its entrance requirements rose from completion of grammer school to high school graduation to two years of college. It expanded its program to three years and earned the approval of the American Association of Law Schools.

In his inaugural address McVey had declared: "It is time to recognize the fact that the University is a great latent force that can be utilized in many directions. It ought to be closely related to every department of the state." That was not empty rhetoric; it was a high ideal in which McVey firmly believed. "To Be the Servant of the People" became the motto of the McVey administration: extension courses, correspondence study, research that would benefit the state, lecture series, service on and to state boards. Thirty faculty members were ready to blanket the state with 300 lecture topics. Although inadequate funding never allowed McVey to realize his dream of a full-blown extension program, the University made a gallant beginning.

McVey brought a kind of renaissance an intellectual awakening - to the campus. He cared about those things that stimulated the intellect, improved the mind. Whether by the design of policy or by the spirit of his presence, things that 

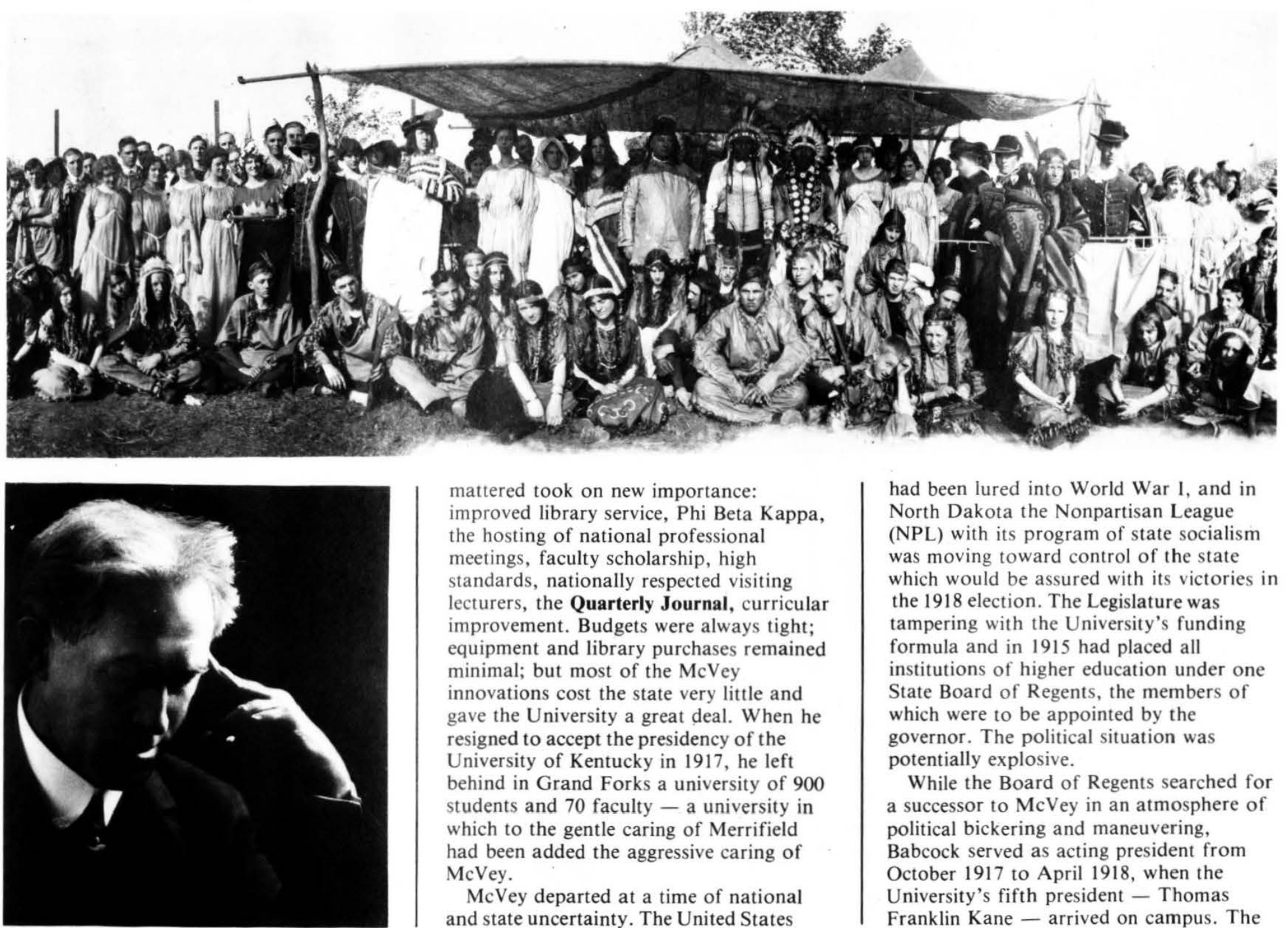

mattered took on new importance:

improved library service, Phi Beta Kappa, the hosting of national professional meetings, faculty scholarship, high

standards, nationally respected visiting

lecturers, the Quarterly Journal, curricula improvement. Budgets were always tight; equipment and library purchases remained minimal; but most of the McVey

innovations cost the state very little and gave the University a great deal. When he resigned to accept the presidency of the University of Kentucky in 1917, he lef behind in Grand Forks a university of 900 students and 70 faculty - a university in which to the gentle caring of Merrifield had been added the aggressive caring of McVey.

McVey departed at a time of national and state uncertainty. The United States had been lured into World War I, and in North Dakota the Nonpartisan League (NPL) with its program of state socialism was moving toward control of the state which would be assured with its victories in the 1918 election. The Legislature was tampering with the University's funding formula and in 1915 had placed all institutions of higher education under one State Board of Regents, the members of which were to be appointed by the governor. The political situation was potentially explosive.

While the Board of Regents searched for a successor to McVey in an atmosphere of political bickering and maneuvering, Babcock served as acting president from October 1917 to April 1918, when the University's fifth president - Thomas Franklin Kane - arrived on campus. The
"Pageant of the Northwest,"

presented on the

coulee banks in 191 during the meeting of the Mississippi Valley Historical Association, the first major tion, the first majo conference to bociety on campus.

Earle J. Babcock, dean of engineering who served as acting president, 1917-1918. 
Thomas F, Kane, president, 1918-1933. s-year-old Kane came with impressive credentials and a reputation as a capable administrator.

The broadly educated classicist, who had been trained at Johns Hopkins, had taught for five years at Olivet College after he received the $\mathrm{Ph} . \mathrm{D}$, and had edited some standard classics. In 1900, he went to the University of Washington as professor of Latin and shortly thereafter was appointed dean of the graduate school. In 1902, the Board of Regents selected him as acting president. Although the Washington Board would have preferred a person of national reputation, it settled for Kane who had earned a campus reputation as a patient, hard-working, judicious and friendly professor and dean.

Kane's Washington presidency (1902 1914) was a time of hectic expansion. Enrollment mushroomed from about 600 to 2,824 ; faculty positions jumped from 48 to 177 of which in 1913 only 11 were not filled by Kane appointees. For the most part, he handled the expansion with little trouble and his relations with the faculty remained relatively peaceful. $\mathrm{His}$

reputation became national when in 1913 he served in the prestigious position of president of the National Association of State Universities.

Kane, like most progressives, had a strong faith in democracy and believed that expansion of democratic principles would have a positive effect on the country. $\mathrm{He}$ fostered reforms that would give students more responsibility and the faculty more voice in decision-making. In 1908, with student participation, he overhauled the Washington fraternity system; the student newspaper hailed his action as a "sweeping

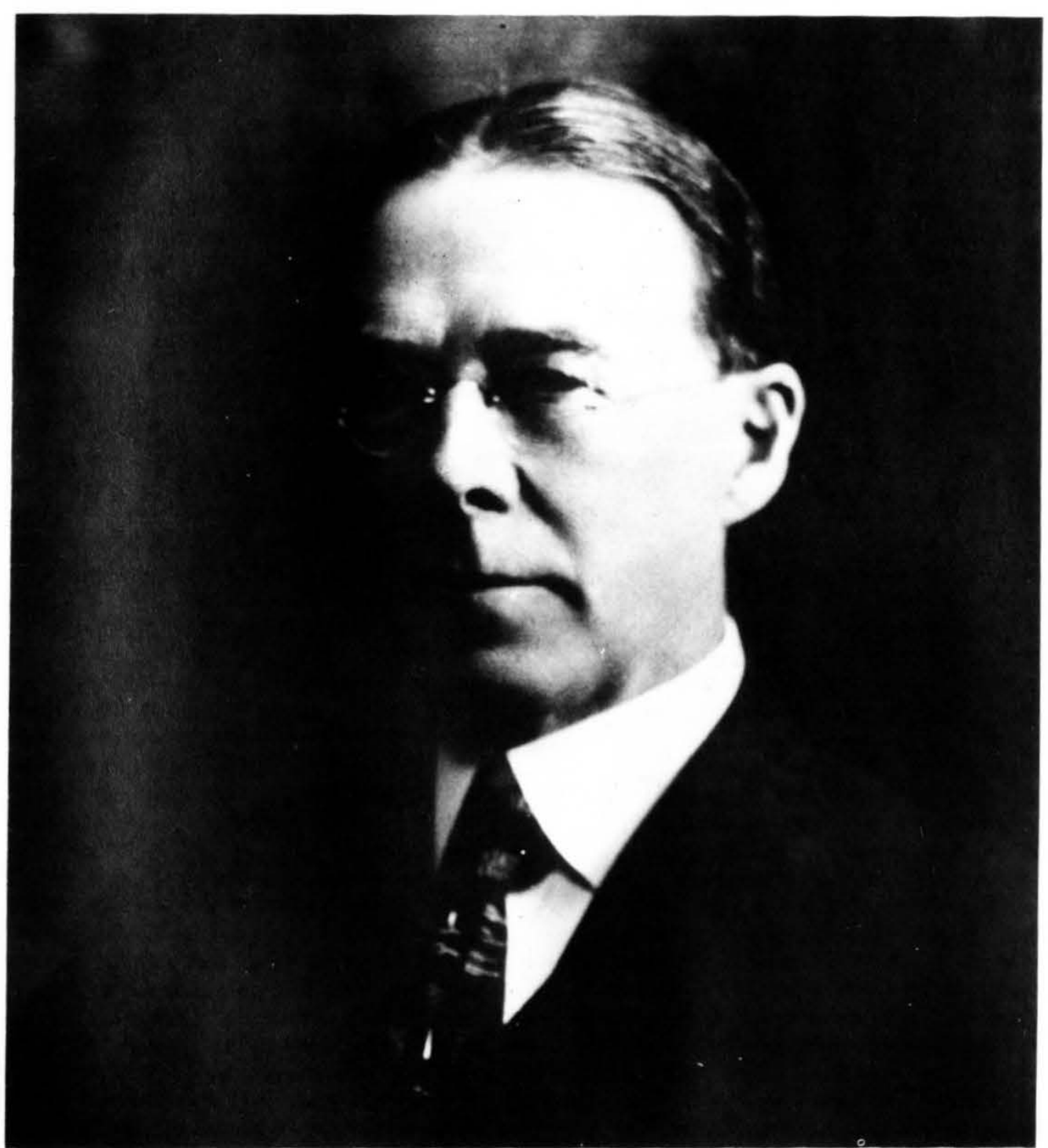


reform of social abuses." He insisted that the faculty share in the administration of the University and with them forged a constitution that would formalize faculty governance. In 1911, Kane presented the document to the Board, arguing that the University of Washington should be as democratic as the state itself and protected from "arbitrary decisions." The Board, however, refused to approve the

constitution because diffusing power within the University placed too many limits on the president's authority.

This rejection of the constitution marked the beginning of strained relations between Kane and the regents. Two incidents in 1912 created a permanent breach. The Board banned partisan political speakers from the campus. Kane claimed that he opposed the ban; but he enforced it, creating student unrest. The unrest turned into rebellion when the Board, without consulting Kane, accepted a gift of 12 bells from the publisher of the Seattle Times to many a man of dubious reputation. The students, who viewed the gift as "tainted money," attempted to use the student newspaper to attack the Board, but Kane, who was forced to support the Board in public, stopped the presses, angering the students. The students, however, circulated a pamphlet which condemned the Board. The following year the Board requested Kane's resignation; he refused; it fired him. In the public controversy that attended the dismissal, when Kane characterized the Board of Regents as "reactionary," the Board responded that the university had outgrown Kane.

The trouble with the regents in

Washington resulted from Kane's philosophy of university governance which differed sharply from that of the Board. It wanted an authoritarian president who would carry out board policy without the participation of the faculty. "I fear the kind of man you are picturing for yourself," Kane told the regents, "is the type of University president that is fast leaving the stage." According to Charles Gates, historian of the University of

Washington, "Kane was ahead of his time."

After a four-year interlude that included the presidency of Olivet College, Thomas Kane accepted the North Dakota position. Any new president faced a difficult task. McVey was a formidable act to follow. The faculty had been devoted to McVey; after all, he was one of them, a practicing scholar. The political climate was volatile. In 1918, the Nonpartisan League swept all three branches of government in its drive to set up its system of state industries. The Independent Voters' Association (IVA) a coalition of disgruntled Leaguers, old progressives and conservatives - waged a bitter counterattack. The intense political fight touched the University when the League, in one of its efforts to gain control of all state boards, abolished the Board of Regents and placed the state's colleges and universities under the Board of Administration which it came to control.

President Kane's inaugural address which was delivered on commencement day, 1918, outlined his views on the University to the people of North Dakota, the Board, the faculty, and the students. To the people of the state he declared: "The call is for citizens who are actively and positively good, men and women who understand the spirit and meaning of our institutions, who understand the blessings, the obligations, and the responsibilities involved in the sovereignty of the state.

This is the first object of the state

university." He pledged to the people that their sons and daughters would receive the best-possible classroom instruction and that "we are going to drive them (the faculty)

hard." He warned the Board not to allow "political or personal controversies to affect the University in any way whatsoever."

"The only thing. . . we have to do," he declared, "is to make it clear that we are running the University impartially." Academic freedom, according to Kane, was important "not primarily for the sake of the teachers, but we want it, first of all, so that the students in the first instance and the state finally may have in full the best that all our men have to give." The new president informed both faculty and students that his views on student discipline differed greatly from those of the University's faculty committee on discipline. He denounced the severe penalty that it had imposed on a fraternity. "It raises the question in my mind," Kane declared, "whether we are practicing social justice or whether we are just preaching social justice."

Kane's candid statements must have pleased North Dakotans and certainly students. Some faculty, however, took exception to what, with some justification, they thought to be inappropriate public comments about an internal matter. The tone of the speech, they believed, had revealed the new president as one who 
The students of 1920 many of whom were involved in the controversy surrounding the early UND years of President Kane.
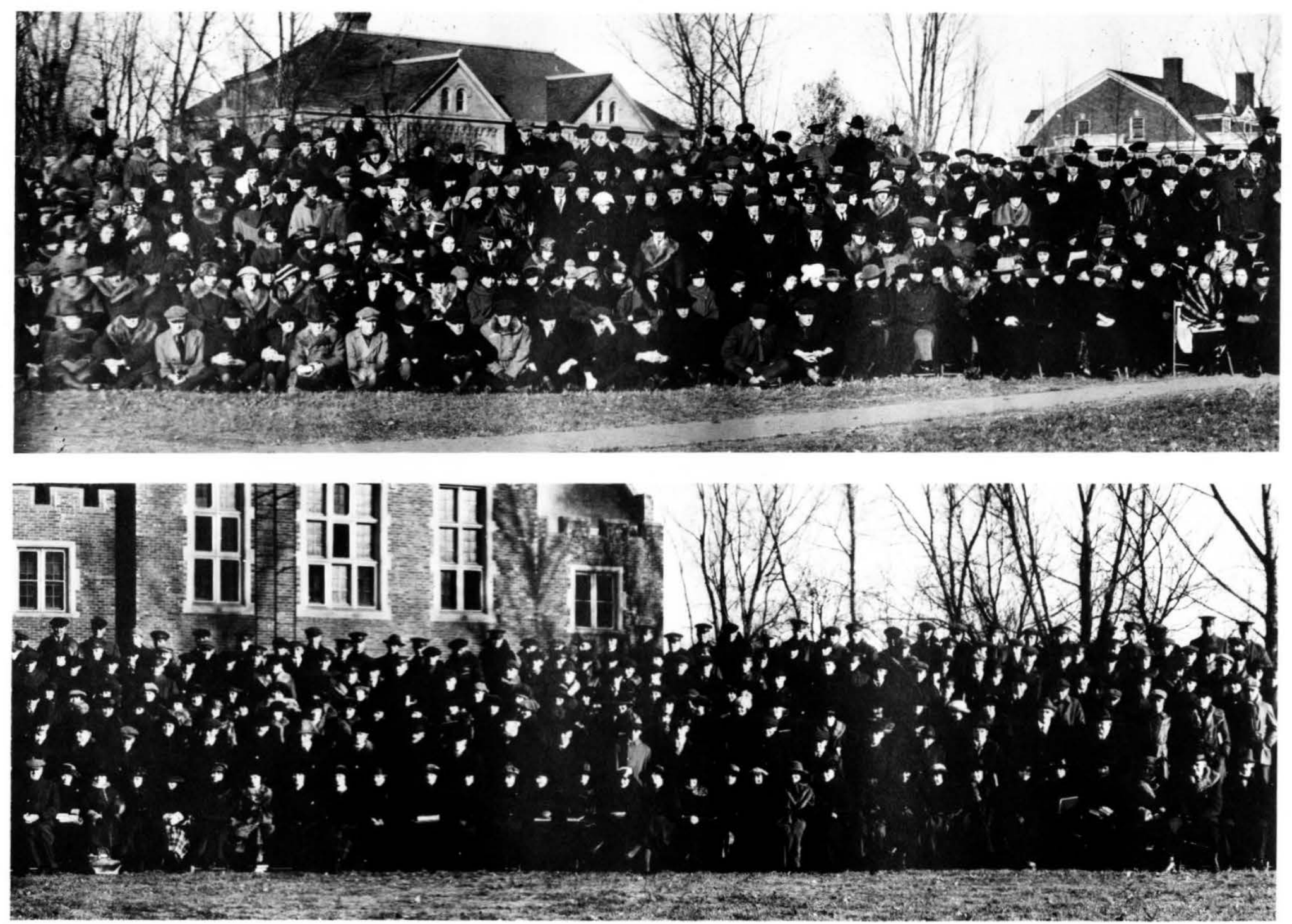

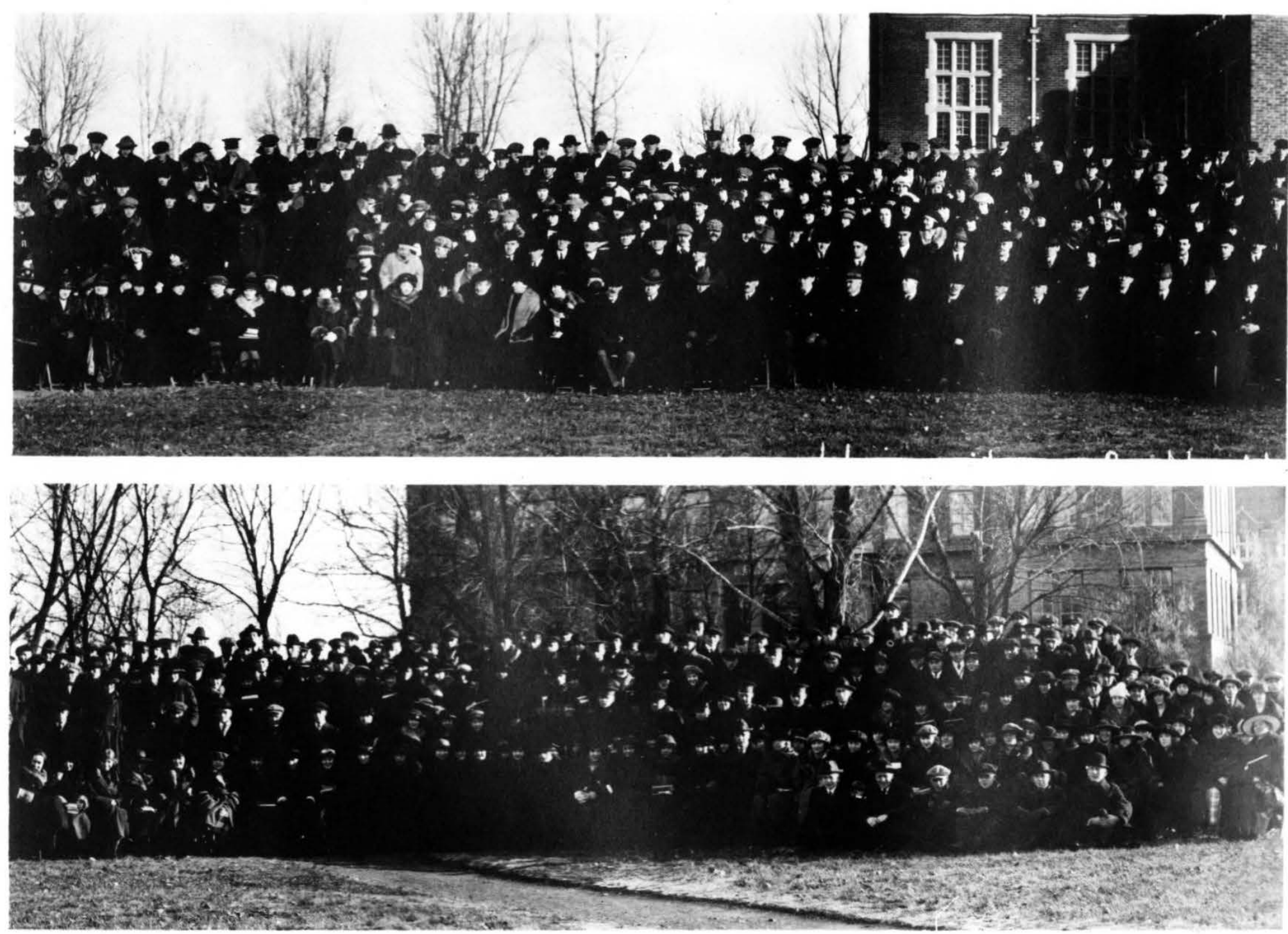
President Kane, in center with hat, supervises a campus clean-up in 1924. lacked standards and an understanding of the role of a faculty in the university. They were angered; yet, they knew where the president stood.

The University could not escape the heat of the political battle which had engulfed the state. Kane was, in the eyes of the faculty members who were in sympathy with the NPL, in the IVA camp. An antiKane faculty faction worked behind the scenes with NPL board members and state officials throughout 1919 in an attempt to undercut and remove the president. When that failed, they came into the open during early 1920 , issuing a document,

"Memoranda of the Unfortunate

Happenings at the University of North Dakota." The petitioners, including longstanding faculty leaders as Babcock, historian O. G. Libby, sociologist J. M. Gillette, A. J. Ladd in education, and Hugh Willis of the Law School, had little upon which to build a case, but used inflamatory words such as irresponsible, inefficient; negligent, morally vacillating, intellectually weak, and stubborn, to characterize Kane. Although the faculty coup failed, it opened the University uproar to the public. In late February Gov. Lynn Frazier, himself a UND graduate, journeyed to Grand Forks, urging a solution to the embarrassing bickering. A short time later, the president, deans, and board agreed that the president would be the "official channel" between the Board and the faculty and that "no adverse discrimination" would be taken against the faculty. The damage, however, had been done. Kane found it impossible to work with several of the coup leaders and in 1921 recommended to the Board, circumventing the University's constitution which he claimed had not been officially approved, the dismissals of Ladd, Libby, and Willis. The Board requested an investigation by a faculty committee which, after a thorough study, concluded that "where all have sinned, judgments should not be too severe."

The Board of Administration supported the dismissals of Ladd and Willis, but gave Libby a chance to reconcile his differences with the president. When Libby failed to respond, the Board voted to dismiss him after the 1922-23 academic year. It ordered Kane to abide by the constitution. Libby's dismissal, however, was later rescinded because of his long service to the state. $\mathrm{By}$ 1923, North Dakota's political turmoil waned as the NPL and IVA shared in governing the state. Tensions remained, but the hostile political battle was ebbing.

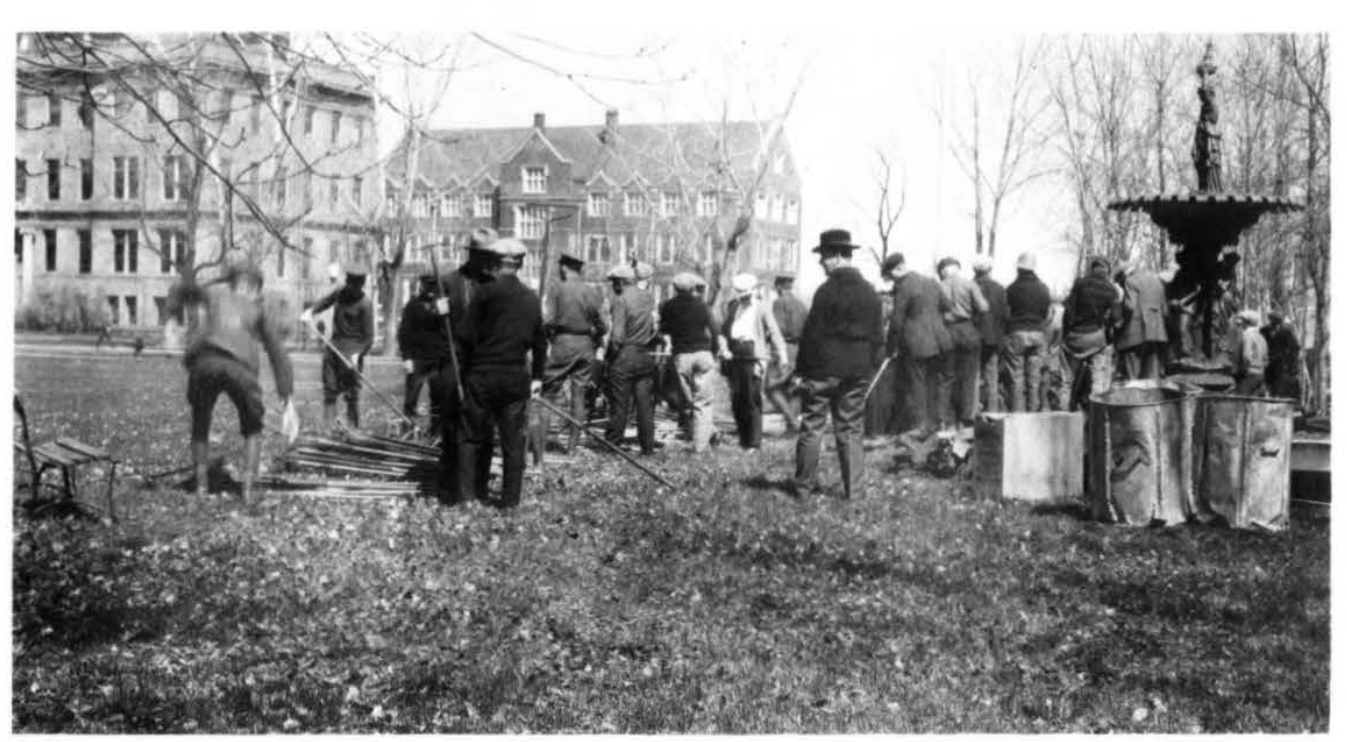
ending its most turbulent years.

It is ironic that a president who was "ahead of his time" at the University of Washington should face immediate militant opposition by progressive faculty at the University of North Dakota. Why would a president who had lost his Washington presidency defending faculty governance, almost lose his position and circumvent the constitution because of North Dakota's faculty revolt? Certainly Kane's inaugural address stirred up the faculty leaders men who under McVey ran, or believed they ran, the University. Faced with a dislocations of World War I and the NPL IVA conflict to begin his administration. Men like Gillette and Libby, both scholars with national reputations, refused to give
The same was true in the University, mutiny, Kane had little chance amid the 
him that chance. The shadow of McVey would not let them. Kane was the

University's first administrator-president; the day of the teacher-president like Merrifield or the scholar-president like $\mathrm{McVey}$ was over. The adjustment was painful.

Ten years of generally peaceful administration followed the unfortunate interlude. Disputes arose over the football coach and faculty reductions at the end of the Kane era, but the business of the University went on without serious interruption. Under Kane the University grew from under 900 students to a high of 1,826 in $1929-30$. Considering the impact of the agricultural depression, appropriations held up fairly well, and faculty positions doubled.

Change came in many areas but most markedly in the University's organization and in student affairs. A reorganization plan, begun in 1919, resulted in the complete separation of the School of Education and the College of Liberal Arts in 1924. That same year the School of Commerce under Dean Ezra T. Towne began, reflecting the national trend toward business schools. In 1927 the Graduate Division was organized (UND's first Ph.D. degree had been awarded in 1914). The Extension Division grew rapidly and the professional schools continued to raise their requirements. The University pioneered public radio with KFJM. Kane moved quickly to give students more

responsibility. In 1920, he inaugurated a “self-government plan", which led in 1927 to a student four-member advisory committee which sat with the faculty's student affairs committee. That same year the position of dean of men was created. When housing on campus became tight, Kane devised a scheme wherein nonprofit industrial building associations would incorporate and bond themselves for building dormitories - reducing dependency on the legislature to provide funds.

Kane's presidency ended as the depression began to strike the University. In 1932, the University suffered a 20 percent budget reduction and had to reduce its faculty by 17 positions. The reductions caused serious disruptions, and partly due to that, Kane decided to retire at age 70 amid rumors that he might be removed.

In May 1933, the president of the University of Wyoming wrote to UND's president-elect, "I am writing to congratulate you on jumping from the frying pan into the fire." The Board of

Administration had just named 48-year-old John C. West, superintendent of schools in Grand Forks, to the position. The

Wyoming educator aptly characterized West's new job when he used the word "fire." The 1933-1935 appropriation stunned the University, slashing the president's salary from $\$ 8,000$ to $\$ 3,000$ and those of the faculty by nearly half, and reducing drastically the budget across the board. The nation, North Dakota, and the University had entered the Great Depression. Dependent upon the one-crop wheat economy, North Dakota fell victim to low prices and poor crop yields. The state and its University had not faced such an impending catastrophe since 1895 .

In selecting West, the Board opted for someone who had developed contacts across the state, had demonstrated administrative ability, and understood the problems of the University and the state.

"From what I can observe,"' wrote Board chairman Nelson Sauvain in 1934,

"President West is receiving that wholehearted unanimous cooperation on the campus that is essential to efficient management. And with his experience as an educational administrator, he is accustomed to making decisions and expressing them so that they are not mistaken for questions." The Board wanted a manager who could harmonize the faculty and cope with the financial crisis.

West brought such training and skill to his new office. Born in 1885 on a farm near St. Cloud, Minn., he had taught rural school and attended St. Cloud Normal. Even before he received the B.A. from Fargo College in 1915, he had served in superintendencies in Minnesota and North Dakota. In 1920, he became superintendent of schools in Bemidji, Minn. While there, he began graduate study at the University of North Dakota, receiving the M.A. in 1926 and the doctorate in 1930. In 1929, he had moved to Grand Forks, and while he held the superintendent's position taught educational adminstration at UND during summers. West was well known to the University's faculty, most of whom enthusiastically supported his selection. Considering the situation at the University, West was a logical choice. It urgently needed a shrewd financial manager - one who could bring people together in a common fight for survival. West did not claim to be an academic leader, and he essentially left that role to the deans and the faculty. He saw himself - as indeed 


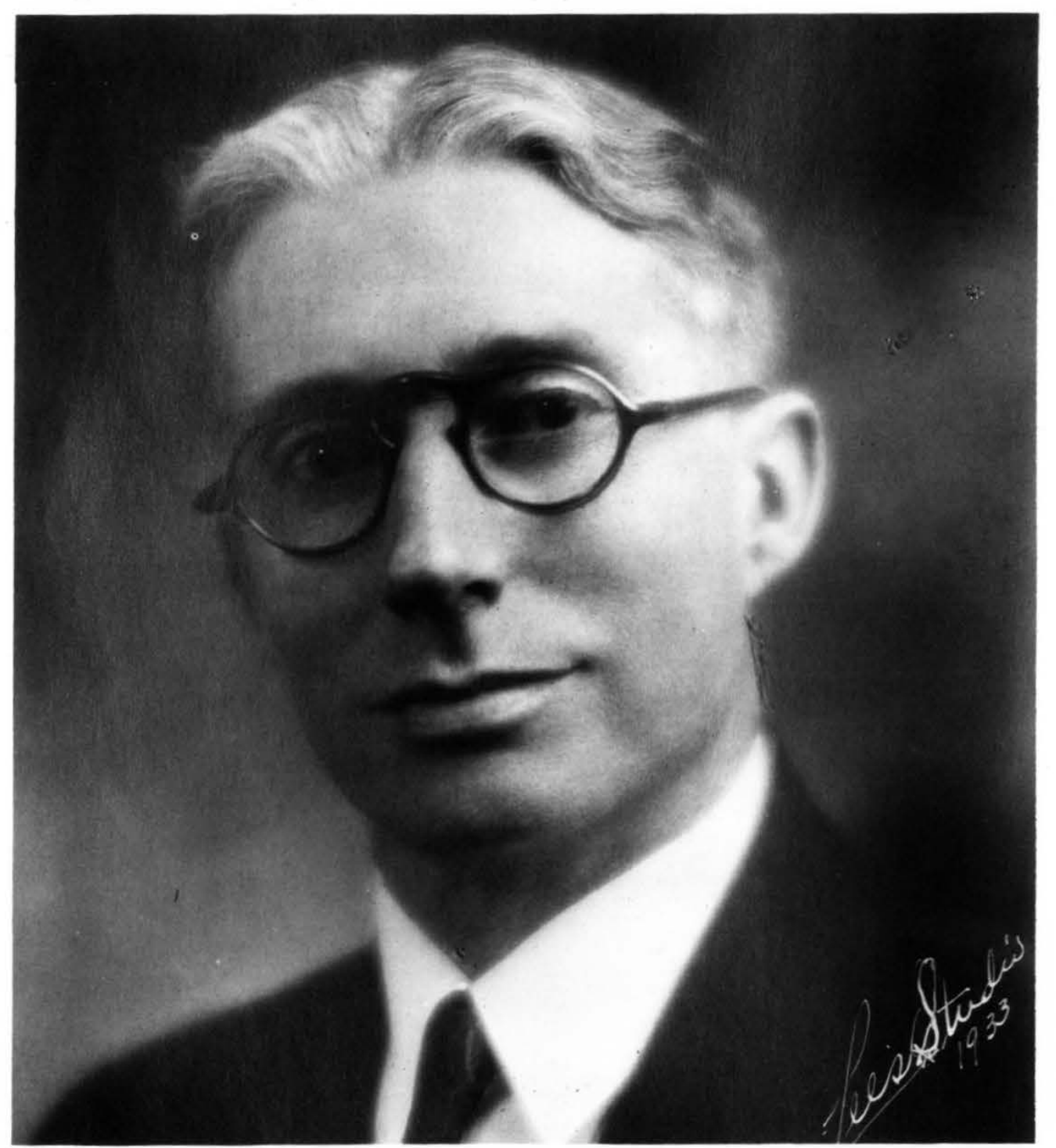

did others - as a practical and trustworthy administrator who could explain the

University to the people, compromise differing viewpoints, and work with legislators for the school's well being.

Although the University suffered immensely during the depression, it maintained stable enrollment over the decade $(1,826$ in $1929 ; 1,960$ in 1939). Library and equipment acquisitions

dropped to almost nothing. The Quarterly Journal and the Law Review ceased publication. The University's low salaries made recruitment of new faculty very difficult. In 1936, the Medical School los its accreditation; it regained its standing during the following biennium but remained on year-to-year probation until 1951. Had it not been for New Deal programs - FERA, WPA, NYA - the University's situation would have been even more desperate. Due to West's

ingenious common sense and astute public relations, the University avoided

involvement in the state's stormy politics, escaped additional faculty reductions, and maintained all but two academic programs West gave public relations a high priority. In a 1939 memorandum to the faculty he underscored "the crying need for more perfect interpretation of the efforts of the University to those who pay for these efforts ..."'He traveled widely around the state, explaining, in. simple terms, the meaning of the University. On campus West promoted such events as Dad's Day, high school week, freshman orientation week, religion and life week vehicles through which to make students and the public aware of the University. $\mathrm{He}$ encouraged faculty members to develop ties 


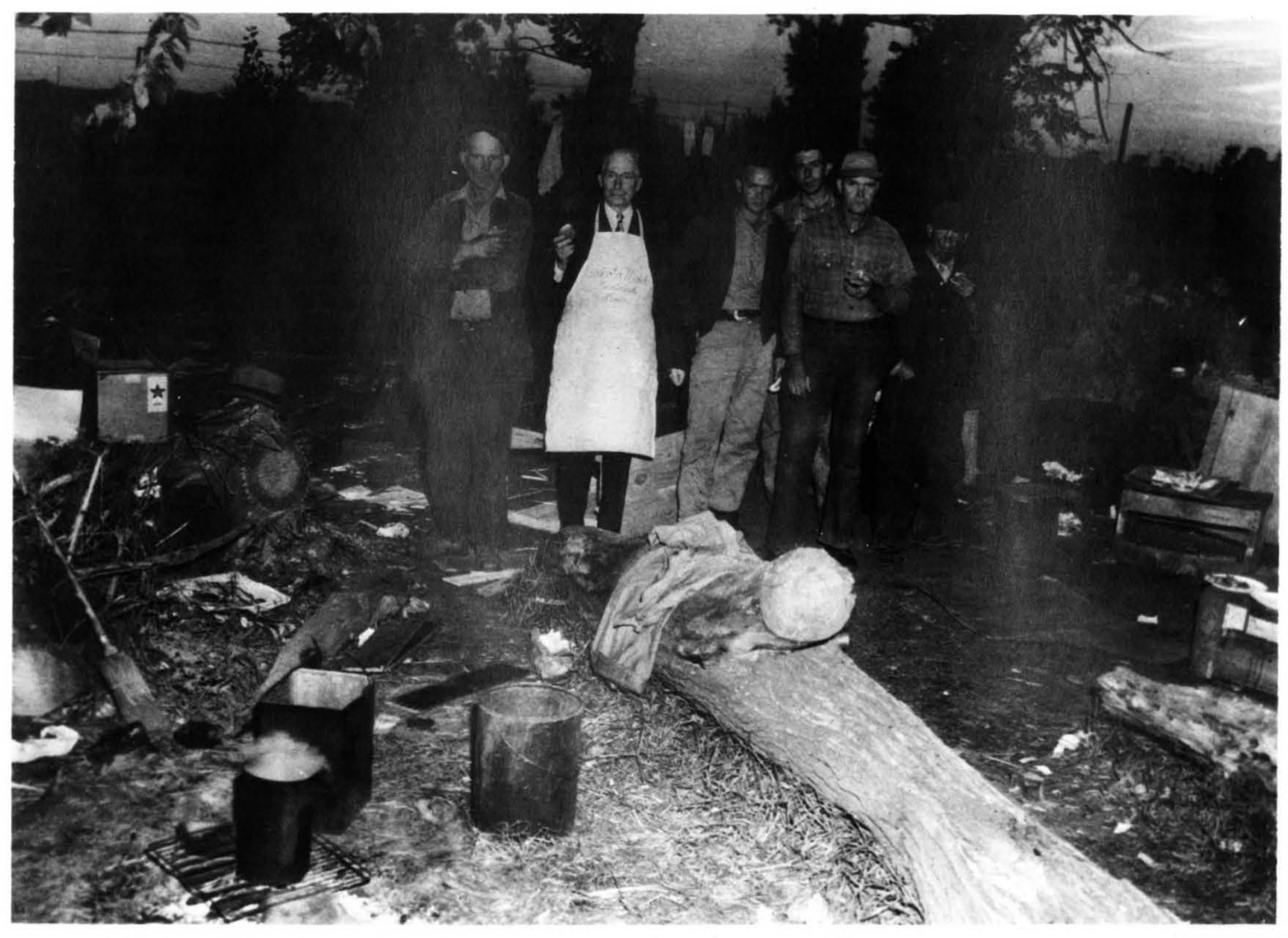

PRESIDENTS

for out-of-work men

in the Grand Forks

Hobo Jungle during the Great Depression. 
Commendations to UND for its service to the Armed Forces during World War II were frequent; this one from the U.S. Navy was accepted by President West, right, and John Penn of the Speech Department.

President West stroll. on his beloved UND campus. with the public. As late as 1947 West reminded deans and department heads that in hiring new faculty "I like people who can make commencement addresses and things of that kind.'

In 1938, a committee representing the North Central Association of Schools and Colleges gave the University a satisfactory report card. The Agricultural College, enmeshed in the politics of the Board of Administration, had not been as fortunate two years before, losing its accreditation because of the Board's political tinkering with the school. West served as interim president of the AC from mid-1937 to mid1938 - a year in which voters abolished the old Board and accepted a non-political Board of Higher Education.

"'Our problem for the past ten years has been to preserve a staff for the

University," West observed in 1944. "In other words, it has been defensive rather than offensive." With the coming of World War II, prosperity had returned but not for the University. The defensive battle continued. Enrollment plummeted to less than 800 in 1943-44, and several departments lost almost all their teaching staff. Government training programs gave the University a role in the war effort and provided revenues essential to keep it alive.

The end of the war brought changes for which the University was ill-prepared. Returning GIs flooded onto the campus, swelling enrollment to over 3,000 in 1947 48. The depression had ended; the war was over; UND was booming. But the problems of the immediate post-war years were many. The College of Engineering had to build an almost entirely new faculty. Other departments were not much

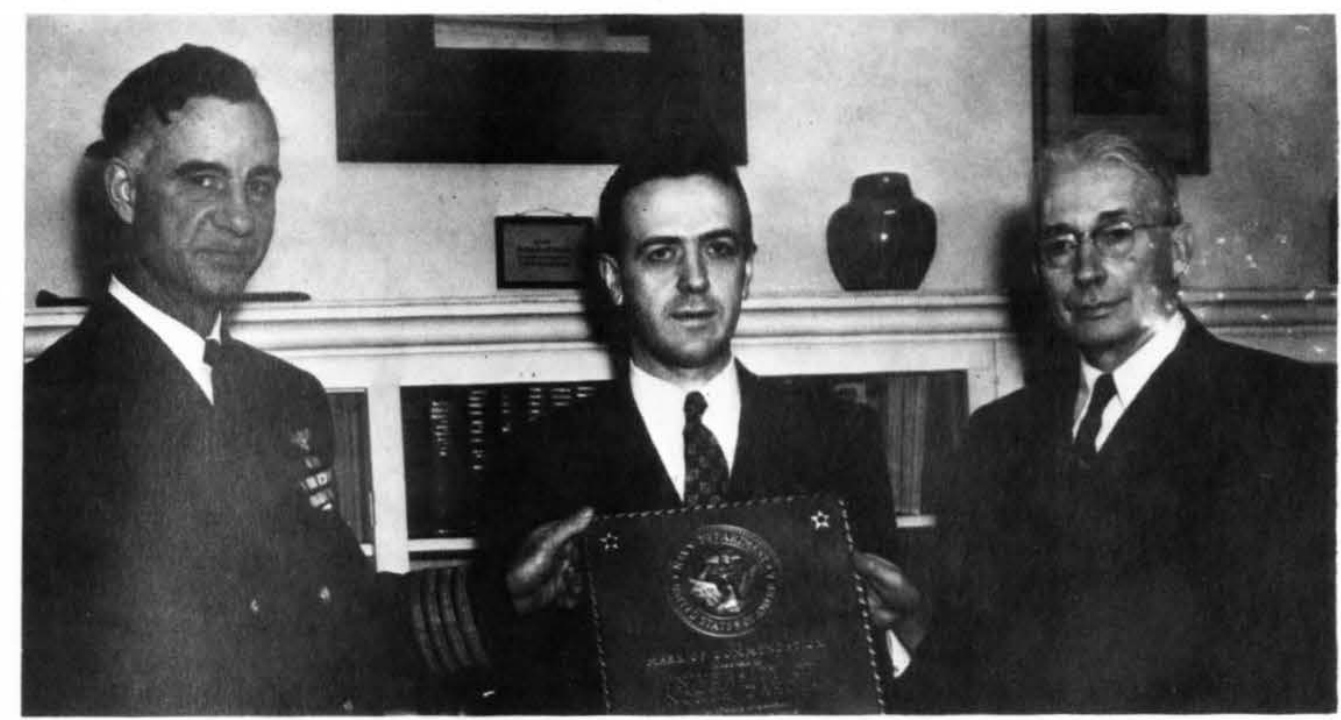

better off. Housing was totally inadequate; classroom and laboratory space was severely strained. Faculty additions and salaries did not keep pace.

In spite of the severe limitations, growth brought change and progress. The legislature of 1949 and 1951 responded with large building authorizations that would in a few years double the University's space. New graduate programs emerged and old ones attracted more students. The Medical School, now

supported by a special levy, outstripped the other colleges in faculty strength and research endeavors. New programs such as management, occupational therapy, and industrial arts, entered the catalog.

Much of the change, however, seemed undirected. West's health began to deteriorate under the increasingly heavy

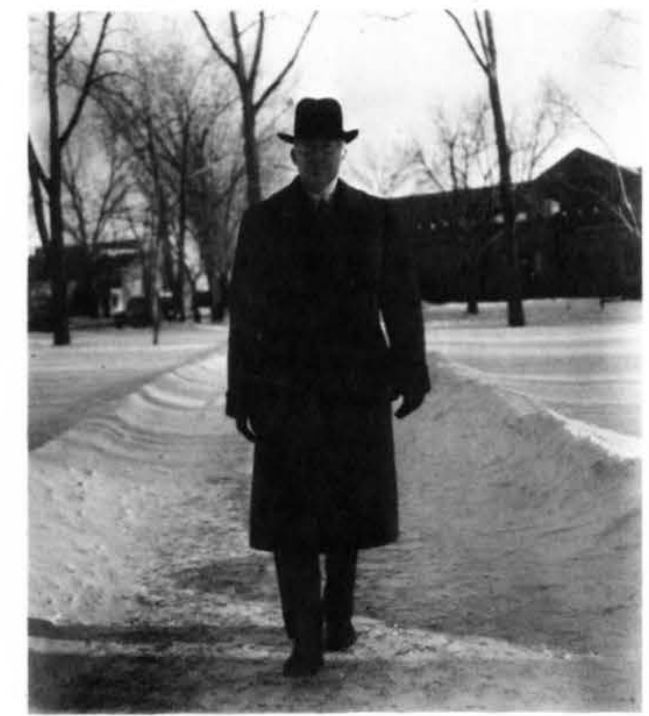


burden of his presidency, and his assistant, D. J. "Jack" Robertson, tended to a grea deal of the office's paperwork. In 1947 an AAUP committee representing about 85 percent of the faculty recommended in a three-page document a reorganization of the University's administration. Of prime importance in the scheme was the creation of a vice presidency, "the ranking administrative office directly under the president concerned with all matters other than business." The vice president would handle, among many other matters, the "development and growth of the

institution." Although implementation of the proposal would have strengthened the University, West thought it was too late in his presidency for such sweeping change.

After 21 years - UND's longest

presidency - John C. West retired in

1954. With exceptional skill he had steered the University through the depression and

World War II years. He had waged a wellcalculated and determined defensive campaign to keep the University a respectable institution during a most troubled time.

In contrast to West, George W. Starcher, who was named president in 1954, had spent his career in university classrooms and administrative offices. Born in 1906 in Ripley, W. Va., Starcher grew up in rural West Viriginia and Ohio. He worked his way through Ohio University (summers on the family farm and school years at a campus restaurant), graduating with honors in 1926 . He

distinguished himself in graduate study at the University of Illinois where in 1930 he earned the Ph.D. in mathematics. He returned to his alma mater and taught until

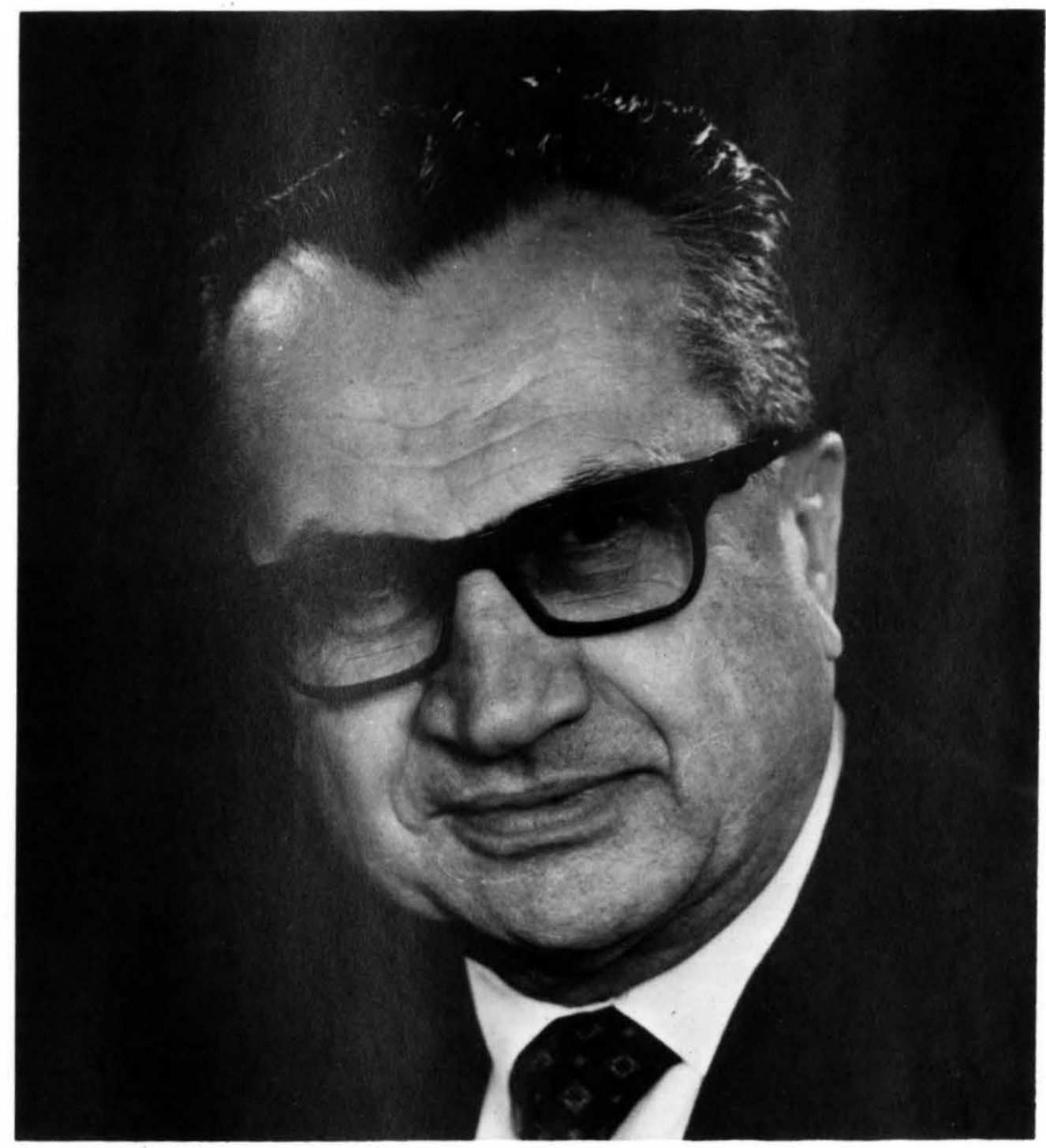


1943 when he was appointed as acting dean of the Graduate College and of the College of Arts and Sciences. While Starcher was on leave studying in the human relations program at Harvard University 1945-1946, he made the commitment to a life in university administration. As Ohio University's dean of University College (1946-1951) and Arts and Sciences (1951-

1954), he earned the reputation as a progressive, capable, and energetic administrator. That reputation earned the 48-year-old dean the presidency of the University of North Dakota in 1954.

The University had not had forceful academic leadership since the days of McVey and in many ways, Starcher did for the University what McVey had done 40 years earlier. Both men placed a high priority on academic standards and intellectual growth of faculty and students. The new president inherited a university whose budget did not reflect the state's post-war prosperity, whose structure had changed very little since World War I, and whose facilities were still inadequate. $\mathrm{He}$ stunned many with his optimistic plans which he outlined in his inaugural address and frequent public remarks: comprehensive building program, many additional faculty and higher salaries, expansion of graduate study and faculty research, modernization of student and faculty governance, improved counseling and scholarship programs for students, the upgrading of student achievement and the intellectual life of the campus, and private funds to enhance the University's programs. To a faculty and public who vividly remembered the economic ravages of the Great Depression, the newcomer's bold program for the future must have seemed like an unrealizable dream.

The 17-year presidency began with a flurry of activity as Starcher implemented his ideas and those of the faculty, who saw in the new president a chance to move the University into a new era. Because the University was small (2,634 students in the fall of 1954), the president saw himself as not only its external representative but also its internal academic leader. During his first year he and D. J. Robertson worked together, fashioning University College a college which, according to Starcher, would "stress basic education and preparation for specialization." In 1955, with Robertson as dean, it began the advisement of entering freshmen. Starcher believed that the new college would give students a chance to review all fields of academic work before making a career decision. That same year, again after consultation with faculty, the University inaugurated a senior honors program to provide the brightest students with the opportunity for greater intellectual development. In 1961 it became a four-year program.

Starcher soon realized that with the University's rapid growth $(4,130$ in the fall of 1960), he would no longer be able to oversee all phases of management. When he assumed the presidency almost all paperwork, including such requests as the replacement of faucets in a dormitory room, crossed his desk. Gradually he decentralized the University's operations. In 1959, he chose Thomas J. Clifford, dean of the College of Business and Public Administration, as vice president for finance; Clifford, known for his mastery of money matters, began reorganizing that aspect of the University's operation.

The revitalization of the old programs and the beginning of new ones came slowly but surely throughout the 1960 s. For example, in 1959 the Division of Nursing became the College of Nursing; its dean, Margaret E. Heyse, the first woman to join the ranks of academic deans, led the new college to accreditation in 1963. The explosion of federal funding and the pressures of increasing numbers of faculty and students (over 6,000 in the fall of 1965 ) caused Starcher to create the office of vice president for academic affairs and appoint William E. Koenker of the economics department to the post. A third vice presidency - student affairs - was created shortly thereafter to coordinate a proliferation of student service departments.

Traditional subjects found new forms (department of religion, 1963, and the humanities program, 1966); new fields (computer science and aviation, 1969) entered the catalog. No innovations made a more visible impact on the campus, the state, and the nation than did the New School of Behavioral Studies in Education. As a result of a state-wide study that recommended an ambitious program to train nearly 2,000 North Dakota elementary teachers with Masters Degrees by 1975, the United States Office of Education poured federal money into the New School, headed by Dean Vito Perrone. The New School, which co-existed with the traditional College of Education, emphasized a more personal and open teacher-student relationship, giving rise to the term "open classroom." 


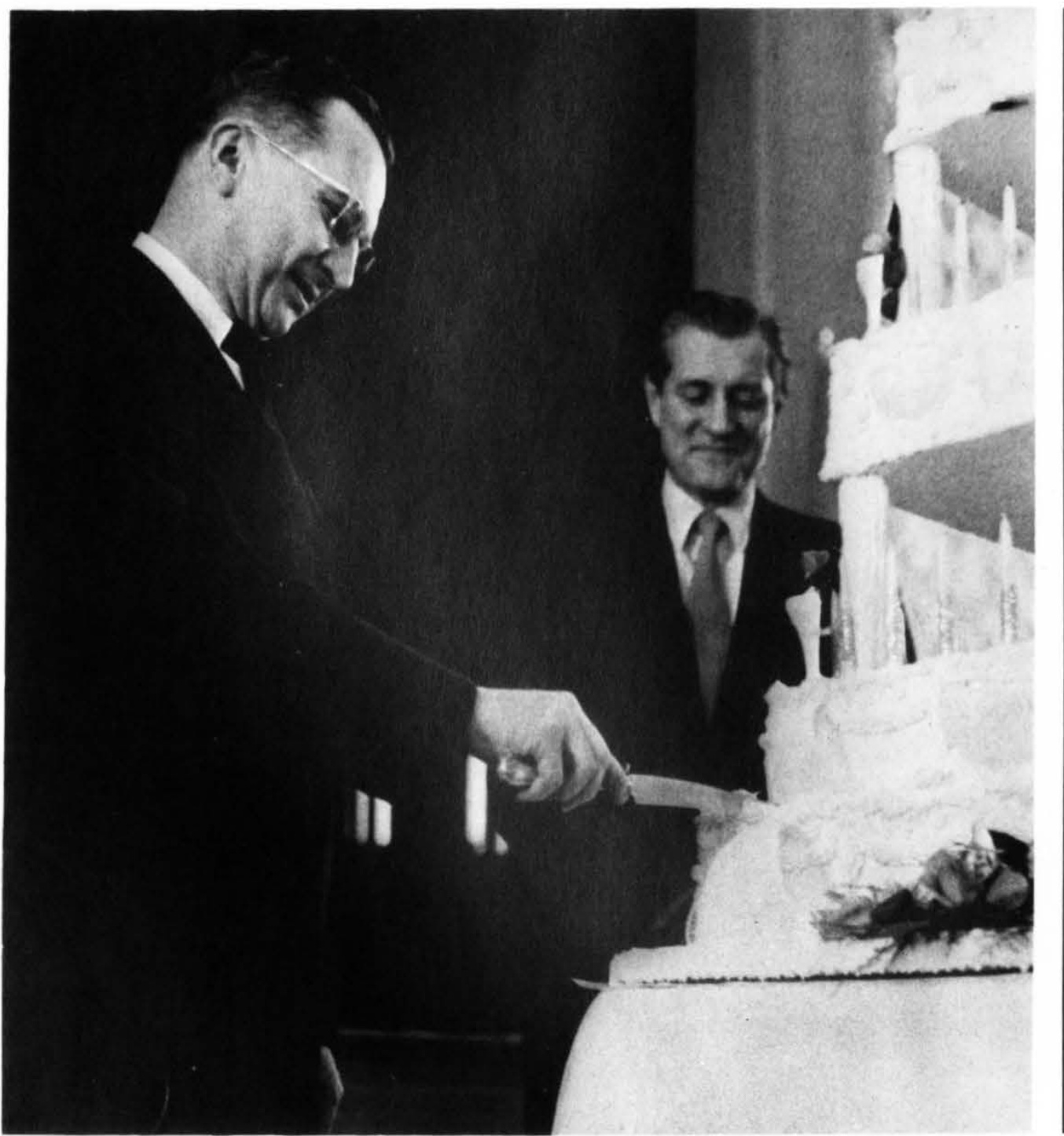

Starcher placed a premium on the improvement of campus intellectual life. Within two years, and with the help of many, he rejuvenated the library, inaugurated Fine Arts Week, brought national figures to campus, revived the North Dakota Quarterly, established a faculty lecture series, and supported special events that created a climate for a mature university. For good students, scholarships became more plentiful. He persuaded the State Board of Higher Education to provide financial help for North Dakota's best students. Private donors responded: Chester Fritz and Maxwell Upson, among many others, set up trust funds for scholarships. For the faculty, Starcher gained state support for research in 1958 - only $\$ 5,000$, but it was a beginning. In 1964 , a tenure policy was adopted and a year later the Board accepted Starcher's proposal to reward distinguished faculty with the rank of University Professor. Distinguished teaching awards became annual, and the president recognized excellence in publication with public receptions.

When Starcher became president he dreamed about private funding that would allow the University to go beyond the bare bones of education. Much of what was accomplished during the Starcher years came about because of his and the Alumni Association's dogged search for private gifts. Private donors such as Chester Fritz and Dr. Robert Campbell made possible that "something extra" in the University's quest for excellence.

Few realized as the Starcher

administration began that a third partner would play a vital role in the University's

The cutting of the 75th Anniversary cake in 1958. Broadcast journalist Eric Sevareid looks on. 
President Starcher at his desk in the new Twamley administration building, 1963.

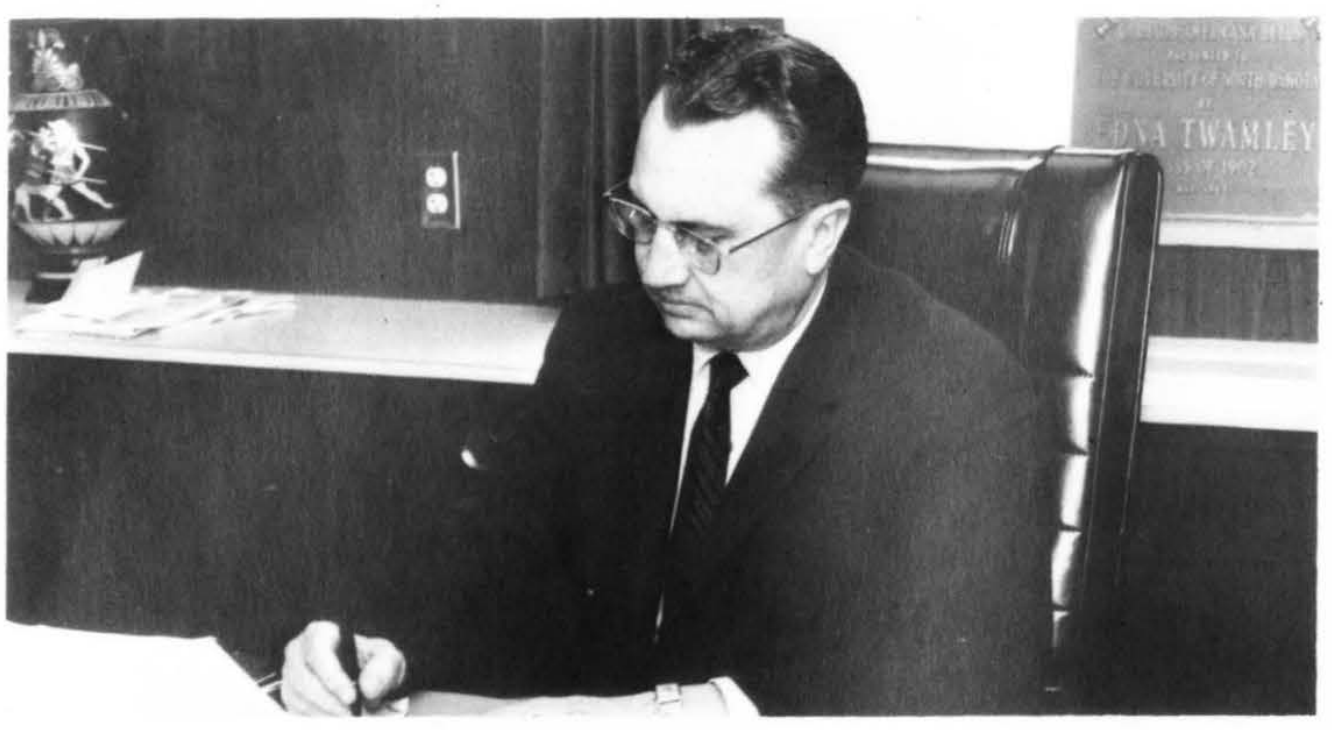

life - the federal government. In 1957

UND received its first grant $-\$ 63,500$ for a summer science institute for high school teachers. That would soon be "small potatoes" as Washington - especially with the Great Society programs of the 1960 s funneled billions into higher education and millions into the University of North

Dakota. Few were the departments that did not benefit from the new outpouring of aid to research, teaching and student financial assistance through work or scholarships.

Starcher cultivated and enjoyed good relations with the faculty, the public, and students. Very early in his administration he supported student involvement on committees and the development of a University Senate. The most serious threat to that harmony came in 1965 when 25

"Young Turk" faculty members chastised the president for moving too slowly on academic and organizational reforms and the University for giving North Dakota "an inferior educational product."

Dissatisified because of rapid faculty turnover, heavy teaching loads, inadequate salaries, and the power of older faculty members, the "Young Turks" embodied a frustration that was typical of campuses in the $1960 \mathrm{~s}$.

Events soon tested Starcher's relationships with the people of the state letter"' words in the Dakota Student and the appearance on campus of Communist presidential candidate Gus Hall upset some North Dakota conservatives who demanded that Starcher intervene. He refused to take repressive action. Growing student unrest, including marches, vigils, and resistance to and the student body. The use of "four the draft also stirred the campus. The climax came in May 1970, when severa students were killed at Kent State in Ohio. Starcher, who believed that student "restiveness is largely an expression of their desire for identification" and that "its objective is a more harmonious and free society," steered the University on a moderate course, avoiding large-scale disruption and, at the same time, recognizing the meaning of the students' actions. For his defense of academic freedom, Starcher received the 1969 Alexander Meiklejohn Award of the American Association of University Professors; because of his educational leadership, in 1964-1965 he served as president of the National Association of State Universities and Land Grant Colleges.

When Starcher retired in 1971, the University had far surpassed his own prediction of 5,000 students by 1970 reaching 8,129 . He could look back with satisfaction as the president who led the University to the status of mature university.

The transfer of the presidency from Starcher to Thomas J. Clifford in July 1971 was smooth, largely because the new president had been within the University since 1945 and had been vice president for finance for 12 years. Born in 1921 at Langdon, Clifford was a product of smalltown rural North Dakota. He attended the University of North Dakota where he earned a reputation as an athlete and bright student (B.S. in commerce, 1942; J.D. in 1948). During World War II he served with the Marines in the Solomon Islands, Saipan, Tinian and Iwo Jima 


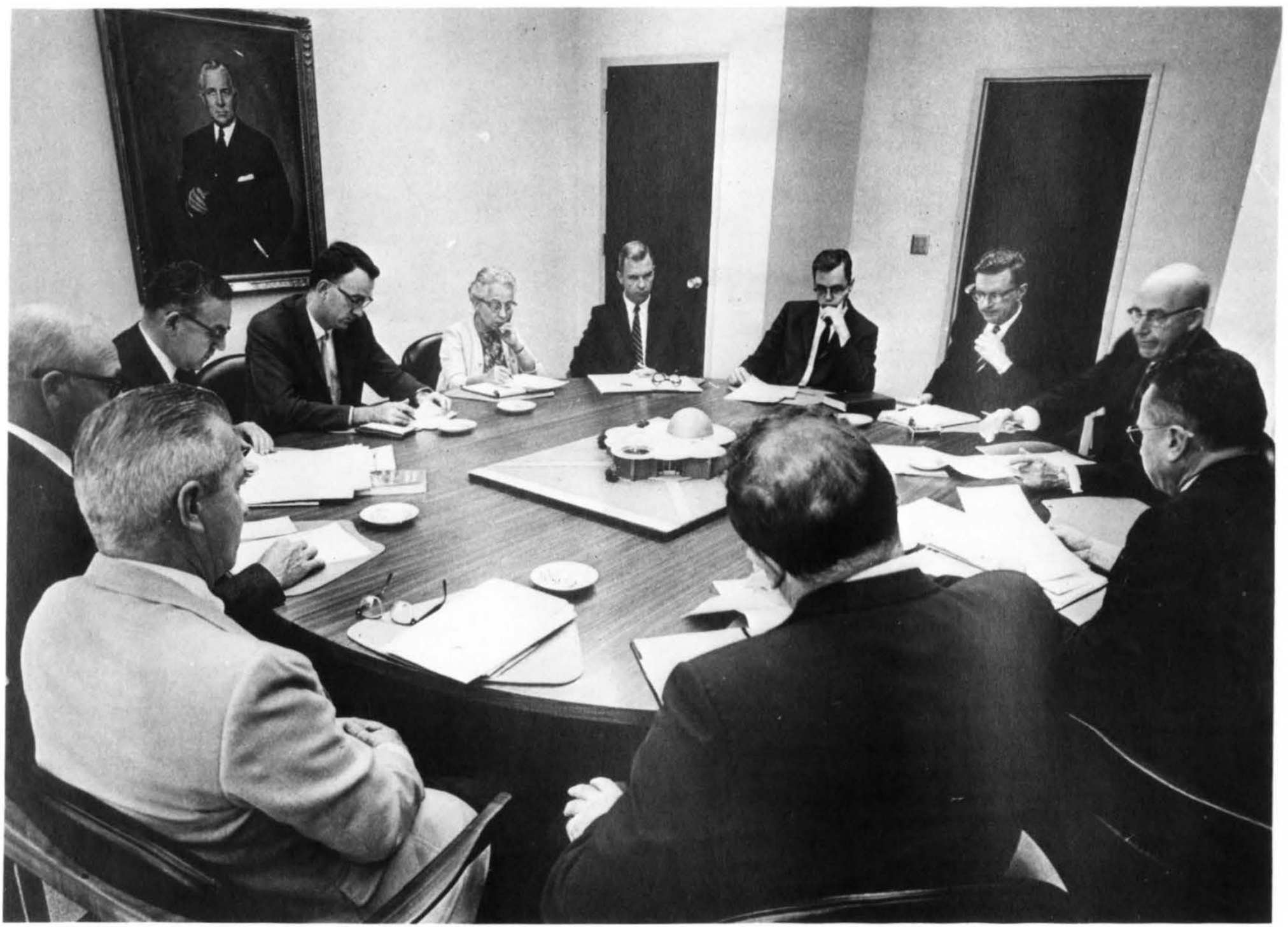

The senior ad-

ministration in 1967.

President Starcher in

lower right. To his

left, Thomas Clif-

ford, D.J. Robertson,

Martelle Cushman,

H. Cunningham, A

William Johnson,

Margaret Heyse,

Ronald Barnes, M.

Larson, Bernard

O'Kelly, and William

Koenker. 
Starcher and President-Elect Thomas J. Clifford, 197 campaigns. His gallantry earned him the Purple Heart, Bronze Star and Silver Star, and he rose through the ranks from private to major.

After the war he returned to UND as an instructor in accounting and business law and became a C.P.A. in 1949. President West saw strong leadership potential in the young professor and in 1950 appointed him to the deanship of the School of

Commerce. Clifford buttressed his academic qualifications with graduate study at Stanford University, receiving the Master's Degree in 1957. In 1959, Starcher promoted him to a vice presidency for financial affairs. As an expert on taxation, management, and business organization, Clifford often spoke throughout North Dakota and developed strong ties between the University and the business community. As a native North Dakotan, Clifford's knowledge and understanding of the state and the University was invaluable.

The president's inaugural address reflected both his business background and the climate of the early 1970s. "It has often been said that principles of business management cannot be applied to an educational institution," he told the audience. "I don't believe it. My orientation in business administration leads me to believe that an academic system that gave birth to the management concept surely should be able to adapt its teachings to solve its problems." Since Clifford believed that "the watch-word of the seventies will be 'accountability',' he emphasized the need for the University to plan for the future and to evaluate itself. "We will have to know what we are doing, and why we are doing it. We will have to

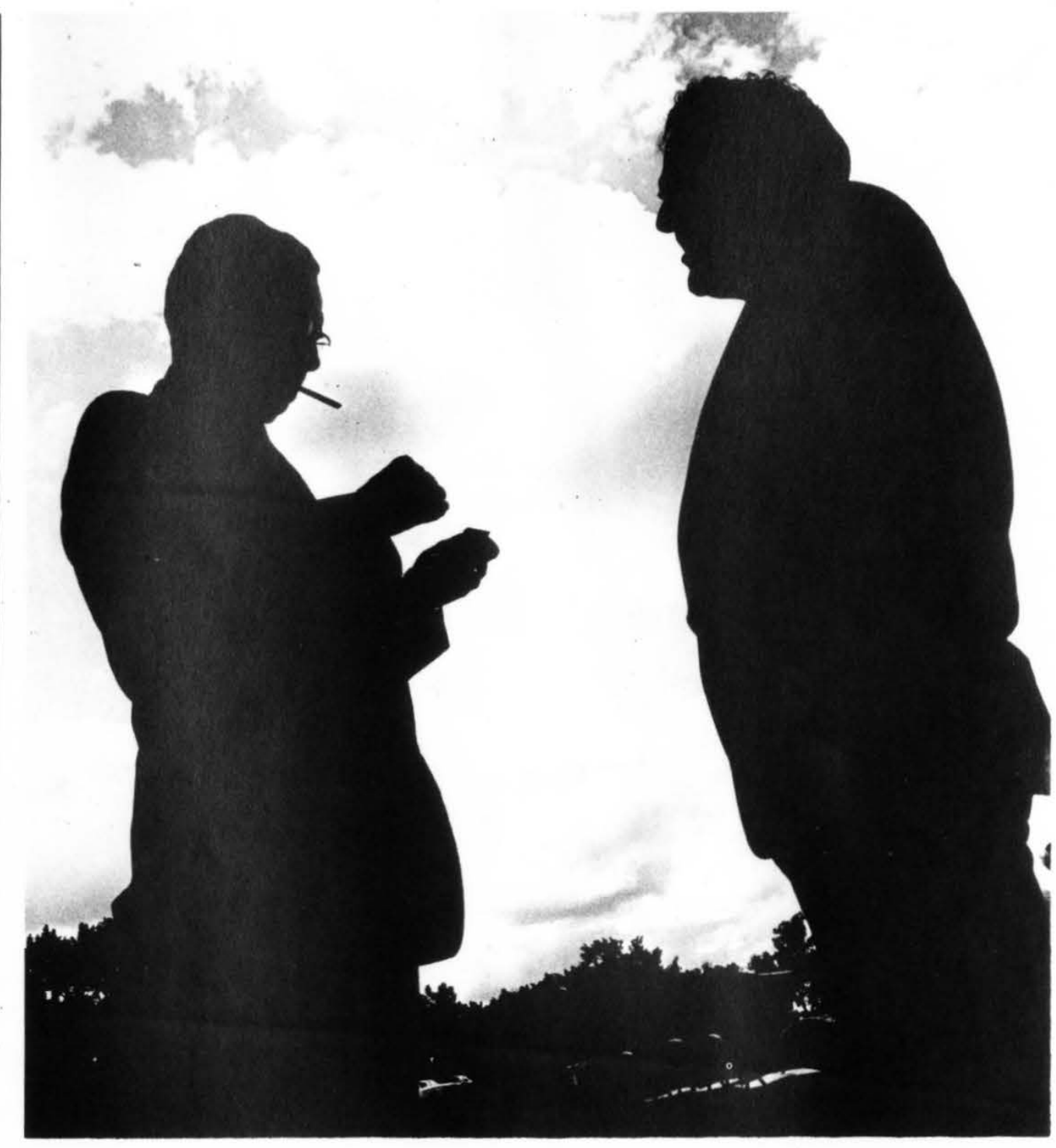


be ready and willing to make changes to find new ways of performing our basic

functions." While opposing change for its own sake, he admonished the University to take a good hard look at itself and to make those changes that would allow it to serve better.

Clifford wasted no time in translating his inaugural promise into action. The "good hard look" began with a full-scale

planning effort - the Study Committee on Planning and Evaluation. Involving 350 administrators, faculty, students and citizens, the so-called SCOPE report, issued in 1973, contained 246 recommendations for action and became a valuable instrument in the University's quest for excellence during the 1970s. The Graduate School undertook a systematic and thorough evaluation of its programs in order to offer students the strongest possible courses of study. As the 1970s closed, the University underwent another mammoth task of goal setting, followed by an intensive program evaluation. Never had a decade of the University's history been dedicated to such extensive selfscrutiny. President Clifford's pledge of accountability had been kept, and the University was a better place because of it Clifford's drive for accountability was in part a response to the sagging relationship between the University and the people of the state. Although the University had escaped the full force of the student protest movement of the late 1960 s and early 1970 s, its reputation emerged tarnished in the eyes of some North Dakotans. The new president spent a large share of his time on the road, visiting most North Dakota communities and chatting with the people in a successful effort to restore confidence in the University. In 1975 the University beat back an attempt by Robert McCarney, Bismarck auto dealer and political maverick, to refer UND's appropriations to a vote of the people. At ease with the folks of the prairie and plains, Clifford brought the University into a closer alliance with the legislature and the people, who through taxes supported the school.

On campus, the new president

overhauled the finance and operations areas, introducing a systems management approach. Clifford brought the offices of buildings and grounds and auxilliary services together under a new vice presidency for operations to which Loren Swanson, University graduate and longtime employee, was appointed. Gerald Skogley, a UND graduate who succeeded

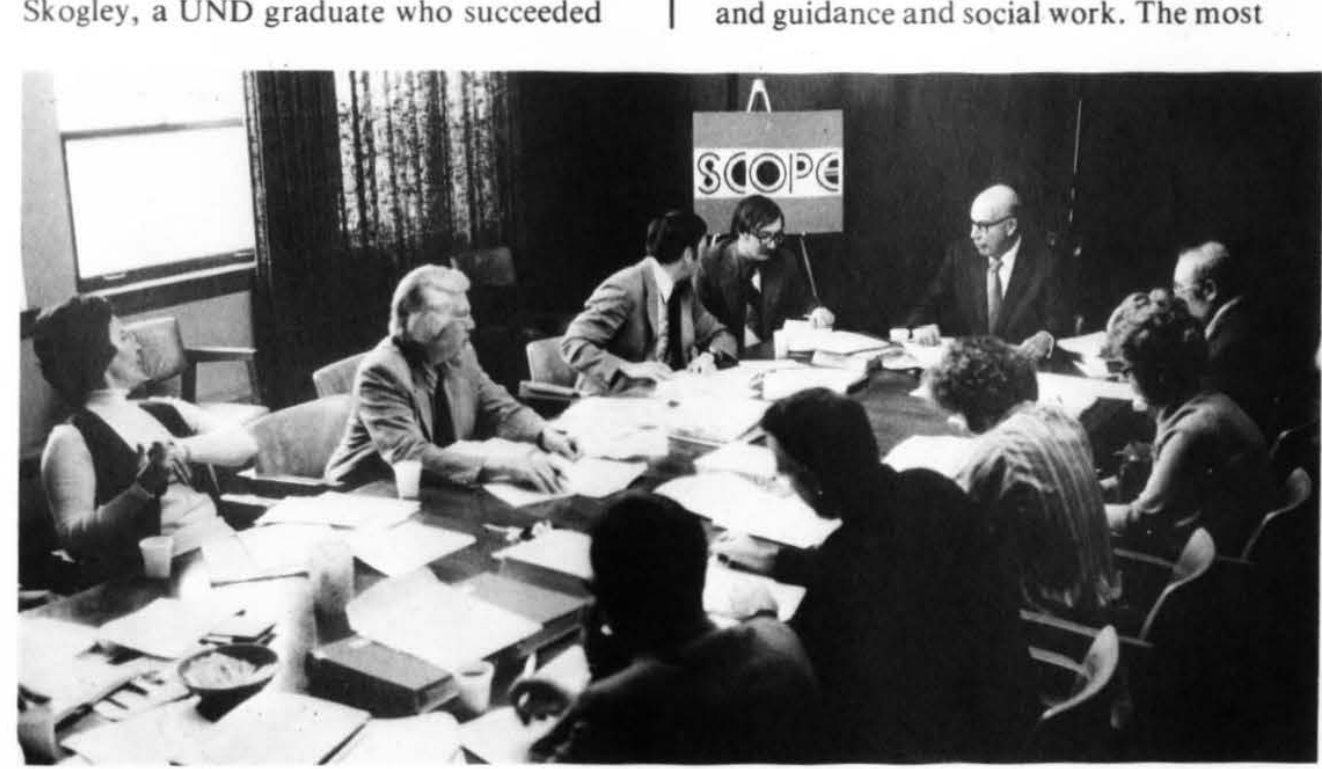

Clifford as vice president for finance, spearheaded reorganization of the moneymanagement system. "We just had to do something that would bring our business operations up to date in the age of the computer,"' Clifford explained in a 1981 interview.

Organizational changes, some of which were in the wind or approved during the Starcher presidency, occurred during and were facilitated by the Clifford presidency. The College of Fine Arts enrolled its first students in January 1972, giving theater arts, music and visual arts their own autonomy. A new College for Human Resources Development, with a focus on training professionals for human services, pulled together and coordinated the programs of departments such as counseling and guidance and social work. The most

The SCOPE longrange planning comfirst year of the Clif- 
President Clifford in 1980 , relaxed, as usual, and at his persuasive best as he ap pears before the State Board of Higher

Education.

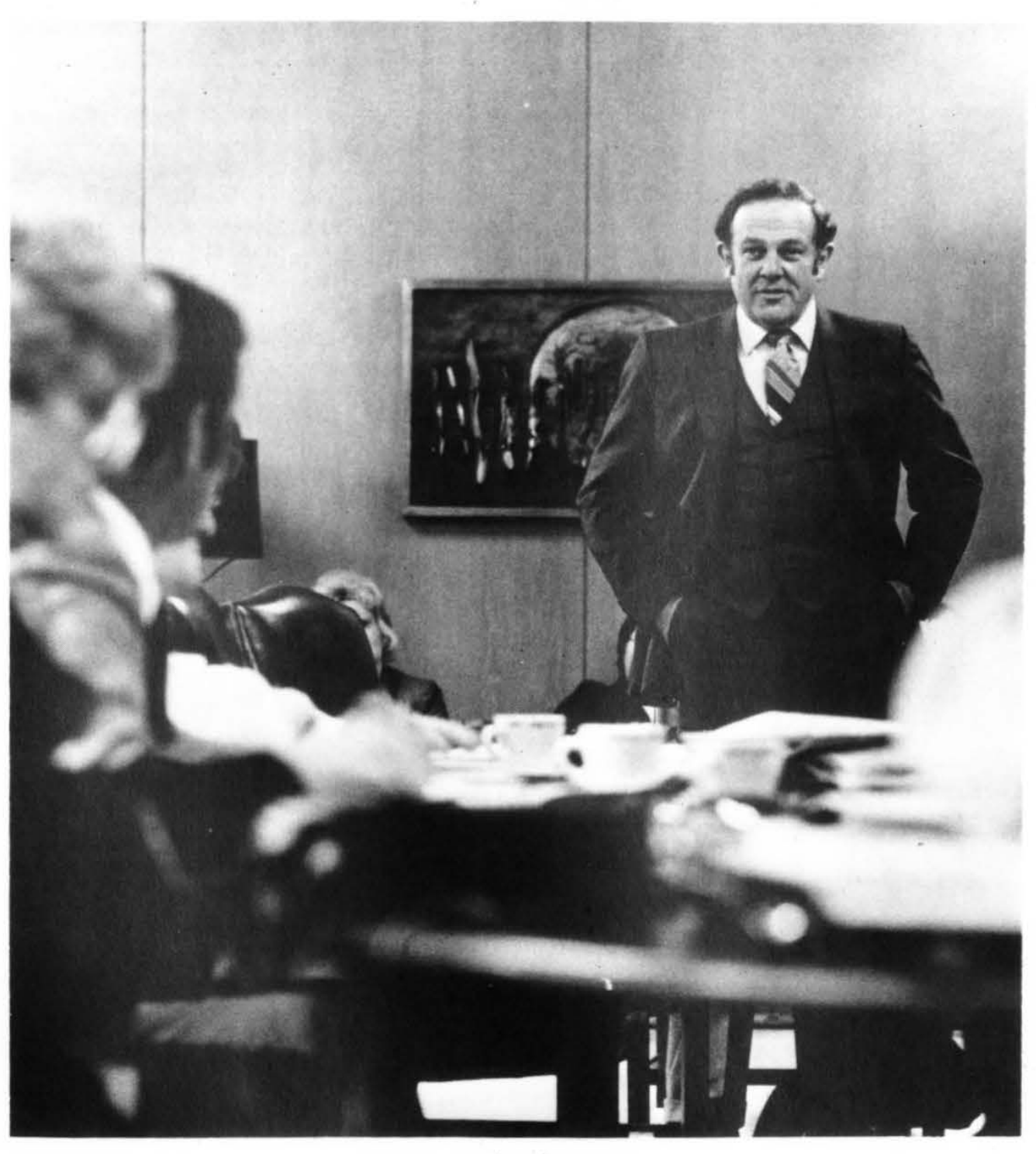

ticklish organizational problem was the merger of the traditional College of Education with the revolutionary New School of Behavioral Studies in Education. After months of negotiations, in July 1972 the two came together as the Center for

Teaching and Learning under Perrone's deanship. Less noticeable reorganization, such as the creation of the Enrollment Services Office in 1979, took place throughout the decade.

The strengthening of the professional schools became Clifford's top academic priority during his first decade. "In 1971, 1 reviewed the status of all colleges and concluded that the professional schools needed strengthening," he commented in 1981. "We have done a good job in upgrading those areas." Indeed, the professional schools, including the College of Business and Public Administration, did grow in program, faculty, students and facilities. For example, Law blossomed as a school that no longer feared the evaluations of accrediting teams. A strong faculty with beefed-up salaries and a modern library breathed new life into a school that had struggled for years. Engineering emerged from unsuccessful talks about consolidating it with NDSU as one of the region's most effective schools. The most dramatic change in the professional schools came in medicine. The transformation from a two-year to a four-year school in 1973 enhanced both the University and

medical practice in the state. In May 1976, the School of Medicine graduated its first class. Based upon a plan that involved physicians throughout the state in a unique far-reaching organizational structure, 
UND's School of Medicine emphasized family medicine. In 1982, it abandoned its policy of sending students for a third year to the University of Minnesota or Mayo Clinic for one that trained them in North Dakota, truly implementing the four-year concept.

During the Clifford presidency new programs reflected the changing panorama of American education. Archaeology,

Indian studies, meteorology and women's studies came to be popular and respected programs. No program was more

successful, however, than aviation.

Enrolling 750 majors, the Department of Aviation exemplified the University's growing emphasis upon professional

education as well as its ability to support new programs. By 1983, students could choose from over 130 programs of study

- testimony to the University's mature status.

The Clifford presidency -12 years as UND celebrates its centennial -

encompassed a broad spectrum of other achievements: gigantic research projects such as Project Lignite, a greater and expanded rehabilitation hospital, public service through a reorganized Division of Continuing Education, the development of a full-blown physical plant, accessibility of facilities to and programs for the

handicapped, more involvement of students in the decision-making process, an exciting instructional development program that sharpened the University's focus on the improvement of teaching, an operating budget of over $\$ 100$ million. And, of supreme significance, the University's enrollment - contrary to projections and national trenids - continued to grow: from 8,395 to more than 11,000 students,

evidence of the University's pre-eminence as the university of the Northern Plains.

During its one hundred years, the

University has had its failures, its

disappointments, its times of trouble. But in his inaugural address, President Clifford captured the essence of that century when he declared: "To those who say we should completely disregard the past I can only reply, in view of the impressive record of this University, that somebody must have been doing a great many things right."' 


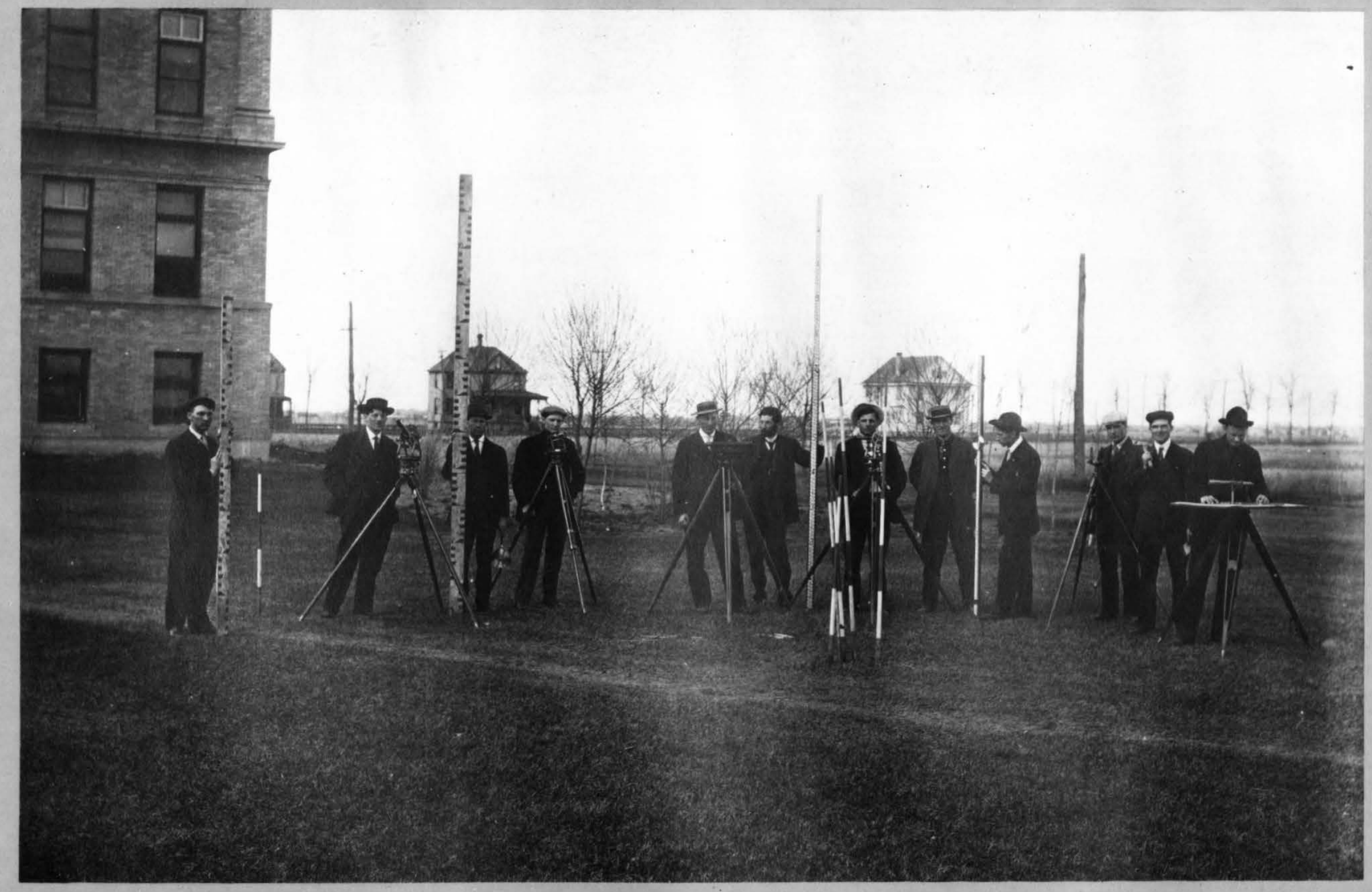




\section{Professors}

By Robert P. Wilkins

Professor Emeritus of History

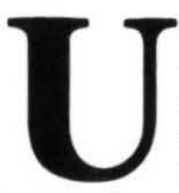

ndergraduates who take an interest in their instructors as persons are the exception. To most of their fellows the teacher is little more than an adversary to be

outsmarted as the semester progresses. Such questions as why are these men or women standing in front of these classes at UND, what problems do they confront, what satisfactions do they find here, what standing have they in their little corners of the world of scholarship, come to few minds. The University, for its part, discouraged students from learning something of their teachers when in 1950 it dropped from the catalog the traditional brief resumes of their education and experience.

Explanations for teachers finding themselves at North Dakota are not easily come by. The case of the first faculty, three in all, presents special difficulties. In 1883, North Dakota had a population of $152,000-$ most of it scattered about the countryside on tarms. Grand Forks, with 6,500 people, was an amazing instance of "instant civilization," boasting unexpected conveniences and services; nevertheless, the contrast with Evanston where the Reverend William Blackburn had taught Church History at Northwestern University's McCormick Theological Seminary or the thriving Cincinnati which he left to become UND's president and professor of mental and moral science, was startlingly great. The same stark contrast existed for Henry Montgomery of Toronto, the "professor of the natural sciences,"' and Webster Merrifield of New Haven, the "professor of the Greek and Latin languages and literatures." In the 1880 s, Toronto and all of Central Canada stagnated and Canadians streamed into the United States and North Dakota. As for Merrifield, he, in 1879, had visited his family's land holdings south of Grand Forks where to this day a village perpetuates their name.

Louis G. Geiger, to whom all who write or think about the University of North Dakota are indebted, in his University of the Northern Plains, suggests that Blackburn was a victim of "Dakota Fever," A fellow clergyman described the country for him in terms that could induce that disorder: "You need not discount the stories ... of the wonderful fertility, the immense resources of the Red River Valley.

They are substantially true. It is a magnificent country - as flat as the poorest sermon ever preached, but vastly richer and more productive."'

Whatever the deciding factor for Blackburn, Montgomery and Merrifield, the move to North Dakota did not afford the opportunity academics so often profess to be searching for: better students and facilities. Of the class of 79 that enrolled in 1884 , only 28 were ready to begin high school subjects. None qualified for beginning college courses. There was no library, no laboratories. But opportunity, areas for exercising the creative function in the erection of an institution abounded.

These three men were creators, not inheritors. President Blackburn taught reading and United States history as well as ancient history, algebra and geometry. Montgomery taught English as well as chemistry, physiology and hygiene.

Merrifield met classes in Latin, Greek, algebra and geometry. John Macnie, of a second generation of instructors, taught French, German and physics. Horace B.
Engineering students and faculty survey the campus in the early $1900 s$, a scene still seen annually at $U N D$. 
Prof. John Macnie, dressed for the winter of 1886 .

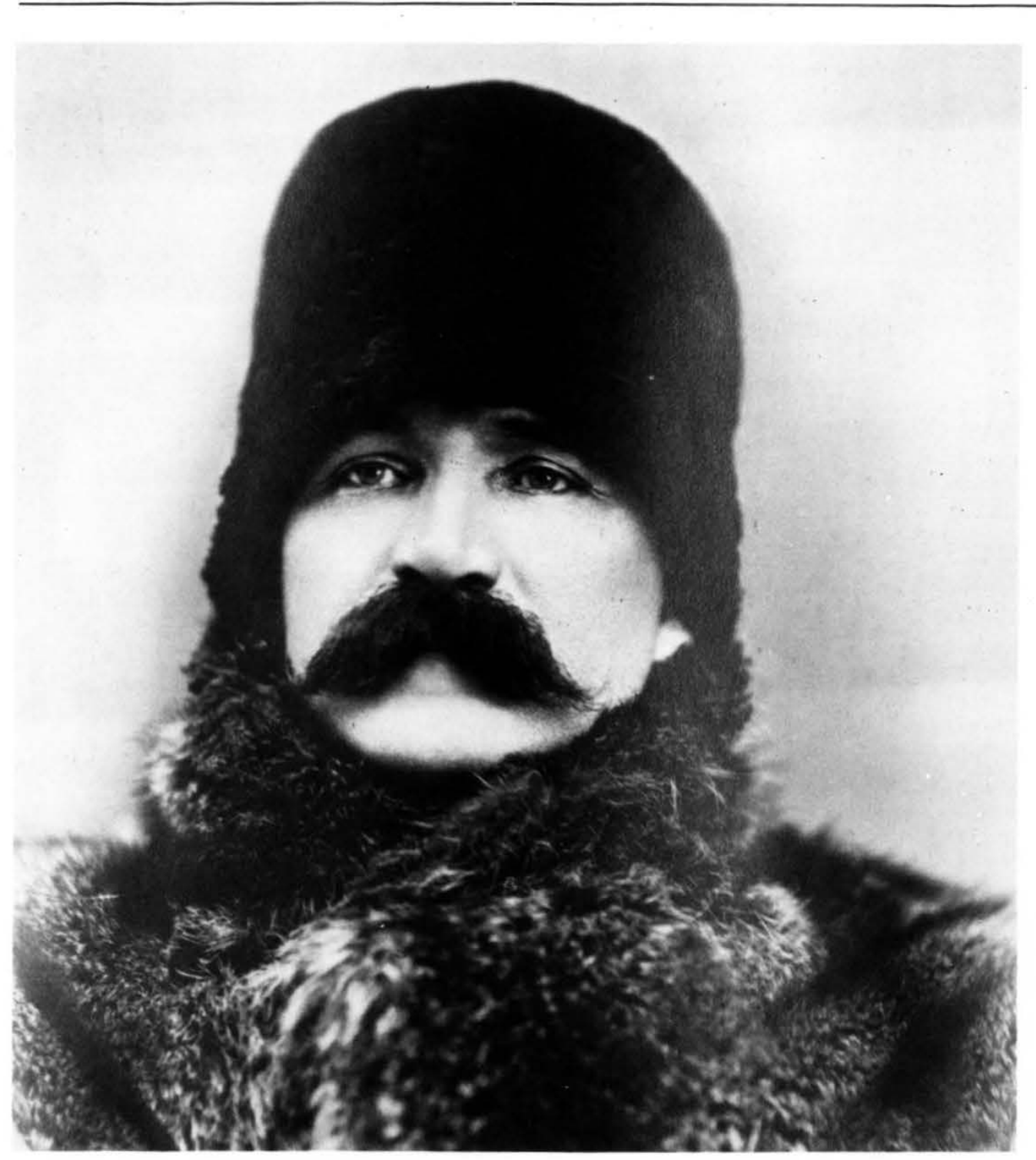

Woodworth was appointed professor of mathematics, physics and astronomy, but until 1890 taught most subjects - except chemistry - offered at any level. In this period with small enrollment, primitive

facilities, and the general nature of the faculty's preparation the 19th century idea of higher education - "Mark Hopkins on one end of a $\log$ and the student on the other" - was approximated here.

With Ludovic Estes, the first holder of the Ph.D. was added to the faculty; the number of doctorates doubled when George Thomas arrived to teach classical languages. Melvin Brannon earned the degree before closing his career at North Dakota. The creation of a modern faculty began in earnest with the McVey era which opened in 1909. Men such as O. G. Libby, James E. Boyle, A. H. Taylor and George A. Abbott with his Massachusetts Institute of Technology Ph.D. were added. But in most instances no record survives as to what motivated them to come. For many, then and later, UND provided the chance to break into college teaching. It was the first rung on the ladder of academic success. A few years here could give them the credentials for a move to more prestigious institutions more centrally located geographically and of fering greater opportunities for specialization as well as higher salaries. Throughout the middle years of the "Golden Twenties," when UND stood $41 \mathrm{st}$ in the nation in salaries paid to professors, resignations numbered more than 30 a year. North Dakota, President Kane reported to the Board of Administration, was becoming a "training school" supplying experienced teachers to 


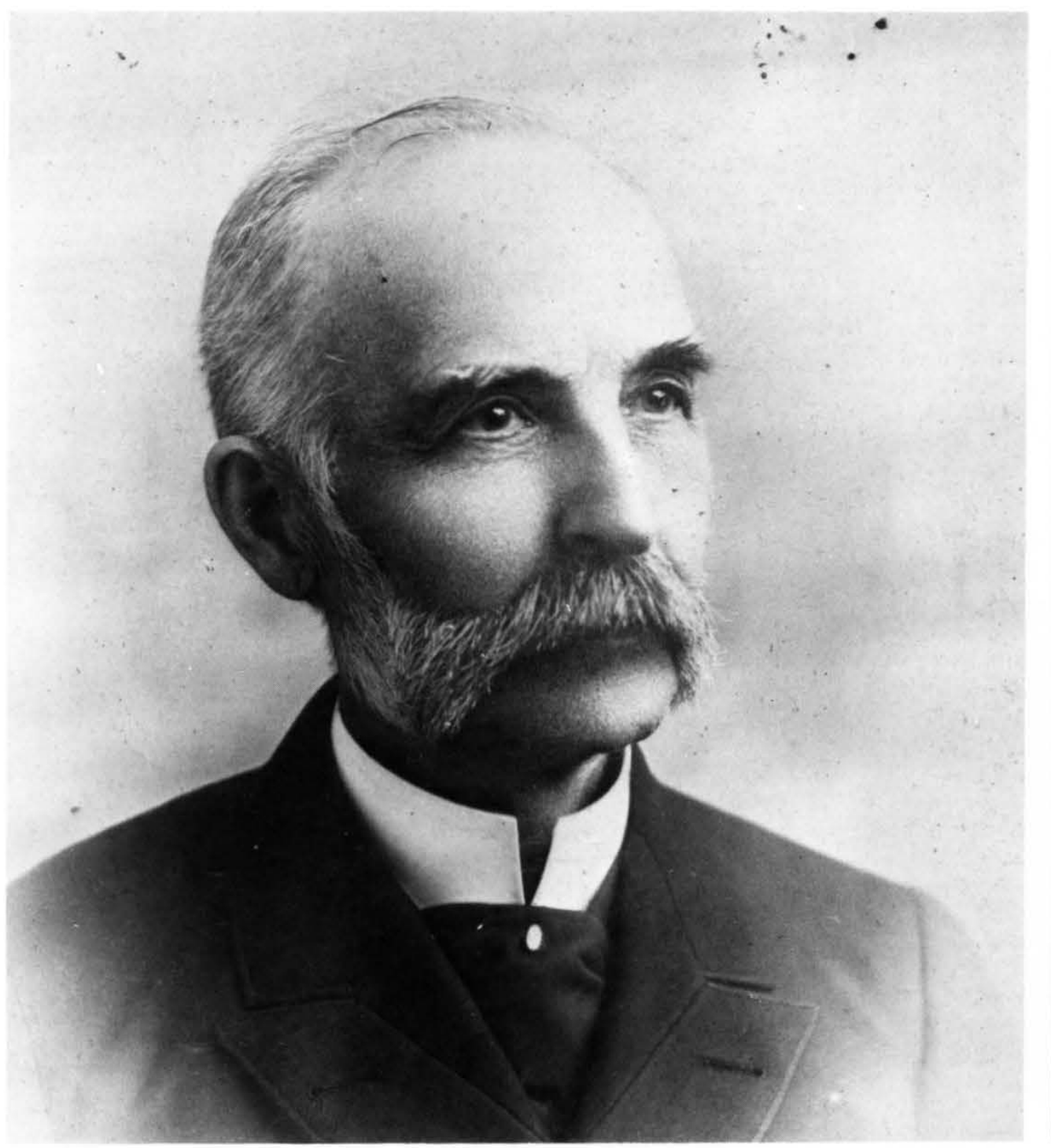

other institutions. Between 1927 and 1930 the School of Commerce had a complete change of staff; during the same period 19 outstanding teachers left the campus.

As late as 1945 department heads were telling new instructors that UND was a

"good place to go from" and go they did, particularly in the "Soaring Sixties" when federal intrusion into higher education brought an undreamt-of expansion nationwide. The flow of teachers in and out demoralized those that stayed. The departure of colleagues to all parts of the nation raised questions in the minds of those who remained. Why were they staying? Were they incapable of meeting the challenges elsewhere? Were they, the ones who stayed, "second-rate" as Kane had hinted 40 years earlier was true of those who stayed then?

Those who remained for any

considerable length of time developed differences of opinion as to what it was they should be doing. Disagreement as to exactly what higher education should be arose early. Montgomery and Merrifield in 1884 elaborated a course of study for the Bachelor of Arts strong in Greek, Latin and modern languages. What these men proposed, from the Oxbridge mold of the British Isles, was already making way elsewhere - especially in the state

universities - for a more distinctively

American version aiming at practicality. President Blackburn lost the battle of the curriculum to his two subordinates - as well as his presidency - but the tradition honored by Montgomery and Merrifield was soon modified in the direction which he had favored. Gradually the classical languages were dropped, first as a worth, who in the early days taught virtually every course at the University. 
requirement for admission and then for graduation, prompting lamentation for the better days of the past.

Another period of acrimony developed in the mid-1930s when William G. Bek, long-time professor of German,

campaigned as dean of Arts and Sciences for introduction of the Ph.B. degree. So long established in the older institutions of the East that it was losing ground there, it met opposition from professors who viewed it as a lowering of standards. It allowed students to opt out of foreign languages. Its opponents called it Bek's "moron degree," but it received faculty approval in 1935 and survived until 1968.

The influx of students in 1946-1947 encouraged professors recently arrived on the campus to argue for the raising of standards. Opponents of any such stiffening of requirements were alleged by one of their young critics to believe that "the University is already better than it ought to be."' They appeared to think that young North Dakotans could not measure up to the challenge of college education; standards set for them should be lower than those at better-known institutions. These persons, perceived by the newly arrived critics as defenders of low standards, were men - and women with records of long service. They had survived the spirit-breaking years of the Great Depression. Their piece-meal

retirement and the large number of young teachers added to cope with the tidal wave of veterans after 1946, cut resistance to new, more demanding standards. These rose as assignments in that "laboratory of the humanities," the library, increased in the years before the "paperback revolution.'

Major challenges to the old ways and disagreements within the faculty multiplied with the coming of George Starcher as president in 1954. He insisted on a larger place for the humanities in a student's firs years, even if he be headed for a career as an engineer, medical doctor or scientist. Objection to the intrusion of humane. studies into the training of technicians became vociferous. But this was only preliminary to other disagreements; the first of these arose over Starcher's advocacy of an Honors Program. The president's supporters advanced it, straightforwardly, as a "new route to graduation" which disregarded old procedures and requirements and they carried the day. As the years passed, some of these champions turned on the program, declaring that its real consequence was degrees for students who knew less of the disciplines than did their fellows who did not bear the "Honor Student"' badge.

Developments in the 1970s which saw students shift from liberal arts to business administration and aviation revived controversy in faculty ranks over the functions of a university. Financial stringency kept the budget too small to freely provide more teachers to handle the steadily increasing enrollment of the 1970 s and 1980 s and for salary increases to match inflation. A new aviation department under John Odegard grew in student favor. Many faculty members took a stand rather like that of Merrifield and Montgomery almost a century earlier, objecting that aviation had no place in a university curriculum. They clung to the view favoring "education" over

"training," but they lost; aviation in the aerospace age was in the catalog to stay and to expand.

The controversies over educational philosophy during the Starcher years left a bitter aftertaste. Stronger resentment grew from the new president's attack on the system of department headships. In the McVey years (1909-17) of small enrollments, a department typically consisted of one well-trained senior scholar and one, two or three younger men. The latter, with their newly awarded Ph.D.s or that badge ("union card") nearly in hand, were only briefly on the campus. But after 1945, slightly enlarged departments were staffed by men and women with terminal degrees, interested in staying. Soon friction developed between department heads who cherished the old autocratic role and the young looking for a voice in matters involving themselves and their students.

President Starcher proposed in 1962 changing "heads" into "chairmen" with a system of "rotating" the position among department members. With enthusiastic support of younger faculty, the plan for "rotating," elective chairmanship was implemented. However, the hostility toward Starcher by the chastened heads and some other, senior, members approached that of the elegant but frustrated "economic royalists" in Peter Arno's 1930s New Yorker cartoon with its cutline which read "Come along. We're going to the Trans-Lux [newsreel theater] to hiss Roosevelt."

In the Seventies as a part of the ferment stimulated by the Vietnam War, "faculty governance" principles were written into 


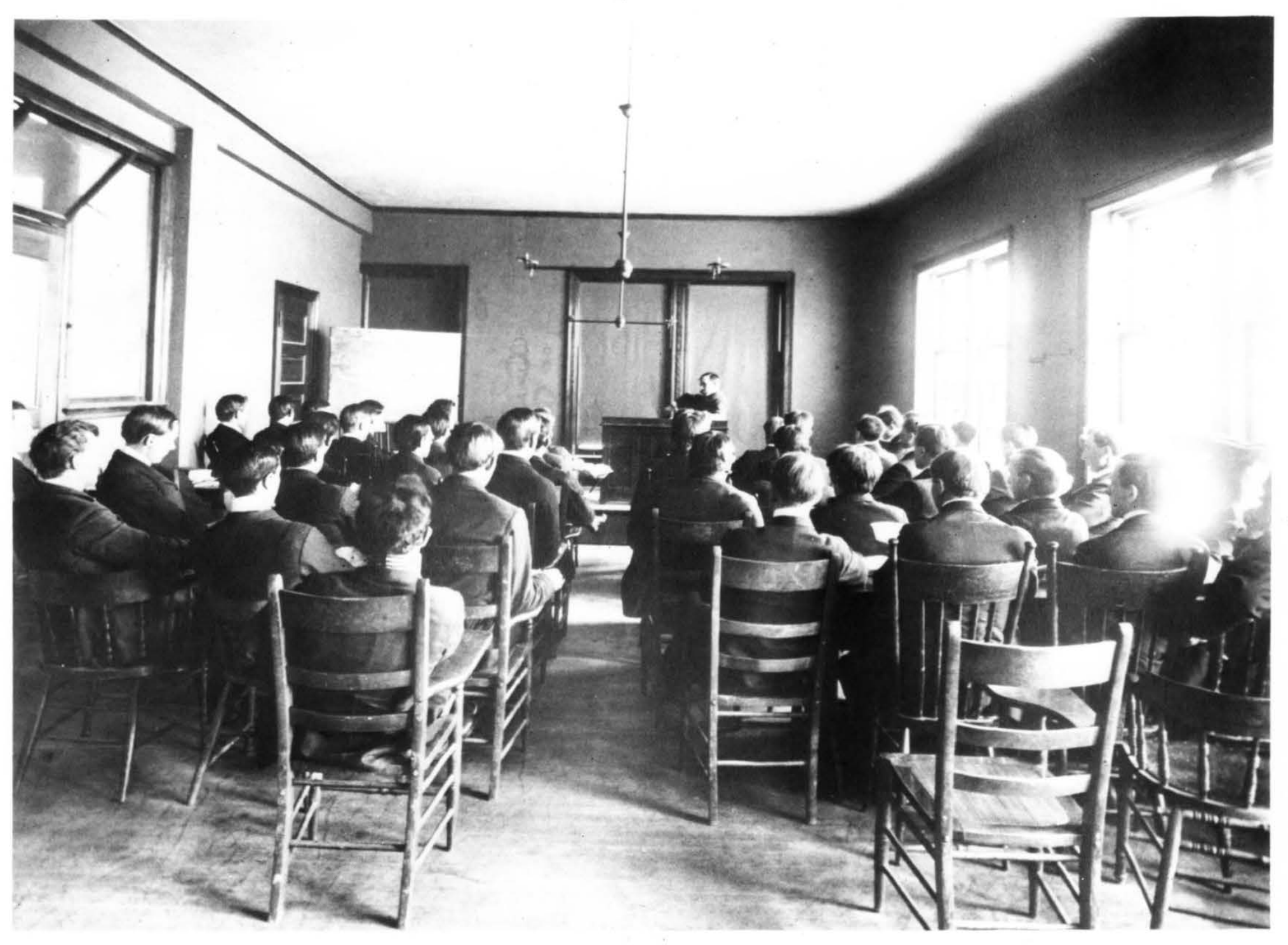

PROFESSORS

Law lecture, 1904. 
38 PROFESSORS

The faculty gather in September 1969 for President Starcher's
annual meeting on annual meeting on
the opening day of fall semester.

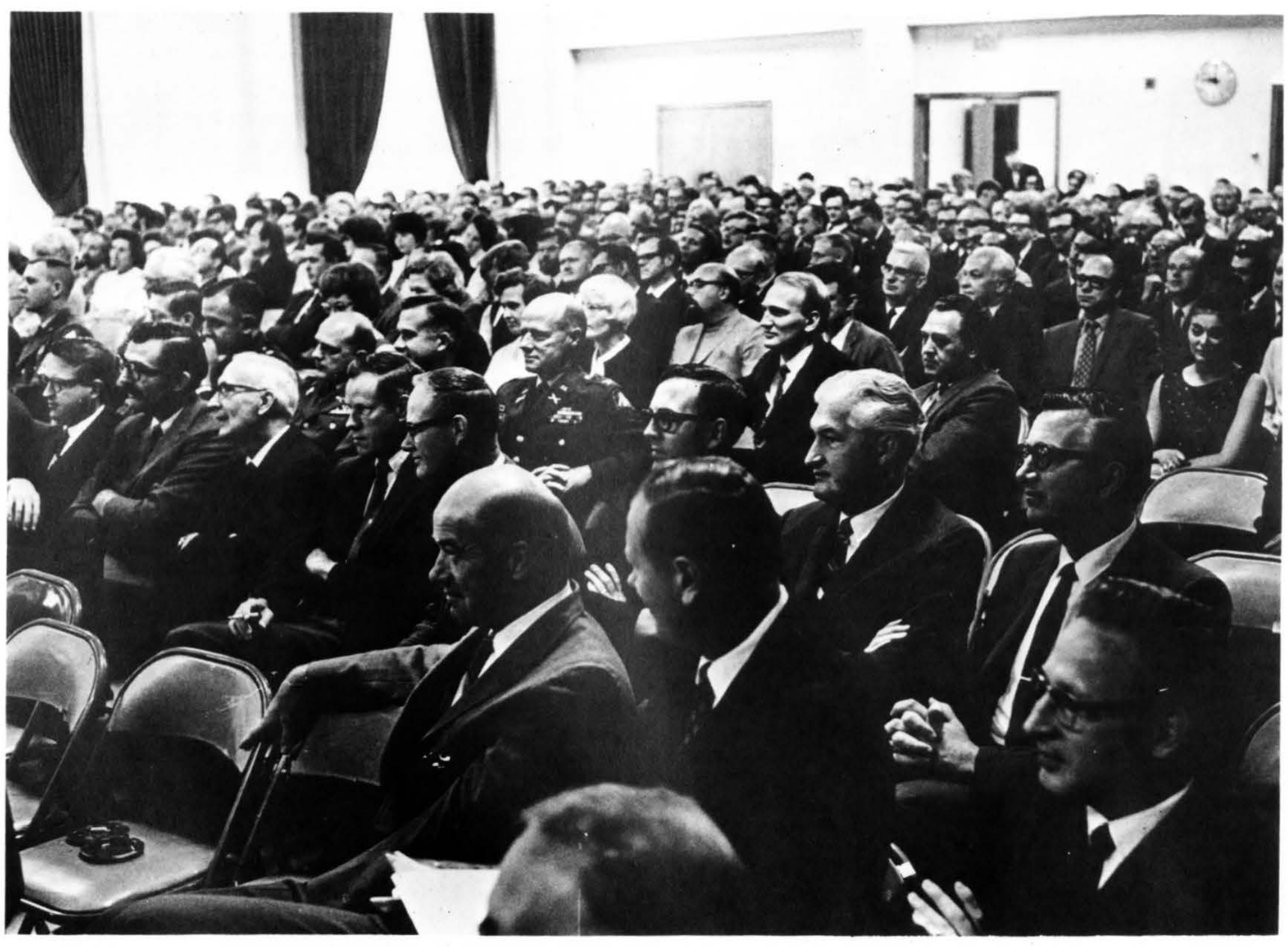


departmental and college bylaws. The result was much more committee work for the teaching staff but also more clearly defined policies on such matters as tenure and promotion, both of great importance to faculty morale.

Nonetheless, discontent remained, in part kept alive by growth in the administrative structure. From earliest times American colleges and universities differed from those in the British Isles in the presence in them of powerful administrators in place over the faculty. The NPL-dominated Board of

Administration in 1919 remarked upon the "wrong practice"' in North Dakota, as well as elsewhere in America, of rewarding these administrators more generously than teachers. It concluded that "it is not scientific ability but administrative force that is glorified, and this is in itself a perversion of every sound scholarly ideal.' The Board found that the policy's defenders came from the ranks of administrators who benefited from it. During the "Soaring Sixties" with the involvement of the federal government in higher education, administrative staffs mushroomed. In no small part, the growth was dictated by the volume of paperwork demanded by Washington's regulations. Federal aid was not without its price. In some measure, the growth in numbers represented the secretarial and other services which UND's professors of 30 years ago could not call upon. Nonetheless, many teachers felt that they were losing ground to the non-teaching element in the institution; that they were being overshadowed by that part of the University thought of officially as

\section{"support staff.'}

To enhance their influence on their fortunes, and to some extent on the general direction taken by the University, faculty members three times closed rank for collective action. The triumph of the Nonpartisan League in the November 1918 election put North Dakota in the national spotlight. It also stimulated activity throughout the state by persons who were progressive or liberal in outlook, working people and university teachers included. Trade unions grew in strength and the organizing impulse reached the campus. The great General Strike of 1919 at Winnipeg, 150 miles north of Grand Forks gave additional impetus to collective action. At UND, Local 134 of the American Federation of Teachers was chartered on Nov. 26, 1919, under the name "Associated Teachers of the State University of North Dakota." The petitioners for the charter, numbering 12 , included Dean Hugh E. Willis of the Law School, John M. Gillette, sociology, O. G. Libby, history, E. T. Towne of the School of Commerce, Henry A. Doak of English and William G. Bek of German. Norma E. Pfeiffer, botany, was the lone woman. The success in earlier organization of a local at the Agricultural College at Fargo helped bring in 106 members at the University The local participated in union affairs statewide, sending delegates to several of the annual conventions of the North Dakota Federation of Labor. Short-lived, it disbanded on Feb. 1, 1922

A dozen years later as organized labor was gaining strength under New Deal legislation of the Franklin D. Roosevelt era, a second local (No, 361) of the
American Federation of Teachers was chartered on Dec. 14, 1934, with 14 members. Included were a few department heads; howeyer, no members of the 1919 local were counted among its members. Membership after rising to 25 had declined to 10 when the local disbanded on March 1, 1936.

Another decade elapsed before the faculty again resorted to collective action on its own behalf. Drastic salary cuts during the war years had left summer school pay a mere pittance accepted by teachers without means to do much else during the vacation months. The prospect of such poor compensation in the face of inflation after the coming of peace in 1945 forced the faculty to act. It was agreed, and announced, that without very substantial increases in pay they would not teach the 1946 summer session. In those days before television, paved roads and regional shopping centers, the summer school brought public school teachers and their families to UND to enjoy what seemed like the many cultural and recreational advantages of the campus and of the city of Grand Forks itself. The threat to close this important operation brought a dramatic increase in salaries that made teaching in summer worthwhile in financial terms as well as of service.

The summer salary issue prompted a third effort at organization. Some leaders suggested affiliation with the Teamsters, others proposed a third local of the AFT. Both suggestions were rejected in the face of arguments for a local of the Farmers Union. The Farmers Union was the largest non-religious organization in North Dakota and, as a champion of the New Deal-Fair 
Alvin Austin, right, of journalism and John Howard of music calculate the winners of the 1948 Flickertail Follies - a student activity frowned upon by many faculty.
Deal programs, an ally of the state's Democratic Party. President West relied on

two Grand Forks Republicans - Senators Joseph B. Bridston and Carroll E. Day to look after the University's interests in the Legislature. But he agreed with young faculty liberals such as W. E. Koenker and somewhat older Democrat Bernhard G. "Ben" Gustafson that establishing ties with the Union might be prudent. George C. Wheeler, biology, and R. D.

Koppenhaver, accounting, played

important roles in setting up the local

which Koenker served as secretary-

treasurer. Its life was short and little record of it survives anywhere.

Faculty members concerned themselves with the mission of the institution, with their personal financial welfare and with student activity. They exercised great authority over the student body in the first four decades. Regulations on the use of tobacco, liquor and dancing represented the standards of behavior of a majority of professors. During the 1920s this control weakened, but as late as the 1950s faculty members were present as chaperons at dances held by campus organizations and filed reports on unseemly conduct with the deans of men and women.

At the opening of the Twenties, Roy French, chairman of journalism, influenced student activity in a way that lasted almost four decades. In 1924, he attended a convention at Indiana University. The meeting coincided with the annual run of the student show, "The Jordan River Revue." French saw the spectacular production, and on coming to UND resolved that it should have a similar one.

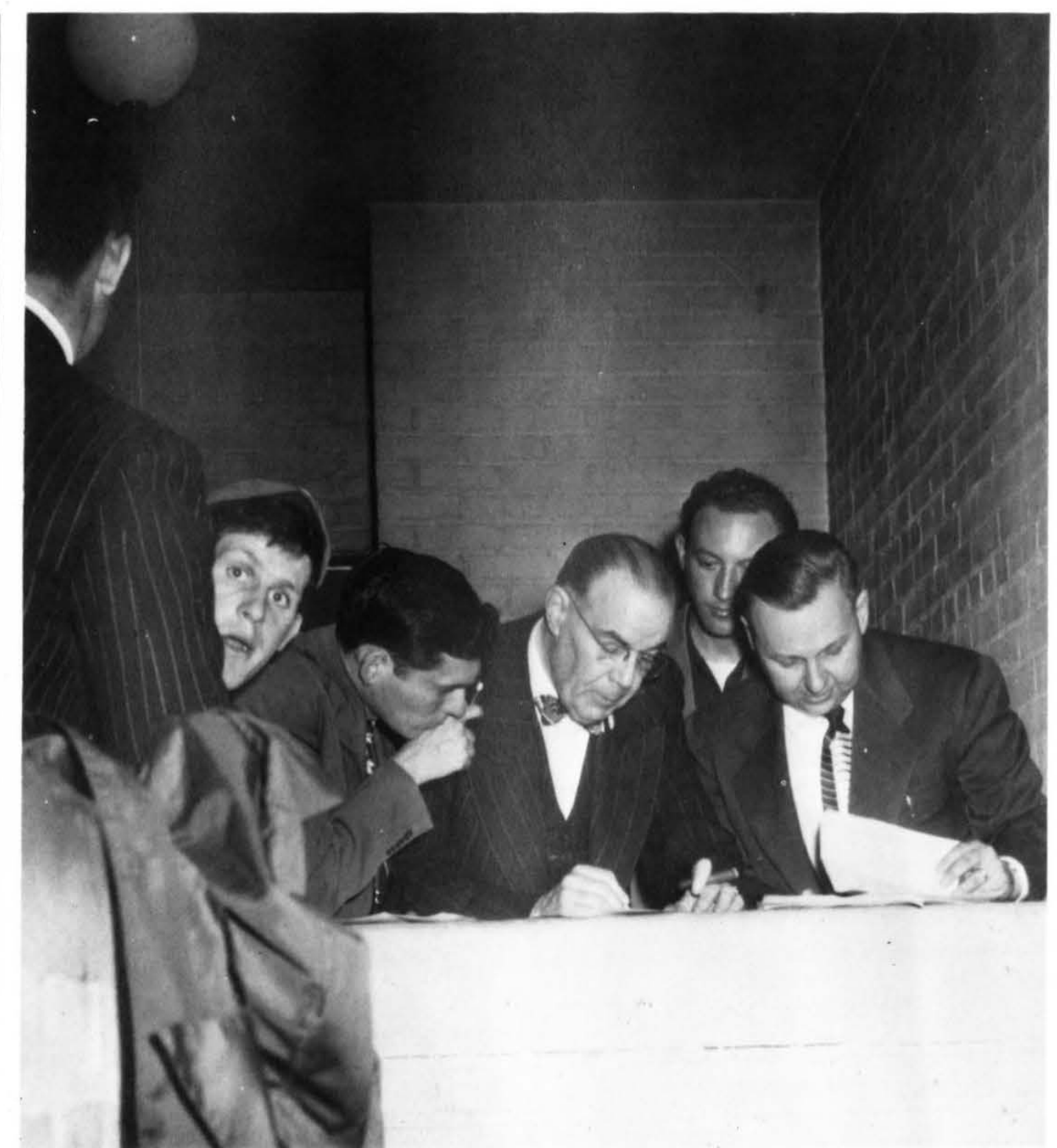


From 1925 onward the journalism honorary Sigma Delta Chi sponsored the Flickertail Follies. There had been occasional variety shows earlier at UND but nothing to compare with the Follies which became the special preserve of the Greek letter fraternities and sororities. However, the show which received massive and enthusiastic support from Grand Forks and outlying communities enjoyed no favor with the new breed of young professors who arrived on campus after 1945. But their incessant denunciation of Follies as a distraction from the University's principal purpose did not of itself kill the show. For years its promoters had pleaded with the Minneapolis Tribune's entertainment critic, Will Jones, to journey to Grand Forks to see the show. At last, in 1961, he came only to heap scorn and ridicule on the performance in his widely read column

"After Last Night." Thereafter, faculty pressure intensified and in 1962 Sigma Delta Chi announced a one-year suspension which proved to be a death sentence on a show that exceeded in attention lavished on it any other aspect of University life.

The disagreements arising in faculty ranks noted above and in the tempest-in-ateapot over the Follies are, in retrospect, minor. There were, however, periods of genuine crisis and peril. Looking back as far as the 1890 s, Melvin A. Brannon wrote in 1922 that the University had "had varied and disturbing experiences at different times in its history." And indeed, three times in a century the University was subjected to extraordinary stress. The first, a decade after its opening, grew out of an oversupply of post-secondary institutions in the state at a time when the public school system was only taking root. Politicians agreed that there had been unwarranted expansion of institutions at the very moment that they - Populists and Republicans alike - struggled to weather the downturn in the fortunes of northern Dakota which began just as the University opened. The nationwide depression beginning in 1893 worsened conditions in North Dakota so that in response to stories of distress, shipments of blankets, used clothing, and food poured in.

The state government lacked money to pay its bills. Facing up to the situation, Governor Roger Allin, British-born Red River Valley farmer, in 1895 carried through his pledge to match expenditures to revenue. For the University, that mean money for only a janitor's salary and maintenance of the two buildings. There was no money for faculty salaries. Grand Forks leaders rallied to raise around the state $\$ 25,900$, a very considerable sum in the 90 s. Success of the appeal for funds was assured when the professors accepted a 25 percent cut in salary and dramatically rejected the offer of Montana authorities to take them all, from President Merrifield down, as the faculty of the new University of Montana.

In its first crisis, the faculty and

President Merrifield stood side by side in their resolve to stay with UND, winning thereby the admiration of champions of higher education throughout the state. Two presidencies later, that solidarity was missing and the public was treated to an unedifying spectacle. The crisis had its roots in the selection of a successor to President Frank McVey. Upon announcing his impending move to the University of
Kentucky, he had brought the faculty into the selection process in a "major" way.

No one knows the reason for their agreeing to Thomas F. Kane. Fired as president at the University of Washington, Kane had, as one man away from UND put it, "applied for everything in sight from a country cross-roads academy to a university and finally a little one-horse college, Olivet, took him in ..." This record did not trouble the faculty representatives who were ready to call him from his post in Michigan. Yet they expressed shock when he used his commencement address in June 1918 , to dispel the aura which leading faculty members conceived as surrouding them. He promised, without a hint of whimsy in voice or demeanor, that he was "going to drive them hard" and estimated that if judged by results - as college football coaches were -25 percent would be dropped from the payroll.

The "attack" on the faculty can be seen as making sense to a man who had lost a previous position. North Dakota was rural -70 percent of its people lived on farms in that day when farmers were not the sophisticated high school and college graduates they are today. Along with classical musicians, opera singers, and diplomats, professors were widely perceived, as a class, to be affected and supercilious - fair game for ridicule and disdain. Kane was reaching out to those in the population who had doubts about the men who staffed the people's institutions. As events demonstrated, he enjoyed their support.

The faculty attitude toward the president was summed up by a senior professor at this time when Earle J. Babcock, so 
Prof. Orin G. Libby, the historian and scholar who often was at the forefront of battles for faculty rights.

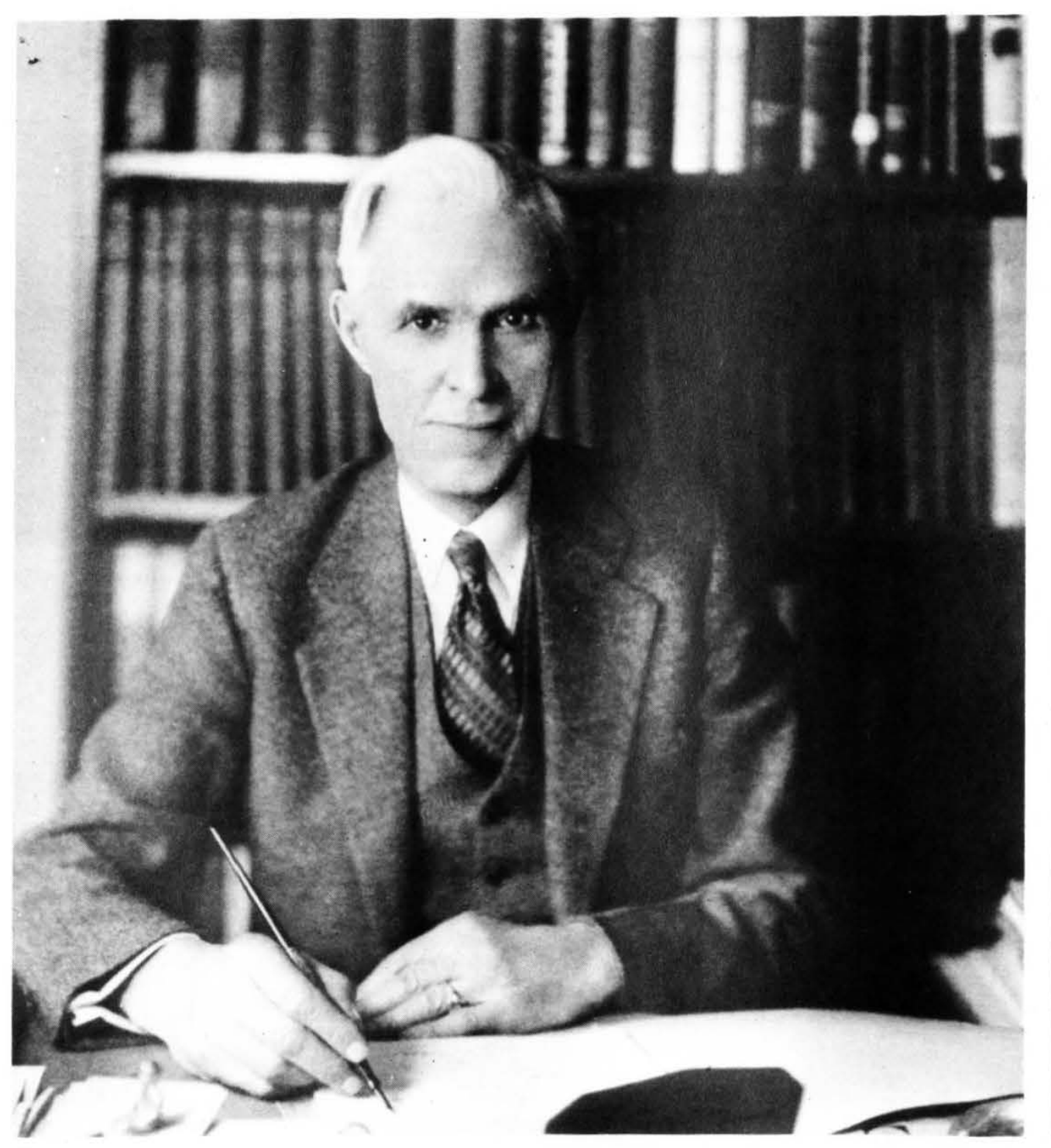

conspicuously linked to development of North Dakota mineral wealth, seemed to be under pressure from Kane: "You can pick up a president anywhere; experts in coal and clay are exceedingly rare." By June 1919, a 12 page "bill of particulars", of Kane's offenses was prepared by five faculty men and sent to the Board of Administration at Bismarck.

After some months the NPL-dominated Board decided to terminate Kane as of June 1920. But Kane received the support of the anti-NPL Grand Forks Herald, as well as that of the student body. So appealing was Kane's case against professors Gillette, Henry Brush, Libby, and Dean Willis that as a demonstration of support for him only 60 of the 1,200 students enrolled that year registered for the second semester at the appointed time. The professors' appeal to the League leaders, and the entrance into the fray of F. Halsey Ambrose, the rabble-rousing pastor of the Presbyterian Church with his "Get in Line or Get Out"

oversimplification of Kane's case, brought matters to a head. Politicians arriving from Bismarck worked out with the president and deans a settlement, preserving the status quo ante, known as the "Hagan Agreement" of Feb. 24, 1920.

The armistice held, and in 1921 Kane's fortunes improved. That year the NPL lost control of the executive branch of the state government and the new, more conservative, IVA occupant of the governor's chair proved to be a Kane ally. With Gov. Ragnvold A. Nestos attacking the president's critics as subverters, by sarcasm and sneering attacks, of the religious faith of the students, Kane moved 
against his enemies. He notified Dean Willis, A. J. Ladd and Libby that they were dismissed. The American Association of University Professors (AAUP), defender of academic freedom and champion of orderly dealings with campus problems, was not called in despite a strong UND chapter having been organized in 1914. The beleaguered professors had hoped to enlist the support of Federal District Judge Charles F. Amidon of Fargo against Kane's disregard of provisions of what Amidon querulously called the University's "blessed constitution."

The anti-Kane faction also cooperated with Upton Sinclair, the muckraking socialist author of the famous novel The Jungle (1906), who was then preparing a book on American higher education called The Goose Step. The 1919-20 events at UND appear in a chapter, "A University of Wheat." As the publication date approached Ladd and Libby feared the effect on North Dakota opinion of the muckraker's no-holds-barred treatment of the controversy. They hoped that Amidon might prevail upon Sinclair to "suppress" the names of Kane's opponents or to delay publication of the book until after North

Dakota's June 1922 primary. They, clearly, were not confident that the public would view with any favor Sinclair's attack on Kane and the conservative, anti-NPL portion of the electorate which appeared to back Kane in the showdown.

In the end Kane had his way with Willis who joined the faculty of Indiana

University and with Ladd, but pressure from alumni saved Libby, the most distinguished of the three and the institution's outstanding scholar.
Responsibility for the years of tumult has been placed, typically, on Kane. Little consideration has been given to the possibility that the ouster from his presidency sought by the men who initiated the crisis in 1919, might have been excessive punishment for his offenses to that date. The long, acrimonious controversy was not easily forgotten. Memories of it lingered through the years following Kane's 1933 retirement. In 1937, Gottfried Hult, classics, celebrated the struggle against "Kane and his nastiness" in a play of which no copy survives.

The third crisis, in the 1930s, coincided with the economic catastrophe which overwhelmed the state and the nation and with the rise of the second Nonpartisan League. The Great Depression tightened its grip on the University in 1931 when hard times combined with drought to give North Dakota the unenviable distinction of being hardest hit of the 48 states. A 20 percent budget cut led to a faculty reduction of 17 in 1932. A further setback came from the Taxpayers Association which put on the ballot an initiated measure to cut state salaries 20 percent and impose a $\$ 2,400$ ceiling at colleges. Dismayed faculty members were further depressed by Board of Administration orders not to campaign against the measure lest they antagonize the public and enhance the measure's popularity with voters.

The unworldly professors reassured themselves with the thought that the businessmen of Grand Forks, the civic leaders, would speak out strongly against the measure. They rejected warnings by Archie J. Scott, who was "high in Nonpartisan [League] councils," that his fellow businessmen did not care about the professors' egos and pocketbooks. Even greater mental anguish and despair

followed the refusal of the North Dakota Education Association, with 8,000 public school teacher members, to oppose the salary cuts for college faculties. The Association maintained silence on the matter until six days before the election. The stunned faculty, through the AAUP, proposed that each student send home 10 letters denouncing the measure with the chapter ready to provide money to any student unable to afford the two cent first class postage. It also paid substantial sums - for the times - to Scott fo “"propaganda purposes.'

It was all in vain; the measure passed. Most shocking to the faculty was the wide margin by which it carried in Grand Forks county and in the city of Grand Forks itself. Their plight, the blows to their pride and their bank accounts, was nothing to the majority of people in whose midst they labored.

December 1932 brought another cut in salary, this time 10 percent, and word

from their friend "Chairman Scott" that the new NPL Gov. William Langer's policy would be "sudden and drastic." Orin G. Libby, with 30 years service the most senior of faculty members, wrote at the end of the year: "We are lacking in esprit de corps, depressed and unhappy ....'

$\mathrm{He}$ and Gillette, among others, sought to enlist the new governor, a UND Law School graduate, in the fight against the impending cuts, going so far as to track him to his sickbed at Bismarck's St. Alexius Hospital in order to present their 
Camp Depression, the most visible symbol on campus of the hard times that decimated the faculty in the 1930s.

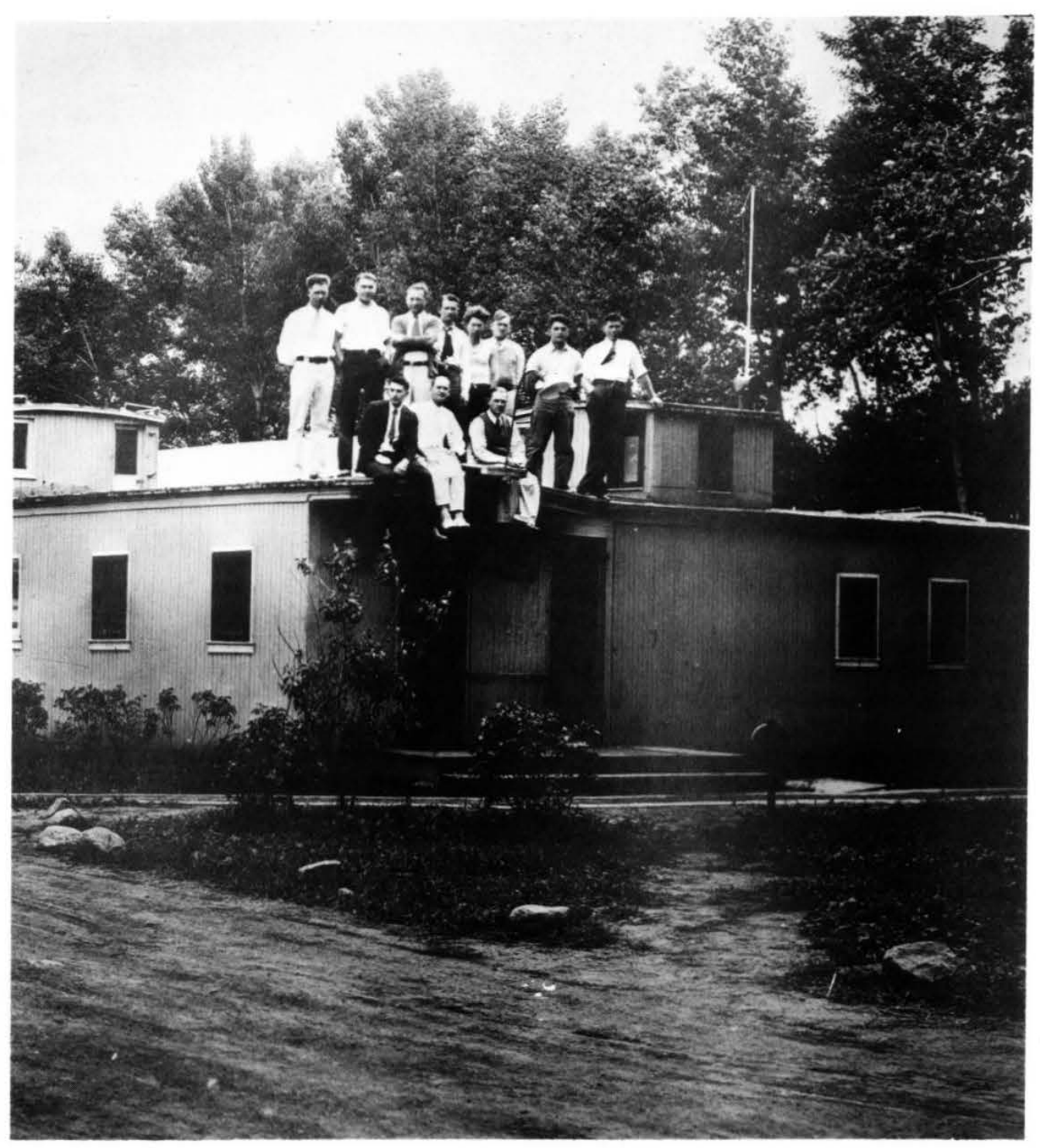

case in charts and graphs prepared by Gillette.

The University budget moved haltingly through the Legislature which assembled in January 1933. Kane was advised, on Feb. 20 , by a coterie of the Grand Forks

businessmen on whom he had depended so much since 1917, that in the face of the budget's dismal prospects in the NPL-

controlled legislature he had to step down. They handed him a telephone and he submitted his resignation to the Board of Administration.

Gov, Langer, calling for a list of all graduates between ages 35 and 40 , stepped into the process of selecting Kane's successor. Fascinated with the idea of having a young alumnus as the next president, he showed no interest in having the faculty participate in the selection. But in March he came to the campus for a banquet attended by more than 600 and conferred with Gillette. The latter, after discussion with four of his colleagues, proposed John C. West for the post. Langer, who returned to Grand Forks in April, had intended to install West as president of Minot Normal but now agreed to him as the man to place at the apex of the state's educational system.

The feeling about Langer, who had replaced Kane with a man chosen unofficially by faculty leaders, was bittersweet. At the very moment of West's elevation, word came from Bismarck that all persons on the state payroll would be assessed five percent of their salaries in support of Langer's weekly newspaper The Leader and another two percent "for bad debts." News that 78 professors had signed ti.c AAUP resolution to resist the impost 
was headlined in the anti-Langer Herald. The following morning, June 1 ,

engineering students and others threw a Langer collector into the English Coulee and absconded with his briefcase. Two days later Langer was rumored to have a detective on the campus "picking up what he can," for faculty members were suspected of complicity in the incident.

Langer resented what he considered to be "disgraceful mob violence." At no time during his long, triumphant career in politics, which as governor and U.S. senator lasted until 1959, was he invited by the faculty to the campus. This neglect reflected a generally conservative tendency in the University transmuted in the minds of a large part of the electorate into an unjustified perception of the institution as a "sinkhole of reaction."

The governor struggled to lessen the misery brought on the state's farmers and businessmen by the Great Depression. The UND faculty shared in that misery. Cuts of almost 60 percent incorporated in the

1933-1935 budget brought salary reductions ranging from 48 percent for full professors to 32 percent for instructors.

These reflected a populist attitude toward education and toward the treatment of people. North Dakotans were suffering deprivation, and teachers at state

institutions had to share it - with those who had and earned the most making the greatest sacrifice. The extreme cuts at the professorial level paid handsomely in the case of Clarence Perkins, history. A traveling book salesman for Harper and Brothers took up Perkins' plight with the company's editor at New York. For Perkins it meant the profitable opportunity, offered out of pity, to write Ancient History (1936) a volume in the Harper's Historical Series edited by Guy Stanton Ford.

In consequence of cuts all salaries at UND fell below the offensive $\$ 2,400$ ceiling stipulated in the 1932 initiated measure. Faculty members had to drop memberships in professional societies and subscriptions

to journals - this at a time when the campus library, as its book purchases dwindled, also pared its list of periodical subscriptions. Drastic reductions in money for travel to professional meetings cut them off from stimulating contacts with the leaders of their disciplines.

The cutback in pay - not out of line with the desperate plight of the state and its people - led the inspection committee of the North Central Association of Colleges and Secondary Schools in May 1938 to refer to UND's "absurdly low salary schedule." Indeed, it was then only 40 percent below the average for the 51 land grant institutions. the 1935 and 1937 legislatures having restored some of the 1933 cut.

The impression left by the great debacle was indelible. Joseph Tamborra, who was to teach French for more than a quarter century, in 1947 viewed "the crash of 1929 and the subsequent University budget slashes and thinning of salaries as the biggest news of his [then 20-year] stay . . ." The estimate was widely shared by colleagues who like him saw UND through the storm.

Periods of crisis appeal to readers and writers alike as they provide putative heroes and villains to cheer or to boo. But tranquillity and success based on understanding cooperation are of greater importance. UND enjoyed two eras of generally good feeling and marked advance. The first came with Frank McVey, president from 1909-1917, when faculty size grew from 50 to 70 . Book publication, including Gillette's pioneering Rural Sociology (1913), during these preWorld War I years numbered 20, a figure never equaled in any later decade. Men who did not produce books, Earle J. Babcock (mining), O. G. Libby (history), Albert H. Taylor (physics), and Frederick Koch (theater), among others, engaged in research and writing that in Koch's case took him to a professorship at North Carolina which made him part of the history of American literature.

During this Progressive Era, with a spirit of reform in the air, earnestness was the dominant response to challenges of the industrial order then coming to maturity. Faculty members fanned out across the state to lecture engagements as McVey adapted the University of Wisconsin concept of "The State is Our Campus" to North Dakota. Sometimes the message they carried was not popular. In 1916, Gillette, at the annual convention of the North Dakota Bankers Association, responded to bankers' criticism of working people's failure to save. He startled the bankers by suggesting that businessmen promote saving by paying their employees a living wage so that they might have a little something extra to deposit in a bank account. Libby, in a May 1915 address, declared that only with a halt to expenditure on armaments, "the curse of preparedness," could the world's "poor and . . . oppressed, as well as the rich and 


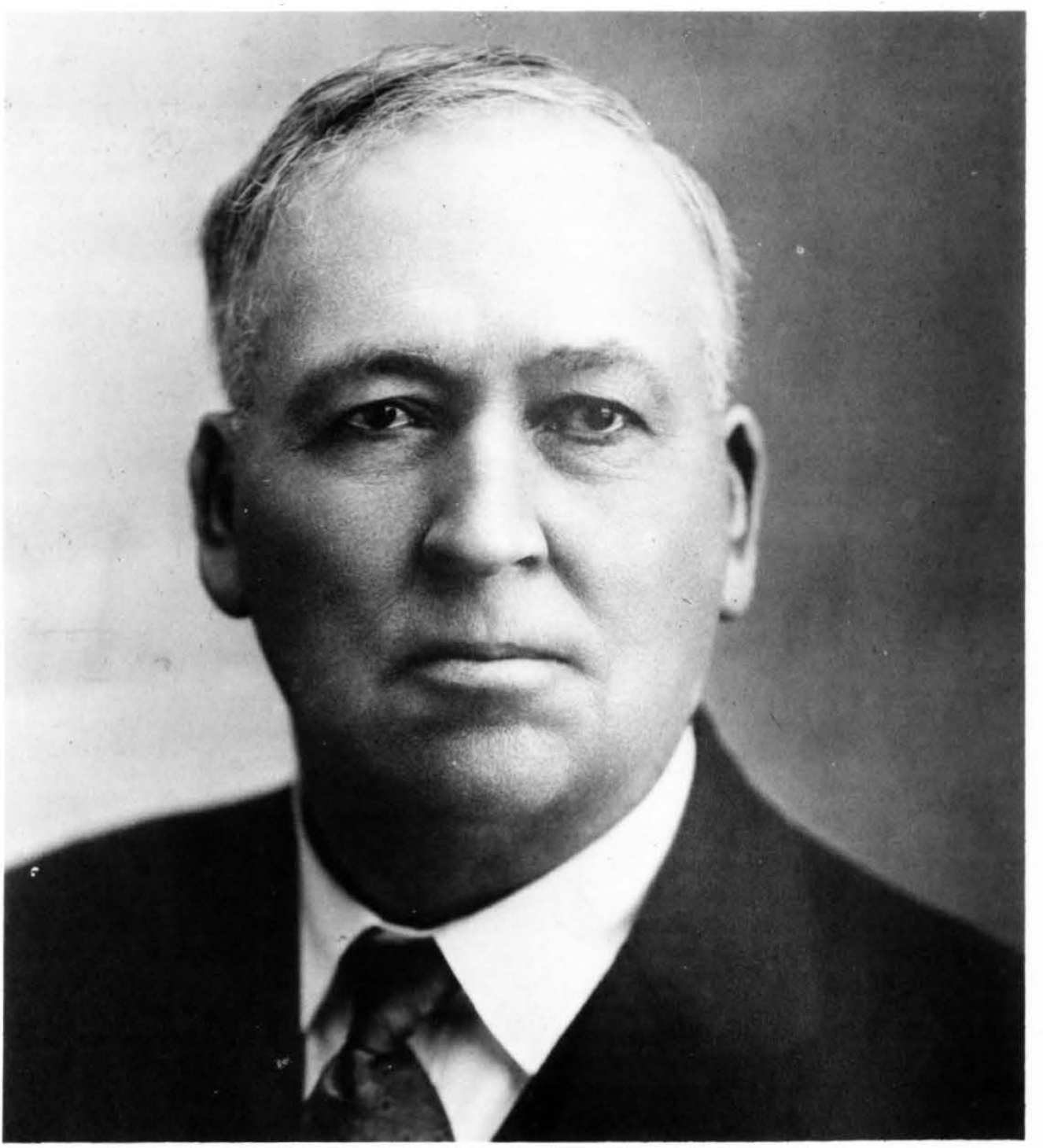

the mighty ... really begin to live." In a state notable for the strength of the

Church he passed a severe judgment on

institutional Christianity: "The place of the

Church in a modern community is .

precarious in view of its dependence upon

predatory wealth and its subordination to

the organized selfishness of its principal supporters."

During the 1920s, the University grew in enrollment and by the addition of

promising scholars to the ranks of veterans from the Merrifield-McVey days. But the

Libbys and the Gillettes maintained a lower profile in discussion of political and social issues, devoting themselves to research and writing rather than to outside concerns.

Much of the crusading spirit of the progressive period was gone, stifled in part by the rancorous struggle looked a above.

The post-World War II years brought a second period of quiet and saw UND

arrive at maturity, achieving true university status with acceptable staffing of its old professional schools and the establishmen of new specializations. Following Pearl Harbor in December 1941, most students had left and many teachers followed them into the military or to other wartime duties. By the fall of 1945 enrollment dropped to 700 , less than half its pre-war level. Most classes consisted of a few rejects from the armed forces $-4 \mathrm{Fs}-$ and a handful of young women. The demobilization of the forces after VJ Day brought in 1946 a tidal wave of students and with it problems for administrators and a new challenge for professors. Teachers had to be secured in a hurry and the temptation was to hire the school's 
Final exams in the Armory, 1949, as the University struggled to handle the postwar enrollment boom. own recent graduates, persons who knew the region and its peculiarities and were known quantities to chairmen. This practice is frowned on in academic circles and was deplored by the outsiders brought in to fill some vacancies. President West recognized the probability that deans and department heads would nonetheless choose this easy way out. He admonished: "Watch the inbreeding."

The G.I. Bill - Public Law 346 - one of the master strokes of American political leadership - brought a challenge to the teaching staff, veteran and novice alike. Never had such students populated the campus. They were not callow youths newly graduated from high school. Rather, they were men who had come of age in combat - or in the boredom of inactivity - in every part of the globe. Tension sometimes developed as the veterans fresh from the real world bridled at seemingly petty stipulations by their teachers. Wayne Lubenow of the Dakota Student staff in 1951, at the height of the Cold War, was moved to comment equivocally about the faculty: ". . . they're our allies just like the Russians,"

During those early Cold War years when the issue of Communism in the universities surfaced, North Dakota escaped the unpleasant infringement on academic freedom that troubled many institutions around the country. No loyalty oath for faculty was required by the Legislature and liberals on the campus appeared to have carried the day in 1952. That year the Dakota Student endorsed Adlai E. Stevenson, the Democratic candidate for president in preference to the Republican standard bearer, Dwight D. Eisenhower.

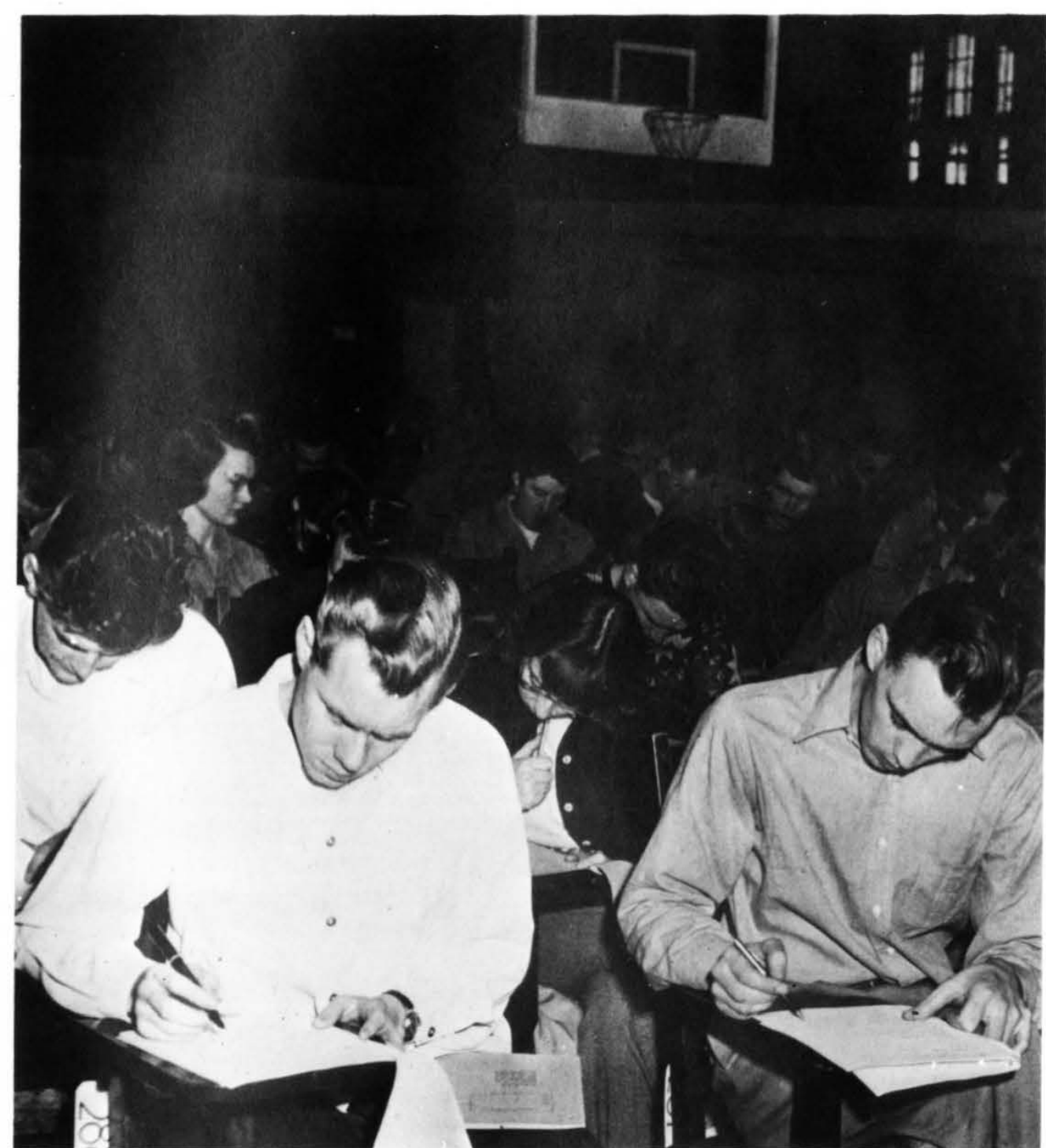


Its editor, Lloyd Omdahl, after a career in state government, returned to the campus in 1967 to become a professor of political science.

At a time when most contract, tenure, promotion and salary matters were informal and unwritten in a legal sense, relations between the administration, ensconced in crumbling Old Main, and the faculty were surprisingly good. Such did not prove to be the case at some other state schools. At the North Dakota Agricultural College, President Hultz's firing of the "Fargo Five" - professors deemed guilty of "disloyalty or undermining ... [the] administration" put the school on the AAUP's blacklist of censured institutions. But as West told his successor, George Starcher, when

confronted with vehement dissent he had "laughed it off", in the belief that "any staff member may differ with the president on matters of ideology without being subversive."

In West's time - West being a practical man, not a theorist or philosopher -

vocationally oriented disciplines such as chemistry, social work, physical education, medicine, business administration and engineering prospered. Yet West surprised many faculty members when he appointed as successor to Adolph Rovelstad, who had ever fewer students in his Greek courses,

the European-trained publishing scholar, Demetrius J. Georgacas. Similarly he delighted his critics on the campus by deciding to retain the University's radio station KFJM and begin its upgrading to make it an even greater source of satisfaction and contentment to faculty members and their families.
In announcing his retirement West told the assembled faculty that UND needed as his successor a better president than he had been if it was to move forward. He made his final contribution to the institution by helping the faculty to secure a significant role in the selection process that brought George Starcher from Ohio.

A renaissance had begun in the West administration with renewed growth in the size of the student body, and the retirement of professors wearied by the uncertainties of depression and war. The young newcomers who replaced them arrived with fresh ideas, and as noted earlier, serious reservations about the standards and facilities which they had inherited. They found the new president, George W. Starcher, receptive to innovation. Their relationship with the 48 year-old president has been recorded in an incredibly detailed 20,000 word account of the Starcher years by Elwyn B. Robinson in the Spring 1971 issue of the North Dakota Quarterly.

As Robinson remarks, Starcher found himself in a crossfire of objections from generally older conservatives headed up by a group identified as the "Wranglers" and a faction of the younger, progressive newcomers labeled "Young Turks." Two leaders of the latter were Playford $\mathrm{V}$ Thorson Jr. (history), and Don M. Gillmo (journalism), whom Starcher had selected to be the Honors Program coordinator Distressed by the high rate of faculty turnover, which they viewed as merely the symptom of a general, all-pervasive malaise Starcher had failed to deal with, a committee headed by Thorson put out a questionnaire to the 32 teachers who resigned in the spring of 1965 . Remoteness of Grand Forks, the long cruel winters and low level of salaries figure prominently among reasons given for leaving. Yet many mentioned failure on the part of an entrenched older generation of leaders to welcome wholeheartedly new ideas, and to provide scope for enterprise. Anticipating this perception of the institution's situation Starcher, in the spring of 1962, had appointed William E. Koenker as the University's first vice president for academic affairs. He early addressed the confused and demoralizing pattern of inexplicable discrepancies in salary levels among and within departments and colleges. A new elan began to emerge.

But the Sixties brought the Vietnam War and a revival of the question of freedom of campus opinion and activity from external control. Starcher, who had opposed loyalty oaths in the closing phase of the McCarthy era, now supported full freedom of classroom presentation and discussion for professors. For his bold stand faculty leaders, acting as officers and members of AAUP, secured for him the prestigious Meiklejohn award conferred by the national association for defense of academic freedom. The war, as it continued, polarized the nation and prompted protest and violence on campuses - including quiet, orderly vigils and rallies at UND. Starcher believed that these admittedly minor upheavals were to some extent stimulated by anti-war, antiNixon faculty members who were using students as surrogates to express their outrage over, and opposition to, the war.

Throughout its history UND had been a teaching institution whether the prep 
Prof. W.E. Cornatzer of biochemistry, one of the new breed of research-minded faculty who replaced the Old Guard in the 1950 .

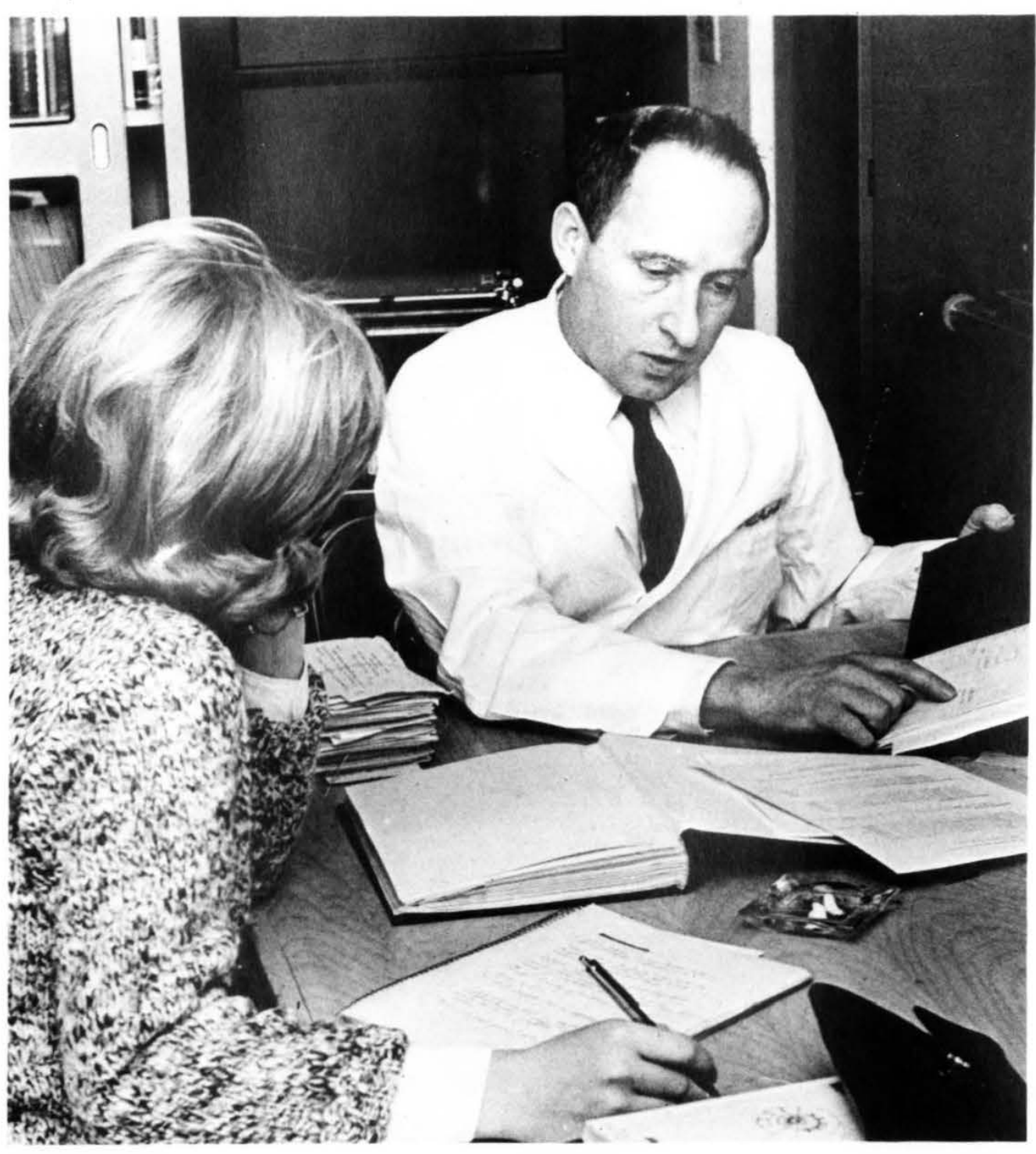

school of the late 1880 s, the growing University of McVey and Kane or the one to which Starcher came. The creation of new knowledge through research was a minor interest of its staff. The first state funding for it came in 1907 in the new School of Mines for work with North Dakota clay and lignite. Earle J. Babcock, who came in 1889 as a teacher of chemistry, conceived of research as preliminary to creation of an "industrial region" of manufacturing and mining in the western part of the state. Much work in locating and evaluating its wealth in mineral resources was carried out by Arthur G. Leonard (1903-1932) in his first years as professor of geology and state geologist. During and after World War II conversion of lignite to gas for pipelines and the dehydration of potatoes engaged members of the engineering faculty. When from the 1950s onward money poured from the federal treasury for research in medicine, the Medical School received a share. This increased when the gift from the Guy and Bertha Ireland estate provided housing for laboratories devoted to the investigation of cancer. From the department of biochemistry poured a stream of papers as William E. Cornatzer, director of the Ireland Research

Laboratories, displayed great skill at procuring financing for, and published results from, a growing staff. Federal money also financed projects such as engineering's "Man in the Sea" program.

Starcher hoped to promote research by non-scientists by securing from the Legislature in 1958 an annual $\$ 5,000$ allocation of state funds for small projects. The years following 1945 saw a considerable 


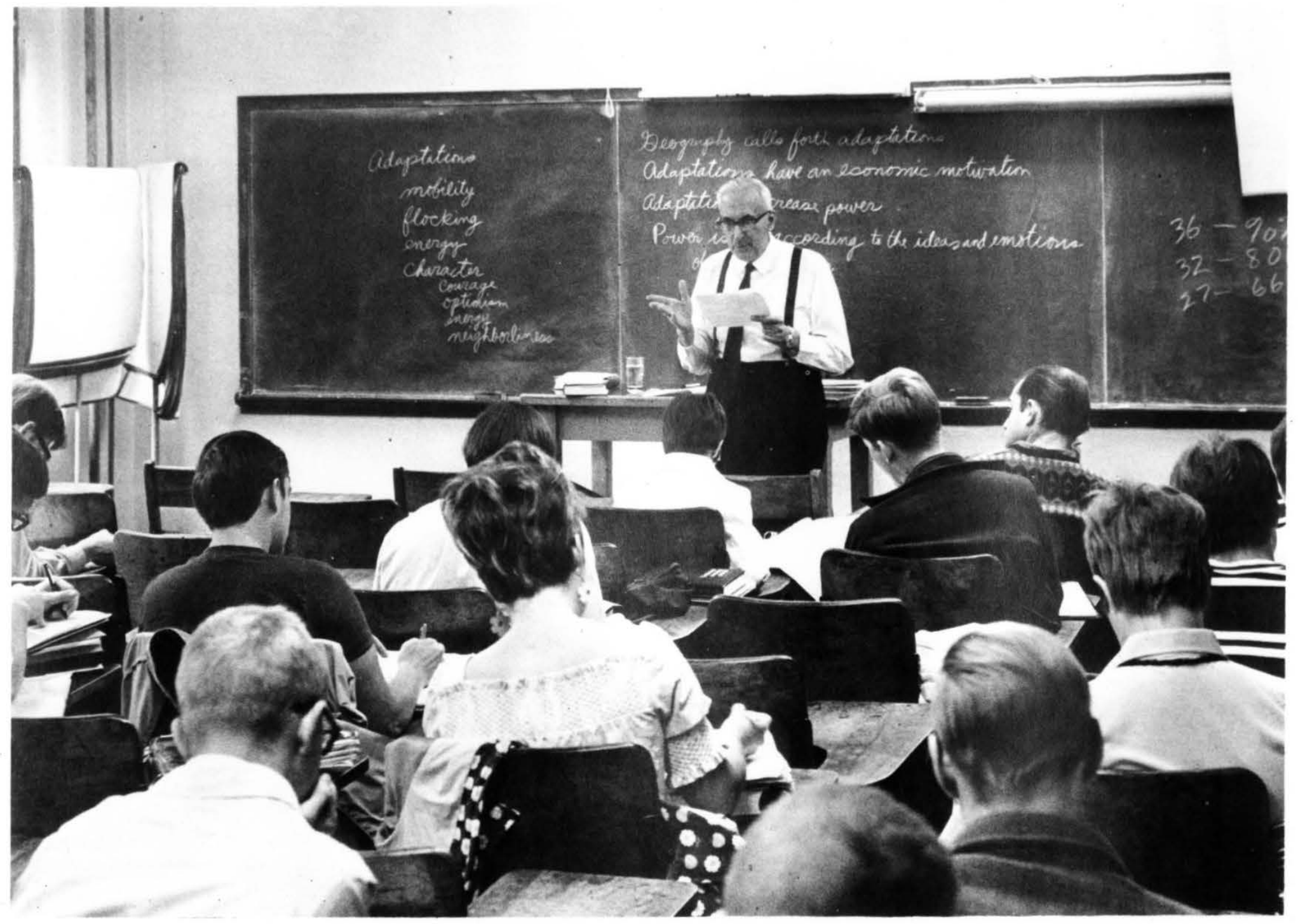

Prof. Elwyn B.

Robinson, who com-

teaching with superior

scholarship,

publishing in 1966 the

seminal work,

History of North

Dakota. 
output. Among scholars publishing books during the post-World War II Renaissance were: Richard E. Beringer, The Anatomy of the Confederate Congress: A Study of the Influence of Member Characteristics on Legislative Voting Behavior, 1861-1865 (1972, with Thomas B. Alexander); Historical Analysis: Contemporary Approaches to Clio's Craft (1978); Robert G. Brown, Fervomechanism Analysis (1953, with George Thaler); Louis G. Geiger, Joseph W. Folk of Missouri (1953); University of the Northern Plains (1958); Elizabeth Hampsten, Read This Only to Yourself: The Private Writings of Midwestern Women, 1880-1910 (1982) Bruno Hildebrand, Strukturelemente der deutschen Gegenwartshochsorache; Phone und Phonaden. (1976); A. William Johnson, Ylid Chemistry (1966); Kenneth J. Klabunde, Chemistry of Free Atoms and Particles (1980); William E. Koenker, Tax Equity in North Dakota (1960); Post-war Banking Trends in North Dakota (1955); Jung Young Lee, Cosmic Religion (1973) and The I Ching and Modern Man (1976) among others; George F. Lemmer, Norman J. Colman and Colman's Rural World (1953); Donald W. McCaffrey, 4

Great Comedians: Chaplin, Lloyd, Keaton, Langdon (1968); The Golden Age of Sound Comedy: Comic Films \& Comedians of the Thirties (1973); Three Classical Silent Screen Comedies starring Harold Lloyd (1976); Peter A. Munch, A Study of Cultural Changes: Rural-Urban Conflicts in Norway (1956); Stanley N. Murray, The Valley Comes of Age: A History of Agriculture in the Valley of the Red River of the North 1812-1920 (1967); Louis Palanca, Prose Artistry and the Birth of
Rhyme in St. Zeno of Verona (1972); Ronald E. Pynn, Watergate and the American Political Process (1975); Daniel F. Rylance, Ever Westward to the Far East (1982, with Chester Fritz); Glenn H. Smith, Langer of North Dakota: A Study in Isolationism, 1940-1959 (1979); D. Jerome Tweton, The Marquis de Mores: Dakota Capitalist, French Nationalist (1972); Years of Despair: North Dakota in the

Depression (1973, with Daniel F. Rylance); Depression: Minnesota in the Thirties (1981); George C. Wheeler, The Ants of North Dakota (1963, with Jeanette Wheeler); The Amphibians and Reptiles of North Dakota (1973, with Jeanette Wheeler); Myrmecological Orthoepy and Onomatology (1956); Robert P. and Wynona H. Wilkins, God Giveth the Increase: The History of the Episcopal Church in North Dakota (1959); North Dakota: A Bicentennial History (1977).

Authors of successful textbooks included Bonnie Jean Christensen, Notes Toward a New Rhetoric (new ed. 1978, with Francis Christensen); Donald H. Ford, Basic FORTRAN IV Programming (1971); Melvin E. Kazek, North Dakota: A Human and Economic Geography (1956); Ralph $\mathrm{H}$. Kolstoe, Introduction to Statistics for the Behavioral Sciences (1969, and later revisions); Robert W. and Mary Griesz Kweit, Concepts and Methods for Polticial Analysis (1981); Implementing Citizen Participation in a Bureaucratic Society: a Contingency Approach (1981); Philip J. Potter, Power Plant Theory and Design (1959); Ronald E. Pynn, American Politics: Changing Expectations (1981);

Thomas J. Robinson, Algebra and

Geometry (1970); John L. Rowe, Typing
300 (1972, with Alan C. Lloyd and Fred Wenger); D. Jerome Tweton, North Dakota: Heritage of a People (1976, with Theodore B. Jelliff); Bernt L. Wills, North Dakota: The Northern Prairie State (1963); North Dakota Geography and Early History (1967). Elwyn B. Robinson's landmark History of North Dakota (1966) provided the people of the state, which he had then served for 31 years, the first account of their land in its political, economic, educational and social development from the earliest days to modern times. In his Montgomery Hall office, Demetrius J. Georgacas from the seventies onward devoted himself to a project which when published will be the capstone of a lifetime's work, a Modern Greek-English dictionary.

The output of creative writing did not keep up with publication based on research. Charles. M. Linkletter's look at an Iowa childhood in Cricket Smith (1959) appeared shortly after his arrival at UND. William Borden's Superstoe (New York: Harpers, 1968) revolves about three men who had taught at a university in Great Spoons, North Dakota.

Starcher took other steps to increase research and writing by the faculty. $\mathrm{He}$ had thought much on ways to encourage older scholars to get out of the summer school classrooms, where they supplemented their winter salaries, and into library or laboratory. Establishment of a Faculty Lecture Series represented one such attempt to stimulate scholarship. The years 1954 to 1971 saw 84 lectures differing - as was to be expected - in subject matter, presentation and worthwhileness. The first by Richard Beck, a veteran from the 
middle Kane years, dealt with

Scandinavians and the last by Robert $\mathrm{P}$.

Wilkins, from the West era, looked at

Senator William Langer's view of

American foreign policy. As a further spur to writing and publishing Starcher in 1956 revived the University's Quarterly Journal which had ceased publication in 1933 after 23 years, during which A. J. Ladd (19101922) and Ezra T. Towne (1923-1933) served as editors. Resuming publication as the North Dakota Quarterly, in the care of editors Jon R. Ashton (1956-1959), Joseph F. S. Smeall (1959-1967), Robert P

Wilkins (1968-1981), and Robert W. Lewis (1982- ), Starcher's conception of it as an outlet for campus writing was by no means realized. Far and away the greater number of contributors were from other institutions in all parts of the nation and abroad.

As Thomas Clifford succeeded Starcher the Women's Movement had peaked with protests against the small number of women faculty members. In the University's first year, 1884-1885, the instructional staff consisted of five persons of whom only the three men were classified as "faculty." Emma Schumaker Mott taught arithmetic, geography, spelling and reading. Assisting her in overcoming students' deficiencies in the "basics" was a senior from Grand Forks High School, Cora A. Smith. By 1918, women accounted for 22 percent of faculty strength, most of them in home economics, women's physical education and English. The minority position of women, numerically and in status, was spotlighted by the

Women's Liberation agitation. In response, Vice President Koenker in 1975 appointed a Women's Equity Committee to enlarge

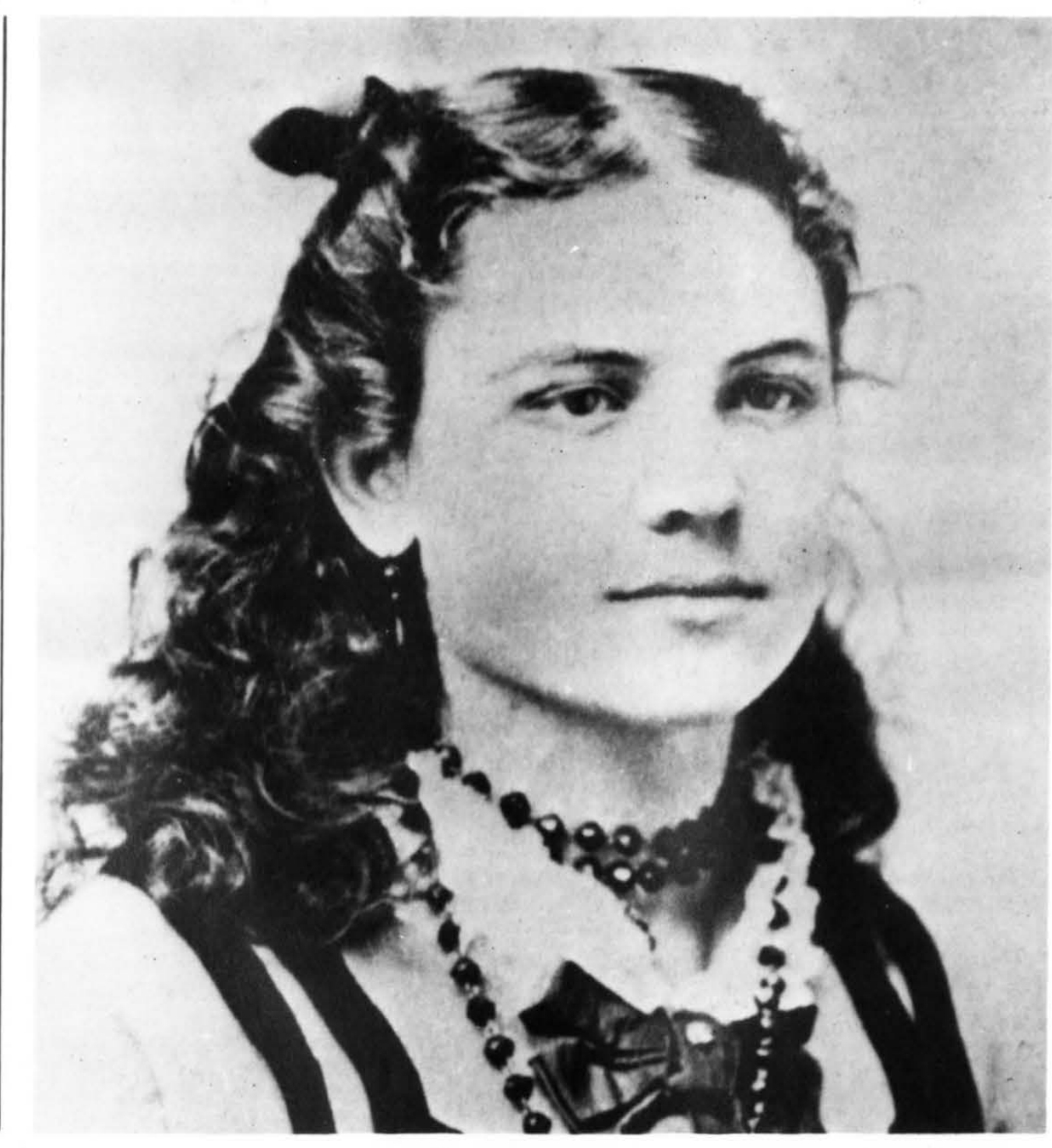


opportunities for women and to reduce the $\$ 2,000$ difference in average salaries for

men and for women. In five years the gap in pay narrowed by $\$ 500$, but the percentage of women faculty members stood at 1918's 22 percent. Of 271 tenured teachers only 40 were women; of almost 50 departments only seven had women as chairpersons.

Innovation has not been the hallmark of instruction at North Dakota, but the University did pioneer and make its mark in one discipline. In 1906, the University of Wisconsin took an important step in the development of collegiate instruction in professional journalism with its "Courses in Journalism." The second "step in the spread of college instruction in journalism" across the country was taken with introduction of a similar program at the University the following year under the aegis of Vernon P. Squires, who was a teacher of English as well as Dean of the College of Liberal Arts. Lawrence W. Murphy, first chairman of the department of journalism, in 1924 was entrusted by the American Association of Teachers of Journalism with sole responsibility, as its first editor, for the launching of the Journalism Bulletin known today as the Journalism Quarterly. Roy French while serving as second chairman of the new department was the first - and only academic ever elected national president of Sigma Delta Chi, the society of

professional journalists.

Nationwide, far more public attention focused on the New School of Behavioral Studies in Education established in 1968 with massive funding by the United States Office of Education. Concerned with elementary education, it introduced revolutionary teacher training aimed at the "freeing up" of the classroom and the curriculum, much to the annoyance of conservatives on the faculty and in some of the public schools around the state.

In 1970, D. Jerome Tweton of the history department introduced the minicourse concept later adopted by other departments here and at other universities. The half-semester, one-meeting-a-week, one-credit courses widened the opportunity for exploration by faculty and students alike in the time-honored fields with topics such as History of Biology, Science vs. Religion, American Anarchism, Symbols of Authority in American Politics, Napoleon, and World War I. Other courses, in "pop culture" fields, dealt with detective stories, adventure fiction such as the Tarzan novels, music of the Thirties, blues and jazz, motion picture "westerns" as well as the history of radio and radio "drama" including thrillers and daytime serials.

Differences in opinion and practices had come with the Vietnam era. In the "Soaring Sixties" unprecedented numbers of young instructors diluted the rather conservatively conventional character of the teaching staff. That meant beards, long hair and blue jeans appeared on the young - and on some of their elders. It meant unthinkable informality such as sitting on classroom desks instead of sitting at them or standing behind lecterns placed on them. Some of the newcomers went so far as to sit with their classes on the floor. Such behavior distressed old-timers who had been the young rebels of the early post-1945 era. Equally disturbing to many senior members was the tendency in the war years of some anti-war professors young and old - to award high grades for poor work in order that male students could retain their deferments from military service. Such generosity, the beginning of "grade inflation," troubled educational conservatives - even those who believed the Southeast Asia war to be a mistake.The problem of grade inflation continued into the Eighties.

The Clifford decade brought changes as the University adapted to the world in which it operates. Growth in the size of the teaching staff - to 584 in $1980-$ of itself has altered the nature of relationships among faculty members. In 1945, they numbered 116 and were concentrated in a few buildings. Contemplating today's large campus with its many buildings sheltering the activities of more than 500 instructors it is hard to believe the close proximity of departments and their teachers a third of a century ago. The Law School building housed in addition to law and its library, the School of Commerce with accounting, marketing and management departments as well as economics, political science and art. Merrifield Hall was home to journalism and the university press, mechanical drawing, English, history, sociology, social work, philosophy, psychology,

mathematics, speech, languages, weather bureau, geology, and geography. In the course of a day, teachers in these disciplines repeatedly encountered one another and were aware, at least

subconsciously, of sharing in a common effort to educate the young.

In those days when there were few secretaries, professors met at the post office where, whether senior scholars or 


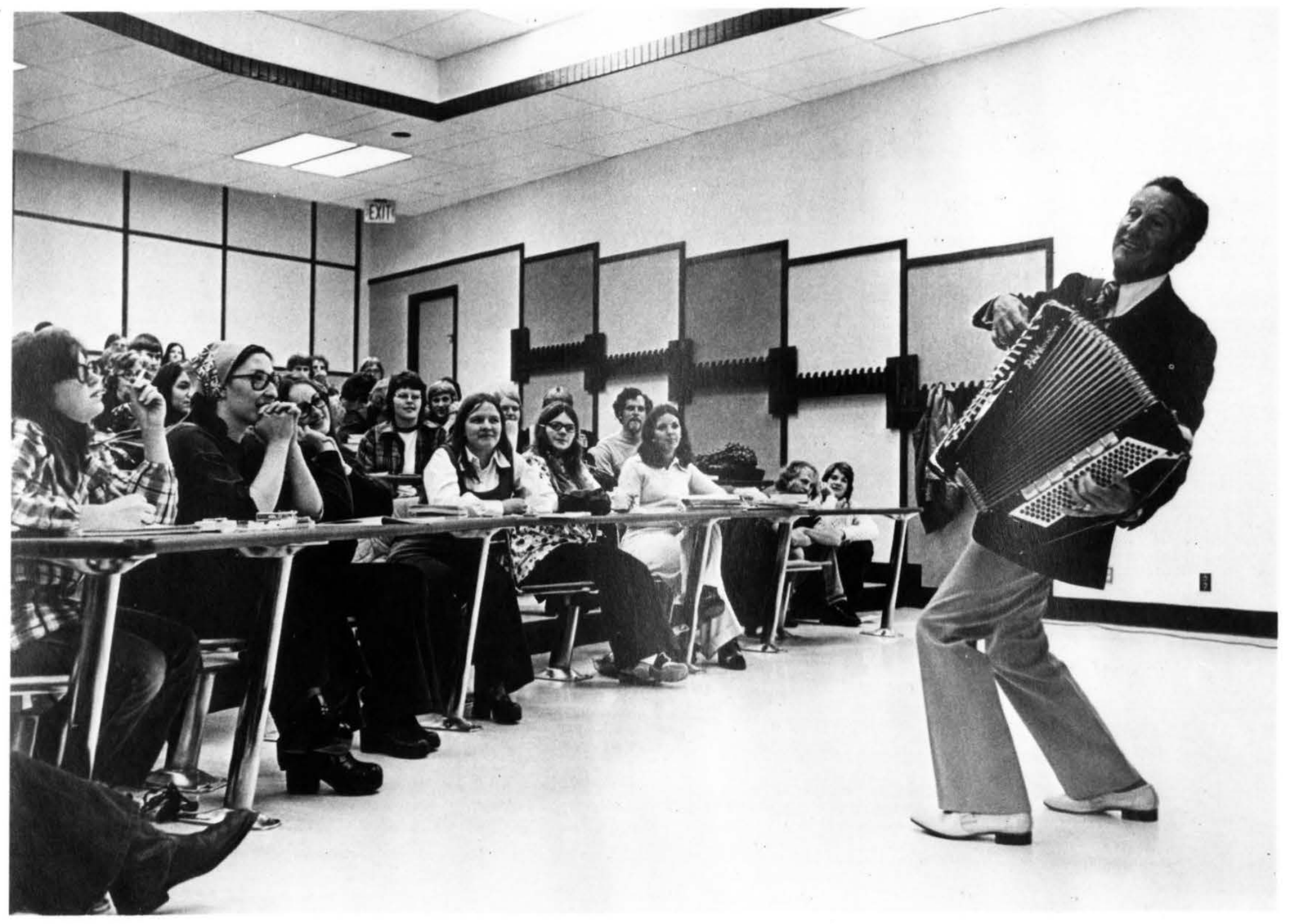

Entertainer Lawrence

Welk "lectures" dur

ing a 1973 mini-

course in popula 
Prof. John Odegard, architect of UND's architect of UND's major of the 1970 major of the ist novices, they were collecting their mail. When offices were few and overcrowded and coffee machines a rarity, they visited with one another over coffee at the Nodak Center, forerunner of the UND Memorial Union, or at the refreshment counter of the bookstore which followed it into the basement of Budge Hall. Continued growth in the faculty's size, and the muchneeded improvement of facilities, has fragmented it, destroying the unity and camaraderie once so characteristic.

During the late 1970s and in the 1980s the University operated under unusua circumstances, a strange amalgam of inflationary prosperity and hard times. Enrollment continued to grow even as the wealth of the state shrank when prices for farm products and revenue from petroleum dropped. Rapidly growing new disciplines, which could not be taught in the low-cost format of a professor standing in front of a classroom, made heavy demands on the budget. By 1981, aviation had 750 majors and computer science could claim 324 These required more instructors and more expensive equipment. Yet any university worthy of the name had to continue offering the traditional, if now somewhat less popular, fields. In an attempt to deal with the problem then-Academic Vice President Conny Nelson in 1977 advanced a new concept, "Faculty Staffing Flexibility," which would bring in instructors ineligible for tenure. The suggestion prompted angry response from faculty leaders (AAUP) that the plan was intended to provide "cheap labor" -

especially in the hardpressed liberal arts. It would establish, as Robert W. Lewis,

English, put it, a "category of second-class

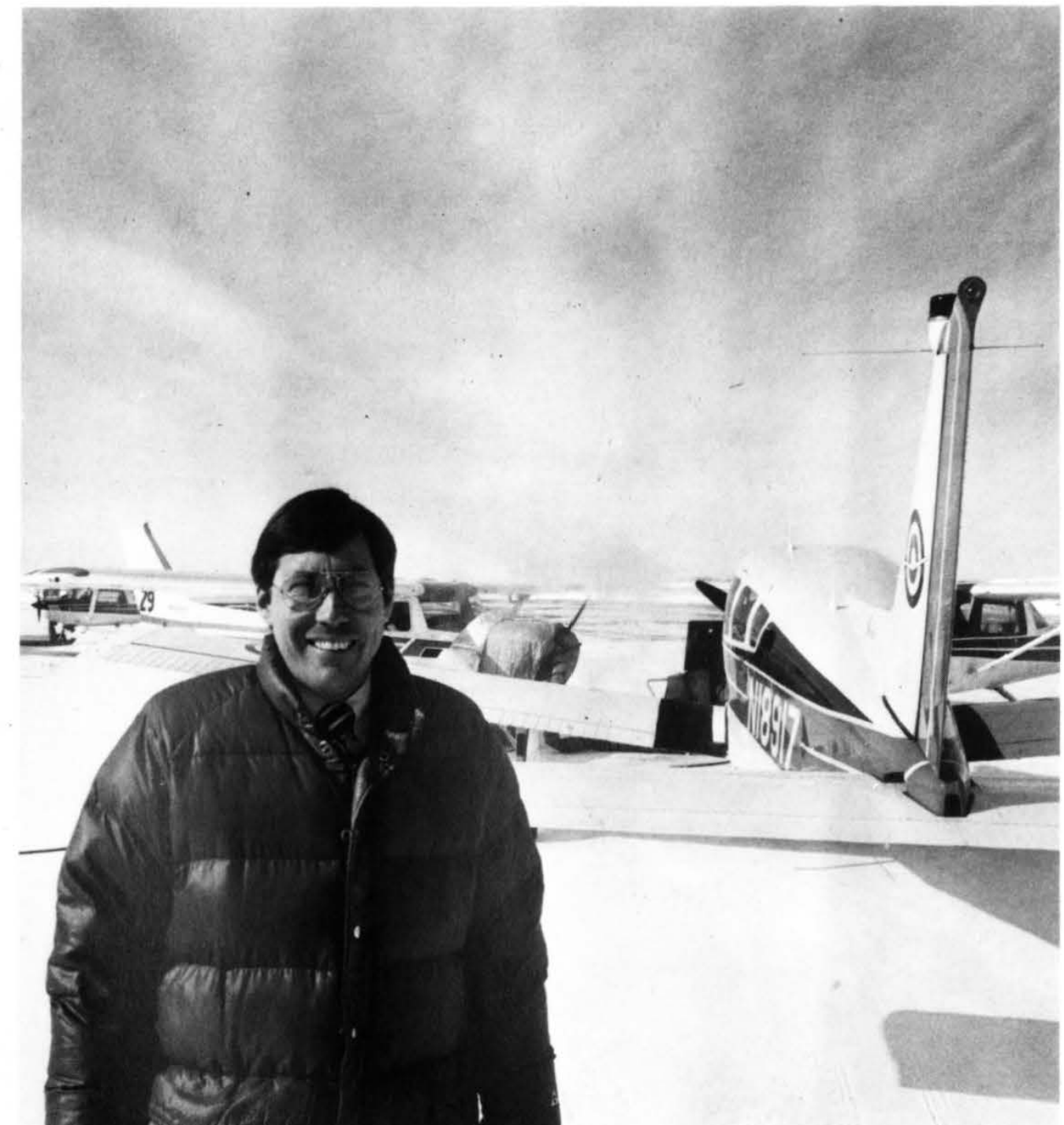


faculty," by writing into law the

arrangement with which UND began in the 1880 s and which, somewhat modified, had continued until World War II.

For a century, through good times and bad, instruction has continued at UND, sometimes hidebound by tradition, at other times innovatively forward looking.

Sometimes the teachers were men and women of exceptional talent who before leaving contributed to the intellectual growth of young North Dakotans. Others were less spectacularly successful in the profession but faithfully carried on across decades. Of all of them it can be said as Henry Adams, who taught at Harvard for seven years, did in his autobiography: "A teacher affects eternity; he can never tell where his influence stops." For a great teacher is not a prerequisite for a young person becoming a great student. During the trying Thirties when many of the most ambitious, success-oriented professors left UND, three graduates won Rhodes Scholarships to Oxford. Others were granted scholarships and fellowships by Ivy League and West Coast universities, as well as such Middlewestern schools as Illinois, Wisconsin and Minnesota.

"Far removed," as President West put it in 1938, "from the so-called cultural center of the country"' at what a 1946 student letter to the Dakota Student described as "a school the legislature forgot," the faculty has turned out many of the state's public school teachers and its business, political and professional leaders. Students and their parents may not always have approved of the philosophical and politica bent of their thinking. But as Zechariah Chaffee once observed, it is not radical teachers who turn out radical students nor conservative ones who are responsible for conservative graduates. Students have a tendency to react against their teachers' points of view, though not in a spirit of ingratitude or overt hostility.

Certainly, many students over the decades shared the appreciation of the

University's teachers expressed by Maxwell Anderson, the most illustrious of its graduates. In his 1958 "Love Letter to a University" he recalled the stimulus he experienced in encountering the faculty of the pre-World War I years - people who "thought the life of the mind was . . important." Their years at the University stimulated in them an attachment to it that can be measured by the generous gifts they make. These are not only of money and property but also of their children sent for an education from the many parts of the nation in which the parents have made successful, rewarding careers for themselves in business, the professions and government. 


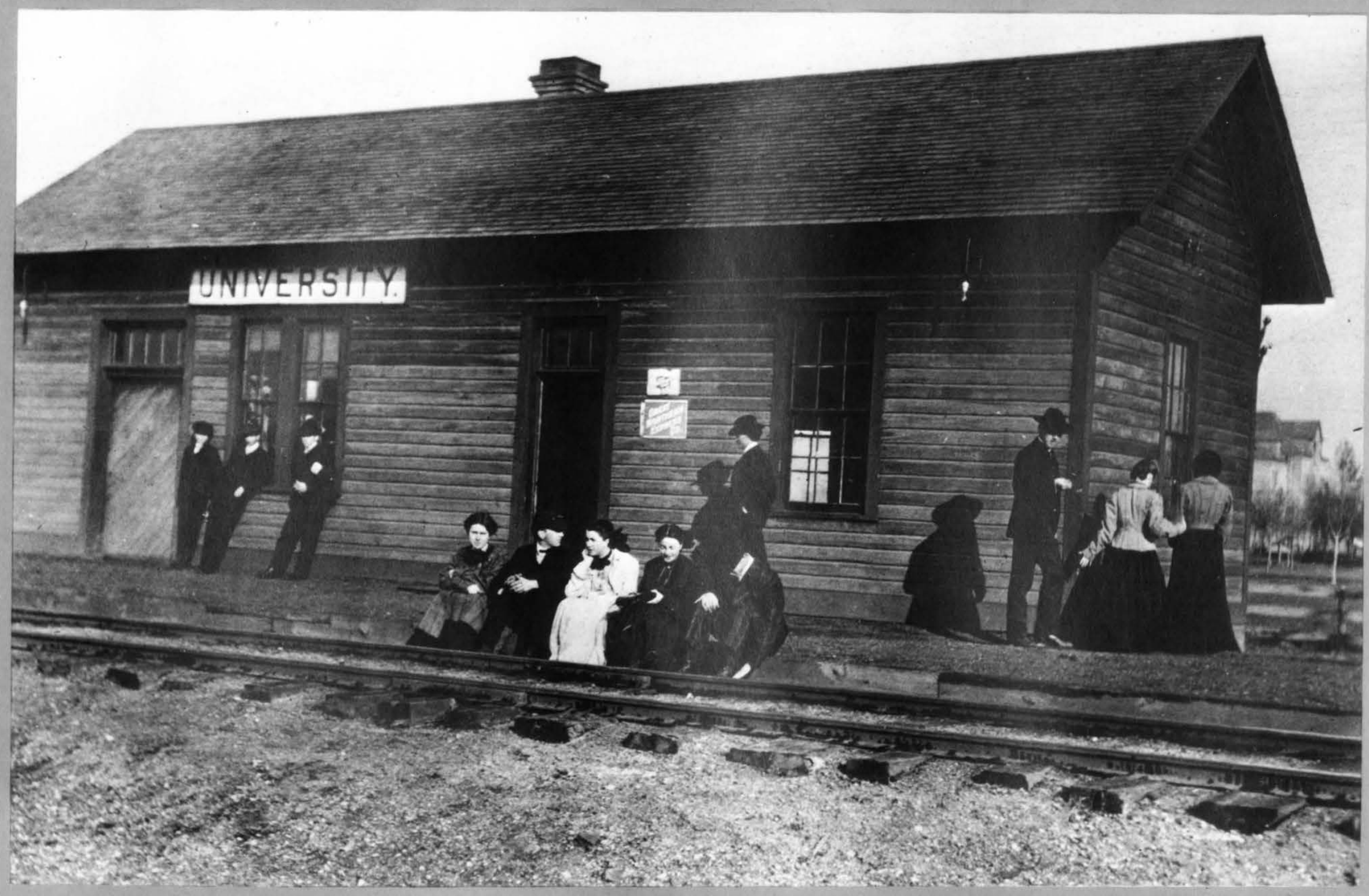




\section{Students}

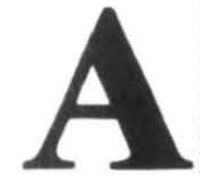
Ima Mater-Foster Mother-the University of North Dakota. She was young when Dakota was young, and, like other pioneer mothers, had to struggle amid hardships and deprivations to nurture her small brood of children. Now, a century later, she stands as an admired dowager of the plains; and her sons and daughters number in the tens of thousands.

When she first opened her doors on Monday morning, Sept. 8, 1884, 11 students enrolled; before the academic year was over, they were joined by 68 more young men and women, mostly from Grand Forks and its environs. Not surprisingly, because there were few high schools in northern Dakota, none of them was qualified to do college-level work. The aspiring scholars were enrolled in the Preparatory Department, which offered elementary and high school subjects. In subsequent years students also enrolled in the Normal Department, which offered a two-year, non-degree program in teachertraining. During the early years the actual college students were outnumbered by those in other departments: 25 to 50 in $1886-1887 ; 20$ to 197 in $1888-1889 ; 35$ to 132 in $1892-1893$. In many respects the University was more high school than college.

Because they were in the minority, the college students had difficulty developing a sense of membership in a true collegiate community. They especially resented those in the Preparatory Department who misleadingly identified themselves as University students. College students achieved some distinctive identification in 1886 , when they alone became eligible for membership in the Adelphi Literary Society. The distinction was further emphasized in 1887-1888 with the founding of the Normal Literary Society and Per

Gradus, a literary society for prep students. College students, however, continued to sense their lack of clearly defined status until the Normal

Department became a degree-granting college (1905) and took over the Preparatory Department as a laboratory school for student teachers (1908).

Regardless of their levels of course work, the early students shared much in common.
There was no great age difference among them. Most young people on the Dakota frontier could attend school only for short periods at a time and often took longer than is now customary to complete their educations. Some of the prep students were well into their twenties. Most students also shared similar backgrounds and goals. As an editor of the University newspaper, The Student, observed in 1894: "Many of us come here from the log cabin in the backwoods and the sod shanty on the frontier. And what do we come here for? To ... rub off the corners and get rid of the greenness."

Life at the University in the 19th century often resembled the frontier existence which many students were seeking to overcome. The campus, located two miles from the edge of Grand Forks, was bleak and isolated-20 acres of plowed ground covered in winter with drifted snow and turned to mud by spring thaws. In 1889 , when the first college class chose the official school colors, they selected green and rose, "suggestive of our green prairies and rosy prospects." But one student, no doubt disgusted with the campus
Waiting for the train track, clear of snow mud in the autumn and spring, was a sper ocializing during much of the University's first quarter cenury of existence. 
60 STUDENTS

Nine of the 79

at UND during its

at UND during its

1884-1885.

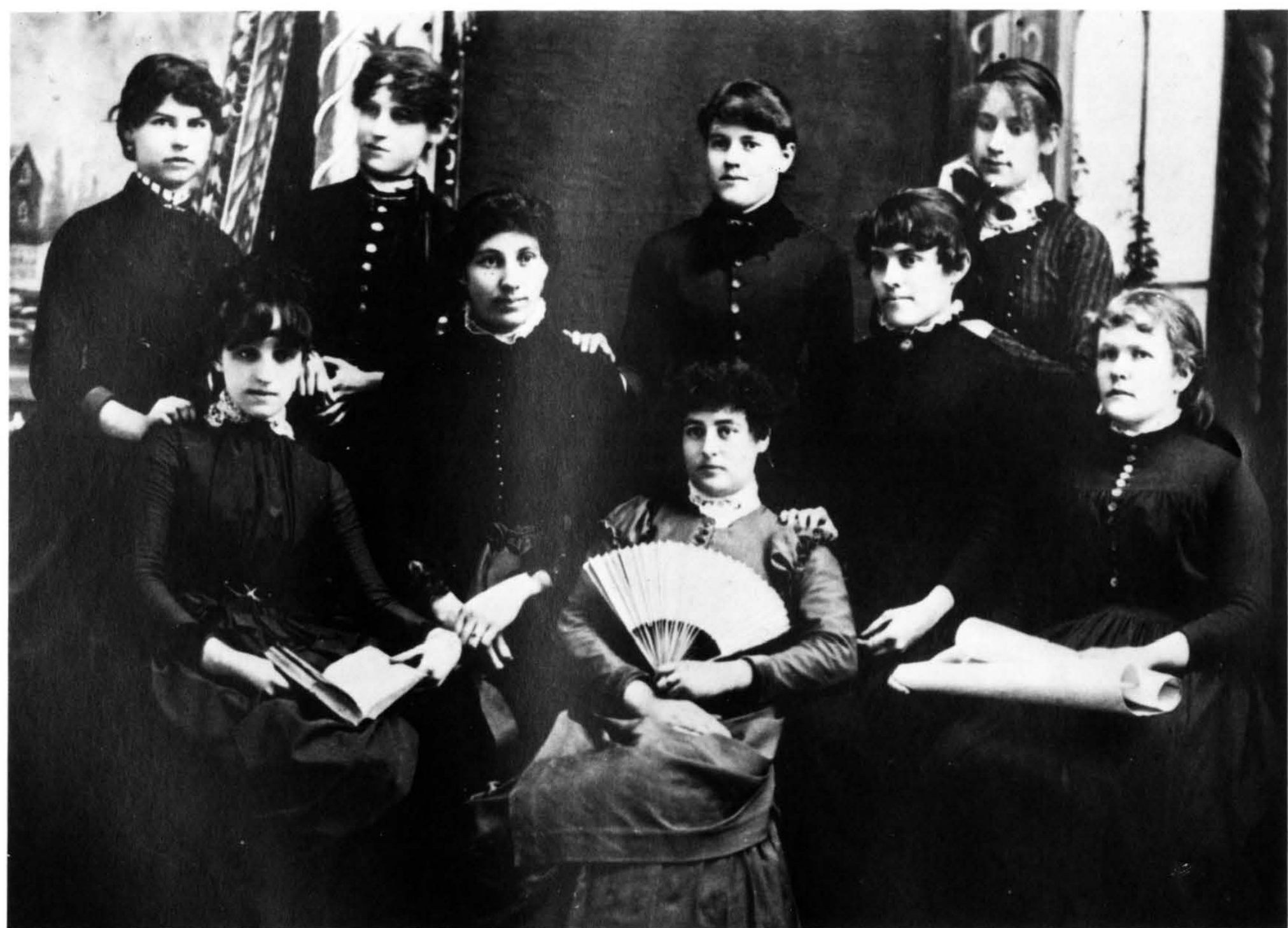


landscaping, suggested what to him seemed a more appropriate choice: "Black, for the mud." Little wonder that Arbor Day was a big occasion every spring, with classes dismissed so students could plant trees on campus. Incidentally, after the first

telephone was installed on campus in 1890 , it was followed by the inevitable telephonepole joke. The Student of May 1891 related that a gentleman from town asked a first-year Normal student, "What is that telephone post on the corner for?" The student replied: "Why, that's not a telegraph pole. It's our class tree." That same issue of the paper correctly predicted: "Future generations will rise up and call us blessed, as they sit in the shade of our vines and fig trees, or plum trees."

Most students lived off campus, renting rooms or staying with friends or relatives in Grand Forks. For them, commuting to campus presented never-ending problems. At times Great Northern trains stopped at the University, but they were often late, especially during inclement weather when they were most needed. The railroad seldom catered to the special needs of the University community. For example, in November 1890 the local passenger agent rejected a petition from students requesting Sunday train service so they could attend churches in town. The University itself tried to provide transportation. At first there was the "Black Maria," a long wagon so dubbed because of its black curtains. This was superseded by another horse-drawn vehicle, a "bus" with glass windows, which made a round trip to town each morning and evening, the snow or mud on Broadway (later renamed

University Avenue) permitting. The fare

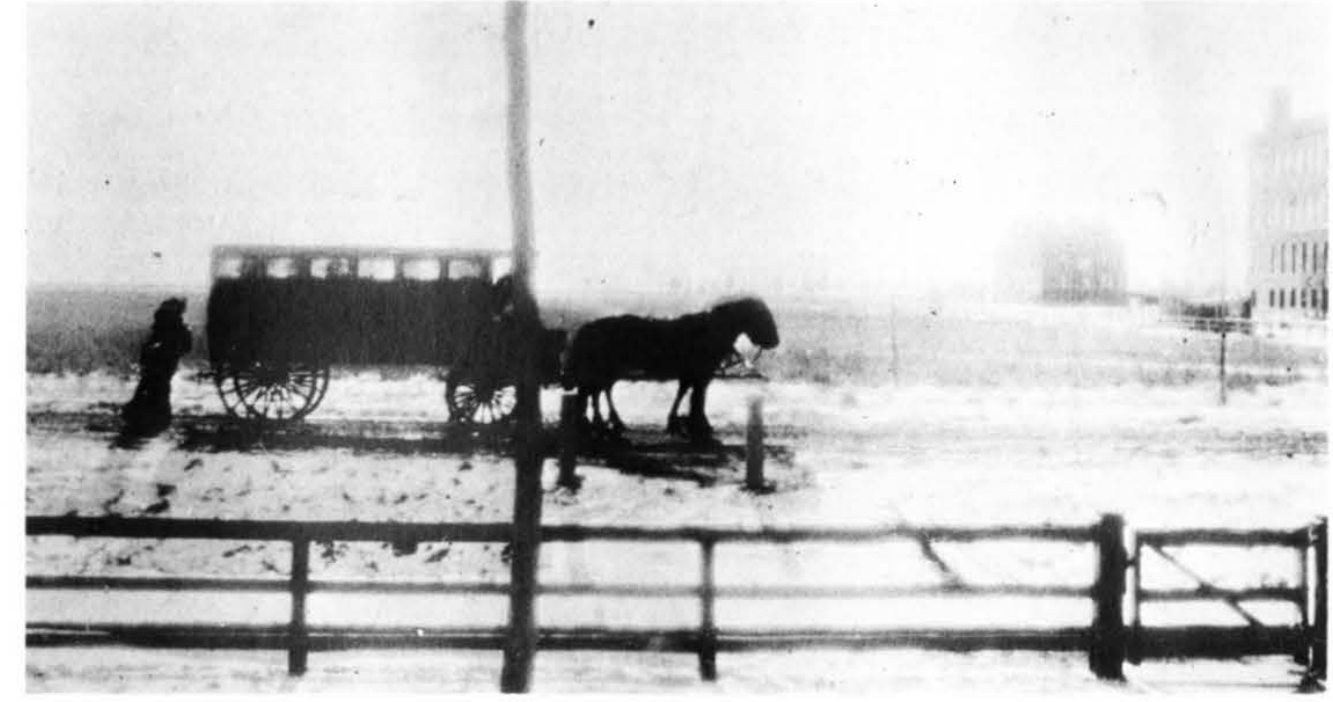

was five cents, and the 16-passenger bus frequently carried twice that number.

Walking was the most dependable way of getting to campus. Because Broadway was impassable much of the year-and petitions to the county commissioners requesting completion of a wooden-plank sidewalk between town and campus went unheeded-the railroad track afforded a better path for pedestrians; but even this, The Student observed in the muddy month of May 1893, "particularly in the freight yards, . . . is by no means a safe road, especially for young ladies."' President Webster Merrifield, recalling the winte hardships which students suffered in getting to campus, found nothing comparable in all of history, "save, possibly, Napoleon's retreat from Moscow,"
For the small number of students living on campus, life was not much more convenient. In 1884-1885, male and female students were housed in the Main Building; this co-educational arrangement-under strict faculty supervision-was abandoned the next year, and the young men had to find quarters in town. In 1888, with the completion of Ladies' Hall (later renamed Davis Hall), which housed 40 women, the men again occupied the Main Building. A male dormitory for 50 students - known at first simply as the prep dormitory and called by the students "the

doghouse" - was opened in 1893. In 1908

it was officially named Macnie Hall.

The young men in the Main Building, which they soon christened the Bull Pen and the Ram Pasture, experienced the fun occupying two large, barrack-like room
The University bus nears the end of its the town of Grand Forks. 


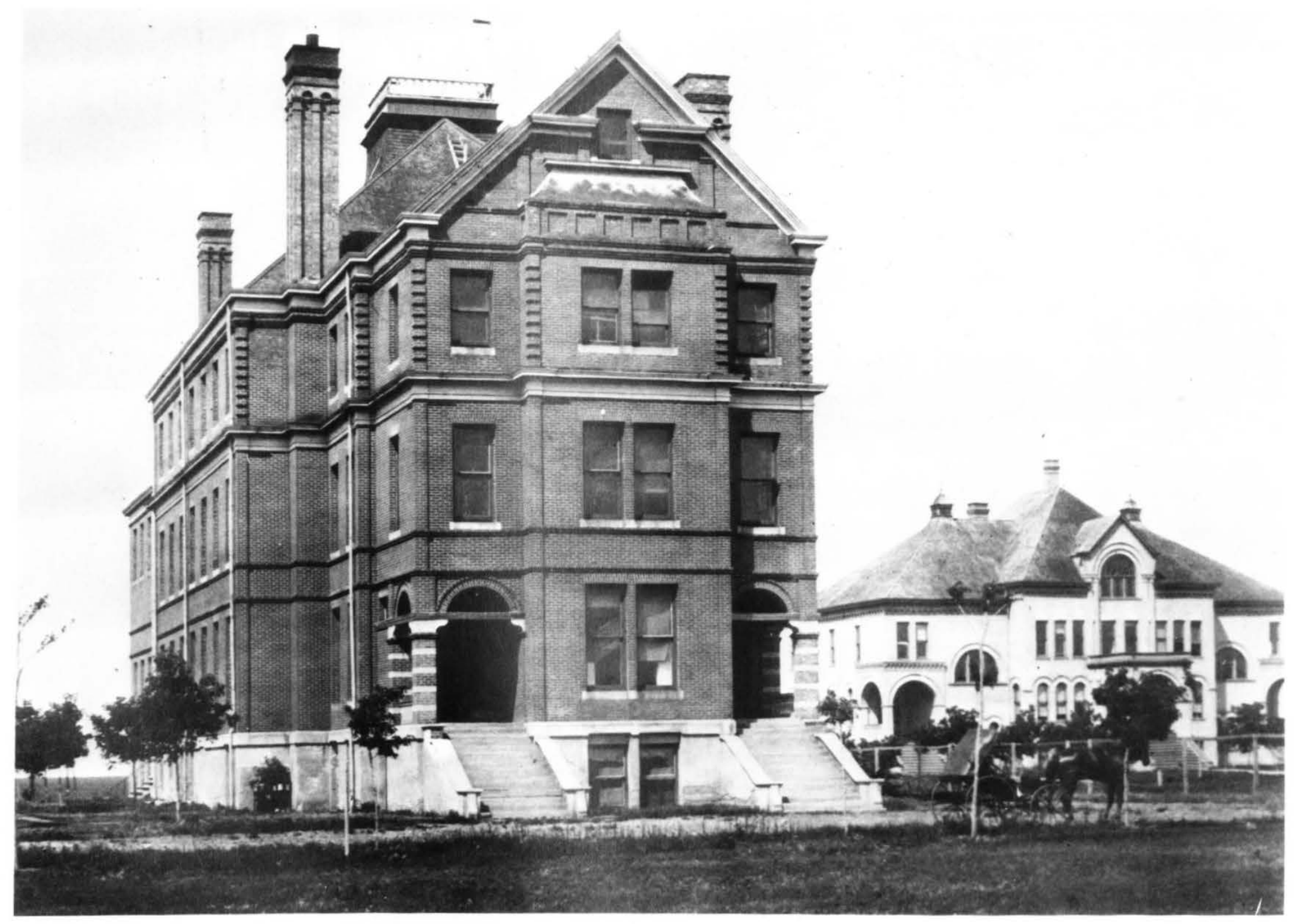




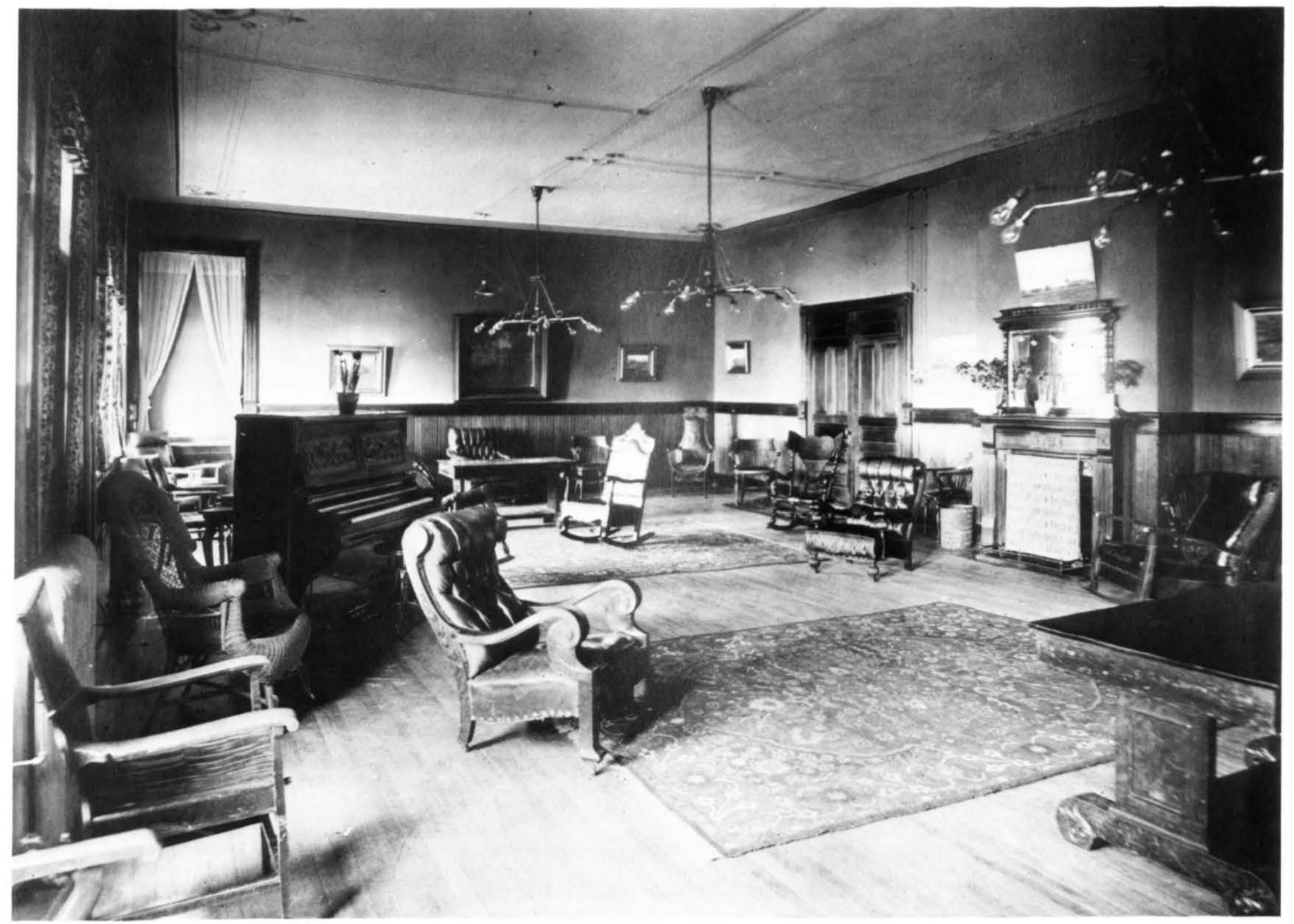

The parlor in

center of campus

social life in the 1880 s

and $1890 \mathrm{~s}$. 
and frustration of crowded communal living. The exciting camaraderie of latenight pillow fights was heightened by the danger of discovery by a snooping professor; and there were problems of coping with "fellow inmates" whose perceptions of social niceties were less than perfect-the would-be orator who never tired of the sound of his own voice, or the "pious prep"' whose loudly delivered bedtime prayers included the names and misdeeds of the whole Bull Pen-but a little frontier-style vigilantism (perhaps a cold dip in the tin bathtub) usually insured a modicum of harmony.

Life in Ladies' Hall was more genteel. As President Merrifield remarked in 1891, "I cannot understand why girls are so much nicer than boys" - one of the few times, The Student quipped, that the President ever echoed the sentiments of the boys. Young women were assigned two to a room, and a roommate was an :mmediate acquaintance with whom to begin the transition to dorm life-unpacking, sharing impressions, and combating the room's starkness with pillows, rugs, and other comforts brought from home. Young women from farms and small towns, perhaps intimidated at first by the hugeness of the building and loneliness of its empty halls, soon felt more at home as they made new friends and adjusted to the expected routine. Many, however, found the regimen to be somewhat oppressive. Weekly dorm meetings, enjoyable at first because of their novelty, lost their charm when it was discovered that they were in reality, as one young woman said, "a kind of "house of correction' where general faults are criticized and rules are read.",

Dorm life was not always conducive to good health, especially in winter when students stayed indoors, "huddled together in corners around the radiators," working on their lessons for want of something better to do. Such confinement, one student observed in 1890, was "harder on the health of the girls than on that of the boys," because the women had no opportunities for indoor physical exercise comparable to the military drill of the men. The following year military drill was made available for women.

Winters were even worse for town students. President Merrifield was certain that many young people who walked to campus on snowy days and then sat through classes in damp clothing were laying "foundations of life-long misery, if not of shortened lives." Epidemics or nearepidemics were as common on campus as elsewhere. For example, the University closed for a month during 1888-1889 because of diptheria; during the winter of 1893-1894, three students died of typhoid fever. Illness and death of classmates were all-too-familiar aspects of the students' experiences at UND

The ways in which students amused themselves reflected simpler pioneer days. The center of campus social life was the large Victorian parlor in Ladies' Hall, where faculty and students socialized at Saturday evening receptions and attended lectures, musical programs, and dramatic performances. After the formalities, the evening might conclude with a taffy-pull or a "popcorn social."' Sometimes there was unplanned excitement, as at a reception in 1894, when an accidentally overturned oil lamp caused a "slight conflagration", which was quickly smothered with quilts and blankets.

Outdoor activities included croquet, sleigh rides, and ice skating on the coulee. Skating took on an added attraction in 1891 , when for the first time young ladies and gentlemen were allowed to skate together. There was also a good deal of impromptu fun, especially on the part of the young men. Halloween was always a time for pranks, and the University bus had an unexplained habit of wandering away from campus on its own: "Was it a nightmare that left it in front of Prof. Montgomery's house one night last week?', querried The Student in May 1888

Alma Mater took her en loco parentis role seriously, looking after the students' spiritual lives in addition to their educations. Non-denominational chapel services were compulsory each morning, except for students with parental excuses; and Sunday evening hymn singing was encouraged in the dorms. In 1889, a Young Men's Christian Association was organized on campus and conducted Bible classes and evening prayer meetings. While the University was non-sectarian, it prided itself on being Christian.

"Discipline in those early days," President Merrifield recalled, "was a much more rigid and eternally vigilant matter than it has since become." The students, certainly, would have agreed with him. As The Student observed in 1892, spring 'brought with it the song of the birds, the murmur of brooks, and the fragrance of 
flowers - and to us new rules." Some of the rules, such as the prohibition of talkin in the library, were reasonable even by modern standards. Less so were rules against talking in the hallways, where the young women from town had to eat their lunches. The Student noted in 1888 that it "is against the rules to talk or laugh in the halls, but the Prof. of Science says you ought to talk and laugh when eating, for the sake of digestion. What are the poor girls to do?" Young men from town had even less freedom at lunch time; they ate in a classroom under the supervision of a professor.

Campus students, especially, never escaped the watchful eyes of the faculty, who enforced "lights out" in the dormitories every night and disciplined students for serious infractions of the rules such as singing college songs after prescribed bedtime. Beginning in 1891 the preps were required to attend "chapel sittings" (study halls) every evening from 7:00 to 10:30. Even the college students were sometimes treated like misbehaving children and "kept in for bad conduct." Rules-there seemed to be rules against everything. Students were given demerits for breaking them; and, if a warning letter to parents did not produce the desired results, explusion was the ultimate solution.

The faculty considered it especially important to keep male and female students separated as much as possible. During study hours and at mealtime in Ladies' Hall, men and women were assigned to different areas in the rooms. There was even a rule against young men and women walking together off campus
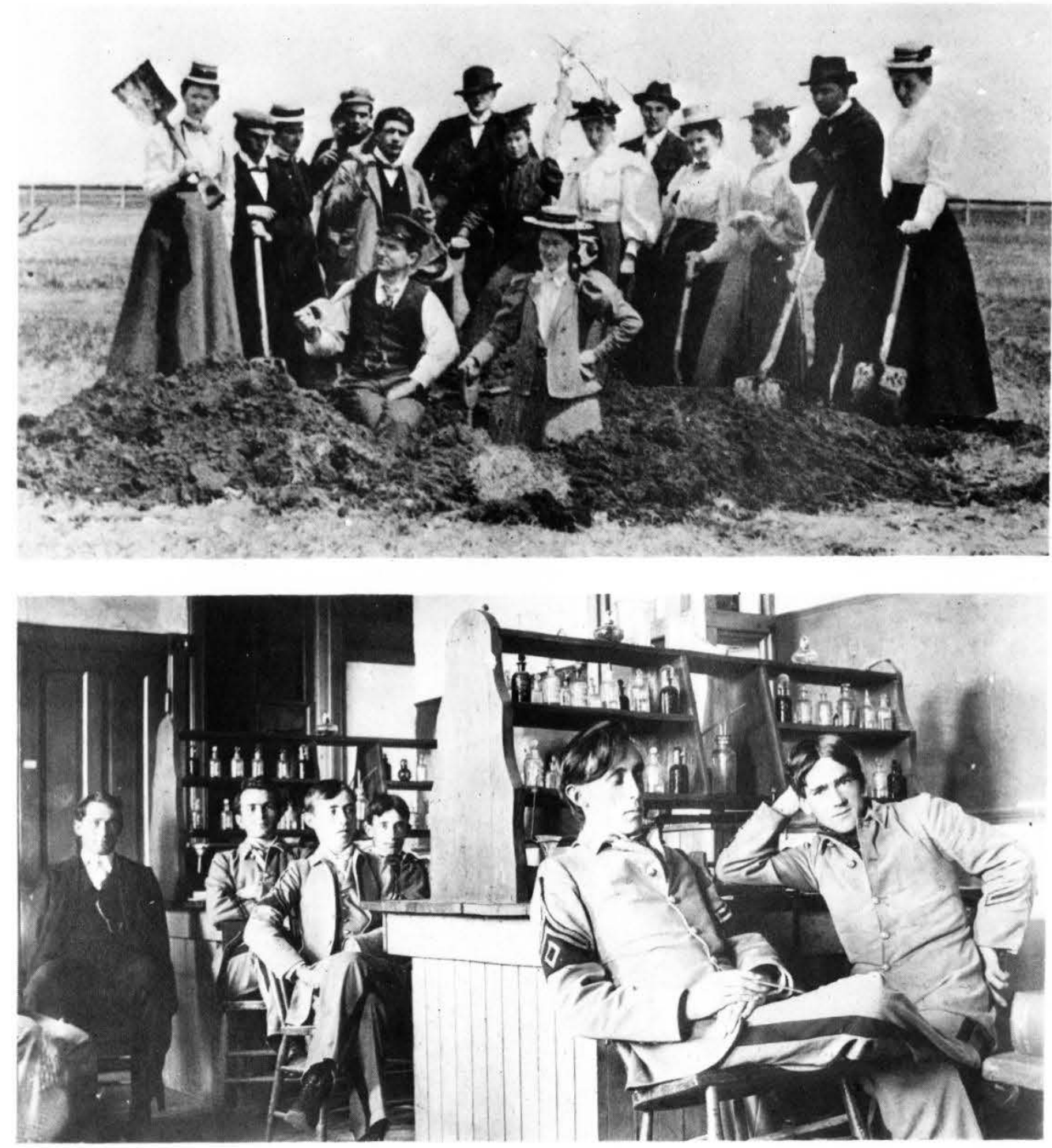

Planting the class tree in the early 1890 s.

Chemistry class, 895. 
without a chaperon. President Merrifield recalled how one day, from his classroom window, he saw a male and female student strolling together along Broadway. Feeling compelled to maintain prescribed discipline, he dismissed his class "and hurried down the avenue as fast as presidential dignity would allow" until he overtook "the erring couple" and sent them back to campus by different routes. But, he admitted, he realized even then the "absurdity" of his action; under his guidance in the 1890 s such restrictions were gradually lessened. By 1901, men and women students were allowed to dance together on campus-promiscuous dancing, it was called in the language of the day. Prior to that time, women danced among themselves in the parlor of Ladies' Hall and the men tripped the light fantastic without feminine companionship in the gymnasium in Budge Hall.

The early students at UND, sensing a lack of school spirit typical of young institutions, created the beginnings of a tradition of school loyalty. Their first attempt, during the closing years of President Homer Sprague's administration, focused on a distinctive school yell, "Rag's Out!" This particular cry originated from the practice of hanging a dinner napkin in the Ladies' Hall dining-room window to signal a lookout in the Bull Pen of the Main Building that a meal was ready. One day the lookout announced the welcome napkin in frontier terms: "Rag's Out!"

This quickly became the standard call, and three times a day men chorused it as they stampeded down the three flights of stairs in the Main Building and ran to the dining room. Soon young men and women from campus and town vocalized it at other times as an expression of school loyalty. In 1891, President Merrifield, concerned with campus dignity and appalled by the "unseemliness", of "Rag's Out,", prohibited its use. Students responded with a protest rally at which they compared their stand to the Boston Tea Party, and The Student defended the treasured yell as the only true expression of school patriotism. Merrifield immediately imposed faculty censorship on the school newspaper, and only under threat of expulsion did the student body accept a substitute yell which had the President's blessing - a strange combination of a Sioux war cry and ancient Greek. Needless to say, such dictated refinement inspired no one and was soon forgotten. True expressions of school loyalty were eventually created - as they must be - by students themselves.

Quaint as many aspects of student life in the 19th century seem today, there was also much that has a familiar ring-including electric bells, first installed in 1893, which convened and dismissed classes. Stodgy professors then as now complained of students' chewing gum in class, of their inability to spell and of their proclivity to put off all work until the last minute. By 1895, the still-current lament was being heard that the dormitories were too noisy for studying, and the tradition of complaining about dorm food was firmly entrenched. As now, many students worked during summers and at part-time jobs to finance their educations.

Women students in the 1890 s, like their present-day sisters, were concerned about their rights in society. Mrs. Hannah Davis, instructor in English and preceptress of Ladies' Hall, conducted what today would be called consciousness-raising sessions at which she presented character sketches of women who had made lasting contributions to society. The issue of woman's suffrage was debated on campus, and in 1895 The Student editorialized that "all promises well for the 'Woman of the Future', and predicted hopefully that she would obtain the right to vote and become a leader "in society and the professions." Young women on campus today who are still concerned with many of these same aspirations have a century-long University tradition behind them.

By the close of the first decade of the 20th century, UND had emerged from the pioneer period; and life for the students was beginning to resemble conditions at older institutions. In 1893, a 14-member Cadet Band, long thought to be needed for school spirit, was organized. In 1894, intercollegiate football was introduced; in 1907, the first athletic field, complete with bleachers, was constructed on campus. In 1899 , electric lighting for the first time replaced kerosene lamps. Indeed, an "old timer" expressed wonder in the first school annual, the Dacotah of 1904, at how student were now enjoying such 20 th century luxuries "as telephones, electric bells, dormitories with small bedrooms, and hot and cold baths in porcelain tubs.' In 1904, the Adelphi hay ride and picnic featured another modern novelty, "a large phonograph" - presaging the much larger phonographs which are standard equipment for many students today and sometimes flood University Avenue with music shared (or inflicted) by fraternities 


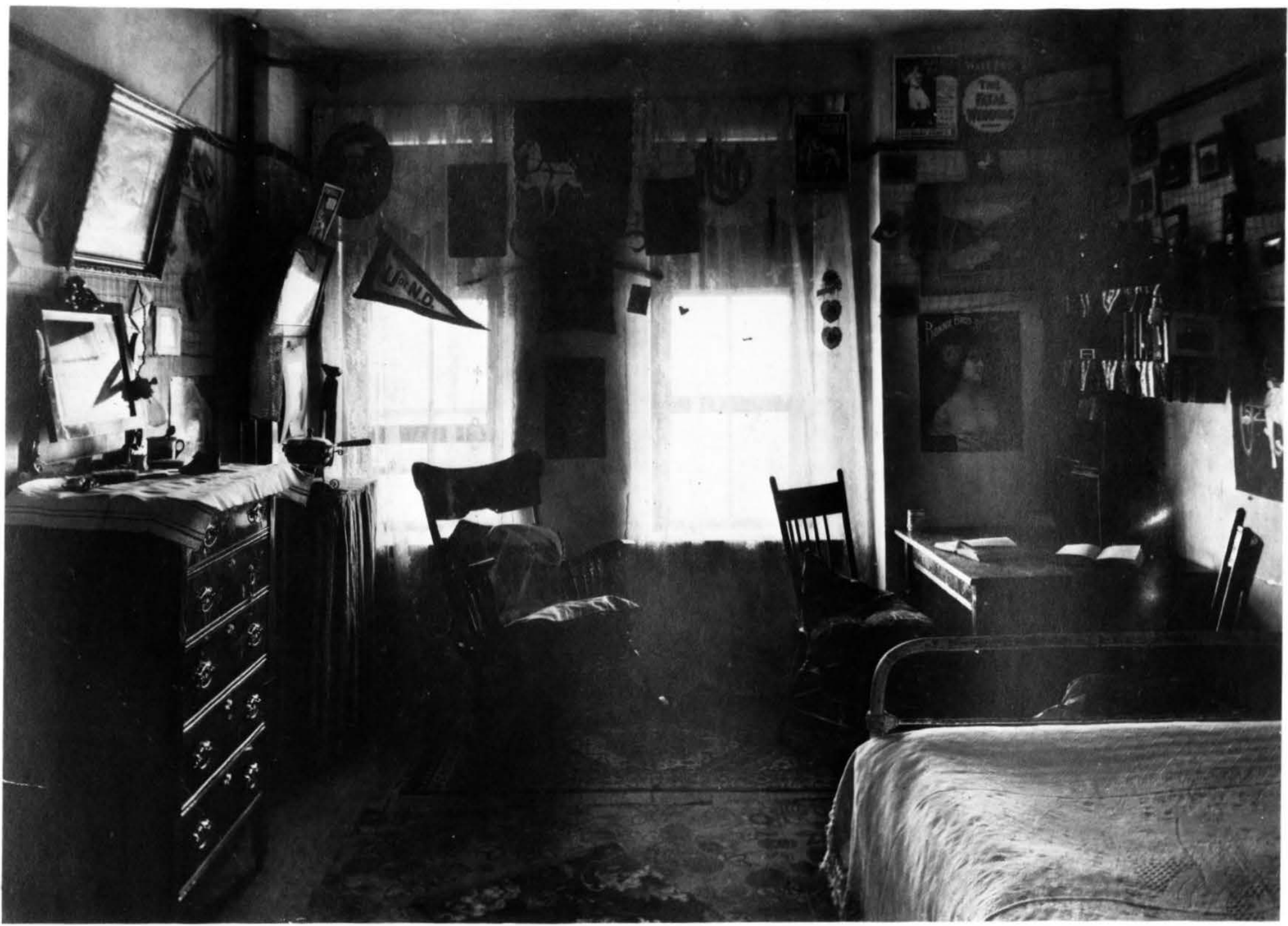


and sororities. In 1904, student isolation was greatly reduced when an electric trolley line began operating between Grand Forks and the campus. Academically, UND was trying to take its place among other institutions of higher education. The national office of the student honor society Phi Beta Kappa denied a request for a local chapter in 1908 because the

University was not properly accredited, but a chapter was installed in 1914. Rules governing student behavior were relaxed, but "proper conduct"' was nevertheless stressed. The University still prided itself on being non-denominational but "strictly Christian"; of the 337 students enrolled for the winter term of 1905 , only 42 were nonchurch members.

Another major change on campus was the burgeoning of social and academic activities which competed for the students' time, certainly to the dismay of the faculty and probably to the academic detriment of the students. Debate teams quickly began to compete successfully with the football team for student interest. As early as 1894 The Student had complained that the literary societies were failing to address national issues of interest to students. College, said the editor, "should be a species of warfare"; debating controversial topics "would arouse a great deal of interest, would divide us into hostile camps and rouse us from the dull stupor into which we have fallen." By 1909, 10 literary societies, claiming over half the student body as members, were answering this need, staging debates among themselves and with other colleges. In 1894, UND held its first out-of-state debate. A team traveled to the University of South Dakota at Vermillion, took the negative position on the nationalization of railroads, and won. Other topics of current or lasting interest, such as the annexation of Hawaii, the length of presidential terms, and the electoral college, attracted much student interest. In 1904, when woman's suffrage was debated on campus, a student vote gave the victory to the opposition; this provoked The Student to observe that "there is a strictly conservative element among us, contrary to the opinion of many outsiders." Such a discrepancy between image and reality would remain a characteristic of student attitudes, even in the turbulent Sixties. By 1920, interest in the debating societies, which had attracted mostly male members, declined as other organizations, especially fraternities and professional clubs, began to offer

alternative opportunities for socializing.

In addition to debate, drama competed for the attention of forensically inclined students. Prior to 1905 drama production at UND had seldom risen above the level of minstrel shows or sophomoric farces, but in 1906 The Student could proclaim with a modicum of accuracy: "The day of clumsy and inartistic work is past." The senior class play that year was Richard Sheridan's "The Rivals." Growing interest led to the organization in 1911 of Sock and Buskin, a drama society limited to 40 students selected for their academic and dramatic ability. Maxwell Anderson was among the early members. The organization, which staged productions on and off campus, especially encouraged students to write plays. In 1914, it presented on the banks of the coulee its first studentwritten piece, "The Pageant of the
Northwest," an elaborately costumed historical spectacle. Sock and Buskin continued for a time to emphasize student writing, but by 1920 it had become a traditional dramatics club.

Music groups also flourished. To the Cadet Band and the Guitar and Mandolin Club, both dating from the 19th century, were now added men and women's glee clubs, a symphony orchestra, and a string quartet. For a brief time, with such features as a free, monthly symphony concert, student interest in and opportunity for musical expression and appreciation flourished as they seldom have since.

For the less extroverted or more academically minded students, the professional schools and some departments by 1910 were sponsoring clubs. While most of these provided social occasions and perhaps academic experiences, a few pursued activist roles. The Sociology Club, for example, secured the designation of the Badlands as a national forest in 1908; it also provided students to operate a settlement-house project established by the University in 1914 to care for 80 needy families.

As faculty responsibility for students' moral and religious training declined - the daily chapel service was abolished in 1903

- private religious societies filled the void. By 1910 the YMCA, first organized on campus in 1889 , the YWCA, organized in 1892, and the Catholic Association

collectively counted over half the students as members. Like later campus religious organizations, the first ones also provided non-spiritual assistance to students. For example, in 1914 the Y's established the first student employment bureau at UND; 
the same year the YMCA took over management of the only recreation room on campus, located in the basement of Budge Hall.

Perhaps surprisingly, given the ethnic backgrounds of many students,

organizations based upon national origins were not popular at UND. Between 1900 and 1910 a Norwegian society, Mimer, the Icelandic Association, and the Celtic-

American Society flourished briefly. One of their main goals was raising money for library books reflecting their literary heritages. In 1906, the Celtic-American Society, which traditionally sponsored a program on March 17 (St. Patrick's Day) rescheduled the event to Jan. 26 (to celebrate Robert Burns' birthday) in an effort to widen its base of support. But ethnicity soon gave way to nationalism, especially with the coming of World War Scandinavians, Scots and Irish were soon associating themselves with the same social organizations which attracted other students.

A growing nationwide trend toward a relaxation of campus social regulations was typified at UND by the changing policy concerning dancing. Soon after the first dance in 1901, others were permitted. A Junior Prom was instituted in 1902; a Senior Prom, in 1908. These became elaborate dinner-dances requiring formal attire. By 1908 informal all-school dances, at which orchestras played decorous waltzes, one-steps and hesitations, were held almost every weekend. Such new step as the "grizzly" and the "bunny hug," done to the less-restrained rhythms of the Jazz Age, were prohibited by the dean of women.
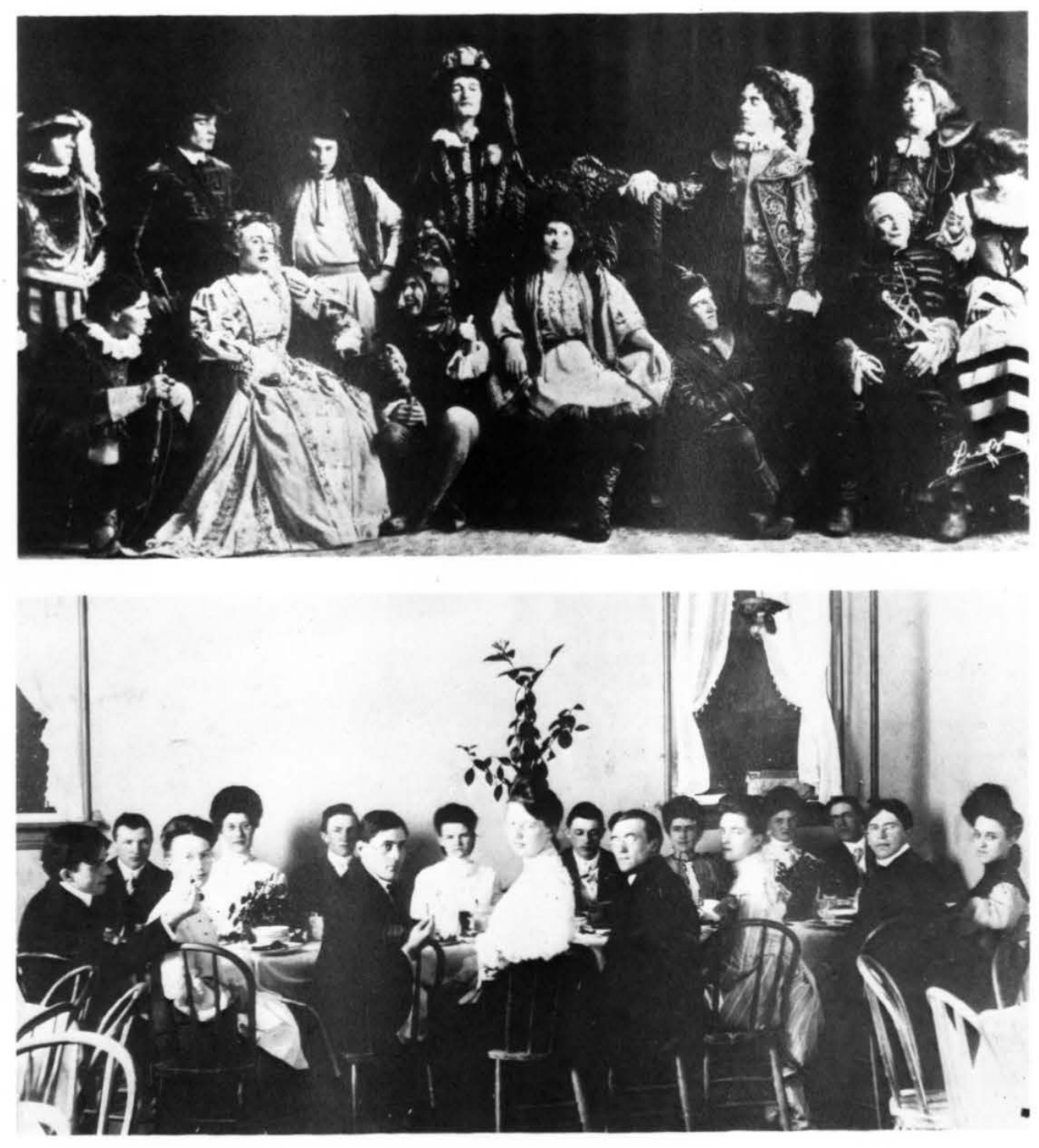

Production of Shakespeare's "Twelfth Night," 1910; future benefactor Chester Fritz is third from right in front row.

A meeting, with guests, of UND's first fraternity, the Varsity Bachelors Club Aater Phi Delta Theta), 1903. 


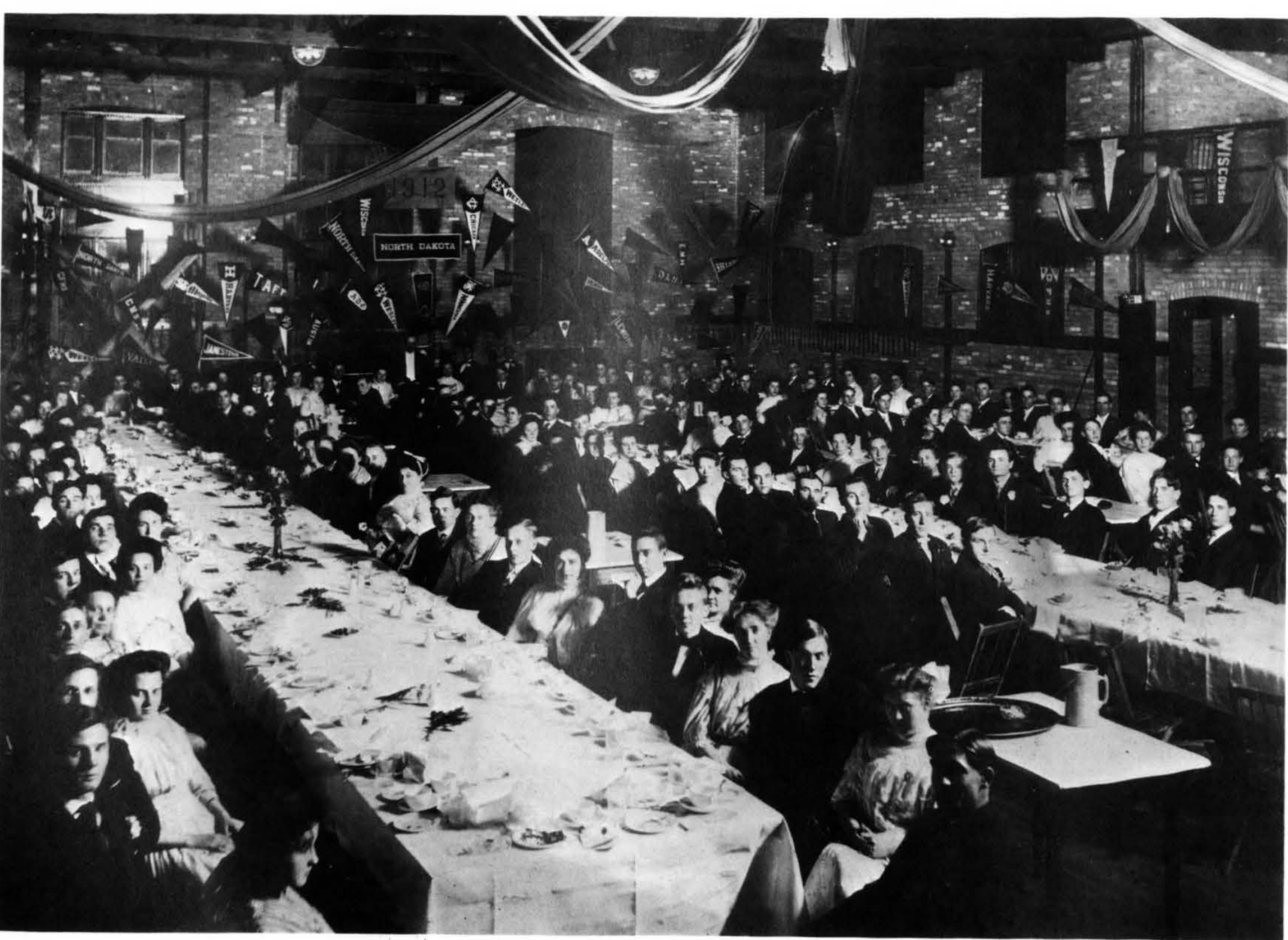


With this growing interest in and opportunity for social life, some students became interested in fraternities and sororities. The primary purpose of these organizations was to provide an exclusive sense of group identity, reinforced by separate housing; their major activity was organized partying. The first fraternity appeared on campus in 1902, when 10 young men, led by William Lemke (a future founder of the Nonpartisan League), established the Varsity Bachelor Club. The early members had the advancement of the University as one of their major purposes, and they took this seriously. After the organization received a national charter from Phi Delta Theta, however, it became indistinguishable from ther social fraternities. In 1906, the Banded Brothers of Bungaloo was organized; in 1909 this fraternity became the first on campus to receive a national charter when it affiliated with Sigma Chi. The first sorority, Alpha Delta (Kappa Alpha Theta), was also founded in 1906 By 1917, there were five fraternities and five sororities on campus; five had nationa charters and nine had their own houses.

The faculty and administration, viewing what had happened on other campuses, were concerned that fraternities might come to dominate student politics and campus social life. Such divisiveness between fraternity members and independent students, however, did not occur at UND prior to 1917 , primarily because fraternities and sororities still had a few social advantages. They were limited to one formal and one informal party each year. The administration tried to preserve student unity by organizing a Women's
League and a Men's Union. These organizations, which sponsored social activities, included all students. Weekly allcampus dances also helped postpone domination of social life by the Greek-letter organizations.

America's entry into World War I in April 1917 temporarily interrupted the normal campus routine. Military training for male students, which had been discontinued in 1904, was reinstated in April on a voluntary basis; 45 percent of the men on campus enrolled in an eightweek program, training with wooden guns made at the University. In November 1917 , military training became a requirement for freshmen and sophomores. Because of the war, enrollment rapidly declined. By midMay 1917,139 of the 490 male students had left campus, 37 to volunteer for military service and the rest to work on farms. In all, 329 undergraduates served in the armed forces; 43 students or former students lost their lives in the war.

The women students who remained on campus did their part for the war effort. In April 1917, the Women's League, which included all female students, began participating in Red Cross work, knitting socks and mufflers and preparing scrapbooks about local happenings to be sent to men in service. "Knitting," the school newspaper observed in January 1918 , "has become the symbol of the spirit which now moves the patriotic American woman." In April 1918, during a War Fund Drive on campus, the women contributed an average of $\$ 6$ each. Three residence halls each purchased a $\$ 100$ Liberty Bond, designating that the interest should be contributed to the Red Cross and that the principal should eventually go to the Student Loan Fund.

By 1918, with most students gone, the University contracted with the U.S Government to provide vocational and officer training to military personnel. Most of the campus buildings were converted to Army administrative and housing needs. The few regular students on campus in 1918 found that only courses considered appropriate for officer training were being offered. This training program, however, closed before it really got started. The University was quarantined on Oct. 9 ,

1918 , as a nationwide influenza epidemic reached North Dakota. Of the $\mathbf{4 7 0}$ military trainees on campus at the time, 320 became ill. Primarily because of the lack of

medical personnel and facilities on campus, 29 of them died. When the war ended in November 1918 , the University shed its appearance of a military camp and returned to its traditional purpose.

During the decade of the 1920 s, enrollment at UND approximately doubled, from about 1,000 students in 1920 to nearly 2,000 in 1930 . Growing numbers, coupled with a nationwide trend toward relaxation of campus social regulations, brought a new lifestyle to some UND students, and to most others at least exposure to new attitudes. Above all, the image of a vital university experience was now dominated by an active social life and involvement in non-curricular affairs.

An important factor in the greater

freedom of UND students to set their own standards of behavior was lack of

dormitory space. Nearly one third of the students, out of necessity, lived in

unsupervised off-campus housing - an 
arrangement facilitated by the appearance of the first student automobiles;

approximately another one third lived in

fraternity and sorority housing, where

University regulations were sometimes

ignored. Relaxed supervision even extended

to the dorms, where closing hours for

women were liberalized to 10:45 p.m. on

weekdays. Beginning in 1921, the

University permitted student organizations

to hold social activities on any Saturday night; but, because of the large number of students not living under direct University control, many unauthorized parties were held. Clandestine drinking and smoking (even by coeds) were not unknown.

Veterans enrolled at the University (the state legislature in 1919 voted them a bonus for educational purposes), being older and perhaps more "worldly wise," also affected the tone of campus life.

Some of the new activities had the blessings of the administration and some of the faculty, who saw their potential entertainment value in terms of good public relations. The May Fete, sponsored by the women's physical education department and dating from 1909, in the 1920 s attracted thousands to the banks of the coulee to marvel at elaborate dancedramas performed by nearly 500 fancifully costumed young women. The parades, football games, and dinner-dances of fall Homecoming brought many alumni to campus. The symphony orchestra, organized in 1911, lost out to the Concert Band, which became a feature at athletic events. Drama groups now rejected student

Troops in training at UND drill on University Avenue, July 23. 1918; 29 of them would soon die in an influenza epidemic.

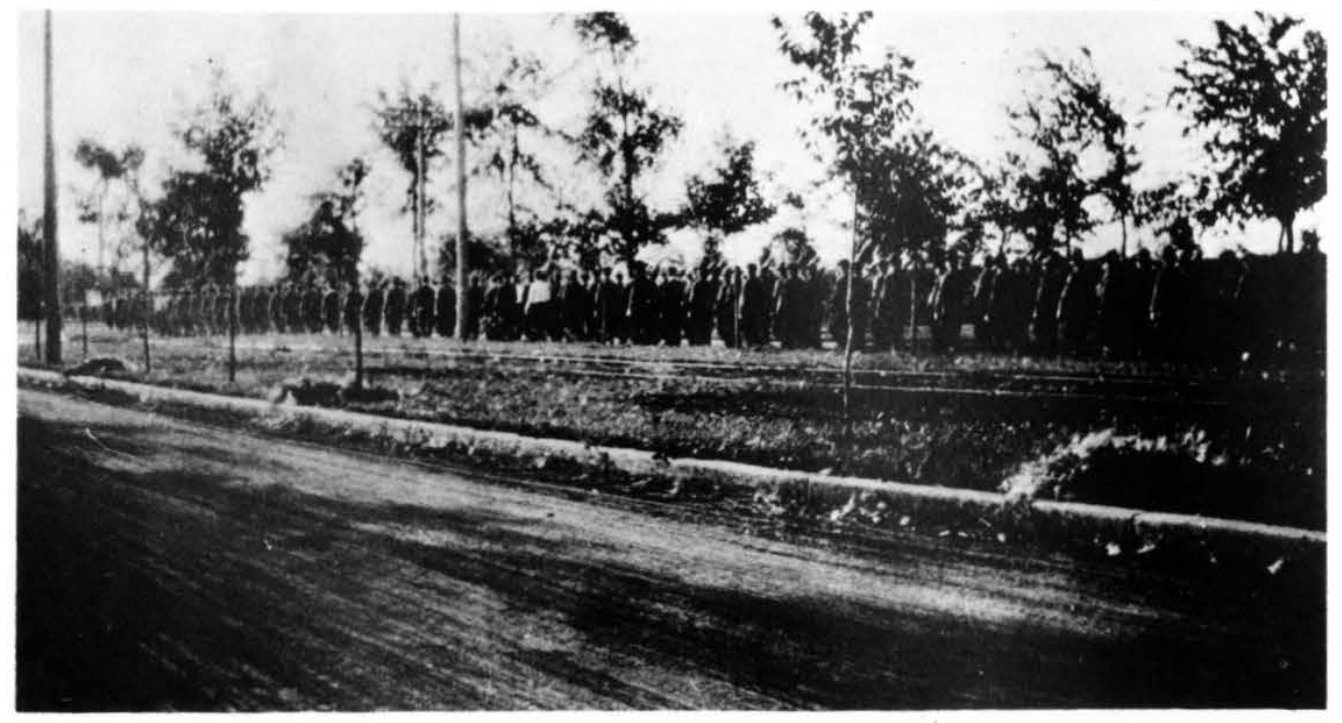

playwrights in favor of more entertaining creators from Broadway. Educational and cultural enrichment was sometimes sacrificed to popular taste, but the University benefitted from its enlarged contributions to the lives of people throughout the state.

One of the student activities dating from the 1920s that proved enduring - indeed, became a tradition that would not die-was the spring variety show known as the Flickertail Follies, originated by Sigma Delta $C$ hi journalism fraternity. This student production, consisting of acts preselected on a competitive basis to ensure quality, was first given in 1925. It soon became a hallmark of student activity at UND, one fondly remembered by many alumni. The Follies attracted national attention in 1950, when Life published a photo-feature on the production. Facult disapproval, based upon the inordinate amount of student time required for rehearsals, had little effect; but when Greek-letter organizations, which had long dominated the productions, began expressing concern in the late 1950s about the efforts required, the Follies were in trouble. In 1962, after nine of the 12 fraternities and four of the seven sororities indicated that they did not intend to participate, the Follies were discontinued. In 1982, however, a nostalgia-minded generation of students revived the production. Members of the Blue Key service honor society took the lead in the hope that the Follies would continue as a cooperative effort contributing to goodwi!l between students from the dorms and those from the Greek houses. 


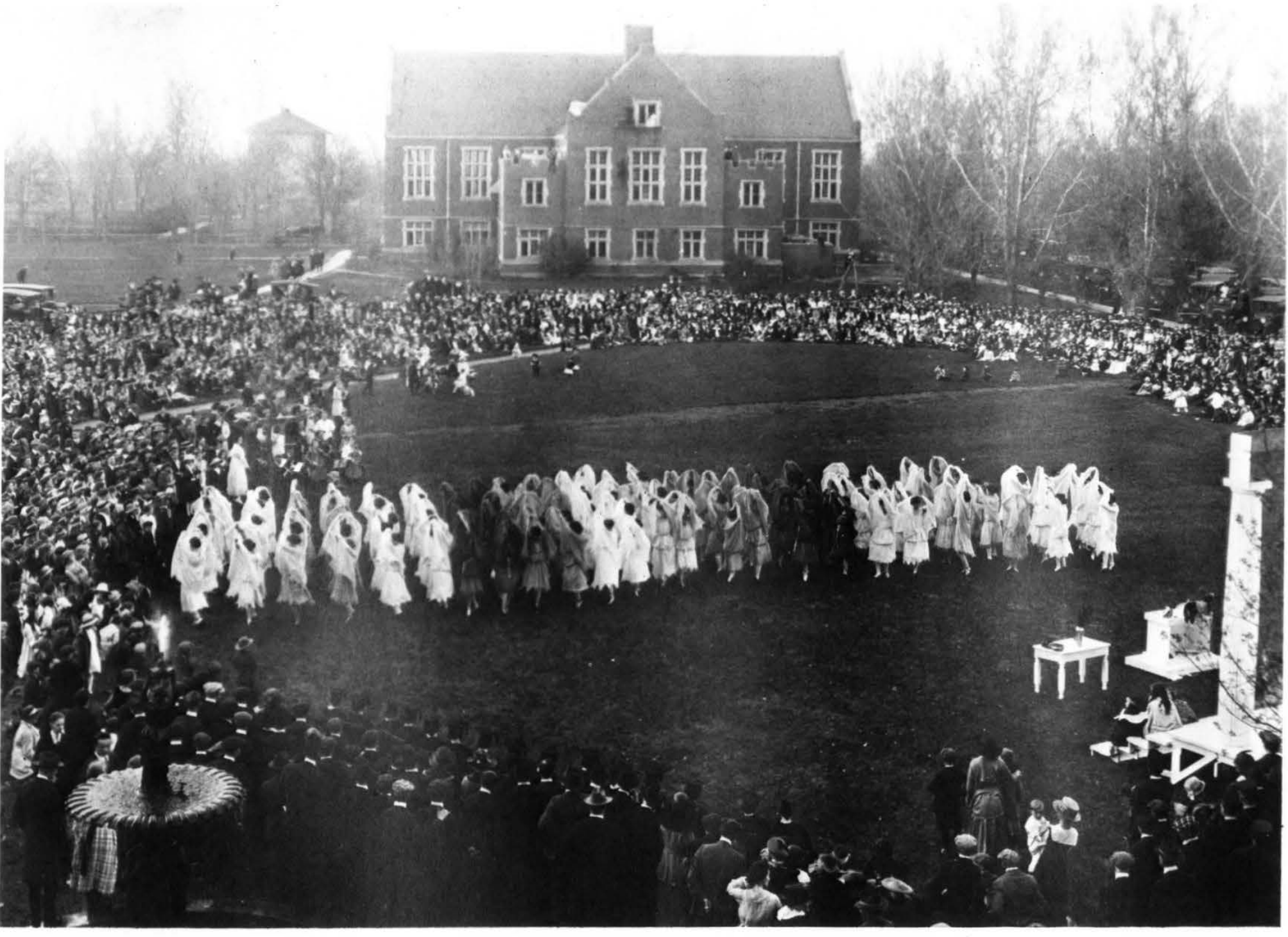


Hazing of freshmen reached its peak in the 1920s; this recep tion line took place in 1915.
The decade after World War I was a high point in fraternity and sorority influence on campus. Fraternity row was developing, and Greeks were dominating the social scene and making their presence felt in campus elections. Indeed, divisiveness between fraternity members and independents was one of the most obvious characteristics of the student body. With the emphasis upon student activity-serving as class officers, for example, or achieving distinction as various campus kings and queens-campaigning was often intense and bitter; elections were not always free from stuffed ballot boxes or other "dirty tricks." The administration and faculty, however, seldom became concerned and more often than not expressed approval of the Greek organizations, appreciating their

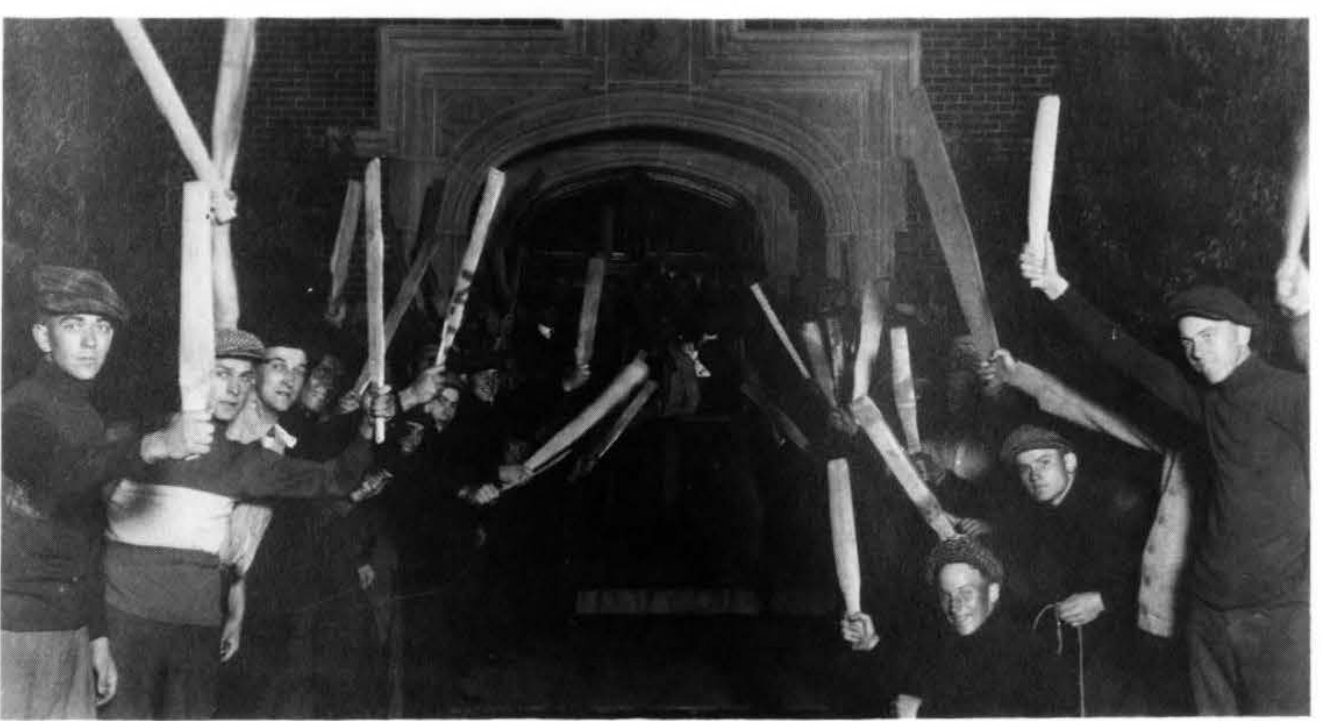

incoming classes increased in size, freshmen found safety in numbers; and their "humiliation" was usually limited to the wearing of green caps.

Despite relaxed regulations and changes in student behavior, the Roaring Twenties at UND, although sometimes set to the jazz beat of the Charleston or Black Bottom, were not all that blaring when compared to older and especially eastern institutions. Students from farms and small towns still held many of the traditional values of their pioneer parents or grandparents. One indication of this in the mid-1920s was the founding and continuing success of the Lutheran and Newman

\section{Foundations.}

Much of the exhuberance and optimism of the Jazz Age gave way to the restraint and uncertainty of the Great Depression of the 1930s. Hard times, always a possibility and sometimes an occurrence in North Dakota because of the vagaries of an agricultural economy, now became a stark reality. Soon more than a third of the state's population was dependent on some form of relief assistance; eventually a third of the state's farmers would lose their land. While this was reflected at the University by a drop in enrollment of only about 20 percent by the mid-1930s,

students now more than ever before had to rely upon non-family support to finance their educations.

The University itself had little money for loans or scholarships; but it helped by accepting fee payments in the form of farm produce and by employing students as

laborers, janitors and classroom assistants to replace full-time workers. In an attempt to reduce student costs, the University in 
1933 set up Camp Depression as a new form of housing. This consisted of 10 abandoned Great Northern cabooses which had been converted into living quarters for about 40 young men, who cooked their own meals and earned their rent by working part-time at campus jobs. Federal relief agencies also provided employment; in 1935 the National Youth Administration was employing about 10 percent of the student body. As the 1930s drew to a close, 85 percent of the male students were contributing to at least part of their support; of these, $\mathbf{4 0}$ percent were totally self-supporting. Because most students in one way or another felt the economic crunch, there did not develop among them a sense of status based upon disparate economic circumstances.

The need to economize in the early 1930s was reflected in student activities.

Production of the Flickertail Follies, beginning in 1932, was discontinued for three years. That same year fraternities cancelled formal dances, and the junior and senior classes held their proms jointly. Informal all-school parties now began attracting Greeks as well as independents. Despite economic hardships, the student body did not deviate from the traditional conservatism characteristic of its

predecessors; few favored solving the nation's ills by liberal or radical methods which received strong student support on many other campuses. During the election year of 1932, most UND students expressed their preference for Herbert Hoover. By the mid-1930s many students were experiencing a returning sense of wellbeing; social life returned to its former, often hectic, patterns. Enrollment, too,

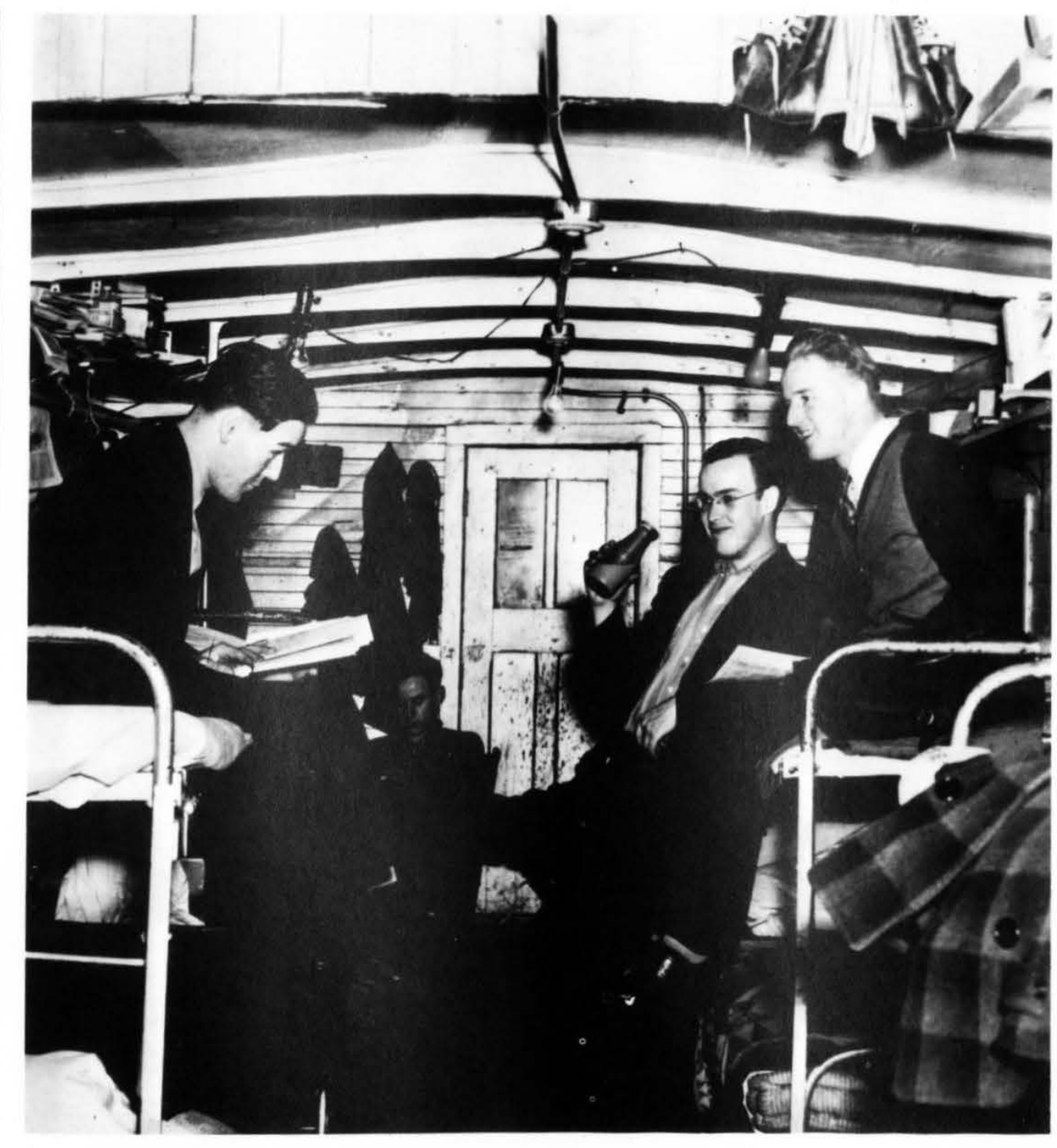

Great Depression era students living in these converted railway cars were able to get by on total an nual expenses of about $\$ 200$. 
One of the many UND students who enlisted during World War II, Thomas J. Clifford.

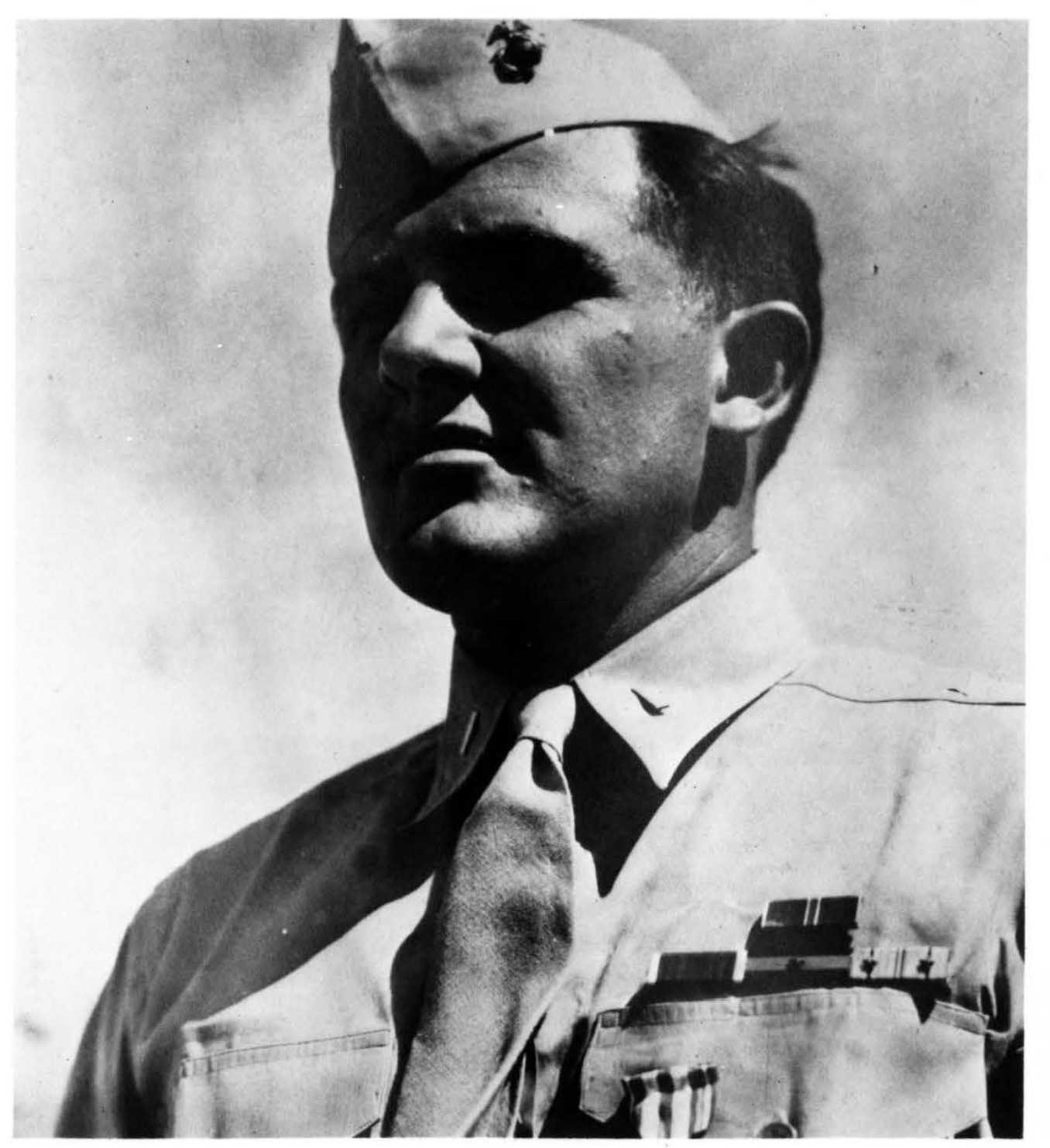

after 1937 resumed its traditional growth, nearing the 2,000 mark by 1939 .

As had been the case during World War 1 , national mobilization during the 1940 s had a marked effect upon the University. In February 1942, male students began registering for the draft. At the end of the year, in December, the atmosphere of wartime was further heightened on campus when North Dakota participated in its first regional blackout drill. With young men going off to war, University enrollment sharply declined, although during the spring semester of 1942, men still outnumbered women, 501 to 330 . By the spring semester of 1944, however, 375 of the 504 students on campus were women.

One hundred and seventy-two former UND students and alumni joined the military honor roll of those who gave their lives during World War II.

On the homefront, the University once again resembled a military base as the faculty contributed to the war effort by providing training for nearly 6,000 military personnel, including engineers, nurses, medics, glider pilots and radio operators. The University students, mostly women, were kept apart from the military

contingent, although they occasionally provided services for the trainees, such as doing Christmas shopping for those who were restricted to campus. Because of the changed composition of the student body, several exclusively male organizations temporarily became inactive. Women students tried to preserve what they could of traditional collegiate life, assuming positions of leadership and service formerly held by men. Most, however, seem to have retained traditional ideas about their roles 


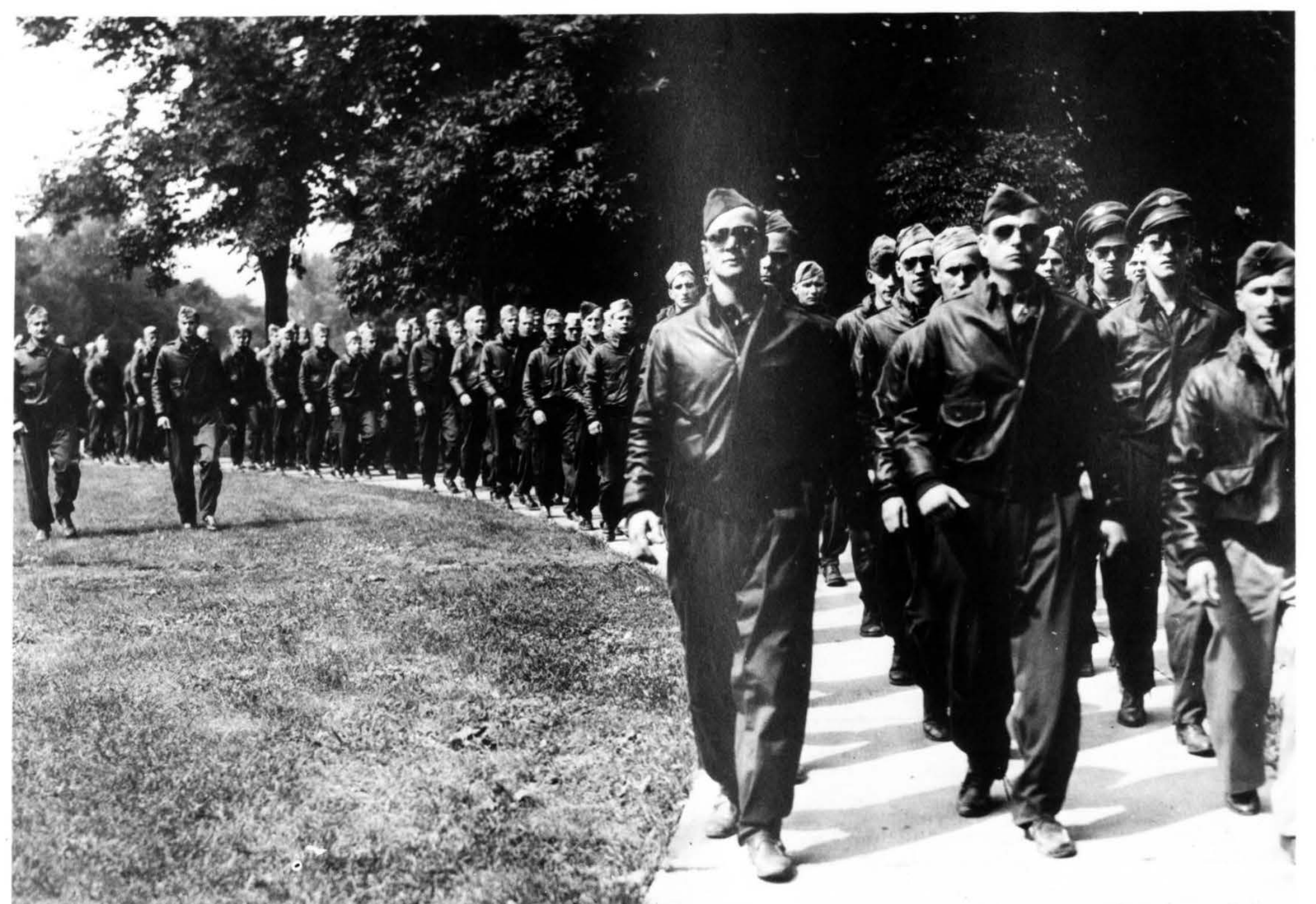


Many of the students at UND in the late

1940 s were older and more serious minded than their

predecessors.
Nothing is more permanent on a university campus than "temporary"

building; this tin hu was still in service in 1975.

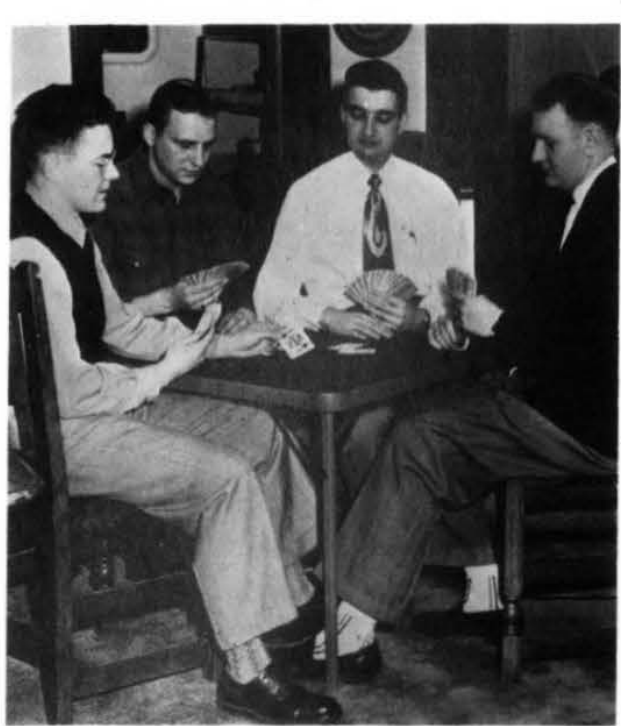

in a male dominated society. In February 1943, for example, one of the women editors of The Dakota Student noted sadly the passing of "pre-war courtesies," commenting specifically on the failure of men to offer women seats on the crowded city buses. Most young North Dakotans looked forward to a return to the lifestyles they were sacrificing to defend and preserve.

Immediately after the end of World War II in 1945, UND's enrollment soared, approaching almost 3,000 students in the fall of 1946. This in itself strained campus resources to the limit. There was a shortage of student housing; classroom space was at a premium; lack of increase in the size of the faculty necessitated a class schedule beginning at 7:30 in the morning and continuing into the night. Recreational facilities and the food service were inadequate. It was even difficult to secure enough textbooks.

A sizeable proportion of this increased enrollment was made up of veterans going to college on the GI Bill. Some 1,500 veterans attended UND in 1946, and until 1950 ex-GIs constituted at least a third of the student body. Korean veterans, who began enrolling at the University in 1952, numbered nearly 900 by 1956 . Although veterans attended colleges throughout the country, their presence was felt much more strongly at UND than at schools with traditionally larger enrollments, where incoming veterans often made up only a relatively small percentage of the student body. At UND veterans were a major aspect of the campus scene for nearly a decade.

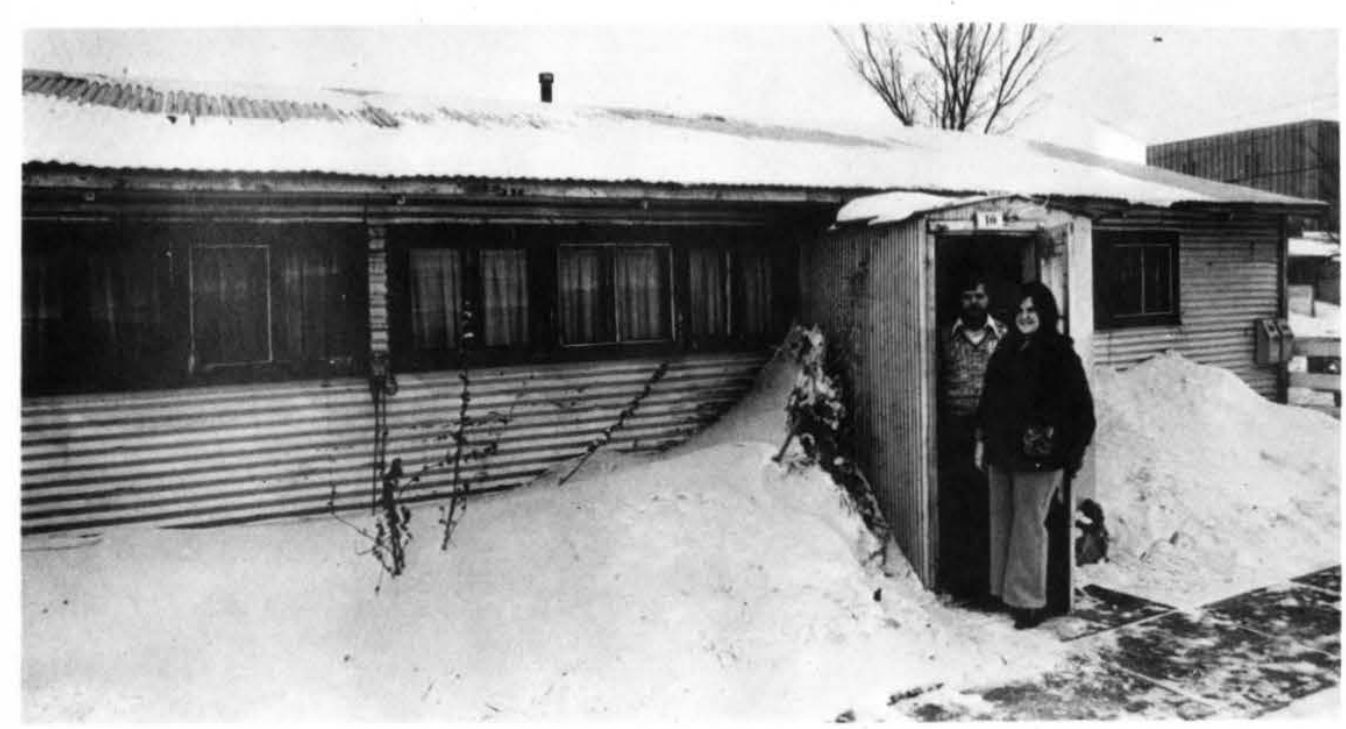

The veterans were typically older than the other students in their classes, often identifiable by their dress, which probably included some form of army issue, and perhaps a little more serious about their studies, if for no other reason than the fact that their benefits were contingent upon periodic certification by the professors that their class attendance and performance were satisfactory. Veterans also brought another new aspect to college life: nearly one fourth of them were married and some had children.

The University at first attempted to meet the need for married housing by makeshift means. Wooden barracks and corrugated iron (tin) huts were acquired from the government and erected on campus, and a trailer camp was established. The phenomenon of the married student, 
however, did not prove temporary. Traditionally, colleges had been for single men and women, free to pursue their educations and extra-curricular activities with the independence and perhaps even the irresponsibility of the young. The married student was a pariah, seen as a misfit by the single students and sometimes unofficially prohibited from enrolling by the administration. Veterans who were married when they came to campus, or who got married while attending school, did much to change this long-standing prejudice and affected the lifestyles of many other students. By the close of the 1950 s, the married student, veteran and non-veteran alike, had achieved acceptance and respectability at UND.

The University recognized this fact and in the early 1950s began erecting permanent brick apartments for married students on the west side of the coulee. In 1956 the tin huts, which had been in use since 1947 , were moved to this site.

Although considered temporary, the tin huts remained in use until their final demolition during the summer of 1982 . Despite their bare concrete floors, drafty doors and windows, and often inadequate heating facilites, many former students who, because of the low rent, were able to bring their families to campus remember them fondly. From such simple beginnings, the University has come to recognize that married housing is a permanent feature of college life. Today, such facilities on

campus feature carpets, paneling,

laundromats and parking lots with plug-ins for car heaters.

The University did not neglect the housing of single students. By the close of the 1950 s, dormitory facilities were available for one third of the student body and an additional one sixth were living in fraternity and sorority houses. Because dormitory construction has kept pace with growing enrollments, this trend of students living on campus in supervised housing continues at the present time, resulting in an enhanced spirit of community on the part of the students, and giving parents, faculty, and administrators a comforting sense of knowing that Alma Mater is in a position to guide the lives of many of her sons and daughters.

The influx of large numbers of veterans onto the campus during the postwar years had other effects on the tone of student life, many of which would have lasting consequences. The hectic pace of partying, the eager, sometimes rebellious acceptance of faddish behavior, the divisive competition between Greeks and independents for campus offices and popularity awards, and the sophomoric hazing of freshmen - all conspicuous features of the campus scene in the 1920 s and 1930s - now lost much of their significance.

Social life did not disappear at UND, but it became more democratic. With the construction of dormitories and a new student center with bowling alleys, pool tables, snack bar and lounge facilities and a ball room, the fraternities and sororities no longer enjoyed exclusive possibilities for comfortable living and enjoyable leisuretime activities. Their clandestine liquid refreshments seemed somewhat juvenile compared to an evening at Whitey's or the Ryan Bar enjoyed by the older veterans.
The spark also seemed to go out of king and queen elections, the exuberance of organized cheering at athletic contests, and the pride in a winning team. Of the traditional activities dating from the 1920 s, only the Flickertail Follies remained alive and well, achieving new heights of the spectacular before an approaching demise. Distinctive male-student costumes, such as the pipe, the rolled-up trousers, and the racoon coat of earlier generations, gave way to fashions accepted by society at large and reflective of middle-class respectability.

Traditional rivalries between Greeks and independents and between upper and lower classmen tended to disappear because of the changing composition of the student body. Older, more mature students, sometimes with family responsibilities, had left the fun of childhood behind them. Campus life was less exciting as a result, but also less chaotic. Much of the political rivalry for student offices and the hazing of freshmen had been based upon clearly defined undergraduate classifications. Now, with mid-year or summer enrollments by veterans, clean-cut,

homogeneous grouping according to class standing disappeared. In fact, formal class organizations disappeared. Representatives to the Student Council, formerly chosen in class elections, were now selected by the various housing units. Lack of conspicuous distinctions based upon economic status also contributed to the cohesing of the student body. As had been true in the past and as would continue in the future, the vast majority of young men and women at UND earned at least part of their expenses, if not out of necessity, then in deference to 


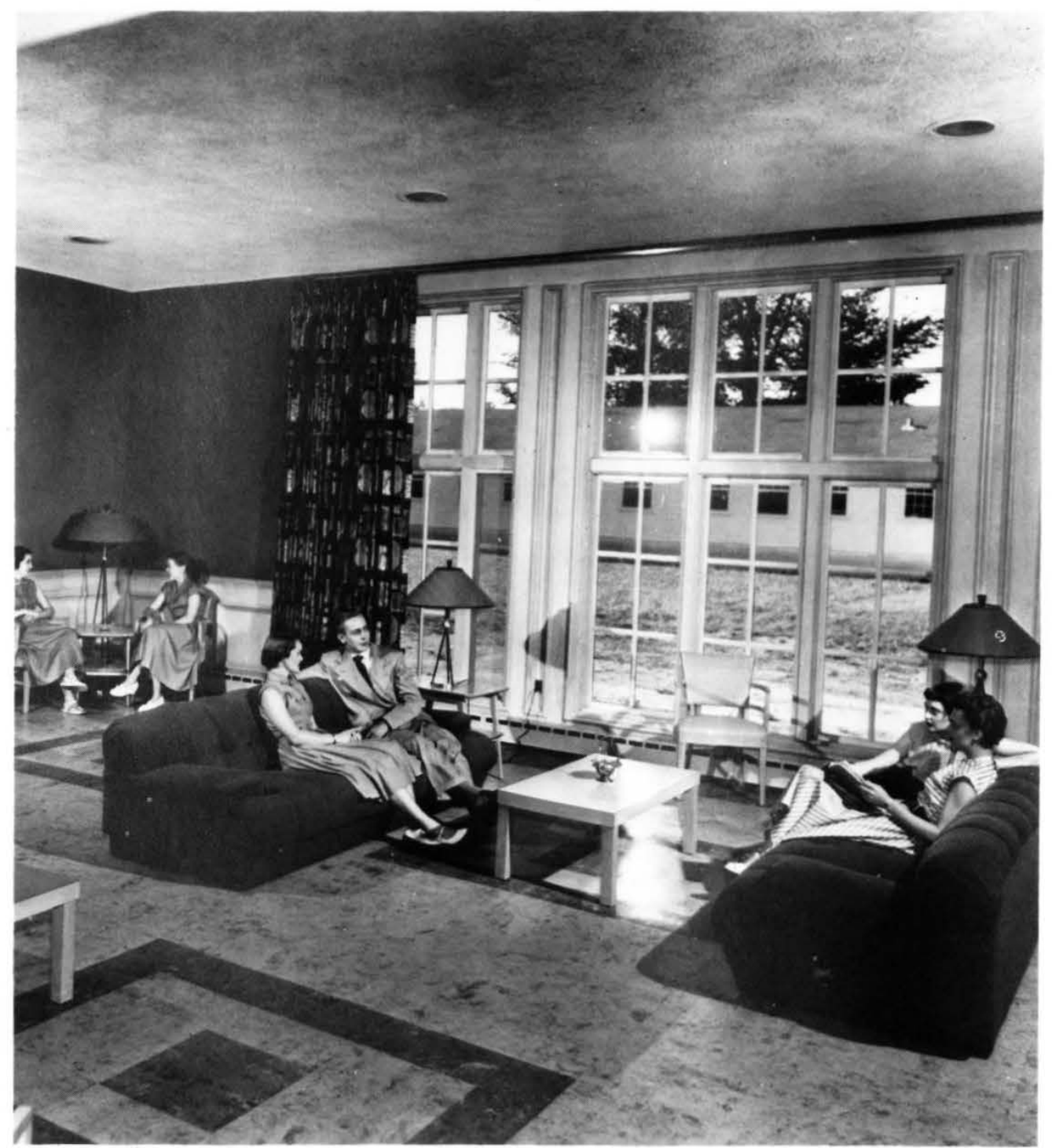

the traditional work ethic of their parents. The creation of a true collegiate

community, unmarred by competing

constituencies, which had been the dream of the first college students at UND, was approaching fruition.

In retrospect, the students of the 1950s would be called "The Silent Generation," because of their apparent apathy or perhaps seriousness of purpose in pursuing future career goals at the expense of immediate pleasures. Judged from the perspective of their predecessors, they lacked the old school spirit; some of their successors in the 1960s would find them to have been lacking in true social awareness and dedication to vital causes for setting the world right. Perhaps, in truth, they were merely pursuing the American (middle class) Dream, which had so recently been threatened by the nightmare of economic depression and world war.

Enrollment at UND continued to grow during the 1960s, going from about 4,000 students to about 8,000 . Most of the students, as had always been the case in the past, came from North Dakota. Much of the growth reflected the increased

availability of student financial assistance in the form, for example, of federally insured loans, a federal work-study program, scholarships, veteran benefits and Indian grants. By 1970, slightly over 60 percent of the full-time students on campus were receiving some form of financial aid. During the decade the percentage of women comprising the student body increased from about 30 percent to 50 percent. In 1970, there were about 100 American Indians on campus 


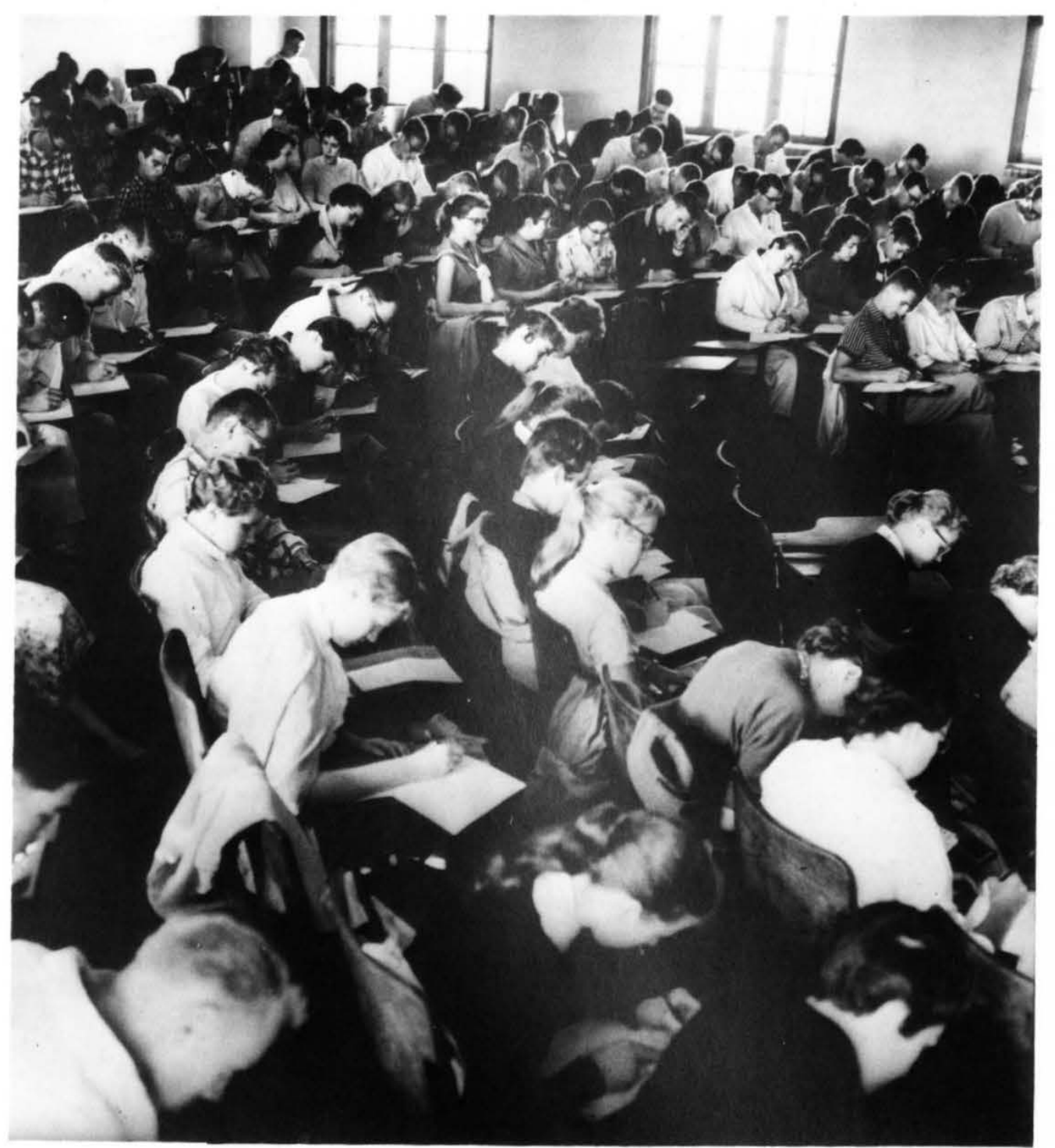

and about 20 blacks. Approximately 25 percent of the students were married. Housing patterns changed during the decade. Students living in dorms decreased from about 50 percent of the total to 40 percent. Students living of $f$ campus increased from about 30 percent to 54 percent. Those living in Greek houses declined from about 20 percent to 6 percent.

With increasing numbers and the declining significance of veterans in the school population, some, at least, of the old school spirit returned in the early 1960s. The King Kold Karnival, dating from the mid-1950s and featuring snow sculptures, a dance and a queen pageant, attracted heightened interest. Rivalry between Greeks and independents again surfaced in king and queen elections; some students complained that school publications were too fraternity and sorority oriented. Drinking, especially by underage fraternity members, became visible problem. Recognizing this, the organizations themselves in 1968 chose

"Facing Up" as the theme of Greek Week, addressing their problems rather than emphasizing festivities. Spring hijinks took on new life. In 1962, a water fight beginning on University Avenue eventually brought out some 800 students, tearing down and burning telephone poles, blocking traffic, breaking car windows and throwing coeds into the coulee. The spring panty raid of 1967 was less destructive. Such activities as these were responsible for the only major involvement of the Grand Forks police in the campus scene during the $1960 \mathrm{~s}$. 
King Kold Karnival ice sculpture in front silon house, 1960.

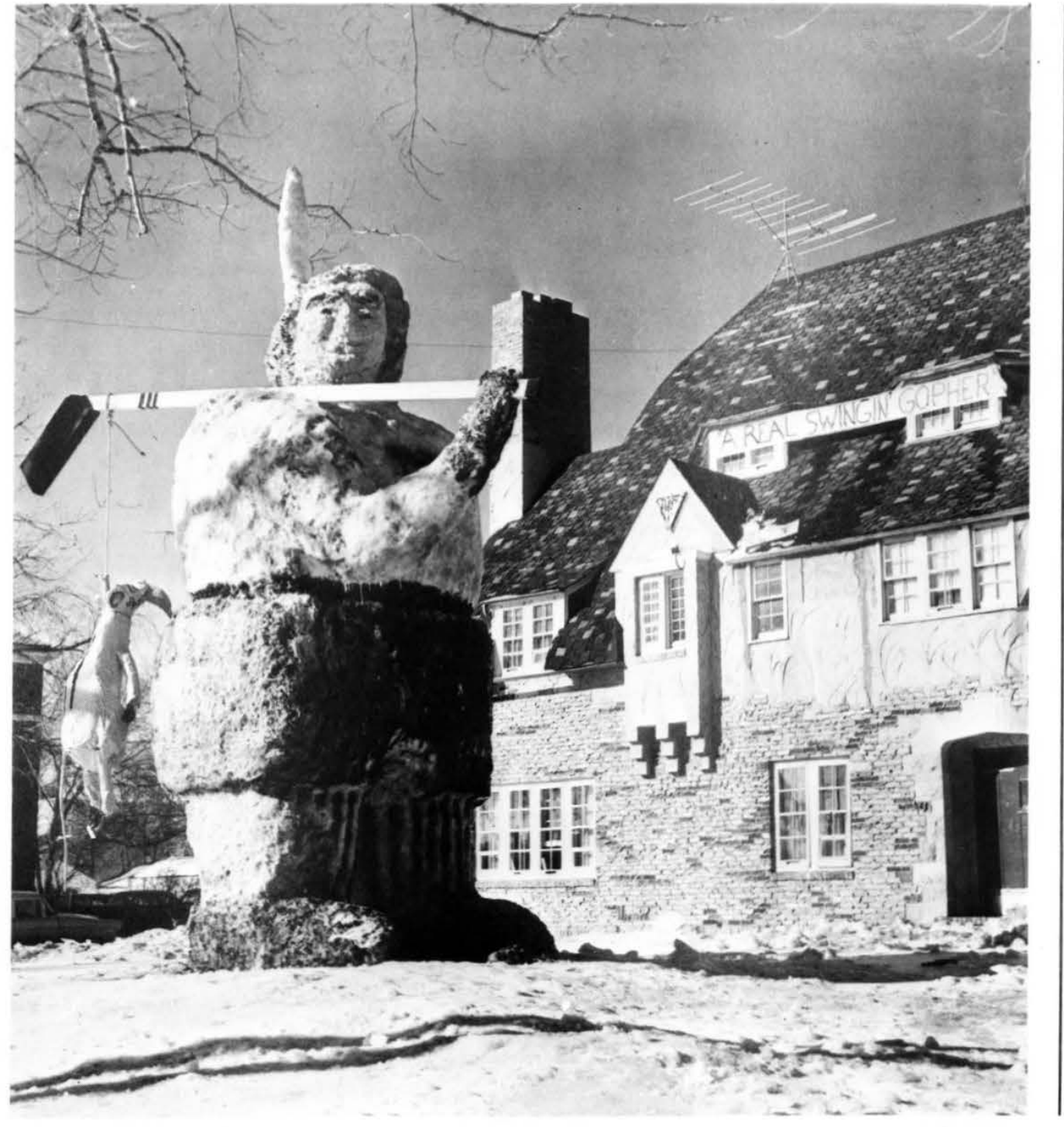

In April 1969 many UND students participated in the "Zip to Zap," a poorly conceived and coordinated student gathering at the little town of Zap, N.D. Some 3,000 students, mostly from North Dakota, sang, danced, and drank in the countryside; about 150 of those in attendance, many of them not students, vandalized the small town, inflicting between $\$ 5,000$ and $\$ 8,000$ in damages. Five hundred National Guardsmen were called in to restore order. Later, UND students contributed to a relief fund for the victimized community.

In many respects, UND students followed national collegiate fads. The Beatles were admired, and the Four Seasons were brought to campus. Men's hair became somewhat longer; women's skirts, somewhat shorter or replaced by the pants suit, which, according to the Dakota Student in 1966, was replacing "yesterday's feminine frills." At a time, however, when raggedness characterized the attire of many students elsewhere, the Association of Women Students at UND found interest in and support for its annual contest to select the best-dressed woman on campus. Controversial figures, including George Lincoln Rockwell of the American Nazi Party and Gus Hall of the American Communist Party, spoke at convocations, arousing more interest of campus than on. Marijuana and other drugs produced much concern but few arrests.

Changes in the relationships between students and university, often the subject of heated controversy and even violence on many other campuses, evolved in relative 
calm at UND. A few students might speak of the impersonal "Multiversity of North Dakota," but Alma Mater usually

responded gracefully to the changing times. Hours for senior women and those 21 and older were abolished in 1967; by 1971

hours for all women had been abolished. In 1971, the first coeducational dorm opened on campus, with men and women over 21 living on separate floors. The Dakota Student published its first "fourletter word" in 1966 and found as much support for freedom of the press among faculty and administrators as among students. In 1967, a pass-fail grading system was introduced on a limited basis. In 1968, the English Proficiency Test was abolished as a graduation requirement. In 1969,10 student members were added to the University Senate, the representative governing body of the University previously limited to faculty and administrators. In 1970, the University adopted a policy of expecting but not requiring class attendance. Often, faculty were as influential as students in bringing about these changes.

The 1960s are remembered as a time when campuses nationwide were politicized in the direction of liberalism or radicalism by anti-war and civil rights movements, but at UND most students continued to exhibit the conservatism of their predecessors. In 1963, the assassination of President John F. Kennedy two months after his appearance in the UND Fieldhouse produced mournful respect on campus but not the widespread sense of personal loss and emotional frustration experienced by many students in other parts of the

country. In 1968, in a nationwide, student- run presidential preference primary, UND students voted overwhelmingly for Richard M. Nixon; nationally, the first choice among college students was Eugene McCarthy. At UND the majority of students, when they expressed concerns, emphasized such things as lack of parking lots and adequate seating at athletic events, the quality of food in the dorms, and the price increase (in September 1968) from five cents to ten cents for a cup of coffee in the campus snack bars. Male students became increasingly concerned about the draft and their college deferment status, but only about 20 of them attended a meeting in October 1967 to discuss resisting the draft. Draft-card burning never became an acceptable form of expression on

campus. Perhaps the editor of "Ignite," a short-lived underground publication at UND, did not overly exaggerate in 1968 when she observed: "There is a complete lack here of the radical thought which dominates the youth movement all over the world."

Those students at UND who actively opposed the war in Vietnam, although dedicated and vocal, were always a small minority. For example, when 16 faculty members conducted an eight-hour "teachin" on the war in November 1966, about

350 students attended; some of those complained of the one-sidedness of the anti-war sympathies that were expressed. A similar teach-in in November 1967

attracted about 600 students. During a

"Peace Week" held in April 1967, 40 students signed a protest against the war. Shortly thereafter, the Student Senate refused to endorse an anti-war resolution.

The civil rights movement also attracted

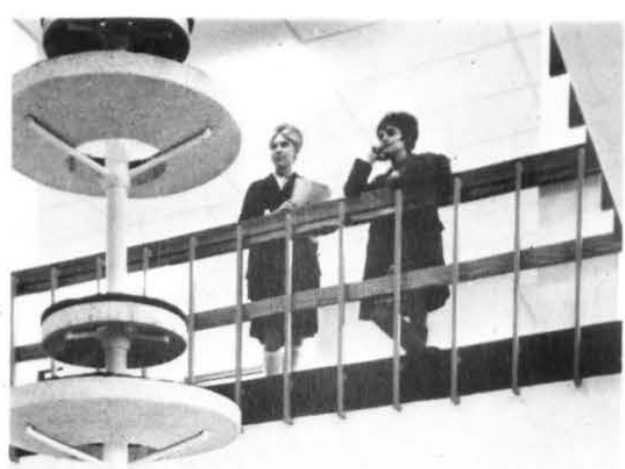

Scene in the

Memorial Student

Union, 1964.

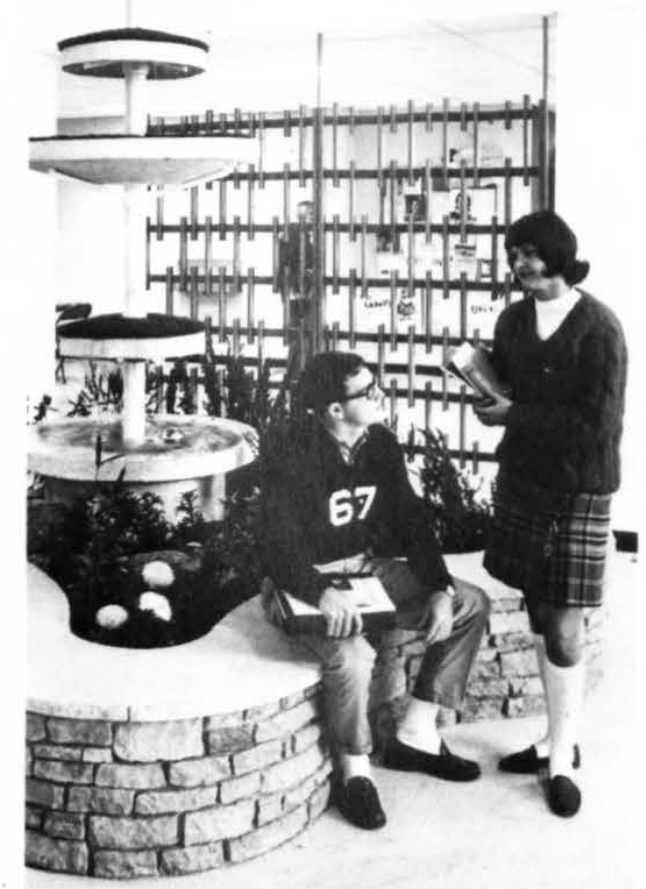


little interest in North Dakota, which in 1969 was second only to Wyoming in having the smallest number of black college students in the nation. That year there were only 56 black undergraduates in the state; 15 of them were enrolled at UND. Beginning in 1966, some fraternities and sororities on campus faced problems because of discriminatory clauses in their national charters, but this was eventually resolved without serious damage to the reputations of the organizations. In 1968, in the aftermath of the assassination of Martin Luther King, the history and English departments each added a course dealing with the black experience; the history course attracted an all-white enrollment of 14. In October 1968 at a

"Time Out" meeting to discuss state and national issues, attended by about 500 students, two black students addressed the subject of racism and expressed pride in their own heritage. During the spring semester of 1969 six black students interrupted a session of the black history course, objecting especially to its being taught by a white "honky." They were later invited to lead class discussions and express their viewpoints. In 1969, the English, history and sociology departments jointly offered the first course on campus dealing specifically with women. In 1968, the UND Indian Association was formed by 17 members, especially for the purpose of encouraging Indians to attend college; in 1971 the Association dedicated the Indian Cultural Center on campus. The Black Student Union would also acquire permanent quarters on campus, and a Women's Center would be established in response to feminist concerns.
The killing of four students by the National Guard at Kent State University on May 4, 1970, was the occasion for the largest student demonstration at UND. While many colleges across the nation were closed by student strikes, at UND classes were offically cancelled on May 5 for a day of mourning. A crowd of between 1,500 and 2,000 students gathered in front of Twamley Hall, where speeches and a rock band dominated the proceedings. Many students, unsympathetic to the methods of protest dominant on other campuses, found the idea of a "peace picnic" and a "rock concert" involving the cutting down of an American flag and inflammatory speeches to be irrelevant and inappropriate to the solemnity of the occasion. Some were concerned lest their attendance be construed as support for the anti-war and anti-ROTC cause. A small group did gather at the UND Armory, shouting at the commanding officer; but when a door glass was accidently broken, some students took up a collection to pay for it. The next day 50 students, calling themselves the Strike Committee, tried to keep interest alive, but the best they could manage was a "psychological strike." Students returned to classes, but they were encouraged to continue discussing the issues of the day. Many did so in classes, in the dorms, and in fraternity and sorority houses; but shock at what happened at Kent State did not significantly change student attitudes or methods of expressing concern.

During the decade of the 1970s,

enrollment, although growing more slowly, would reach 10,000. Men and women students continued to make up about equal proportions of the student body. There would be lingering traces of the 1960 s on campus, visible in such forms as blue jeans as the standard dress for men and women, and an occasional beard, but these were no longer signs of protest. Even for the Greeks, blue jeans replaced the blazers of fraternity men and the matched sweaters and skirts of sorority sisters. In appearance at least, the 1960s had a leveling effect on campus.

Many students of the early 1970 s seemed to lose interest in most contemporary issues. In February 1971 Dr. Beulah Hedahl, director of the UND Counseling Center, told a faculty audience that current student apathy and listlessness were as disturbing as the protests and demonstrations of the previous spring. "Students," she concluded, "seem to be saying what's the use in trying, we won't be heard, nothing will happen anyway." Some students, also concerned with the situation, formed RAP, a student-run counseling service. Sixty students in 1970 volunteered to staff the service; the Counseling Center provided training seminars for them. Hundreds of students visited RAP's office or telephoned to discuss personal problems with fellow students between 7 p.m. and 7 a.m., when other counseling service was not available. In May 1971, students organized a

"Festival of Love and Life" to combat the growing feeling of negativeness, but it was poorly attended. Only about 200 participated in an evening march from campus to town.

Although not overly vocal, students did have opinions. In a campus poll conducted in the spring of 1971 , nearly 90 percent of the UND students now favored military 
$\sum_{0}$

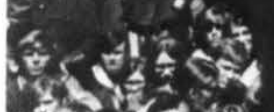
$\rightarrow \rightarrow x^{2}$ $x \rightarrow t^{3}$ $\rightarrow-1$

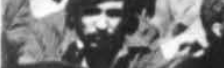

VIf

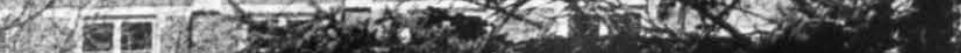

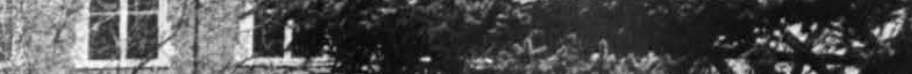

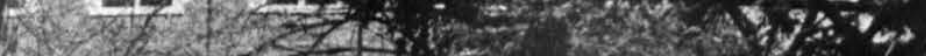
A 1 $+101+2-i$

- 1)

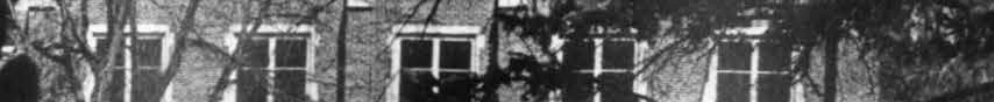
11 Hit Lin is Ins

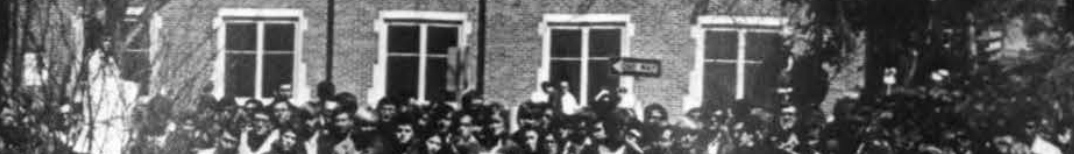

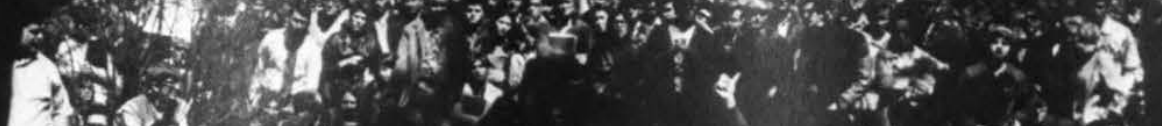

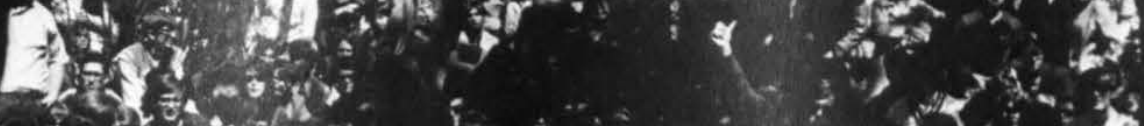
Q

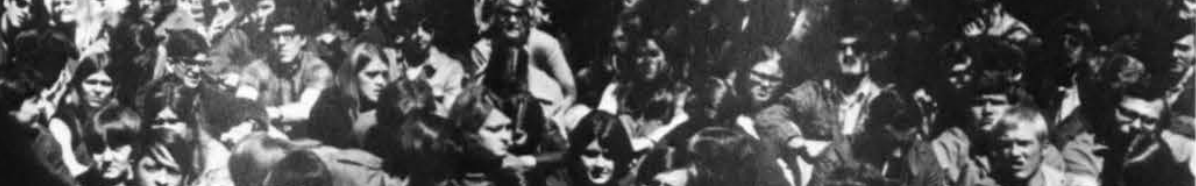

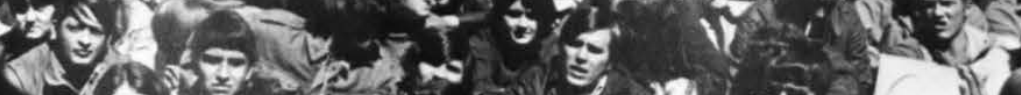

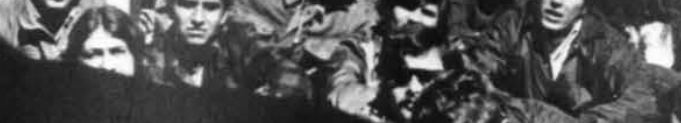

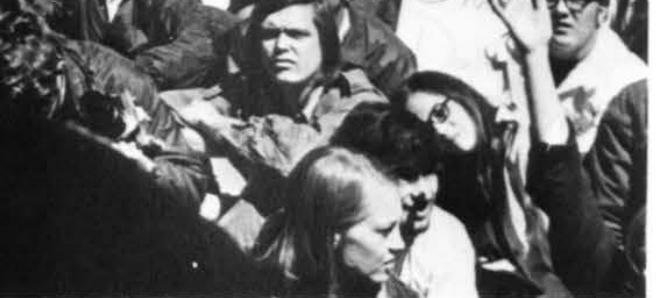


On the way to class, late 1970s.

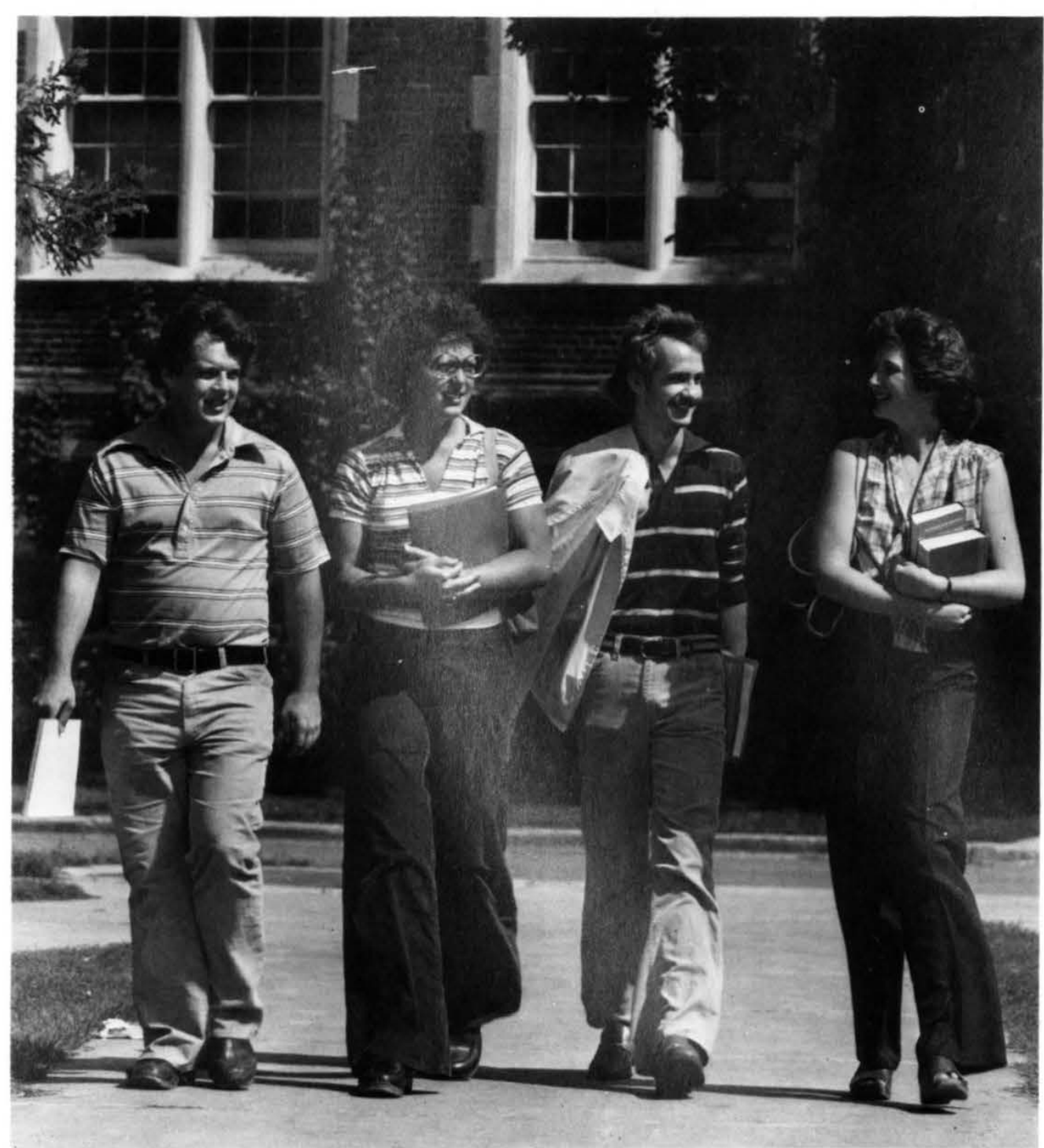

withdrawal from Vietnam. As the 1970 s progressed, student concern turned to other issues. "Earth Week" programs addressed such environmental issues as strip mining in western North Dakota and the use of DDT. Some students became involved in

local and state politics. Others agitated for the right to have refrigerators in the dorms; some favored a referendum on 19 year-old drinking in the state. Need for

facilities for the handicapped were discussed and effectively met by the University. Some students felt that there was a significant need for more rock concerts on campus; Three Dog Night played to a crowd of 8,000 in the Fieldhouse in 1973, but most other such ventures resulted in financial losses.

Women's Lib, as it was called in the early 1970 s, continued to attract attention late in the decade as the Feminist

Movement. The pros and cons of abortion remained an issue even after the Supreme Court decision of 1973. So did birth control, equal economic opportunities, and sexual harrassment on the job. In 1971,

concerned women succeeded in getting the University to rescind its policy of always considering the husband to be the head of the household when determining eligibility for assignment to married housing. A Women's Center, first opened in 1972 in Budge Hall and then moved to the University Center, in 1974 occupied its present quarters.

With the exception of spectator athletics, few campus activities produced widespread interest or a closeknit sense of community. This was reflected in the discontinuance of the Dacotah annual with the 1972 issue, and the tongue-in-cheek appearance of two 
male candidates for Homecoming queen in 1973. Generally speaking, small groups of students went their own ways in pursuit of their particular interests. By 1973, there were 120 recognized student organizations on campus offering a multiplicity of activities. Even these did not seem to cater to the interests of all students; some, in increasing numbers, turned to the solitary rewards of jogging.

By the mid-1970s Greeks were again dominating campus elections, but more from lack of interest on the part of others than from their own renewed political activism. In fact, Greek organizations began losing some of their appeal. Rush figures for fraternities dropped from 420 in 1969 to 308 in 1970; sorority rush figures from 430 in 1969 to 323 in 1970 . By 1974 about 15 percent of UND undergraduates belonged to fraternities and sororities.
Greek life, however, began to take on new vitality toward the close of the decade as new chapter houses were built or older ones remodeled and enlarged. In 1980 , there were eight sorority houses and 12 fraternity houses on campus.

To many of the faculty, at least, the students of the 1970s seemed reminiscent of earlier generations. There was still a touch of the concern characteristic of the 1960s; there was also the seriousness of purpose of the 1950s, and some of the anxiety of the 1930s, now produced by inflation, unemployment and the uncertain future of federal student financial assistance; there was even an occasional hint of the playfulness of the 1920s. All this, of course, was tempered by the pioneering spirit and cautious conservatism of the first sons and daughters of Alma Mater.
The students of the 1980 s, the Centennial generation, are still making their marks on the University. For most of them, as for those who have gone before, their college experiences will be the stuff of which fond memories are made. As The Student editoralized in 1904, "College life is, like all other life, sweet or bitter just as you will have it." For most, it has been sweet. The valedictory speaker for the Class of 1890 affirmed that "we shall always hold in our hearts a warm place for the University of North Dakota, and all connected therewith." In 1980, a graduating senior and sports editor for the Dakota Student, separated by a change in literary style but not in sentiment from that valedictorian of nearly a century before, signed his last column: "Hey, UND, see you later. I'm gonna miss ya.' 


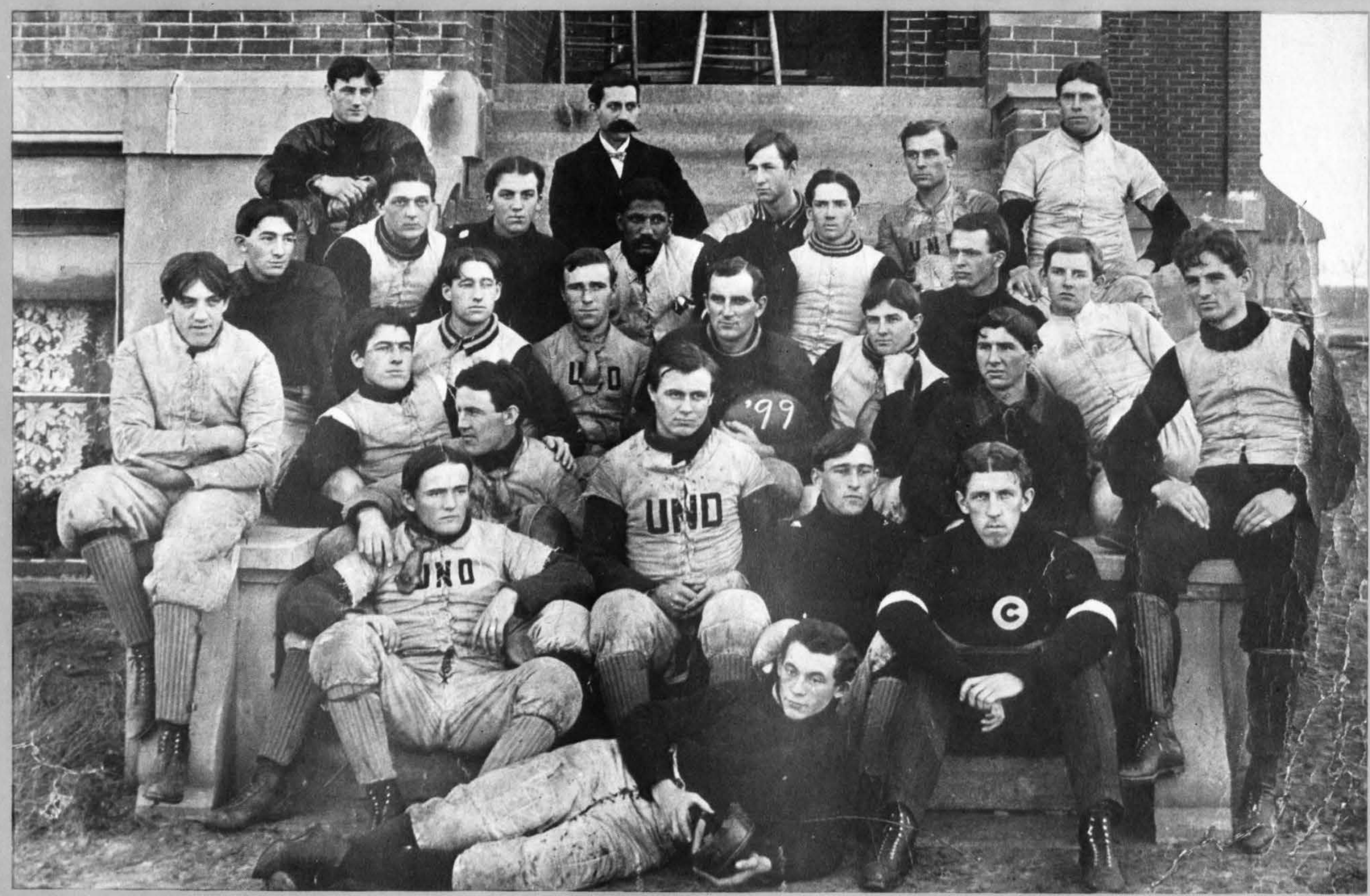




\section{Athletes}

\section{By Lee Bohnet}

Sports Information Director

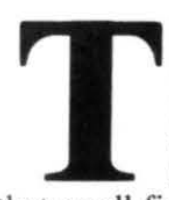

he University was founded in 1883 with no plans or provisions for organizing athletics of any kind.

Possibly the only activity for that small first class of students on the western prairie was ice-skating on the

English Coulee. The second president,

Homer B. Sprague, who had observed the emergence of Yale as the nation's athletic colossus before he came to North Dakota, put the vacated basement dining room of Old Main to use as a gymnasium with dumbbells, trapezes and bars, but because of the low ceiling, this proved

unsatisfactory. In 1888, Sprague suggested that the students form what he called the Olympic Athletic Association. This student-run group's primary concern was the preparation of playing fields for baseball, croquet and tennis. Sprague and the faculty absorbed the expenses. In the spring of 1889 , the year North Dakota was admitted to the Union, the Olympic Athletic Association organized a baseball team, and played two games against a

Grand Forks amateur team, winning both. It was the first athletic contest played by a
University team. That same spring heavy rains washed out a field day (track meet). Sprague apparently knew the value of diversification and in 1890 asked the Legislative Assembly for $\$ 10,000$ for a gymnasium, which was not appropriated.

The Dakota Student decried the lack of physical activity and argued in favor of a football team. But not until several faculty members took interest was one formed in

the early 1890 s. Professor Adoph F.

Bechdolt, who taught English and education courses, had seen the game played at Lafayette and assembled a team in 1892 , but it played only intra-squad games. Bechdolt's first team was captained by John S. Macnie and included Goldwin Sprague, Bardi Skulason, Samuel J.

Radcliffe, Colby Rucker and Rolla Currie. The arrival of a head for the military department, Lieut. Charles S. Farnsworth, in October 1893, and the presence of Willian Patten, young professor of biology, was the catalyst that led to the formation of a real football team that would play outside competition.

Farnsworth, who rose to the rank of major general of infantry in World War I, had played football at the U.S. Military Academy and Patten had played at Harvard.

The students hailed Farnsworth as a godsend, but he was handicapped by players who had little experience, and by weather. Neither Farnsworth nor Patten played in games against collegiate

opponents that first season but did against the local high school, when not enough

players were available. The first game was played on Oct. 22, 1894, and the University pummeled a Grand Forks team, 54-6, with Farnsworth at center. In the first collegiate game, the North Dakota Agricultural College (NDAC) beat Farnsworth's charges, 20-4 on Nov. 4. NDAC used some faculty members, giving rise to University resentment and bad feelings. Five days later the University again defeated the city team, 18-4, and in a return contest at Fargo, the "Farmers" won again, 24-4.

Farnsworth again served as coach in 1895. Only two games were played, resulting in a 42-0 victory over NDAC and a 12-4 loss at Fargo on a field covered by several inches of snow. Farnsworth, a
Future Governor Lynn Frazier, holding ball, was the captain of the undefeated football team of 1899; to his right is future congressman and Presidential ca didate William Lemke, in front of Frazier is future State Chief Justice William Nuessle, to Nuessle's right is Joe Flanagan. later selected as the top athlete of $(/ N D$ : first half century. 
popular coach who also taught mathematics, reorganized the Olympic

Athletic Association into the University

Athletic Association, which controlled the financing and handling of athletic events. Football under his direction in 1896 took a sudden rise when the great Joseph

Flanagan arrived on campus from Gardar. Flanagan, who earned seven football letters as a student in the high school preparatory department and four years of University courses, later was named the University's greatest athlete of the first 50 years. He led the team to a 52-0 victory over the

Crookston city team and over NDAC, 58 12. Road games were cancelled because of heavy snowfall.

Melvin A. Brannon, who would become UND's first dean of medicine, had seen the game played while a student at Wabash College and had helped Bechdolt organize the 1892 and 1893 teams, became coach when Farnsworth was recalled into active military duty in 1897. Brannon knew the rudiments of football and directed the team for two years. His 1897 team shut out NDAC twice, 39-0, and 20-0, but lost to Carleton College, 20-0. In 1898, the team defeated NDAC, 39-6, 15-0 and lost to Superior (Wisconsin) Teachers, 11-0.

In the summer and fall of 1899 , with the assistance of University benefactor William Budge, the first football field was laid out on the open prairie area north of the railroad roundhouse. Before 1899, games had been played on the nearby YMCA field. The University Athletic Association secured the plot by paying $\$ 150$ in back taxes. Budge helped players Lynn Frazier and William Nuessle sell advertising space on the fence, and with that income paid for the fencing. Students supplied the labo for leveling the field. Football players supplied their own uniforms and half the players purchased green stockings and the other half red ones. Each wore one of each color in games.

Bardi Skulason, a 1895 alumni and a Grand Forks attorney, spurred the fledgling Alumni Association to raise $\$ 200$ to employ ex-University of Minnesota and University of Chicago athlete, Harry C. (Babe) Loomis, to coach the football team for six weeks. Loomis became the University's first paid coach. He arrived in late September 1899, and soon put togethe a strong team that won all six of its games, giving up only five points while scoring 179. After the season President Webster Merrifield, who had seen Yale's rise to athletic dominance, at a post-season banquet for the football team told the assemblage: "I encourage athletics because I believe they do more than all of the preaching and all the teaching in our colleges toward keeping young men in the colleges of our land from dissipation and toward promoting among them clean living and pure thinking."

Flanagan, who ran roughshod over all opponents, was the star of this famous 1899 team. It also included captain and center Lynn Frazier, who was the first alumnus elected governor; William Nuessle, who became the chief justice of the North Dakota Supreme Court; William Lemke, who became North Dakota attorney general, a Congressman and a major figure in organization of the Nonpartisan League; Victor Wardrope, the first alumnus appointed a University trustee; and Skuli G. (Scoop) Skulason, brother of Bardi, who later was a prominent attorney in Portland, Ore.

Loomis did not return in 1900. In his place the Athletic Association hired Victor L. Littig, who had played at the University of Iowa and was practicing law at

Davenport, Iowa. Littig was here only three weeks and won three of four games, losing at Minnesota, 34-0. Turn-of-the century football was a brutal battle of brawn. Passing was illegal, so the ball moved along the ground with the help of human battering rams. To protect the runner, offensive linemen would lock arms and mow down anyone in the way.

Littig did not return in 1901 so the Athletic Association turned the coaching over to Nuessle and "Scoop" Skulason, now students in the Law School. This team compiled a 3-4-0 won/lost record. H. C. Tweet, who had played at Minnesota in 1899, coached the team two weeks before meeting Minnesota which won, 10-0.

The University-Agricultural College rivalry already was heating up with the flames fanned by the daily papers. They were temporarily doused in 1901 with the formation of a Northwest Athletic Conference, composed of UND, NDAC, Hamline University, University of South Dakota and Carleton. Complaints that UND had played men such as Flanagan for seven years led to the formation of the conference.

Loomis returned in 1902, but with the standouts of the great 1899 team gone, the University could manage only a $3-2-2$ record. One of the losses was the 47-0 defeat to NDAC before a crowd which included 250 fans who had accompanied the team to Fargo. 


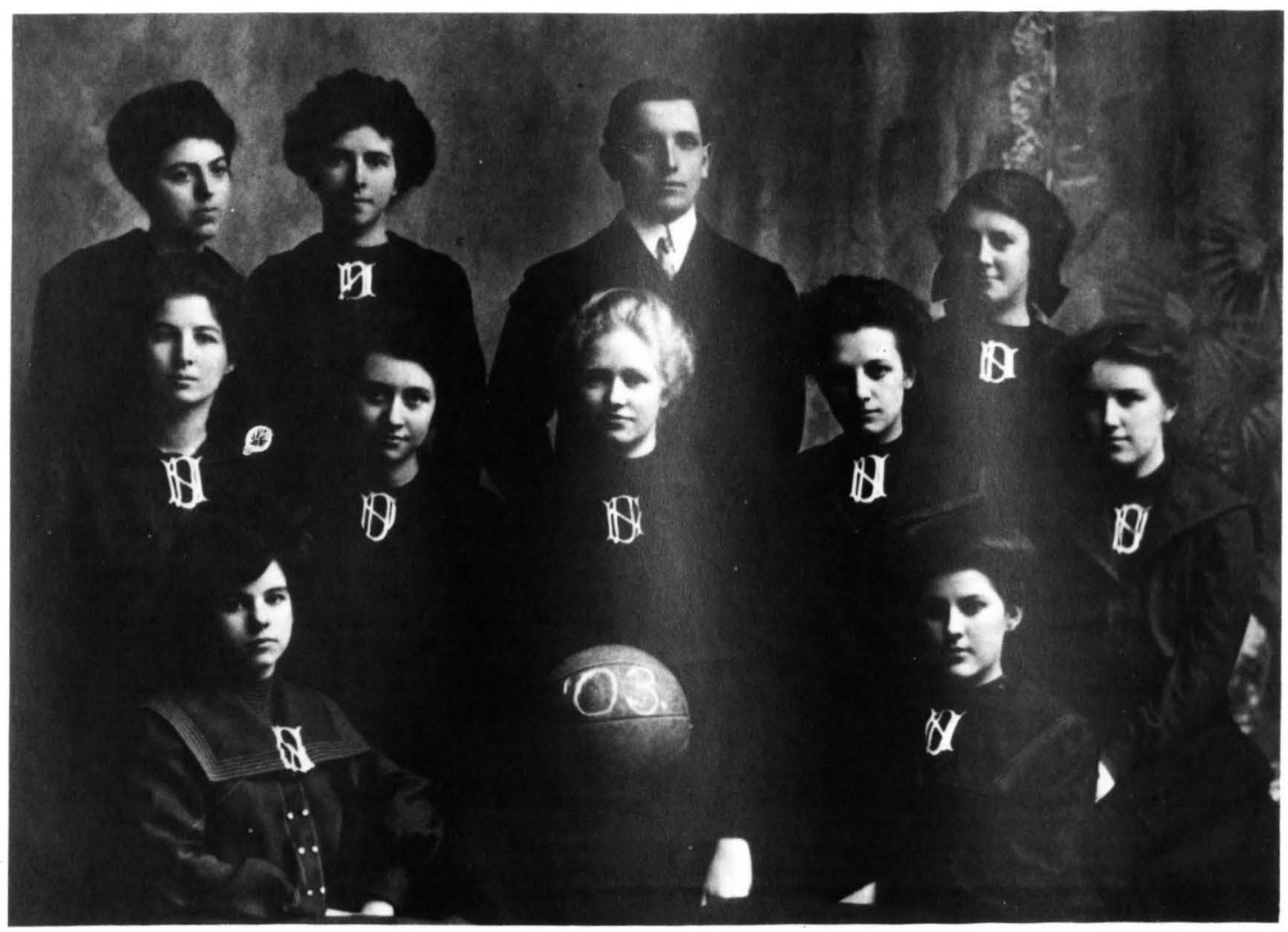

WTHLETES 
The Dakotg Student in 1902 began agitating the formation of a men's basketball team. It asked: "Every college of any repute at all in the country supports its own basketball team. Are we then, a state university, going to be without one?", Its answer, "Of course not."

During the winter of 1902, the Student reported: "The boys had cleared a large section of ground north of Old Main for a large rink and with the material on hand there is no reason we cannot have a winning hockey team."

Thomas D. Campbell, "the wheat king," recalled the first hockey efforts:

I well remember the first hockey team North Dakota ever had and we played the Grand Forks city team in the winter of 1902 03. I had learned something about hockey while attending the Upper Canada College for Boys in Toronto and, like every North Dakota boy, had learned to skate very young. We flooded the rink from a hydrant. I was elected captain and have been trying to remember the names of the other players on our team. All I remember is Roscoe Fawcett (later head of the Fawcett Publishing Company) and Harry Gotzian. We won that first game. Billy Hanrahan, a well-known Grand Forks baseball player, was captain of the Grand Forks team. We played in an old board shed with some center supports downtown. We had an ex-
Canadian professional coach with us for a few days.

Nevertheless we had a wild.

rough game and that seemed to be the end of hockey that winter. But it certainly was the first hockey ever played by the university.

During the summer of 1903 , the University Regents hired the first full-time athletic professionals. Walter Hempel was appointed director of athletics and physical training. He had played professional

baseball and football in his native Chicago, graduated from Harvard's famous Summer School of Physical Training, and later received a bachelor's degree from Harvard. $\mathrm{He}$ had served as athletic director at Knox College in Illinois and as an assistant coach at Northwestern University. Immediately he proceeded to shake things up. The othe coach, Rex B. Kennedy, had played end - and tackle at the University of Chicago for the legendary Amos Alonzo Stagg. His football team won all seven games, outscoring opponents, 274-11. He remained only one year.

Inflamatory relations with NDAC continued as the University insisted on playing a man in his fifth season. Local partisans did not know it at the time, but the "Farmers," as the papers called the NDAC team, were playing men who were receiving pay from Fargo businessmen.

To replace Kennedy and Hempel when they left in June 1904, the Regents hired George J. Sweetland who had a B.S. from Union College and the M.D. from Northwestern's Rush. Led by Victor Wardrope, the team under Sweetland had a
6-1-0 record, losing only a road game to Minnesota, 35-0. A newspaper wire account of that game from Minneapolis made what is believed to be the first

official use of the nickname "Flickertails" to describe the UND team. That nickname stuck and remained in vogue until

September 1930, when the Athletic Board of Control officially adopted "Sioux" after the Dakota Student campaigned for the change.

In 1904, due to Sweetland's insistence, the Athletic Association also approved funds for a men's basketball team, which he would coach. Students had clamored for a men's team for some time, but many of the men considered it a game for women only. The men and women practiced and played in the confining Budge Hall basement, which had only a 10 -foot ceiling and two steel I-beams eight feet above the floor running the length of the small court. That first team, captained by Glenn $\mathrm{O}$. Taylor, won seven of nine games, with both losses to NDAC.

Sweetland's 1905 football team won six games, tied NDAC 11-11, defeated NDAC 23-5, and as usual lost at Minnesota, 45-0. UND and NDAC squabbled over the eligibility of two UND players that season and the issue remains clouded, with UND supporters leveling counter-charges at NDAC. Athletic relations with NDAC finally were disrupted publicly in 1906 , whereupon UND tightened its eligibility rules to require that every athlete pass 12 hours of course work in two successive semesters before being allowed to compete. Furthermore, UND stated the school's refusal to schedule any school that did not 


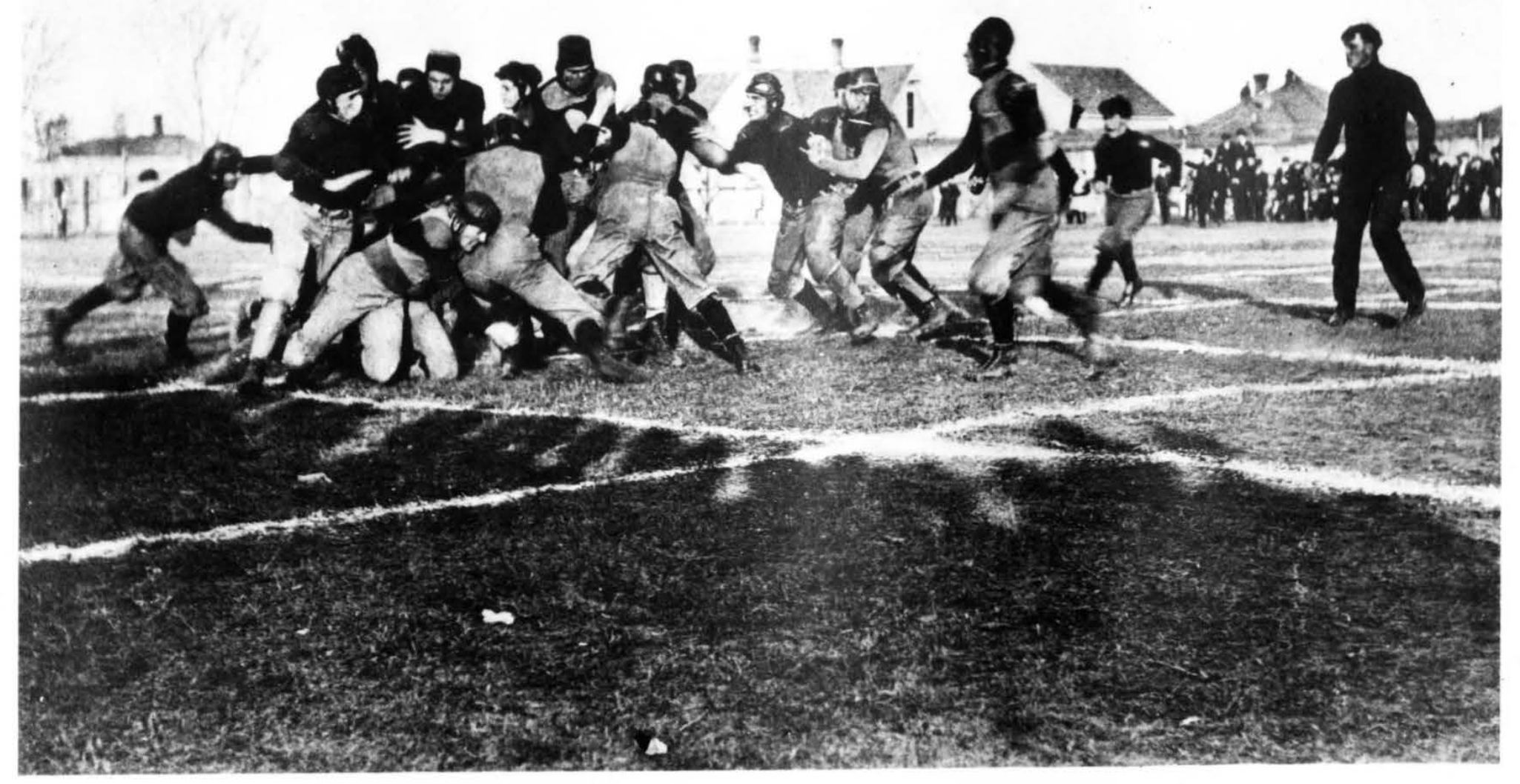


observe a similar requirement. Thus in the spring of 1907 the University suspended athletic relations with NDAC "in the interest of good fellowship,"' according to President Merrifield. The track team and baseball team moved to a new field laid out northwest of Chandler Hall, between the president's residence and the English Coulee. The track was small, 19 laps to the mile, but was used until 1911 when a new quarter-mile oval was constructed on the east side of the campus.

In 1907, when the football team had an indifferent year, students complained that the University's official colors, pink and green, "were too weak," but the vocal alumni resisted and the colors remained, although in the 1920 s athletic teams wore green and white uniforms. The Athletic Board of Control officially changed the athletic colors to green and white in 1947.

The 1907 legislature appropriated $\$ 25,000$ for construction of an assembly hall and gymnasium, which today is known as the West Gymnasium. It had a clear floor 109 by 52 feet and with its lofty ceiling was an ideal place for basketball. It had provisions for men's and women's shower and dressing rooms as well as offices for the staff.

In January 1907, Sweetland went to Everett, Wash., to practice medicine. His replacement was David Lewis "Dunny" Dunlap, who in 1906 received the M.D. from Michigan where he had played on coach Fielding H. "Hurry-Up"' Yost's famous "point-a-minute" teams. Immediately upon arrival, Dunlap set up an athletic training table at the Commons and personally supervised the meals of the players. "Dunny" was a popular and effective coach, leading his first football team in 1908 to a 5-2-0 record, and his basketball team to 10 wins in 12 games. Athletic relations with NDAC resumed, but feeling ran high as Dean Elwyn $\mathrm{F}$.

Chandler recorded: "Sometimes in those days the emnity was so heated as to result in fist-fights during games or afterwards on a public street, not only between players and coaches, but even leading faculty men." Chandler was well qualified to report on such matters. His involvement in athletic management ended in 1928 after student members of the Athletic Board of Control protested his handling of matters. A track aficionado, he worked as a meet official until 1934 when the press of other duties prevented his participation.

Chandler also planned and supervised the construction of all football fields, including Memorial Stadium, first used in 1927 tennis courts, tracks, gymnasium, and the armory.

A new era in UND's life began with the coming of Frank L. McVey as president in 1909. On the athletic front where results had been indifferent, McVey was determined to stop the "revolving door" coming and going of directors and hea coaches. In 1914, he brought in colorful Thomas A. Gill, a football star at Indiana University. Gill immediately began revitalizing the program as McVey restructured its administration.

The major decline in UND athletic fortune was due to the outmoded studentrun University Athletic Association, which provided inadequate financial support. McVey's initial insistence on student involvement in intramural sports and general physical education hurt the program. In 1914, the alumni (some of whom were powerful legislators) again became involved because of meager successes of teams. McVey sensed the drift of public sentiment. Soon a faculty proposal that the student-run Athletic Association be replaced by an Athletic Board of Control, composed of three faculty members, three students, the athletic director, and one alumni member, was unanimously accepted at a studen mass meeting. Several months later a student petition to reinstate the $\$ 2$ per semester fee for athletics, which McVey had dropped in 1909, was approved by the Board of Trustees. Gill, still in top physical condition, as a member of his scrub team often would catch punts, return kickoffs and run with the ball against the first team during practices.

Gill had over 50 football players in 1915 , but most of them were new men, and it showed in the University's 2-2-3 record. Gill had another green team in 1916, bu the season highlight came with the first UND Homecoming. The 1916-17 basketball team, led by the redoubtable Henry Murphy, won eight of nine games, with "Caesar"' averaging 22.6 points per game - astronomical in those days and representing 58 percent of the team total. The United States entered the European War in April 1917, and the 1917 football team was Gill's poorest, showing only a 2 4-0 record; but his cagers went undefeated. The draft, an influenza epidemic on the campus and Gill's departure in the spring of 1918 led to suspension of all football games, but the 1918-19 basketball team managed a 6-2 record.

Return of students with the 1918 ending 


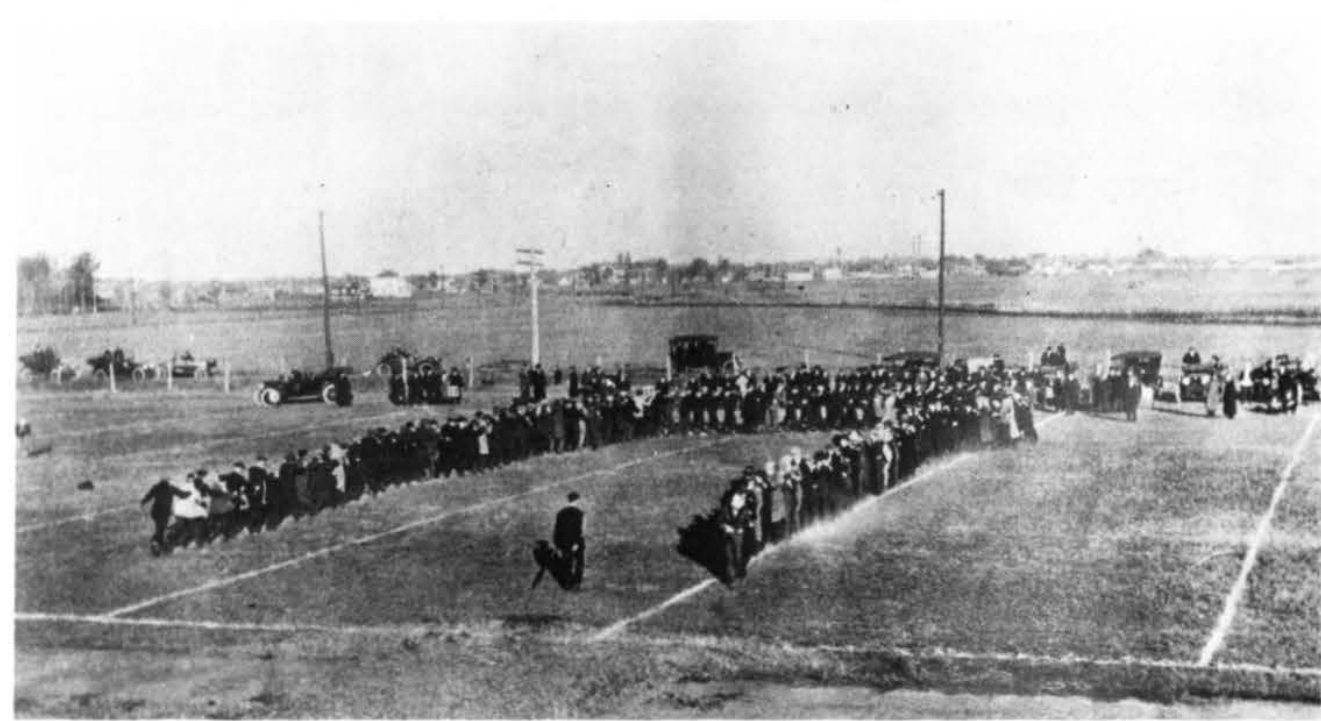

of World War I provided conditions that improved UND's athletic fortunes. The 1920 Flickertails sustained two of their three losses in intersectional play with Marquette and Valparaiso. The basketball team with a 16-0 record was the last UND hard-court quintet to go undefeated.

World War I, which disrupted athletic activity, did provide a new facility. Begun as a Student Army Training Corps drill hall in 1917 it was finished with a $\$ 35,000$ state appropriation. It served as an ROTC armory and home for basketball teams and athletic department offices until 1951.

UND inaugurated it with a 79-8 victory over Concordia College. The end of the 1919-20 season also marked the demise of the loosely-knit Minnesota-Dakota

Conference, whose father had been Dean Elwyn F. Chandler. With the blessing of however, received special attention. In a poll conducted by the Alumni Association, Joe Flanagan was the runaway winner in the voting for the greatest UND athlete of the school's first 50 years. Quarterback Douglas McKay (1913-16) came in second, all-round athlete Robert Lowe (1912-1915) third and Edgar T. "Dutch" Houser, fourth.

In 1924, troubled relations between Athletic Director and Football Coach Paul J. Davis, Kane and the alumni surfaced. Davis' 1924 football team won only one of nine games, scoring a skimpy 26 points. This was the second poorest record in University history. Basketball was not much better. The next year, Davis, who came in 1919, and Kane agreed to hire Clement W. Letich, B.A. Upper lowa 1920, who had brought a national high school basketball championship to Yankton, S.D. "Silent Clem,"' as he soon became known to writers and fans, directed his first team to a 14-4 record and a second place finish in the NCIAC.

Despite Davis' efforts to improve the overall athletic success of UND, constan meddling by the alumni and Kane brought about his departure after the 1926-27 season. Davis, who possessed great public relations talent, had powerful friends and had organized the Flickertail Club in 1923 to assist in the building of a new football stadium and in recruiting the top high school athletes in the state. Forced out of coaching by Kane, who reacted quickly to alumni complaints, he continued at UND as athletic director until 1928. Before he quit and with the assistance of Robert Murphy, president of the State Board of Administration, he hired a new football
Half time of the UNI) is. Montana game, 1915. 
Early airview of Memorial Stadium, dedicated in 1927.

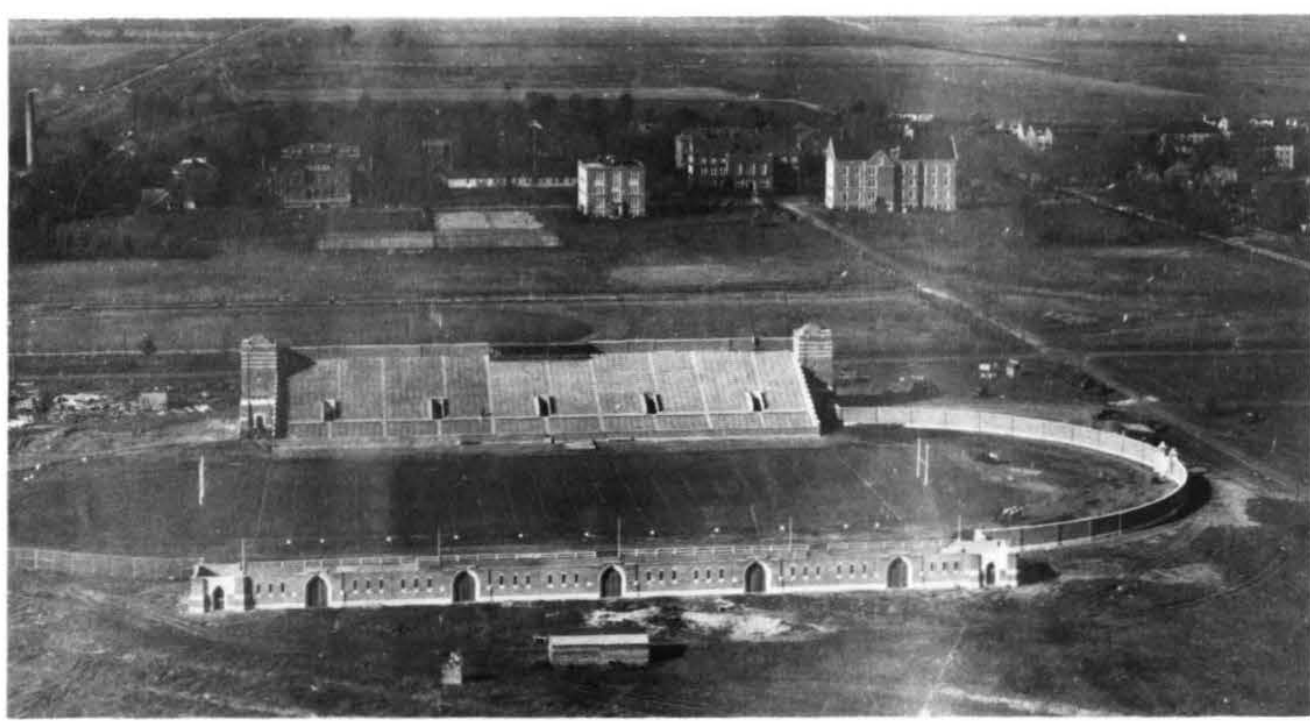

coach, Ferdinand A. (Tod) Rockwell, who had played at Michigan under Yost and had been head coach at Salem (West Virginia) College. His first team in 1926 was 9-4 and finished second in the NCIAC. The 1927 eleven lost the dedicatory game in the new Memorial Stadium on Oct. 8, 1927 , to Creighton, 7-0, before an "electrified" crowd of 7,000. Letich fared better as his basketball team, 1927-28, won the NCIAC championship with a 6-2 record and finished 13-4.

The first radio broadcasts of UND athletic contests were made by the University's KFJM, which went on the air Aug. 13, 1923. Elmer Hanson, one of the station's early full-time announcers, made the first basketball broadcasts from the Armory in 1926-27. Hanson also broadcast the first football game from Memorial
Stadium Oct. 29, 1927, when the Sioux beat NDAC, 13-0.

Rockwell went to Louisiana after the 1927-28 school year and Kane hired successful SDAC coach “Jack" West, who had been at the South Dakota school for six years, to replace Davis. West, a Coe College graduate, soon became known as the "wonder coach" and brought his star SDAC grid pupil, Clyde L. (Buck)

Starbeck to be his assistant. His 1928 football team won the University's first NCIAC championship on a 4-0-0 record and 6-1-1 overall. Clem Letich's cagers also made history as they undertook the longest, most extensive road schedule to date en route to a 17-11 season record and a second place NCIAC finish at 5-3. The trip began at Minnesota, where they won, 25-24, moved to University of Chicago,
University of Illinois, Chicago Loyola, Illinois Wesleyan, St. Louis University, Utah State, Brigham Young, Southern California and University of Washington. Stars of this team, which was plagued by injuries on the long trip, were Captain Paul Boyd, Lewy Lee, Hal Eberly, Victor Brown and the coach's younger brother, Al. The team became known as "The Nomads of the North."

Prior to the 1929 season West gained approval from the Athletic Board to install lights in Memorial Stadium at a cost of $\$ 3,443$ and night home football games were in vogue until the lights were removed in 1966. West's 1929 team won the NCIAC championship on another 4-0-0 record and finished 9-1-0 overall, losing only to the powerful Haskell Indian Institute from Kansas at home, 13-6. Center Stuart MacMillan and halfback Glenn L. (Red) Jarrett were the stars of this team.

Nationally known sports writers John McGovern and Walter Eckersall of the

Chicago Tribune termed "North Dakota. . a menace for national honors under Jack West." After the season West was chosen by the Denver Post to head up an NCIAC All Star football team to meet the Rocky Mountain Conference stars at Denver on New Year's Day. The NCIAC won, 13-7. Letich's cagers dropped to 8-8 overall and again finished second in the NCIAC at 5-3. West also promoted the second hockey team, coached by student Joe Brown. The ice sextet beat Minnesota, 4-1, but lost to a team called Bison Jockey, 4-1.

West began expanding the UND football schedule in 1930 when he booked Army at West Point, which resulted in the only loss, $33-6$, in a 9-1-0 season with another 


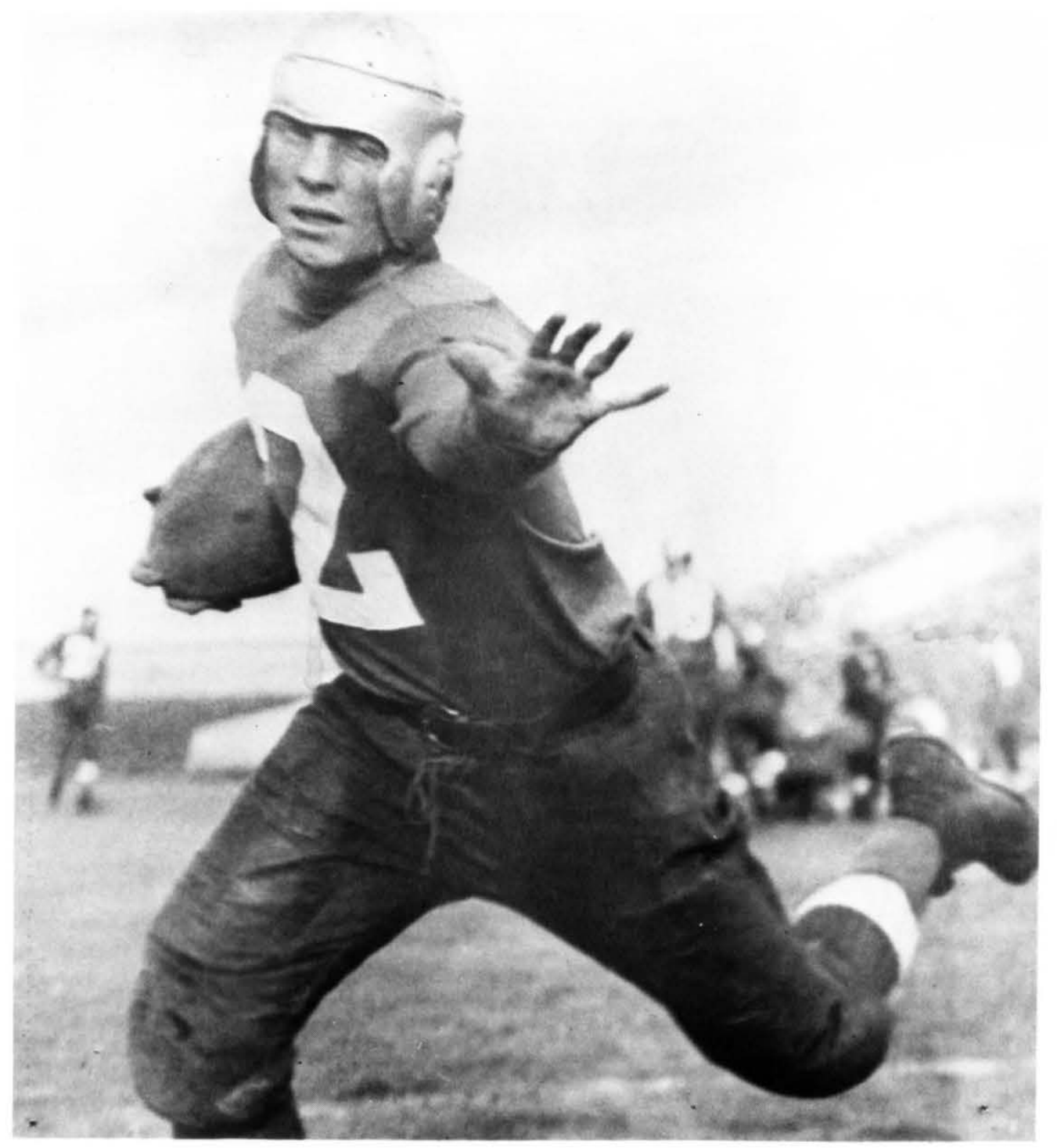

NCIAC title. Jarrett, who scored the touchdown against Army, was named to the New York Herald-Tribune All America team at halfback, the first UND player so honored. On Christmas Day, West and the Sioux beat the Los Angeles Firemen, a team of west coast major college all stars, $14-9$, in a Shrine benefit game in the Los Angeles Coliseum. Fred "Nip" Felber, named the most valuable player in the game, was held over to play in the EastWest Shrine game in San Francisco on New Year's Day. Felber had been named to the Associated Press major All America second team. A star on the basketball team, he led the cagers to another secondplace finish in the NCIAC and 10-4 overall record. During the summer of 1931, West had a nine-hole golf course built in the vicinity of the present day East Hall. Joe Brown's hockey team lost its only game of the season, 5-0, to NDAC.

West's gridiron team raced to a fourth straight NCIAC title in 1931 with a 8-1-2 record. It tied Dr. Clarence Spear's Oregon Webfoots $0-0$ before a crowd of more than 11,000 in a Homecoming game described as "the greatest ... ever played here."

Letich's cagers wound up in second place in the NCIAC again at 6-2 despite the standout play of Felber and 6-foot-7 Ted

Meinhover. West also introduced boxing as an intercollegiate sport in 1932. Prof. Howard H. Russell of the English department coached the team which beat NDAC handily in its only match. Edward O'Connor was a star of the team and was entered in the Olympic tryouts at Penn State. No hockey was played in 1931-32.

West's strangle-hold on NCIAC footbal finally was broken in 1932 when the team
Glenn "Red" Jarrett, three-sport star at from

1928-1931, and later coach and athletic director. 
The original Winter Sports Building, constructed as a WPA project in 1936. finished second at 2-1-0, losing only to NDAC, 7-6. The gridders finished 6-2-0 overall, including victories over Howard University, the black school at

Washington, D.C., DePaul, and New Orleans Loyola. Letich's cagers again finished second in the NCIAC on a 6-2 record and 16-2 overall despite playing 13 road games, winning all but one.

In 1933, Letich's basketball team took some of the sting out of a poor football showing when it won the NCIAC

championship, his second, on a 7-1 record, 15-3 overall. Herman Witasek, Ted Meinhover and Kenneth "Pinky" Mullen were the court stars. Witasek of Lankin, who later became the University's first pro player, was termed the greatest player ever developed in the state.

West returned the Sioux to the NCIAC throne in 1934. The team had a 7-1-0 overall record, losing to NDAC, 7-0; but UND shut out all of its other opponents. Irving Kupcinet, who later became a nationally-circulated newspaper columnist and a television personality in Chicago, and Jack Charbonneau were the quarterbacks of this fine team. Letich captured a second straight NCIAC basketball championship, going 9-0, and losing only at the University of Nebraska for a 19-1 season mark. Such success was not to be duplicated in 1935 . The football team dropped to second in the NCIAC and had a 6-2-2 overall record due in part to losses on the road to eastern powerhouses, Western Maryland and George

Washington.

West, a shrewd all around director and sound business operator, used the Works Progress Administration work relief

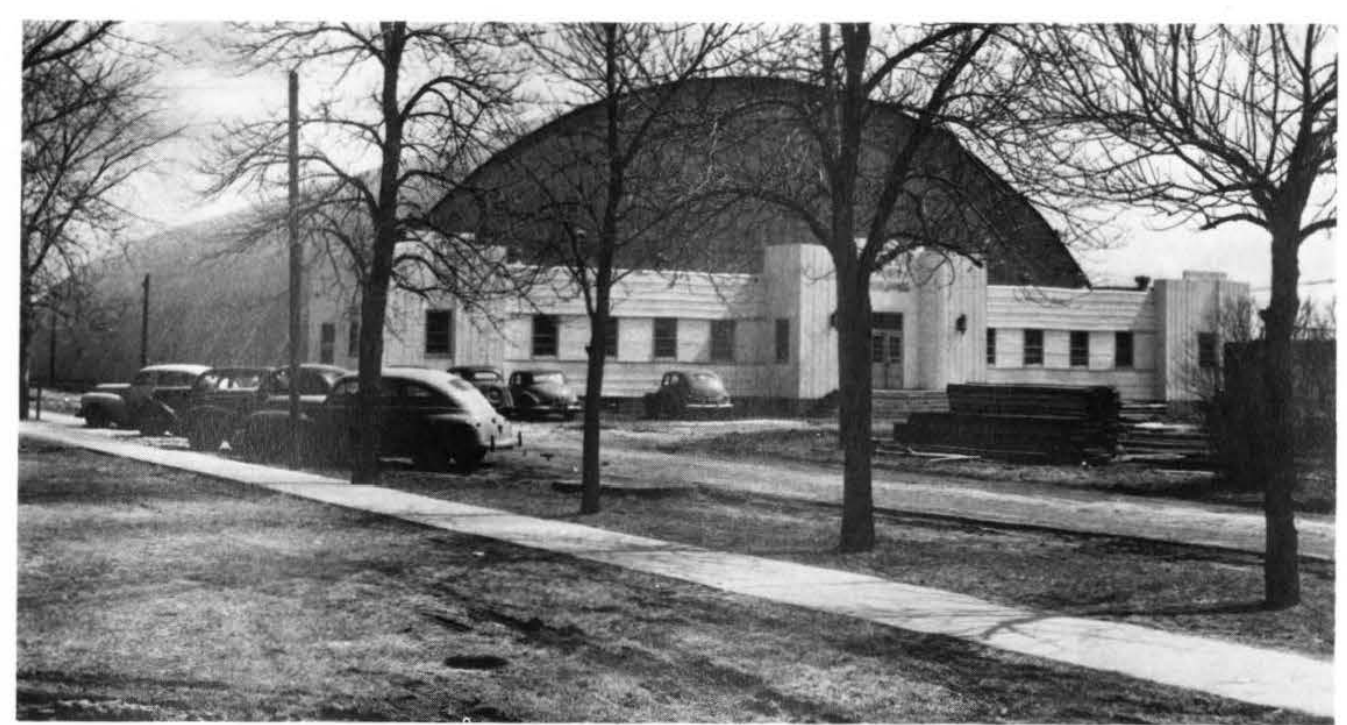

program in 1936 to obtain a $\$ 43,000$ Winter Sports Building for ice activities. The 132- by 323-foot Quonset-type, tinroofed, unheated structure had natural ice and became the home of the hockey team. Dr. Ralph E. Leigh, a local physician, member of the Medical School faculty, and remembered as one of the fathers of the Alumni Association, had become involved in local amateur hockey. When the Grand Forks Park Board, headed by attorney Tracy Bangs, turned down Dr. Leigh's proposal to sponsor the structure, he turned to West for help. West used the facility for student skating, indoor football practice in inclement weather and some track meets. Artificial ice was installed in 1954 after expanded major college schedules were being played. The United States Men's Curling Association championships were played in the building in the spring of 1961

Led by triple-threat back Frederick (Fritz) Pollard who had transferred from Northwestern, and outstanding linemen, the brothers Martin and Chuck Gainor, the Sioux recaptured the NCIAC championship to UND in 1936 on a $4-0-0$ record. The team went 9-2-0 overall. Pollard won a bronze medal in the 1936 Olympic Games at Berlin in the high hurdles despite a serious leg injury. He never did run for UND despite his considerable talent. After graduation he had a successful career in the United States Department of State. Although Pollard was the first black star, another black all-round athlete, Horace (Hoss) Johnson of Cheyenne, Wyoming, led UND to a third straight NCIAC track championship by winning the dash events. 
Emmet Birk and Bob Finnegan were standouts on the fourth straight NCIAC champion basketball team in 1936-37. Despite the availability of the new Winter Sports Building no hockey was played.

In 1937, with Pollard, tackle Jack

Mackenroth and guard Lloyd Amick, the Sioux captured their seventh NCIAC title in 10 seasons under West. They joined the cagers in second place the following year, a position from which they rebounded in 1939. Not so Letich's basketball team, which closed the between-the-wars era in sixth place.

World War II brought changes. Before entering the Navy, Glenn Jarrett took over football for the 1942 season. Letich, who during all his years of coaching the Sioux cagers taught mathematics at Central High School, died June 26, 1944, after a short illness. He had won five NCIAC championships and 223 of 329 games during 18 years. West soon followed him, resigning in December 1945, to become head coach of the professional Winnipeg Blue Bombers for three seasons. His

Winnipeg teams of 1946-48 won 13, lost 15; he lost both Canadian national championship Grey Cup final contests in his first two seasons there. After retiring from his Winnipeg position, West returned to Grand Forks to sell insurance and to indulge his passion for bridge. He died following a heart attack at his home Oct. 29,1957 . So ended the era of North Dakota's two "wonder coaches" who directed Sioux teams through their first golden era.

Jarrett had returned from the Navy late In 1945 and took the cagers to a 13-5 record in 1946, with future coach Louis

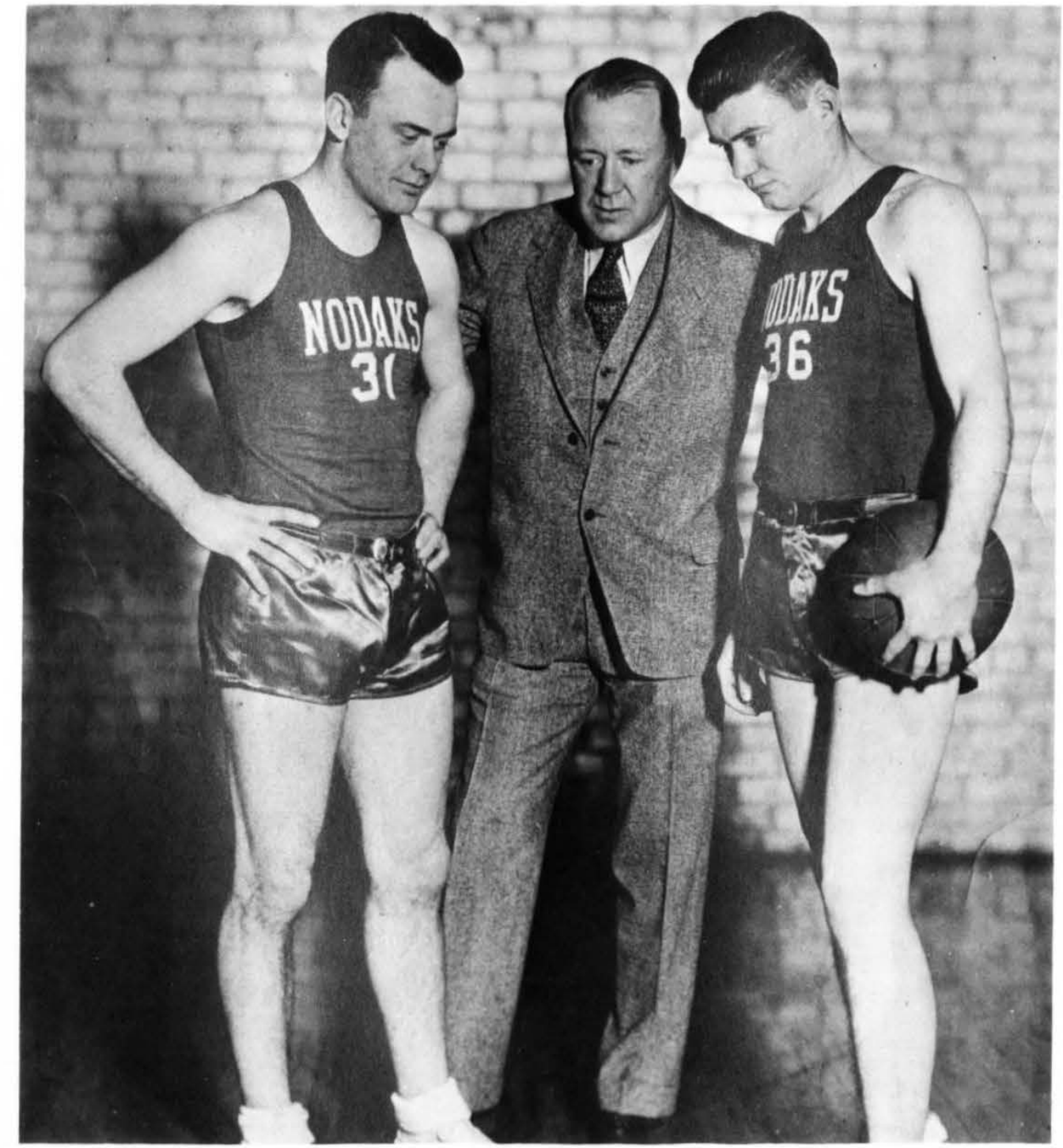

Basketball coach Clem Letich and stars Emmet Birk, left, and Bob Finnegan, who led UND to a fourth straight conference championship in 1936-1937. 
Bogan and big Tom Amberry as his stars. Jarrett had been named acting athletic director when West resigned and had the basketball and football coaching assignments. His 1946 football squad of over a 100, many of them World War II veterans, earned a 4-3-0 overall record, finishing 2-2-0 in the NCIAC, which had resumed operations. He was named athletic director in January 1946, and immediately hired Leonard R. Marti to head the physical education program. Marti, a public school principal in Bismarck, immediately organized a gymnastics team, but found the going tough since no North Dakota or northern Minnesota high school sponsored the sport. Jarrett also hired graduate student John C. Jamieson, a Canadian who played semi-pro hockey, to coach the hockey team, which had a 7-6 record in 1946-47 with only American players on the squad. To coach the basketball team, Jarrett hired Harold "Cookie" Cunningham, who had gained fame as an All America football end and basketball center at Ohio State in 1925 and later as both a pro footballer and basketball center for the famous New York Celtics. Cunningham's first cage team had 14-12 record and finished second in the NCIAC. Jarrett coached football in 1947 and had a 4-4-0 record. Graduate student Donald Norman, who had been hockey coach at St. John's University in

Minnesota, was hired to coach the skaters. With Jarrett's assistance and the work of team-member Calvin C. Marvin of

Warroad, Minn., Norman assembled a very strong team. On Jan. 10, 1948, the Sioux shocked Michigan's Wolverines, 6-5, at Ann Arbor. That milestone victory marked North Dakota's entry into big-time hockey.

Increasing enrollment and interest in sports by students prompted Jarrett and President West to ask the 1947 legislature for funds for a new athletic and physical education facility to replace the Armory. The work of Jarrett, President West,

faculty members R. D. Koppenhaver and Bernhard "Ben"' Gustafson, local State Senators Joseph B. Bridston and Carroll E. Day, convinced the legislature to appropriate $\$ 500,000$ for a fieldhousegymnasium. However, the ambitious building plans drawn by Jarrett and Marti could not be covered by the $\$ 500,000$ so the project was held in abeyance until the 1949 assembly appropriated an additional $\$ 375,000$ to finish the work in proper style. Jarrett's 1948 football team could win only three of 10 games and finished third in the NCIAC at 3-3-0. Cunningham had the return of Louie Bogan, who had been sidelined with a knee injury the season before, plus Wisconsin guard transfer Frederick "Fritz" Engel and Ed Weber in gaining a 14-15 season record and ending in third place in the conference. Cunningham resigned after the 1948-49 season to enter business. He had been at odds with Jarrett as to the type of basketball to be played. Jarrett wanted him to use the fast-break which pleased fans, but Cunningham favored and used the slower, pattern-type game. Jarrett decided in the winter of 1949 to give up football coaching and take over the cage program again. To replace himself as grid mentor he hired two varsity assistant coaches at the University of Oregon, where he had been studying for a master's degree. The two new coaches were Richard Miller and Frank A. Zazula, who had been together 15 years, first as players at Canton (Ohio) McKinley High School, then at Akron University. Jarrett also hired John L.

Quaday, former athletic director at Wahpeton High School, as teacher and coach.

Miller's first and only football team, in 1949, produced a 4-3-1 record, tieing for third in the NCIAC. Jarrett's cagers had a 14-9 overall mark and finished second in the conference. Norman had been replaced as hockey coach by Clifford "Fido" Purpur, a Grand Forks carpenter who had played 14 years of pro hockey, the last four in the National Hockey League at Chicago, Detroit and Toronto. Purpur's infectious enthusiasm and outspoken, earthy, public statements soon attracted crowds of 3,000 to the drafty, unheated Winter Sports Building with its crowded and uncomfortable seating. The 1949-50 hockey team fashioned a 15-6-2 record but failed to get a bid to the NCAA tournament. UND had become a NCAA member Sept. 1, 1949. Standout brothers, Milton "Prince', and Russell "Buzz' Johnson, and center James Medved were the stars.

With Miller's resignation, Zazula took over football in 1950. His first team had a 5-2-2 overall record and was third in the NCIAC. One of the losses was a humiliating $83-0$ beating administered at the University of Kentucky - the worst loss in UND football annals. Jarrett had the cagers a final season in 1950-51 and ended with a 12-12-overall and fourth in conference standing. He had been grooming Bogan, who with Weber had 


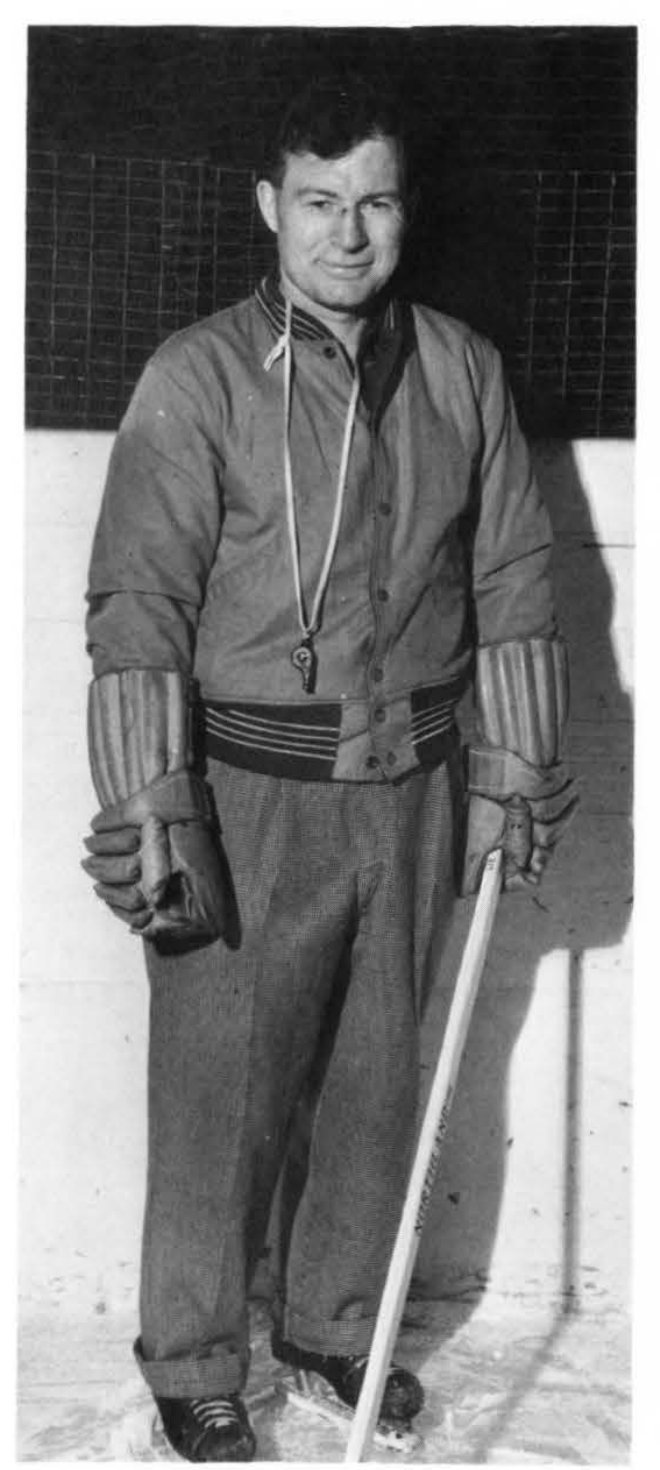

coached the freshman team while studying for a master's degree. All major UND teams were affected by the federal call-up of National Guard units and reservists in January 1951 as a result of the outbreak of the hostilites in Korea the previous June. Sophomore Kenneth Johannson was the star of the hockey team, which finished 12 . 12-2. Defenseman John Noah, a

Crookston, Minn., native, was named

North Dakota's first hockey All American in 1951 .

The 1951 football season was marred by a NCIAC reprimand for alleged recruiting violations by Zazula and his staff. The charges were never proved. The conference, acting on reports from a Minnesota junior college, alleged Zazula had attempted to induce junior collegian to transfer to UND before their eligibility had expired. The penalty assessed by the conference was cancellation of all 1951 non-conference games except a contracted home game against Beloit. Additionally, the NCIAC asked President West to rebuke Zazula by letter, which he did. As a result of the recruiting sanctions imposed by the NCIAC, morale ebbed and with the loss of some top players in all sports to the military for Korean service, the football team fell to a 2-4-0 record and finished fourth in the conference that season despite the standout performances of Francis Breidenbach, Loren Devine, Lloyd (Boom) Hallada, Richard (Rocket) Ryan and Lawrence Stone. Louie Bogan's first basketball team had a 9-11 overall record and finished third in the conference and probably would have fared better all around had it had the services of standout junior forward Charles Wolfe, who had suffered a serious back injury, which required surgery that summer. The western schools playing hockey, among whom UND was a pioneer, organized into a new league in October 1951 at Ann Arbor, Mich. The new league was named the Midwest Hockey

League. Its members were UND, Colorado College, University of Denver, University of Michigan, Michigan State, Michigan Tech and University of Minnesota. Purpur's charges finished fourth in the new loop and 13-11-1 overall, led by freshman scoring sensation, Ben Cherski.

The new fieldhouse-gymnasium was dedicated Nov. 30, 1951, before a $66-59$ victory over Montana State. Present for the dedication ceremonies were

Congressman and former Gov. Fred

Aandahl, President West, State Sen. J. B

Bridston and other state and local officials Thomas J. Clifford, chairman of the

Athletic Board of Control, presided before a crowd of over 7,000 .

Zazula, with a numerically small squad on which he did not have enough men some days to scrimmage during practice, had a 3-6-0 overall record despite the hard work of quarterback Richard G.

Koppenhaver. Bogan's second team had a 14-10 overall mark with the return of Wolfe who had recovered completely and new star Jon Haaven of East Grand Forks. By spring Purpur had gained a third-place finish in the MHL at 11-5-0, having opened the season with 10 consecutive victories en route to a 15-5-0 overall record. Jarrett was now coaching track.

The 1953-54 season was a good one for Sioux fans. Zazula, with only 21 players in uniform, had a 6-1-1 overall mark and went 4-1-1 in the NCIAC. Bogan had 
Ben Cherski, hockey star of the early

1950 s.

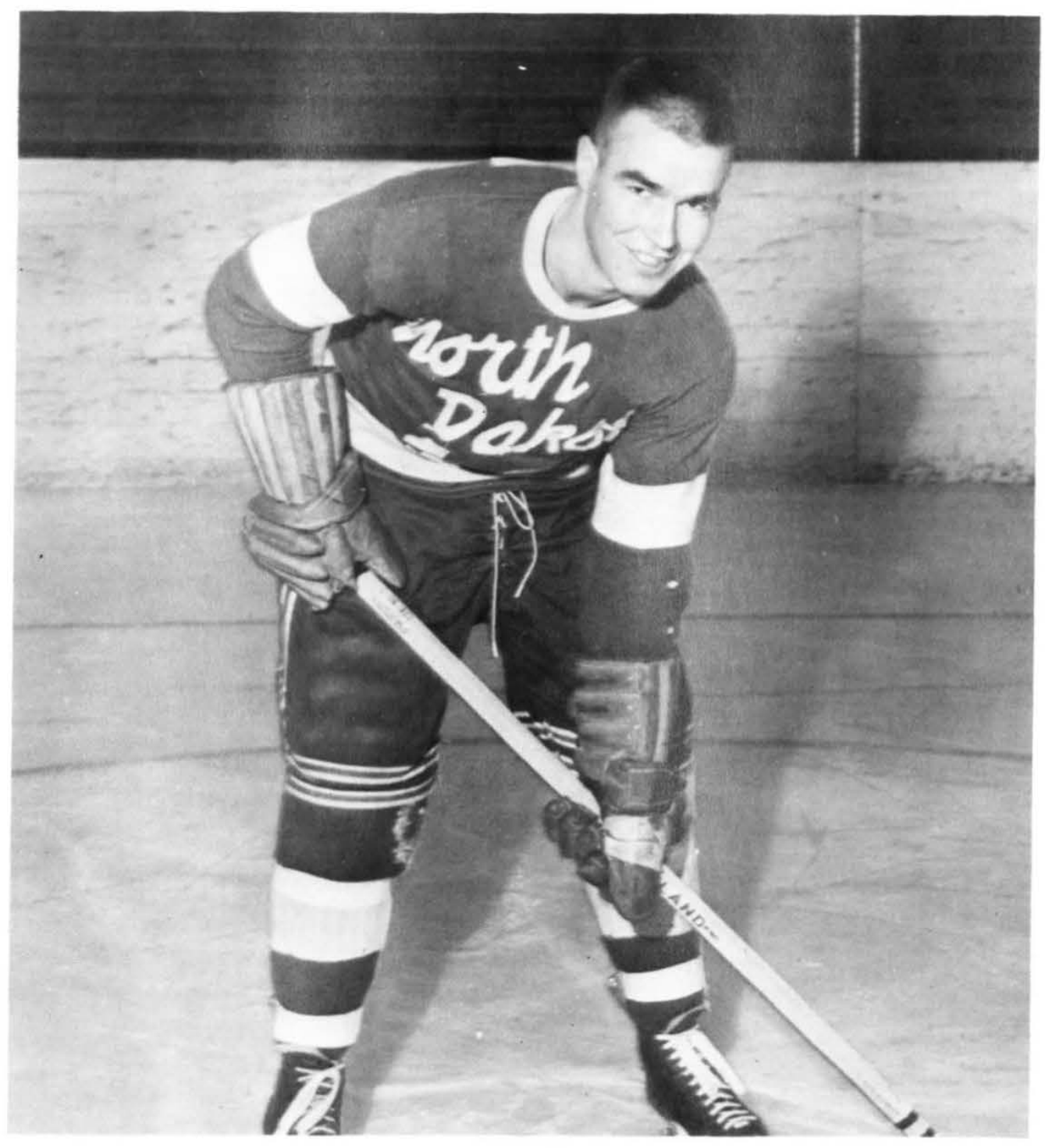

found another star, Donald (Red) Augustin of Rugby, to team with Wolfe and Haaven and this trio led the Sioux to a tie for the NCIAC championship, the first in 16 years. The MHL was reorganized with the same teams and renamed the Western Intercollegiate Hockey League (WIHL). The fifth Purpur team had a third place finish in the WIHL and a 14-12-1 overall mark behind the heroics of Cherski and goaltender Gerald (Spike) Schultz, both of whom were named to the All America team. Because of the uncertainty of the availability of natural ice for an expanded hockey schedule, the Athletic Board installed artificial ice at a cost of over $\$ 76,000$ and the fieldhouse swimming pool was finished at a cost of $\$ 83,000$.

Zazula's 1954 football team was a tough one but could manage only a 4-5-0 record He was hampered by lack of scholarships to attract the top players required for a conference contender despite his repeated warnings to Jarrett and the Athletic Board about the situation. The basketball team won the NCIAC title outright behind Don Augustin and fellow footballers Jack "Bull" Anderson and Jack "Soup'

Campbell. Haaven had gone into the army for two years after the 1953-54 season. The skaters finished 14-13-1 overall and fifth in the WIHL at 9-12-1. Sophomore center Bill Reichart and Ben Cherski starred and Reichart was named to the All America team. Football improved to 6-3-0, with all three losses at home. Stars of this team were center Ronald Kavadas and All America guard Steve Myhra. Place kicker for the Baltimore Colts, 1958-1963, Myhra was featured on the cover of LIFE when his skill brought the Colts a victory over 
the New York Giants in the National Football League's first overtime game.

In Purpur's last season, the hockey team won 11 of 28 games, tied one and finished sixth in the WIHL. Purpur resigned after the season, upon hearing alumni call for his ouster. The man Jarrett hired as Purpur's replacement was popular Allan M. Renfrew, a former star at Michigan who had been coach at Michigan Tech five seasons.

The 1956-57 season was Zazula's last. His team had a 2-6-0 overall record and wound up sixth in the seven-team NCIAC despite the outstanding play of Steve Myhra. To replace Zazula, Jarrett hired Macalester graduate Marvin "Whitey" Helling, highly successful at Minneapolis Washburn High School. Zazula stayed on as track coach and a physical education instructor. The basketball team skidded to a 5-18 overall record and finished last in the NCIAC at 2-10, mainly because key players had been lost to injuries and

ineligibilities. In Renfrew's only season at UND, he directed the Reichart-led Sioux to an 18-11-0 overall record and finished third in the WIHL at 13-9-0. Sophomore

defenseman Bill Steenson was named to the All America team, as was Reichart. Steenson was also named All American his junior and senior seasons, the only player to date so honored. To replace Renfrew, Jarrett hired Canadian Robert H. May, a former UND player (1948-51), who had coached at Oakes, Grand Forks Central and Minneapolis Roosevelt.

In 1957, the Grand Forks Chamber of Commerce initiated annual scholarship fund drives in exchange for free seat locations and tickets for the three highly visible sports. Improved standings did not come at once in football, fifth in the

league, or in basketball, 5 and 7 in the NCIAC. But May's skaters, after swamping Harvard 9-1 in their first NCAA national tournament, lost the title game to Denver 6-2.

Ambitious recruiting of Upper Midwest standout players brought the NCIAC championship to UND in 1958 in Helling's second season. The team had a 5-1-0 conference record and finished 5-3-0 overall. The title, first since West's 1939 team had tied for the top honor, came behind the outstanding play of quarterback Bob Falos, halfbacks Jim Jarrett and Donald Stueve and guard John Hennen. May, an able recruiter and fiery lockerroom orator who employed prayer to motivate his players, and a shrewd on-ice

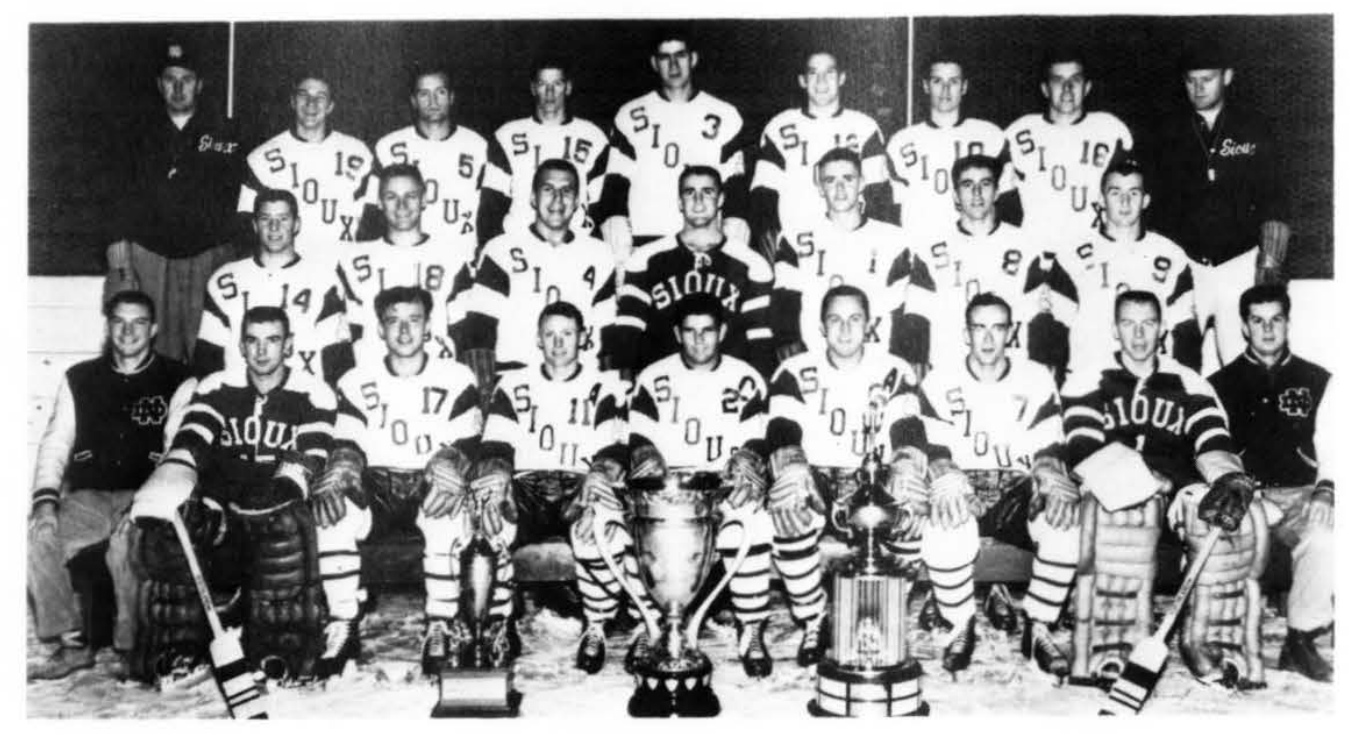

tactician, handled his charges expertly. In 1958-59, he fashioned a 20-10-1 record and went on to capture North Dakota's first national hockey championship at Troy, N.Y., beating St. Lawrence University and Michigan State by identical overtime 4-3 decisions. The WIHL disbanded at the close of the season after a variety of grievances led several schools to withdraw. The 1958-59 season demonstrated that the lack of a league structure worked against the best interest of the western teams; they reorganized themselves into what they named the Western Collegiate Hockey Association (WCHA). May resigned in April to become head coach of a new pro team in Denver and his assistant, Winnipeg native Barry Thorndycraft, was named head coach.

Leonard Marti, who had headed the

The University's firs national championship hockey team. 1958-1959. 
Coach Bill Fitch and All-American guard Paul Pederson, 1965. men's physical education program since September 1946, was named acting athletic director in September 1958. Jarrett had developed a terminal illness, which claimed him April 28, 1962, at age 53. Marti became director before the 1960-61 fall semester began and held the joint positions of athletic director and chairman of the Department of Health, Physical Education and Recreation. He retired in 1975.

Helling's third team in 1959 fell to a poor 2-5-1 record and finished last in the NCIAC at 1-4-1. The hockey team finished third in the WCHA at 14-7-1.

The Marti era began inauspiciously with poor showings in football, 1-4-1,

basketball, 3-19, and hockey third in the new WCHA, despite the efforts of All

America center Reginald P. Morelli. Littıe changed in the 1961-62 basketball season and Bogan resigned. He remained on the staff in a teaching position and later coached the golf team very successfully.

To replace Bogan, Marti and the administration selected Bill C. Fitch, the head coach at Coe College. An ambitious and very effective recruiter and harddriving, no-nonsense coach, Fitch directed the cagers to a 14-13 overall record and third place in the NCIAC at 6-6. This team also took the longest road trip of any UND team when it visited four cities in Alaska, winning all four contests. Thorndycraf and the hockey team brought home North Dakota's second national hockey

championship after it whipped Boston College, 8-2, and Denver, 6-5, at Boston College's McHugh Forum. Wing Alan McLean, defenseman Donald Ross and center David Merrifield earned All America honors.

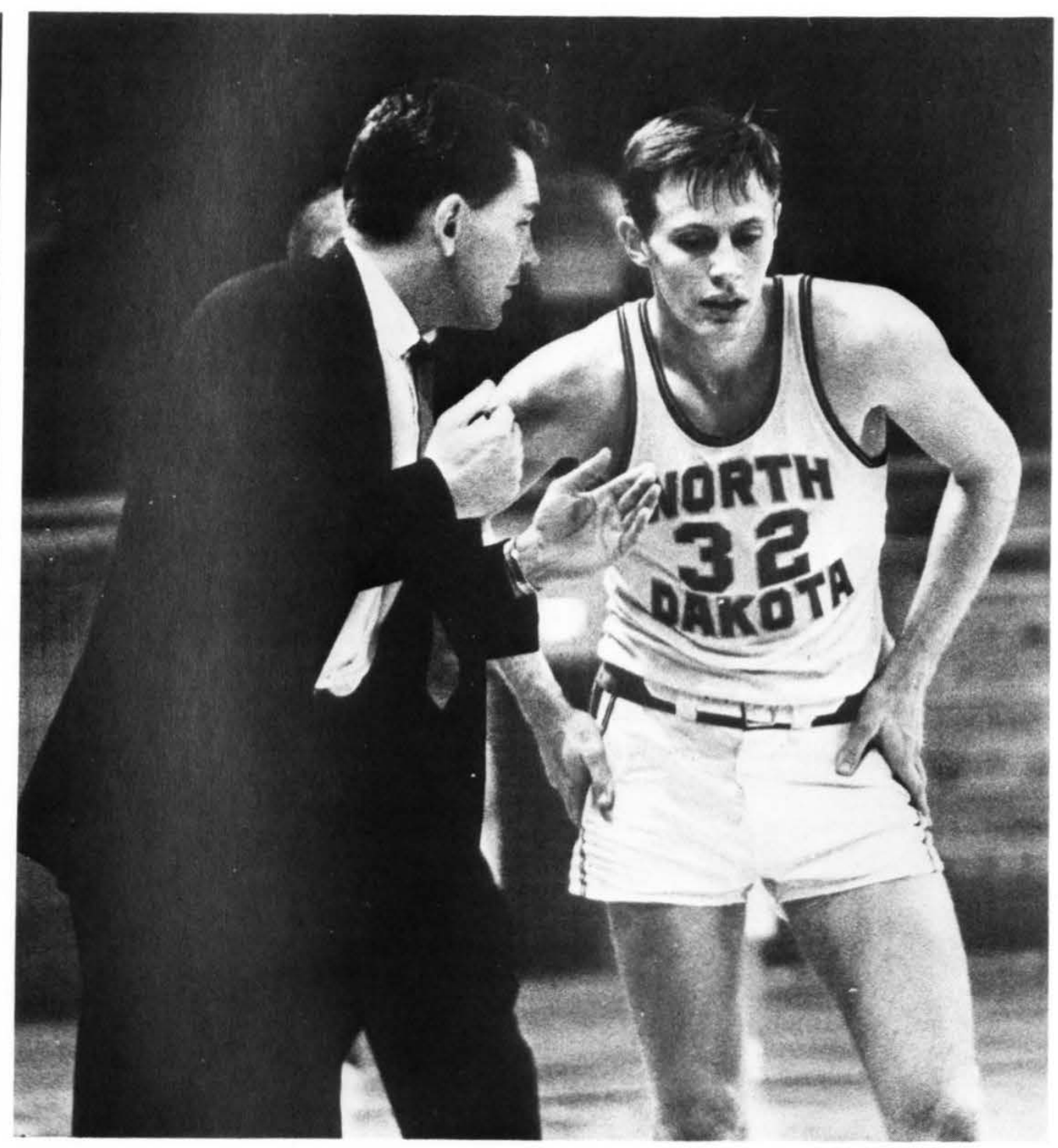


The 1963 football team beat North Dakota State University an 11th straight time in finishing 6-3-0 overall. Neil Reuter of Williston was named to the Little All America team at tackle. Guard Tom Nesbitt led Fitch's second team to a 10-16 season record, with seven of the losses going to major college teams.

Thorndycraft, who had come to UND on a student visa, was "deported" after the

season despite administration dealings with Washington immigration officials. His las team had a 12-11-2 overall record and 5-8 1 in the WCHA. Robert H. Peters, an exSioux goalie, was named head coach, promoted from his assistant status.

Four Sioux teams won championships in 1964-65. Helling's eighth UND team lost only to Iowa Teachers (now University of Northern Iowa) in a nine-game schedule and the victory skein over North Dakota State University (formerly NDAC) reached 12 behind such stalwarts as halfback Dave Osborn of Cando who went on to stardom with the Minnesota Vikings and All America tackle Jerry Jacobs. Fitch assembled a talent-laden team that produced a 26-5 season record and won the first of three straight NCIAC basketball championships. This team with sophomore forwards Phil Jackson, Paul Pederson, Jim Hester and Tom Nesbitt averaged 80.8 points, to remain the highest scoring team in UND history. Invited to the NCAA College Division tournament at Evansville, Ind., it finished third among eight teams. The first hockey team Peters coached won the WCHA title on a 13-3-0 record, went $25-8$ on the season, finishing third in the NCAA tournament at Providence, R.I. The golfers captured the NCIAC championship. A new baseball field was located west of the campus in what formerly was the old city airport "clear zone" purchased by the University in the early 1960 s for expansion purposes. Laid out during the summer of 1964 it was first used April 15, 1966, in a doubleheader sweep of visiting Wisconsin-Superior. Later the University named the field after

Kenneth Hyslop, a 1904-06 baseball player and a major University benefactor. It was dismantled in 1982 to make way for the new Center for Aerospace Sciences.

En route to a 9-1-0 season record,

Helling's 1965 team suffered only a 6-3 loss to NDSU. In the post-season Mineral Water Bowl the Sioux beat pass-oriented Northern Illinois, 37-20, behind their own gifted passer, quarterback Corey Colehour. The basketball team, led by All Americans Phil Jackson and Paul Pederson, finished with a $24-5$ season record, took the NCIAC title with an 11-1 record, and placed fourth in the NCAA national tournament. Center Terry Casey was named to the All America team. Peters resigned his hockey coaching duties after his team had a 17-12-1 overall record and tied for second in the WCHA at 13-9-0.

The three highly visible sports all won team championships in 1966-67. The football team tied with North Dakota State University for the NCIAC title on 5-1-0 record and went $8-2-0$ overall. The team won the NCAA sponsored Pecan Bowl game at Abilene, Texas, beating now-defunct Parsons

College, 42-24, on $\mathrm{ABC}$ regional television. The Jackson-led basketball team captured a third straight NCIAC championship on a 11-1 record and won 20 of 26 games. The
New York Knickerbockers drafted Jackson in the second round after the season in which he established 24 scoring and rebounding records. He was the first UND player ever drafted for pro basketball.

Fitch also departed the scene, going to Bowling Green State University,

Minnesota, and the Cleveland Cavaliers and the Boston Celtics of the National Basketball Association. When Peters left for Bemidji State, Marti named another assistant coach, Bill Selman, a UND player in 1960-63, to take over that program. His first team fashioned a 19-10-0 overall mark and finished fourth in the NCAA tournament at Syracuse, N.Y., losing, 1-0, to eventual winner Cornell and dropping the consolation match to Michigan State, 6-1. Defenseman Jerry LaFond of Dawson Creek, B.C., was named to the All

America team.

Helling's last football team in 1967 fell to a 4-6- 0 overall mark and tied for third in the conference at 3-3-0. He resigned to enter the insurance business in the Twin

Cities and his first assistant, Jerroll

"Jerry" Olson, who had been on the staff several seasons after obtaining a master's degree from the University, was named head coach. A Hoople native, Olson had played all sports before graduating from Valley City State College in 1955. The first Jim Rodgers-coached basketball team had a 15-9 overall record, finished second in the conference race and won the inaugural NCIAC holiday tourney. Selman's second, and last, hockey team produced a 13-8-1 WCHA record and gained an NCAA tournament berth by beating Michigan Tech twice at Houghton, Mich., in classic games 1-0 and 3-2, during the WCHA 


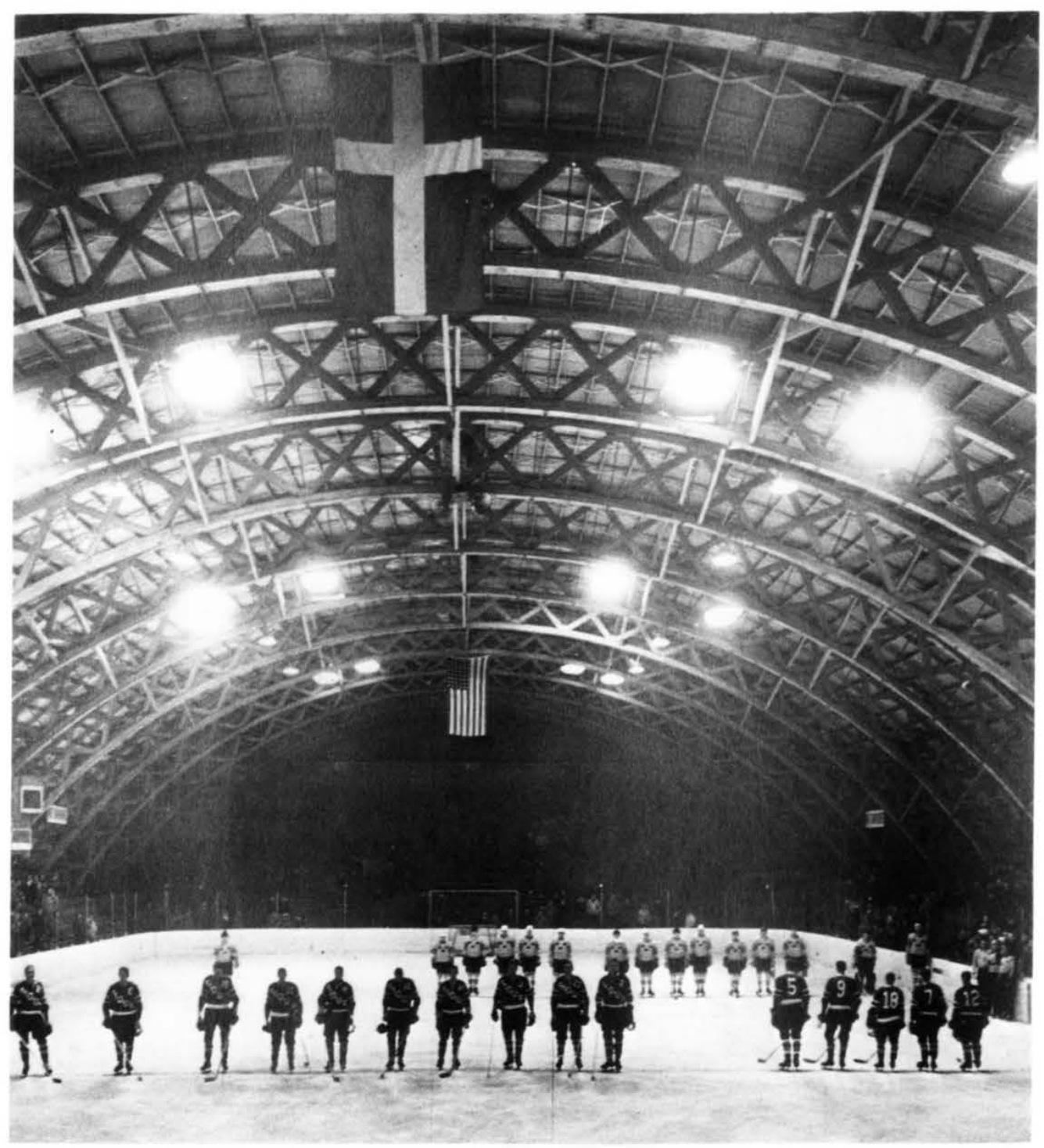

playoffs. In the NCAA tourney at Duluth, the Sioux gained a measure of revenge by beating Cornell, $3-1$, in the first game but lost the title match to Denver, 4-0. Selman resigned after the season to coach at

Minnesota-Duluth, which had been admitted to the WCHA in 1966.

Ruben Bjorkman, a former University of Minnesota star and Roseau, Minn., native, who had been coaching at the University of New Hampshire, was named head coach. Center Bob Munro of Geraldton, Ont. and defenseman Terry Abram of South St. Paul, Minn., were named to the 1968-69 All America hockey team. A nine-hole, grass-green golf course constructed

just south of the campus on an 80 -acre site donated to the University by Raymond Richards, a 1906 UND graduate and Tulsa, Okla., oilman, was opened May 1, 1968.

The 1968-69 season produced some third place winners. Jerry Olson's first football team in 1968 had a 3-5-0 overall record and tied for third in the NCIAC. Rodgers' second team dropped to 11-14 overall and tied for third in the conference. Finally, the Bjorkman-coached skaters finished third in the WCHA with a 15-7-0 record and a 18-10-1 overall record. Defenseman John Marks of Winnipeg was selected for All America honors. Considerably less attention was paid by the public to Arjan Gelling, the top distance runner in University history, who won the NCAA Division II six-mile run as he went on to earn nine All America honors in track and cross-country. Dave Gunther, an All-Big Ten forward at Iowa who played for the professional Detroit Pistons and San Francisco Warriors, arrived that spring as replacement for unsuccessful Rodgers. He 


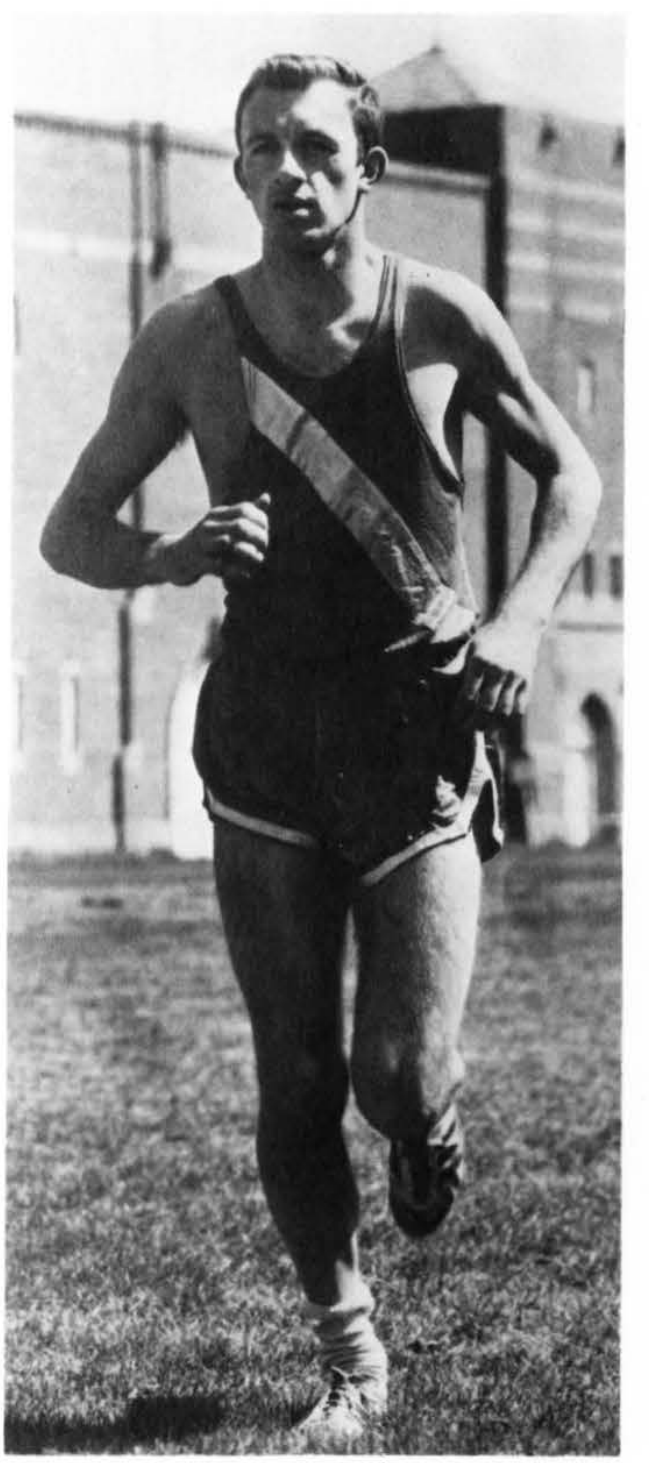

helped with the recruiting and immediately started a summer youth basketball school, which he was still operating in the 1980s. The skaters had a 14-15-1 record in

Bjorkman's second year and went 12-13-1 in the WCHA despite the standout play of All America defenseman John Marks and David Hudson, both of whom later turned pro.

Linebacker Jim LeClair, end Greg

Schneider and defensive back Dan

Martinsen were standouts on the football team that improved to 5-3-1 and finished second in the NCIAC at 4-1-1, with NDSU stretching its winning string of victories over UND to six.

The improvement in football fortunes, thanks to the skills of Jim LeClair, continued into the 1970-71 season, but was not matched by Bjorkman's third team which closed play with 14-17-2 overall and 10-15-1 WCHA records. The big news on the hockey scene was an announcement that the University would build a new, heated facility for its long-suffering fans and teams on a site east of Memorial Stadium. Marti, then President George W. Starcher and current PresidentThomas J.

Clifford were prime planners of the \$2 million facility. Grand Forks businessman John O'Keefe directed the local fund drive, devoting nearly a year of his time to the drive. The new Winter Sports Center seats 5,951 .

The 1971 football team improved to 6-31 overall and won the NCIAC title with a 5-1-0 mark. The big game was a 23-7 Sioux triumph in the mud and rain at NDSU, which ended a string of 36 Bison victories which then was the longest in the nation. LeClair, named to the Little All America first team, went on to become defensive captain of the Cincinnati Bengals. The hockey team achieved a 21-14-1 overall mark and wound up third in the WCHA behind the standout play of All America defenseman Alan Hangsleben, center Jim Cahoon and wing Earl Anderson.

A 22-17 loss to NDSU prevented a perfect 11-0 football record in 1972 and threw the NCIAC into a three-way tie between UND, NDSU, and the University of South Dakota. But the Sioux were selected to represent the conference in the NCAA-sponsored Camellia Bowl game at Sacramento, Calif., where it defeated

California Polytechnic - San Luis Obispo, 38-21. Stars of that team were Mike Deutsch, who later was named to the first

All America team, quarterback Jay Gustafson, tackle Frank Landy and defensive end John Miklesh. The hockey team opened a new era in the new arena (dedicated Jan. 12-13, 1973) on November 10, 1972, by beating Colorado College, 5 4. The skaters broke even on the season 17-17-2; but their seventh place finish in the WCHA race detracted from the enthusiasm generated by the arena.

In 1973, after 42 years, football relations were resumed with Minnesota, with the Gophers winning, 41-14. The team posted a 6-4-0 record behind the passing combination of quarterback Jay Gustafson throwing to flanker back Ron "Magic" Gustafson, end Lawrie Skolrood and standout tackle Dave Fennell. The latter turned pro after the season to become the top defensive lineman in Canadian pro ball while playing with the Edmonton Eskimos. Hockey, to the chagrin of fans, skidded to
Arjan Gelling, winner Division II six mile

run. 
Sioux football achieved new prominence in the decade of the

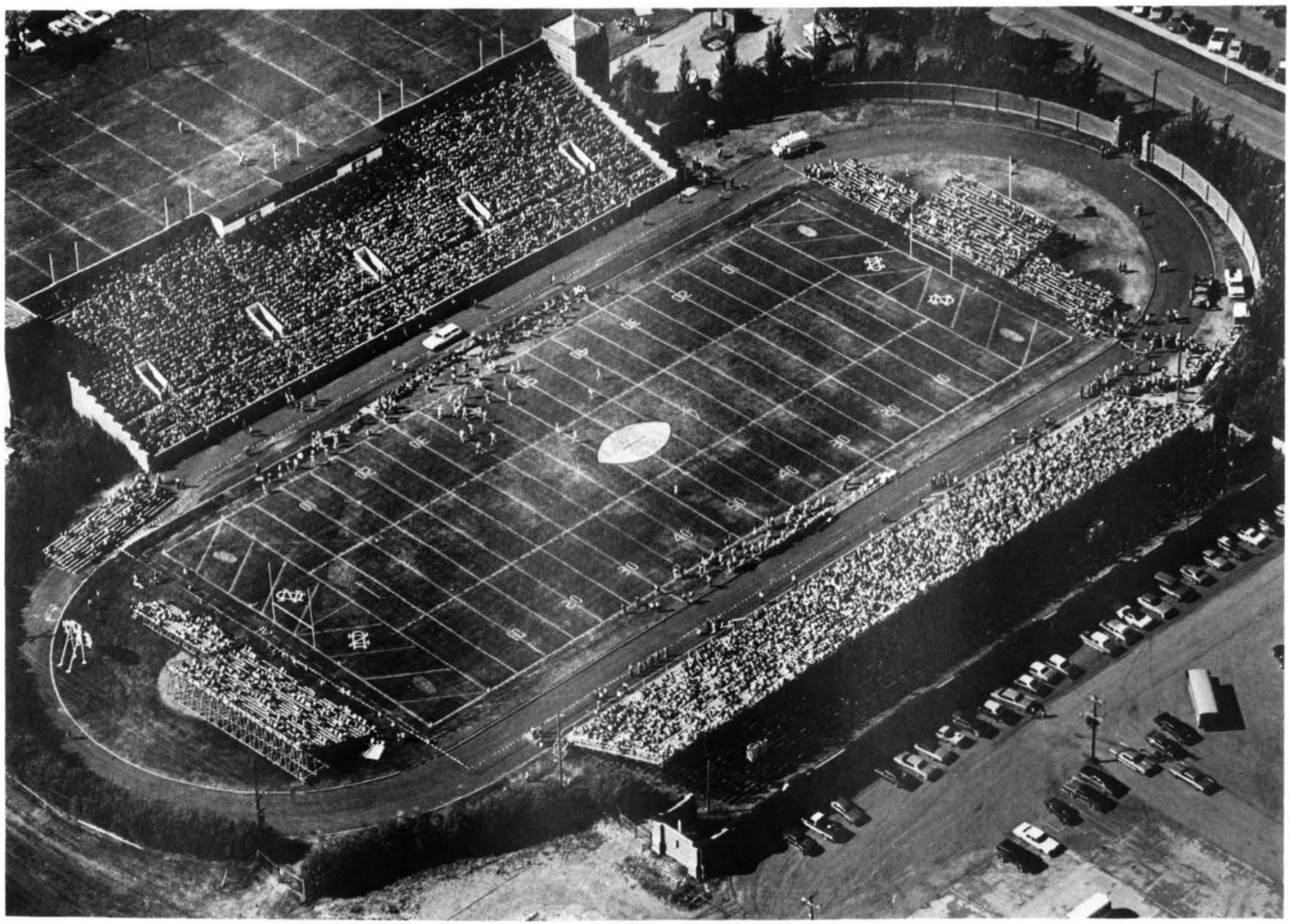


a 10-23-1 overall for a last place finish in the WCHA.

In 1974, the Sioux football team scared Minnesota at Minneapolis before the Gophers claimed a 42-30 victory. Running backs Bill Deutsch and Dale Kasowski and Ron Gustafson were the top players on the team that also beat NDSU, 31-20, en route to a 6-4-0 overall record and a three-way tie for the NCIAC top place. Conference and NCAA regional basketball

championships came in 1974-75 on records of 12-2 and 22-7 overall behind the strong play of center Mark Lindahl and Jim

Goodrich. The hockey team fell to a 6-28-2 overall mark and again finished last in the WCHA in the least successful season ever for a hockey team.

The year 1975-76 began extremely well for Olson's eighth football team which missed a perfect 10-0-0 record when it was ambushed, 34-14, in the NCAA playoffs by Livingston (Alabama) University at Grand Forks. Disappointment over the outcome was compounded by the fact that the bitter cold of the late-November afternoon was expected to give the edge to the Sioux. Bill Deutsch became the second member of his Fargo family to earn All America honors. Gunther's basketball team won a third straight NCIAC title and also captured the regional championship on records of 11-3 and 22-7. Bjorkman's eighth hockey squad improved to 15-21-0 overall, but still finished last in a three-way tie at $12-20-0$

Marti's 30-year tenure as athletic director and physical education head came to an end in June 1976. A long search for a successor ended the previous April when President Clifford named Carl R. Miller.
With the doctorate in athletic administration from North Texas State University he had spent five years at the University of South Dakota. In his first year the football team suffered through a 1-7-1 season. One of the reasons for this sudden decline in 1976-77 was a strong schedule that included Division II national champion University of Delaware and Wisconsin's Badgers on the road. The loss to Delaware was a humiliating 59-17. Gunther directed the 1976-77 cagers to the University's best season in 42 years with a 26-4 overall mark and a fourth straight NCIAC title. The team's fortunes changed in the subsequent NCAA quarterfinals. Olson resigned after the Sioux finished 4-6overall in 1971. To replace Olson, Miller promoted Eugene V. Murphy, a 1963 UND graduate who had been an assistant coach for 12 years. Bjorkman resigned after a 15 22-1 hockey season and a fifth-place finish in the WCHA at 13-19-0. To replace Bjorkman, Miller and Clifford named John "Gino" Gasparini, a 1968 UND graduate who had been on the coaching staff for 10 years. His appointment came as a shock to the Grand Forks Herald which boldly predicted that Ned Harkness, former Detroit Red Wing coach and general manager who had coached at Rensselaer Polytechnic and Cornell, would be named. Almost lost in the uproar over the coaching changes was the outstanding play of defenseman Bill Himmelright, goalie Bill Stankoven, forward Mark Taylor and wing Doug Smail. The basketball team, after reigning as NCIAC kingpin four straight seasons, finished third in the league.

Murphy, an outstanding recruiter and motivator of players, had a 5-5-0 overall record and finished fourth in the conference his first season in 1978-79.

Gunther, who probably has "stolen" more NCIAC coaching wins through his shrewd tactics than any other NCIAC coach, had the Sioux in the title hunt but wound up in a tie for second in the league on a 7-5 record and 19-9 overall. The cagers again were invited into NCAA regional play, but could not get past Green Bay and Nebraska-Omaha. The most startling development of 1978-79 was the outstanding play of the hockey team, which won the WCHA title on the last day of the season at Minnesota through its aggressive defensive and hard skating style. After sailing through the WCHA post-season playoffs unscathed, the Sioux were invited to the

NCAA tournament at Detroit's aging Olympia Stadium, where it defeated Dartmouth and lost a heart-breaking 4-3 decision to Minnesota in the championship game. Two of the brightest ice stars were freshman center Kevin Maxwell and goaltender Bob Iwabuchi, both named to the All America team.

Murphy's second, and last, football team had 10-2-0 overall record in 1979 and won the NCIAC championship with a 6-1 record. In NCAA post-season play the Sioux were again victimized by a team from Dixie, this time little Mississippi College at Jackson, 35-15. Tight-end Paul Muckenhirn of Mahnomen, Minn., was named to the All America first team. North Dakota hockey partisans, who had suffered through years of frustration in their new rink, exulted when the Sioux won a third national championship at 


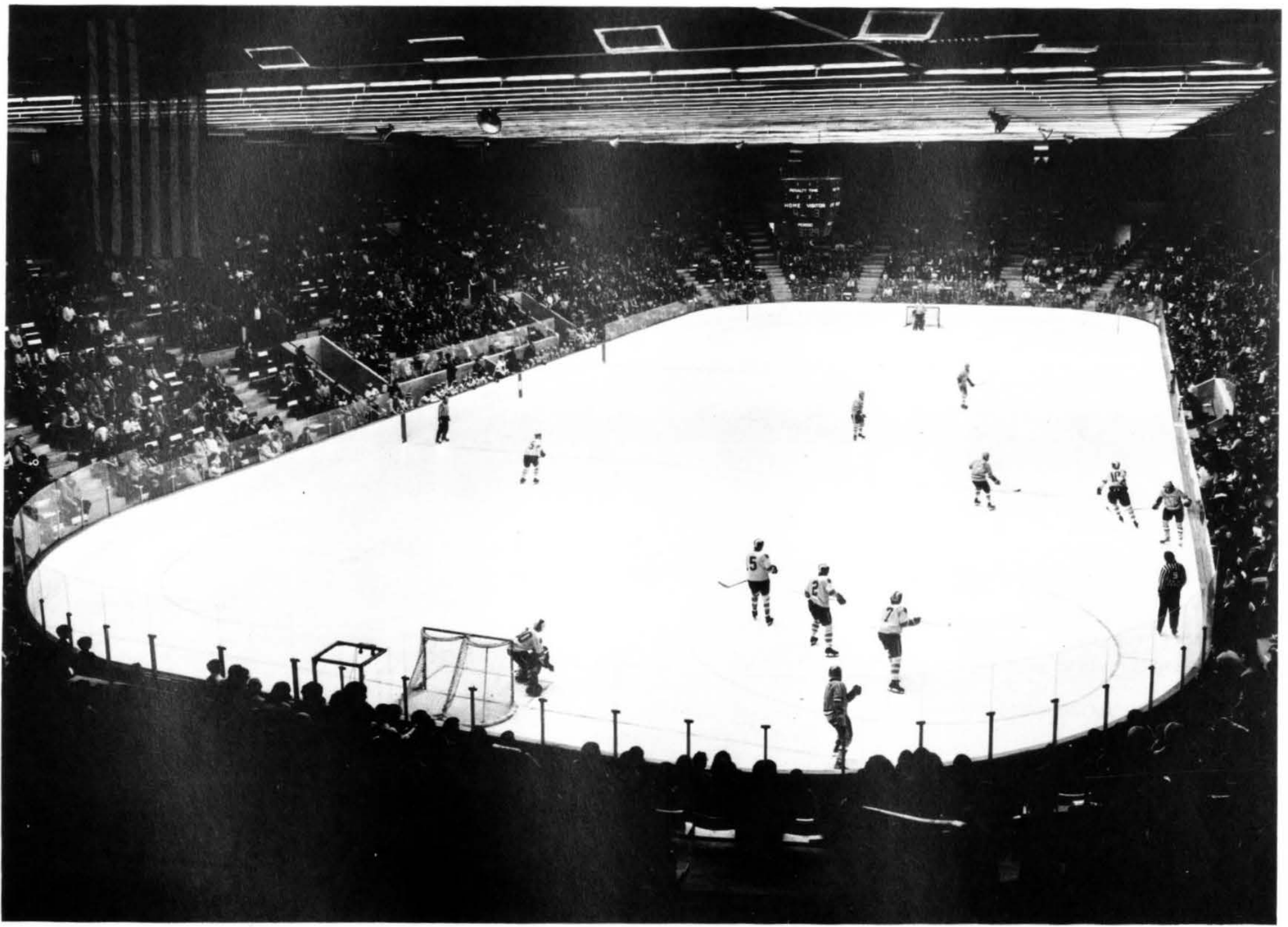


Providence, R.I., by beating Dartmouth, 41, and Northern Michigan University, 5-2.

Doug Smail scored four goals in the championship game. Gasparini, despite having lost David Christian to the United States Olympic team and Maxwell to its Canadian counterpart, was lauded by the media for achieving a 30-11-1 overall record. Senior center Mark Taylor, a grandson of the legendary Canadian proplayer "Cyclone" Taylor, and freshman defenseman Howard Walker were named to the All America team.

The Eighties brought a bittersweet blending of success in league competition and setbacks in post-season play. Murphy, an ambitious coach, resigned in late December 1979, and went to Division I California State-Fullerton as head coach. Miller replaced him with Patrick Behrns who had been on the coaching staff five seasons after coming from New Mexico State. His 1980 team, beset by numerous injuries, achieved a 6-4-0 record and tied for second in the NCIAC at 5-2-0. Tackle Todd Thomas, who turned pro with the Kansas City Chiefs, was named to the Little All America first team. Gunther's 11 th basketball squad, built around transfer students center Dan Clausen and guard Aaron Harris plus Todd Bakken finished 23-8 overall. After winning the NCIAC post-season tournament for the seventh time in eight seasons it was invited to the NCAA regionals, but at Green Bay lost the championship round, 72-60. Gasparini's third hockey team, after a successful first half in which it was ranked for several weeks the number one team in the country, had a record of 21-15-2 and finished fifth in the WCHA at 14-12-2.

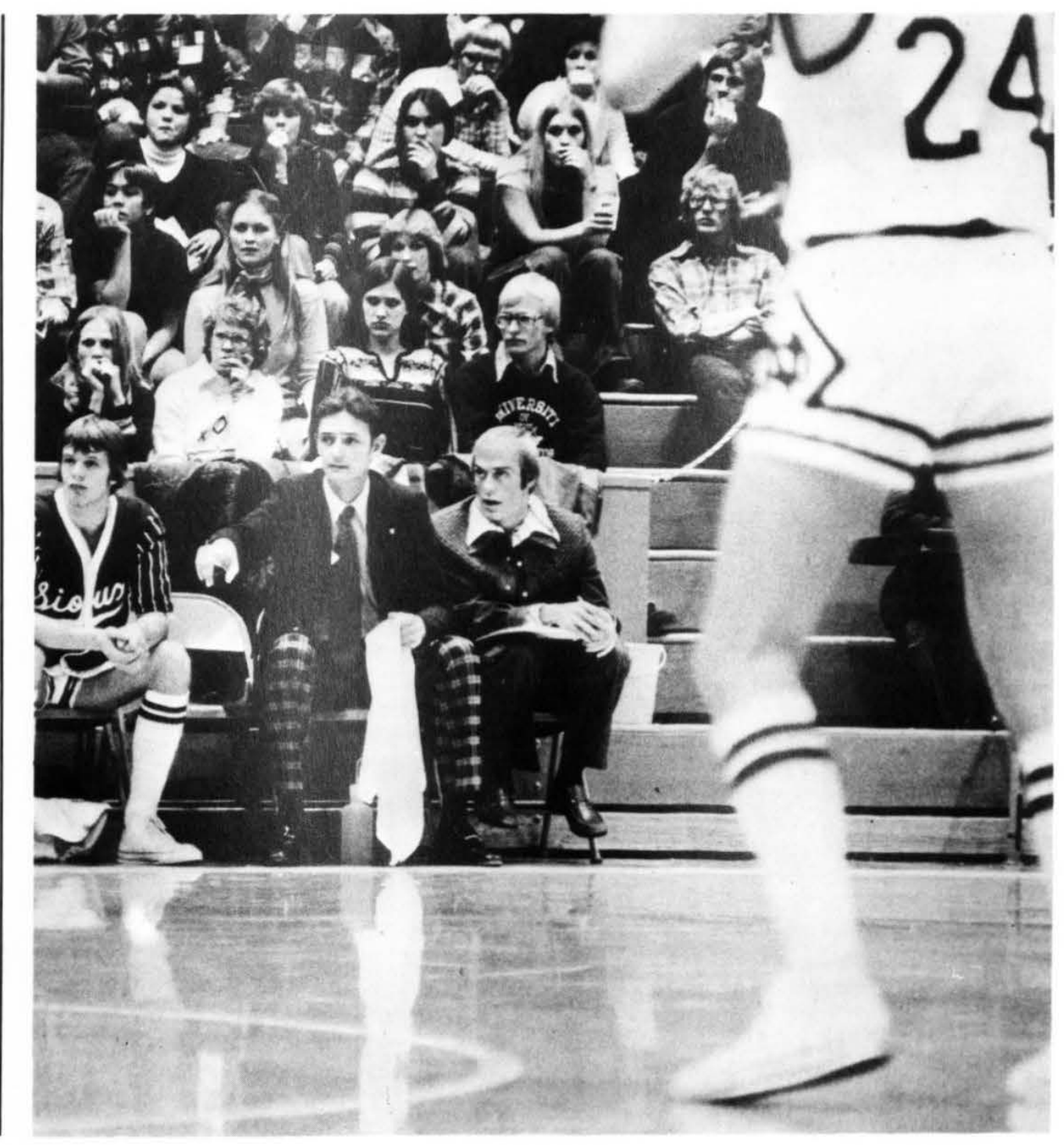
his 1976-1977 team which completed a 26-4 season. 
Senior defenseman Marc Chorney was selected to the All America team, the 27th UND player so honored since 1951 . He turned pro with the Pittsburgh Penguins of the NHL and appeared with them in the Stanley Cup playoffs. With the close of the season he returned to the campus to obtain his undergraduate degree, dispelling in some measure the notion that studentathletes fail to advance to degree status. Football co-captain Doug Moen of West Fargo was recipient of a $\$ 2,000$ NCAA post-graduate scholarship and entered the UND Medical School.

The 1981-1982 hockey season began indifferently with troubling reminders of the less successful teams of the $50 \mathrm{~s}$ and 70 s, but the Sioux strengthened to win the WCHA and NCAA championships. The fast, hard-checking game which for several years had won for them from journalists around the nation the unfair appellation "goons" was attracting the pro recruiters. Kevin Maxwell, Doug Smail, David Christian, John Marks and Marc Chorney had found berths on National Hockey League teams in the United States and Canada. Now with the third national championship in four years, Phil Sykes, Cary Eades, Troy Murray and Craig Ludwig, signed NHL contracts.

Sports with less involvement in widespread recruiting and with professional leagues include golf and wrestling. Competition in golf began in 1929 with townspeople as coaches. With players from North Dakota and nearby Minnesota, UND won NCIAC championships in 1937, 1942, 1956, 1963, 1964-66, 1968, 1970 1974 , and 1979-82. Teams after 1948 were coached by John L. Quaday; those after
1971 by UND graduate Louis Bogan. In the 1968 NCAA Division II tournament Quaday's players finished 14th in a field of 21 teams and in 1970, 13th of 36. Jeff Skinner, UND's first All American, in the 1981 NCAA tournament finished 18 th in a field of 120 .

Wrestling, a conference sport since 1963, has produced eight All Americans: Frank Anderson (1967), Rick Lee (1975), Ken Gabriel (1976), Harvey Kruckenberg, Paul Marquart, Jerome Larson (all 1980), Jeff Tescher (1981) and Jerome Larson (1980, 1982). Despite outstanding individuals attracted by scholarships, the teams have not been very successful in the NCIAC, rated the nation's toughest and best balanced conference.

Until the 1970s the history of major intercollegiate competition at UND is a recounting of male prowess. The only woman to play on a varsity team was Nancy Pope, a tennis transfer from Wisconsin. In 1972, she earned the number three singles position. All other women played on women's teams. Attention to these rose and fell with the interest of male athletic directors and of students

themselves. Tennis for women appeared in the $1890 \mathrm{~s}$. In the winter of 1901-02, Professor E. F. Chandler organized a basketball team that competed with some area high schools. Anna Ueland captained the team of Eva Bull, Mabel Metzer, Anna Larsen and Fannie Robinson. After World War I interest increased and by the 1920 women were competing in basketball, baseball, field hockey, markmanship, track and field, and volleyball in skimpy

schedules against area colleges. Era Bell Thompson, a black English major who had been raised on a farm near Driscoll, and who had stunning success at Bismarck High School, enrolled and became an immediate star through her superior performances in every sport. Another great woman athlete of the mid-1920s was Grace (Osborne) Rhonemus, who came from nearby Emerado. Both were state record breakers in track competition and Thompson tied a national intercollegiate 60 -yard dash record in a telegraphic meet in 1926. Thompson and Rhonemus, on May 21, 1981, were the first two women inducted into the University Athletic Hall of Fame. Thompson, who received an honorary Doctor of Humane Letters from the University in 1969, became a nationally known writer and editor of Chicago-based Ebony magazine. Rhonemus, nationally known as a teacher of dance, taugh physical education at the University 33 years before retiring in 1975

Interest in women's intercollegiate competition waned in the 1930s. Little remained save for limited intramural and extramural activities sponsored by the Women's Recreation Association. The pace continued until Marti approved extramural expenditures of $\$ 1,000$ for the 1965-66 season. By 1981, the budget for women's athletics exceeded $\$ 200,000$.

Implementation of Title IX legislation in the 1980s forced all institutions receiving federal grants to increase sponsorship of women's athletic teams; equal access to facilities and scholarships for women was necessary for remaining in compliance at the opening of the 1980s. To the credit of Marti and Miller, the University was ahead of all colleges and universities in the Upper Midwest (with the possible exception of 
Varsity athlete, 's volleyball, 1979.
Minnesota) in Title IX compliance.

Facilities were increased through wise

planning of these two men by converting fieldhouse areas to women's locker rooms and making its training room and weight room accessible to coeds.

In the University's table of organization, supervision of women's teams, which had risen to 12 in 1980-81, has been through a women's athletic coordinator directly responsible to the athletic director. The first coordinator in 1965-66 was Patricia Mauch. She was followed by Mary Ann Engen in 1967-68, Patricia Warcup in 1968-69 as well as 1972-73, and Fay

Youells in 1970-71. Since 1972 direction to the program has been supplied by Dr. Helen Smiley, now associate athletic director.

Women's extramural athletic competition existed in every one of North Dakota's 13 higher education institutions in 1966-67. However, as early as 1959, women's athletic leaders of NDSU, Concordia College, Moorhead State, and the University began talking about a conference to set guidelines, codify rules and regulations and prepare schedules. Finally in 1965-66, the Minn-Kota Conference was preliminarily organized with charter members UND, NDSU, Concordia, Moorhead State and Bemidji State. In April 1972, Mayville State, Valley City State and Minnesota-Morris were admitted to membership. The Minn-Kota Conference, beginning official competition in 1972, operated until it was dissolved after the 1978-79 season when the Minnesota members withdrew to form an all-Minnesota Conference. In 1980, UND and NDSU, bereft of conference affiliation

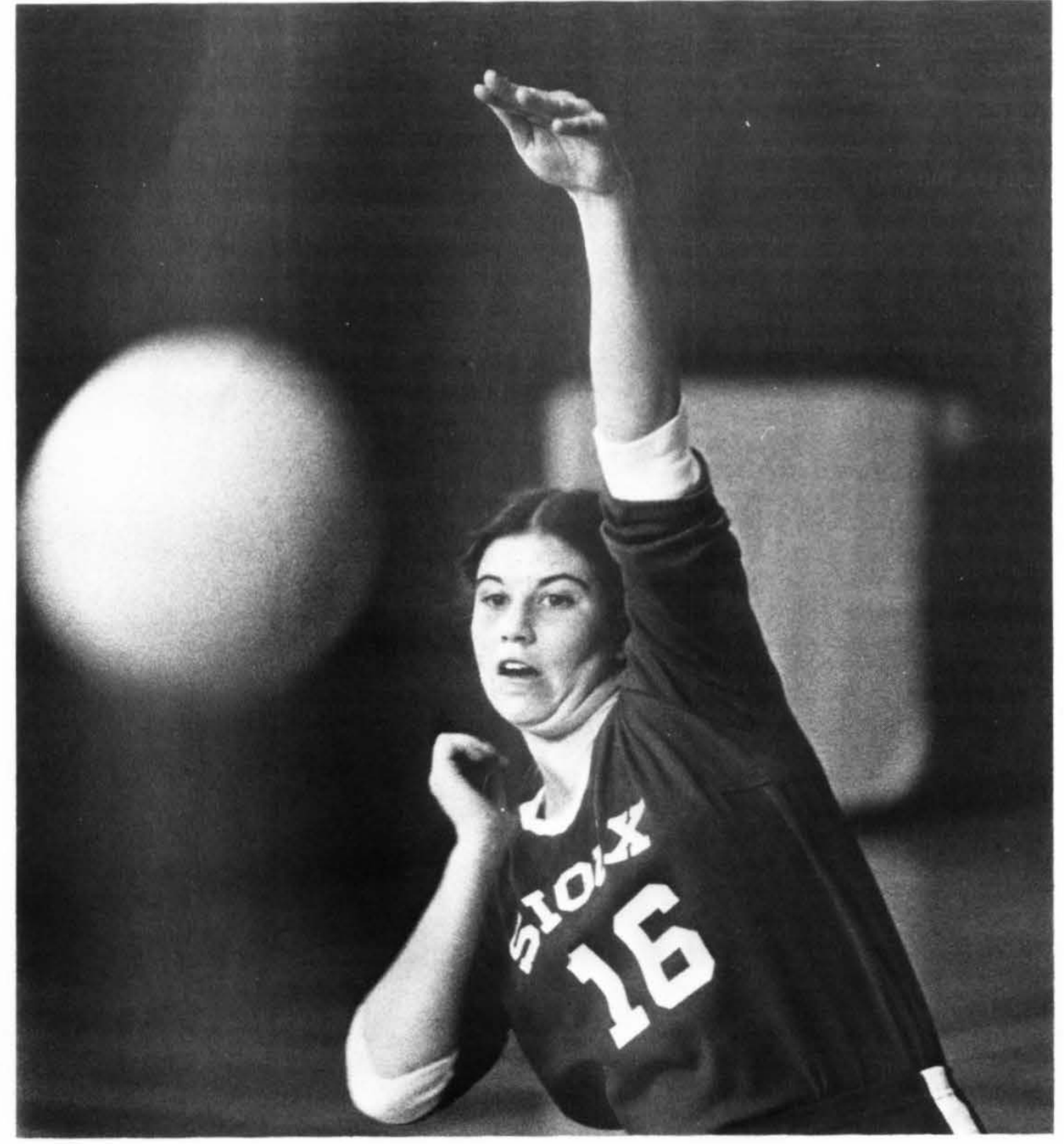


and having only the Association for Intercollegiate Athletics for Women (AIAW) for official post-season competition, were incorporated in the NCIAC. However, in April 1982, NCIAC members voted to sponsor championships in all sports, forsaking AIAW affiliation.

Women's basketball in the 1960s and 1970s was coached by Warcup. She had some minimal success despite the lack of scholarship aid to attract top players. In 1974-75, Dietta (Dee) Watson was

employed by Marti to coach and teach. She tutored women's field hockey and basketball teams five seasons, compiling a mixed record in them both, records of 3$12,20-5,8-14$.

After the 1977-1978 season, performance in field hockey improved under Margaret Peterson, a 1977 graduate of the program. Her 28-7 record in 1980-81 carried her team to a sixth place finish in the AIAW national tournament at Southern Illinois University.

With the spectacular rise of professional sports in the 1960s and 1970s collegiate athletic departments have been heavily criticized for serving as training centers for the big leagues - especially basketball and football. Charges fly that many young high school athletes are exploited to produce winning teams for colleges and then discarded. UND has not been entirely free of criticism. A survey by the Athletic Board of Control of the 549 men and women in competitive sports between August 1976 and August 1981 showed that 116 dropped out without a degree and 168 graduated. Percentages of players of the "highly visible" sports - football, basketball and hockey - who graduated were respectively, 67, 72 and 60 against 71 percent for all UND sports and the national graduation rate of 60 percent.

Athletic activities have become part of the public's perception of the institution; for many persons the principal, if not the only, way in which it exists is as a fielder of teams against those of the best known, high profile, universities. So, until the disintegration of the WCHA, hockey associated UND with Notre Dame,
Michigan and Wisconsin. In achieving this prominence, past and present UND administrations have determined athletic policies and regulations with effective control and student input. Athletic leaders over the years have been cognizant that intercollegiate athletic competition provides a powerful motivational force, encourages development of body strength, skill and agility and offers student-athletes

invaluable lessons in self-discipline and cooperation. The competitive games and events themselves have provided students, faculty and staff, as well as thousands of area residents, recreation and

entertainment while contributing toward student loyalty and morale. Furthermore, when student-athletes have achieved All America honors in any of the 22 men's and women's sports, or when one of the teams earns a national championship the state citizenry, to say nothing of thousands of loyal alumni elsewhere, proclaim their pride and exult in the knowledge that a university in a rural state can compete with and defeat the best teams in the country. 


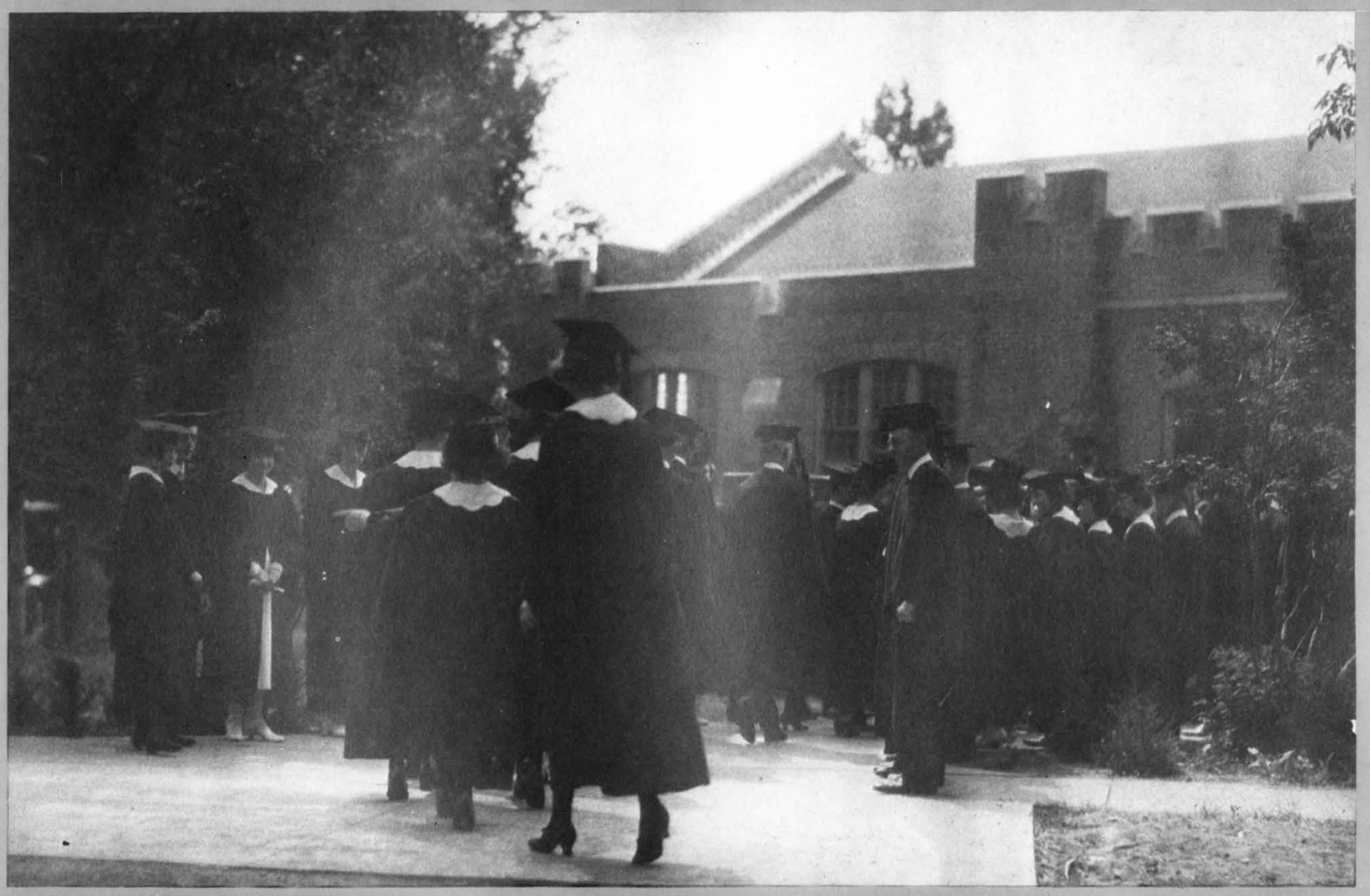




\section{Alumni}

By Dan F. Rylance

Assistant Professor of History

Coordinator of Special Collections

Chester Fritz Library

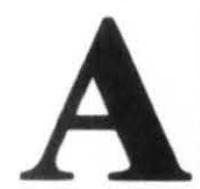

lumni are the elders of the University. They provide a unique and special attach-

ment to the institution which is different than

that of each generation of students, faculty and administrators. For some their

attachment is nostalgia. For others it is

concern as parents. For still others, a

loyalty based on later success or simply the

realization that the University played an

important role in their lives.

President Thomas Kane expressed this unique relationship of the alumni to the University in 1925:

We all know but we do not always realize that a university is made up of faculty, students and alumni. . . Alumni are members of the household the same as married children never loose their ties with the old home. The same holds true for all former students, whether graduating or not, that they keep up the old home ties.

The names of Frances Allen, Genevieve
Arnold, Clinton de Groat, Ben Ingwaldson, Irene Mares, Cora Smith, Marie Teel, and Mary Travis are not among those of the University of North Dakota's most significant people. In the historical context of the Centennial,

however, these six women and two men are important. They comprised the first graduating class - the class of 1889 , the first eight alumni. Moreover, when Frances Allen signed "the Roll of Honors" at the first, organizational, meeting of the Alumni Association on June 13, 1889, in the

University Parlors, immediately following commencement, she placed her name at the head of a long and never-ending list now of over 50,000 graduates as the Centennial approached.

Most alumni, like the class of 1889 , remain obscure to later generations of the University family. Their experience as students remains highly personalized and for the most part private. Some transfer, some drop out, most graduate. Some establish outstanding academic records, all learn, and a few fail. A substantial minority achieve international, national, regional or local recognition, but the majority do not. A small percentage repay their institution with truly substantial endowments, a higher percentage gives

generously, but the majority gives nothing. Many alumni later become parents, some of whom encourage their sons and daughters to follow in their footsteps. In the autumn years of life, many alumni recall what then seem the carefree, golden days on the campus, and return

In the formative years of the Alumni Association, the only formal activity for those who returned centered on hosting the banquet for the new graduates immediately following commencement. According to historian Louis Geiger "The fact that it was a highly select little band stimulated pride in the University and each annual meeting helped to fix the body of recollections and memories that go to form a tradition."'

The first generation of alumni and students sought to establish permanent institutional symbols for the fledgling university. The official colors of the

University, pink and green, were selected on April 6, 1889:

We have chosen the college
Creating new alumm at commencement ceremonies, the Armory; 1923. 
colors at last,

the prettiest ever seen

Bright pink for the dewy prairie

rose,

and for its leaves, the green.

A rousing "fight song" or liturgy to accompany the official colors came three years later. The first song, taken from a native American Sioux cry, was written because the school had "no hoary past to look back upon with pride," and "no college yell to make us furiously patriotic:"

$$
\begin{aligned}
& \text { Odz-dzo-dzi! } \\
& \text { Ri-Ri-Ri } \\
& \text { Hi-yah! Hi-yah! } \\
& \text { North Dakota. }
\end{aligned}
$$

Competition appeared as a natural byproduct of the newly established traditions. In the fall of 1892, based in part on the argument that "every other University, college, or similar institution of any pretensions, whatever has its football team" UND established one too. A school band followed in 1893 and the first intercollegiate debate was held in 1895 .

Early alumni paid particular attention to athletics. A winning tradition, especially in football, during these early years was the ultimate symbol of success. Accordingly alumni encouraged the hiring of the early professional coaches and sometimes paid their salaries. They promoted and supported the improvement of physical facilities and better athletic equipment. Ultimately the product turned out by these contributions was to be tested against

tough competition from established out-ofstate schools.

The alumni investment in football produced positive results. The school played its first game against an out-of-state foe in the fall of 1897 when it defeated Carleton in Grand Forks by a score of 207. The next year the University played its first out-of-state game against the "Golden Gophers" in Minneapolis. Although Minnesota won, 15-0, members of the UND family considered the low score, against a major school, a great moral victory for the University and the state. Moreover, the sting of the defeat was lessened by a 39-5 drubbing of the Agricultural College before the team returned home. Alumni and students joined together in Fargo and sang this song directed against their greatest in-state rival:

$$
\text { Oh A.C., oh A.C. }
$$

Why don't you learn how to

play ball

We wish you good luck

But you haven't the pluck

To win from our dear U.N.D.

We'd rather be rooters for our plucky team

than preside over farmers galore you're the worst ever was and we beat you because You're A.C. Poor A.C.

Success in athletic competition produced the school's first popular heroes. Joe Flanagan, who in 1895 began a six-year career in football, baseball, and track, was the first acknowledged "super-jock" and in 1933 was selected as the University's greatest all-around athlete. In addition, the roster of the early football teams reappeared as a Who's Who of state leaders. Athletic success as a student was transformed to political success as an alumnus. Footballer William Nuessle became Judge Nuessle, chief justice of the North Dakota Supreme Court. Footballer Lynn Frazier became Gov. Frazier and then U.S. Sen. Frazier, the first University graduate to be elected to either position. Footballer William Lemke became Atty. Gen. Lemke, Congressman Lemke and in 1936 the state's first and only presidential candidate.

Alumni who attended the University during the first two decades of its history shared common memories of North Dakota's only university. The picture in their minds was likely the same as the description of the campus written by a newly arrived faculty member in September 1897: "Three very plain buildings were standing on a twenty-acre lot in the midst of a great wheat field." Most of them had come to escape the farm and get an education. Dr. Walter J. Marclay, class of 1891 , recalled his first day and his motives for attending: "I was an overgrown, round-shouldered boy of seventeen; poor, painfully poor, but ambitious for an education." Others reminisced about a favorite past time of fall and spring:

See them walking on the (Great Northern) track, walk a piece and then turn back, Lessons are forgot, alack!

All shared a common tradition shaped by a small campus, an absence of fraternities and sororities, isolation from town and the spartan simplicity which characterized those early years:

The life here is a typical life. It is a western life. It is a pioneer life. As is the parent, so is the 


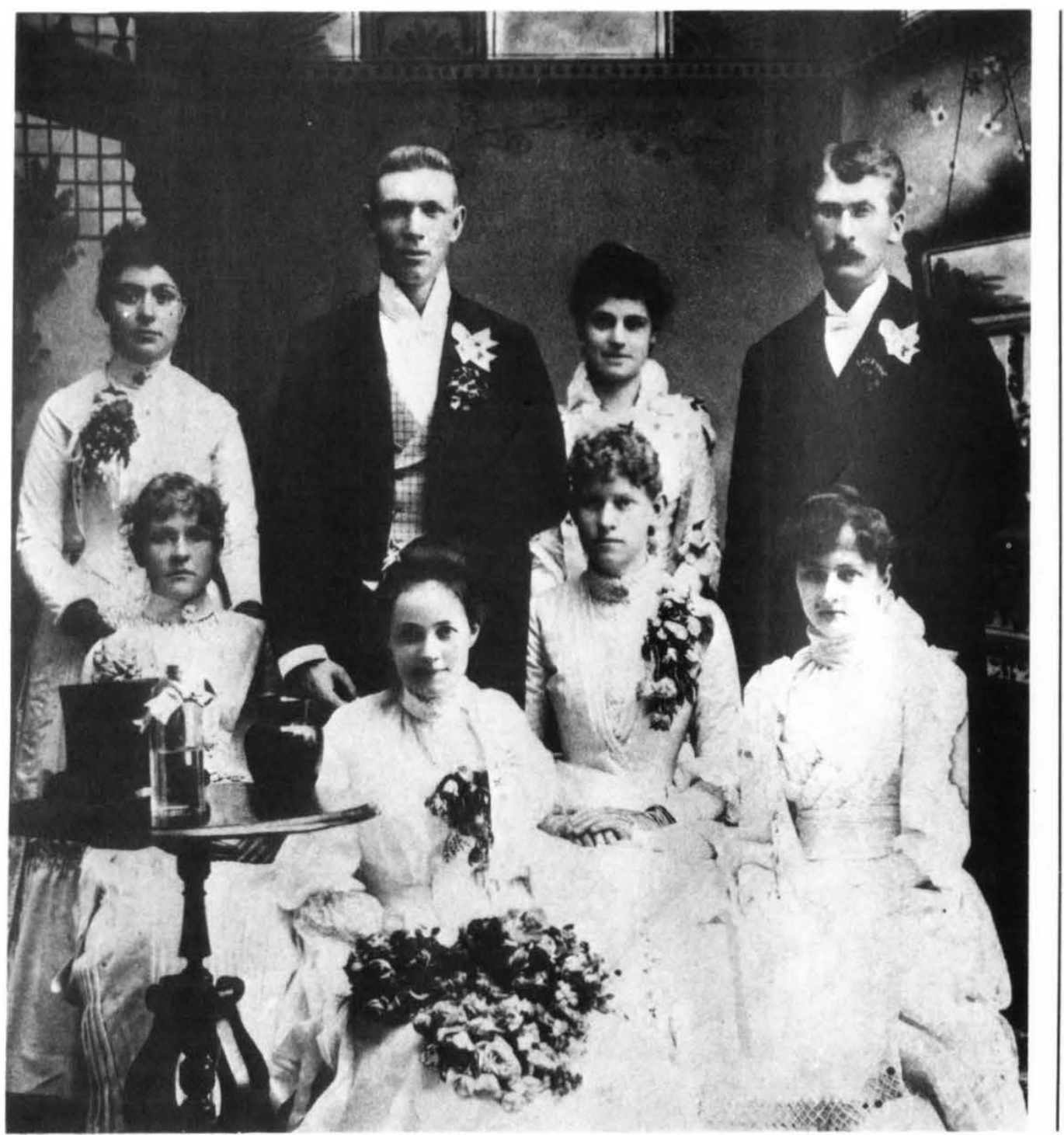

child, as is the environment, so

is the product; as is the state, so

First graduating class, is the university.

Presidential leadership, positive suggestions by graduates, and growth in student enrollment precipitated changes in the scope of alumni relations. These

developments took place primarily between 1904 and 1916 and have survived with some modification to the present.

Webster Merrifield in his last years as the president used his public speeches to answer the question "What can the alumni do to help the University?" He urged alumni to create local clubs, appoint a local press agent, recruit the best high school graduates and return each year for commencement. This annual return to the campus should be used to give

"encouragement to the president and faculty," to "renew old friendships" and to experience "a new baptism of loyalty and love for alma mater." Merrifield identified Neil C. Macdonald, class of 1900 , as the model alumnus and challenged others to emulate his work: "When N. C.

Macdonald was superintendent at

Lidgerwood he sent some years nearly his whole graduating class to the University, although Lidgerwood is situated in a region remote from the University, with almost "impossible" railway connections.

Had the university a Neil Macdonald as superintendent of even half of the high schools of the state she would have a thousand or twelve hundred students attending her various colleges today."

Merrifield stressed three major reasons for becoming an active member of the Alumni Association. First, to repay the 
The Adelphi Fountain, presented to the

University in 1905 by

alumni of the Adelph

Society, UND's first

student organization.

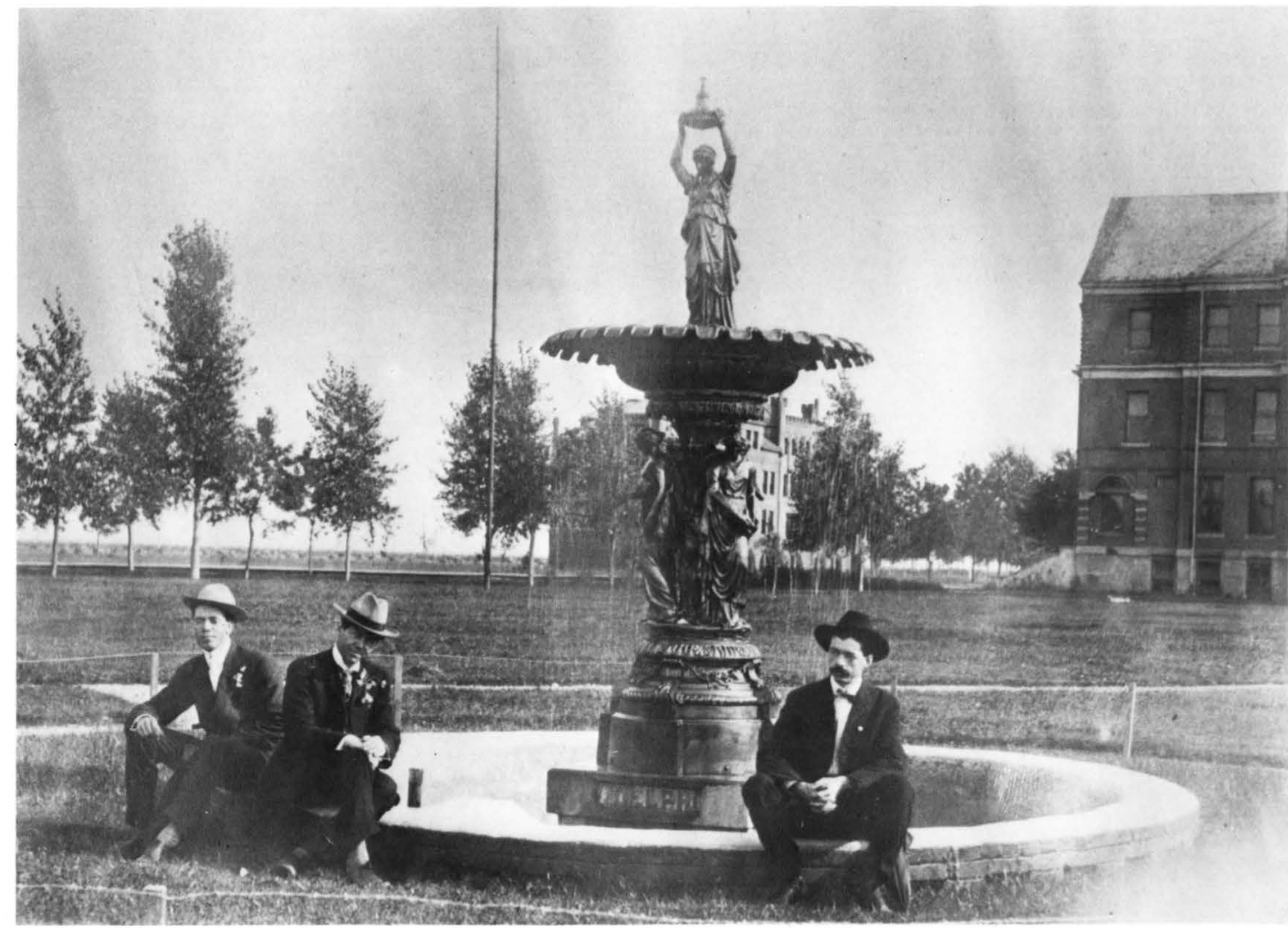


University "which has done much for you"; second, to help "keep you out of a rut"; third, to facilitate one's career. On this latter point Merrifield spoke candidly: "It is going to mean a lot to you in the next twenty-five years, if you are in politics, business or professional life to have the good will of the University alumni, who, by that time, will constitute the most influential nonpolitical organization in the state."

The University gave itself another tradition when it celebrated its first Founders Day on Saturday, Feb. 27, 1904. The day selected by the faculty to be observed as the official birthday of the University was the one in 1883 when the signing of several separate acts established a territorial university at Grand Forks.

The first observance of Founders Day began with a debate on Friday. Student speeches and a girls basketball game followed a Saturday morning convocation. In the evening, Bardi Skulason, class of 1895 , representing the alumni, spoke on "The University and the State." President Merrifield closed the festivities with an historical reminiscence of "The University - Its Past.” By 1910, Founders Day had an established pattern of a basketball game, a faculty-student-alumni dinner, and speeches by prominent alumni, board members or state officials.

Three important alumni-related events occurred in 1907. Devils Lake accepted a Merrifield challenge and organized the first local alumni chapter. The Grand Forks Herald supported the University's effort to establish the North Dakota High School Debate League. The declamation event

\section{THE ALUMNI REGISTER}

No. 1

$\begin{array}{ll}\text { Vol. } 4 & \text { NOVEMBER, } 1913 \\ \text { For North Dakota-To Unite the } 1 & \text { Published by the AlumniAssociation } \\ \text { Alumni to Serve the University } & \text { of the University of North Dakota }\end{array}$

\section{Football Situation at University}

The annual football season at the was devoted to the hiring of an asU. N. D. has just closed and while the sistant coach for the football team. results in the way of winning games It can be conservatively figured were not satisfactory, the varsity that elose to $\$ 3,000$ is directly chargeclosed the season by taking into camp able to the football branch of athletics our old rival the Agricultural college so that the feeling which has existed by a score of 20 to 14 . The A. C. had among some of the alumni that the all the best of it in the first half but university is not spending enough in the second the varsity came back money to insure a strong football with that fighting spirit that charac- team is hardly warranted. It is a fact terized university teams of old and that the university has been rather played their opponents off their feet. unfortunate in the choice of football This was the only game won during coaches but this can be traced to the the season, defeats being suffered at fact that the coach is hired for the the hands of St. Thomas college, Ham- year and is required to coach not only line university, Carleton college and ter, and track or baseball in the the University of Minnesota. Two of spring. The athletic director devotes the ganes were lost by close scores his entire time to the various classes while in the game against the Goph- in physical culture, attendance in ers the university made a splendid from tooth coaches and newspaper from

In order that the alumni may understand something of the athletic situation at the tuniversity and what is ing fots are given. The university is now spending a total of $\$ 4,000$ for instruction along various athletic lines This includes the satary of the director for men, the football coach and the dollars is spent yearly in equipment and in care of grounds, while the expense of maintaining the gymnasium is approximately $\$ 2,500$, In adation to these sums a total of $\$ 800$ is paic this sum is spent by the athletic board as it sees fit. The money this year garding plans that may work to a better advantage toward securing better results in football. It has been ve hired in acdition to the coach for the various other teams, the latter to act as his assistant. In other words in assistant director in athletics could be sectron who would assist in coachguired duties as a coach throughout the year, while a special football coach could be hired by the athletic board with the subsidy furnished by the unialumni. This is one suggestion offered. If you have another that appeals to you send it along. 
Neil C. Macdonald, one of many early graduates who

became embroiled in the state's political battles, and his wife Kathrine Belanger Kactome Belanger

Macdonald (later Tiffany), who became an influential benefactor of UND. held each spring on campus combined with a track meet and served to give many North Dakota high school students their first look at the University. Finally, the Association made major a revision of its constitution and organization.

With funds raised by the one dollar dues collected after 1907 and $\$ 100$ from the administration, the expanding Alumn

Association published two volumes of the Alumni Register (October 1910-July 1912). It was the first alumni magazine. The Register listed all known alumni by name, degree, address and occupation, as well as providing a geographical location and class membership. It was an important document and served as a forerunner to the UND Alumni Magazine which was established in 1925. Its publication prompted one alumnus to write about his reaction to new caps and gowns which first appeared at the 1911 commencement: "It looks strange to me, but it looks good. It seems more in keeping with the spirit of the day than the motley assortment of costumes when I graduated.'

The University had 628 alumni in 1909. Approximately 75 percent of them lived in the state or immediate area. The institution could count at least one lawyer and one teacher in each county of the state as well as graduates in 25 other states, Canada, Panama Canal Zone and the Philippine Islands. Statistical analysis of the class of 1908 demonstrated the marketability of graduates and usefulness to the state. Of 89 graduates of the class of 1908 , only two were unemployed in 1909. Seventy-two remained in the state or immediate area while 17 migrated elsewhere. The largest categories were the three professional

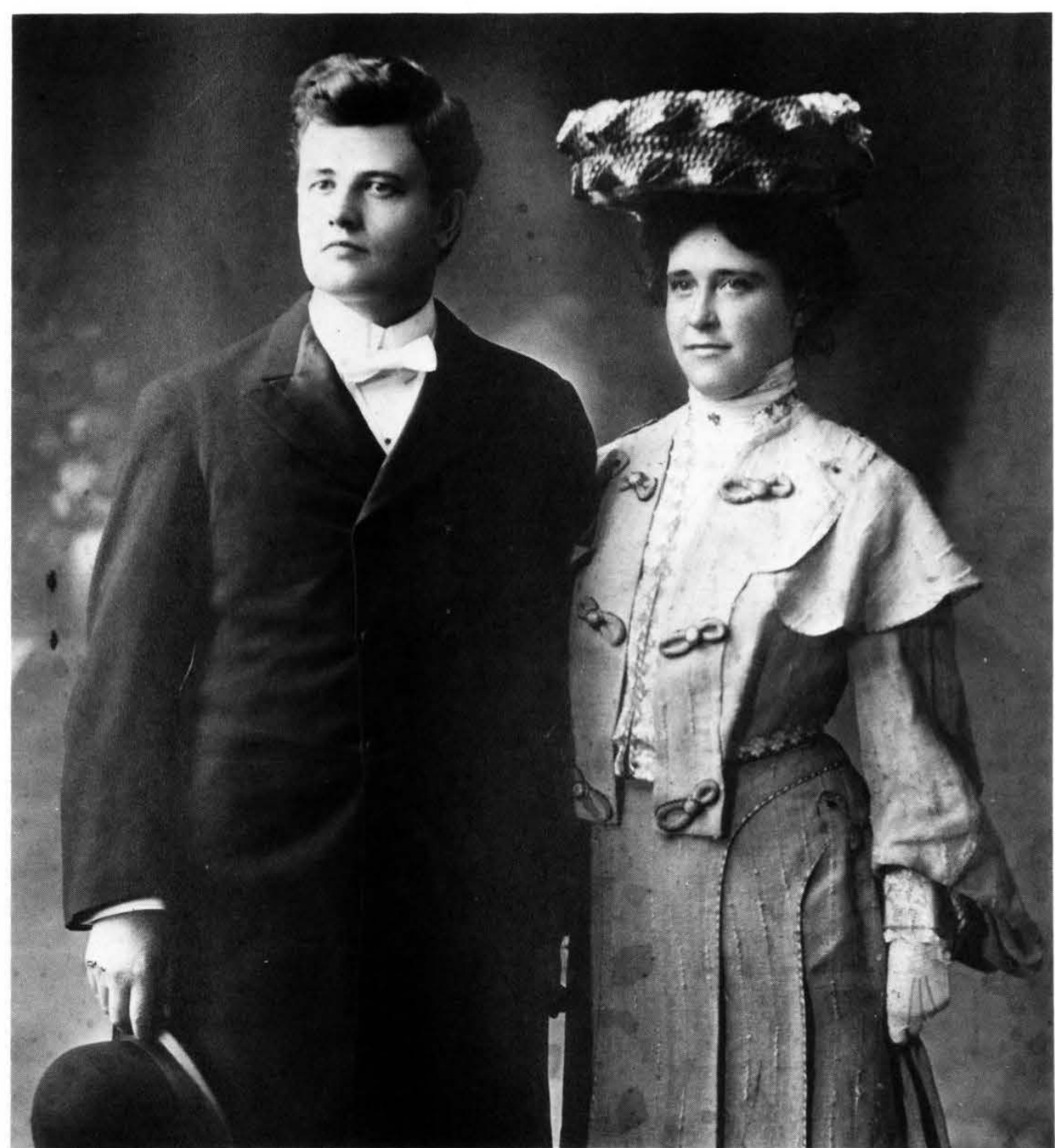


fields: law, education, and engineering, although 12 graduate students, four government employees and one minister were also identified. Clearly the University was growing with the state.

By 1912 , alumni began to gather by class at commencement except for "the politicians who gravitated to one table." They had become active and visible members of the Legislature, especially interested in the size of the University appropriation. County and city alumni groups increased in number and importance. In 1915, the Association incorporated and the University combined the position of alumni secretary with a fulltime position in the Department of Extension. In 1916, the University celebrated its first autumn Homecoming Alumni liked the "tradition" and for many it soon replaced commencement as their time to return to the campus.

North Dakota returned to a more conservative brand of politics at the opening of the twenties. Historically it was a time of bitterness, one of the worst in the entire political history of the State. A noholds-barred donnybrook developed within the Republican party between the Nonpartisan League (NPL) and the Independent Voters Association (IVA) for control of state government.

Suddenly the first generation of North Dakota-born University graduates who had played together on football teams battled with one another in the political arena. What began as a friendly difference of political philosophy within the walls of the Varsity Bachelor Club escalated into a vicious public debate between state capitalism and free enterprise, socialism and Americanism, isolationism and intervention, the red flag and the Stars and Stripes. When the dust had settled, NPL alumni defeated IVA alumni and vice versa; a few had chosen to compete as Democrats.

It started in 1916 with the Nonpartisan League political prairie fire which elected Lynn Frazier, William Langer, and Neil C. Macdonald to the offices of governor, attorney general and superintendent of public instruction. It continued for Frazier and Langer in 1918 but ended for Macdonald who was defeated for reelection by Minnie Neilson (IVA). It also included Harrison Bronson (NPL), elected to the North Dakota Supreme Court. In 1920, Frazier, still NPL, defeated Langer, now IVA, in the Republican primary for governor and J.F.T. O'Connor, a Democrat, endorsed by the IVA for governor in the November election. O. B. Burtness (IVA) was also elected to the U.S Congress. In October 1921, voters recalled Frazier (NPL) as governor and William Lemke (NPL) as attorney general and replaced them with Ragnvold Nestos (IVA) as governor and Sveinbjorn Johnson

(IVA) as attorney general. In 1922, Frazier (NPL) was elected to the United States Senate by again defeating J. F. T. O'Connor (Democrat). William Nuessle (IVA) was appointed to the North Dakota Supreme Court in 1923.

Most people living in the 1920 s enjoyed contests. The University was no exception. Student-sponsored events came in all shapes and sizes. They ranged from beauty contests, both male and female variety, trivia and any number of other events. The alumni, in conjunction with the University of North Dakota Press Club, also promoted a contest to identify the 10 outstanding alumni of the University. The 10 , all men, were selected on the basis of a survey conducted by the Press Club and the winners were announced in April of 1925. They included Maxwell Anderson, class of 1911, playwright and Pulitzer Prize winner; O. B. Burtness, class of 1906 , U.S. congressman and later district judge;

Thomas Campbell, class of 1903, "the world's greatest wheat grower"; John Lee Coulter, class of 1904, president of North Dakota Agriculture College; J. Francis Douglas, class of 1896, construction executive; Lynn J. Frazier, class of 1901, governor and United States senator; John M. Hancock, class of 1903 , business executive and financier; Howard $M$ Huston, class of 1918, an official of the League of Nations; Ragnvold A. Nestos, class of 1904, governor; and Vilhjalmur Stefansson, the famed Artic explorer. Three were graduates with more than one degree; Stefansson had been suspended.

Three UND alumni in 1927 served as elected attorney generals of North Dakota, Montana, and Massachusetts: George Shafer, class of 1912, later governor, in North Dakota; LeRoy A. Foot, class of 1906, in Montana; and Arthur K. Reading, class of 1909, in Massachusetts. The latter presented the final summation for the prosecution at the Sacco-Vanzetti trial and debated the celebrated Clarence Darrow on Dec. 15, 1927, at Boston's Symphony Hall on the topic "Capital Punishment as a Suitable Crime Deterrent."

In 1933, President Franklin D. Roosevelt appointed J.F.T. O'Connor as comptroller general of the United States. It was an 
Pulitzer Prize winning playwright Maxwell Anderson, class of 1911, who was named 1911 , who was nam in 1923 as one of

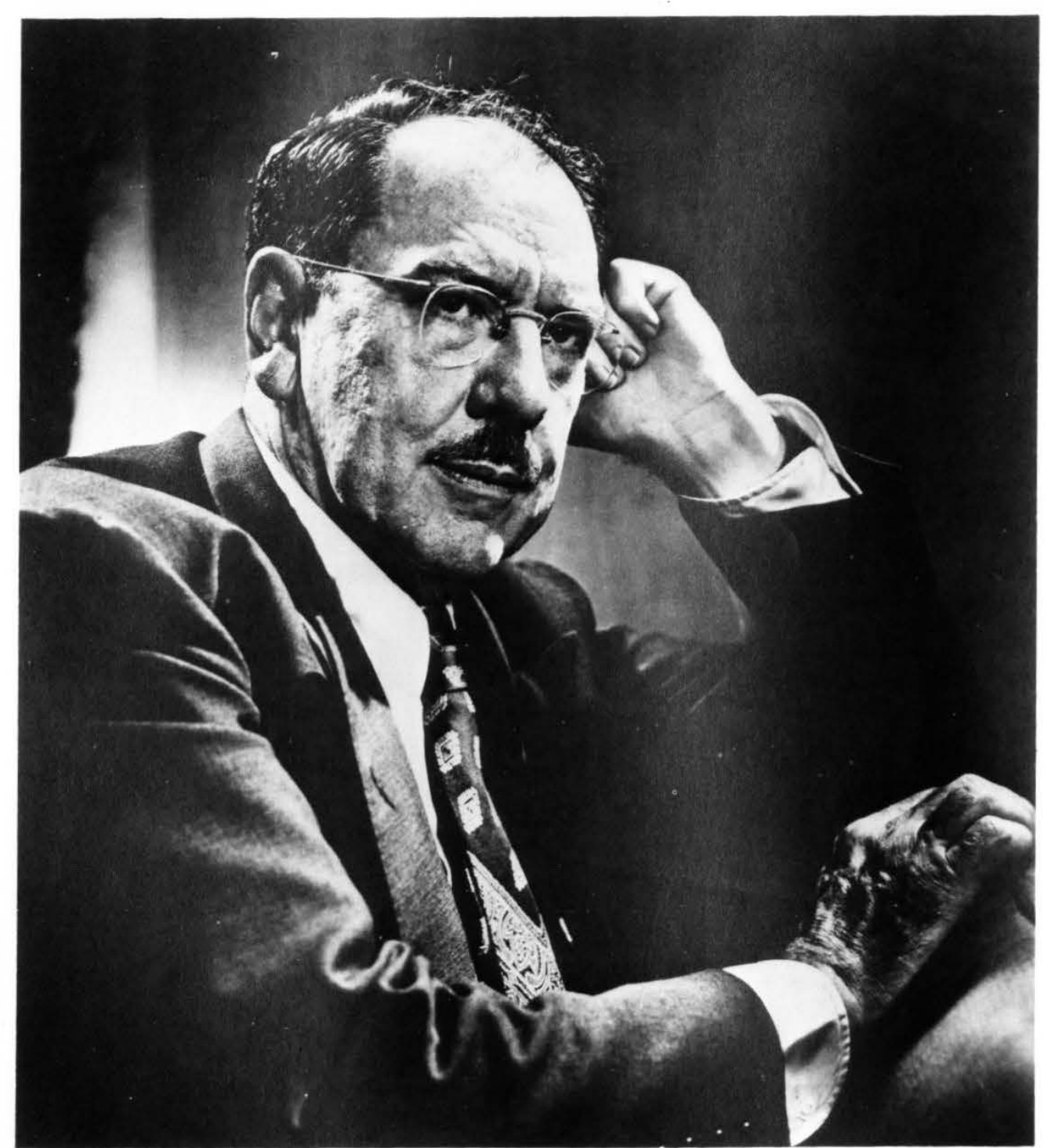

important national assignment to

reorganize the nation's banking system.

Sen. David Reed, Republican of

Pennsylvania, objected to the appointment of O'Connor: "He has never been an

officer of a bank. He has never been a director of a bank. He has never been counsel for a bank. He knows no more about banking than any depositor would know from having a checking account.'

With one-sixth of the banks in the country closed, the comment seemed more like an endorsement than a criticism. O'Connor replied that "The depositor's interest comes first."' The administration characterized O'Connor's personality,

background and training as

"doggedness." He got the job.

The advent of the radio on campus did not escape the attention of the alumni KFJM, the first radio station in Grand Forks, began broadcasting in the fall of 1923. One alumnus admitted his only contact with the University was listening to the radio and urged more and better programming. In particular he suggested the use of faculty for continuing education programs and complained that too much noise during the basketball games made it impossible to hear the play-by-play descriptions.

The University administration responded negatively to the use of faculty. James Wilkerson, business manager, replied that

"We find it rather difficult to persuade them to talk over the radio. They are somewhat diffident and feel that in most cases their lines of work are specialized.' As to the noise during the basketball games, Wilkerson added: "What we need is a new gymnasium." Although greater 
use of the radio came later, early prodding by the alumni contributed to a change in attitude by the administration and to more educational programs at KFJM.

The 1923 Founders Day speech delivered by John Hancock, class of 1903 ,

enunciated the basic themes of the

American success story. Born 21 days

before the University was established,

Hancock as president of the Jewel Tea

Company epitomized the ultimate busines success of the UND graduate. He recalled his student years as being "the best kind of a business deal I have ever made." $\mathrm{His}$

prescription for success was quite simple:

"Take hard courses, with hard professors and work hard!" According to Hancock,

North Dakota offered a unique

environment to prepare one's self for

success in the business world: "Life in this

state is hard. It is practical. It is good that it is so." Hancock also stressed the importance of athletics because "They teach man to quit being a quitter." $\mathrm{He}$ stressed

loyalty to his alma mater: "No man can knock the institution of which he is a part."

While Hancock spoke in Grand Forks, the New York Times billed Thomas Campbell, class of 1903, as "the world's greatest wheat grower." It described the 80,000 acre Hardin, Mont., farm with 109 tractors, 500 plow bottoms, 100 seeders, 80 binders, and 8 combines as the world's largest and most efficient farm operation. Campbell predicted: "The farm is going to be a place where the skilled mechanic will find a good job, under the best working conditions and at high wages. Ten years from now we may have a million such men working on farms. The time is coming when people will no longer call the farmer a 'hayseed' or a 'hick.' The farmer of the future will take his place in the world where he belongs, as a great industrialist."

With only a part-time secretary, little financial support - even by successful graduates - and no regular publication, the Alumni Association was ill-equipped to handle basic record keeping for an increasing number of graduates. Seymour Anderson, who worked full-time in the Extension Division and part-time as alumni secretary in the early twenties, confided to one alumnus: "I realize more and more everyday that I am in the office that the central organization of the association has gotten very much out of touch with alumni. For example, it took nearly two months to discover what your present address was."

Individual alumni also complained about the lack of a strong association. One letter argued that paying dues to join the Alumni Association was an insult to every graduate of the University. Another letter complained: "I paid dues one year and during the entire year did not receive a solitary thing - no, not even a dun, appeal, roast, news or scratch of a pen.'

The alumni at their regular June meeting in 1925 proposed the following change in the constitution: "Any person who has at anytime matriculated in any department of the university may become an associate member of the Alumni Association. Associate members shall not be allowed to vote or hold office in this association.' Although approved as a compromise, it still left many former students critical of the association as being exclusive and undemocratic. Vilhjalmur Stefansson, who always enjoyed controversy, responded indignantly to a request for dues in 1927:

"I should have been very glad to send you my check for $\$ 10.00$ but I thought you were not eligible at North Dakota unless you had a degree.'

Prestige through athletics continued as an alumni priority throughout the 1920s. It was not accidental that the most ambitious fund raising project attempted by the Alumni Association in 1925 called for $\$ 500,000$ to construct a University

Memorial Field, a complex to include a memorial stadium, gymnasium and athletic field. The Association sought to honor both the University's 43 sons who died in World War I and President Webster Merrifield who did so much to build the University. Paul Samuelson, class of 1923, who headed the drive, conceded it was a "mammoth task" but it offered "the first opportunity our former students have had to participate in establishing a worthy memorial at our Alma Mater." The project was selected because the Association believed that "a new stadium, gymnasium and field will be a fitting memorial to our university and it will serve to place North Dakota on a par with any institution in the country.',

In the spring of 1925 the Association announced its plans to publish the UND Alumni Magazine. Although it agreed to publish the first issue, it also indicated that "subsequent issues must pay their own way." Both the University administration and the Association, however, attached a great significance to the magazine's future role. "A successful magazine will mean a bigger, better and stronger Alumni 
Only the Memoria Stadium was completed, but the fund drive for an athletic complex stimulated the growth of the Alumni Association in the 1920s.

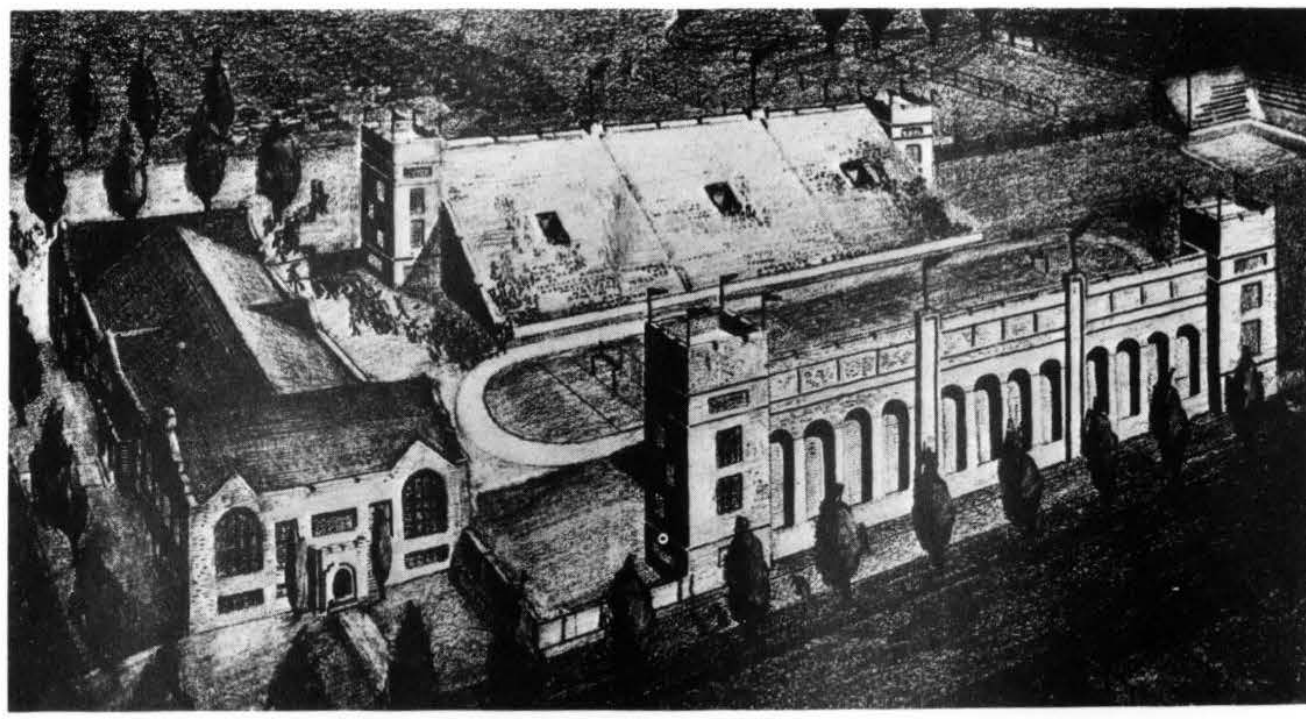

Association and it will mean a bigger, better and stronger University.',

Economically, the years after 1925 were not good ones in which to succeed in a major fund drive or to sell subscriptions to a new magazine. Moreover, if the late 1920 s were bad, the 1930 s were worse. During the years of the Great Depression alumni support slipped mainly to sentiment. By the spring of 1931 finances of the Association hit bottom. In June, Frank Webb, its secretary, announced publicly that it was $\$ 1,200$ in debt. Of a total of 4,000 graduates and 9,000 former students less than five percent, or 800 , contributed. When pledges for the

Memorial Stadium dwindled, the memorial corporation hired a local law firm to collect delinquent payments. Irate alumni complained and called for a halt to the legal action; Webb responded that "this is a business proposition and the university's hands are tied."

With rising unemployment, graduates and former students expected the Alumni Association to locate openings and write letters of recommendation for them. The effects of the depression on school teachers, the elimination of positions and the cutting of salaries were uncommonly severe. One alumnus wrote in the spring of 1931 that "this is the time of the year when we lousy school teachers start looking for a job for the coming winter to help battle the unemployment situation.' His letter indicated a preference for a change in schools because "I have been in this dump for two years and must say that it is the worst place in the state that the University could possibly send a teacher.'
The thirties produced a major change in an important institutional symbol. In the fall of 1930, the nickname of the University teams was changed from Flickertail to Sioux. Supported by the Alumni Office, administration, faculty and students, the formal announcement on Oct. 2 prompted much enthusiasm and little opposition. Frank Webb, alumni secretary, said the name Flickertail "hampered publicity for the University against larger institutions." Coach “Jack” West admitted the name Flickertail conveyed an inferior image which was a detriment to his teams - "the idea of hunting our hole as

soon as we see the opponents." Dean William G. Bek, of Arts and Sciences, labeled the name change "the most aggressive thing we have done for a long time." His predecessor, Dean Vernon P Squires, interviewed on his sick bed, strongly argued that the institution to which he had devoted "his life" should no longer be represented by a tiny animal on which a bounty had been placed.

Privately, conservative members of the Alumni Association expressed reservations about the new nickname particularly with its relationship to the image of North Dakota. Fred Traynor, Alumni President, wrote to Frank -Webb about this: "It seems to me there is already too much of a notion abroad, especially in the east, that we are still Indian territory and that there isn't much else in this state except Indian wigwams and that we all go around with war paint on our faces and feathers in our hair. The adoption of the name Sioux to our football team would certainly add to that idea."

Moreover, in support of retaining 
Flickertail, Traynor argued that the animal projected the idea of "quick action" and "quick thinking" as well as

"resourcefulness," all attributes of a good football team. In addition, the name Flickertail was "no more lowly than the gopher or the badger or the jackrabbit," nicknames applied to other regional schools.

Between World War I and World War II, institutional symbols of morality and decency although minor remained a recurrent theme of alumni concern. More often than not, alumni interpretation of the symbols reflected their own concerns as parents. It was often rigid, intolerant of a younger generation and somewhat inflexible in understanding the enormous complexities of change in American society.

Patriotism met with concensus but conflict over personal morality appeared regularly in a low key manner between the wars. During these 20 years, the Alumni Board formally discussed the changing nature of student publications at the University. In 1925, at its June meeting, the Board adopted resolutions condemning the "Harpoon," an anonymous studen publication, and offering "a reward of $\$ 200$ for evidence leading to the prosecution of the editors or the publishers." In 1930, the Board again discussed the issue of scandal sheets and also occasional statements published in the Dacotah yearbook. It referred to them "as detrimental to the best interests of the University."

The satire section of the 1931 Dacotah, however, caused the greatest consternation. Fred Traynor, a 1904 law graduate, Devils

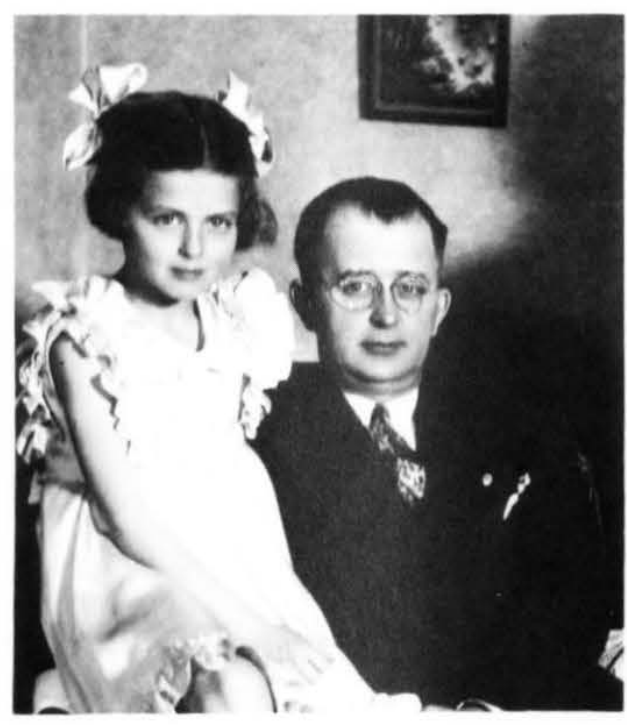

Lake lawyer-legislator and president of the Alumni Association, wrote to Frank Webb in June 1931 urging him to "cut the satire section before these books go out to the high schools." If already too late, he suggested the annuals be returned to the University in order to have "the satire section expunged." Traynor's letter, in part, probably reflected the concern of William L. Nuessle, chief justice of the North Dakota Supreme Court, who was embarrassed by the following joke which appeared in the satire section:

One argument in favor of drink:

Alcohol made me a Cadet

Colonel'-Robert F. Nuessle.

Judge Nuessle, a close personal friend of Traynor and one of "Merrifield's boys," was an alumni stalwart who had earlier confided to Dean Squires that "I am, I think, almost fanatically loyal to the University." Moreover, his response to the joke reflected a basic element of the University of North Dakota tradition instilled in him during the Merrifield years - "the building of character and training in morality." To have his own son identified with alcohol as a positive factor in his college career even in satire deeply offended the judge's personal sense of morality and the essence of the UND tradition he had acquired a generation earlier.

Offcolor jokes which treated social contacts between Greek fraternities and sororities also caused concern, primarily because they would offend parents of potential students:

$$
\begin{aligned}
& \text { Sigma Chi: "2818 Central. } \\
& \text { Hello, how are you tonight?" } \\
& \text { Pi Phi: "Lonely?", } \\
& \text { Sigma Chi: "Good and lonely?", } \\
& \text { Pi Phi: "No, just lonely." } \\
& \text { Sigma Chi: "I'll be right over." }
\end{aligned}
$$

Beta: "How are all the little

pigs down on the farm?"

A.T.O.: "Fine. How are all the pledges at your house?"

The fact that all the annuals were returned to the University and sent back only after the satire section was removed, demonstrated the seriousness of this issue for the alumni family.

During the depressed late 1920 s and 1930s the University celebrated two former students whose daring exploits gave strength and courage to all. Carl Ben Eielson, class of 1921, ranked as the greatest all-around University alumni hero 
during the years between the wars. His daring flight over the North Pole with Sir Hubert Wilkins in 1928 placed him second only to Charles Lindbergh in the eyes of his fellow North Dakotans. His heroic death in November 1929, in an ill-fated rescue mission off the coast of Siberia, brought him national and international recognition. Fellow explorers around the globe paid their respects by attending a huge funeral in his home town of Hatton while his own country awarded him

posthumously the Congressional Medal of Honor.

Nor was Eielson forgotton by his alma mater. Blue Key preserved his Arctic parka in a glass case inside the south entrance of Merrifield Hall; the 1932 Dacotah dedication read "To preserve his name is our purpose."' In the meantime, Professors Richard Beck and Gottfried Hult eulogized Eielson with their poems "Eielson Come Home", and "Rough Rider.'

\section{Rough Rider}

He rode his 'plane enough on high and far

to make it cast its shadows on a star.

He spurred his air-mount with intrepid soul

to clear the iceberg hurdles nigh the Pole.

That Badlands too has now its cause for pride

He taught the sky's rough-riders how to ride.

-Gottfried Hult

The expulsion or suspension of Vilh jalmur Stefansson (Willy Stephenson

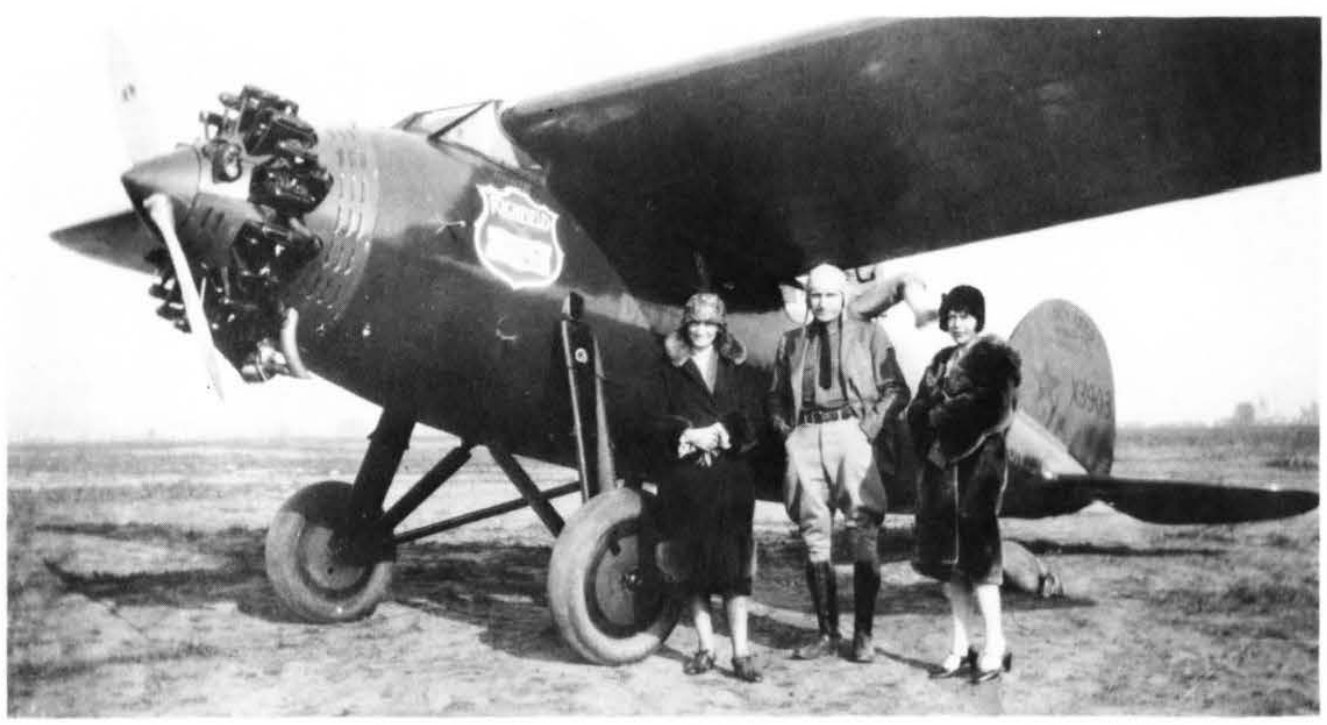

before 1899) from the University in 1902 came ostensibly on the grounds of poor attendance and "failure to attend to his duties." Stefansson's ability to excel in things academic while playing lazy was the key to his popularity as a student. The acceptance of this public image by the administration and faculty was also the key to his suspension although secretly he was "an intense, hardworking student." According to a recent biography: "The colorless academic routine seemed alien and meaningless to a young and brilliant individual who had long known his own abilities, and all of those visions were underscored by the idea of personal greatness. He was impatient with things as they were, and his impatience continually boiled up in outbursts of irreverence and iconoclasm - sometimes, one suspects, more for effect than substance. In curiously modern tones, he scoffed at the type of formal learning to which he was being subjected. As an educational process, it was stagnant and useless."

Even with suspension and subsequent graduation from the University of Iowa, Stefansson remained a loyal son of the University. In 1930, UND of ficially declared that Stefansson had been suspended and not expelled which allowed him to receive an honorary L.L.D. degree. Ironically, the Alumni Association's 1932 directory which contained the list of all persons who received degrees from the University omitted his name. The omission prompted a sharp reply: "It took me something like a quarter of a century to ge a UND degree so I am correspondingly disappointed that my name is missing. No 
one else would notice the omission but I noticed it a lot - or else I think it is funny that after all the hard trying I am not yet quite within the fold.'

World War II brought many changes to the nation, the state and the University. At the University it was simply called "A New Day." Between 1946 and 1954, the last eight years of the West presidency, the Alumni Association spearheaded a comprehensive development program. Its seven major goals included: a state medical center, a new gymnasium, a student union, better alumni records, a stronger Alumni Review, increased contributions and a new alumni university development fund.

Alumni generously responded. They contributed over $\$ 300,000$ between 1945 and 1950 . The new day at the University coincided with the Aandahl administration in Bismarck. Gov. Fred G. Aandahl, class of 1921, although a fiscal conservative, was a loyal alumnus. His administration made executive recommendations for badly needed buildings and more staff. The enrollment of his daughters among 125 second-generation students at the

University demonstrated a strong continuity between one generation and another.

Institutionally the person most responsible for the revitalization of the Alumni Association was its new executive secretary, J. Lloyd Stone. His appointment effective Dec. 1, 1945, at a salary of $\$ 5,000$, established the first full-time alumni employee paid exclusively out of non-university funds. Stone's hiring came from a motion by Joseph B. Bridston,

Grand Forks businessman and prominent Republican state senator. At the fall 1945

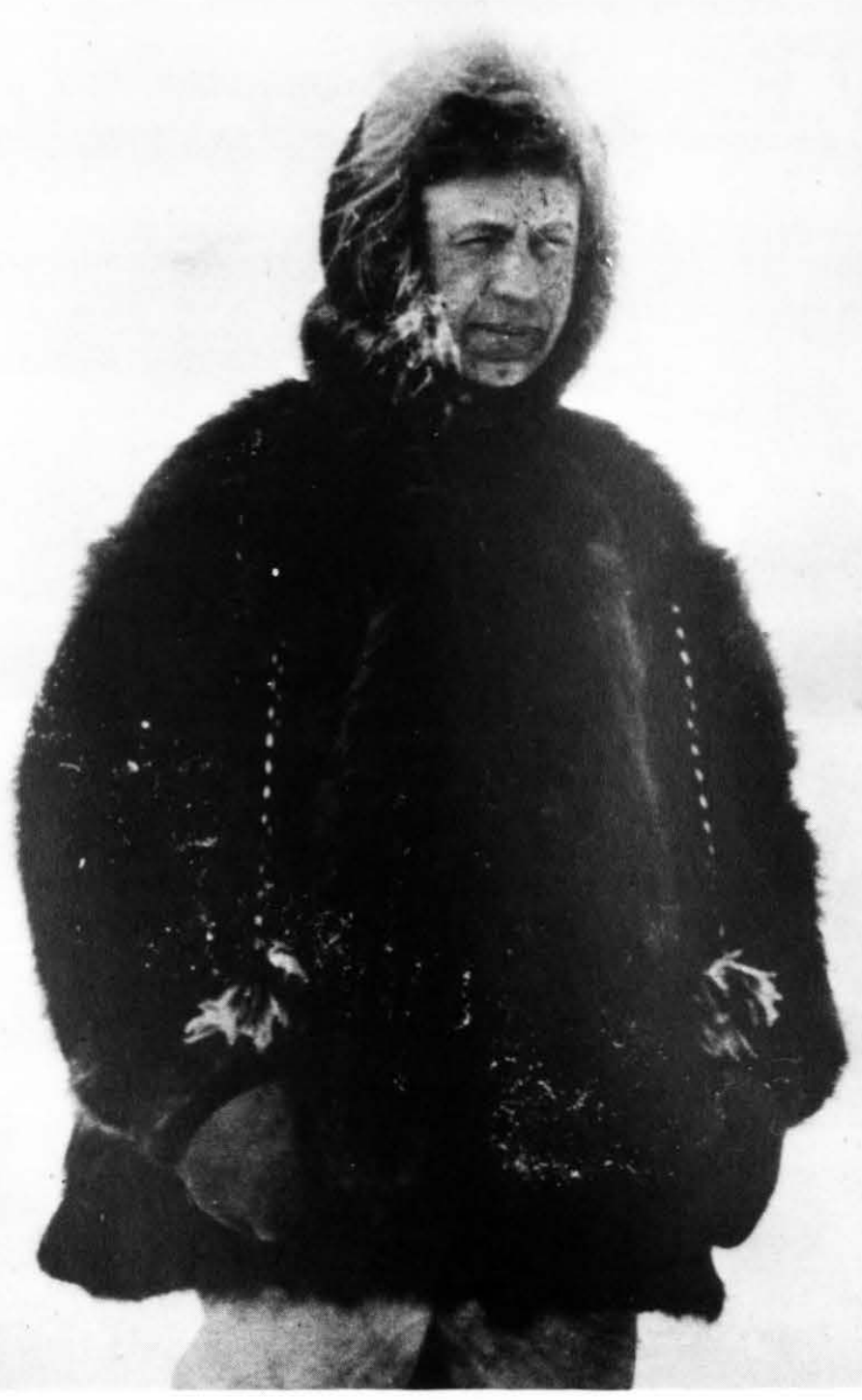

Arctic explorer Vilhjalmur Stefansson, who despite being suspended for his practical jokes, remained one of UND' most loyal boosters. 
J. Lloyd Stone, appointed Alumni Association executive secretary in 1945, visits with 1 .

Beatrice Johnstone, Beatrice Johnstone, receive an honorary receive an honorary its first century. meeting of the association, Bridston presented his plan for a stronger alumni association. He proposed the immediate hiring of a full-time secretary and the establishment of an active Grand Forks alumni chapter. In support of his plan, Bridston personally offered to obtain fund to pay for Stone's salary for the first year.

Stone brought a varied administrative background to the position. With undergraduate (1930) and graduate (1936) degrees from the University, he served as principal and superintendent of schools in Hazelton, Inkster and Drayton, N.D. From 1937-1942 he worked for the National Youth Administration, first as deputy administrator in North Dakota and then as a regional supervisor. During the war Stone was a commissioned officer in the United States Navy serving in the South Pacific. Tall, with a broad, relaxed smile and an outgoing personality, he made alumni feel important.

In the twilight of the West presidency, the Association made important changes in its own organization. In 1946, it approved a constitutional amendment which allowed all "former students" to be members of the alumni family. More importantly Stone changed the organization from one requiring the payment of dues to one of automatic membership with a free subscription to the Alumni Review. He also launched a vigorous program to update addresses, expanded the number of local chapters, initiated tours and established an annual reunion at Camelback Inn in Arizona.

Externally the Association also

demonstrated a broader approach to its support of University programs. Athletics

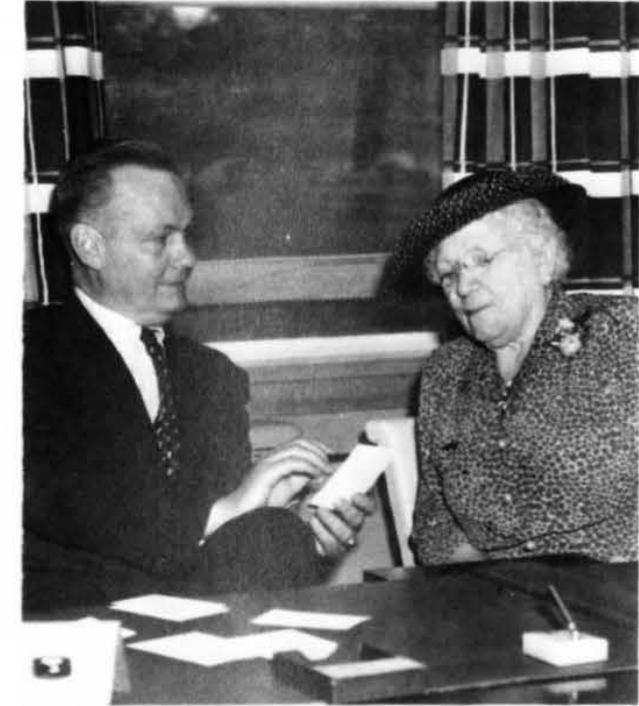

remained a high priority and alumni made important contributions for an ice plant at the old Winter Sports Building and a swimming pool in the new fieldhouse. But alumni also contributed to the Memorial Student Union and increased the number and value of student scholarships. Yet, their most visible project during this period was promotion of the Medical School. Aided by a strong advisory group and ably assisted by Dr. Ralph Leigh and attorney Harold Shaft of Grand Forks, the Alumni Association pushed hard for the establishment of a state medical center as an administrative arm of the University. The Legislature approved the enabling legislation and appropriated funds to build it. Voters of North Dakota by a separate constitutional measure gave their approval to the plan "for more doctors" by approving a statewide one mill levy to support the medical school.

The rejuvenation of the Association coincided with the presidency of George W. Starcher who became the seventh University president on July 1, 1954. Starcher quickly established institutional goals in the same manner Frank McVey had done in 1910. Unlike his predecessors Kane and West, however, Starcher was more aloof and independent and did not seek direct influence by the Alumni Association.

Starcher and Stone shared many goals. Both sought more student scholarships. more dormitories and increased appropriations by the Legislature. In time, however, their ideas on means of achieving these goals conflicted; particularly in President Starcher's personal efforts "to seek out gifts from alumni, foundations and friends of the University." In time, the president's office and not the Alumni

Association's became the leading recipien of gifts. In his first six years as president, Starcher received donations of over $\$ 3$ million.

The University did not escape new challenges or avoid new tensions after the end of World War II. In 1960, the voters of North Dakota after 77 years of supporting only one university, approved a second one. On.Nov. 8, 1960, by an overwhelming vote of 175,556 to 86,106 , voters changed the name of North Dakota Agricultural College to North Dakota State University of Agriculture and Applied Science. The vote ended once and for all the issue which had been first voted on and rejected in November 1958. It also terminated over two years of bickering 
between alumni of UND and NDSU, the Grand Forks Herald and the Fargo Forum, the Grand Forks and the Fargo Chambers of Commerce, as well as faculty and students of both institutions.

The voters' decision ultimately altered the course of higher education in North Dakota. The 1960s and 1970s witnessed unparalled growth for the Fargo campus. North Dakota State University of Agriculture and Applied Science became simply North Dakota State University. The mission of NDSU became whatever its constituents requested and the State Board of Higher Education approved most of them. Agriculture remained strong and received solid financial support during a period of tremendous growth in new programs.

The constitutional establishment of a second state university did not precipitate, however, a decline of the University of North Dakota. The 1960s and 1970s also witnessed unparalled growth for the Grand Forks campus. Strong presidential leadership supplemented by substantial private donations brought to the University of North Dakota a quality of education not available from state appropriations alone. The establishment by the Legislature of a four-year medical school in 1973 gave the University a new state mission equivalent to agriculture at Fargo. The medical budget soon became a budget within a budget at the University and on a par with agricultural funding at North Dakota State University. More important the University of North Dakota could now request and receive in the name of medicine the special funding which previously only North Dakota State

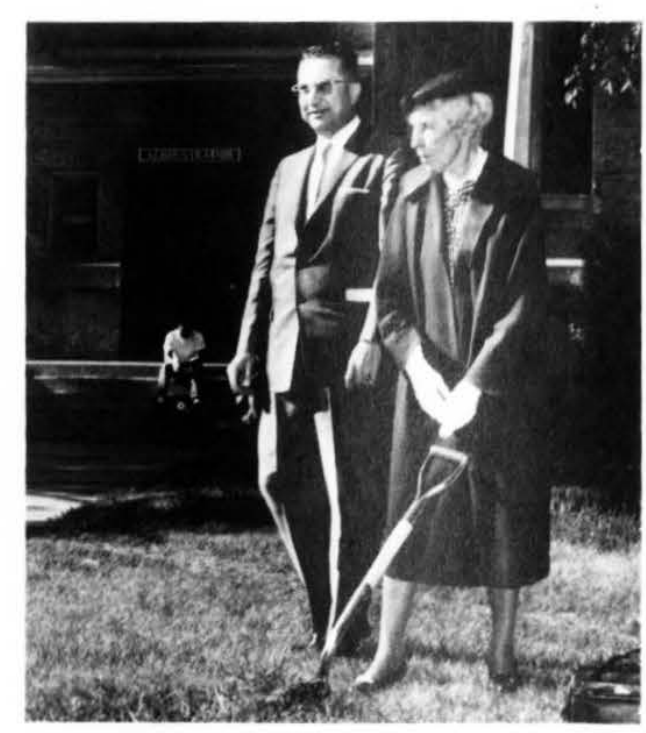

University could request and receive in the name of agriculture.

Nevertheless for members of the alumni family who had attended the University of North Dakota prior to 1960, the name change did cause some problems. Primarily they considered themselves as graduates of the state university and resisted the

identification of their school with another institution. A popular response to the whole controversy for alumni who grew up on a diet of the University versus the

Agricultural College went something like, "Well they can change the name but they can't change the smell!' Yet, graduates of the University since 1960 (and they

comprise the majority of the alumni body) do not refer to themselves as graduates of the state university but only as graduates of the University of North Dakota in
Grand Forks. For a time the name change also altered another major difference between the two institutions: the final score of the annual Sioux-Bison football game. When NDSU ended a 16-year string of football defeats in 1965 and established a six-year winning streak, UND alumni voiced concern. The loss of prestige in football, however, was compensated for by a new-found success in big-time hockey. Moreover, no one was proposing a constitutional amendment to establish a hockey team at NDSU. Alumni reluctantly accepted a loss in football, but a defeat in hockey was unthinkable!

The decade of the 1960 s, or more accurately the years 1966-1972, produced the greatest conflict within the University family over the correct interpretation of patriotism. The issue was debated regularly on the pages of the Dakota Student and most often by three of its editors: Mike Jacobs, Ted Fredrickson, and Chuck Haga. They were generally supported by student government leaders and vocal liberal faculty members under a tolerant president, but were monitored closely a the same time by North Dakota newspaper editors, the alumni board, state legislators and parents.

The greatest single incident, in the fall of 1967, centered on the Jack Stewart essay contest. Stewart, an alumnus and hosit to the alumni reunion at the Camelback Inn in Phoenix, Ariz., each winter, announced a $\$ 100,000$ gift with the interest to finance annual awards at the University. One, of $\$ 500$, was to go to a student outstanding for sportsmanship. Another $\$ 5,000$ of the income would provide a $\$ 1,500$ first prize and lesser awards to winners in an annual Starcher, here with Edna Twamley at the groundbreaking for the new administration building, took direct hand in

soliciting gifts from alumni and friends. 
Jack Stewart, left, at his Camelback Inn with Ed O'Connor. Dewey Balch and Ar min Rohde (Stewart's min Rohde (Stewart's patriotism created patriotism created controversy on cam 1960s).

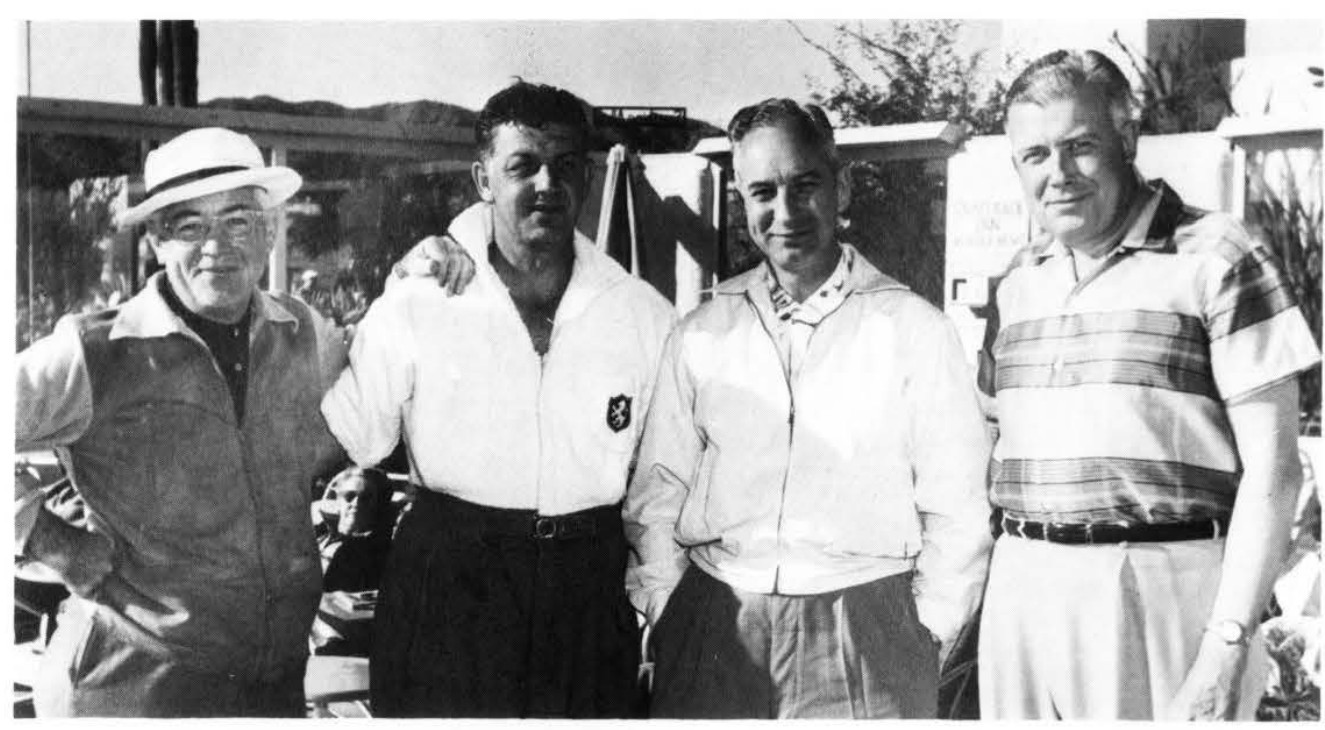

essay contest. Stewart stipualted, however, that the subject of the first contest would be "Our American Heritage: How Can it be Eternally Yours?'”

"The Prostitution of Patriotism," an editorial onslaught by Mike Jacobs in the Dakota Student of Sept. 15, shredded the concept of the essay contest and the older meaning of patriotism. To Jacobs, a philosophy and religious studies major from Stanley, reared in the strong North Dakota tradition of isolationism and a critic of American involvement in Vietnam, the contest sounded "like something the John Birch Society, the American Legion or the Farm Bureau might sponsor for a North Dakota high school.'

Jacobs argued that his generation had "grown tired - very tired - of old ladies in furs and men in uniforms or business suits waving flags.' Jacobs concluded that: "It is the prostitution of freedom, truth, of Americanism to pay $\$ 1,500$ for the best plan to preserve something that is corrupted by those who seek to preserve it, by those who wave flags and spout words in preference to action.'

A swift response came from the North Dakota newspaper fraternity and the Alumni Association. Jack Hagerty, editor of the Grand Forks Herald, although supporting the young editor's right to his own opinion, labeled the editorial "the vaporing of a confused and immature mind" and charged it was an "insult to one of the University's loyal and proven supporters." The Alumni Board through its lawyer Gordon Caldis called for censure. In late September, Caldis appeared before the University Board of
Student Publications and urged them to take "disciplinary action" against Jacobs for the editorial. Caldis testified that the Alumni Association "strongly protested the editorial" calling it "one of the most rude, irresponsible and damaging articles he had ever read."

The controversy ran into October. The Walsh County Record at Grafton, owned by the Morgan family who had lost a son in World War II, announced its intention to sponsor yet another essay contest on patriotism with a $\$ 100$ first place prize to be judged by Mike Jacobs and "other intellectuals of his caliber." On the same day, the Board of Student Publications by a 6-5 vote censured Jacobs for "breaching the highest literary and journalistic standards.'

Jacobs gave the whole incident a parting shot in an editorial of Oct. 20 entitled "It is an Old Man's World." $\mathrm{He}$

acknowledged difficulty in trusting anyone over 30 . Those younger he claimed only

"want to live, to decide, to do their own thing." Although Jacobs yearned for a dialogue between generations, he admitted frustration: "The old instead of listening, ignore them, secure in their sacrosanct suburbs, dark, business suits and expensive furs, ignore them, force age upon the young before they have been young, force sterility before orgasm, force death before life."

The two awards were made later, but Stewart permanently withdrew the $\$ 100,000$.

Not all people over 30 disagreed. One former United States senator, Gerald P. Nye, returned to the campus in November 1967 , under the auspices of the history 
department. He commented on his warm reception: "My this is wonderful, to see so much interest in the past. You may no understand all that I am trying to tell you. But I don't understand all that you tell me either. I think we must all try."

On Vietnam, Nye stated, "We hadn't ought be there and those who got us there should get us out." $\mathrm{He}$ urged the country to withdraw "even if it means a loss of face."

The University, the alumni and the Association survived the ' 60 s and 70 s. Presently the Association stands firmly on the Stone foundation. Stone added Earl Strinden as assistant director in 1969. With a varied career - the Marine Corps, public school teaching, 10 years in retail business, city and state politics - Strinden brought an ambitious and aggressive approach. During the years 1969 to 1974 , he served not only as assistant to Stone but also as assistant House majority leader in the North Dakota Legislature under Rep. Bryce Streibel. With the retirements of Stone and Streibel in 1974, Strinden became executive vice-president of the Alumni Association and majority leader in the North Dakota House of Representatives.

Since 1974 a number of importan changes have been made in the Alumn Association. The most important was the incorporating of the University of North Dakota Foundation to replace the UND Development Fund as the recipient of alumni and private gifts. Assets of the Association increased from $\$ 350,000$ in 1974 to approximately $\$ 12$ million by 1982 .

In 1980, the Foundation received the largest gift in the history of the University.
Ken Hyslop, a 1906 graduate, donated over 6,000 acres of Red River Valley land with a value of $\$ 5.2$ million. After his death in 1981 , the University received an additional $\$ 2.7$ million in stocks and bonds from his estate. The Hyslop gift made the UND Foundation and ushered in a new era of Alumni Association participation in University life.

Under Strinden, the Alumni Association also made important internal modifications. Those include a computerized records operation, the improvement of the Alumni Review under the capable hands of David H. Vorland, director of university relations, a sophisticated approach to annual fund raising, more alumni tours (but no Camelback Inn reunions) elimination of the use of student fees to support the Association, more subscribers, increased attendance at alumni events, insurance programs for alumni and faculty, and a financial planning service for prospective donars.

In Bismarck the power of the Alumni Association was never greater nor legislative support stronger. The wearing of two hats by Earl Strinden - chief executive of the Alumni Association and until the election of 1982, as House majority leader - coincided with important gains for the University.

During these years, all of higher education, including UND, benefited from Dakota experienced a strong economy and large general fund surpluses. For the University, this resulted in unequalled growth of the Medical School, the enactment of unprecedented catch-up salary increases for faculty and staff in 1975 and again in 1981, as well as the

funding of important physical additions to the campus, including a major library addition, Starcher Hall, an addition to the Memorial Union, and a $\$ 6.5$ million physical education, intramural, and recreation addition to the UND Fieldhouse

In 1981, the Alumni Association moved its offices from the fourth floor of Twamley Hall to the beautifully restored home of early University presidents, known to recent alumni as Oxford House. A campus committee spearheaded efforts to save the old mansion from demolition even against strong administration objections by placing the structure on the National Register of Historic Places in 1973. Later the Association became interested in the unused building as a permanent office and promoted the financing of the restoration project. The total cost of the project came to $\$ 640,000$ with $\$ 340,000$ in private contributions, $\$ 200,000$ in federal grants, and $\$ 100,000$ from state appropriated funds to make the building accessible to the handicapped. The facility was dedicated during 1981 Homecoming activities and renamed the J. Lloyd Stone Alumni Center.

During the Clifford presidency, improved relations developed between the office of president and the Association. In fact, Thomas J. Clifford was the first active Alumni Board member to serve as the president of the University. In the spring of 1971 when a University-wide search committee recommended five outof-state candidates as finalists to replace Starcher, the Association nominated a sixth 
Earl Strinden, Alumni Association executive vice

president since 1974.

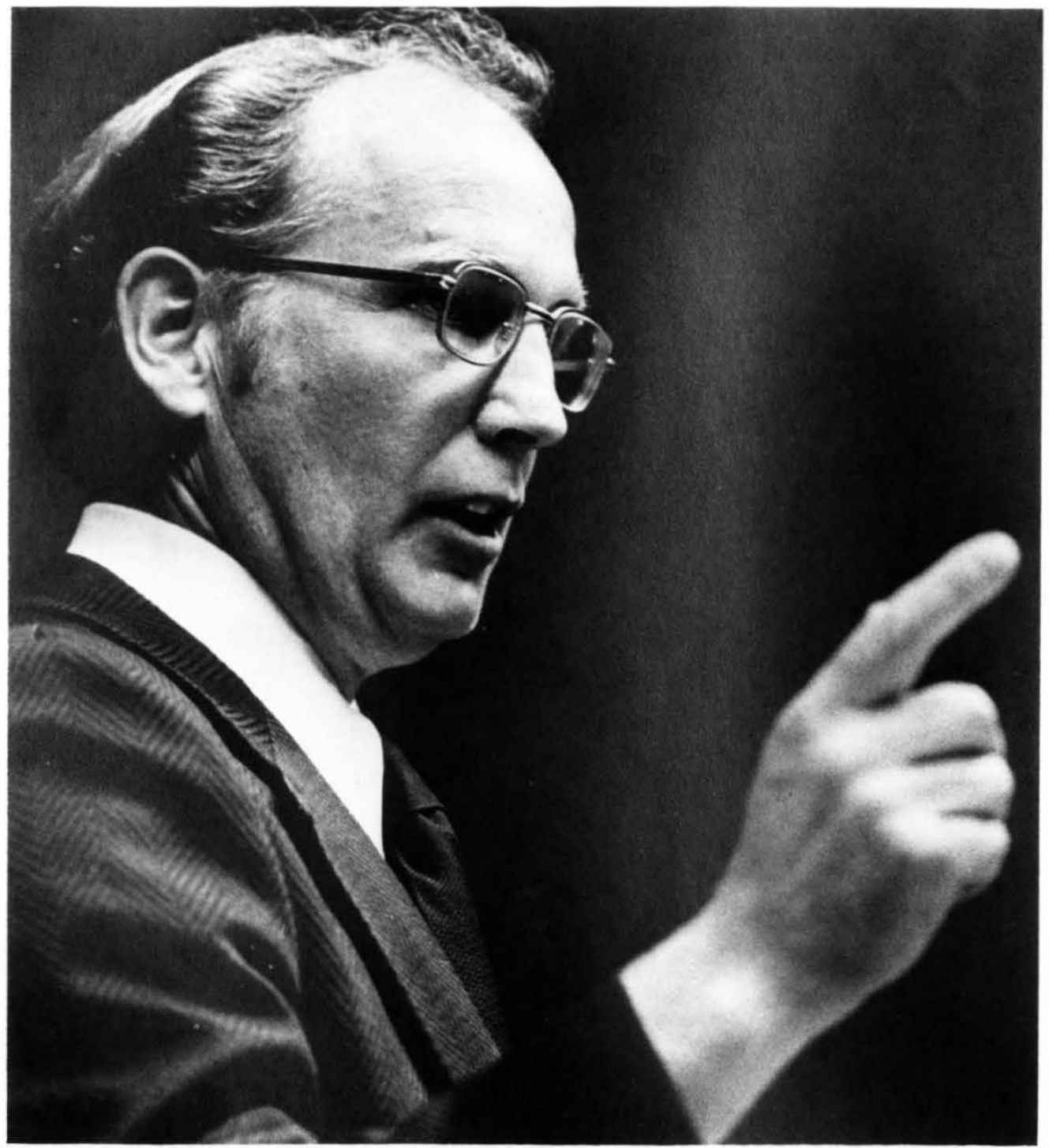

candidate, Vice President Thomas Clifford of the University. In negotiations with the State Board of Higher Education, the Alumni Association played a "major role" in a "concerted effort" to have its candidate selected as the eighth presiden of the University of North Dakota.

As the University celebrates its centennial, alumni of all ages will also pause to honor the occasion. Letters from the past and actions of the present will speak louder than today's words, however, about the intricate but complex legacy of this institution for each alumnus.

But what motivates an alumnus to give a fortune to his or her institution? How can anyone really comprehend the enormous significance of the contributions of Chester Fritz, the University's best known benefactor, or Ken Hyslop, the University's least known benefactor?

Chester Fritz and Ken Hyslop shared a common heritage. Both were born first generation sons of Red River settlers. Fritz in Buxton on March 25, 1892; Hyslop near Inkster on May 19, 1885. Both men made substantial fortunes. Fritz became an international precious metals trader, and Hyslop a quiet but efficient international business executive. Fritz filled his rice bow with gold and silver. Hyslop invested in Red River Valley farm land. Fritz gave earlier in his life and designated specific purposes and conditions for each gift. Ken Hyslop preferred to give his gift later in life with no conditions. Fritz reared by Neil C. and Kathrine Belanger Macdonald Tiffany, his uncle and aunt, "was brought up to admire and respect the University of North Dakota"' while Ken Hyslop's father, 
George, is found among the list of contributors who helped keep the

University of North Dakota open in 1895 . 1896.

In the final analysis, loyalty to their institution explains the motivation of

giving for both Fritz and Hyslop. They did what many alumni talk about but few accomplish - on the bottom line they gave their fortunes to the University of North Dakota.

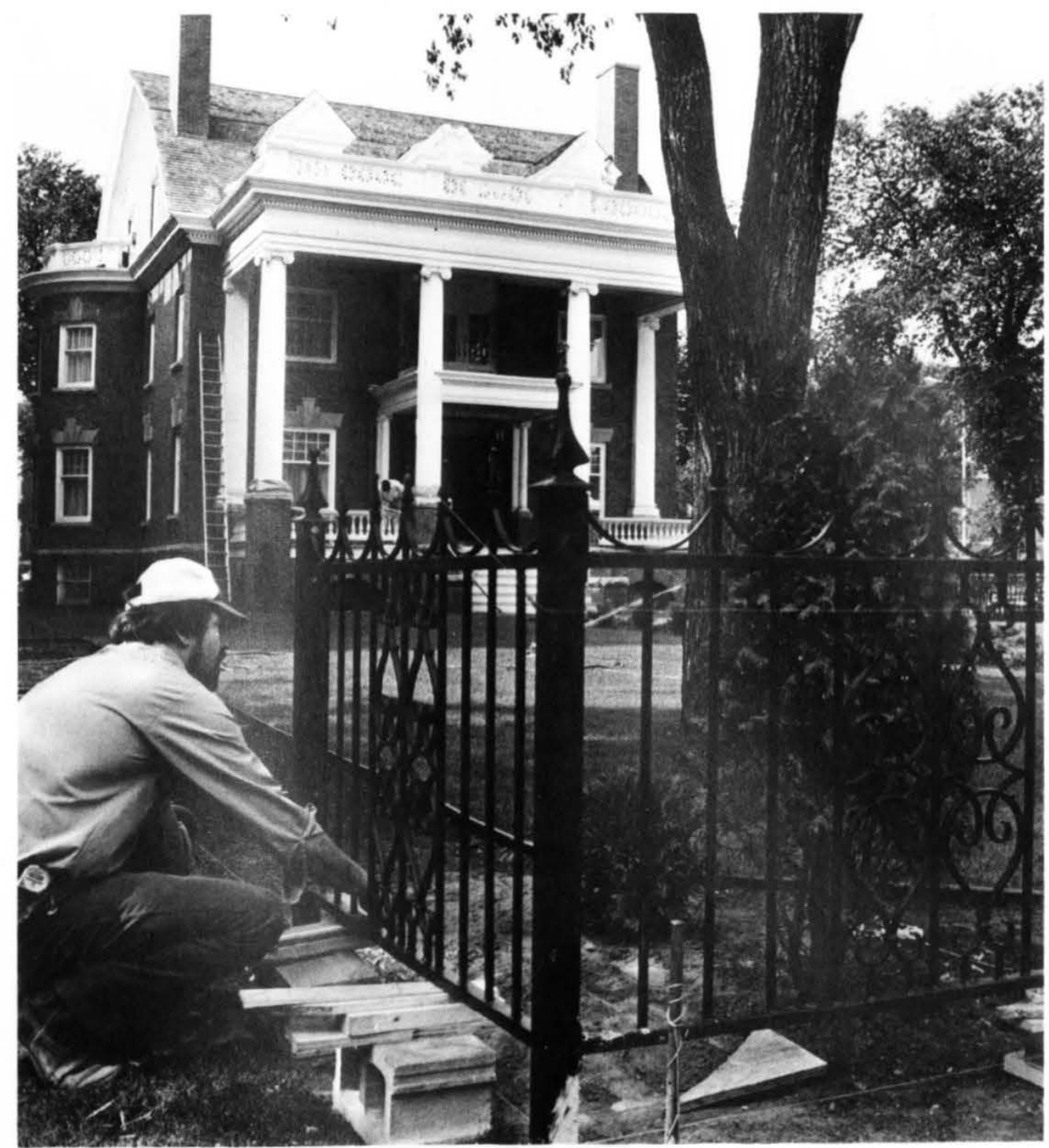

Final details are completed on the refur.

bished former presi-

dent's home, now the J. Lloyd Stone Alumni Center. 


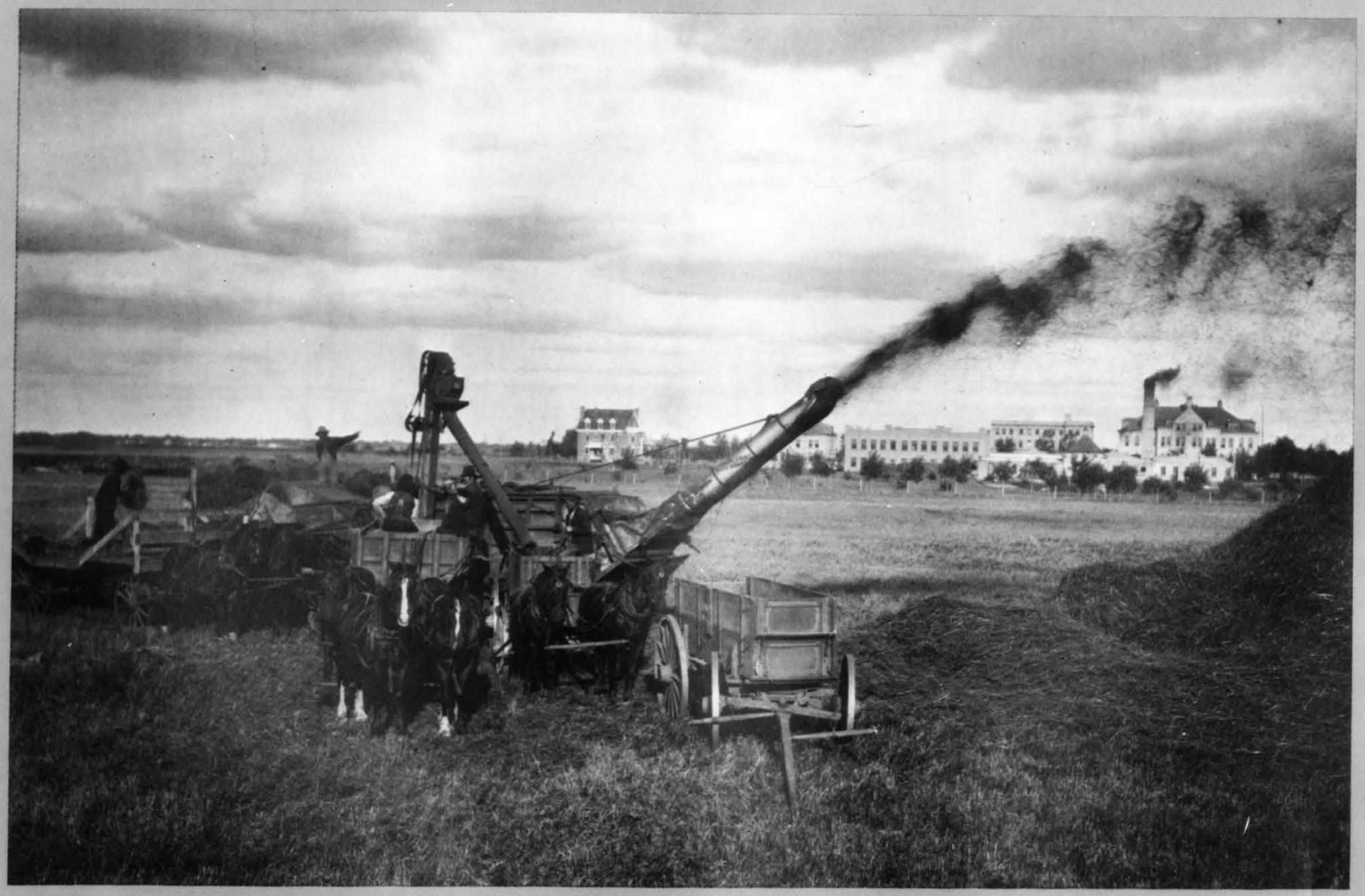




\section{The Campus}

By James F. Vivian

Professor of History

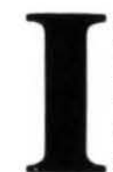

$\mathrm{n}$ the beginning, the University of North

Dakota amounted to little

more than a commitment

to build an all purpose

edifice on 20 acres of newly donated prairie land fronting 300 feet of the English coulee at a bend about two miles west of Grand Forks. The town itself had been incorporated for fewer than 10 years, and statehood lay six more years into the future. A century later, the main campus embraced 470 acres, proudly displaying more than 76 major academic buildings and a host of auxiliary structures, ranging from housing complexes to specialized services, satellite operations, and support facilities.

The "turning point" in the University's growth came, as former President George Starcher noted, about 1955. Physical development prior to that time had been slow and irregular. World War I found the University with 10 buildings and three dormitories housing 711 students. At the close of World War II, UND had managed to acquire only two more permanent buildings but still possessed the same three decrepit dormitories, even though the student enrollment had almost tripled. So keen was the competition for insufficient space that the Dakota Student wryly commented, "some students are reliving their army days.'

In 1883 , the campus might have been located along the Red River, in the vicinity of Riverside or Lincoln parks, except that William Budge, an early homesteader and speculator who owned much of the unimproved land west of town, offered twice the acreage otherwise available. The entire University comprised two buildings when instruction commenced in September 1884: Main (rechristened Merrifield Hall in 1912), then the largest structure in the northern half of Dakota Territory, and Budge's enlarged claim shanty, which served as bunk-house for construction workers, and afterward, a barn for the janitor's livestock. Both buildings called for a willing surrender to privation water was drawn from the coulee or freighted from town in barrels; kerosene lamps supplied smudgy, flickering light; heat radiated feebly from wood stoves, some of them donated by local merchants; toilet facilities did not exist; and boys bathed in steel tubs sitting near the inoperative basement boiler. Conditions improved not at all when a wind storm in June 1887 destroyed the west wing and severely damaged the upper portion of Main. A disillusioned few talked of starting over somewhere else, but their arguments did not convince the majority.

Life in Main for many years remained a self-contained world of offices, faculty apartments, classrooms, chapel, science laboratories, nascent museum, and a library that in 1888 totaled fewer than 3,000 books. The president and the janitor and his wife, who prepared the meals, lived in the basement, while male students slept barracks-style in the converted recitation halls on the top floor. Privacy was at a premium; reportedly, a "safe place for a tete-a-tete" could not be found even

behind Case $\mathrm{A}$ in the second floor library. Doubtless these tight quarters contributed

to the University's closing in February 1889 , when a diptheria attack killed the janitor's three children. No students died, possibly because of the 750 pounds of stenchful sulphur burned in purging the
The University in a wheat field, as photographed by Sumner H. Mattson in 1904 (photo courtesy Milwaukee Public Museum of Milwaukee County). 
The first University plan, as it appeared on president

Blackburn's official letterhead in 1883; only the Main Building, left, was Building, left, was
constructed like this.

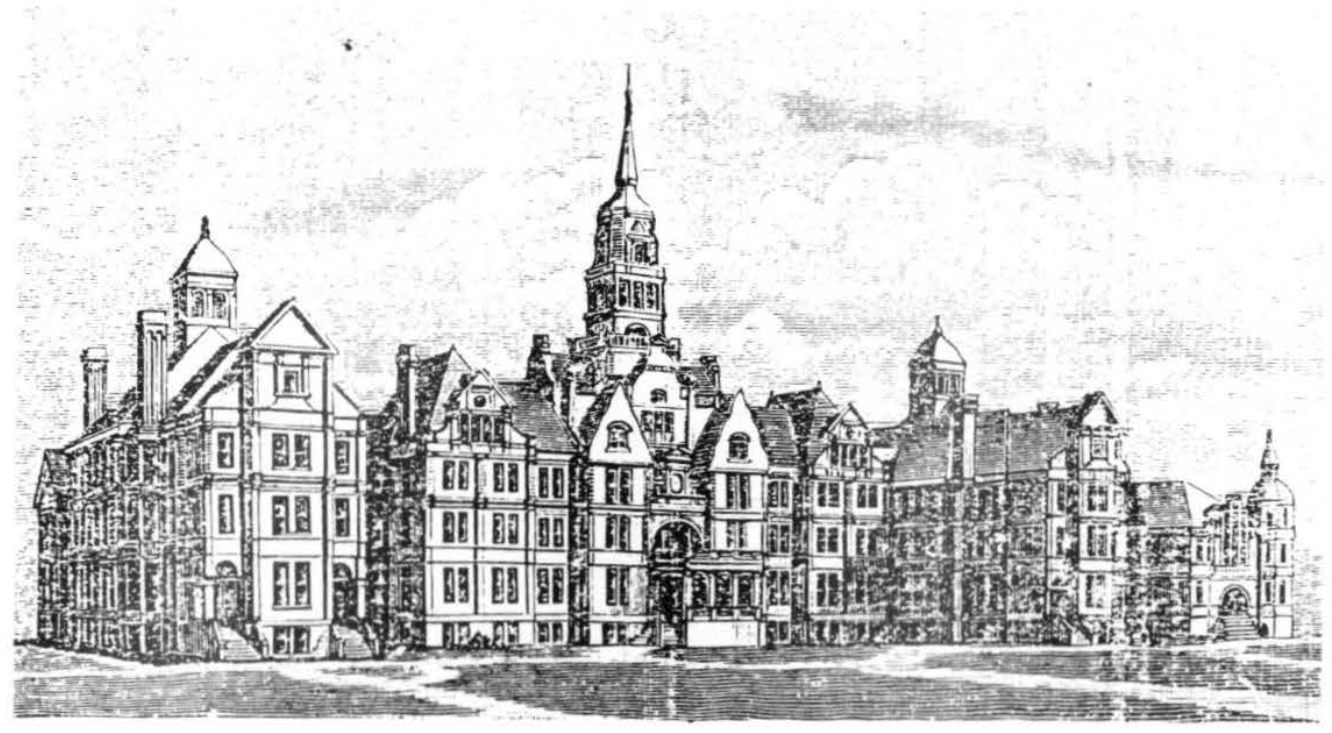

premises.

Three "very plain buildings. . . in the midst of a great wheat field" greeted Dean Vernon P. Squires upon his arrival in September 1897. "A few small trees were growing in front of the Main building and the Ladies' Dormitory; but other ornament there was none save the janitor's cow peacefully cropping the campus grass", inside a weathered five-board fence that ringed the area, and an 800-cord wall of split elm and cottonwood that stretched awesomely off the northeast corner of Main. President William Blackburn personally planted some saplings during his brief tenure, many of them taken from Hamilton Grove (Central Park) along the river. A decade later E. F. O'Keefe, newly hired among powerhouse personnel, voluntarily mounted a second concerted effort to relieve the stark landscape by lining the east coulee bank with cottonwood, then a scattering of ash and willows.

The Ladies' Dormitory (later named Davis Hall), located just west of Main at the north side of the coulee bend, opened inviting hearth and spacious, sky-lit parlor that instantly became the social center of the fledgling institution and the scene of the annual Christmas party. The dining room doubled as a nursery school and headquarters for the Women's League, and the basement kitchen the hub of the home economics department, then the nucleus of the struggling law school, and still later the dim hideaway of the art department. to occupancy in 1888. It contained an
"The Cottage,"' built in 1893 on existing, extra wide footings to support an observatory that never materialized, was enlarged and named Macnie Hall in 1906. It served first as the Preparatory School dormitory, then alternately as a women's and men's dormitory until yielding in 1967 to the advent of Gamble Hall. Nearby, two hand pumps sprouted from the turf at the front and rear of Davis, whose independent water supply spared the campus the ravages of a typhoid epidemic in 1894. Although the University had been connected to the city water system in 1885 , President Webster Merrifield presciently suspected the danger of ingesting water directly from the Red River without benefit of filtration.

A special train brought 400 townspeople to the formal opening of Budge Hall on Dec. 1,1899 . In the ensuing decade, student hazing and kangaroo courts fastened upon this first men's dormitory a singular reputation, depending on one's point of view, for its "barbarous ways" or as the "seat of democracy." The basement of this venerable edifice had been variously employed as an auditorium, gym, armory, YMCA, bookstore, and student union ("Nodak Center") before forming part of the instructional effort. The first Founders Day was observed here in 1904 , after which the floor was hurriedly cleared to accommodate a women's basketball

contest with the Agricultural College team. A runaway fire-prevention sprinkler badly weakened interior sections of the building in 1981, hastening its planned demolition that year.

The southernmost unit of Chandler Hall, today the laundry, also dates from 1899 . 
Davis Hall (Ladies

Hall) and Macnie

Hall (The Cottage) a

The turn of the cen-

tury, with early land-

boardwalks.

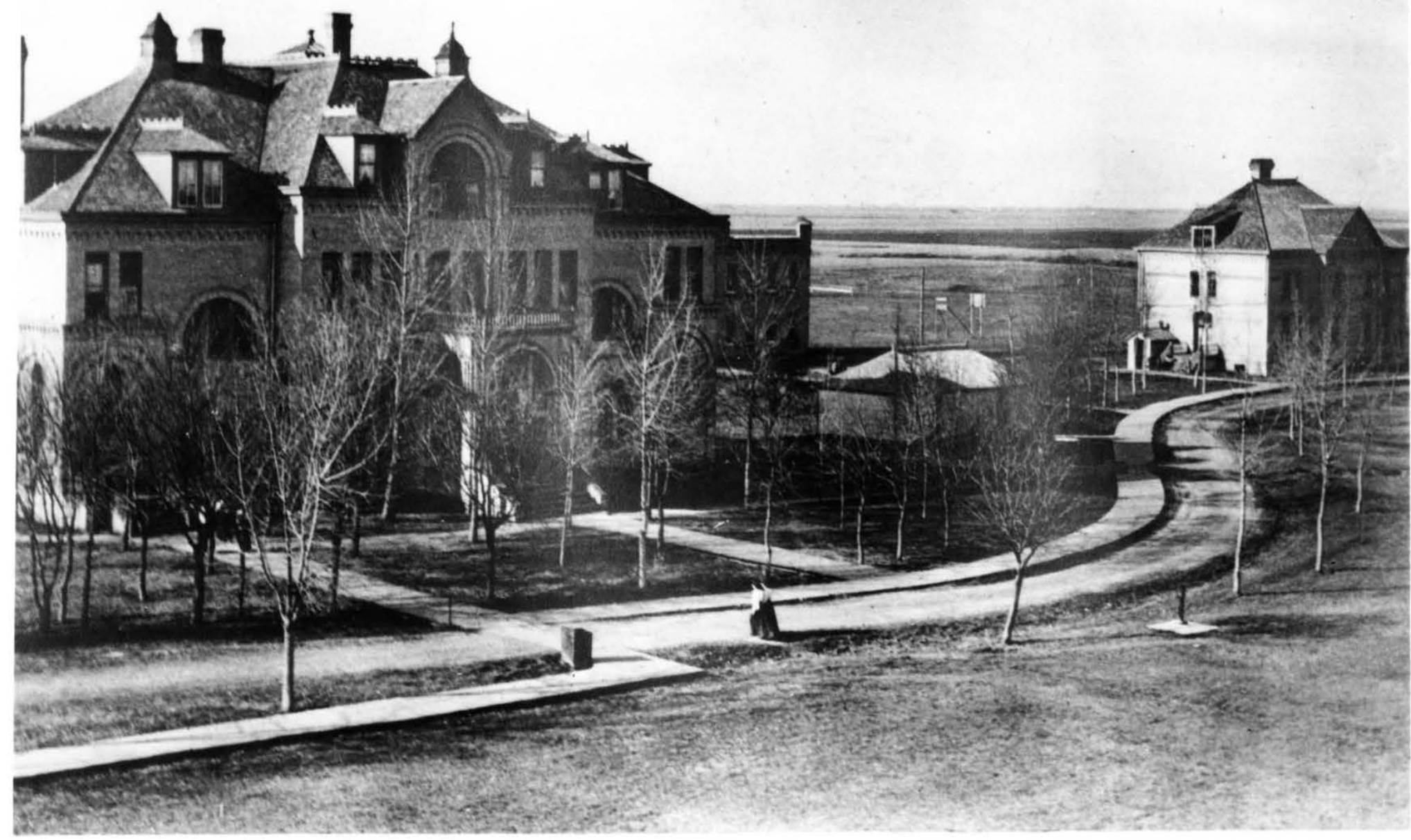


making it the oldest of existing campus structures. The smokestack, until dismantled in 1981, betrayed it as the original powerhouse that effectively ended the era of an independent heating source for each building. However, this location necessitated a railway spur line that partly followed the contours of the coulee and called for an inefficient application of muscle power, both human and animal, to heave and haul lignite-loaded hopper cars. UND entered the 20 th century boasting a 25-watt generator capable of supplying limited and undependable electric lighting (all lights out between 10 p.m. and 6 a.m.), a party-line telephone connection with five extensions, and a newly completed boardwalk along Broadway toward the Kedney warehouse, the predecessor to University Avenue, the summer project of some engineering students.

A class bell system, Science Hall, and the Great Northern Railway depot (now the Parking Office, and the source of the name of "University Station," UND's subpostal service) headed the improvements of 1902 . University Station, originally a crude 8 - by 12 -foot shelter put up in 1888 , stood by the spur line about 100 feet south of Main. The larger, more permanent station erected along the mainline in 1902 acquired screened porticos and a tile roo in 1926 and featured, eventually, a 200foot loading platform for commuter service, notably to Fargo football games ("Beat the Bison" specials) until the eve of World War II. In the 1920s, passenger trains regularly stopped six times daily at the depot, and class schedules conformed to railroad time for the convenience of instructors and students alike.

When ready for use in 1903, Science

Hall, only the second classroom building, strained to welcome the biology, chemistry, mathematics, physics and mining engineering departments, as well as the museum. The state-authorized Public Health Laboratory claimed even more of the cramped quarters after 1907. (Here, incidentally, Chester Fritz, later an internationally known metals trader and UND benefactor, found part-time employment upon his matriculation in 1908 delivering specimens for testing to and from the depot.) Capital repairs in the late 1940 s prevented the weakening structure from expanding beyond the unwanted six inches it had gained since 1903 but not the visible cracking that will persist until completion of a major refurbishment program

State funding provided the second, twostory section, including a blacksmith shop, of Chandler Hall in 1903, the original home of the engineering department. Further elaboration of the campus at this point was owing largely to the remarkable devotion of President Merrifield and the generosity of Mrs. Elizabeth Bull Merrifield, an heiress to the "Cream of Wheat" fortune. The Merrifields loaned the state the money to build the president's mansion (later known as Oxford House, and renamed the J. Lloyd Stone Alumni Center in 1981) and the first home in Grand Forks designed with electricity; they purchased the first 20-acre addition to the east of the campus, deeding it immediately to the state; and they were organizers and stockholders in the local traction company responsible for laying a trolley line on
Broadway (University Avenue) whose service began in October 1904. The president personally instigated negotiation leading to the transfer from Wahpeton and affiliation of Wesley College in 1905, and persuaded philanthropist Andrew Carnegie to fund the University's first separate library in 1906, later the Commons and today the Home Economics Department. The Merrifields cheerfully quit their "incommodious quarters" in Davis Hall for the president's house in the fall of 1903.

Installation of a dial system for a network of 15 telephones, reputedly the first west of Chicago, headed the list of ensuing improvements. These included the introduction of fire escapes and extinguishers, a cinder-surfaced tennis court behind Chandler Hall, a second baseball diamond south of Main, and the appearance of snacks (ice cream and pop) at the cooperative bookstore in the

Main basement. Also, during the summer of 1904,100 pounds of pike, pickerel, and suckers could still be fished from the coulee, thanks importantly to the cistern dug in the mid-1890s that freed the coulee of its function as a disposal for untreated effluents.

Thereupon followed the greatest construction boom in the University's history prior to 1952. Three buildings the library, gymnasium, and the School of Mines (now Babcock Hall) - were dedicated at the June 1908 commencement exercises. The gym (now known as the West Gym) made it possible to assemble commencement ceremonies on the campus; previously they were held downtown, usually at the Opera House, while Wesley 


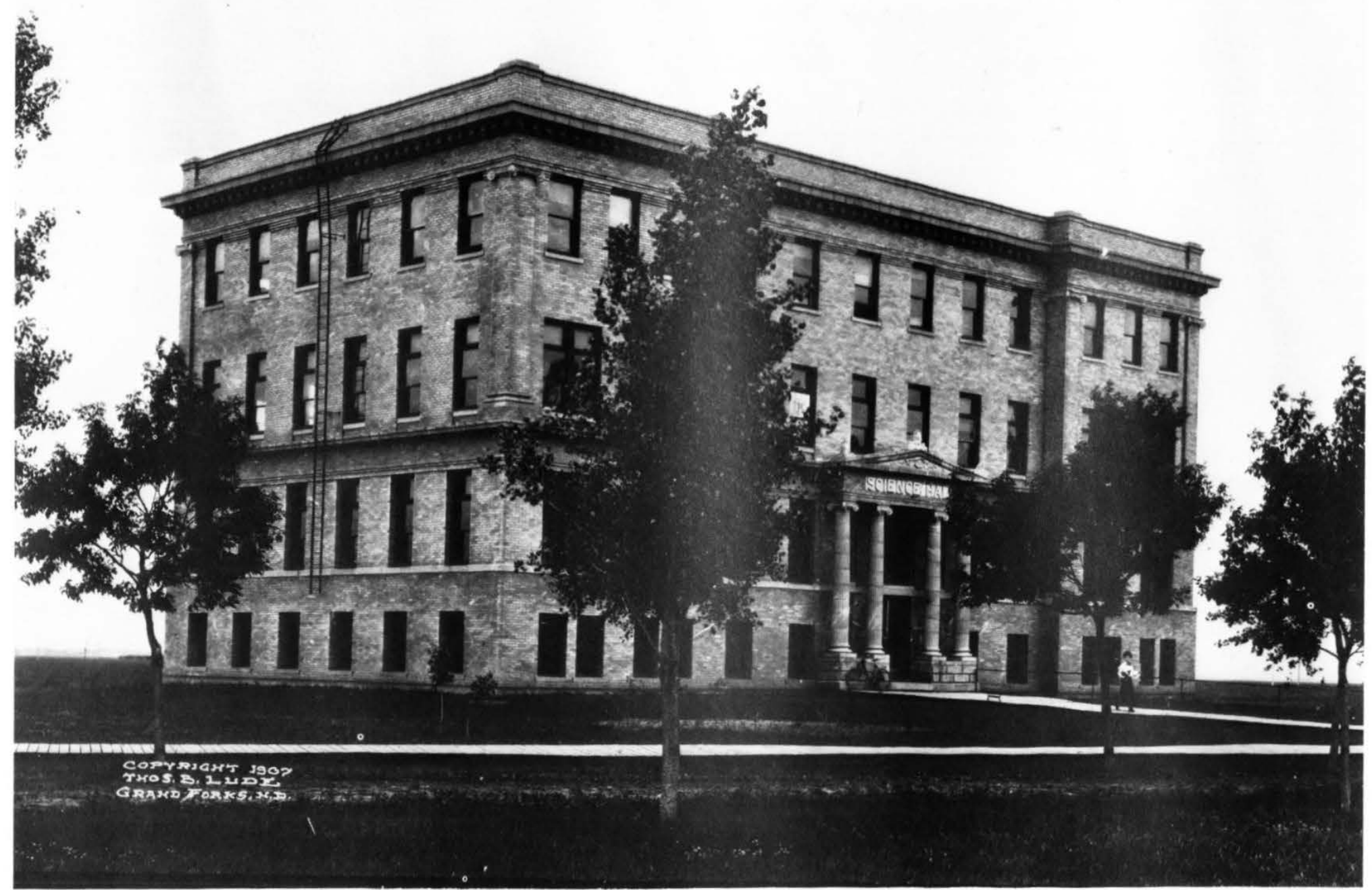


College graduation services remained at the Methodist Church. Erection of three more buildings began the next summer, 1909: the powerhouse along the railroad right-of-

way, Teacher's College (later Woodworth

Hall), and the Commons (later the library, and renamed Montgomery Hall in 1965).

The summers of 1908 and 1909 also

witnessed a professional horticulturalist

systematically landscape the grounds with elm trees, blackthorn hedges, and gravel and cinder walks. The cinders derived, of course, from ash produced by the four small boilers in the powerhouse. President McVey preferred curved lanes and drives in keeping with the meandering channel of the coulee.

Sayre, Larimore, and Corwin Halls, the core of Wesley College, date from 1909.

1910. The addition of Robertson Hall in

1929, thanks to the munificence of a UND alumnus, John Hancock, achieved

symmetry in this Italiannate complex. In

1906, having decided to relocate in Grand Forks, the trustees of Wesley College purchased from William Budge the 80 acres lying between Columbia Road, then the only acknowledged access in the area, and what soon became Oxford Street. Dr. E. P. Robertson, long-time president of the college, inaugurated the practice of naming the north-south streets, including those just mentioned, after prominent educational institutions. Dr. Robertson himself graduated from Hamline University in St. Paul.

Overlooking the coulee, the nearly finished Varsity Bachelor Club (Phi Delta Theta since 1913) held possibly the earliest private dancing party on campus in the spring of 1910 . The Commons, when occupied in mid-1911, completed the quaint University realm through the close of World War I that pioneered an annual series of costumed springtime pageants along the sloped coulee banks. In addition, this decade witnessed the first serious fire, and an increase in both amenities and special services. The fire in the north side of Babcock Hall in 1910 temporarily embarrassed the chemistry department, and the mounting of an electric clock in 1911 in the Main bookstore curtailed class tardiness. At about the same time the University became a meteorological station for the U.S. Weather Bureau, with the instruments, including a flagstaff for storm signals, equally distributed between the roofs of Main and Science. In 1913, the physics department helped establish a shortwave radio link to the Naval Observatory, Washington, D.C., which qualifies as the primitive precursor to KFJM and proved a boon to accurate timing over a wide area. UND completely converted to lignite by 1915 , making it the first large "commercial" user of the fuel in the state.

Military training at the University achieved permanent status during 19181919, when federal authorities sanctioned construction of the Armory and assigned a SACT, afterward ROTC, detachment and field gun to it. Previously, military training had been a fitful proposition that enjoyed its greatest vogue in the decade preceding the Spanish-American War. (One of the elms between Twamley Hall and the Armory commemorates Admiral George Dewey's victory in 1898 at Manila Bay.) World War I produced two memorable events: from July through October 1917, the campus was placed under martial law and access restricted to those holding passes; and during October-November 1918 , the campus was completely closed because of the famous flu epidemic.

Twenty-nine students succumbed in the "death room" on the third floor of the Phi Delta Theta house, the temporary hospital.

As for the Armory itself, an unfinished shell when the war ended, the University innovated the oval jogging balcony, floored and roofed the building, and thereafter put it to manifold uses, including a men's gym, dance hall, boxing pavilion, and weekly convocation center. For more than five decades students also knew the Armory as the inevitable rendezvous for coordinated final exams twice a year, taken to the accompaniment of the raucous sounds of the railroad switch yard. West Gym became the domain of the women's physical education department.

The UND campus of World War I suggested an uncertainty of architectural modes. Science had been done in Renaissance revival, Babcock in Richardson romanesque, and West Gym, Montgomery, and the Armory in modified Gothic and Tudor. Actually an already evident trend soon settled (with allowance for material costs and feasibility) upon modified Gothic-Tudor - or what President Starcher called "Collegiate Gothic." The chemistry building (later biology), finished in 1919, indicated as much. Although the style chosen for the Law School suggested a return to the Jacobean variant of modified Gothic, it served to preserve balance and harmony 
with Montgomery and Woodworth along the north side of the campus. The new Merrifield Hall, whose dedication on Founders Day, 1930, attracted 3,000 friends and supporters, is more indicative of late Gothic revival. However, the general combination of "dark red, vitrified brick of great durability" and reinforcing stone quoins and trim had clearly become the accepted institutional mode, incorporated in the master plan of 1922 , even though it would later prove too expensive to continue in its pure form. The Memorial Stadium, "rushed to completion" for Homecoming in October 1929, with funds collected by popular canvass begun in 1924 to honor 43 graduates killed in World War I, confirmed the choice.

The Law School arrived on campus in
1917, having been situated downtown since its creation at the turn of the century, initially in the top floor of the Security Trust Building, then in the Clifford Building on Demers Avenue. Probably no program suffered more seriously from World War I than this one, to the extent that its faculty and few students wandered the campus in search of an unclaimed classroom. Moreover, it was understood from the outset that the Law School, once labor strikes finally permitted its

completion in 1922, would have to share its quarters with other desperate departments, including commerce (predecessor to

business administration), geology, and art,

the latter occupying the moot court and

what passed for an assembly hall across the corridor.

The addition of the new Merrifield Hall, for many years the largest classroom structure in the state, greatly eased the pressures on Main, solely an administrative center after 1929. In 1924, anxious observers confirmed Main's inexorable deterioration to have produced a five-inch tilt in the building and that, because it was creeping toward the coulee at the rate of one-eighth inch per week, it seemed ben on self-destruction. (Indeed, it had been seriously suggested that indoor marble playing at UND never caught on because all buildings constructed before 1902 failed to allow for the clay subsoil base that caused them to lean toward the coulee.) Yet, although officially condemned, Main underwent salvaging for the benefit of another whole generation by lopping off the upper two floors, fastening braces and tie rods, and reworking the concrete

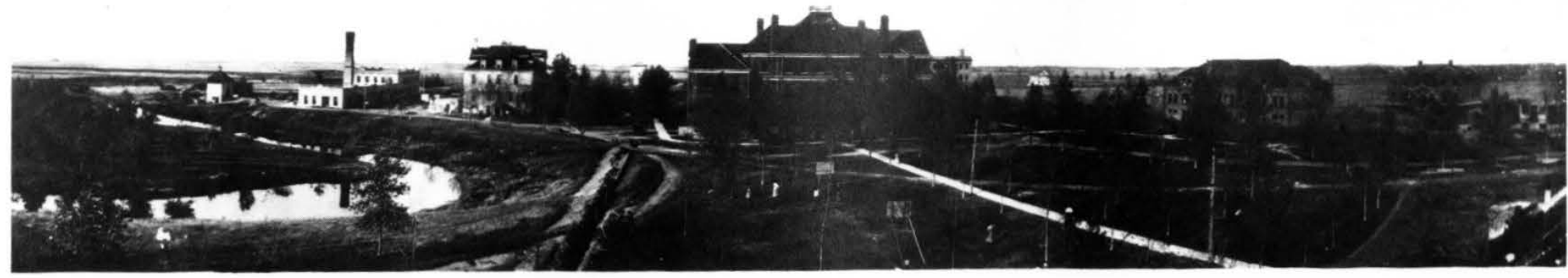


foundations until the cornerstone itself disappeared from view.

The 1920s decade evidenced other contributions to a feeling of stability, including the paving of University Avenue in 1921, the installation of an integrated master control panel in the powerhouse in 1922 , and the arrival of the first noparking sign four years later. In 1923 , UND purchased the rights and 100-watt transmitter of the second commercial radio station in the state from the Electric Construction Company downtown, whose new call letters, KFJM, first aired in October. In 1924-1925, the second, more earnest appeal since the war years rang forth reminding students (to no avail!) to keep to the 15 extant walkways instead of continuing to crease 37 random trails in the lawns. The three improvements of 1925

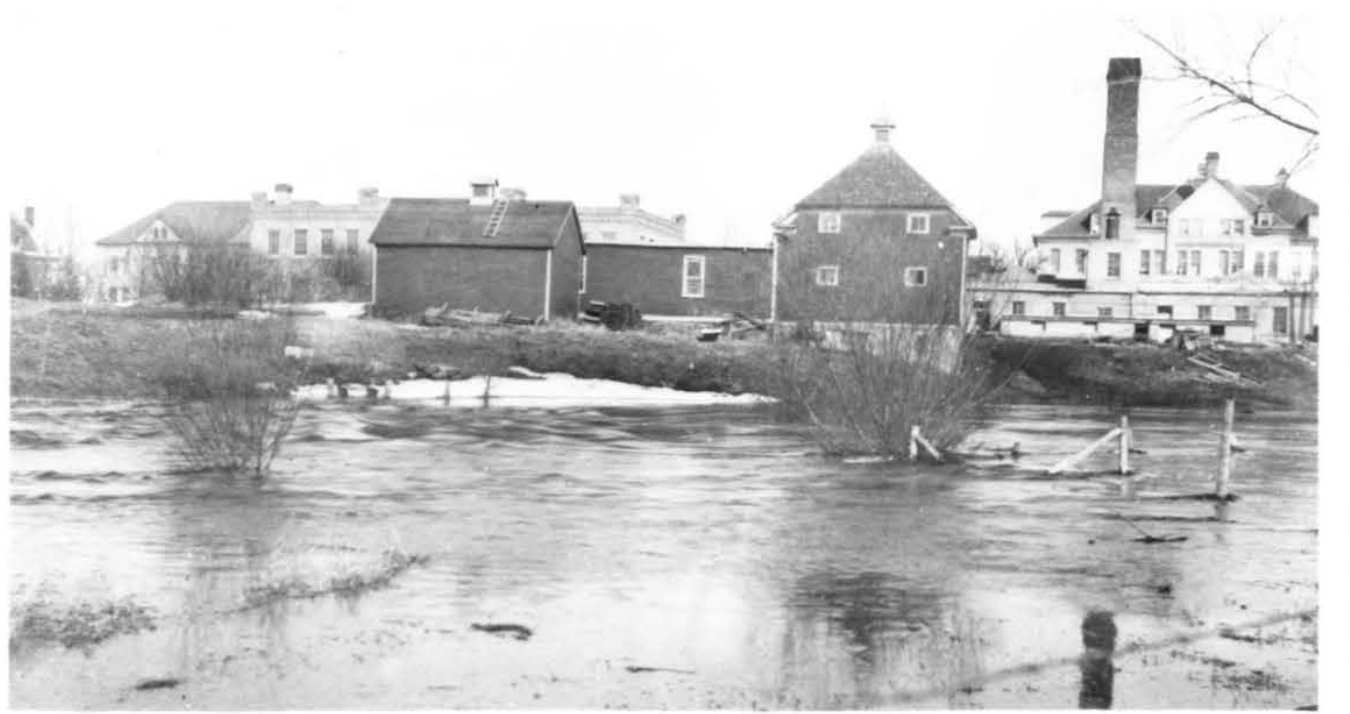

of fset Main's mandatory diminution, quickly came down despite the loss of the 10 precious classrooms and one office it contained. Also, this was the last decade that a pair of dray horses pulled the snow plow periodically around the campus, its walks and roads now considerably straightened according to President Kane's taste.

Survival, the persistent theme of the lean and dry 1930s, meant few changes for UND other than as the federal government appropriated special funds for specific projects that eventually totaled $\$ 1$ million. One exception was the 2,100 feet of 10 inch water main laid down in 1931, replacing the outmoded original of 1885 , and eight reassuring fire hydrants connected to it. Another was the arrival of educational movies with sound in 1932 .

The government's contribution, thanks partly to President West's yeoman efforts, included the Winter Sports building east of the powerhouse and the KFJM transmitter house off Yale Drive, both in 1937; the coulee dam in 1939, now opposite the bridge site near Smith Hall; and the west addition to Chandler Hall. The dam substituted for an older, eroded one built before World War I which students dynamited for the opening of Engineers' Day, 1937 (visitors observed an experimental television display as the second, novel attraction). Although artificial ice-making equipment did not arrive until 1954, long-time custodian A Purpur saw to it that no hockey game in the cold, drafty, Quonset-like arena was ever cancelled for want of a proper playing surface. Perhaps the most notable cancellation occurred on Nov. 22, 1963 
(the day of President Kennedy's assassination), when the White House called UND direct just minutes before a contest began with rival University of Minnesota. East Hall, begun in 1940 as part of an NYA program designed to involve residents directly in its construction, claimed the first-hole fairway of the old nine-hole golf course. A second similar unit and a recreation center did not get under way before Pearl Harbor prompted a shift in national priorities.

The livestock-turned-bus-turned-maintenance vehicles barn, dating from 1889 and situated about 80 feet from the coulee shore behind Chandler, quietly disappeared toward the end of the decade. Likewise, few people today know that UND once had a minesite on the grounds. In 1918, on the rise now dominated by the Hughes Fine Arts Center, the Student Army Training Corps put down a 40 -foot shaft for the purpose of conducting sapper and commando drills. In 1933-1935 the WPA caused the shaft to be reconditioned and enlarged, and a 5-by 6-foot tunnel to be extended toward the coulee at the 20 -foot level. The entire network complemented a foot tunnel to be extended toward the coulee at the 20 -foot level. The entire course in mine safety offered by the Mining Engineering Department, complete with trackage appropriated from the abandoned trolley line that coursed behind today's Alumni Center and terminated at the front of Chandler Hall (Merrifield Hall became the first of four designated bus stops on campus after trolley service ended in 1932).

"Camp Depression," a collection of discarded Great Northern Railway cabooses purchased at $\$ 20$ each, was the innovative brainchild of J. W. Wilkerson, UND business manager. Located in 1933 (UND's modestly celebrated golden

anniversary) between the powerhouse and Winter Sports building, the camp eventually comprised a quadrangle of 10 cabooses, including a "mess," which made it possible for some 40 male students to complete their college education during difficult times. Now the object of considerable nostalgia, particularly among its graduates who held a class reunion in 1977 , this news-making novelty was known to its occupants as the "House of Lords" partly because few women would date its impoverished tenants. It disappeared during 1944 when the government sponsored an experimental lignite gasification plant on the site that was later

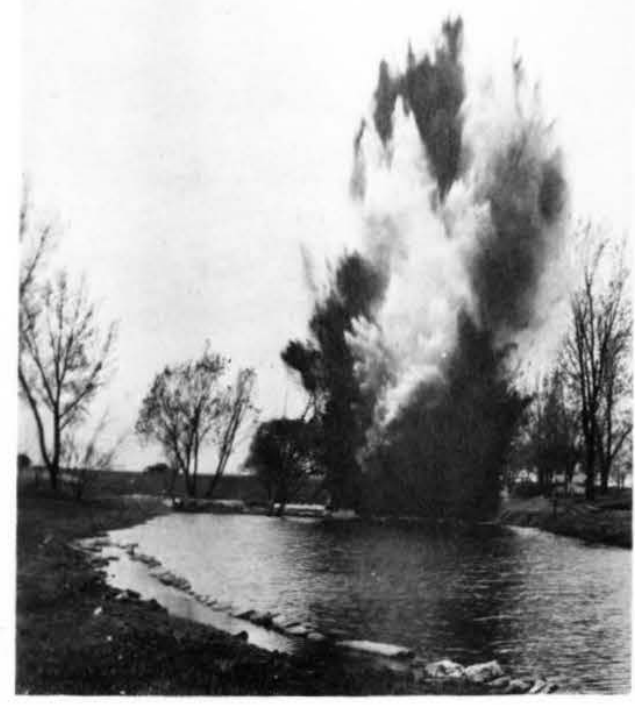

incorporated into the U.S. Energy

Technology Center.

More than $\mathbf{4 5 0}$ students registered for the draft in the Armory on Oct. 16, 1940.

Their induction in World War II

necessitated few physical changes at UND for the duration. Sharky's barber shop moved from Merrifield to the Commons-

Library in 1942, and the coulee got its first permanent bridge, a 72 -foot span designed by the engineering department and constructed by Harry Tannahill, veteran powerhouse engineer, with timber planking supplied by New Deal largesse. Earlier, the coulee acted as an obstacle to the westward expansion of the campus. Access across it on University Avenue consisted merely of a culvert uncertainly filled over with loose earth. For this and other reasons the area between the west bend of the coulee and the President's House had long been devoted to faculty garden plots and one of the larger tree nurseries. In 1943, the University inherited 31 prefabricated units from a defunct CCC camp at Larimore, which it located in the area southwest of the biology building to help accommodate a total more than 5,000 military personnel that would be stationed here during the war. A second kitchen complex at the rear of the new Commons helped meet the meal-time crush. Also, another condemnation of Main occurred in 1943, this time by the state fire marshall who, declaring it unfit for human habitation, urged its early evacuation.

War's end in 1945 found UND with about 70 German prisoners of war billeted in the Armory (whose presence caused six-month cancellation in men's P.E. classes) and with antiquated facilities 
The central mall on the eve of World War II; Woodworth Hall,

destroyed by fire in
1949 , is on the left.

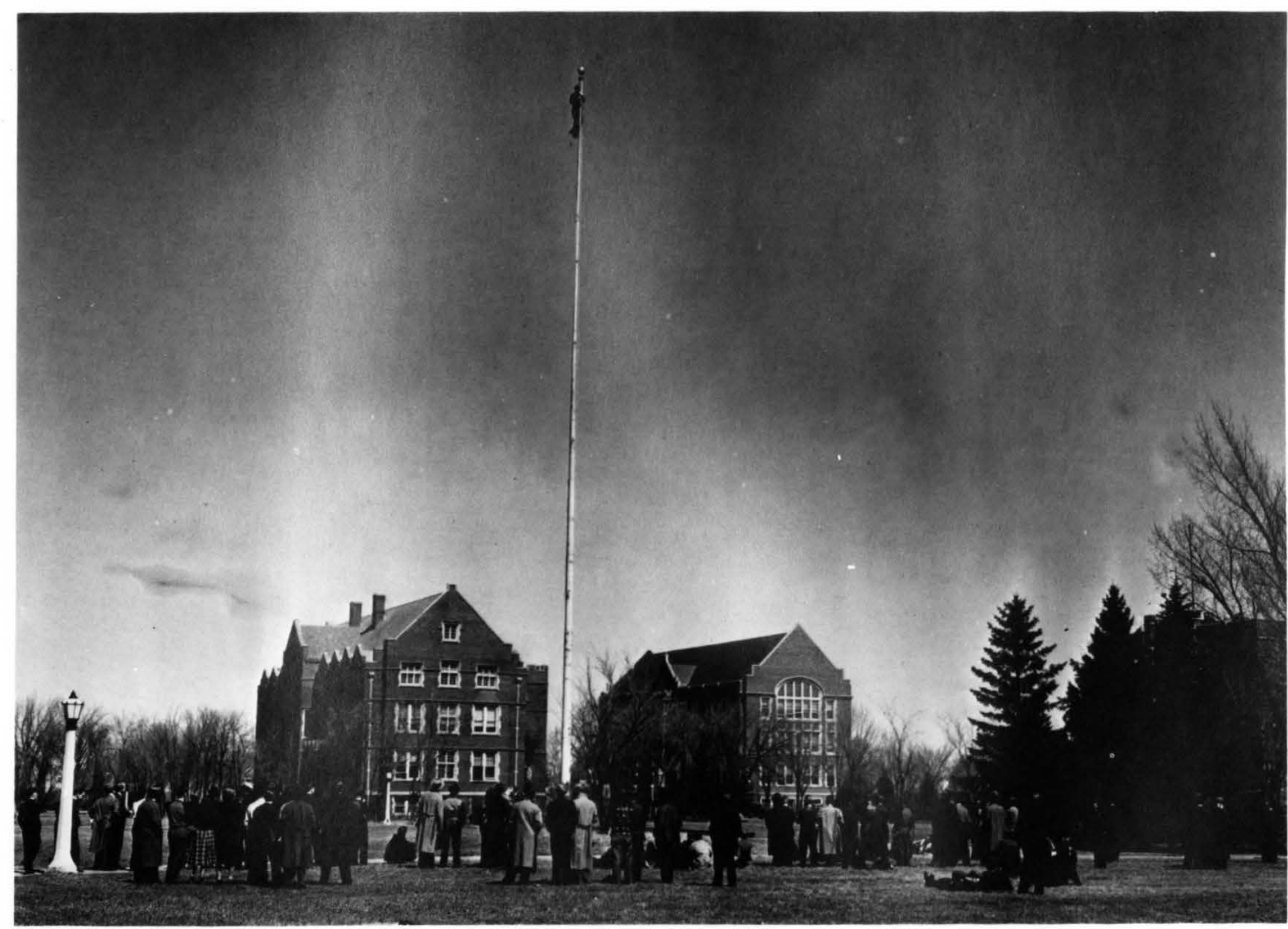


almost wholly incapable of handling the sudden 25 percent increase in enrollment, many of them married students with families, eager to take advantage of attractive veterans' benefits. These were the years the University actually turned away some out-of-state applicants because of the lack of appropriate space, urged townsfolk to consider renting out spare bedrooms, or pressed every conceivable corner of the campus into service: the warming room of the Winter Sports building, the relocated and remodeled railway depot, even the football stadium where most players were quartered. The Federal Housing

Administration helped out, making available 30 surplus house trailers to create Tennis Village in the area now taken by the Fieldhouse, while the leased portion of University Park along 20th Street (now Valley Junior High School) received 98 wartime government metal hutments called Park Village, afterward "Tin Town" on the West Green. Even the museum, the vaunted ambition of some founding faculty, was declared expendable as its space in the locked attic of Macnie Hall could be better utilized for two faculty apartments. The State Historical Society inherited many of the remaining artifacts and mementoes (a replica of "Winged Victory," for example), the residuum of the dispersal occasioned by the Great Depression.

During 1947, the University started converting to flourescent lighting, decreed a one-way traffic flow for the campus drive, and purchased six more temporary buildings, the remnants of a Sioux Falis, S.D., military airfield. Some of these formed the industrial technology center

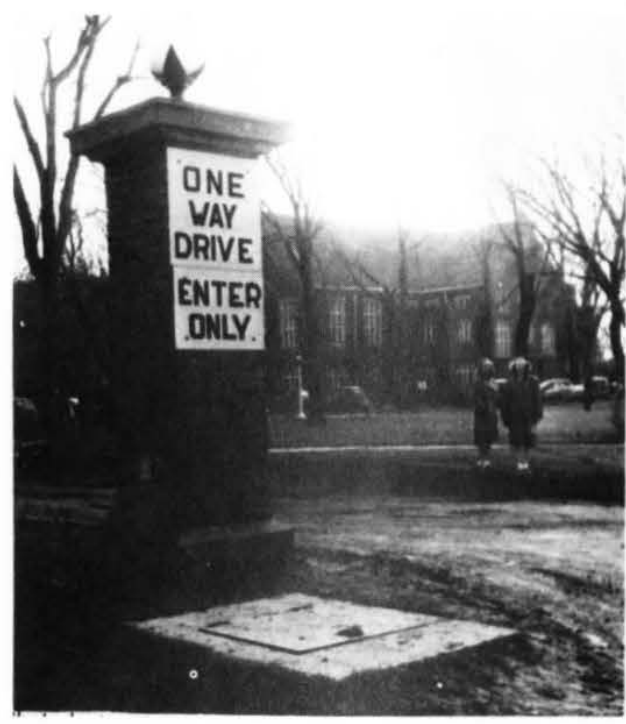

the Law School, housed the education department, KFJM studios, and a variety of faculty offices, and had only recently undergone a major refurbishing of its popular auditorium. (The contractor who razed Woodworth's charred ruins salvaged the handsome fireplace, with inset

University crest, for his backyard use on Conklin Avenue.) Even so, the 1940s ended auspiciously. The original east section of Medical Science was occupied in October 1949. Campus Drive, after being rerouted along its present course (the west portion earlier paralleled Merrifield Hall on its east side) at the cost of 40 mature trees and one of a set of lighted brick pillars that had long graced the main entrance, finally received the layer of asphalt paving planned since 1938. Two new parking lots, also paved, including the one fronting the Armory and West Gym, made their debut.

The worst flooding since 1897 opened

that lasted until the completion of Starcher Hall in 1981, and freed the basement of Merrifield from the noisy, reverberating linotypes of the press after 15 years there. Important developments of 1948 included yet another renovation of Main, President John West's confident declaration that UND would never surpass 3,000 in enrollment, the donation of 13 acres at the east end once Congress authorized creation of a lignite research station under the Bureau of Mines, and the construction of the west half of Science Hall, afterward the Medical Science building.

Easily the most dramatic event of the decade occurred in March 1949 - the burning of Woodworth Hall, which remains UND's largest and costliest conflagration. The building, situated at the head of the " $T$ " intersection across from

the 1950 s, producing among other

problems an inch of seepage in the

Merrifield Hall basement. Campus spirits were little dampened, however, because expansion seemed inescapable. The center section of the Memorial Union, funded by a public subscription launched in 1946 to honor UND's 172 World War II dead, neared completion. It was fitting that its ballroom (twice the area of the Armory floor, long the overcrowded site of every function from athletic contests to formal dances) should open to a junior-senior prom on May 18, 1951. In one stroke a clutch of ancient space problems had been solved, however briefly, notably the dearth of eating facilities. ("The Cave," the larger grocery and fast-food outlet that preceded the Valley Dairy Store, capitalized since the
One-way traffic begins on the Campus Drive (today Centennial Drive), 1947. 
1930s on this perennial shortage.) The Bureau of Mines' lignite center became operational at years' end, 1950. Planning or construction had begun on the fieldhouse, Harrington Hall, and Johnstone and Hancock halls - except for East Hall the first new dormitories in more than 40 years. At this point, the University consisted of 112 acres and 26 primary buildings. The next acquisition, the rectangular block between Oxford and Princeton Streets, had been purchased from Wesley College just after World War II and claimed by a small prefabricated dormitory, a row of relatively comfortable metal huts for faculty couples, and the beginnings of a trailer court that still bears the Princeton name.

Spring, 1951, found UND in the midst of the largest building program since its inception. Parking lots and fines pointed to the new order, as did the widening and repaving of University Avenue as it presently appears, including the introduction of turnout lanes on the narrowed boulevard. The dedication of the Fieldhouse on Nov. 30 was almost immediately followed by an Alumni Office drive to provide for the heated swimming pool, completed in mid-1955, dreamed of since the construction of West Gym. Meantime, the Medical Science building received its first extension in 1952; construction started on the Education building and on the privately sponsored St. Michael's Hospital (today leased by UND); and the old dump ground west of the coulee yielded to a combination playground-picnic area and, beyond, faculty garden plots. That same year the old-English lamp-posts disappeared in favor of 43 tapered steel columns, and practically every summer closed with a richer selection of deliberately intersecting sidewalks that still failed to satisfy far too many indifferent trailblazers. The

Education building, occupied in the fall of 1954 by the art, business, philosophy, and psychology, as well as education, departments, featured the first elevator and second ventilation system, an eight-foot fan.

Meanwhile, the president's house, the "mansion on the prairie,"' had clearly fallen on hard times. It was indubitably nearing the close of a distinguished career spanning UND's first half-century, having beheld or actually entertained visits by William Jennings Bryan, William Howard Taft, Jeanette Rankin, and Franklin D. Roosevelt, as well as numerous state and regional dignitaries. By 1954, however, incoming President George Starcher

refused to reside in it, preferring instead to commute from rented accommodations on Reeves Drive. Condemned and renamed Oxford House, the building was converted to a men's dormitory, and it continued in that capacity until 1964 when the art department moved in for a prolonged seven-year stay that failed to intimidate a larger contingent of the campus' willful pigeon population.

With the removal of Park Village to West Green in 1955, the westward expansion of the campus began in earnest. The Starchers took hurried possession of the new president's home on Yale Drive (so named in honor of the alma mater of UND's first three presidents) just before the holiday season, 1956, the same year that the ground floor of the Rehabilitation
Center (now McCannel Hall) went up adjacent to Medical Science. There the Infirmary found an appropriate permanent home after standing alone as a government surplus, frame sanctuary (called Sioux Hall) just north of Chandler since vacating the library (Montgomery Hall) in 1958 and having been designated the state's blood bank in 1951. (McCannel Hall later absorbed a broad range of student services, partially complementing the expanding facilities attached to the Memorial Union.) A number of disparate yet promising developments excited the University during 1957: the city took a plot of land along the railroad for a patented rivet-free 500,000 gallon water tank to raise needed pressure in the area; most of the last few exposed powerlines went underground; colorful flower beds first enlivened the mall behind Old Science and along the coulee bank; Fulton and Bek halls, women's and men's dormitories respectively, were either dedicated or occupied (Bek's basement originally contained only the second of two student cafeterias); and billboards advertising UND appeared along the three main arterial approaches to the city (one survives on old U.S. 81 north), courtesy of a coalition of local service clubs.

The momentum carried into UND's diamond anniversary with the announcement, first, that internationa businessman Chester Fritz would donate \$1 million toward the construction of a central library, and second, that Bertha Ireland would provide for a 10-laboratory facility attached to Medical Science in honor of her recently deceased husband, a local merchant. Concurrently, fears for the hopeless condition of Main prompted one 


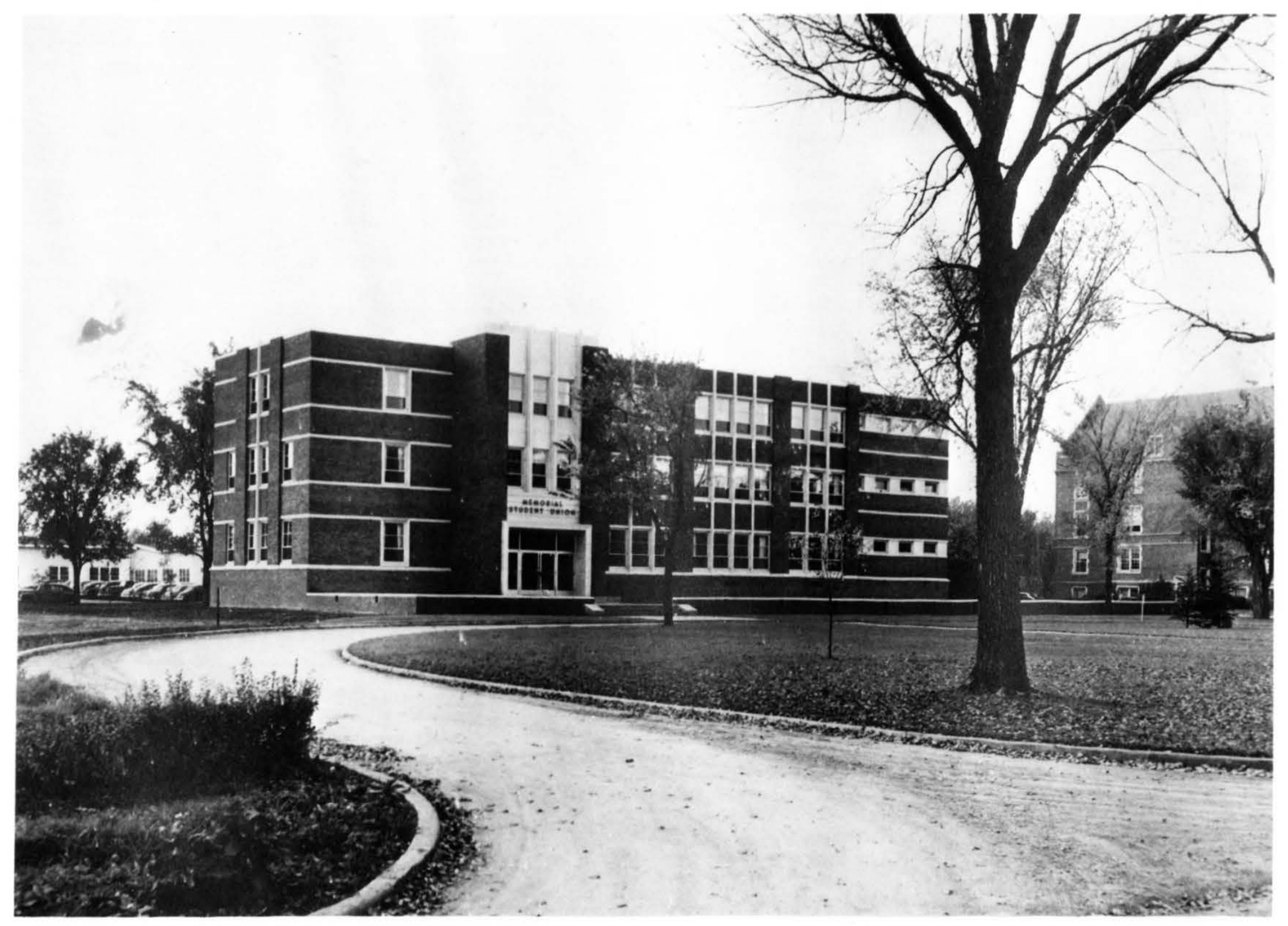

The original

Memorial Union,

opened in 1951 after

a successful fund

drive by alumni, and

since expanded twice. 
journalistic wit to comment that "students have a place both in their hearts and their humor for the venerable structure with the sagging beams." Although Main survived into its 80th year, President Starcher tacitly signaled its imminent demise in 1959, when he announced the prospect of two more capital buildings, a new administration hall and chemistry building, as well as the first 36-unit set of brick six-plexes for married couples on West Green and the Riverdale apartments fronting Stanford Road surplus housing transferred from the Garrison Dam project out west. Two timely, some said belated, campus regulations rounded out the decade: mandatory auto registration and no more parallel parking on Campus Drive.

The "Soaring Sixties" suited UND just fine. The institution had waited a long time to indulge its "edifice complex." With enrollment increased more than 50 percent since 1954 and predicted to take a

"spectacular" jump after 1964 before moderating in 1970, Starcher set the tone of the decade by announcing early in 1960 an immediate construction program that produced three academic buildings and another dormitory within the next two years: Chester Fritz Library, Twamley Hall, Abbott Hall, and Walsh Hall. In 1960 , also, as a collateral development, the state's School for the Blind moved to its present site from Bathgate. During the summer of 1962, no fewer than seven projects were under way simultaneously, including Smith and Squires Halls (the latter originally named Princeton Hall), a three-story addition to the Ireland Research Laboratory, the two-story addition to McCannel Hall, and Burtness Theater. The theater represents the gift of Zoe Burtness in honor of her husband, an alumnus and several-term congressman, both of whom had decried the loss to fire of the 300 -seat Woodworth Hall auditorium in 1949. She did not live to witness the dedication of April 23, 1963; however, Edna Twamley attended the festivities dedicating Twamley Hall the following Memorial Day.

Twamley, together with her 1902 classmate, Kathrine Tiffany, Chester Fritz's redoubtable aunt, easily qualify as UND's preeminent matriarchs. Indeed, Starcher once allowed that Tiffany had been responsible for many more things at the University than will ever be popularly known. The dedicatory plaque in Twamley Hall, for example, is a Tiffany design and composition. Yet Tiffany stoutly declined to have her name personally associated with any landmark save in one instance the graduate study area in the Chester Fritz Library.

There are two features about the Library of special interest. Starcher had hoped to install a carillon in its nearly 83 -foot tower, the highest elevation on the main campus (after the dismantling of the 150-foot powerhouse chimney in 1981). Instead, Edna Twamley separately subscribed $\$ 55,000$ for the purpose, and Starcher selected the Carillon Americana for the Twamley tower - in 1964 the sixth largest of such consoles in the nation. Secondly, former Liberal Arts Dean Vernon Squires, an instigator of the Founders Day tradition, coined the of ficial University motto "Lux et Lex," for the silver anniversary in 1908. In 1962, the Library committee sponsored an open competition for a suitable maxim to dignify the interior lobby entrance of the Fritz Library. English Prof. Foster Y. St. Clair's elaboration of "Lux et Lex" proved the winning entry. "The maxim, in turn, further refined by its author, is the official theme of the University's centennial year: "By the light of knowledge we read the laws of life."

Surprisingly, Main defied the pounding and drilling that accompanied the

construction of Twamley, not to mention at least two generations of joking and derision. Nevertheless, an eleventh-hour wave of nostalgia sought to preserve the truncated artifact as perhaps a museum. Starcher successfully negotiated the issue, without compromising the objective.

Wreckers razed the sad sight in June, soon after Twamley Hall's conerstone was positioned during ceremonies in which some contents of Main's counterpart were transferred to it. The promised memorial, a half-ton grille sphere and its "eternal flame," erected during the fall of 1963 , proved quite agreeable; and the subsequent choice of variegated granite to embellish the plaza released the majority of Main's distinctive red bricks for souvenir hunters and bookend artisans. Some equally unusual events occurred during the hiatus in new construction that briefly followed. First, the 77 -foot flagpole that had stood on the mall since 1903, more or less on the original east property line, was replaced and located at the present site largely to meet the combined requirements of state law, the ROTC, detachment, and the Post Office. Second, the rotted plank bridge having been pulled down some months earlier, the coulee got a temporary substitute in the form of a pontoon bridge 


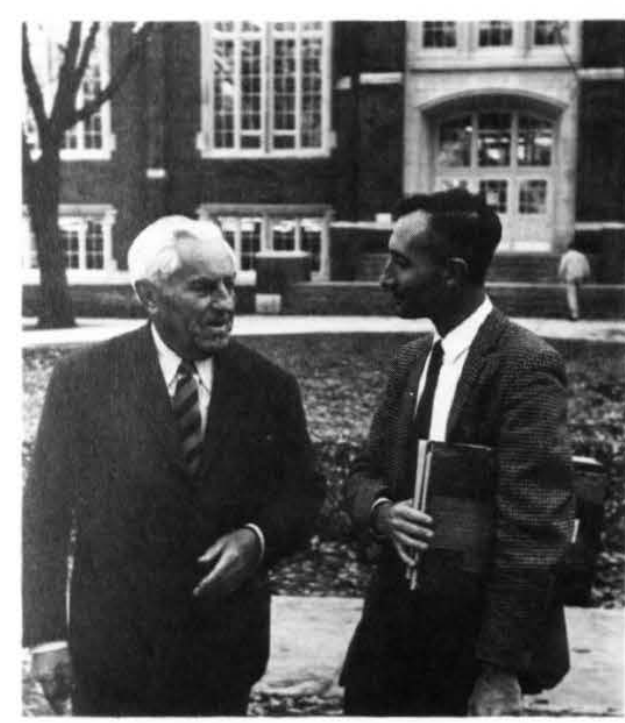

loaned by the North Dakota National

Guard. And third, the fall semester began with the recently installed centrex telephone system now elaborated to permit extensions in each of the Johnstone-Fulton-Smith rooms. Until then, there had been only one pay phone in each of the three lobbies an endless source of anxiety to the sociable Pepsi generation.

Even as President Kennedy's visit in September 1963 attracted 20,000

spectators, probably the largest crowd ever to converge on campus, construction started on the east addition of the Memorial Union and two more dormitories, McVey and West halls. The flow of foot traffic previously had been predominantly north-south. By the 1960s, however, it had definitely shifted to eastwest, necessitating a series of sidewalk re- alignments of which the giant " $\mathrm{X}$ " (dubbed by students the "landing strip") on the north mall is most distinctive. II was also apparent, as then Vice President Thomas Clifford observed, that whereas dormitory accommodations had increased 300 percent since 1954 , classroom and laboratory space had grown a mere 15 petcent. He said nothing about office space, but all faculty knew of no ready solution except for prayer.

Although completion of the eye-catching Leonard Hall in early 1965, for geology and the North Dakota Geological Survey, helped ease conditions somewhat, the surge in enrollment surpassed all expectations. Brannon and Selke halls were filled even as their rooms were outfitted in 1965 and 1967. Gillette Hall, opened to occupancy in 1968 , completed the dormitory complex on the west side of the coulee. Meantime, attention turned to two vestiges of a bygone era, Davis and Macnie Halls, both labeled fire traps by the State Board of Higher Education upon its creation in 1938. Davis was finally demolished during the summer of 1965 , the same summer that UND took possession of Wesley College and its nearby properties, including the president's home, now the Honors House.

The remaining trailers at Tennis Village were removed in 1966, and, after some delay, Macnie Hall gave way in 1967 to Gamble Hall, built in part with a contribution from the Gamble-Skogmo Foundation. The new golf course donated by Ray Richards, a 1906 alumnus whose family operated a dairy farm on the site, opened during the summer. Witmer Hall, in use by the mathematics and physics departments by the summer of 1968 ,
Wilkerson Hall, in operation in the spring of 1969, and the astronomical observatory on the Bronson property, housing a 16 inch, faculty-fashioned Cassegiarnian telescope, ended UND's single greatest experience in rapid physical growth. Gov. William L. Guy helped capture the significance of the moment when the West Green dormitory complex and Gamble

Hall were dedicated separately during one dramatic week in May 1969.

Concurrently, the grounds acquired attributes familiar to its current population. The 75 -foot span of prestressed concrete known as the Fox Memorial Bridge was dedicated during the June 1966 commencement exercises. The armillary sphere, a gift of the Campbel Foundation, dates from the same time and stands approximately where the institutional flagpole once did. Extending and grading of the access road along the railroad right-of-way, to connect Stanford Road with the east end of the campus, began in 1968. Demolition of the 165-foot, wooden KFJM transmission tower near the Adelphi fountain dating from 1936 and reputed to be among the last towers of its kind in the country, also took place in the same summer, when the existing tower was located at the University's Bronson property to the north. (Also known as the North Campus, the 1947 bequest of 160 acres to UND by alumnus Harrison Bronson was being used in 1982 as a location for student housing, parking lots, recreation fields, tennis

courts, garden plots and a city fire station protecting the University.) The freshmen students of 1968 were lucky: they didn't have to resist the temptation to park 
The West residence hall complex under construction, 1967.

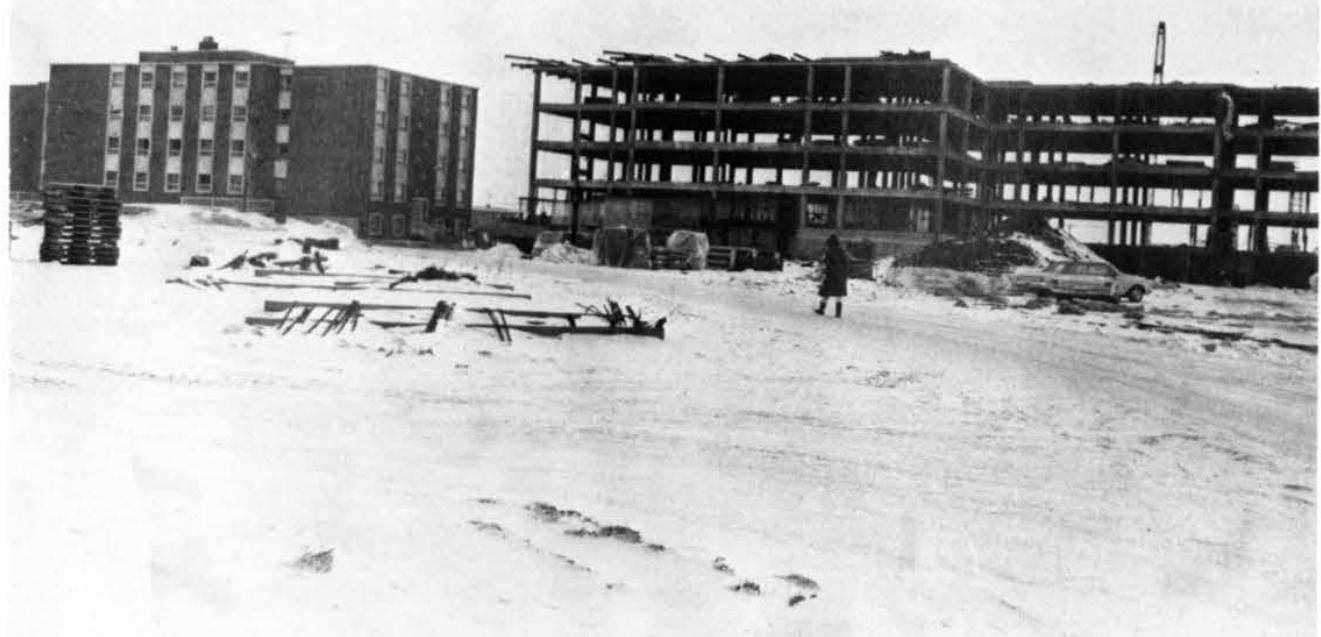

along University Avenue, to exit Campus Drive at the Law School entrance instead of the reverse, or to ignore the one-way signs on certain streets on the north side.

The decade of the seventies opened with the unique U.S. Agriculture Department Human Nutrition Laboratory well under construction, the completion of the top floor of the Chester Fritz Library, the creation of a Scandinavian cultural center at the Honve House, and the preparation of the space adjacent to Harrington Hall for construction of Upson I. The latter effort prompted one faculty member to ask openly if the University was consciously striving "to maintain" the state's reputation for having the fewest trees. Environmental concerns, enjoying a renewed interest, worked both ways, however, as the University ended rubbish incineration in each building and acted on plans to gain control of the coulee between the railroad tracks and Gateway Drive,

mainly to guard against pollution and wanton dumping. The general public and students alike abetted a sudden 300 percent increase in national bicycle sales,

perpetrating a different and novel kind of parking problem reminiscent of the $1890 \mathrm{~s}$ Less easily resolved was the anticipated invasion of Dutch elm disease and its effect on UND's 3,766 trees and shrubs, almost 21 percent of which were elms. Some faculty recommended, and the administration adopted, a long-range plan to substitute alternatives like ash, birch, and evergreens, so that cultivation of the familiar American elm at UND nurseries ceased about 1972. Several original

sculptures, most of them crafted by Stanley
Johnson for both indoor and outdoor placement, helped to soften the institutional regularity at some vantages. And the University's intention, announced in December 1970, to render superfluous a forest of antennae with cable TV services removed an unsightly intrusion upon the "Big Sky" horizon.

Still, these indicated that things of a cultural, service, and an aesthetic focus underlay the continued, although less frenzied, expansion of the decade. Construction of the inter-connected Upson Hall I and II for the computer center and School of Engineering and Mines filled the first four years in two stages (a computer and small nuclear reactor, potent representatives of the current age, arrived coincidentally in 1961). The impressive bulk and modern lines of the Chester Fritz Auditorium and the multidimensional Edmond A. Hughes Fine Arts Center paralled these projects, providing the University with points of interest and cultural and artistic outlets not,

traditionally, very widely associated with it. Some of this applies as well, albeit in a different sense, to the new Winter Sports building following months of controversy and even litigation to regain easement rights over land previously donated to the federal government. Its construction, starting in mid-1971, won the enthusiastic financial endorsement of the public at large. The concrete floor for the central rink, formed in a continuous pouring in October 1972, required most of the month to set and cure.

In 1971, also, the University set aside Anashinobay Aki, the Native American Cultural Center opposite the Human 


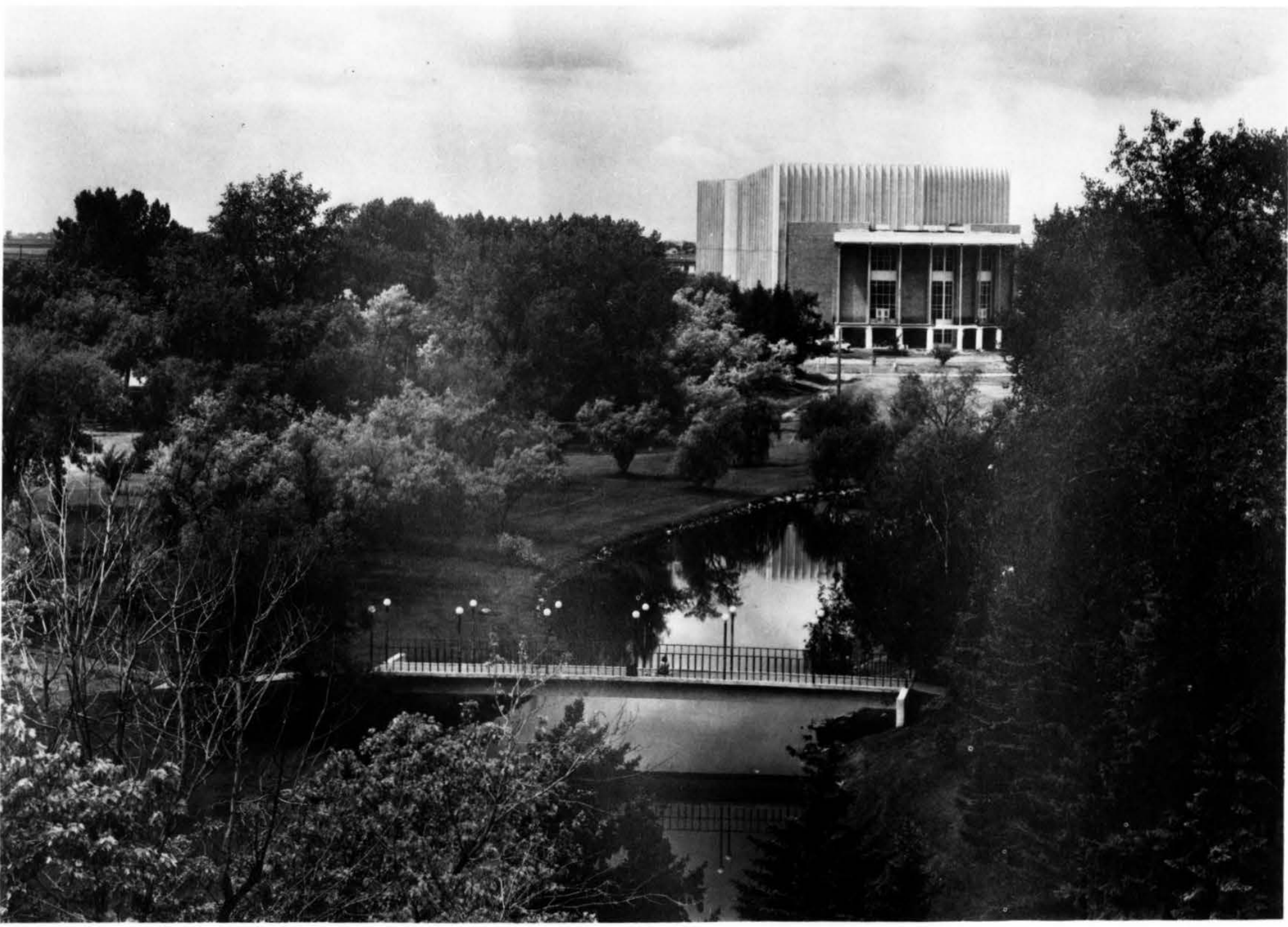

\section{The Chester Fritz}

Auditorium nears

completion in 1972

the Fox Memorial

Bridge was dedicated 
Airview of the cam pus, looking north.

1928.

Airview of the campus, late 1950s.
Nutrition Laboratory, and assigned the Faculty Club a semi-permanent retreat in a house earlier acquired by the Memorial Corporation. The Cultural Center

responded to the last of seven studen "demands" prompted locally by the notorious Kent State incident of 1969. The Faculty Club had its origins in the basement corner of Davis Hall in 1957 and later moved to the Twamley snack bar area. Both locations posed a special problem, whatever the limits of the facilities: regardless of the occasion, refreshments could not legally acknowledge that prohibition of alcoholic beverages had been repealed more than 20 years before. As the year closed, the Afro-American Union moved from its distant home on Dyke Street to Hamline Street, then to its present avenue address, and in 1975, was renamed the Era Bell Thompson Cultura Center in honor of a prominent black graduate of UND. Assistant to the President for Facilities Gordon Kroeber also quashed an improbable rumor that the avenue, if closed to auto traffic as many desired now that Demers Avenue connected to I-29, would be converted to an enclosed, air-conditioned mall.

During the winter of 1972 UND

experienced an unprecedented total of 13 concurrent construction and renovation projects. (The record held until the hectic summer of 1982, when 20 different projects readied the University for its centennial in accordance with President Clifford's promise to free the campus of major construction for the occasion.) These projects included, in addition to those already mentioned, the new, twice-aslarge Rehabilitation Hospital on Columbia
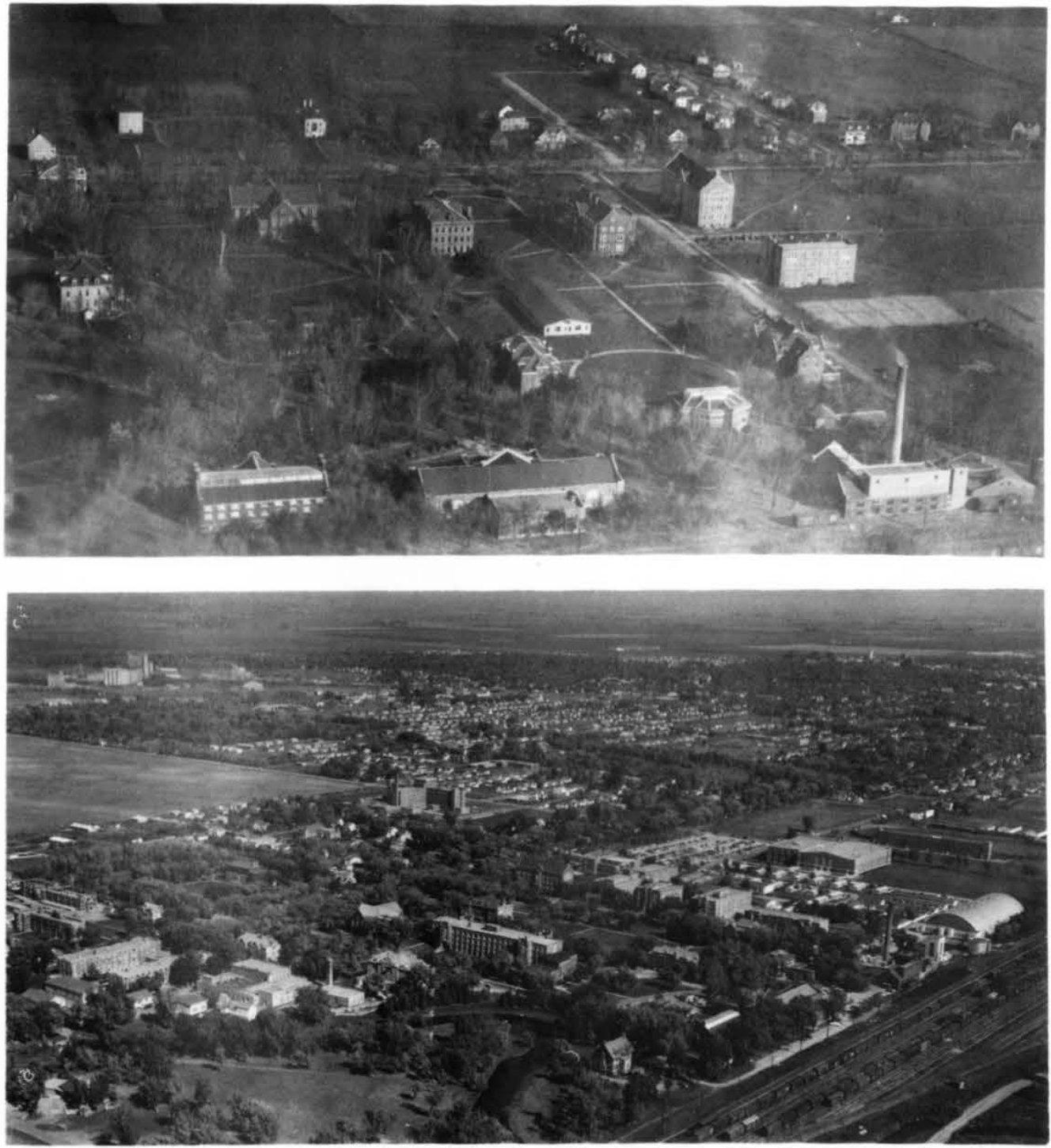


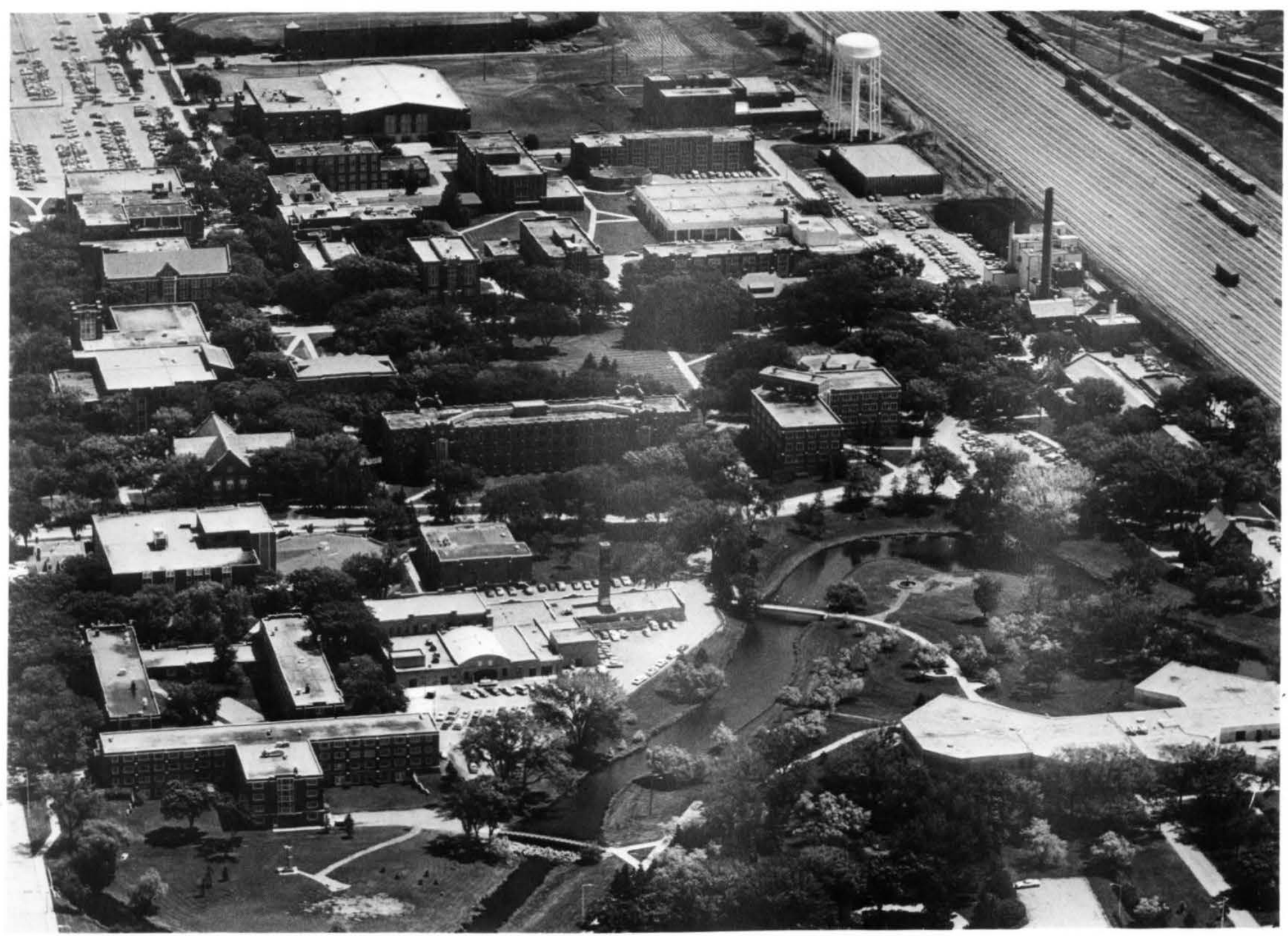

The central campus in June 1981; new in the previous decade on this part of the campus are the Hughes Fine Arts Center, Upson I, Upson II, Thormodsgard Law
Library, Laird Core and Sample Library, Starcher Hall and Chester Fritz Library addition (under way in 1982 were additions to the Memorial Union and the Fieldhouse. 
Road and the start of the award-winning Thormodsgard Library extension to the Law School, the latter completed in 1973 The Central Service Complex, built partly with a second generous contribution from the E. F. Fox family at the southwest corner of the campus, concentrated supplies receiving and storage, and eliminated most commercial traffic from central areas. The nursing program, long scattered all over the campus, got its own spacious quarters in 1976, successfully helping to integrate the Wesley College appendage to the larger institutional definition. UND also tacitly celebrated the nation's bicentennial by graduating its first physician as the result of its 1973 conversion of the two-year school to a four-year M.D. granting program. In 1978 the University constructed a School of Medicine building in Fargo, and leased space in three other cities.

On the eve of its centennial year the University of North Dakota not only appeared but also gave every evidence of having become a mature institution, where renovation, modernization, and refinement rather than aggressive growth seemed the more controlling need. In fact, Starcher Hall, the new home of the departments of biology and industrial technology as of 1981, the Wilson Laird Core and Sample Library, also opened in 1981, and the Center for Aerospace Sciences, a federally sponsored elaboration of the aviation department scheduled for dedication in 1983, may well constitute the most recent, wholly new construction for some years to come.

Other changes are more suggestive of the centennial achievement. The psychology department found its first separate facilities in the renovated Corwin and Larimore Halls. The belated additions to the Chester Fritz Library and the Fieldhouse, the latter renamed the Hyslop Sports Center, correspond more realistically to the record student enrollments of late years. Student numbers and foibles also dictated the sharply defined extension to the Memorial Union and, before that, the permanent retention of a peripatetic litter patrol. The acquisition of the Phi Delta Theta house, christened Gustafson Hall for the Division of Continuing Education, promised greatly enlarged services beyond the proximate environs and surrounding region. The restoration of Oxford House, furnished and trimmed in part according to its original decor and renamed the J. Lloyd Stone Alumni Center, bears apt witness to the continuity between past and present.

And the addition to the Winter Sports Building eagerly anticipates a major athletic tournament while conforming UND's arrival at competitive prominence. Once again, as frequently in the past, timely private sources relieved the institution in its hour of need.

Indeed, the dedication of the Loren $\mathrm{F}$. Swanson Housing Complex during Alumn Days in May 1981, broadly connoted the realization of a fully developed institution, besides belatedly permitting the removal of the "temporary" tin huts (one unit survives for old-times' sake). In addition to building new student housing, the

University moved to acquire privately owned apartment buildings in the University area, as well as to quietly purchase property as it became available between the main campus and the Bronson property. The new, separate electrical switching station, to become operational at the far west end in the opening months of 1983, will triple the supply of available power to meet projected needs. Truly the institution of today embraces complexities, technologies, and requirements scarcely imaginable to any previous generation.

UND's buildings and grounds are prepared for the opportunities and challenges of the institution's second century. The more than 700 loyal and resourceful service, plant, operations, and security personnel have ably demonstrated skills and often talents for prolonging the usefulness of all facilities and for adapting structures built in one era to the changed functions of another. They have kept abreast of the technical and occupational aspects of their particular responsibilities, and repeatedly evidenced a willing disposition to perform beyond routine expectations. And as citizens of the community at large, they have assisted actively in bridging the distance between the University and its locality - wha President Merrifield once termed the "oversight" of 1883.

Yet, the most visionary leadership could not have contemplated student bodies in excess of 11,000 for any given year, while the service and maintenance staffs have never been strangers to fiscal economy, energy efficiency, or the sudden, occasionally capricious exigencies of man and nature. (Consider, for example, the coordination necessary to keep the equivalent of 38 acres of roofing in good repair!) The results are only too apparent: 


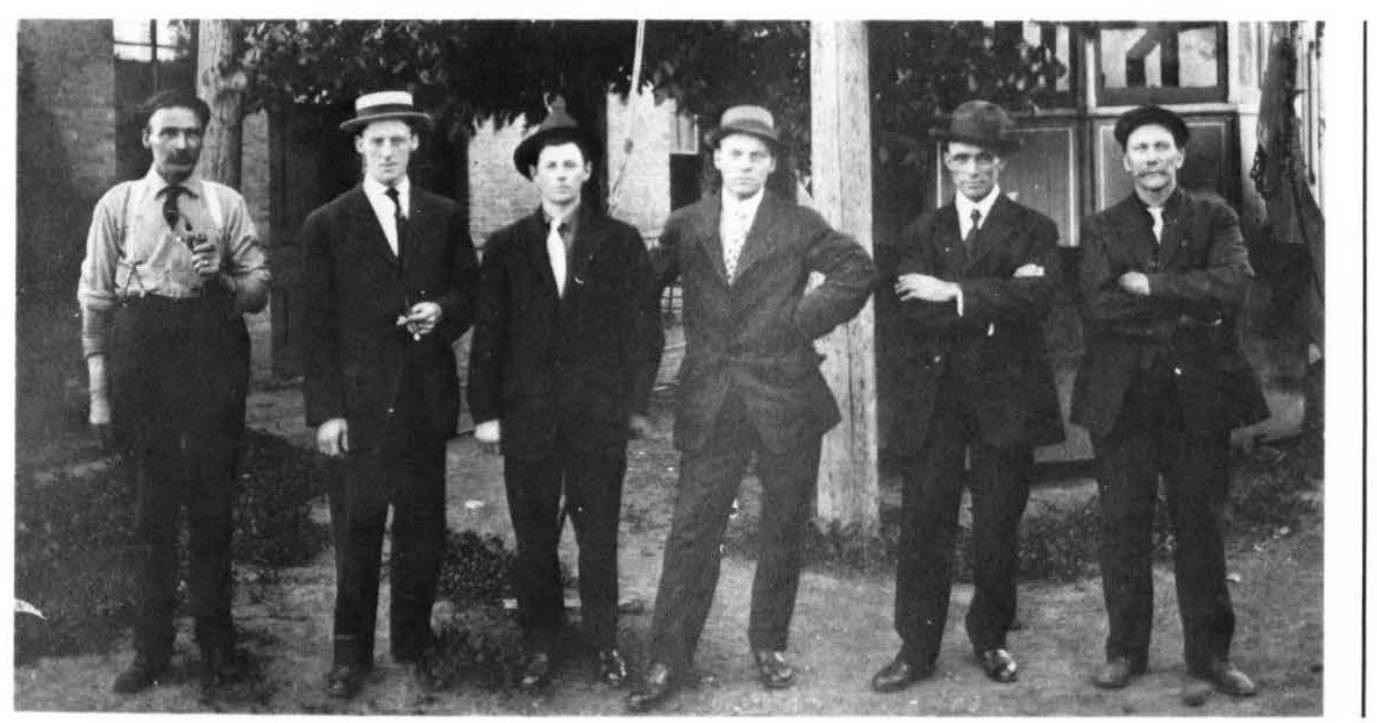

one need not travel far in order to

recognize that unlike many comparable

institutions elsewhere, especially in the

Plains states, buildings and grounds at the

University of North Dakota remain

stylistically uniform, rationally integrated,

and environmentally practical.

Three generations of dedicated plant ser-

vice workers have

made UND's campus

ne of the most

scenic and efficient in

he nation; these

power plant

the camera in 1909. 


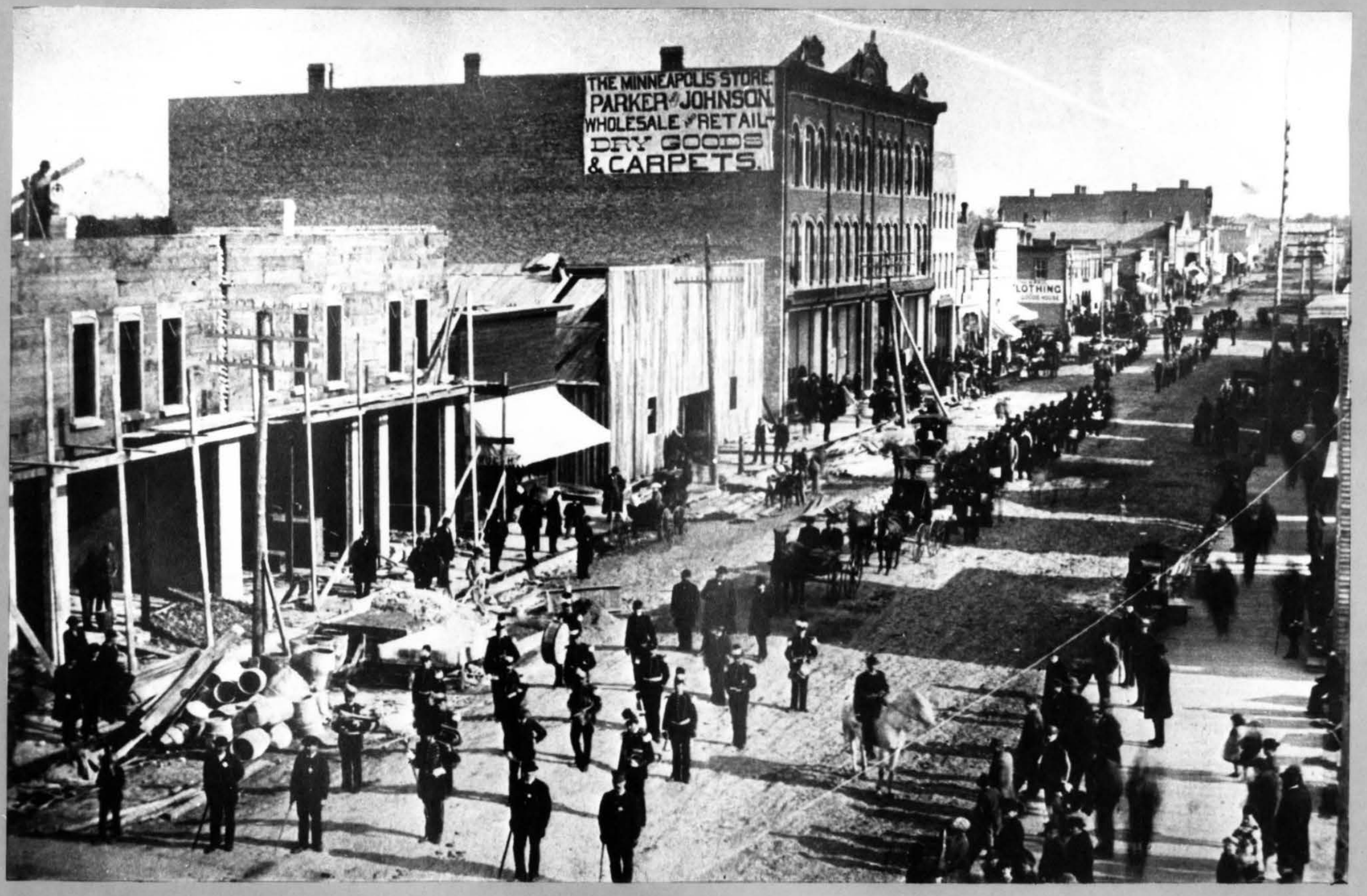


W can calculate the value of a caring community, a vibrant spirit of teaching and learning, a coming of age in an atmosphere of truth and beauty that entices young people to embrace them?

Who can put a price on the value of younger and older people sharing dreams, working together for the less fortunate, planning a better world, espousing great causes with courage and integrity?

Whatever the challenges of the next century we need not fear them. We accept them with a faith and a vision that would not be denied in 1883, not then, not now, not ever.

From a speech by UND President Thomas J. Clifford to public officials and alumni, Jan. 13, 1983.
The boom town of Grand Forks, population 6,500 , as a procession heads for the cornerstone of the Main Building, Oct. 2. 1883 . 
Main Building in the late 1880s; in 1912 i

was designated Mer-

rifield Hall, a name it

would bear until

1930. Until its razin

in 1963, the pioneer

structure was simply

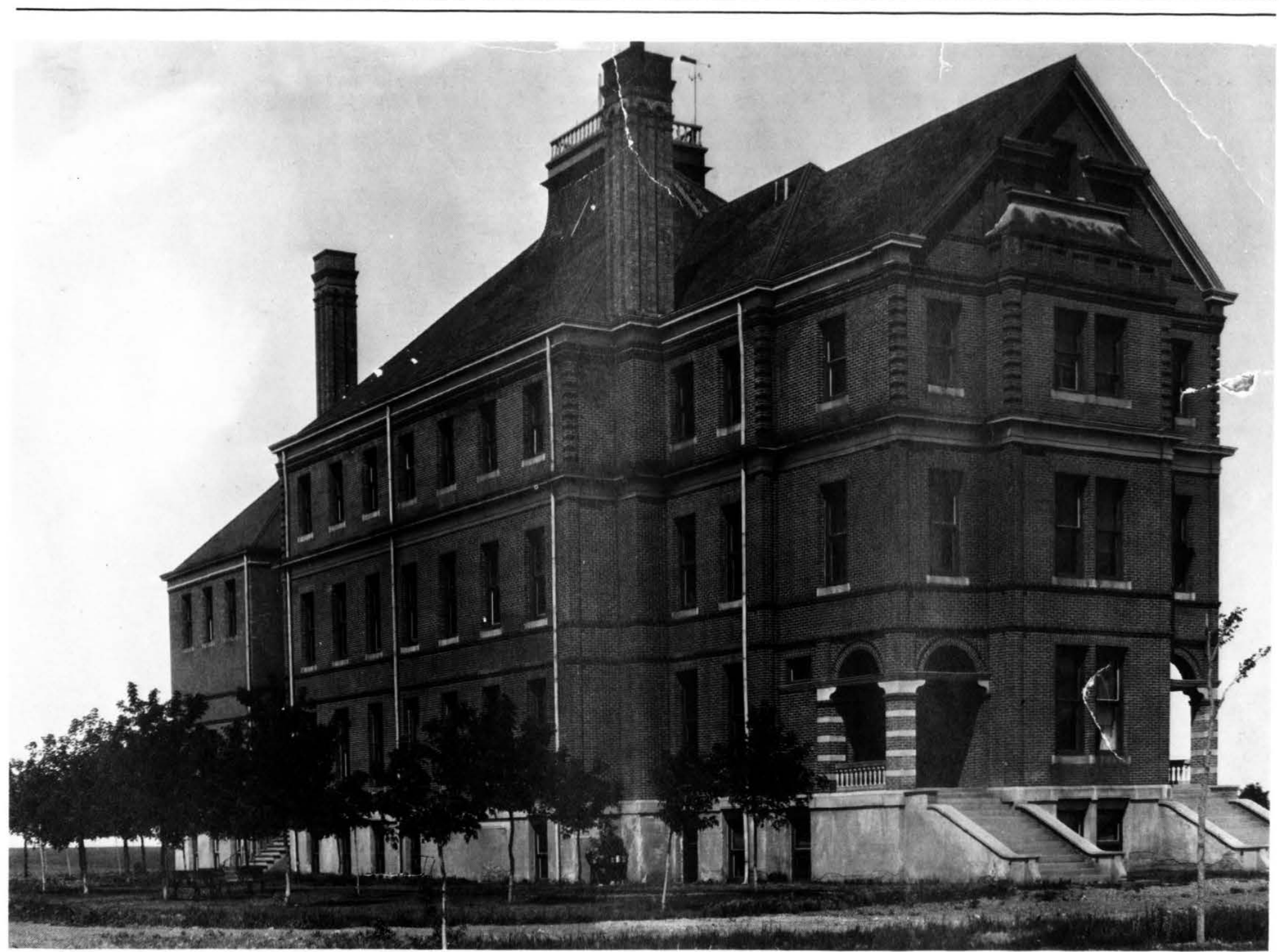


The first years: The University takes root.
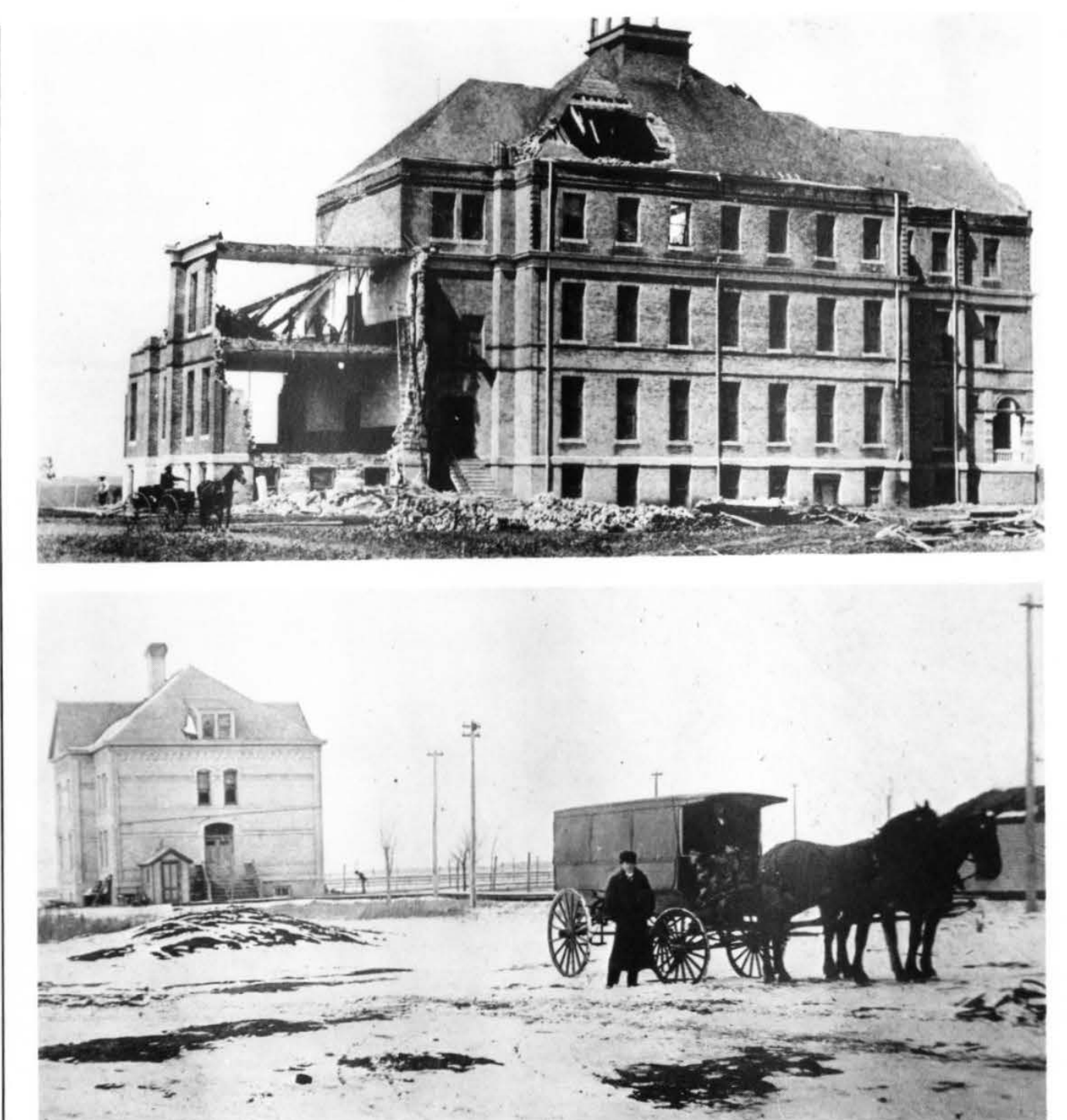

The Main Building

after the destructive

wind storm of June

$16,1887$.

"The Cottage" in

1899 , with the

University bus, or

the foreground. The

girl's dormitory was

expanded in 1906 .

and renamed

Hall in 1908 . 
The University's first depot; the fence in

the background kept

cattle from wandering

on to the campus.

Enjoying the early

spring sun; until well
into the 20 th century,

snow or mud often

limited students to

taking walks on the

relatively dits on the

relatively dry railroad
tracks.
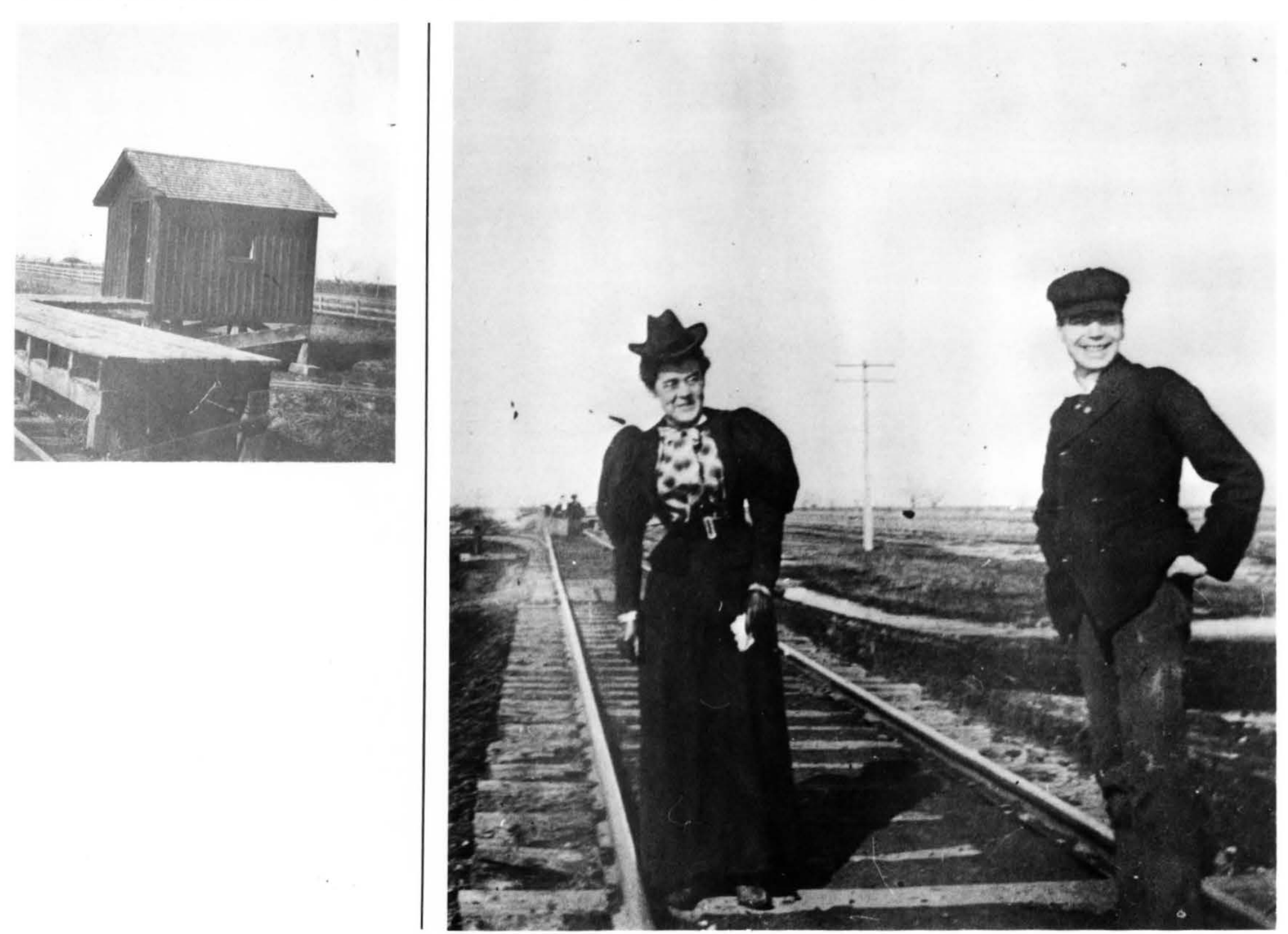


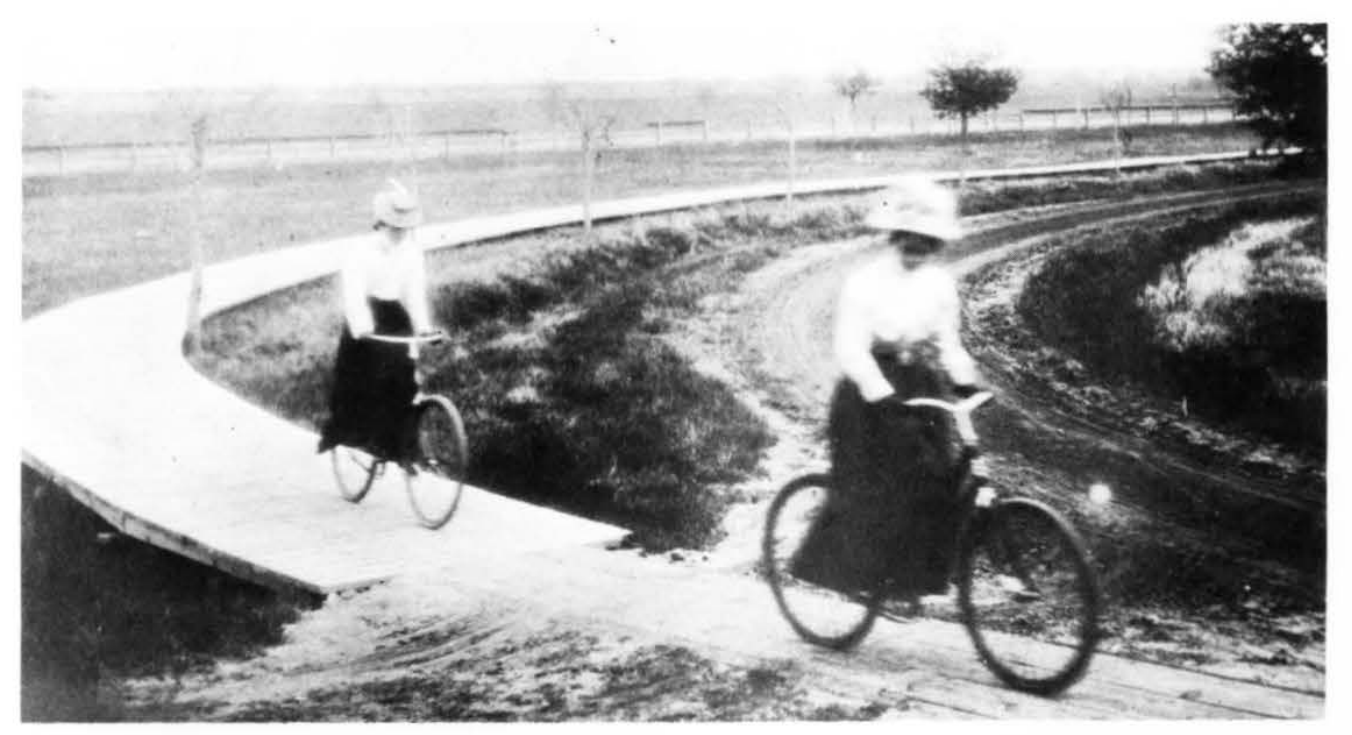

292

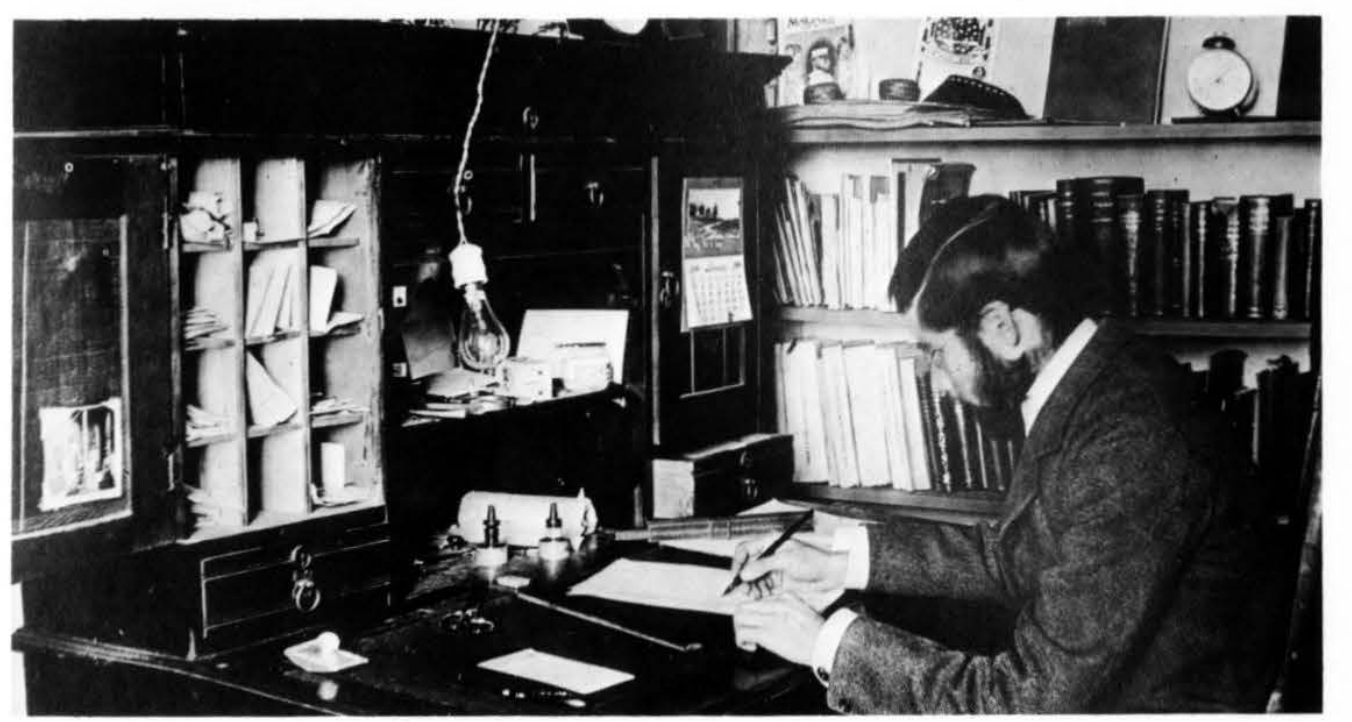

Elwyn Chandler

professor of

desk in Jo, at his

ot immune from

he 19th century 


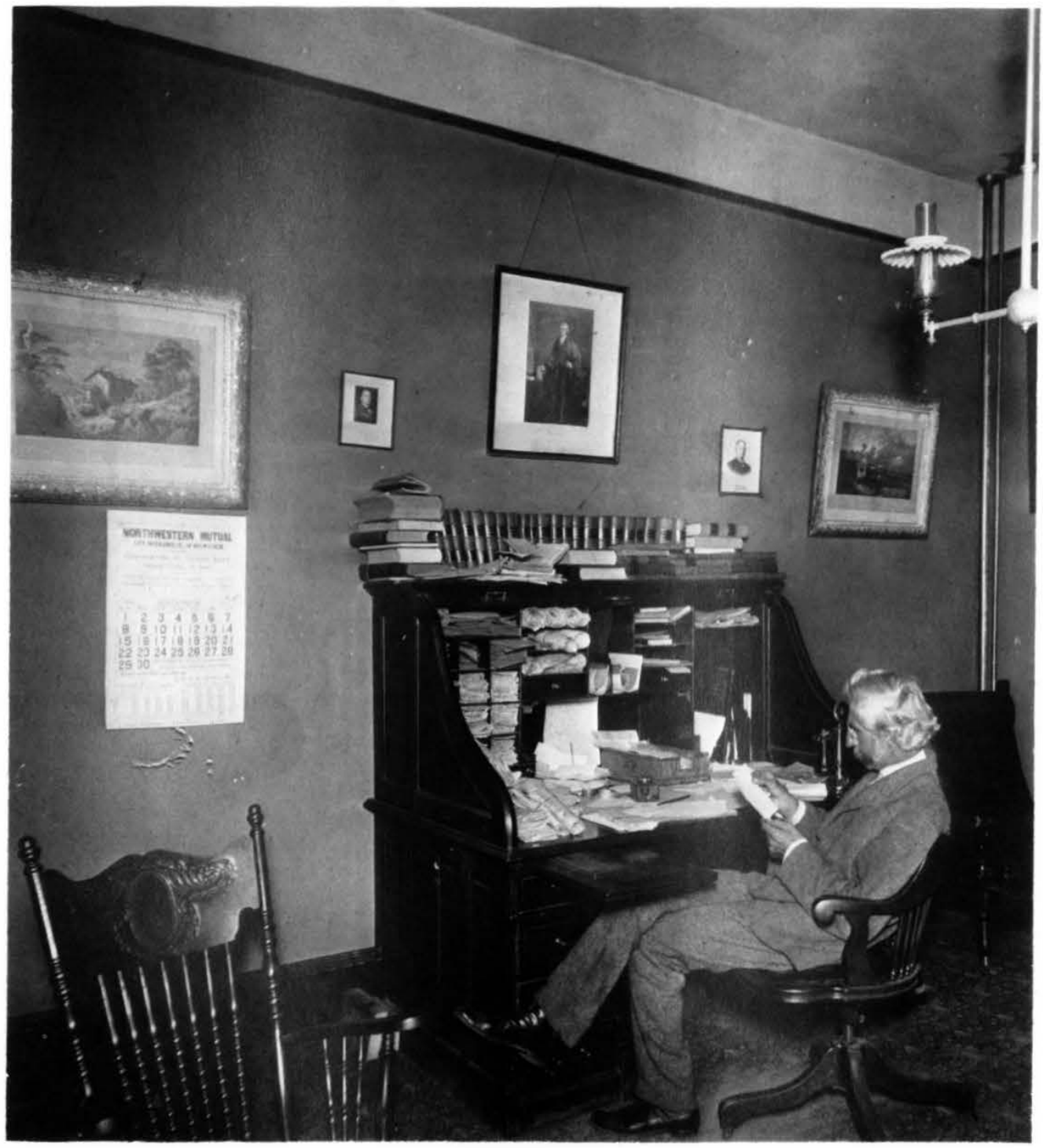

..... the one thing that is done here is to study; here everyone studies; here

everyone talks of study; here the days and hours are laid off in regard to study. ....

-by an unknown writer in 1898 (thought to be Vernon P. Squires) 


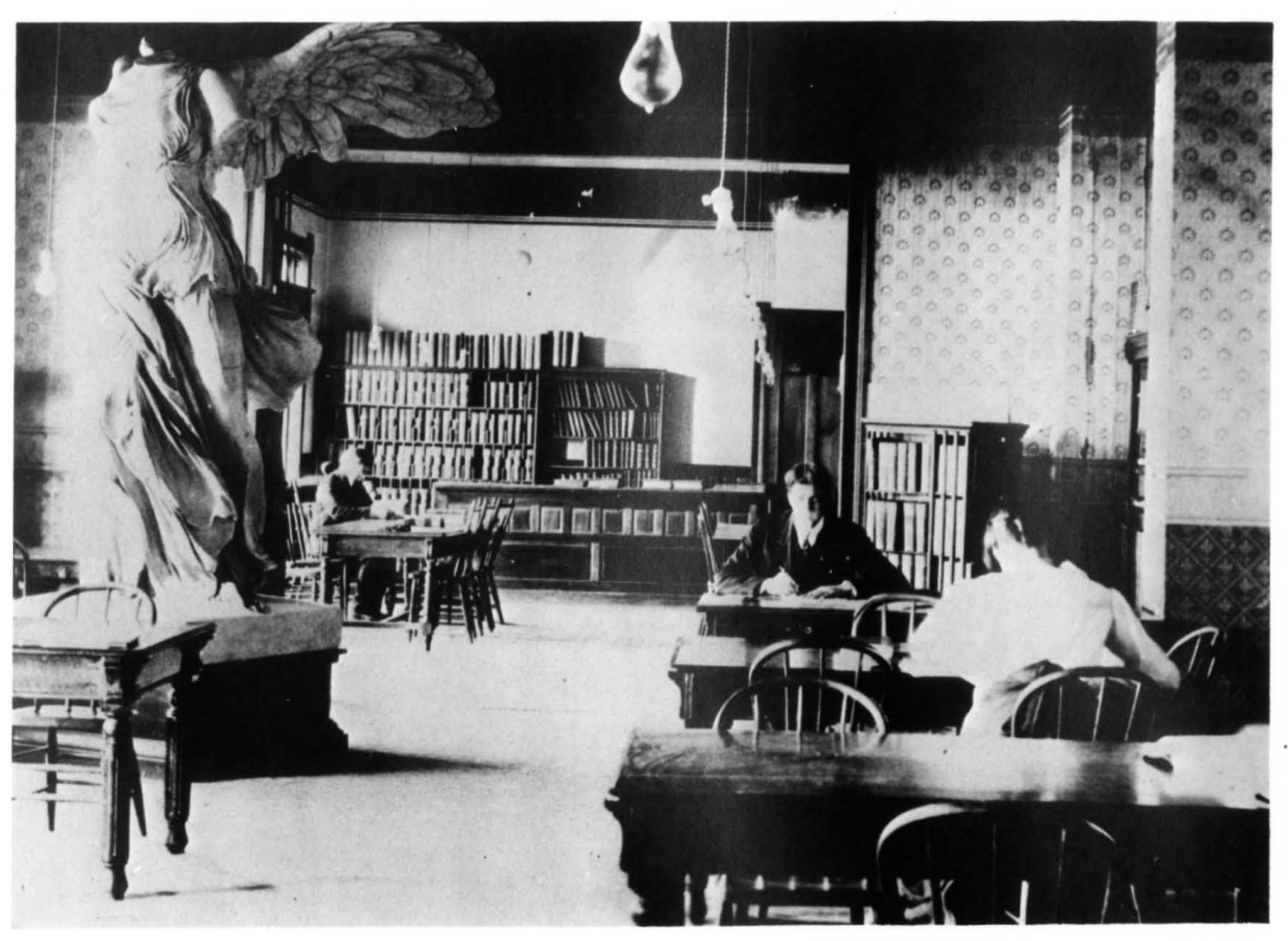

The University's first

library - for many

years, just two rooms

in the Main Building. 
Student enthusiasm for military training

waned after the

Spanish American

the growth of inter

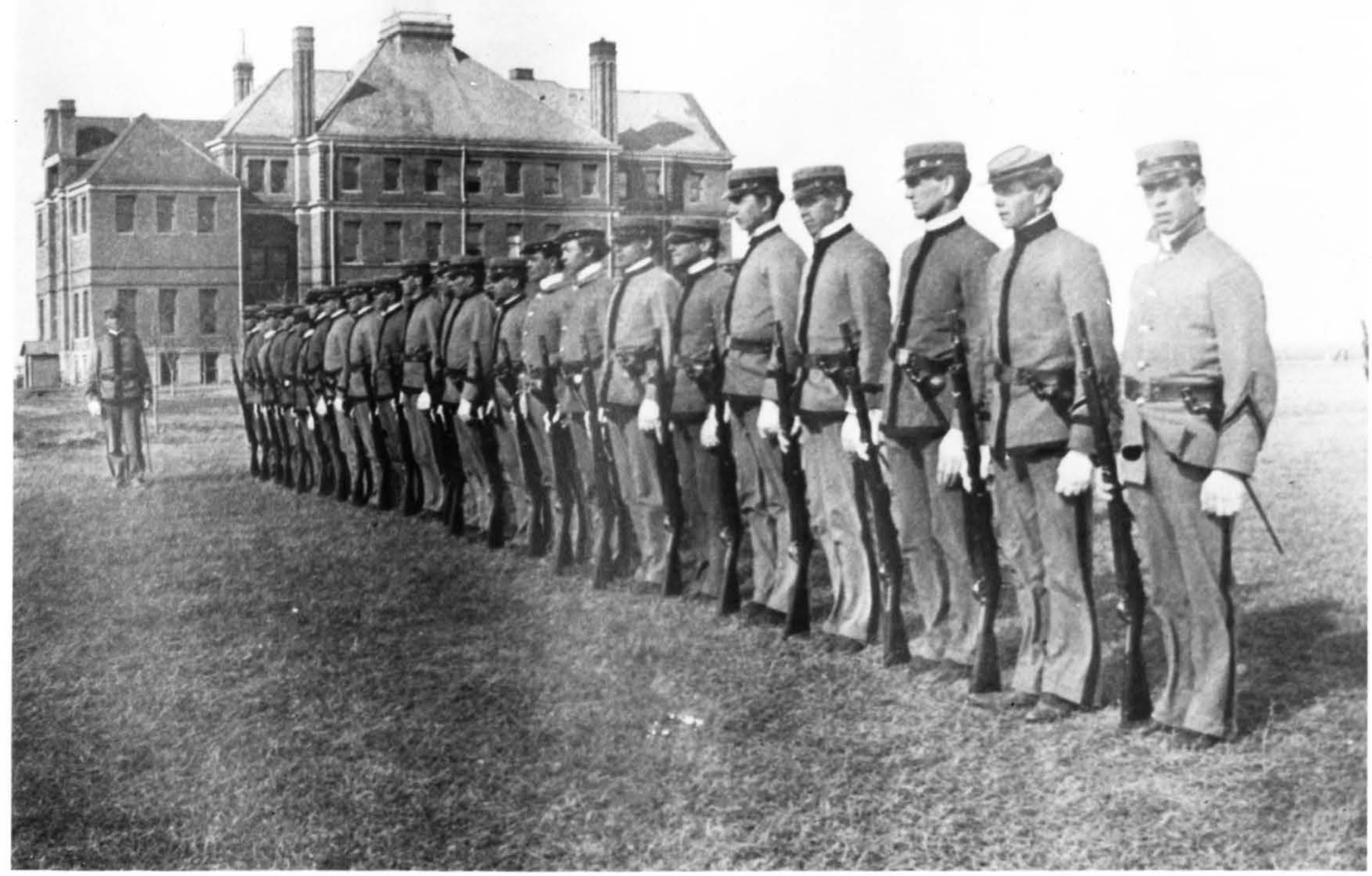


The turn of the century: $A$ true university emerges.
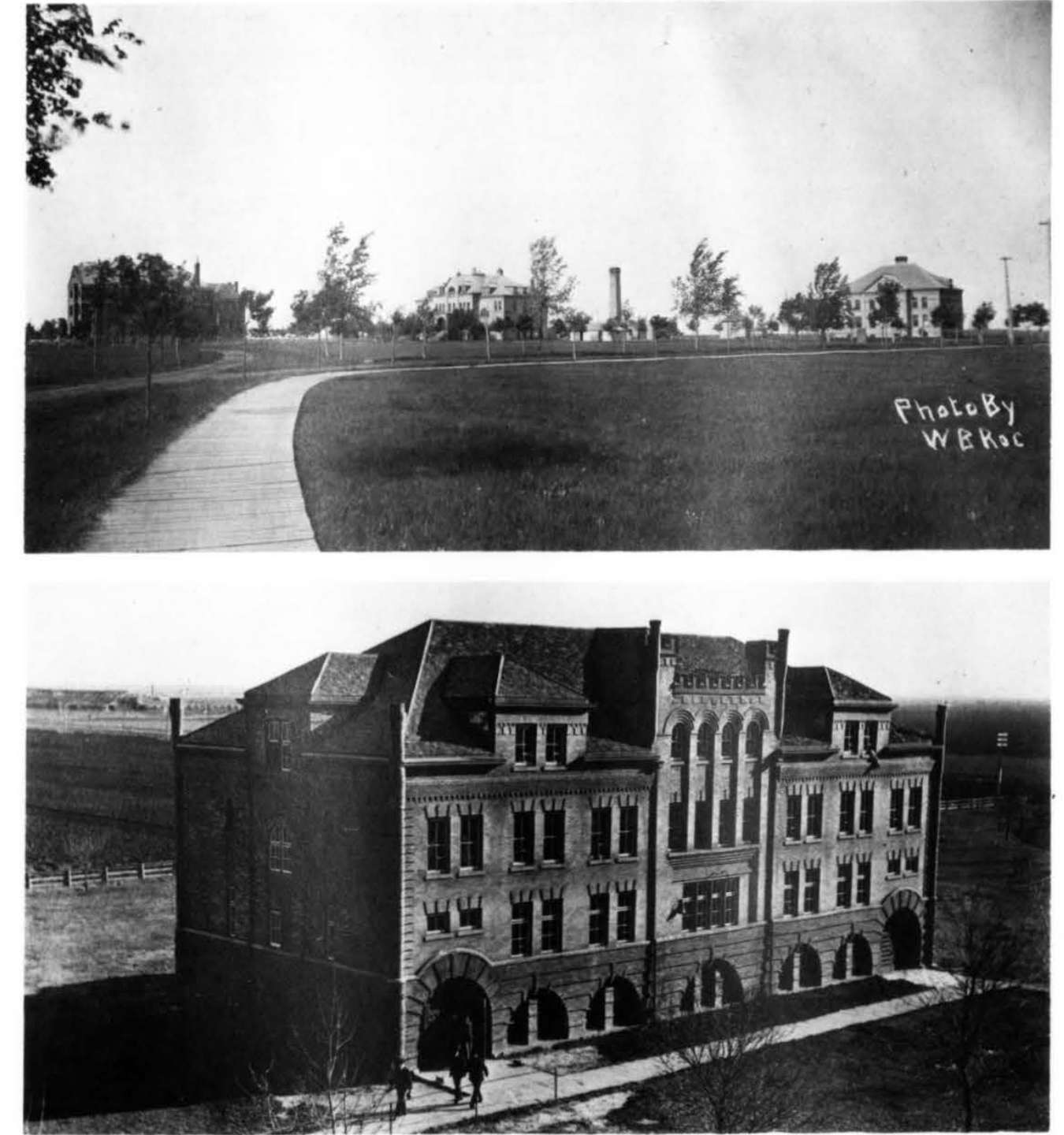

The campus in 1900.

looking toward the

southwest; only the

building know'n as

Chandler Hall still ex-

ists. Its impressive

smohestach was

remored in 1981.

Budge Ifall in it:

prime; it was 


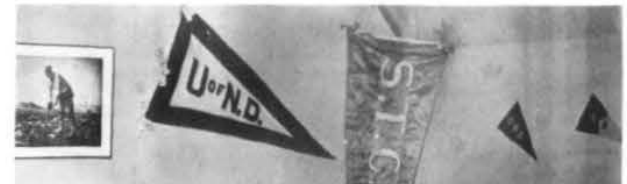

Davis Hall dining room, 1904.

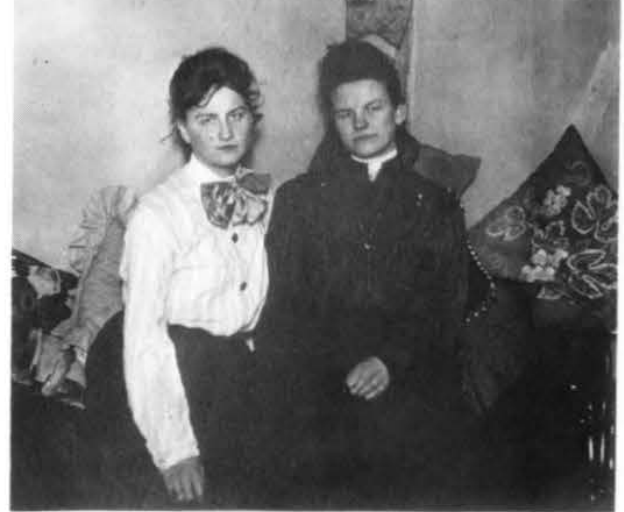

Hitting the books, around the turn of the century at Budge
Hall.
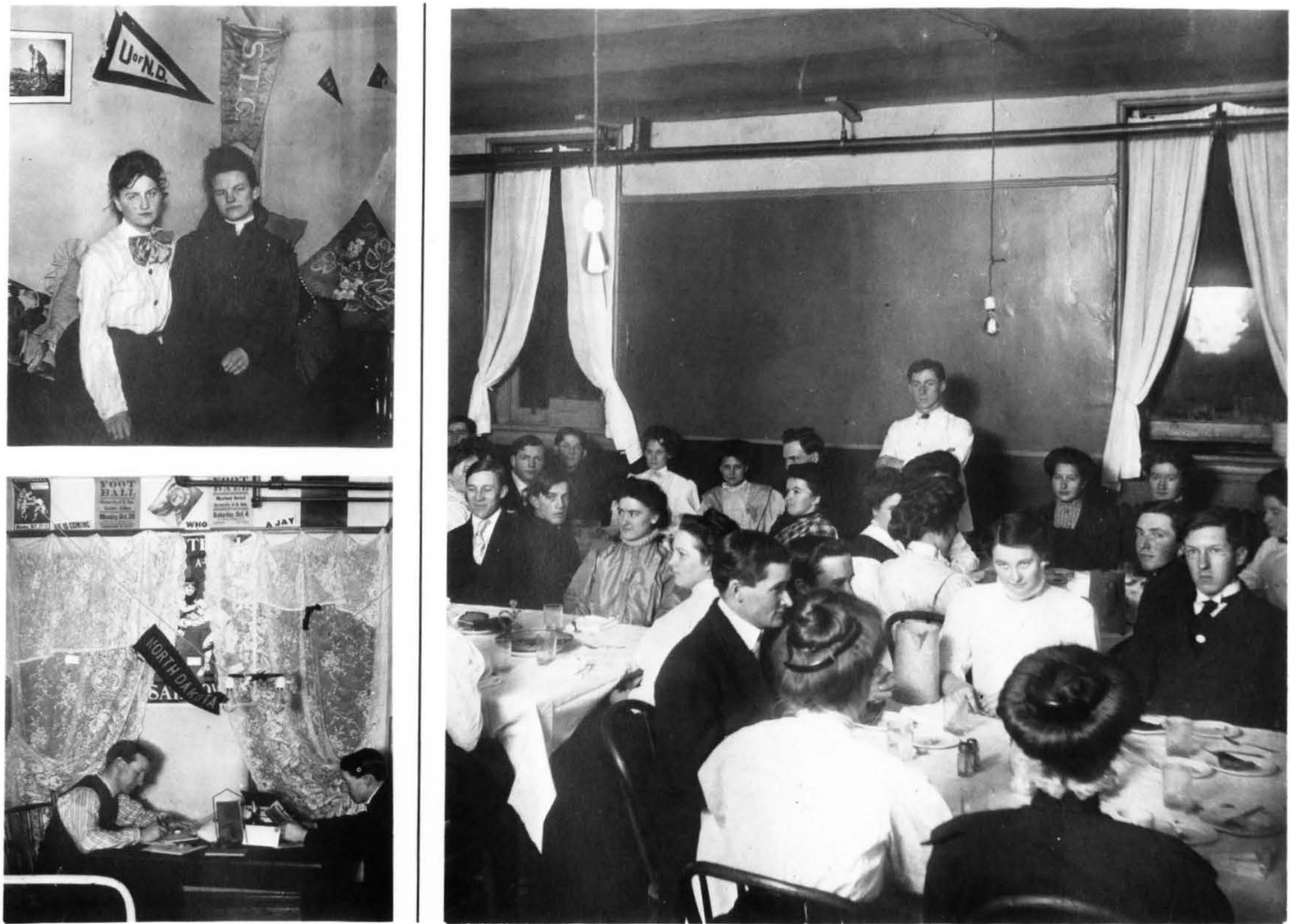


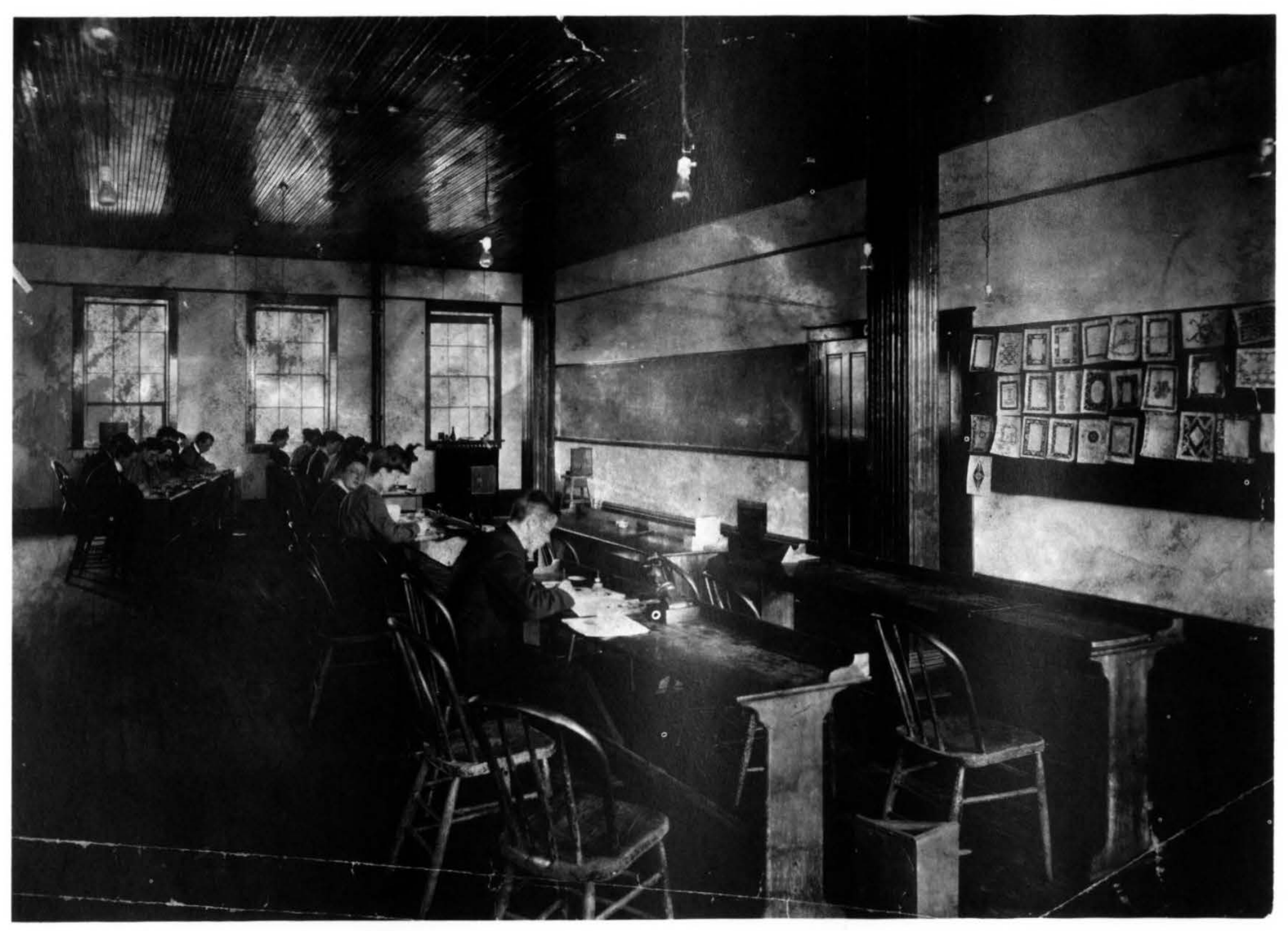

Drawing class in Science Hall, 1903. 
president's residence.

today the J. Lloyd

Stone Alumni Center.

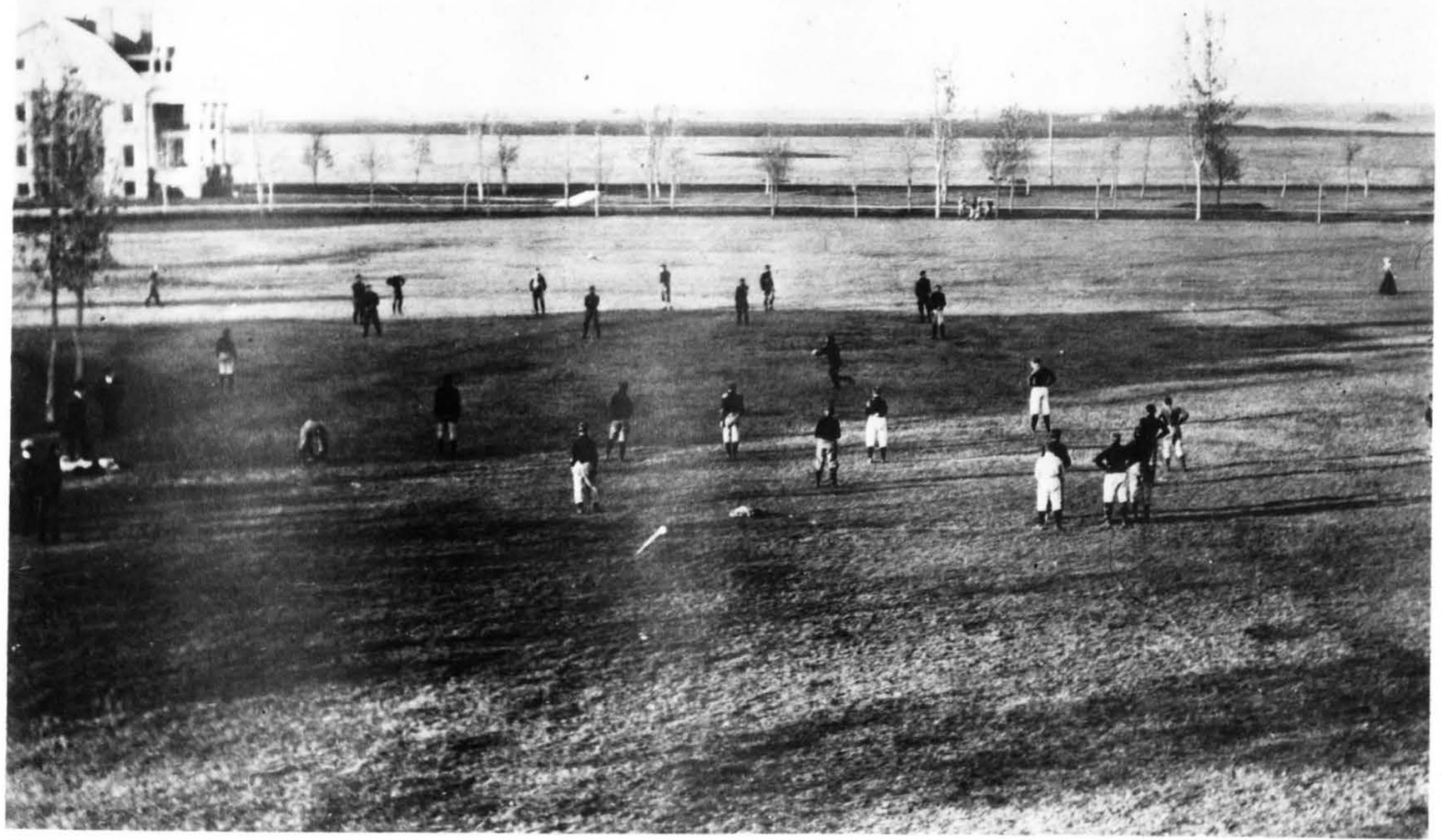




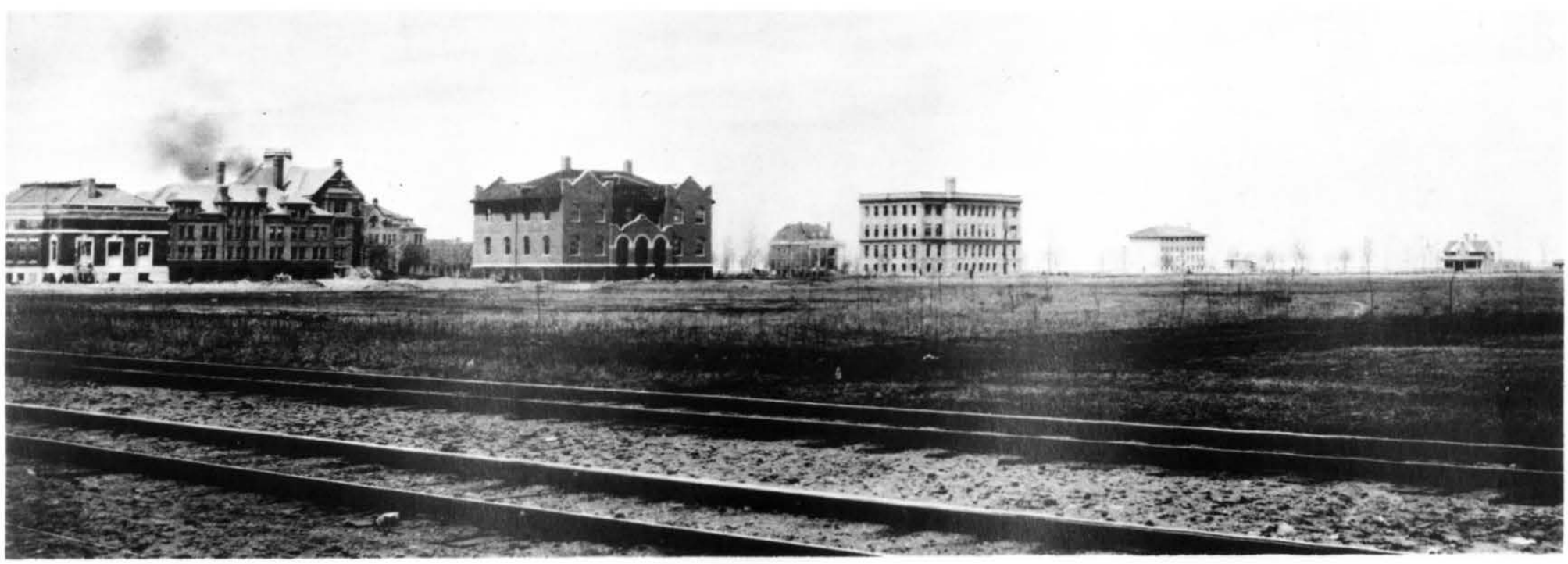

The campus, looking toward the northwest, circa 1910.

4 student artist's

vision of the campus

skyline, published in

the Dacotah annual.

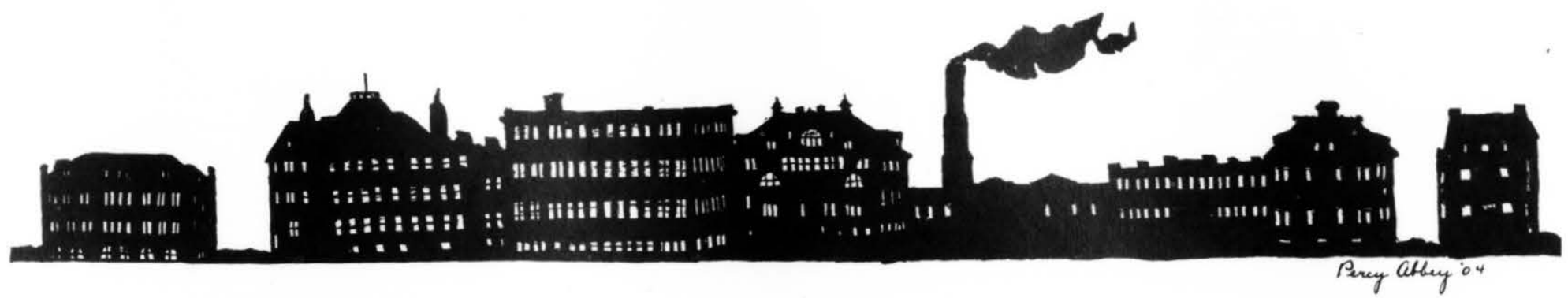


The main circulation desk of the Carnegie Library, opened in 1908; later the building served as the University commons. Today it houses classrooms and ofclassrooms and of fices of the Department of $\mathrm{H}$ om

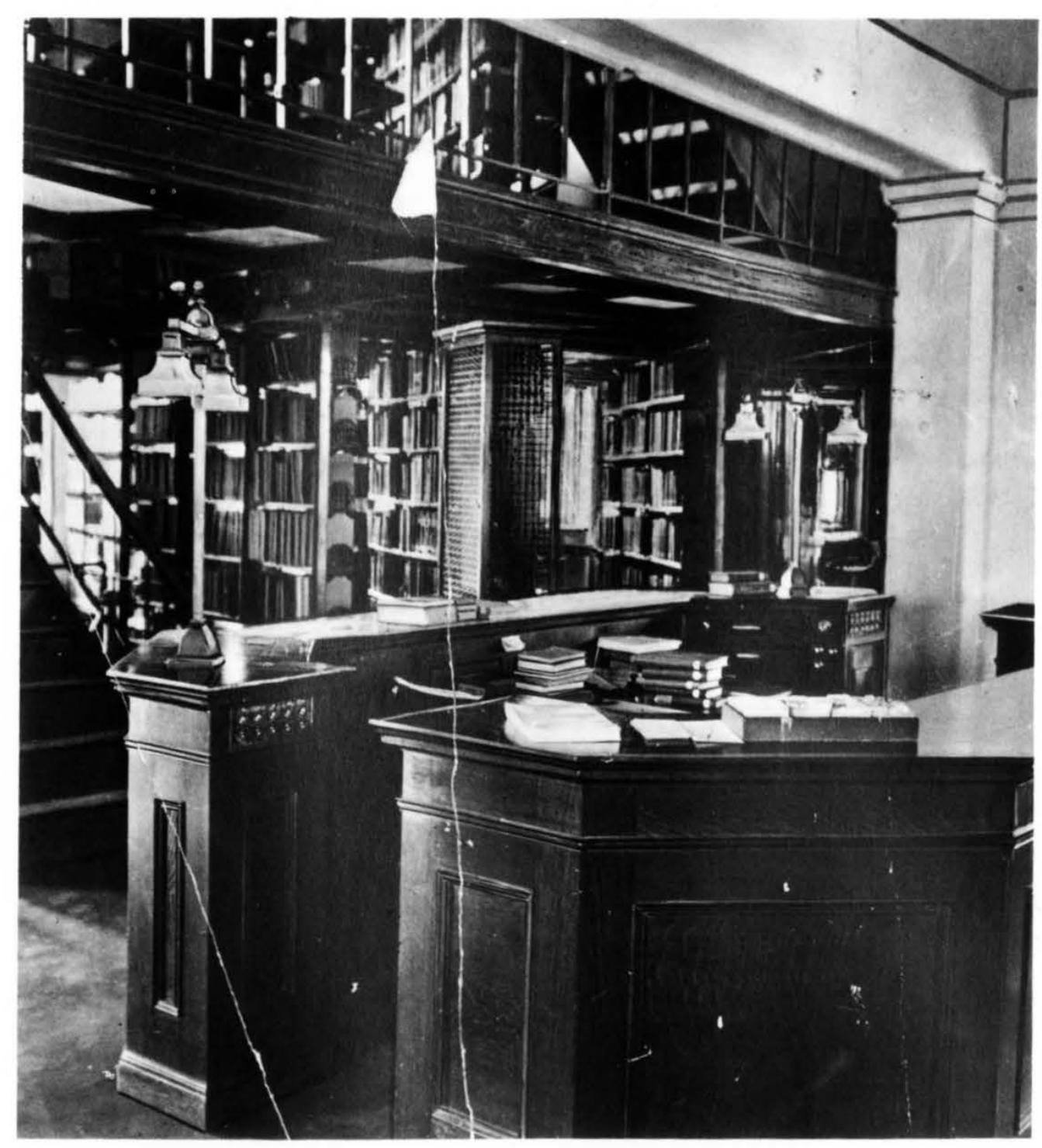

"For the first time in my life I found myself among people who thought the life of the mind was more important than banking, and who respected any attempt to conquer an art form. Professor Gottfried Hult, who taught me Greek, also wrote poetry and sometimes sold it. Professor Vernon Squires, who was Dean of the English Department, made me proud that I was able to quote and tried to write in verse. I found there was a place in society even for an odd duck like me! This is perhaps the most important cultural influence a university can have. In a world given over so largely to getting, using and keeping property, it maintains a retreat for those who are more interested in the creation of beauty or the discovery of truth than in making a profit,

_ "Love Letter to a University," by Maxwell Anderson 


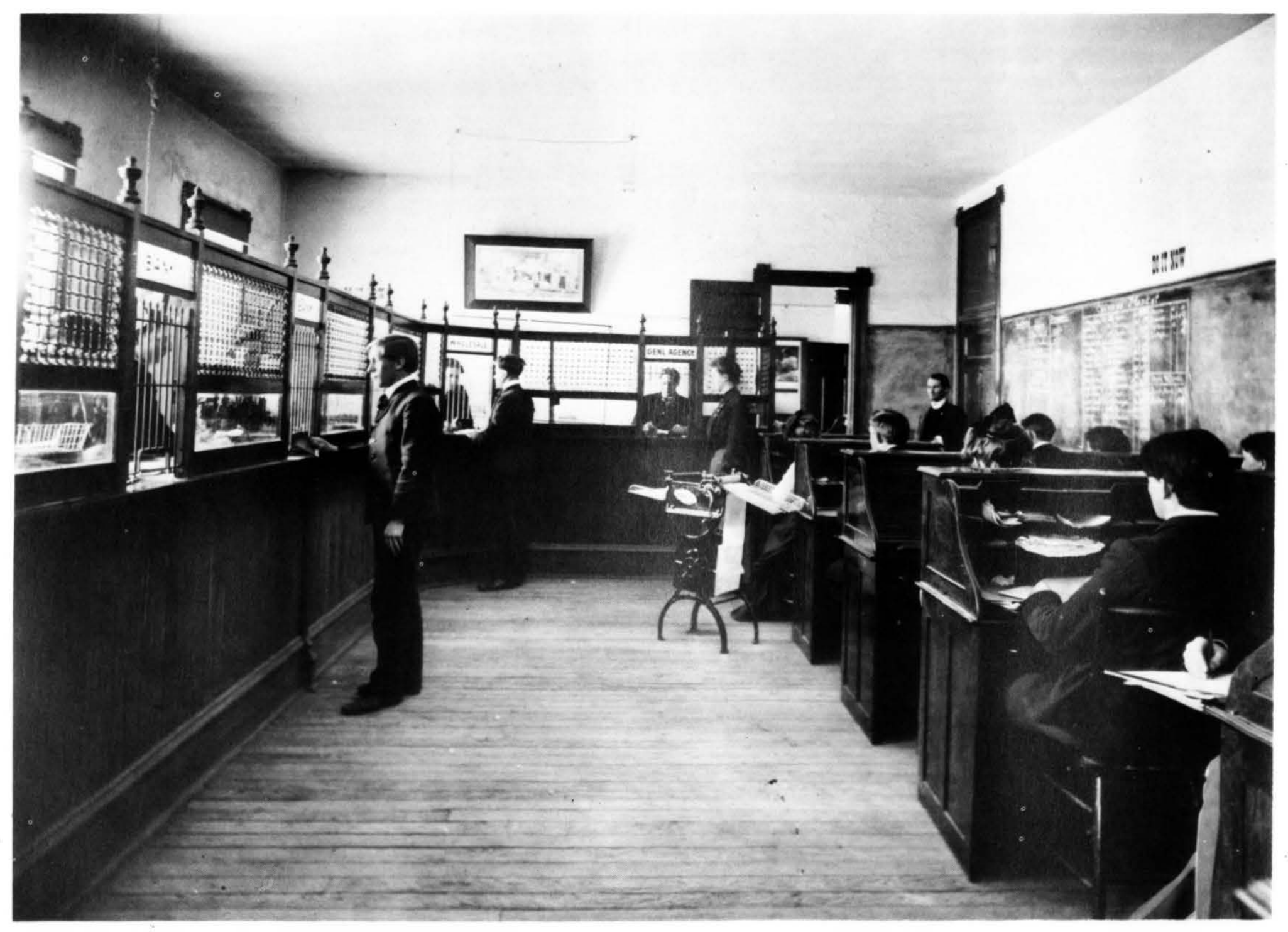

4 pre-W orld War I

"model office," used

in the training of the

I niversity's first

husiness students. 


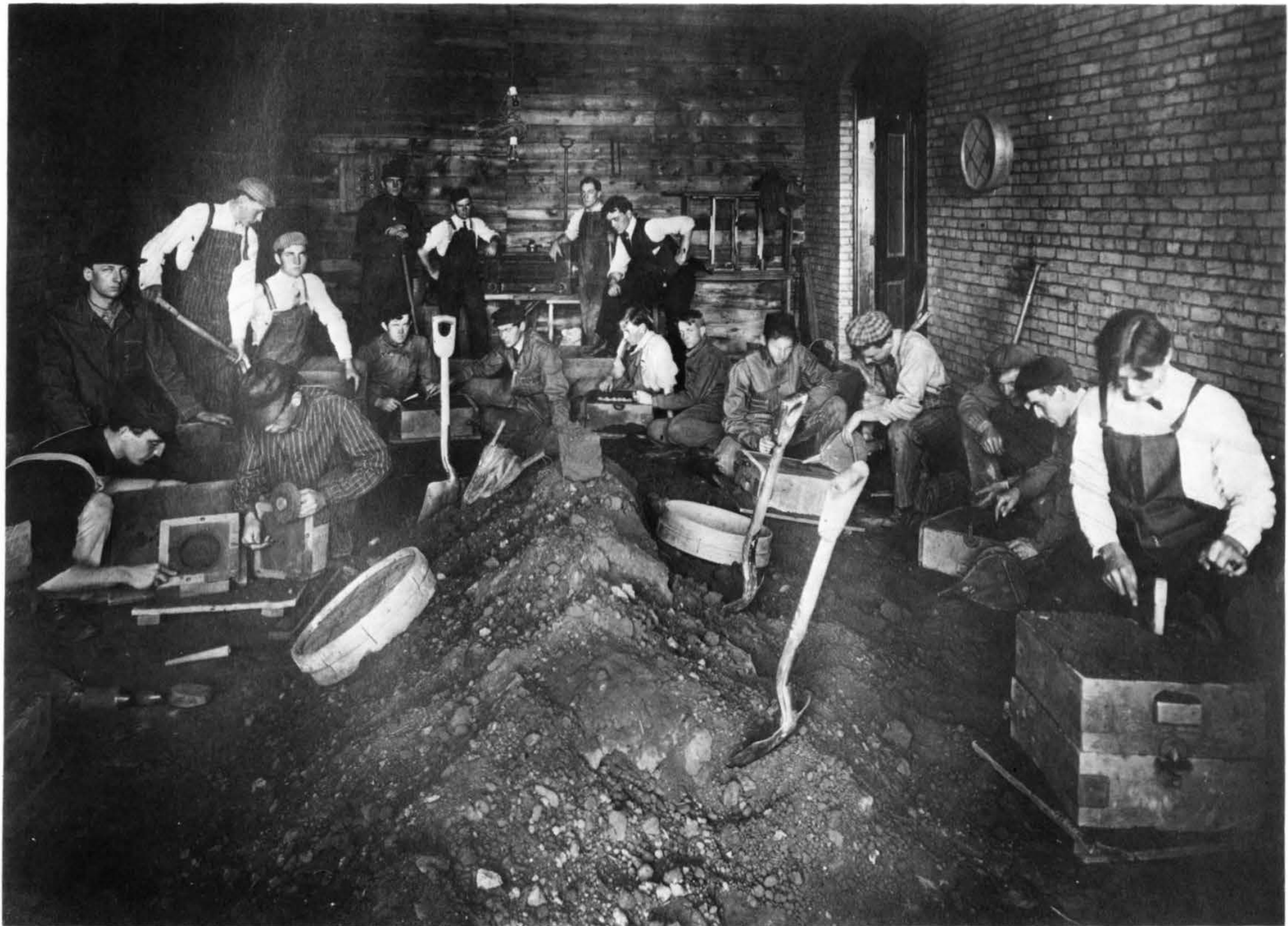



A 1916 prediction of

the University's

future campus;

although the plan was

has been vindicated.

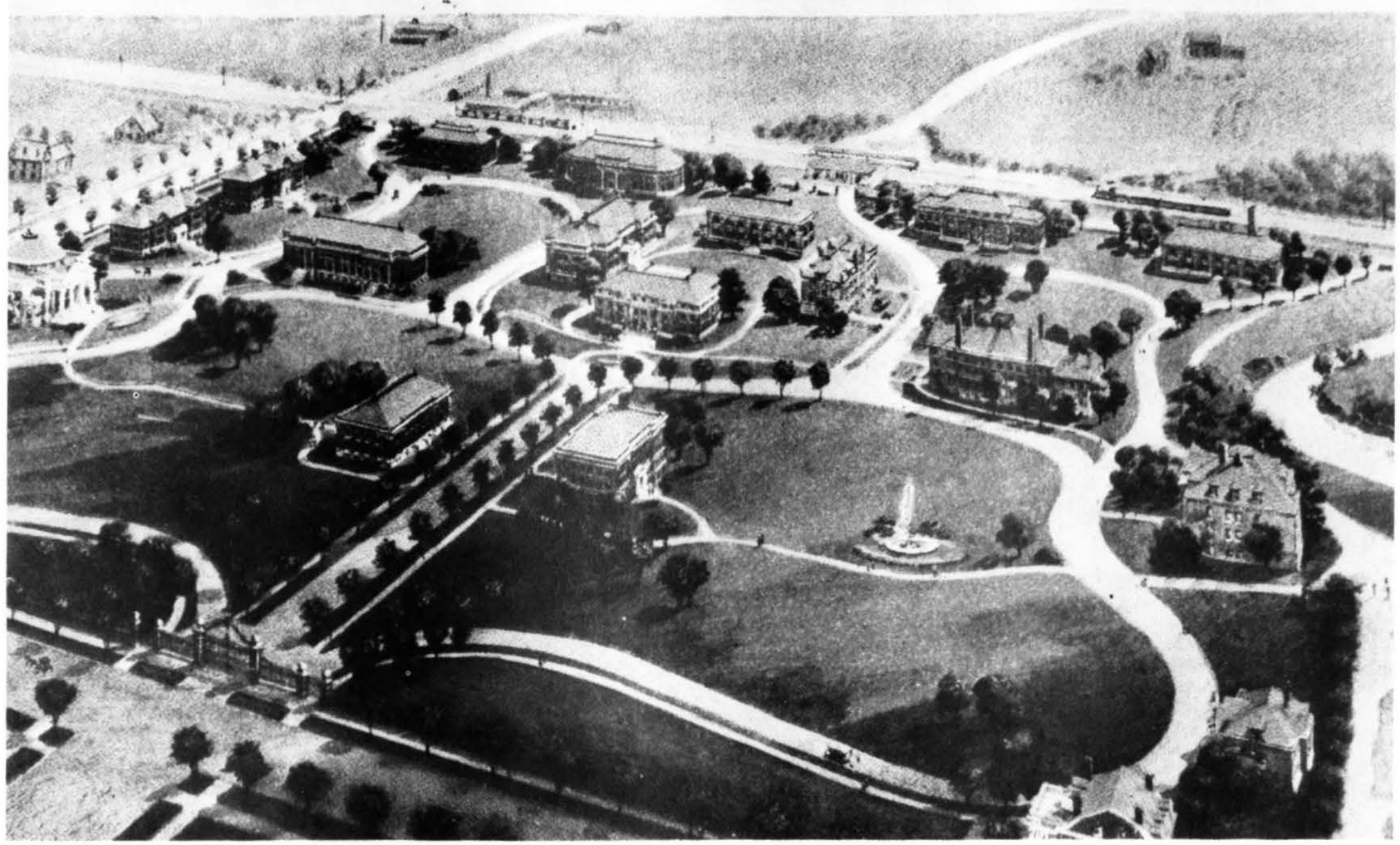




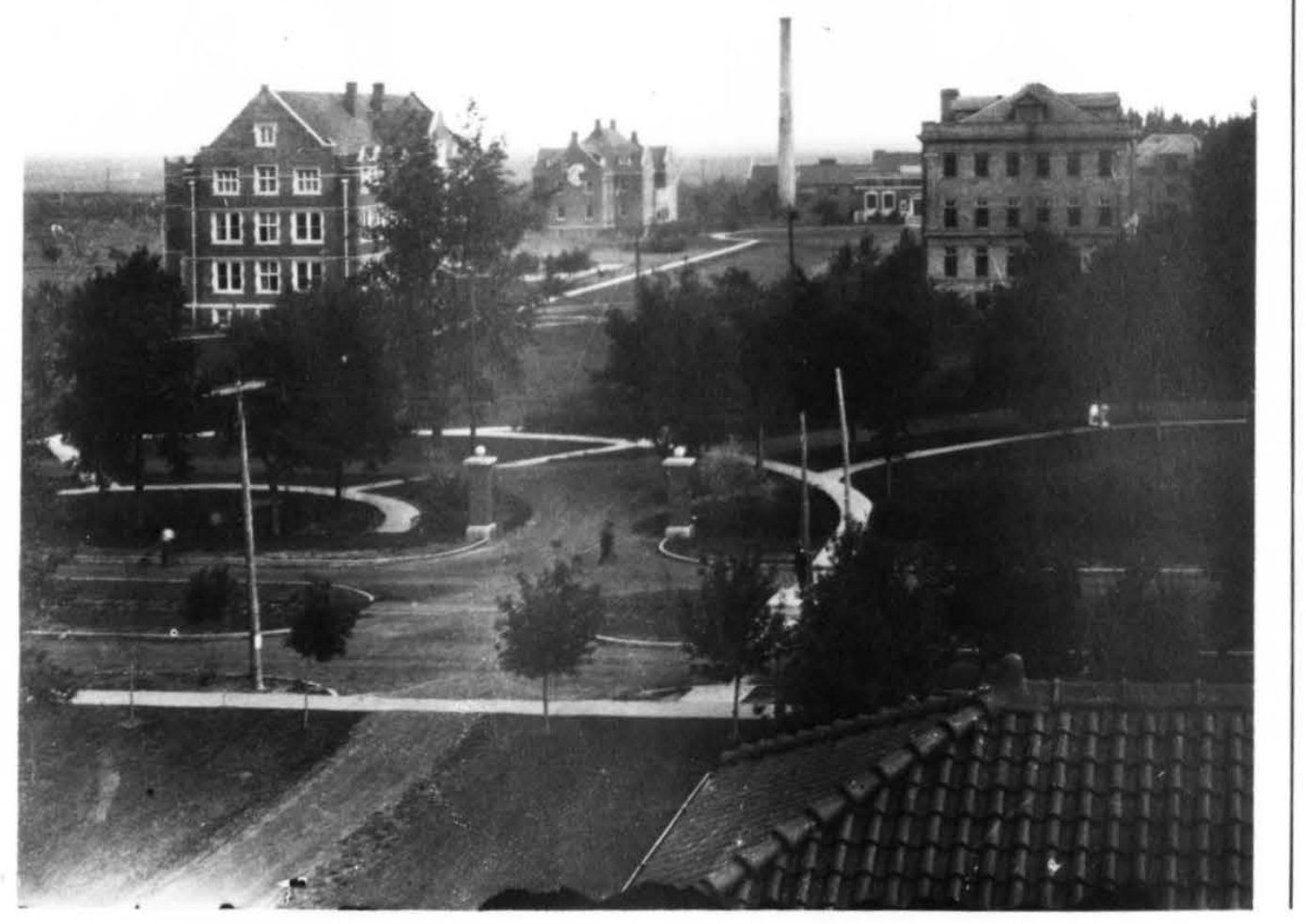

"I shall never forget how bright and cheery the lights gleamed through the windows as we drove up to the buildings; nor how long the halls seemed when we entered; nor how strange and lost I felt when shown into the large parlor to wait for the preceptress. . . I I had often read stories of college life, but this seemed

different in many ways from what I had expected. There was not that coldness and reserve on the part of the students, the rigid rules, the terror of the instructors. It was not a cold, bare place but warm, homelike, full of great possibilities."

-from an early student's essay, "My First Impressions of the University" 
Trolley cars waiting for UND football

fans, probably in the

early 1920s; trolley

service to UND ended

The 1920s: Politics progress mix.
Under the direction

of the gifted ceramic

artist Margaret Cable

(fourth from left).

who taught at UND

from 1911 to 1949, a

style of pottery

which at UND

Dhich atilized North

still prized by collec-

still prized by collec
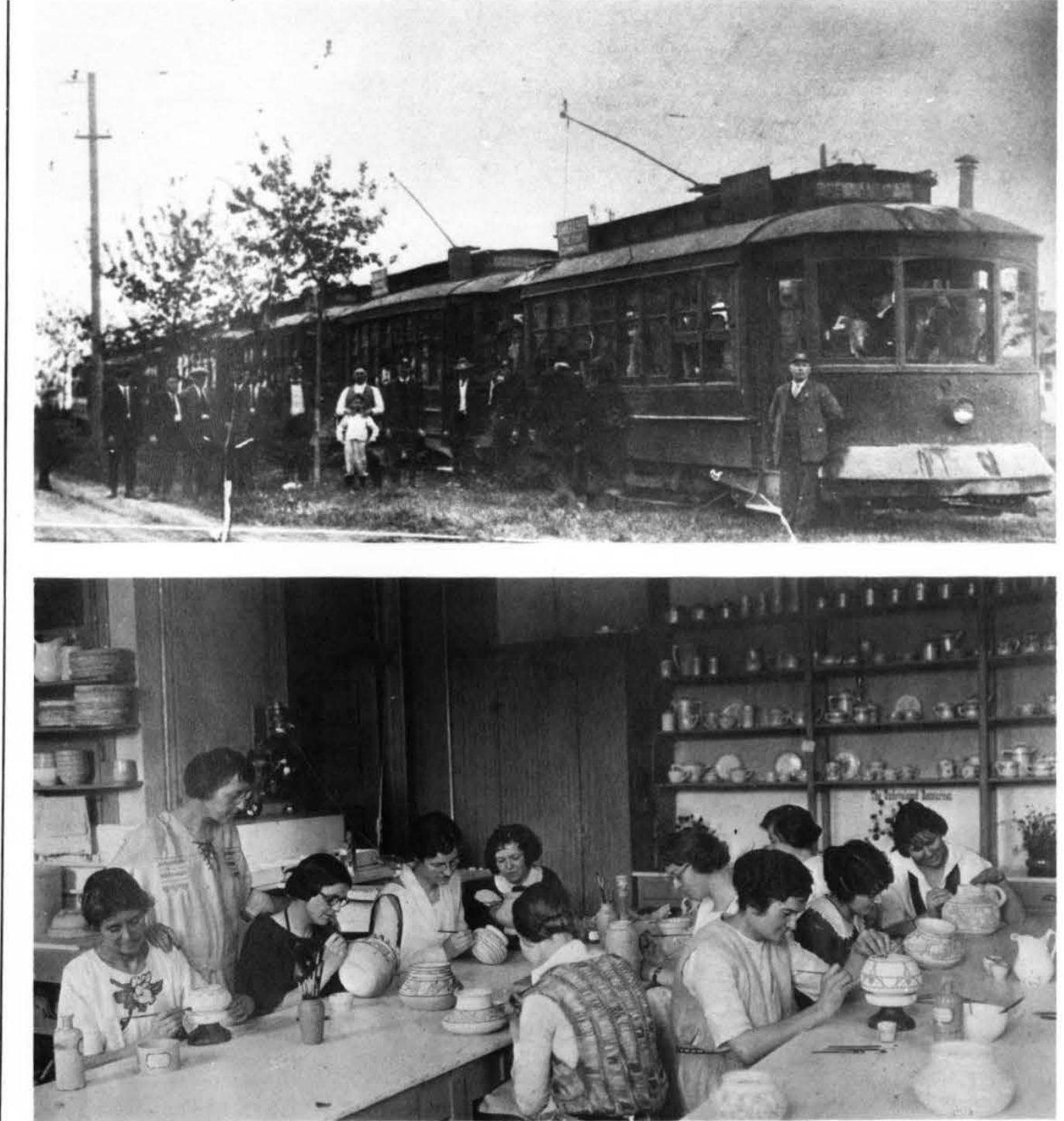


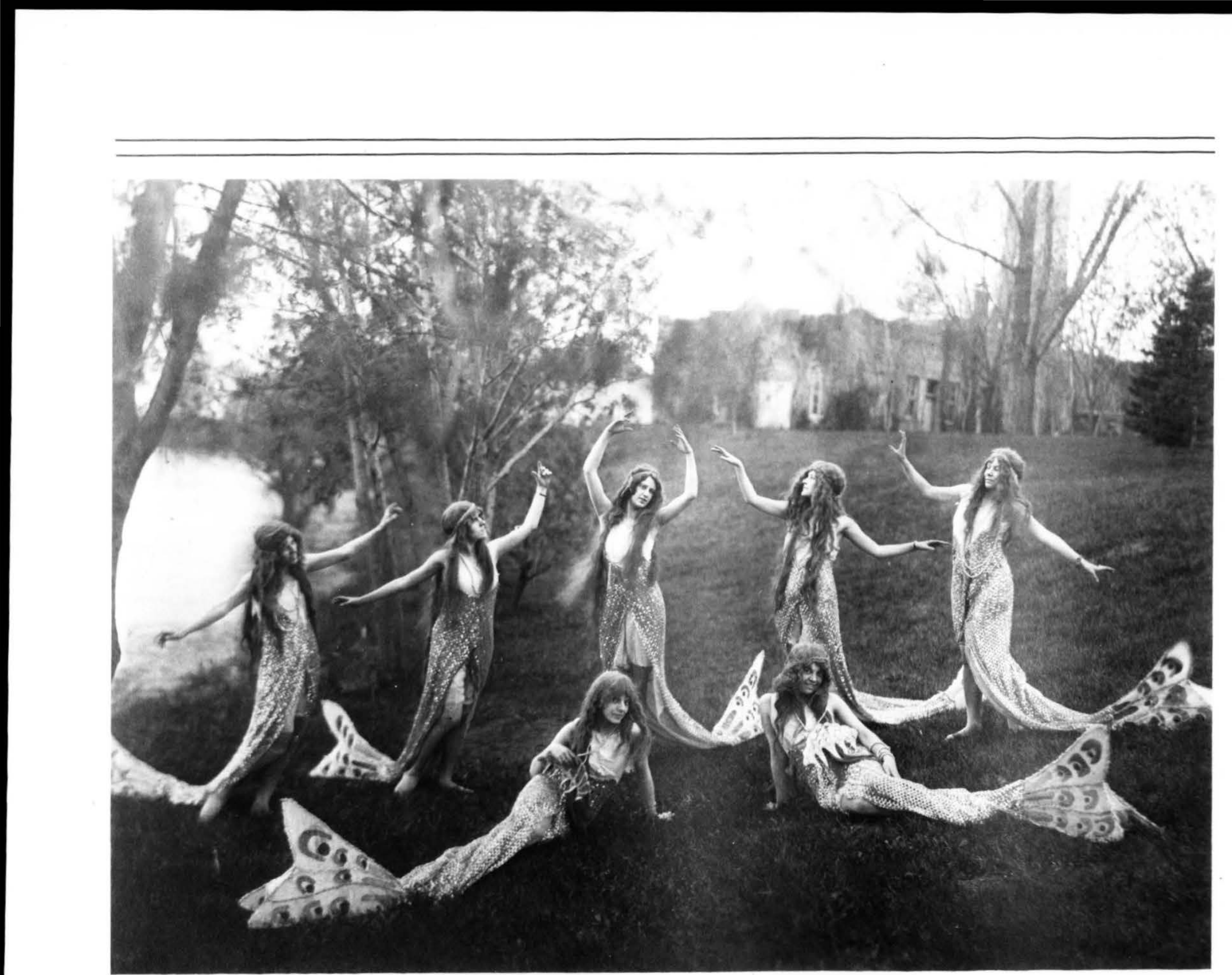


lirecting the first campus lamp post. about 1926, which

were formed at UNI

shops.

President Thomas Kane, perhaps the president in the University's first century, speaks at an outdoors ceremon on the ele of the Greut Depression.

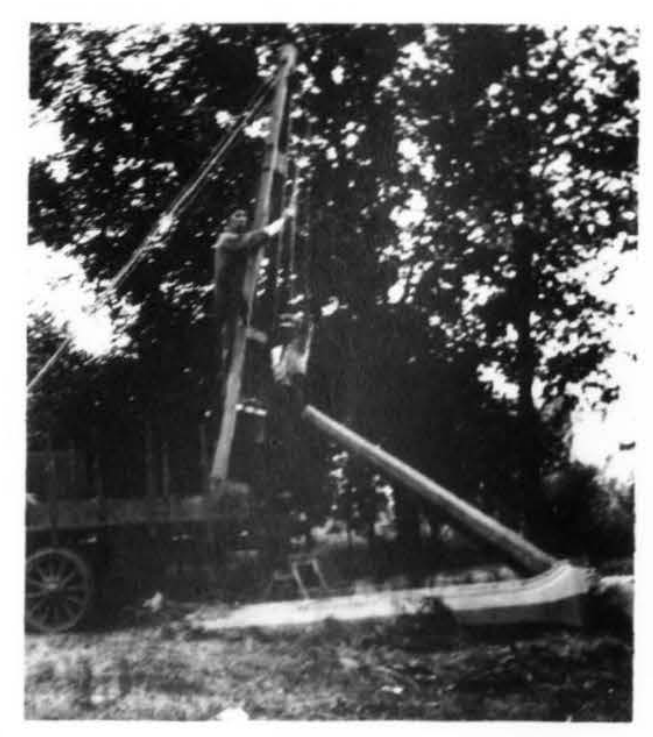

The campus mall in the late 1920s, look ing northeast; the wood frume ...urs wood frame "arts in 1929 upon the in 7929 upon the Merrifield Hall.
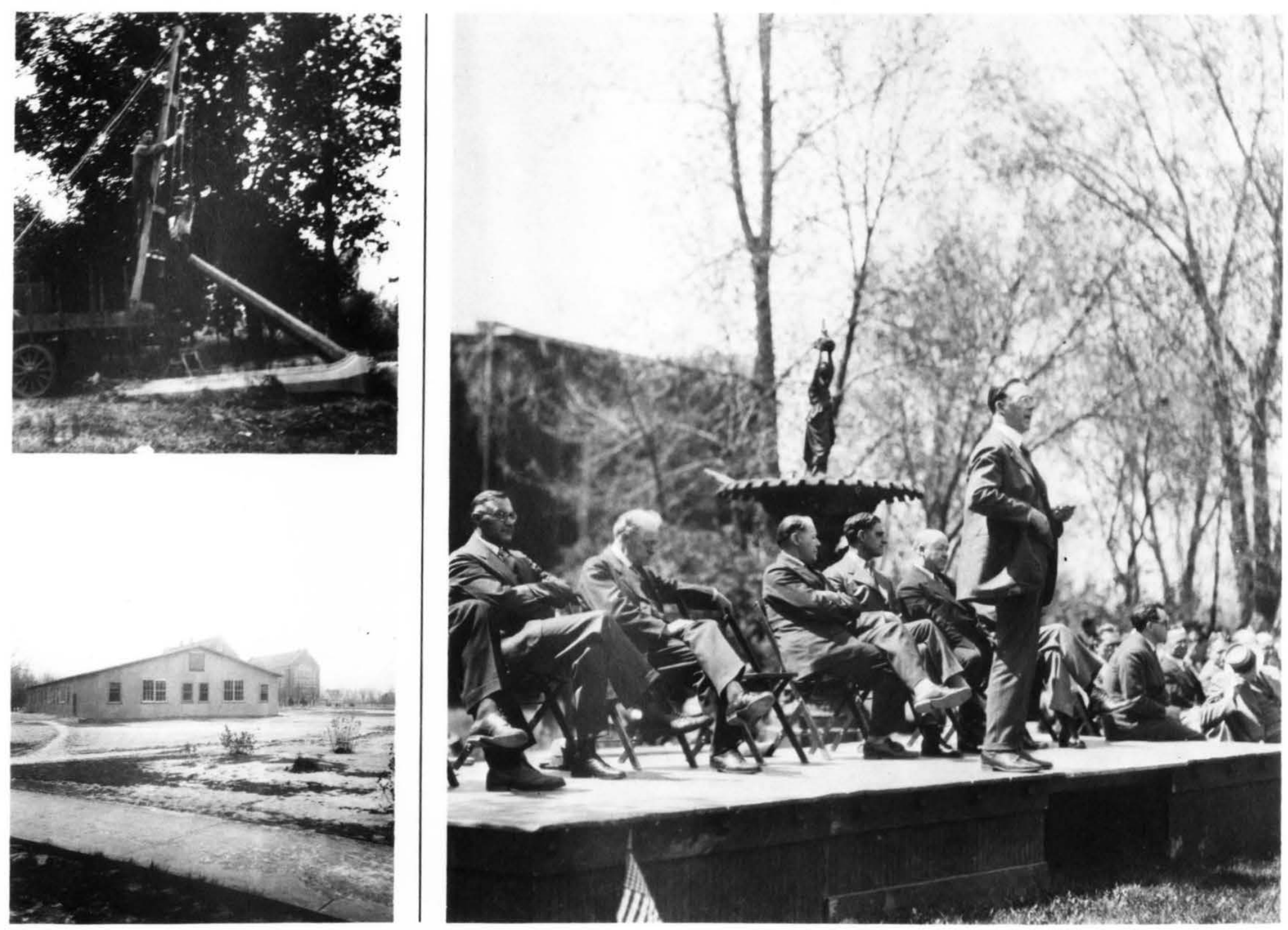

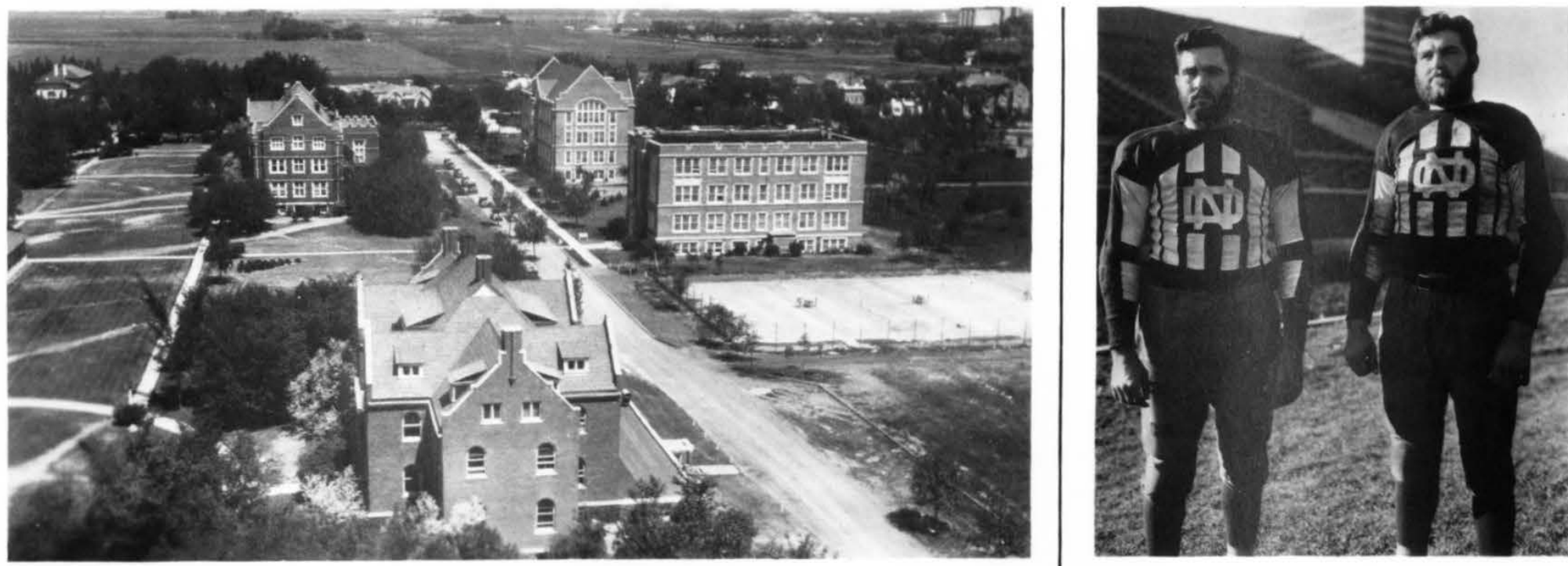

Air view of the

campus, 1929,

looking north;

Babcock Hall is in

the foreground.

The "Smith

Brothers," Vernon

and Austin, whose

late 1920 s football

prowess (and magnifi-

cent whiskers) gained

UND national atten-

tion.

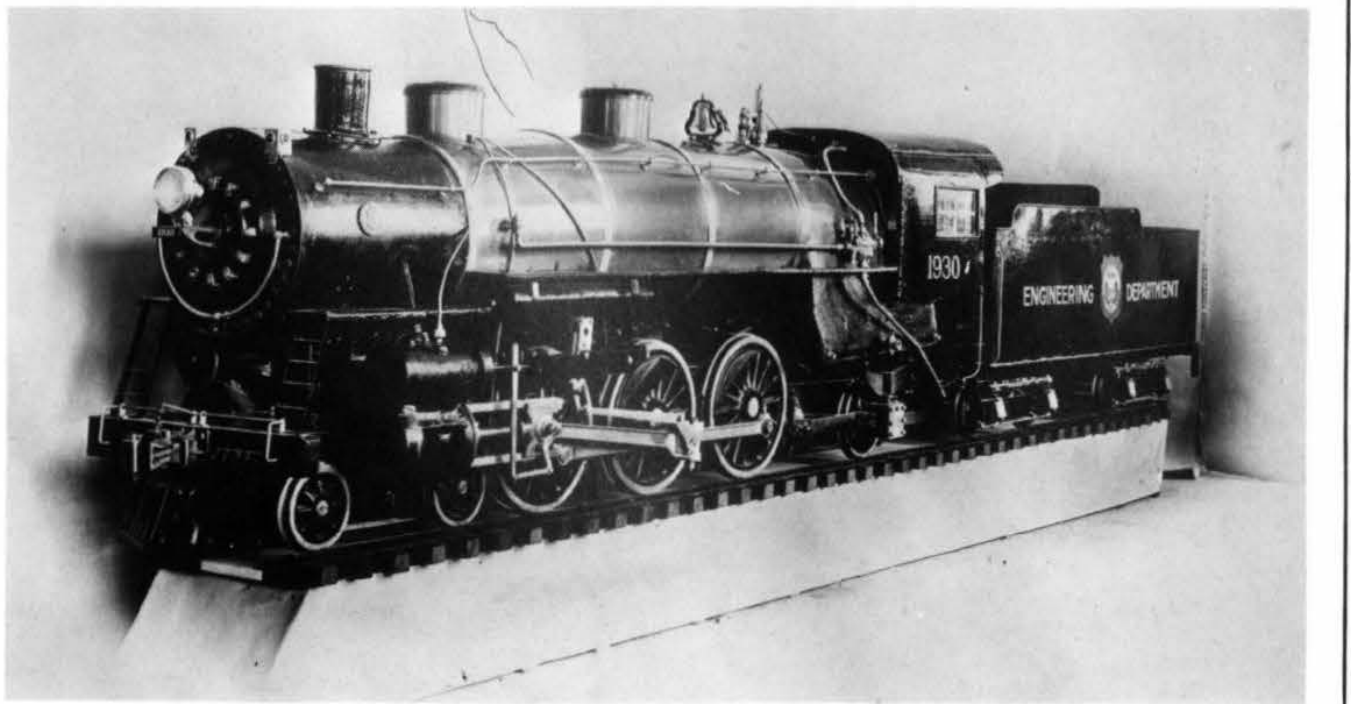

This operating steam locomotive - $381 / 2$ inches tall and more than 16 feet long has 16 feet longwas builh by UND engineering studen in the late listos. Capable at one time of traveling 15 m.p.h. on its own tracks, it remains on display at the School of Engineering and 
The 1930s: The Depression makes its mark.
Registration is always

a hectic time; thi.

crowd filled the

business office in Old

Main, 1935.
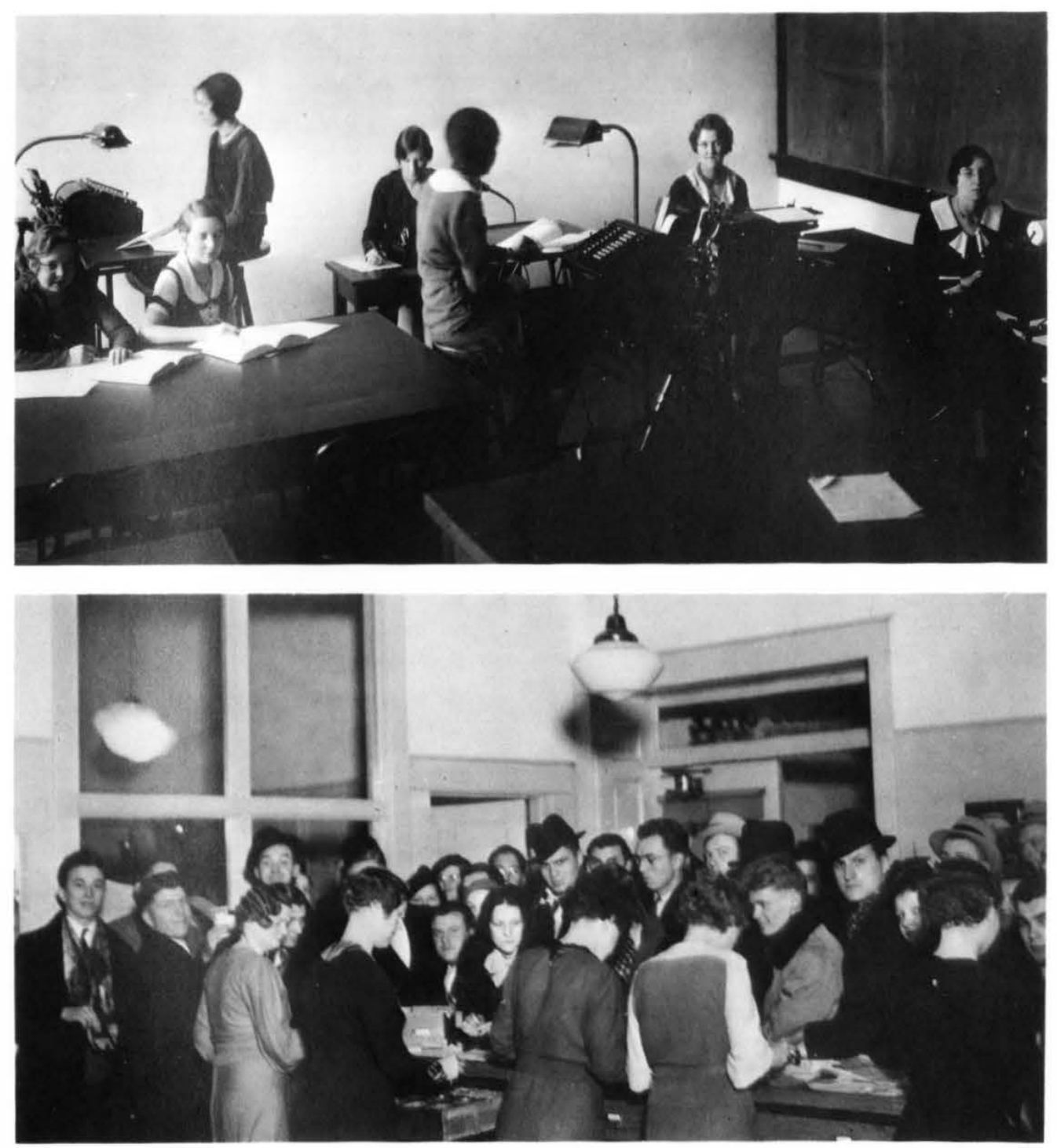

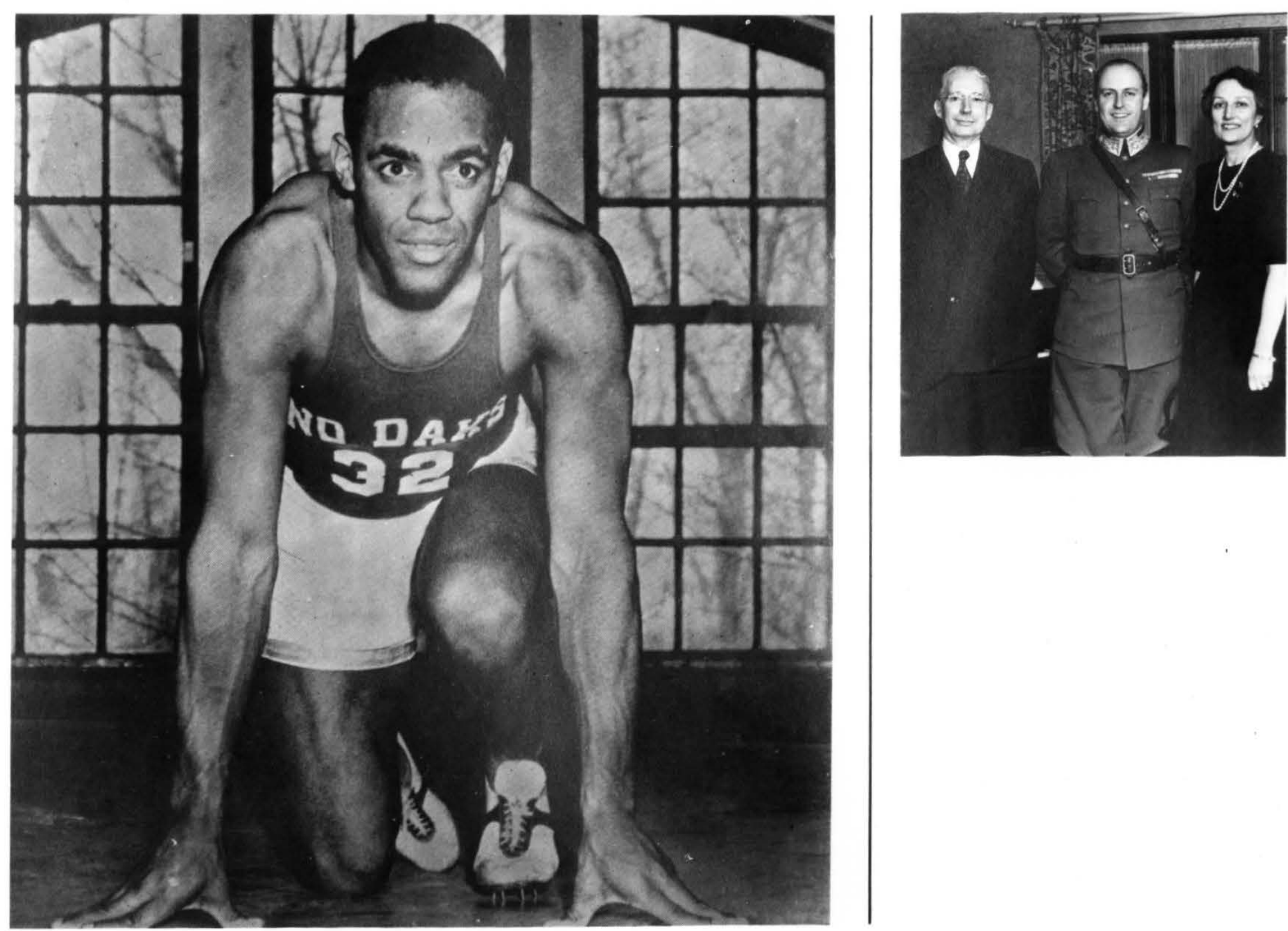

lard wo an Olympic track

medal in 1936, but

was known primarily

as a star football

player at UND.

Norway's then Crown

Prince Olav, center,

with President John

West in 1937; the

future king delivered

the commencemen

address and was

awarded an honorary

degree. 
Gov, Fred Aandahl, a UND alumnus,
crowns the 1948 Homecoming queen.

The post-war era: UND enrollment booms.
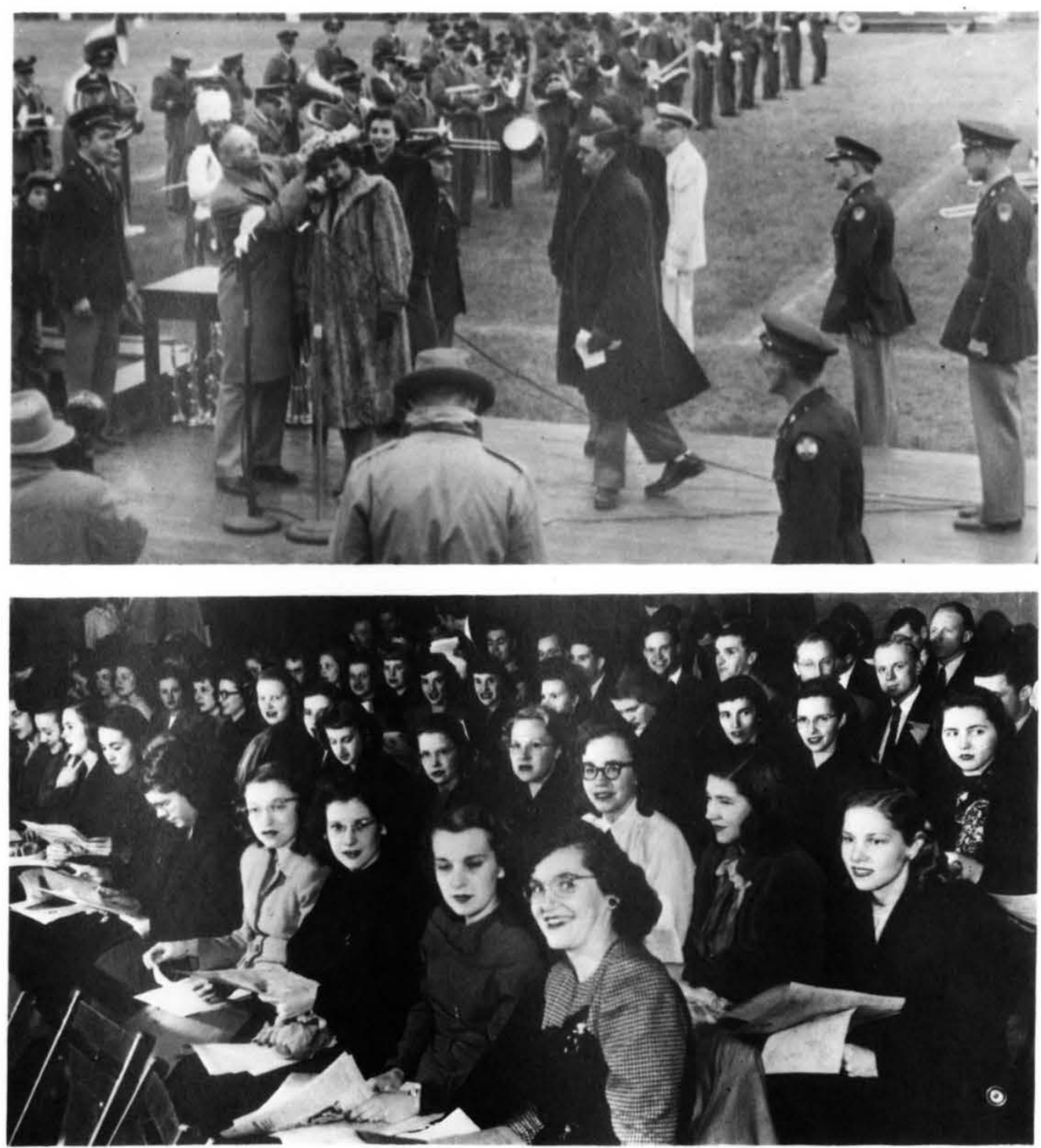


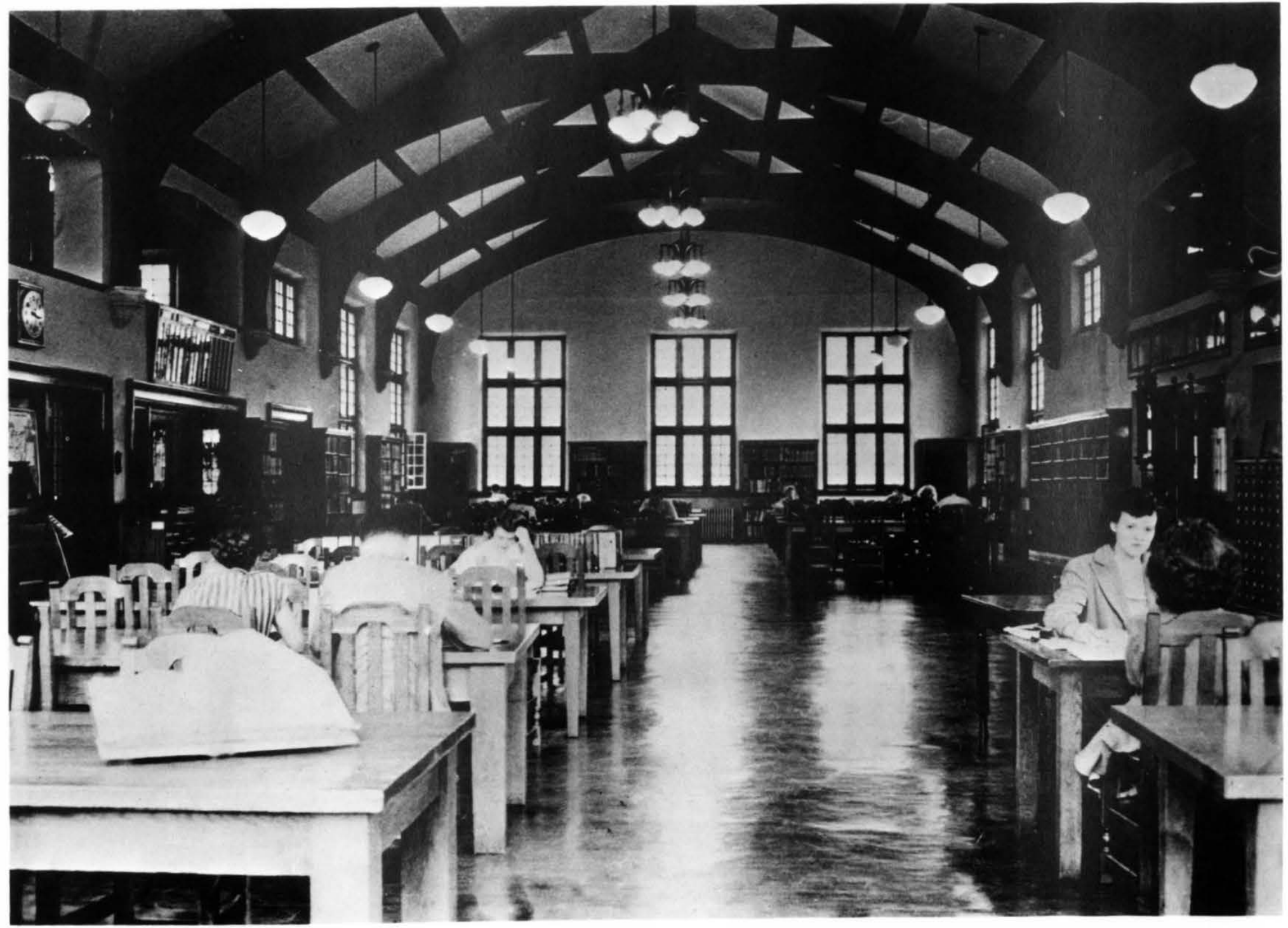

The University's library was transferred from the

Carnegie Building to the former Commons remain there until the opening of the Chester Fritz Library in 1961 ; this picture was taken in the was taken 
The 1950s: The University catches up.

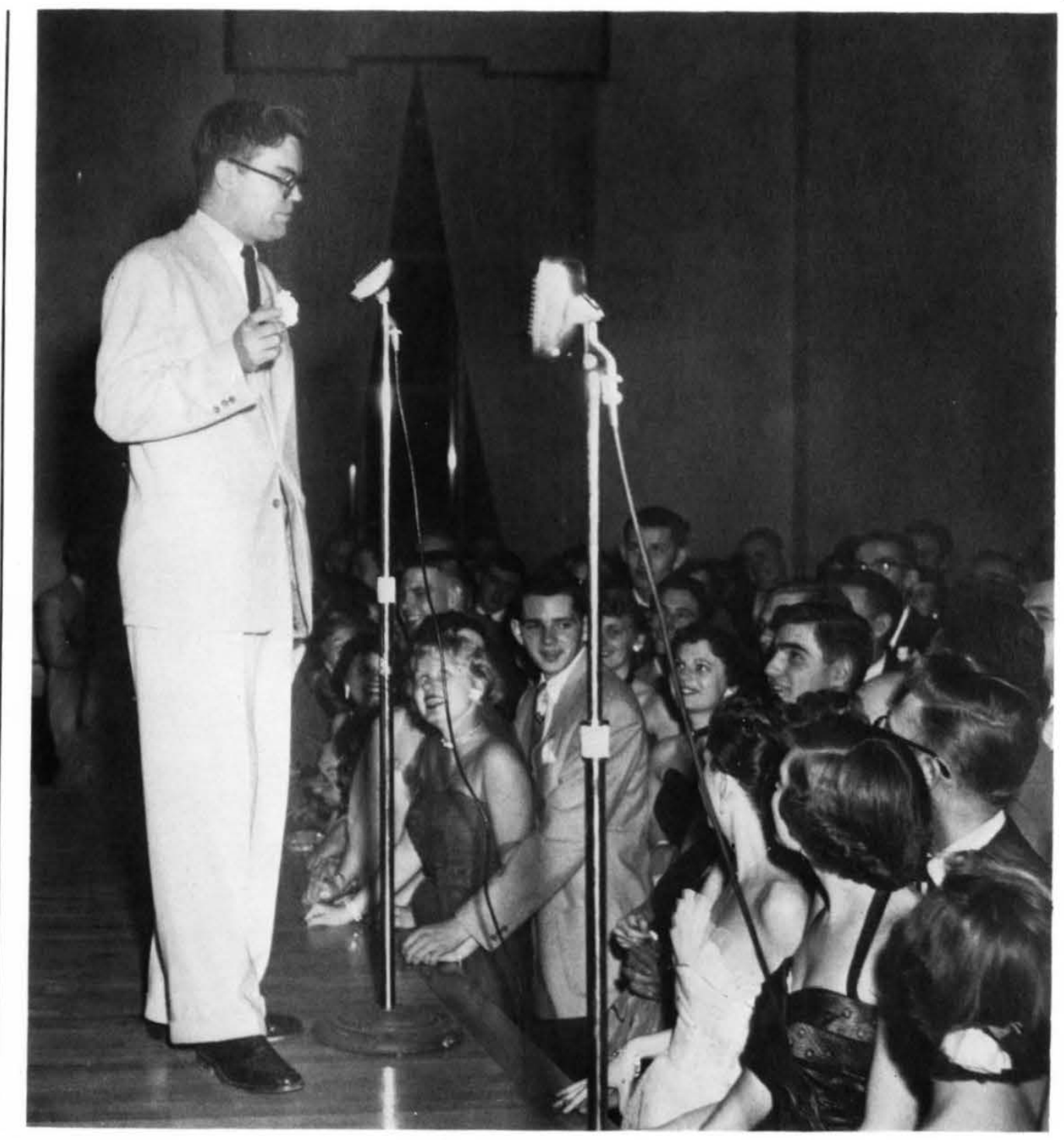



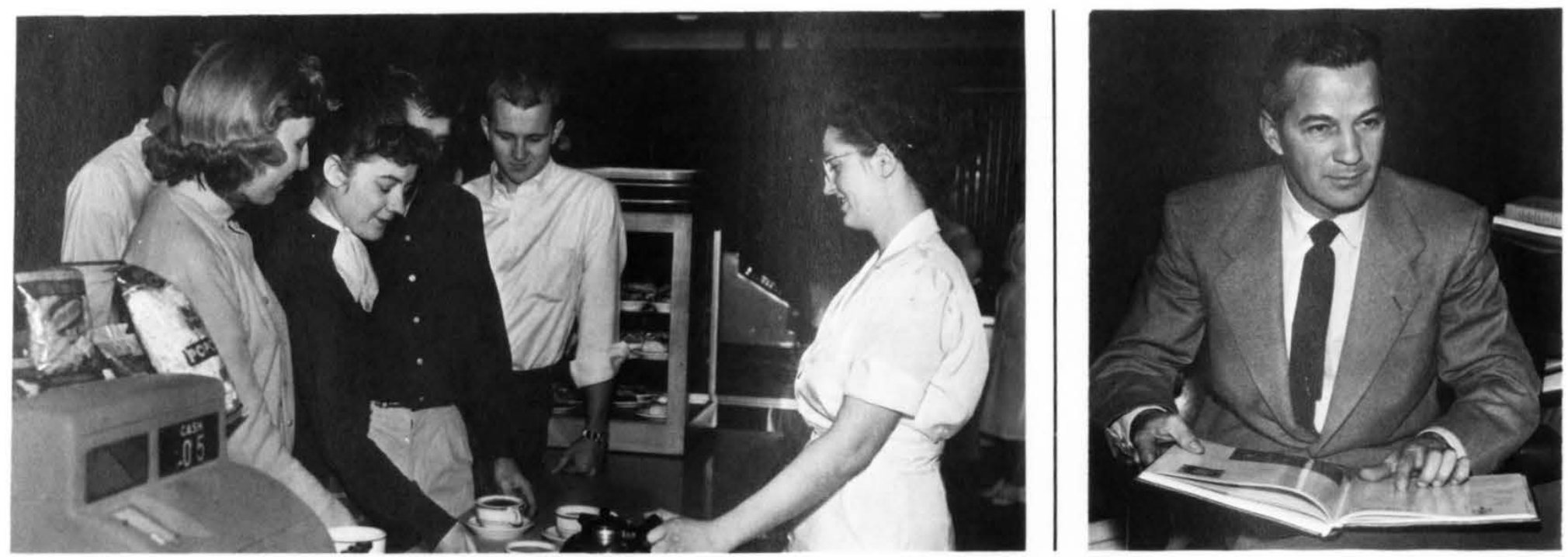

Coffee break at the nickle-a-cup coffee nickle-a-cup coffee
prevailed until 1968.

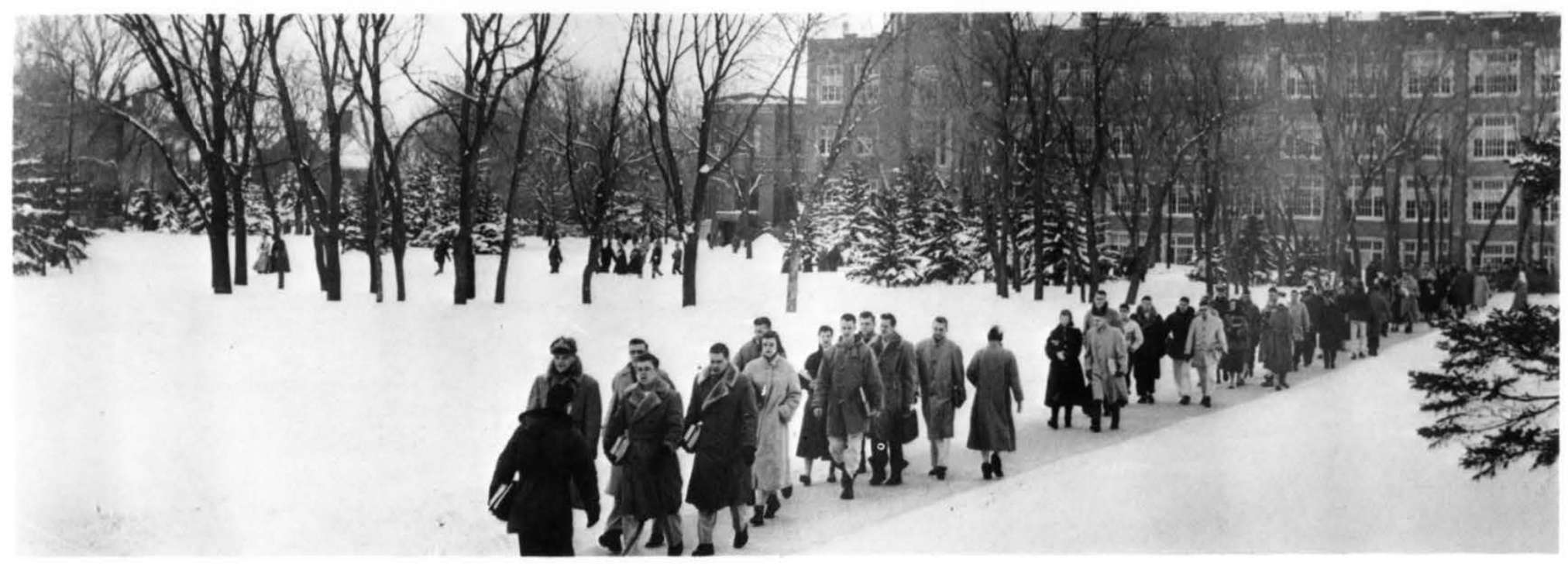

Winter scene on the mall, late 1950s.

D.J. "Jack" Rober son, close adviser

presidents and for

many years dean of

the University, 
President George $\boldsymbol{W}$.

Starcher. third from

left, front row, joins

left, Jront row, joins

Commerce of

Colegation

in 1957 in callin

attention to new

billboards erected

the approaches

Grand Forks.

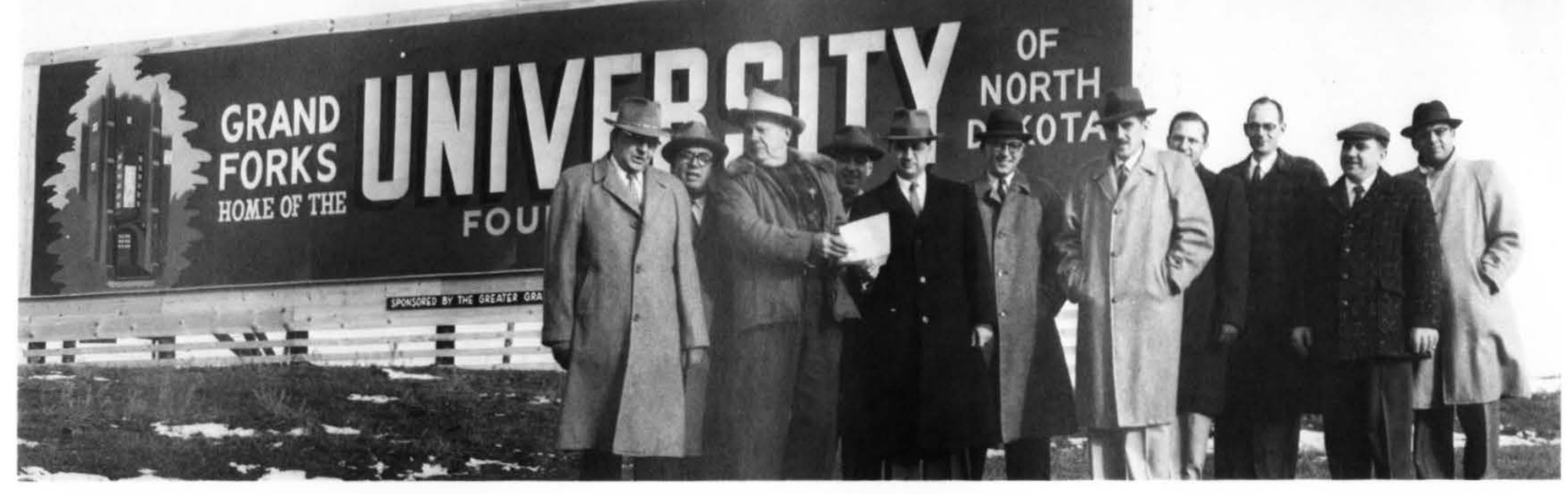

UND football star and alumnus Steve

Myhra, left,

celebrates with

Baltimore Colts

quarterback Johnny

Unitas, middle, and

fullback Alan

Ameche on Dec. 28

1958, after Myhra's

last-second field goal

last-second field go

pionship game us. the

New York Giants

(Ameche's Gouchdown

Ameche's touchdo

won the game in

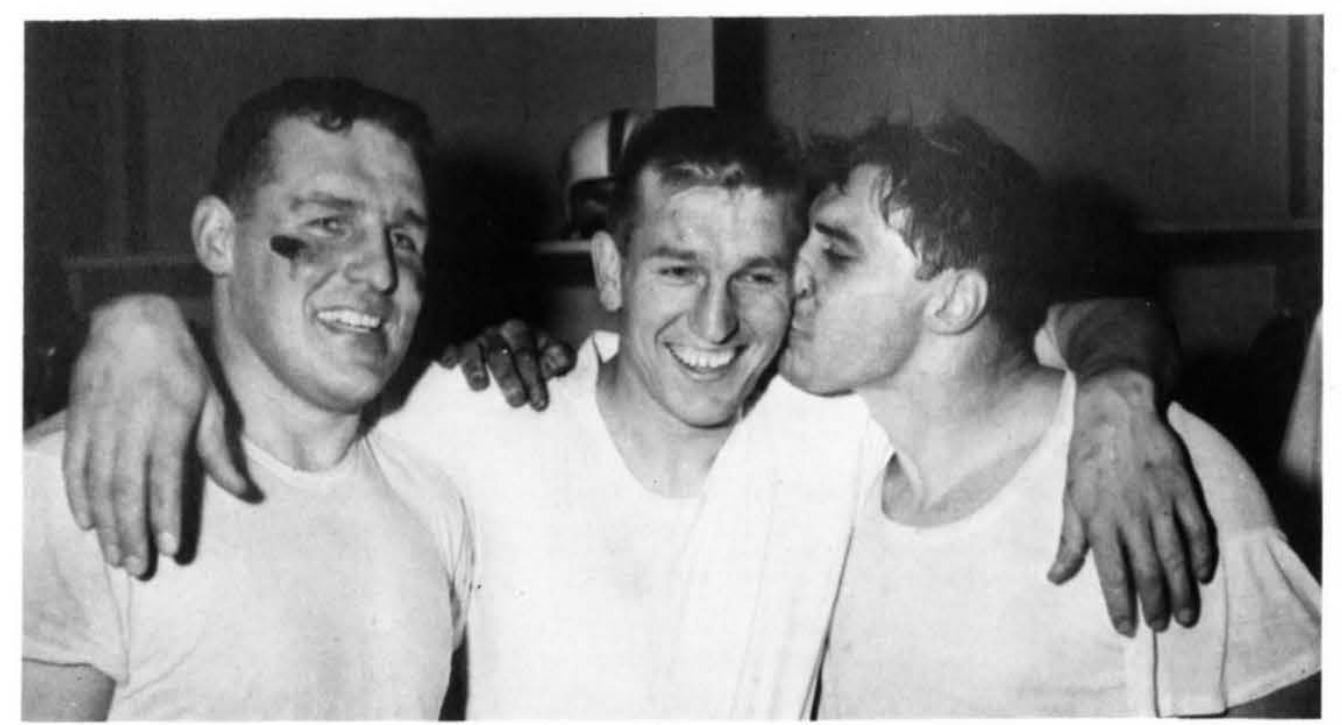


The 1960s: UND examines itself.

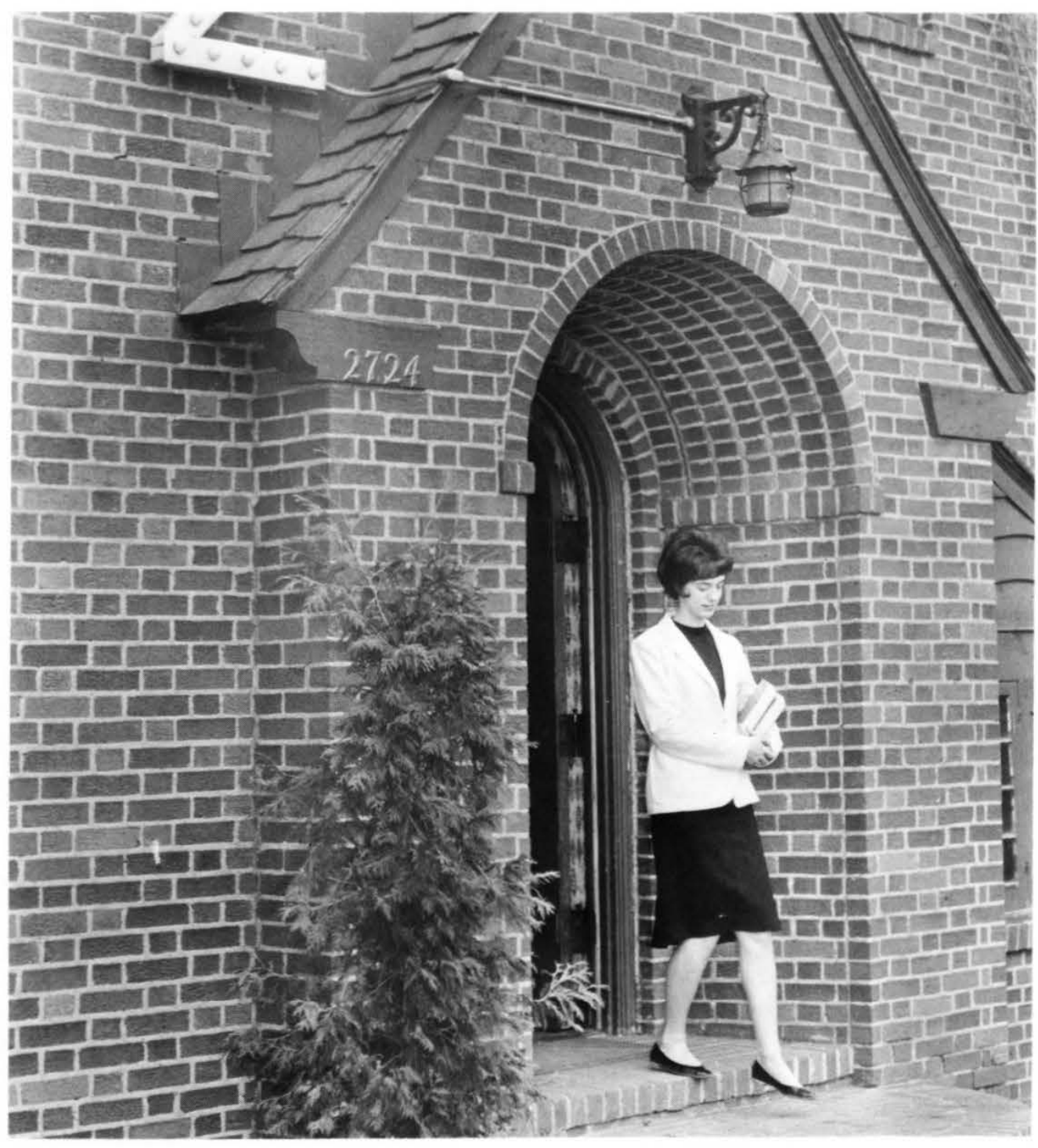

The early $1960 \mathrm{~s}$

witnessed a peak of

fraternity and soror-

ity system at UND. 


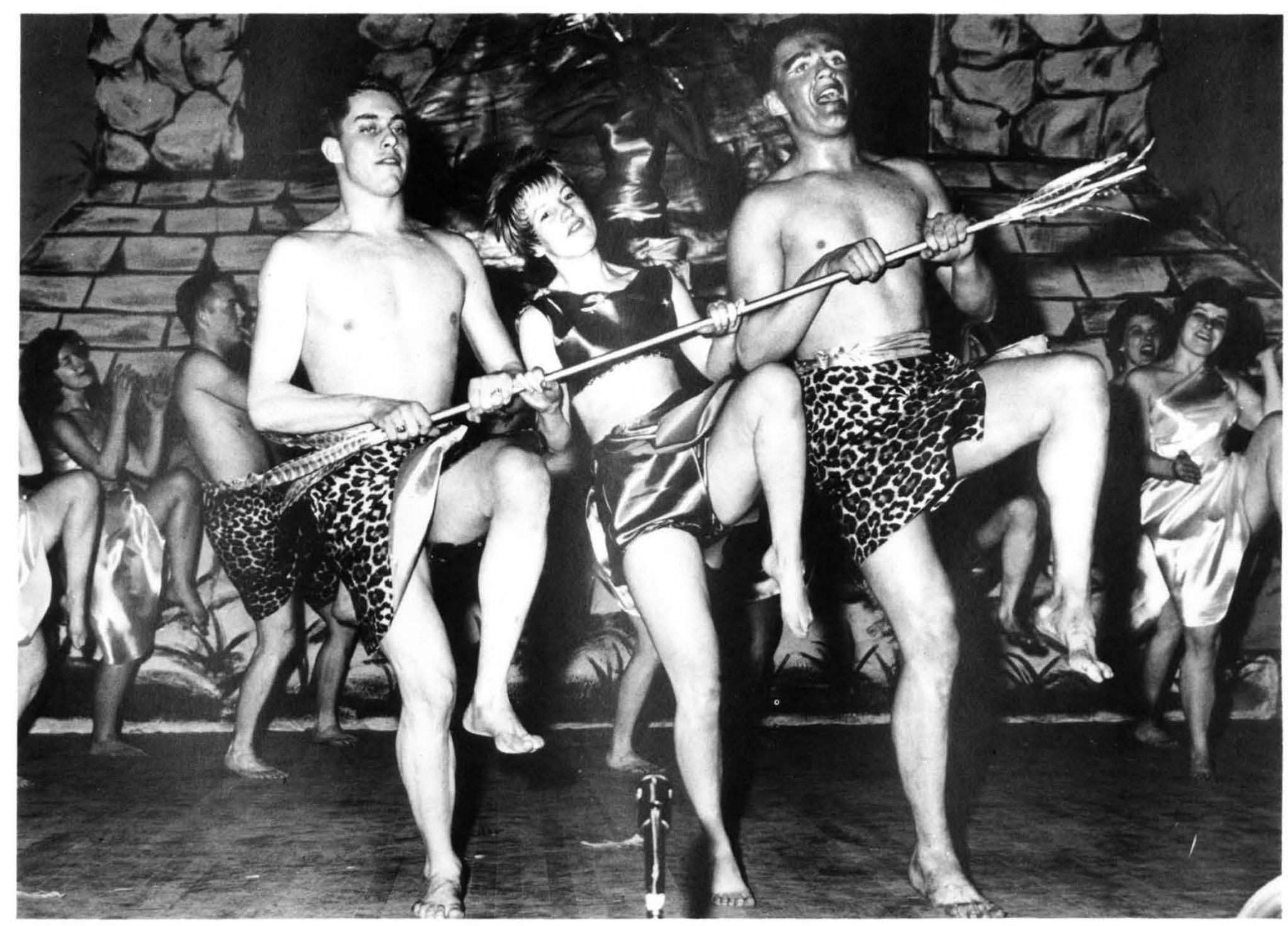




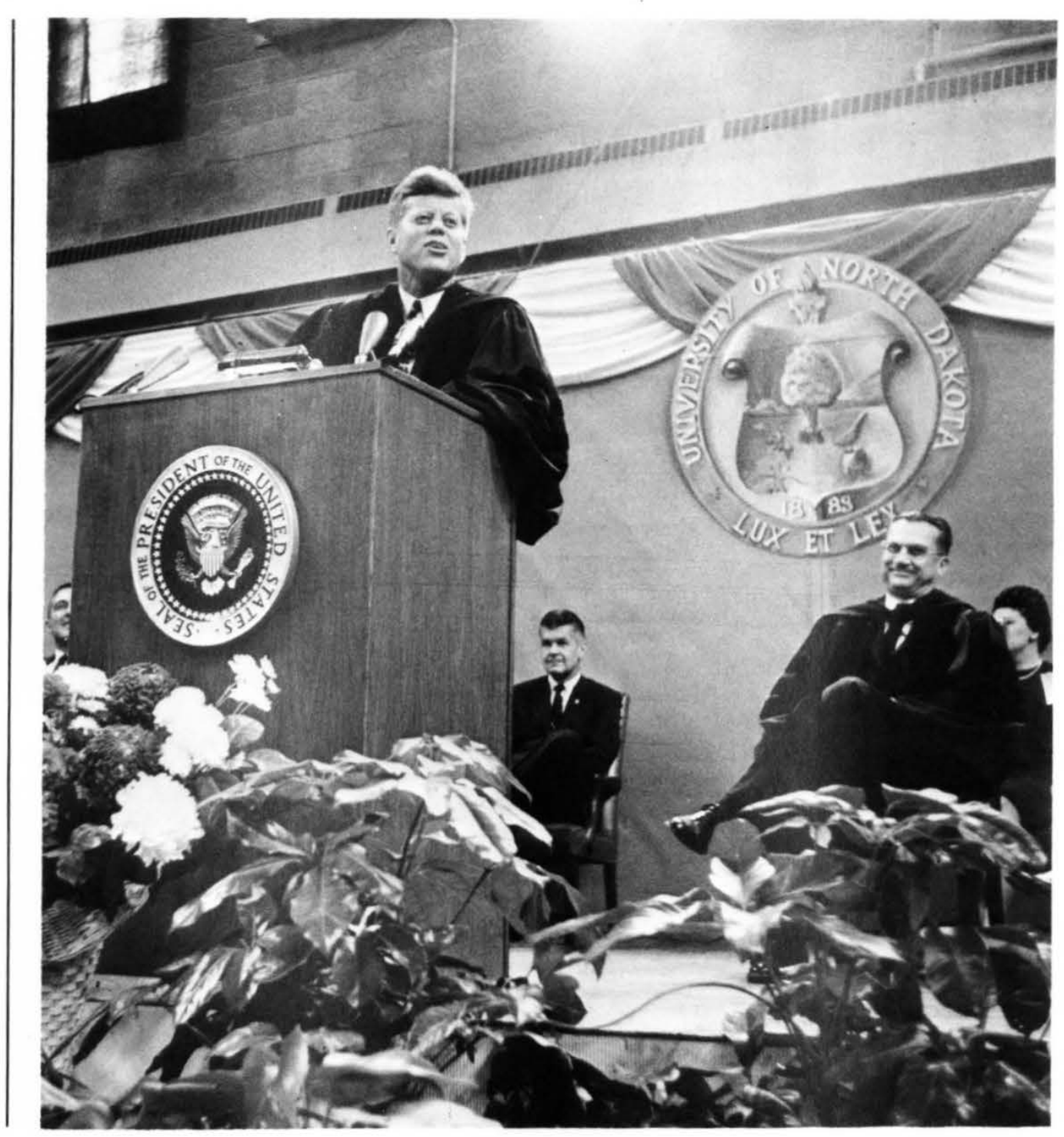

A dramatic moment - President John F. Kennedy visits the University in

September 1963, less

than two months

before his assassination. 
Homecoming event 1965 ; even at tradi-

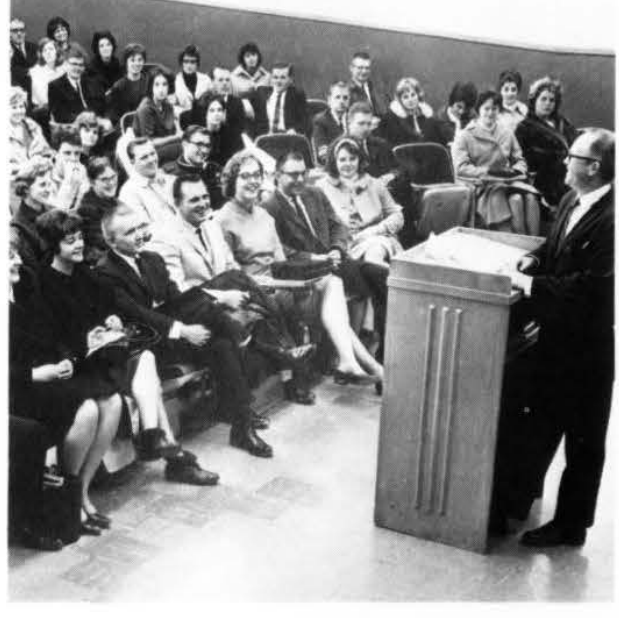

Spring sun bathing a sight much less common beginning in the 1970s when a revised calendar

began to end the se-

cond semester in mid-

May rather than in

June.

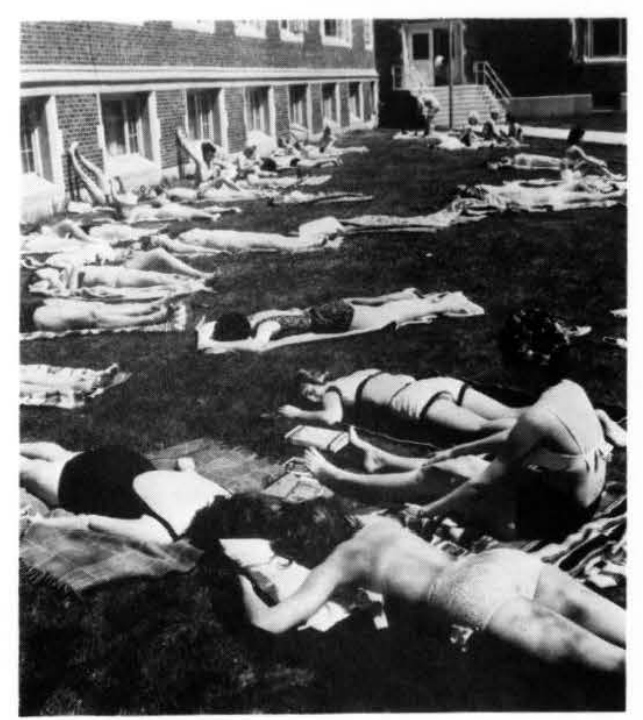

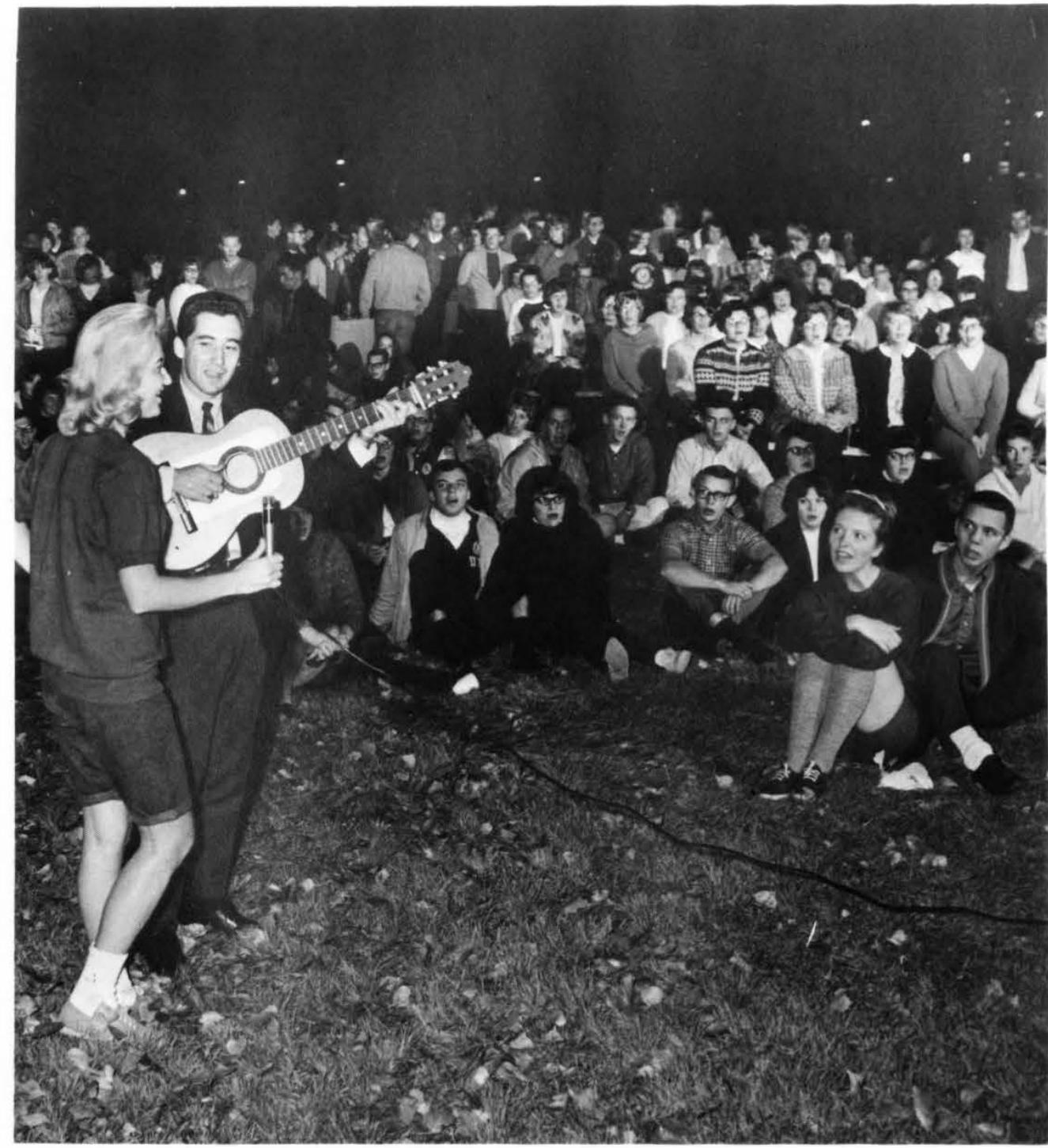




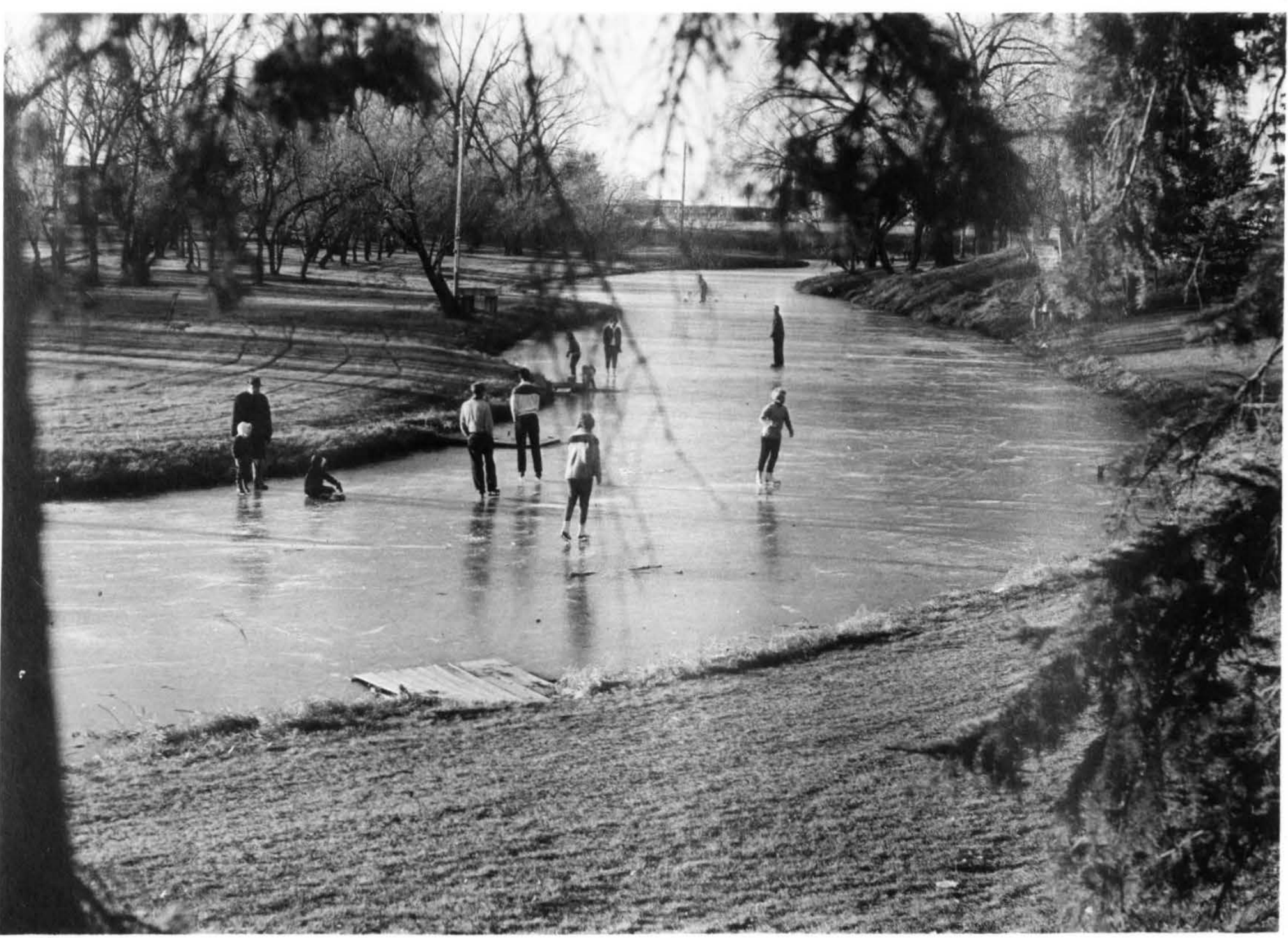

The scenic English Coulee was thought for 70 years as the western edge of the campus; now, after 100 years, it is closer to being the center of the campus. 
A 1965 meeting of the University Senate,

UND's principal

governing body.

Biology class, late 1960s.

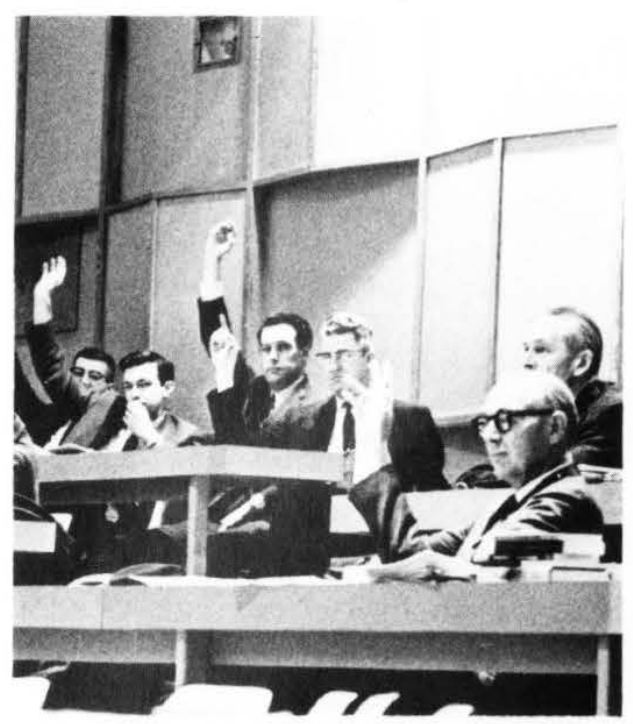

Two-time All

Jackson, who follow-

ed up his success a

ed up his success

professional basket-

professional basket-

ball during much of

1970s.
the late
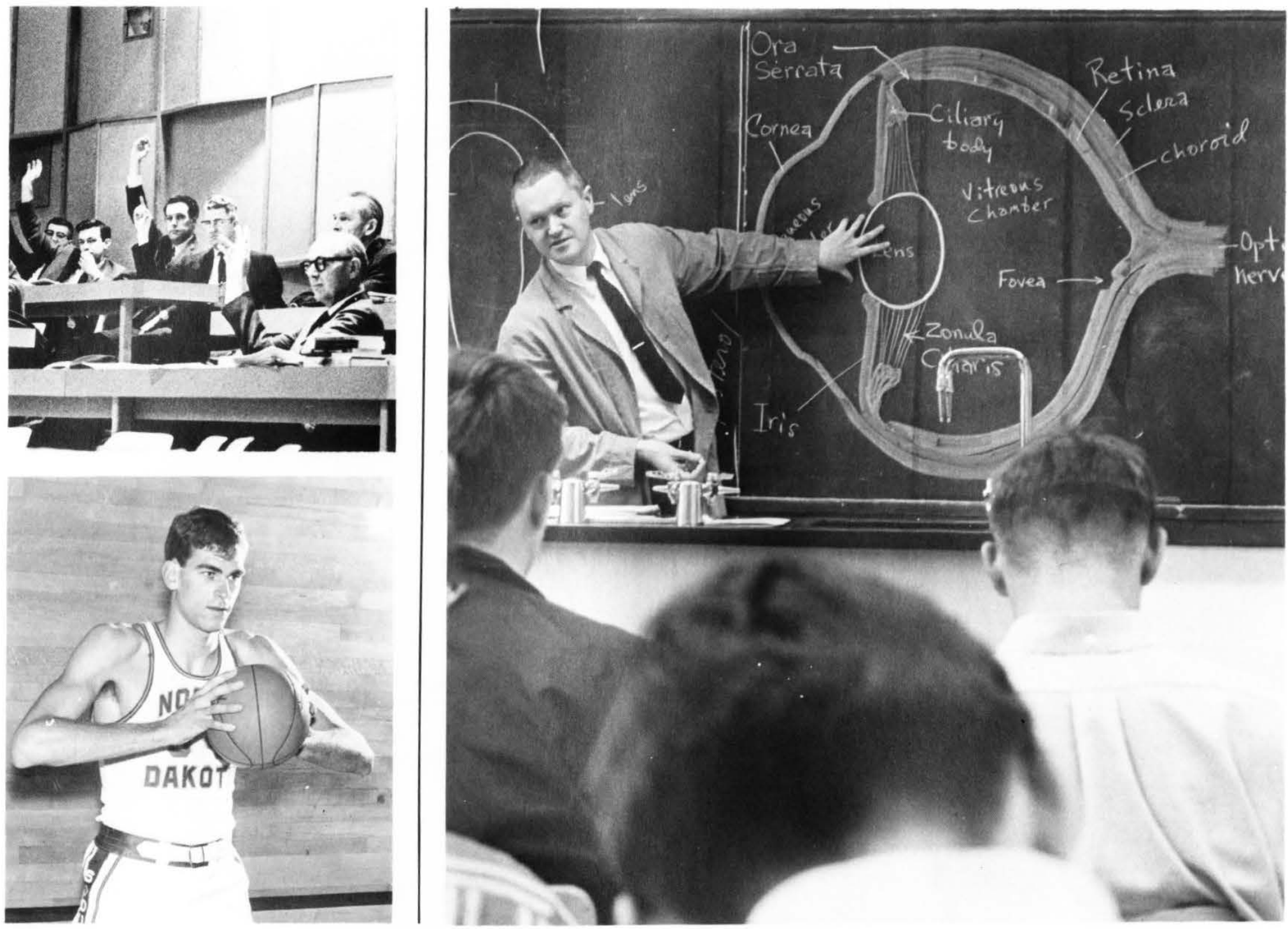
"All of us carry our origins with us forever; the blessings and the handicaps. One of the blessings from here was always the respect for learning, even in the smallest places. So, I long ago cast the balance on the credit side of my private ledger. There is a strength to be drawn from this land, but sometimes one learns that only in the contrast of other places.

I'm grateful to this region. I'm grateful for this return tonight, which is so fulfilling to me."'

- Eric Sevareid, broadcast journalist and North Dakota native, on receiving an honorary degree from UND in $\mathbf{1 9 7 0 .}$
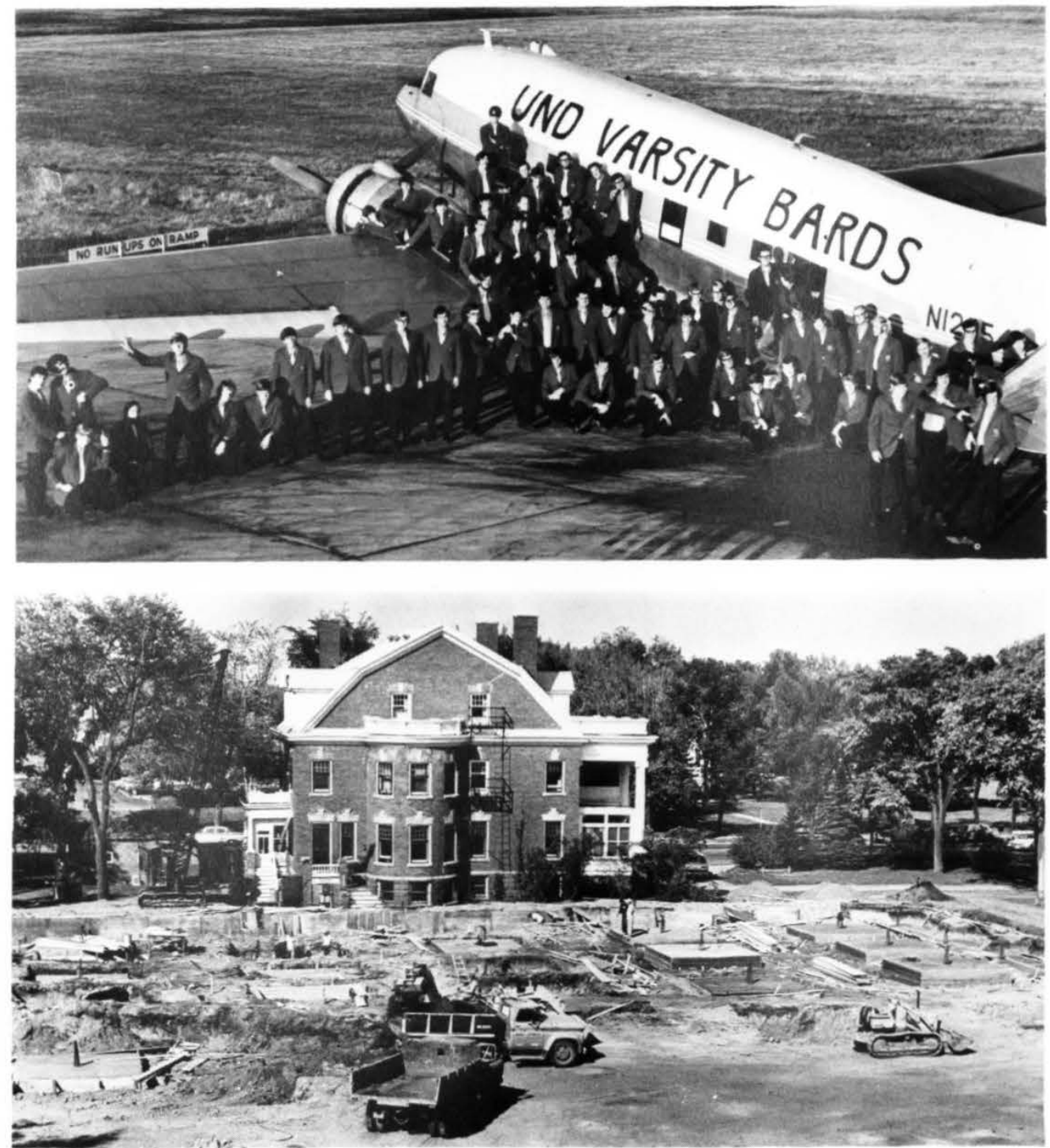

The Varsity Bards, UND's male chorus, have been earning applause for three decades.

When construction began in 1967 on nearby Gamble Hall, most people assumed that Oxford House, the former president's home, soon would be coming down; instead, a successful drive was begun to save and restore the historic structure. 
Peace demonstration,

1969; the sudden

appearance of beards

and long hair on
campus disturbed

some North

Dakotans.

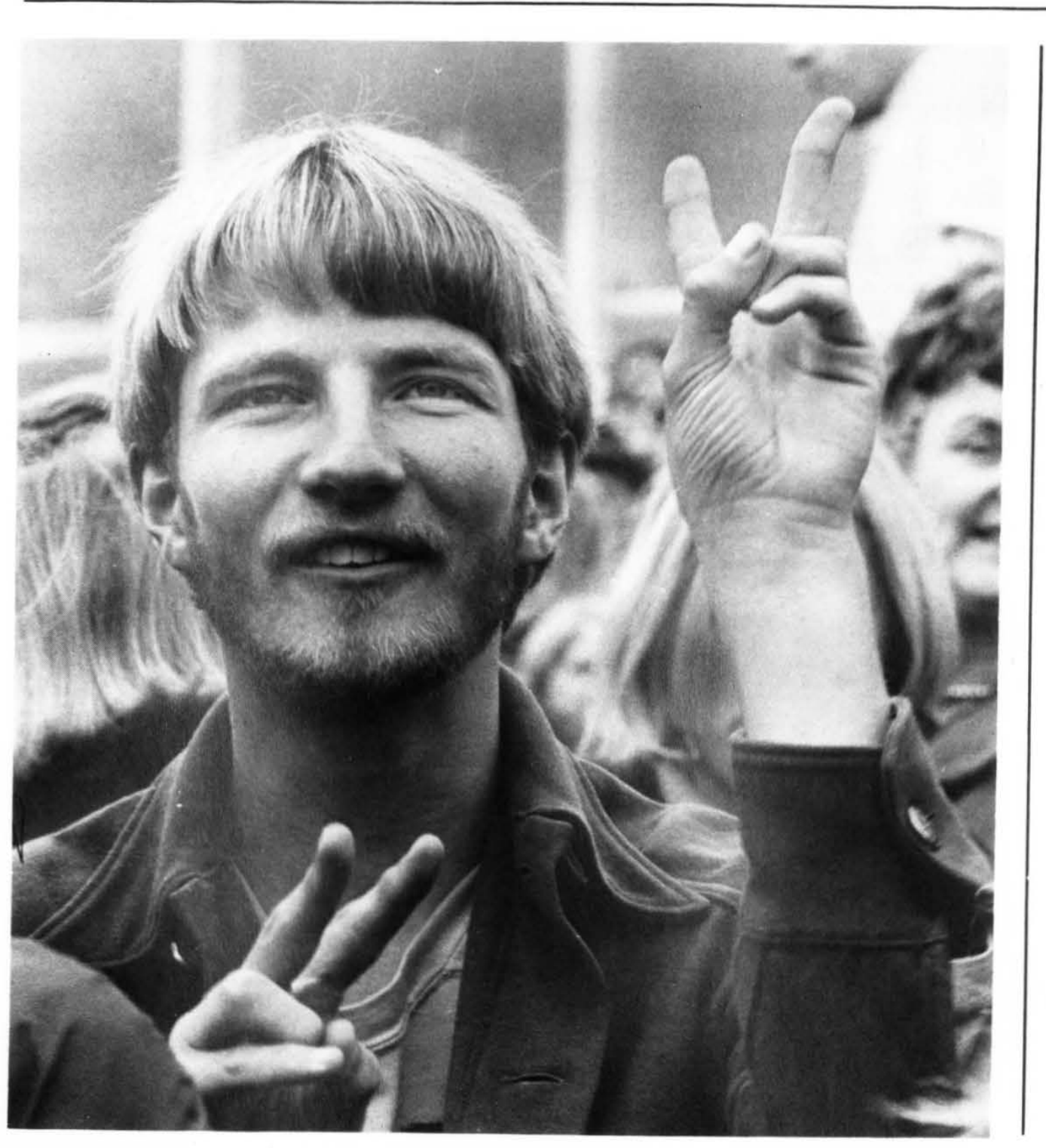


The modern era: $U N D$ reaches for new peaks.

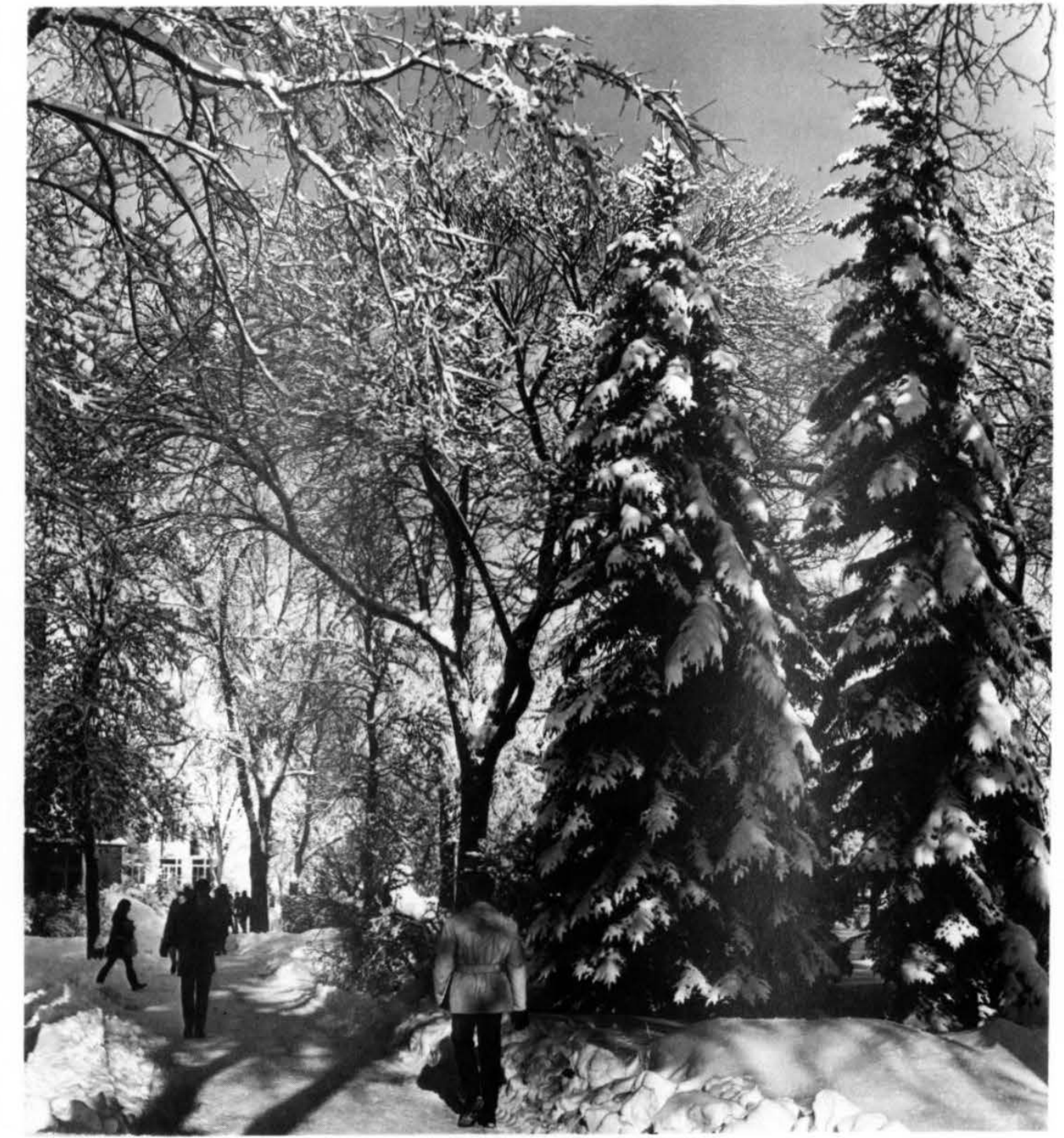

A snow-covered

campus, early 1970s. 

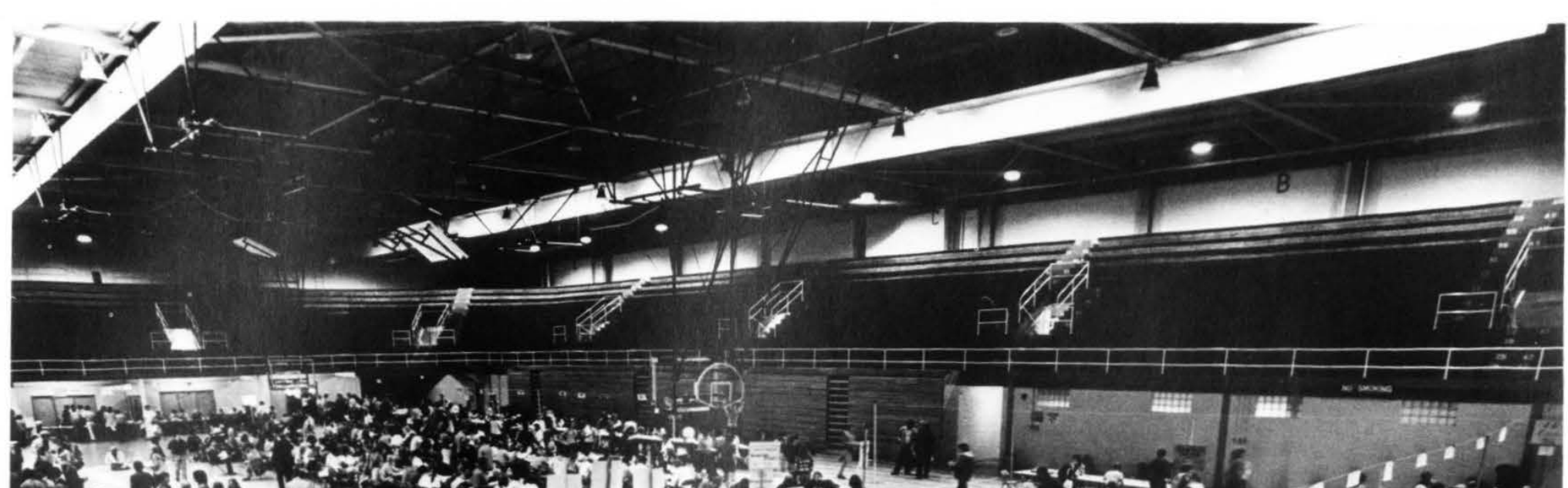

$1 \rightarrow 2$ to

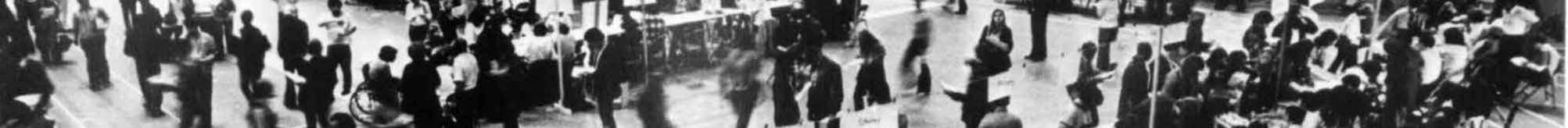

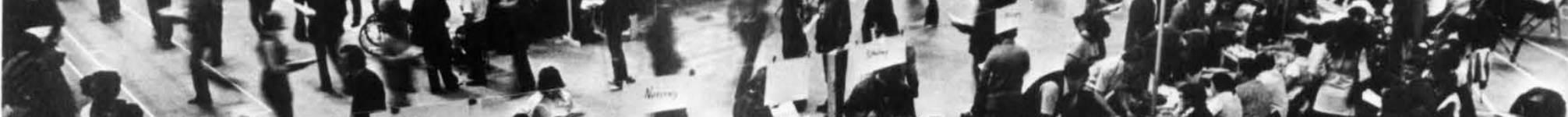

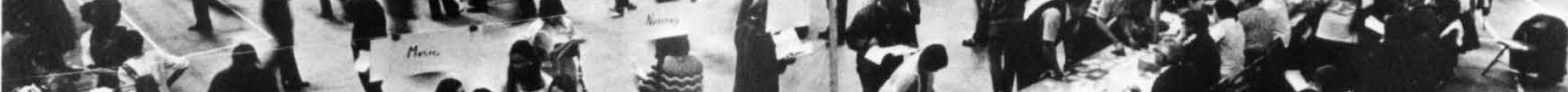
- 13 . I I

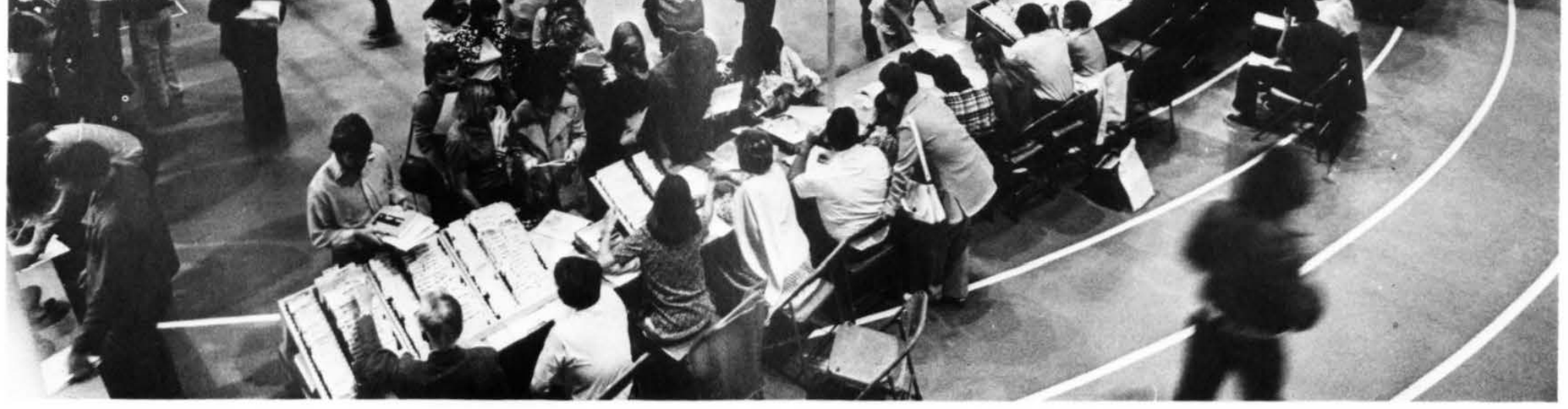




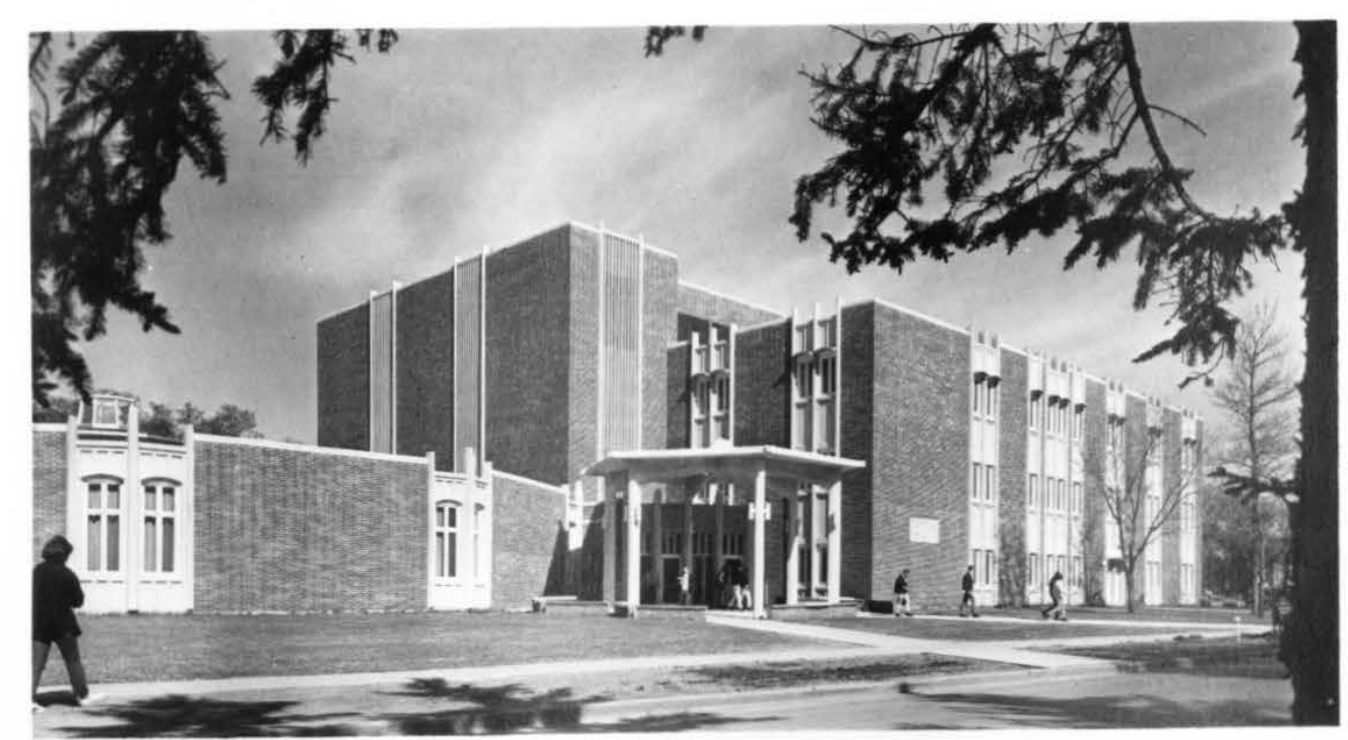

Gamble Hall, home

of the College of

Business and Public

Administration; its

growth helped lead

UND enrollment to

eight straight records.

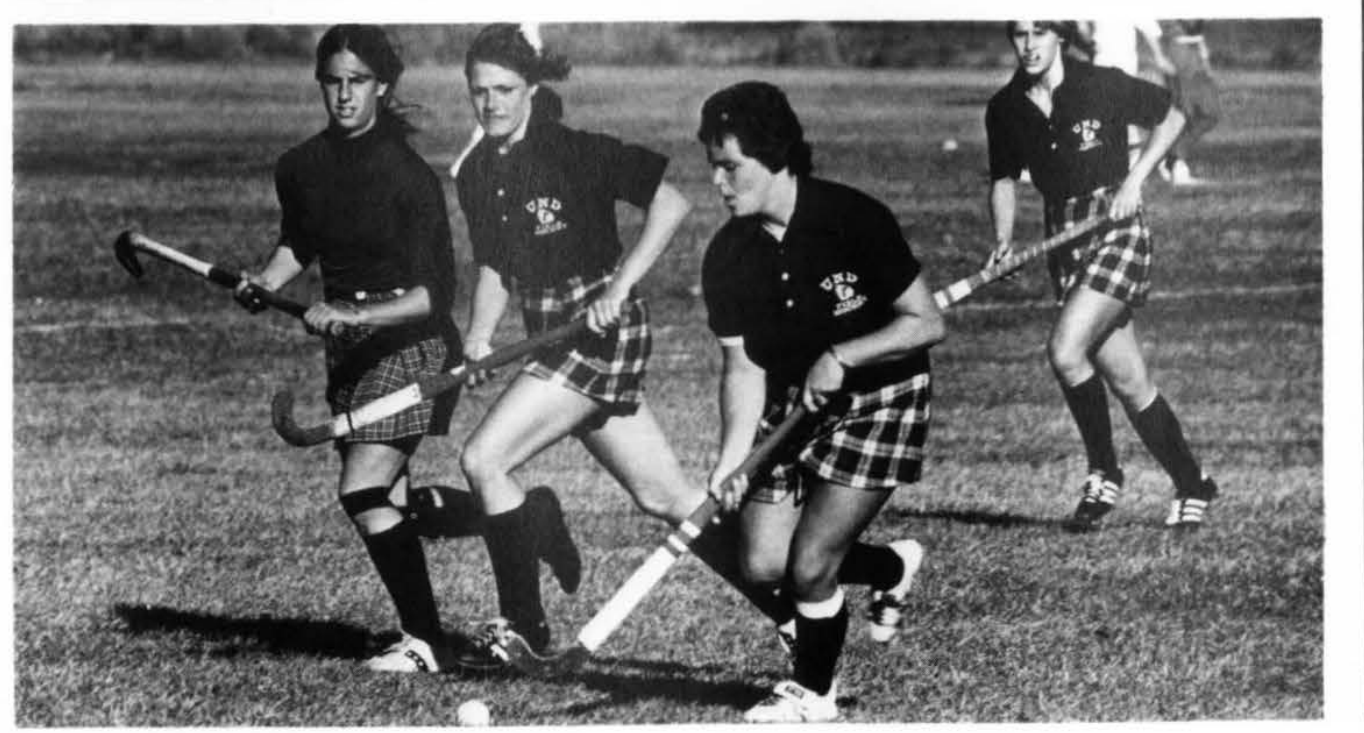

The growth of women's athletics was but one visible sign of a concern for equal opportunity for women which became evident in the 1970s and 1980s. 
Research grew

fivefold in dollar

volume at UND

during the decade

of the 1970s; much

of it was in

energy-related

fields.

Thanks to the spelling of his last name, in

1976 Robert Arusell

received the first

M.D. degree awarded

by the University.
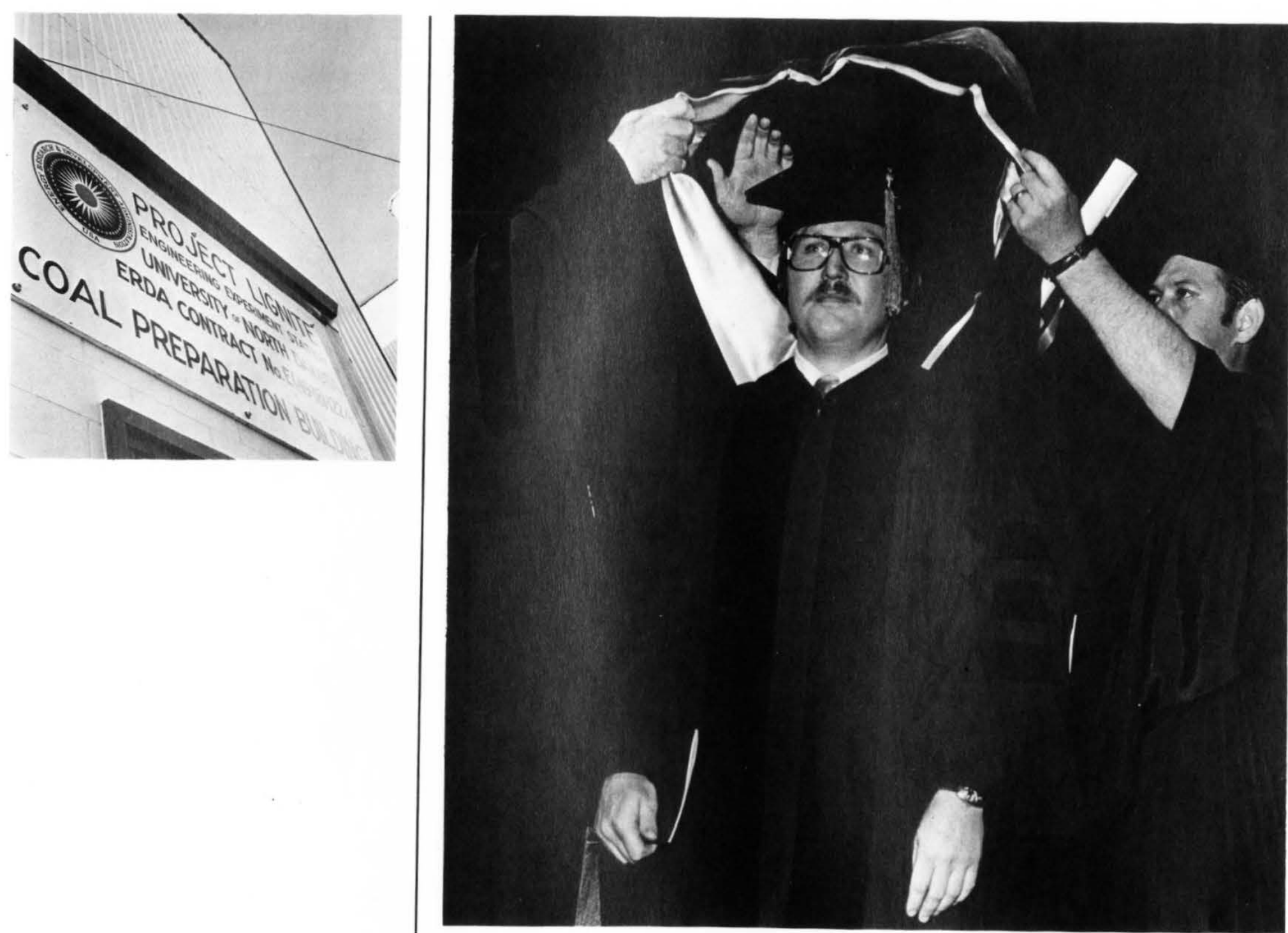


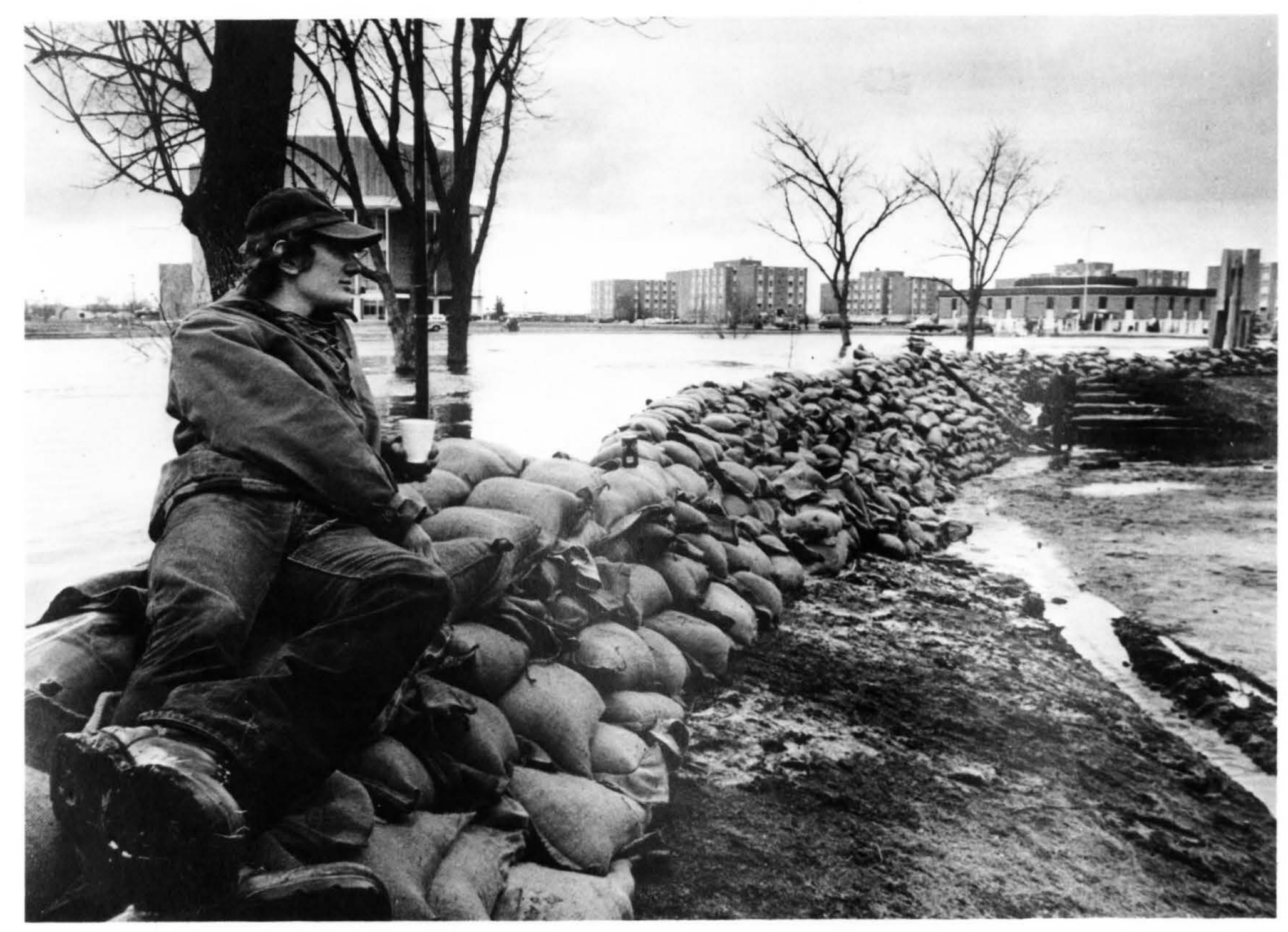

Students joined with

faculty, staff and

area residents to pro

tect the city and the

University from

floods in 1979. 
w. Kenneth Hyslop,

left, with UND

Alumni Association

Executive Vice Pres

dent Earl Strinden,

announced his

multimillion-dolla

land gift to UND

in January 1980.

UND alumnus Allen Olson won the buf-

falo chip throwing

contest (politician's

division) at

Homecoming 1980;

month later he

became the eighth

UND graduate elected

governor of North

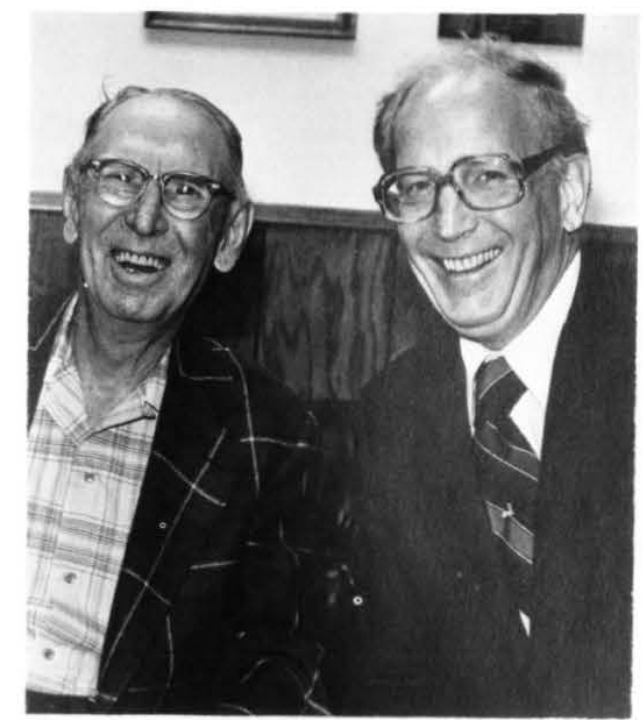

Dakota. 


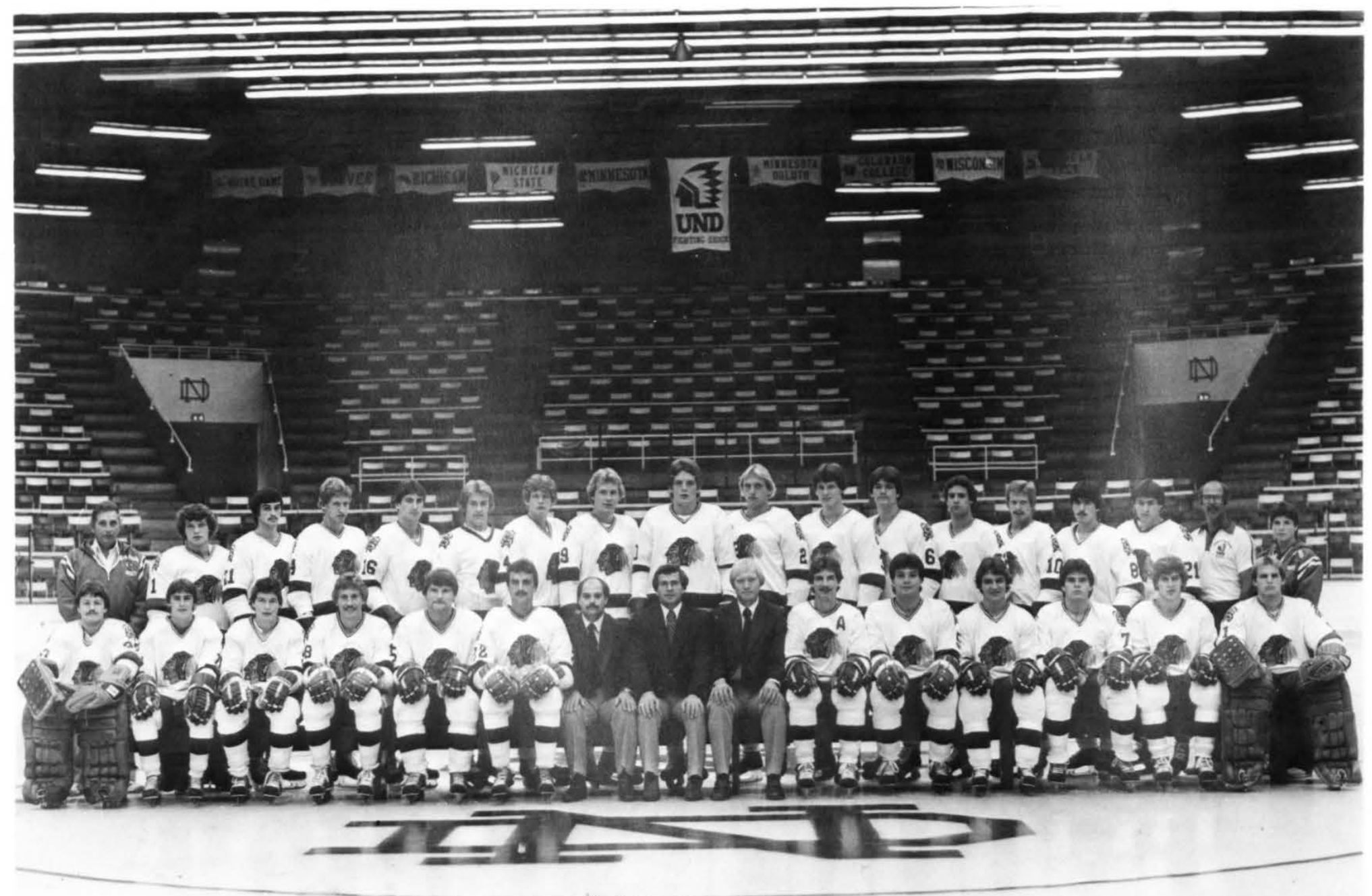


President Thomas $J$. Clifford addresses the UND

ference, spring 1982.

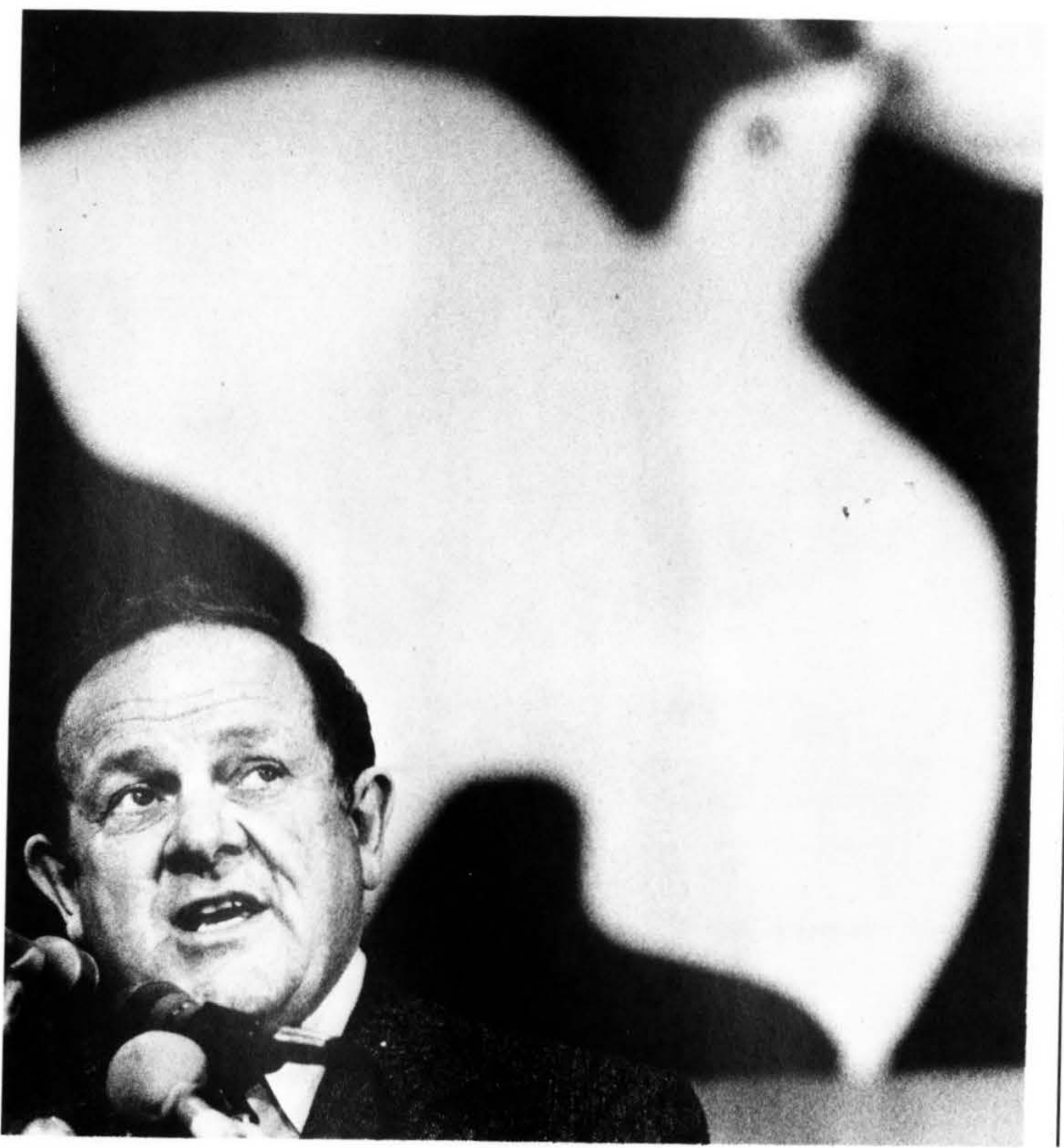

"The atmosphere of a university is the never-ending search for understanding, but it is also a spirit of humility which is not too sure that it is right. Have patience in the name of justice and avoid intolerance in the name of freedom. Let your love for this University be more durable than any moment's impulse, remembering that even where dialogue and discussion fail, violence is worse. ... This year can be an openended venture, selective of the past, critical of the present and oriented to the future. If our purposes are sacred, our regulations are not. But the light requires law, and good law depends upon the light of truth."

-President George Starcher, speaking at the opening convoca 1968-69 academic year, on the subject of "Light and Law," UND's motto. 


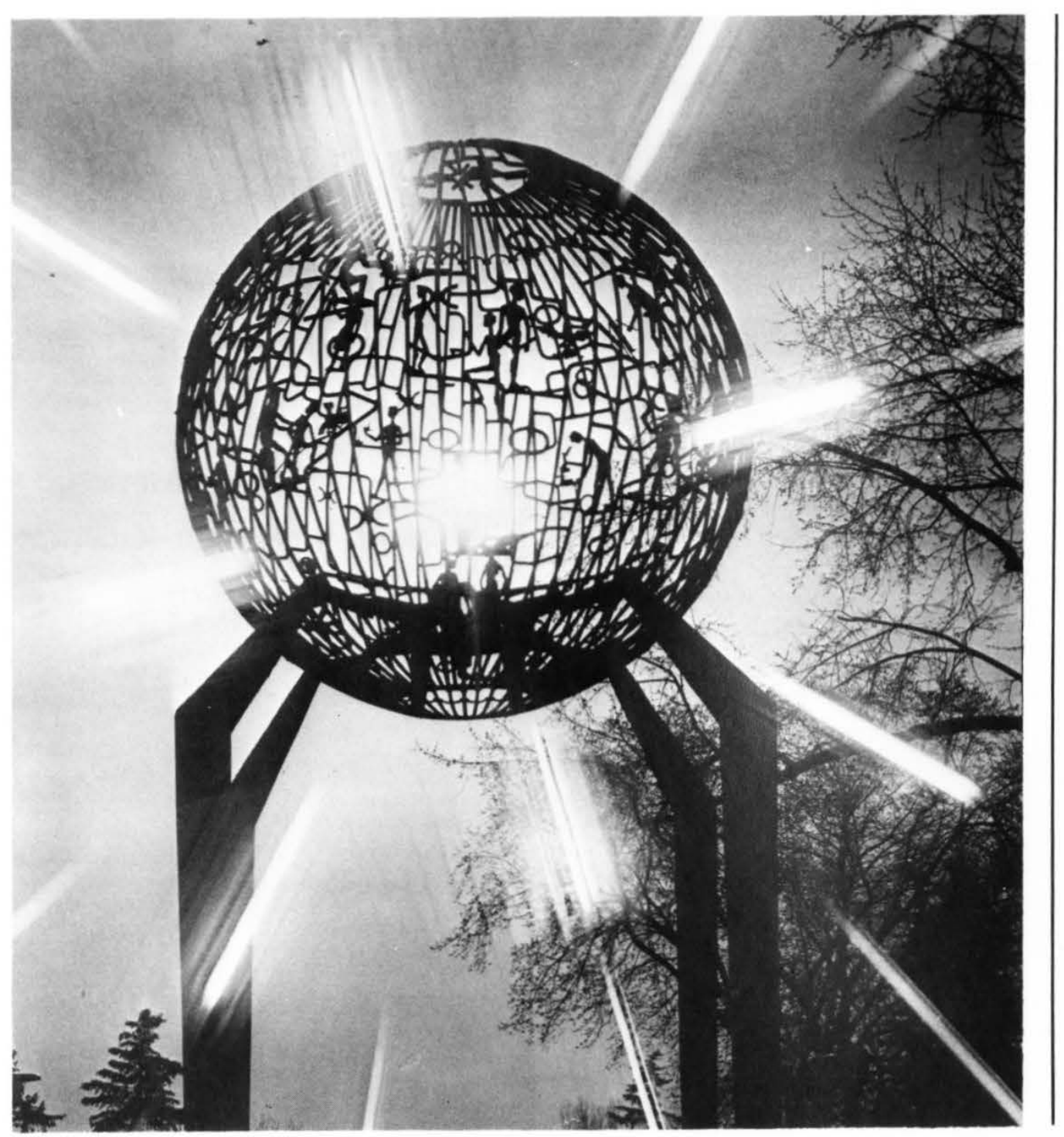

The spot where it began a century ago Memorial Sphere. 


\section{The Contributors}

Lee K. Bohnet, a native of Kulm, N.D. completed high school at Portland, Ore. He entered UND upon discharge from the U.S. Navy and received the Ph.B. in journalism in 1951. After a stint at the Fargo Forum he served as editor of the weekly Hillsboro Banner for a year. Since 1953 he has been sports information director for the University.

Robert P. Wilkins, a native of Hammond, Ind., received the B.A. and M.A. from Indiana University and the Ph.D. from West Virginia University. For all but four years he taught history at the University during the period 1945-1981. From 1964 to 1967 he was at Marshall University and in 1962-1963 was visiting Professor of History at the University of Oklahoma. For 10 years he taught the history of North Dakota and from 1968 to 1981 edited the North Dakota Quarterly. $\mathrm{He}$ is co-author with Wynona $\mathrm{H}$. Wilkins of North Dakota, a Bicentennial History (1977).

Dan Rylance, a native of Fargo, is a fourth generation North Dakotan of Canadian ancestry. Holder of the M.A. in History from UND, he was in 1967 appointed the university's first archivist. He has published "Fred Aandahl and the ROC" in The North Dakota Political Tradition (Iowa State University Press, 1981) and, as co-author, Years of Despair: North Dakota in the Depression (1973) and Ever Westward to the Far East: The Story of Chester Fritz (1982). He is also an assistant professor of history.

Thomas W. Howard, a native of Indiana and an associate professor of history, came to the University in 1969 . He received the B.A. and M.A. from Ball State University and the Ph.D. from Indiana University. His special interests are American colonial and social history. He edited The North Dakota Political Tradition (1981)

James F. Vivian, a native of Arizona, received the B.A. from Coe College, the

M.A. from the University of Nebraska and the Ph.D. from American University. Since 1973 he has taught Latin American history at UND with the present rank of professor.

D. Jerome Tweton, a native of Grand Forks, received the B.A. from Gustavus Adolphus College, the M.A. from the University of North Dakota and the Ph.D. at the University of Oklahoma. After six years as professor of history at Dana College he came to UND as chairman of the Department of History. He is coauthor of Years of Despair: North Dakota in the Depression (1973), North Dakota:

The Heritage of a People (1976); author of The Marquis de Mores: Dakota Capitalist, French Nationalist (1972) and Depression: Minnesota in the Thirties (1981). 
This book, published furing the observance of

the looth anniversary of the

University of North Dakota

at Grand Forks, is one of

several Centernial activities

eommemorating the rnen

and women who have made

this institution what it is

today

\section{UND}

